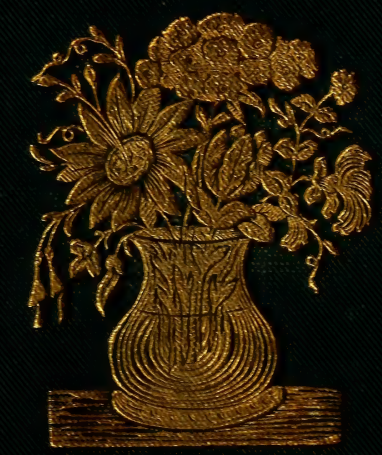




\section{LIBRARY OF CONGRESS,

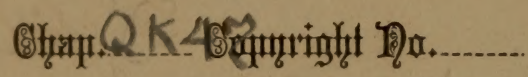 Shelf $\mathrm{W} 875$ \\ UNITED STATES OF AMERICA.}




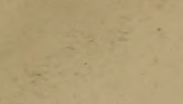
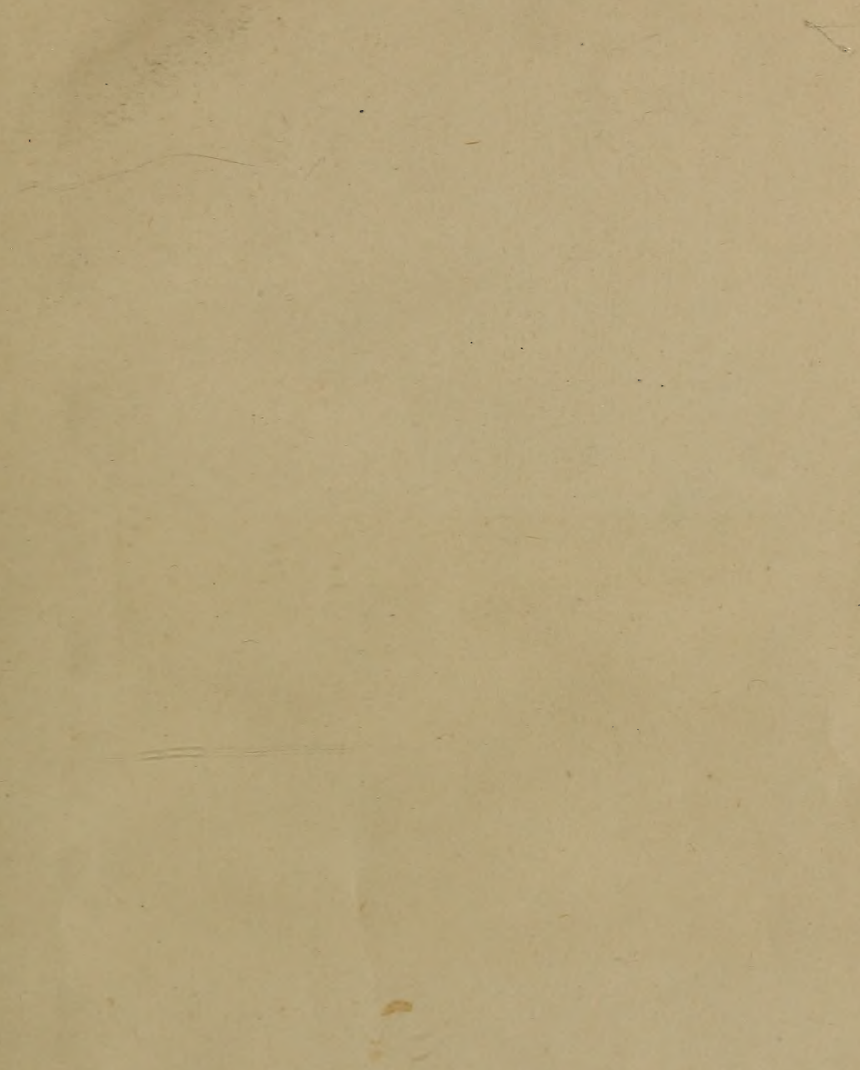





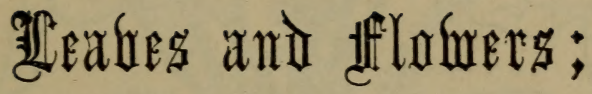

\author{
or:, \\ OBJECT LESSONS \\ IN \\ B O T A N Y.
}




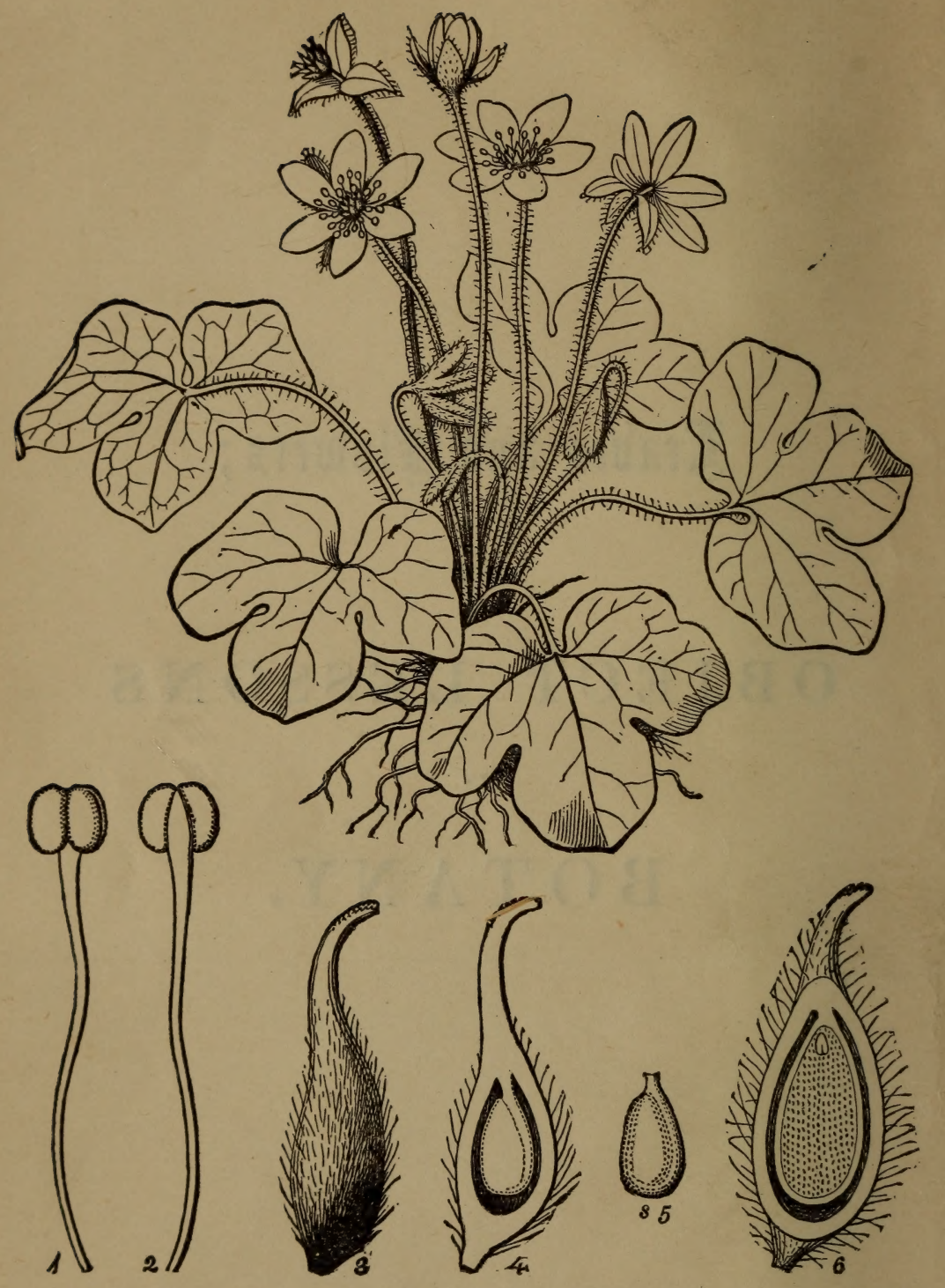

Noвle Liverwort (Hepatica trîloba, p. 147): 1, a stamen seen in front; 2, in rear ; 3, a pistil or carpel ; 4, 5, the ovule pendulous, and anatropous, i. e., bent over on its stalk; 6 , a section of the full-grown seed, showing the 2-cotyledoned embryo at the end of the large albumen. (From "14 Wecks in Botany.") 


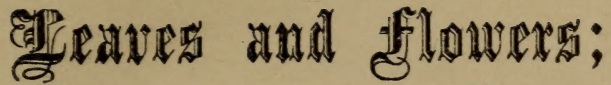

OR.

\section{OBJECT LESSONS IN BOTANY}

\author{
WITH
}

\section{A FLORA.}

PREPARED FOR BEGINNERS IN ACADEMIES AND POBLIC SCHOOLS.

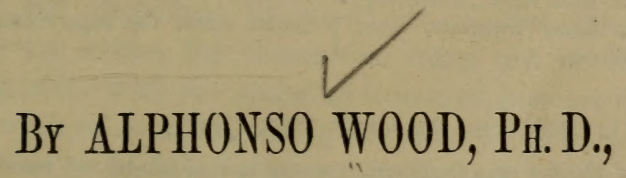

AUTHOR OF THE CLASS-BOOK OF BOTANY, ETC.

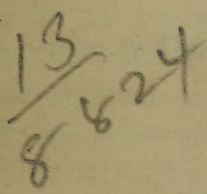

WITH 665 ILLUSTRATIONS.

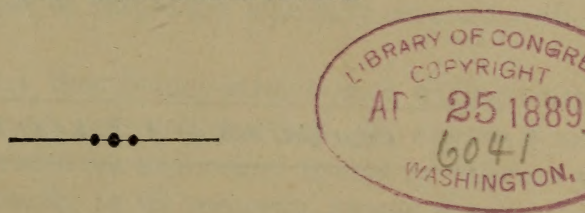

A. S. B A R E \& \& O O P A N Y, NEW YORK AND CHICAGO. NIMS \& KNIGHT, TROY, N. Y. 


\section{WOOD'S BOTANY.}

\section{OBJECT LESSONS IN BOTANY,}

Pleasing lessons for young learners.

\section{BOTANIST AND FLORIST,}

A thorough text-book, comprehensive and practical.

III. THE NEW CLASS-BOOK,

A superb and exhaustive compilation and encyclopedia of the science.

\section{BOTANICAL APPARATUS,}

A complete field outfit, consisting of Portable Trunk, Drying Press, Trowel, Lens, Tweezers, Etc., prepared under the supervision of Prof. Wood.

\section{THE STUDENT'S PLANT RECORD,}

A book of blank forms, facilitating the analysis of plants, and recording the results of such analysis, and the progress of the student.

** The Publishers will send either of above, postage or freight prepaid, on receipt of price.

Copyright, 1888, by A. S. BARNES \& CO. 


\section{P R E F A UE.}

A more the happiest days of our childhood were those devoted to the study of Botany. Pure sunshine rests upon the memory of those ramblea in the fields and woods, amid the opening flowers of Spring, and then in the gay profusion of advancing Summer, in which we made acquaintance with many a floral gem before unknown. We love to think of that wild woodland lake where first we saw the sparkling Sundew, the quaint Sarracenia, and the fair Nymphæa, resting on the bosom of the waters; or of that lowly dell by the brookside, where the Yeilow Violet, the Hepatica, and the Bloodroot bloomed; or of that craggy mountain, where, among the rocks, the Culumbine hung out its scarlet flowers. Then returning home with our gathered treasures, how we entered with a will upon the work of Analysis, toiling for hours as no schoolmaster could have compelled us to do, being attracted to the task by the very love of it alone. Here, then, we have at least one department in learning whose earnest pursuit is so congenial to the affections and tastes of the mind as to be no irksome task, but a pastime,-a perpetual feast; and this not only to maturer minds, but to the season of early youth even in a higher degree, since then the objects of nature are especially invested with the charms of novelty.

Let it not be said, however, that Botany attracts such willing votaries because it requires no labor, no persevering effort. No science is more intricate or profound. It cannot be understood except by vigorous and persevering effort. Consequently, in its successful pursuit there is discipline for the mind as well as for the body; and since the subject itself is replete with refinement and beauty, and fresh from the hand of God, its pursuit must also conduce to the invigoration of the moral nature.

If, then, it be desirable to preoccupy the minds of our children with controlling ideas of purity, refinement, and moral beauty,-with exalted 
thoughts of God, habits of mental activity, strength of judgment, and decision of character; and, moreover, to do all this by means of a sturly whose path, in a donble sense, is strown with flowers, then is the study of Botany desirable; and that labor is not in vain which is bestowed apon the preparation of a work designed, like the present, for primary classes, from the ages of ten to fourteen.

As the title implies, we have aimed to represent to the eye nearly erery subject or form treated of, or described in these Lessons. But, notwith. standing the copiousness of these illustrations, neither the teacher nor the pupil will be satisfied to rely upon their aid alone. Nature alone can afford the proper illustrations in the study of Nature's works, and it is only by comparison with the living specimen that eith $\mathrm{s}$ the picture or the description becomes intelligible. Therefore let specimens in unlimited number accompany every botanical recitation.

Most of the figures are original. Others have been derived from Maout, Payer, Richard, Balfour, Lindley, and a few, by permission, from Darlington's "Weeds and Useful Plants."

Finally, to the children and youth of our country, gathered in schools of every name, this humble volume is dedicated, with confident belief that it will prove to many of them a source of intellectual and moral culture as well as of pure and rational delight.

BrookLys, N. Y., February 23, 1868.

BOTA I I A A PPARATUS.

The Publishers have recently provided and have on sale a set of apparatus of the most approved form for the use of the student in botanical pursuits, and as described in the ClassBook, page 15. It consists of a knife-trovel for digring and cutting specimens, a microscope and tweezers for analysis, a tin-box for preserving them fresh, and a press for drying them. The Set, securely packed, will be sent by Express to order, at a moderato pitce.

\section{The Plant Record.}

"The Botanical Index," a work for Schools and Seminaries, altogether' new and peculiar. It gives blank forms, by which an analytical record can be made of the pl ints and flora, the student may examine.

Also, in the domain of Science, the Publishers offer Steele's 14 Weeks' Course in Astronomy.

$\begin{array}{llll}\text { " } & \text { " } & \text { " } & \text { Chemistry (with Apparatus). } \\ \text { " } & \text { " } & \text { " } & \text { Philosophy (with Apparatus). } \\ \text { " } & \text { " } & \text { " } & \text { Physiology (with Cabinets). }\end{array}$




\section{CONTENTS.}

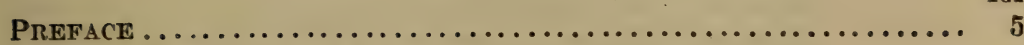

LEsson 1. The Leaf and its parts $\ldots \ldots \ldots \ldots \ldots \ldots \ldots \ldots \ldots \ldots . . . . .6$

2. Veins and Venation of the Leaf $\ldots \ldots \ldots \ldots \ldots \ldots \ldots \ldots, 11$

3. Forms and Figures of Leaves ................... 15

4. Forms and Figures of Leaves................... 19

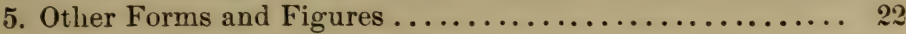

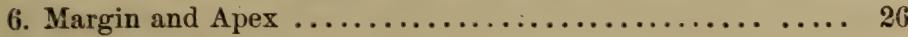

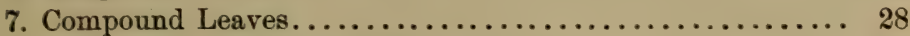

8. Sessile Leaves._Forms of Stipules............... 32

9. Arrangement of Leaves and Buds................ 35

10. Appendages, \&c............................. 38

11. Organs of the Flower ......................... 41

12. More about the Calyx and Corolla................. 43

13. About Adhesions.......................... 48

14. Forms of the Perianth ...................... 50

15. Concerning the Stamens ..................... 54

16. More about the Stamens . . . . . . . . . .

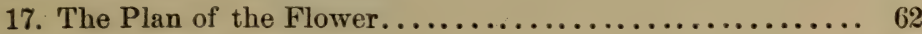

18. Of the Pistils ......................... 67

19. How the Leaves are folded in the Bud.............. 71

20. How the Flowers are arranged on the Plant ......... 75

21. The Inflorescence continued .................... 78

22. Concerning the Fruit....................... 83

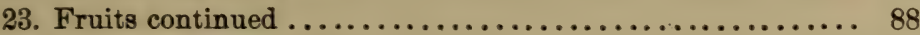

24. Concerning the Seeds....................... 92

25. The Seed becoming a Plant ................. 95

26. Life of the Plant, or its Biography .............. 100

27 Of the Axis of the Plant........................ 103

28. Of the Stem or Ascending Axis ................ 106

29. Plants to be arranged in Classes............... 113 


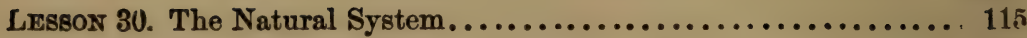

31. More about the Natural System................. 119

32. Of the Analysis of Plants........................ 122

33. How to Analyze a Plant by the Tables ............. 125

34. Various Suggestions and Cautions ................ 128

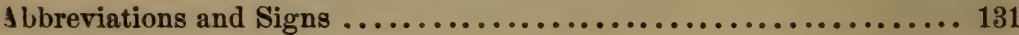

Analysis of the Natural Orders........................ 132

InE Flord.-Cohort 1. The Polypetalous Exogens............. 143

Cohort 2. The Gamopetalous Exogens............ 215

Cohort 3. The Apetalous Exogens .............. 275

Cohort 4. The Conoids (omitted).

Cohort 5. The Spadicifloræ.................... 282

Cohort 6. The Floridiæ ...................... 284

Glossary of Botanical Terms........................... 302

Index to the Names of Species, Genera, Orders, \&c............. 309 


\section{OBJECT LESSONS IN BOTANY.}

\section{LESSON I.}

THE LEAF, AND ITS PARTS.

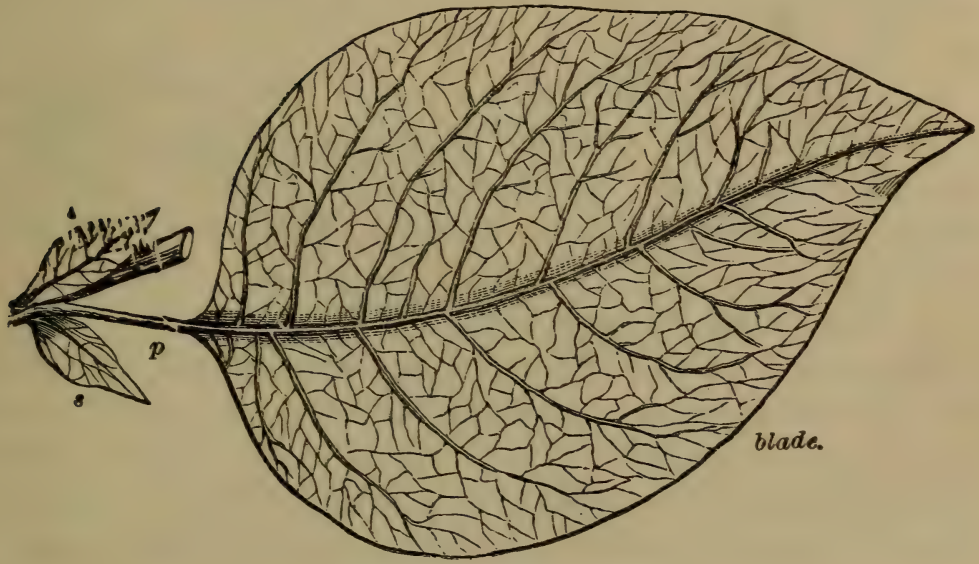

Fig. 1. Leaf of the Quince.

1. WE have before us the picture of a Quince leaf, care fully drawn from nature. It is of a rich green color, very pleasant to the eye. Its outlines are full, even, and gracefully curved, and its upper surface is smooth and naked. Although it is indeed but one leaf, yet it seems to be made up of three parts - $b, p, s s$.

2. The upper part, $b$, is broad and thin, and is called the 
BLADE. The upper end of the blade is the apex, and the lower end is the base. You see at once that the outline of this blade represents a certain form or figure, with an even margin, rounded, and broader at the base than at the apex, like the figure of an egg. So it is called an egg-shaped leaf : or, to use a softer word, ovate.

3. Now see how this blade is supported. At the base it is suddenly narrowed to a foot-stalk, which is properly called the PETIOLE. You see that this part of the leaf is narrow and slender, and in this leaf terete, or cylindrical, in form. But in some kinds of leaves it is flattened. Remember its name,petiole.

4. Lastly, at the base of the petiole you notice a pair of little leaf-like bodies, one on this side and one on that. These we call the stipdLes. Stipules, then, are always in pairs, and placed at the base of the petiole. Their shape is quite various.

5. Thus, when a leaf is complete, it consists of a blade, a petiole, and a pair of stipules. But you will not find every kind of leaf complete. Many sorts have no stipules at all. Can you find stipules on the leaves of the Lilac? Some leaves, moreover, have not even a petiole. See the leaves of Phlox. Such leaves are said to be sessile, that is, sitting.

1. What is the color of the leaf cf the Quince bush? What is the color of leaves generally? Ans. Green, of lighter or darker shade. What of the outline of this leaf?-its upper surface?

2. What is the blade? - the apex?-the base? What is the figure of the blade?

3. How is the blade supported? Describe the foot-stalk. Tell its real name.

4. Describe the stipules.

5. Now state the three parts of a complete leaf. Do all kinds of leaves have stipules? Do the leaves of the Lilac?-of St. Johnswort, \&c. ?-of the 


\section{LESSON II.}

\section{VEINS AND VENATION OF THE LEAF.}

6. The blade of the Quince leaf (Fig. 2) shows many reins running through it, and branching all over it. Examine

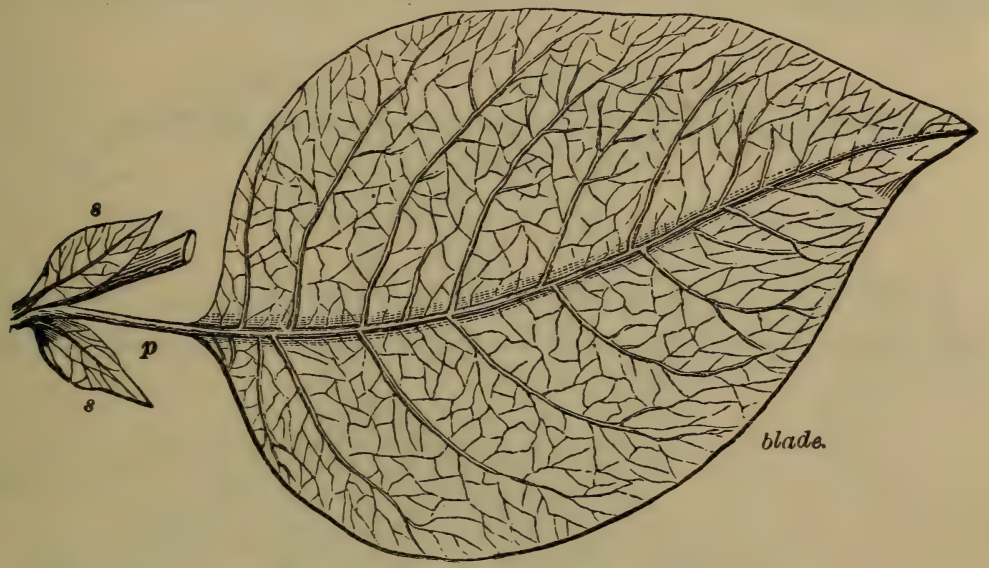

Fig. 2. Leaf of the Quince, showing the veins.

them. First, the petiole seems to be extended and continued right through, from the base to the apex, forming the largest vein in the leaf. This is the midvein.

7. Next observe several large branches sent off from this midvein on both sides, right and left. These are the vernlets. Now, looking at these veins, their arrangement reminds us of a feather, and we call such leaves feather-veined. Therefore,

Violet? Do all kinds of leaves have petioles? - of Phlox, for example \& What do you understand by sessile leaves ?

6. Describe the midvein of the Quince leaf.

7. Describe the veinlets. What is the feather-veined venation? 
we may say that the feather-veined venation consists of ons midvein branching into veinlets. This is very common.

8. Thirdly, the veinlets themselves send off little branches (branchlets) on their right and left, and we call these the veinulets. These again and again may divide, and finally, all the little divisions unite again, forming a complete net-work all over the leaf. Thus we learn what a net-veined leaf is.

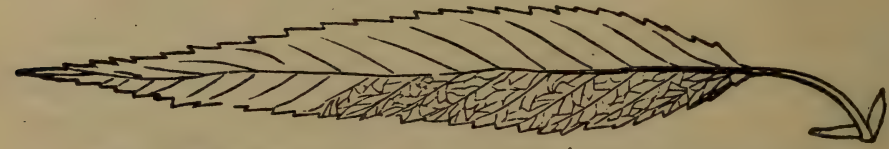

Fig. 8. The Willow leaf. Some of the veinnlets are shown.

9. Here is a picture of the Willow leaf (Fig. 3). You can point out all its parts, and the three kinds of veins in it. In

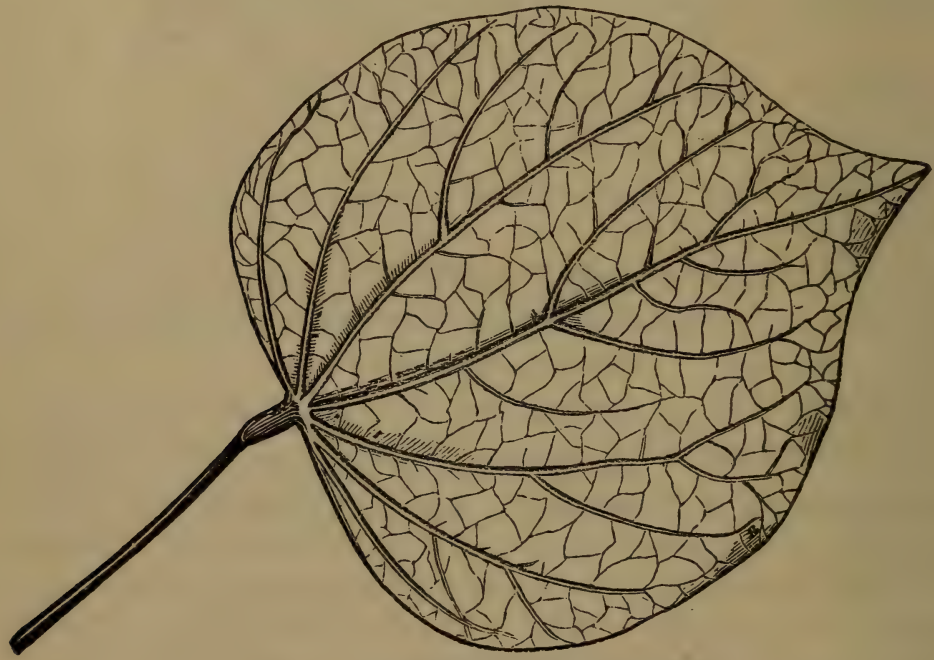

Fig. 4. Leaf of the Red-bud (Cercis).

8. What are the veinulets? When is a leaf said to be netveined? 
the next cut (Fig. 4), representing the Judas-tree or Redbud leaf, you see a different venation.

10. At the base of the blade the petiole seems to diride all at once into five large veins, each running through, one to the apex, and four to the margin. In this case the vein. ing (that is, the venation) is compared to the division of the hand (or palm of the hand) into fingers, and so named pal-

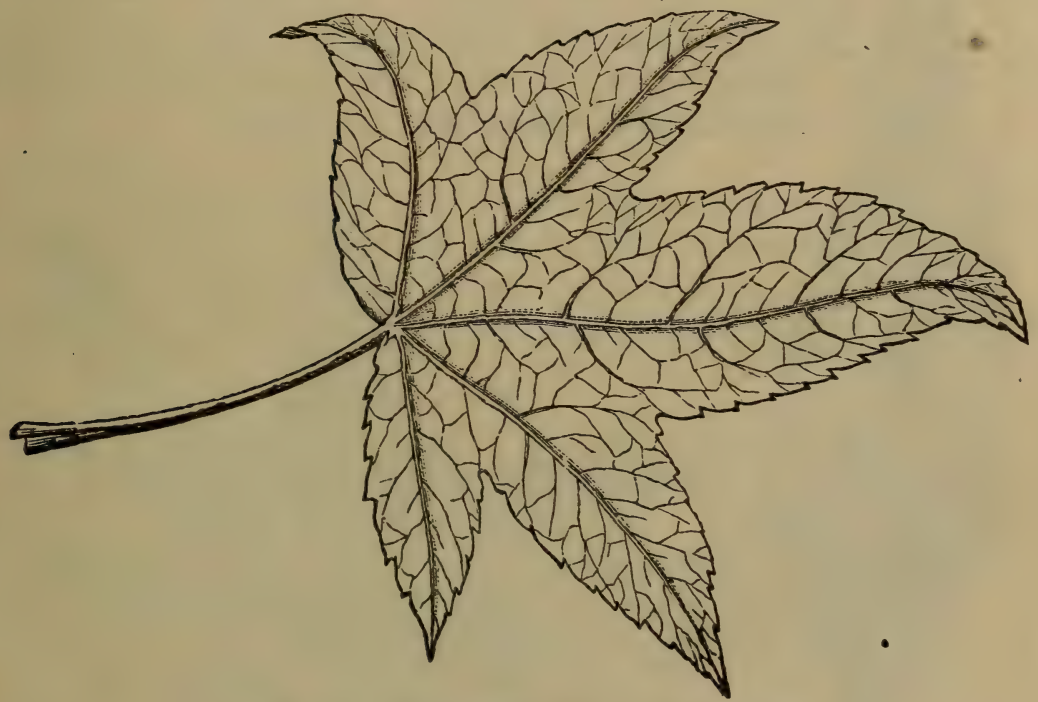

Fig. 4 a. Leaf of Sweet-gum (Liquidambar).

mate venation. Therefore, you may say that the palmate venation consists of about five veins starting together at the base of the blade, each one branching into veinlets and reinulets. Fig. $4 a$ is a lobed leaf of the Liquidambar trec

9. Note the parts of this Willow leaf. Point out its midvein. Its veinlet -veinulets.

10. Define the palmate venation Wliat are the reins? 
with palmate venation. Maple leaves are very familiar es amples of the same.

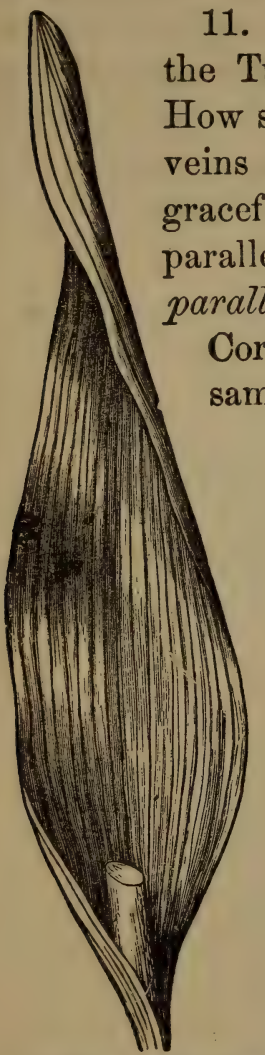

Fig. 5. Leaf of Tulip.

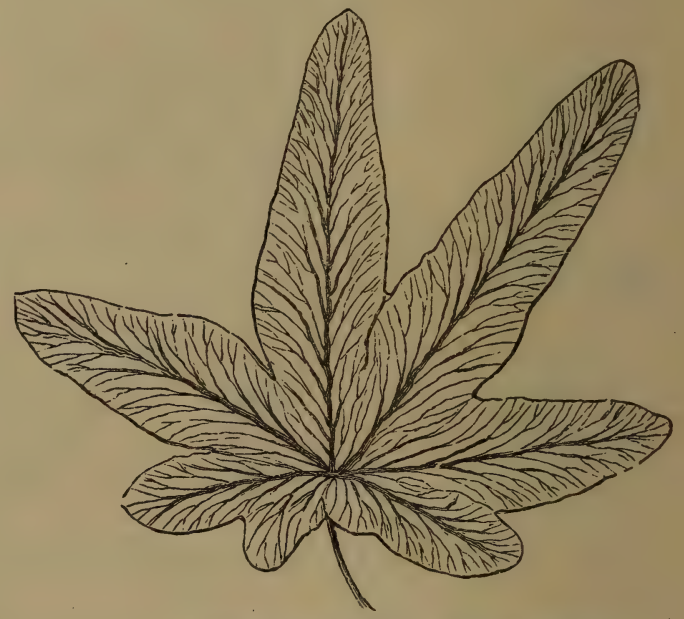

Fig. 6. Leaf of the Climbing Fern.

12. Let us examine one other kind of venation, and the list will be complete. Here is a cut showing the leaf of

11. Define the parallel venation. Mention examples.

12. The forked venation. Examples.

Now repeat the names of the five or six kinds of venation. 
Climbing Fern (Fig. 6). To say nothing of the five reins (which are palmate, as in the leaves of Sweet-gum, Fig. $4 a$ ), you may notice the veinlets, how they fork and run to the mar gin, without uniting again to form a net-work. This is the forked venation. You will find this sort in nearly ail the Ferns.

\section{LESSON III.}

FORMS AND FIGURES OF LEATES.

13. You have already noticed that the form of the Quince leaf, and of most others, is a thin, flat expansion, presenting a large surface to the air. A few plants have thick, solid leaves, as the leaves of the Live-forevers and Ice-plants

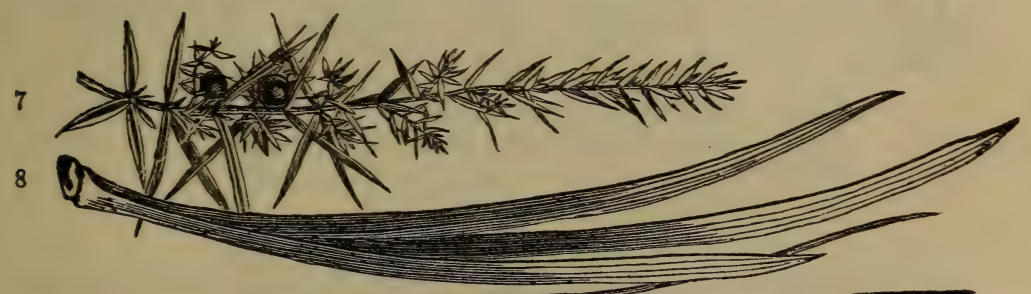

9

Fig. 7. Represents a branch of Juniper, with awl-shaped leaves (subulate). Fig. 8. Leaves of the Fleur-de-lis (Iris); they are sword-shaped (ensiform). Fig. 9. Leaves of the Scotch Pine; they are needle-shaped (acerose).

Other plants have slender leaves, as the Pines. See Figs. 7,8 , and 9.

13. What is the general form of leaves? What plants have thick and solid leaves? What form of leaves has the Pine? the Iris ? the Juniper? 
14. We also spoke of the figure of the outline of the Quince leaf, which is ovate. But you must have observed that there is a very great variety in the figure of leaves, affording a very interesting study. First, we will examine, one by one, the figures of the feather-veined leaves (Figs. 10-21.)
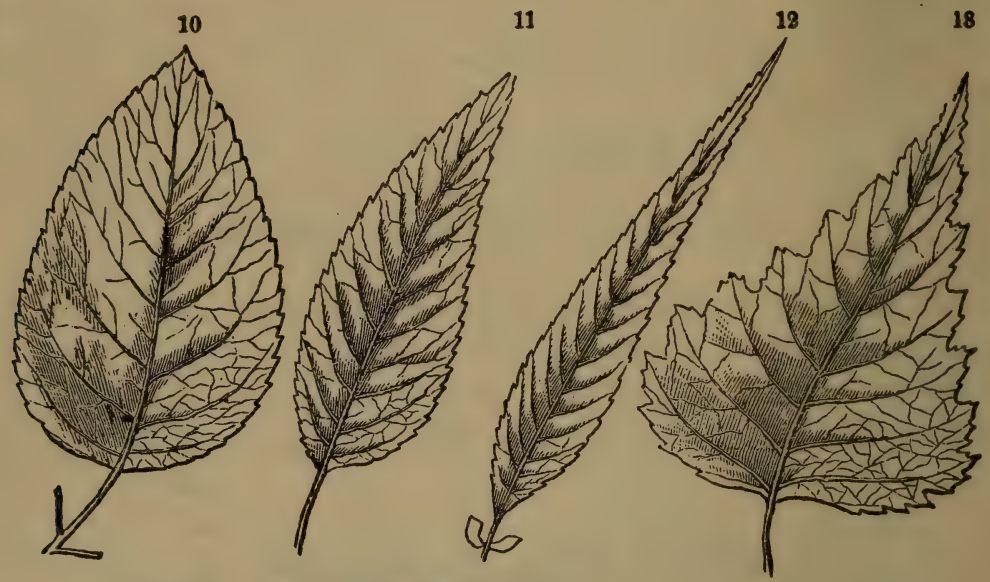

Fig. 10. Ovate leaf of the Pear-tree.

Fig. 11. Lanceolate leaf of the Flowering Almond.

Fig. 12. Narrow lanceolate leaf of the Weeping Willow.

Fig. 13. Deltoid leaf of the White Birch.

15. The leaf of the Flowering Almond (Fig. 11) is lanceolate. It is narrower than ovate, shaped like a lance, having the lower half wider than the upper. This Willow leaf (Fig. 12 ) is narrowly lanceolate. The leaf of the Lombardy Poplar, or of the White Birch (Fig. 13), is so broad at the base as to form a three-sided figure. like the Greek letter $(\Delta)$ delta. Herce it is a deltoid leaf.

14. What is the figure of the Quince leaf?

15. Describe the figure of the leaf of Flowering Almond; of the Weeping Willow; of the Lombardy Poplar, \&c 
16. In the next four kinds of leaves you will notice that the broadest place is midway between the base and apex. Thus the orbicular (Fig. 14), or rounded, leaf is about as l,road as it is long. The oval leaf (Fig. 15) is about one-third longer than broad. This Plum leaf is an example. The $e^{7}$ liptical (Fig. 16) is about twice longer than broad, and the oblong (Fig. 17) is three or four times longer than broad. Here are examples.
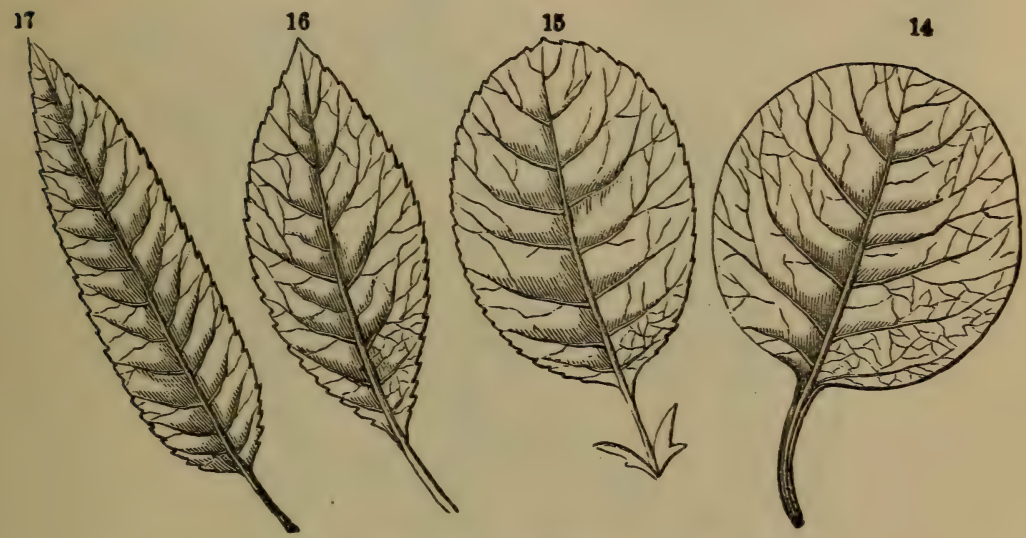

Fig. 14. Orbicular leaf of Winter-green (Pyrola).

Fig. 15. Oval leaf of the Plum-tree.

Fig. 16. Elliptical leaf of Black Haw.

Fig. 17. Oblong leaf of a Willow.

17. We next have four varieties of forms which are broader towards the apex than base. First, the obovate (Fig. 18), like this leaf of the Smoke-tree. Its outline is like that of

16. When is the figure of a leaf called orbicular? Will you show me specimens? Describe an oval leaf, and give specimens. Describe an ellip sical leaf, and give examples. Describe an oblong leaf, and give examples.

17. When will the figure of a leaf become oborate? Give examples of 
the egs inverted. A similar form, but narrower, is the $o b$ lanceolate; that is, the inverted lance-shaped, like the eas of Papaw, or Fig. 19. Next, still narrower, is the spatulaie, a figure compared to the surgeon's spatula (Fig. 21); and lastly, the wedge-shaped, or cuneate, tapering from a broad apex to a slender base, as in Fig. 20.
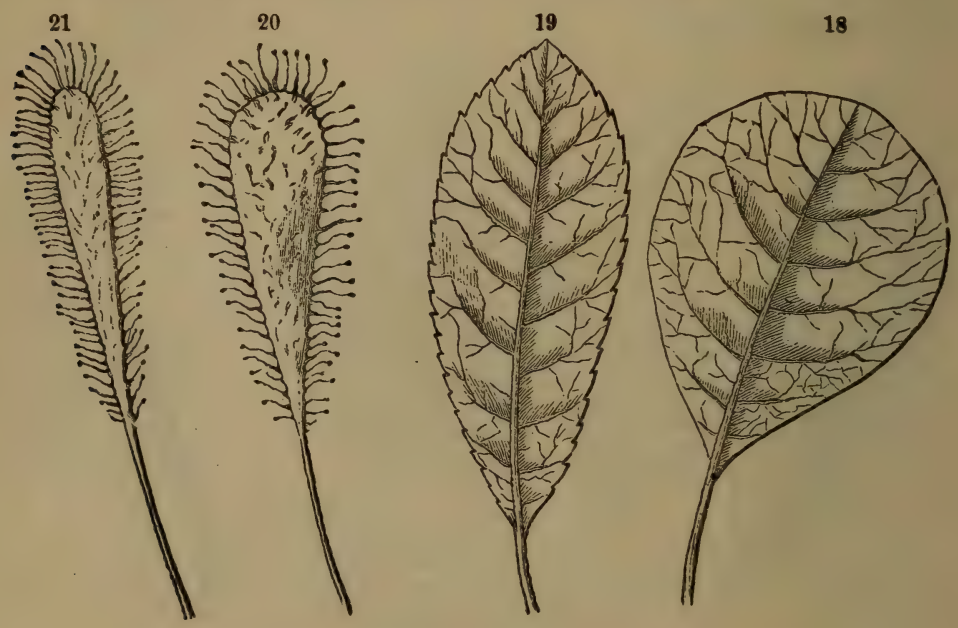

Fig. 18. Obovate leaf of the Smokc-tree (Rhus Cótinus).

Fig. 19. Oblanceolate leaf of Muhlenbury's Willow.

Fig. 20. Cuneate leaf of a Sundew (Lrosera longifolia).

Fig. 21. Spatulate leaf of a Sundew (variety of $D$. longifolia).

18. Thus we have arranged these twelve forms of featherveined leaves into three classes.

such leaves. Oblanceolate? Show us examples. Spatulate? Show us ex. amples. Wedge-shaped, or cuneate? Give examples.

18. Repeat the names of the four leaf-forms hroadest at base;-the four broadest in the middle; - the four broadest towards apex. 


\section{LESSON IV}

FORMS AND FIGURES OF LEAVES.

19. In many kinds of leaves we find the parts at the base more or less enlarged backwards, as you see in this pictur:

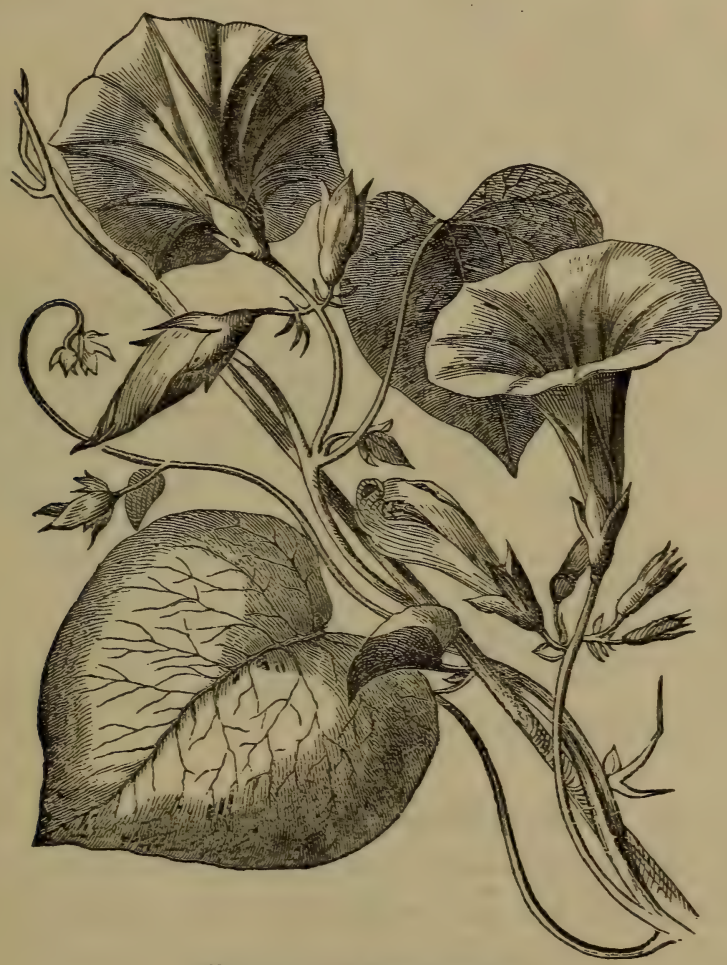

Fig. 22. The Morning-glory.

of the Morning-glory leaf (Fig. 22). This is the heart shaped, or, more properly, the cordate leaf. It is truly an 
elegant figure in this and in the Lilac, \&c. But sometımes this peculiar enlargement at base becomes excessive, and the figures more curious than elegant. Such is the arrow-shaped figure, called sagittate, having long-pointed base lobes, as seen in the Arrow-head (Fig. 47), the Scratch Knot-grass, \&c. (Fig. 26.)

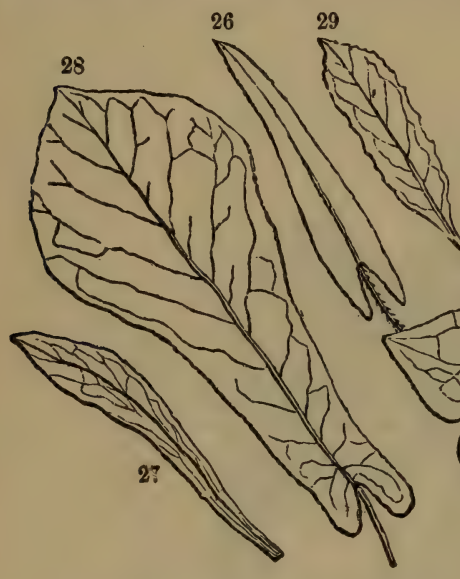

Fig. 23. Reniform leaf of Wild Ginger. Fig. 24. Reniform leaf of Pennywort. Fig. 25. Peltate leaf of Pennywort. Fig. 26. Arrow-shaped leaf of Scratch Knot-grass.

Fig. 27. Spatulate leaf of Silene Virginica.

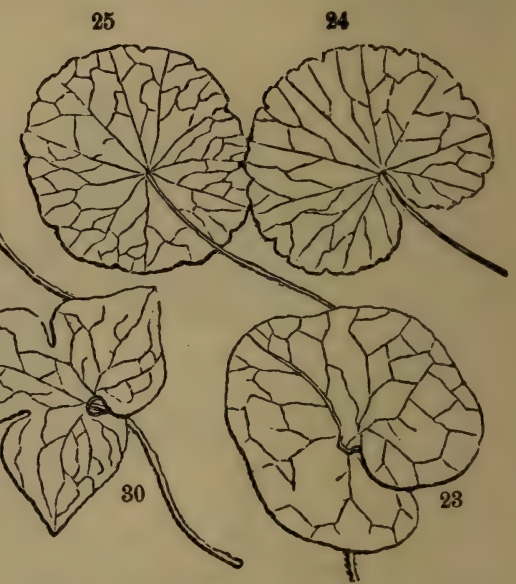

Fig. 28. Fraser's Magnolia: obovatrspatulate, auriculate at base.

Fig. 29. Oblong leaf of the Toother Arabis.

Fig. 30. Three-lobed leaf of Liverwort.

20. In the common Sorrel leaf, and in Fraser's Magnolia leaf (Fig. 28), these base lobes remind one of ears, and such leaves are said to be auriculate (from the Latın auricula, ar

19. Describe the cordate leaf, and give examples. The sagittate, and ex amples.

20. Describe the auriculate form, and give examples. The reniform. Examples. 
ear). In some leaves these lobes are very broad and rounded, giving to them a kidney-shaped form, that is, reniform, as you see in this Wild Ginger leaf (Fig. 23), and in the Pennywort (Fig. 24). The peltate, or shield-shaped leaf (Fig 25-another Pennywort) has its base lobes united, and its petiole fixed to the under side. See, also, Nasturtion leaves.

21. We will next study a class of forms with deeply lobed or cleft blades, not well filled up between the veinlets.

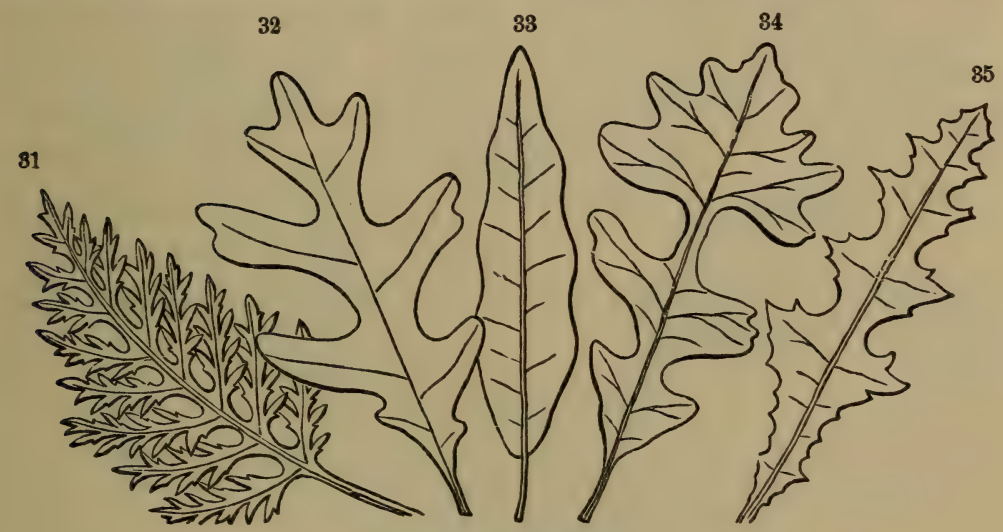

Fig. 31. Bi-pinnatifid leaf of Pig-weed.

Fig. 32. Sinuate-lobed leaf of White Oak.

Fig. 33. Undulate-lobed leaf of Jack Oak.

Fig. 34. Lyrate leaf of Moss-cup Oak.

Fig. 35. Lobed leaf of Mulgedium (Blue Milkweed).

First, look at this Liverwort leaf (Fig. 30). It is cleft in two places, rendering it three-lobed. The Sweet-gum leal (Fig. $4 a$ ) is five-lobed Oak leaves are lobed in many pat. terns, according to the kind. The White Oak has a sinuate-

21. What is the figure of the Liverwort leaf? What the figure of the Maple leaf? What kind of venation have these last two? Define the fig ure of the White Oak leaf. Of the Mossy-cup Oak. 
lobed leaf (Fig. 32), the Mossy-cup Oak has a lyrate leaf, having its terminal lobe larger than any other (Fig. 34).

22. Fig. 35 is the leat of a kind of Milkweed, called Mul-

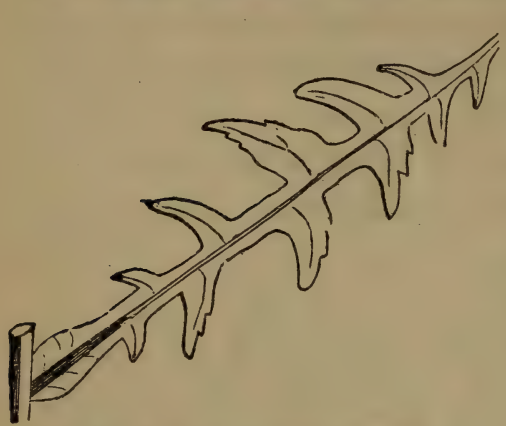

Fig. 36. Leaf of Lactuca elongata, or Wild Lettuce. gedium, with sharp lobes projecting at right angles to the midvein; and Fig. 36 is of the Wild Lettuce, with lobes pointing or hooking backwards. Such leaves are called runcinate. The Dandelion has also runcinate leaves. When a leaf has only shallow lobes, as you see in Fig. 33, it appears with a wavy outline, called undulate. It is a leaf of that beautiful tree called at the West, Jack Oak.

\section{LESSON V.}

\section{OTHER FORMS AND FIGURES.}

23. IT is now time to learn the difference between a simple and a compound leaf. The simple leaf has but one blade, as the Quince leaf, and all the leaves which we have hitherto noticed. We have now before us a compound leaf, one plucked from a Rose-bush (Fig. 39), consisting of several distinct blades on one petiole. It has also one pair of stip-

22. What of the figure called runcinate? Describe the undnlate leal What example? What kind of venation have the last four forms?

23 What is a simple leaf? A compound leaf? 


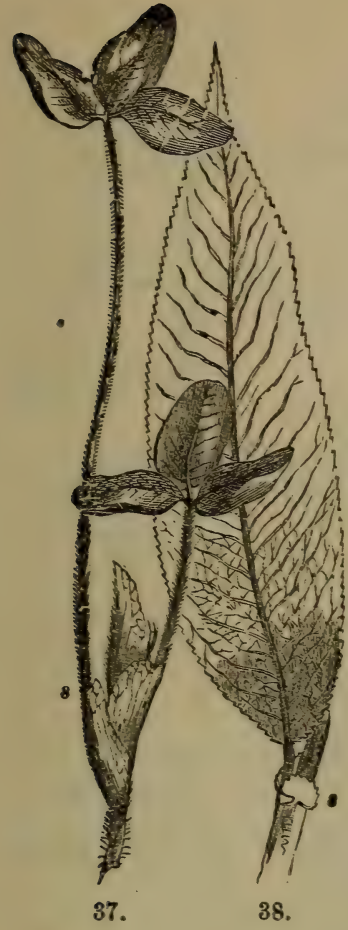

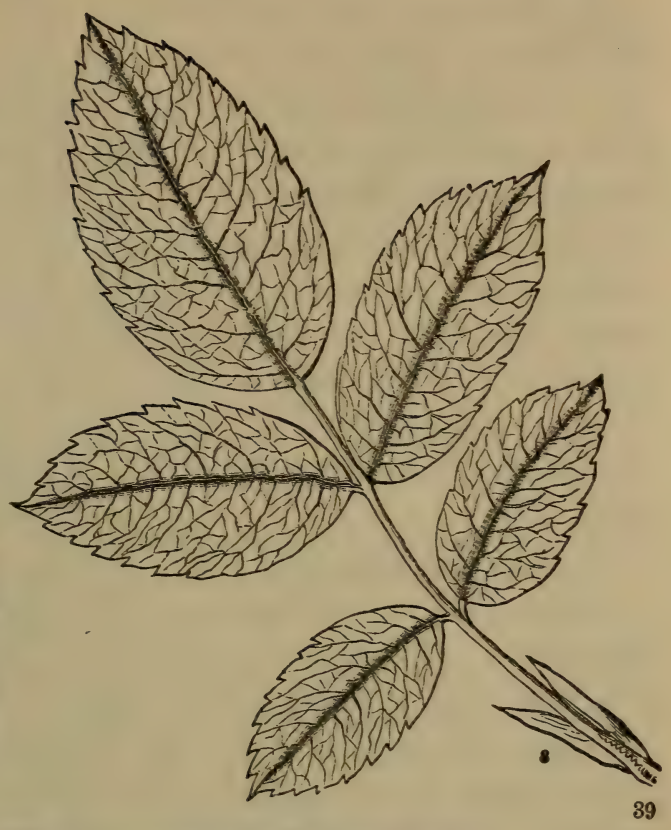

Fig. 37. Compound leaf of Red Clover.

Fig. 38. Simple leaf of Willow (Salis lucida).

Fig. 39. Compound leaf of Rose.

ules, like a simple leaf. This Clover leaf is also compound (Fig. 3i), having stipules (s), as well as this simple leaf of the Shining Willow (Fig. 38).

24. But here is a leaf, the Celandine (Fig. 40), which is almost, but not quite, compound. The blade is featherreined, and deeply divided into several parts, called segments. Such a leaf is called pinnatifid. In Fig. 31, the leaf of a garden weed (Ambrosia), you observe that the segments are themselres pinnatifid, so that the leaf is twice or bi-pinnatifid

24. Please define the pinnatifid leaf. The bi pinnatifid. 
25. But what form of leaf is this (Fig. 41) of the Fennel-flower, with such a multitude of narrow segments? You may call it pin-nat-i-sect, a long word which signifies dissected in a pinnatifid manner. The Thistle leaf is also pinnatisect, although quite different in form.

26. Fig. 42 represents a pedate leaf of a Passion-flower. Observe its palmate venation, each of its veins bearing a segment, and each lower

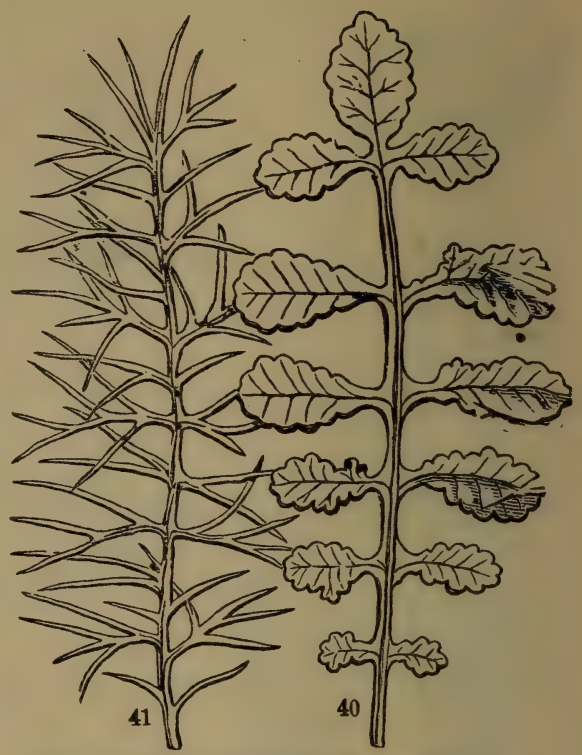

Fig. 40. Pinnatifid leaf of Celandine.

Fig. 41. Pinnatisect leaf of Fennel-flower. segment double, so resembling a bird's foot. Pedate means foot-shaped.

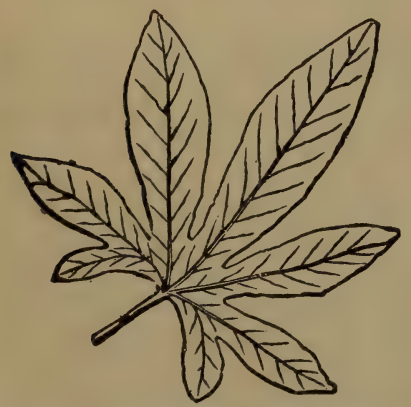

Fig. 42. Pedate leaf of Passion-flower.

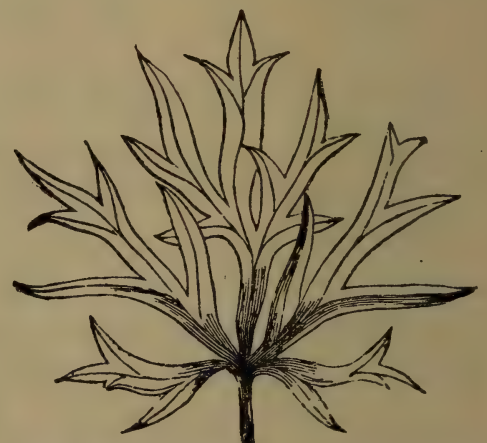

Fig. 48. Laciniate leaf of Monk's-hocd

25. What do you call such leaves as those of the Fennel-flower ? 


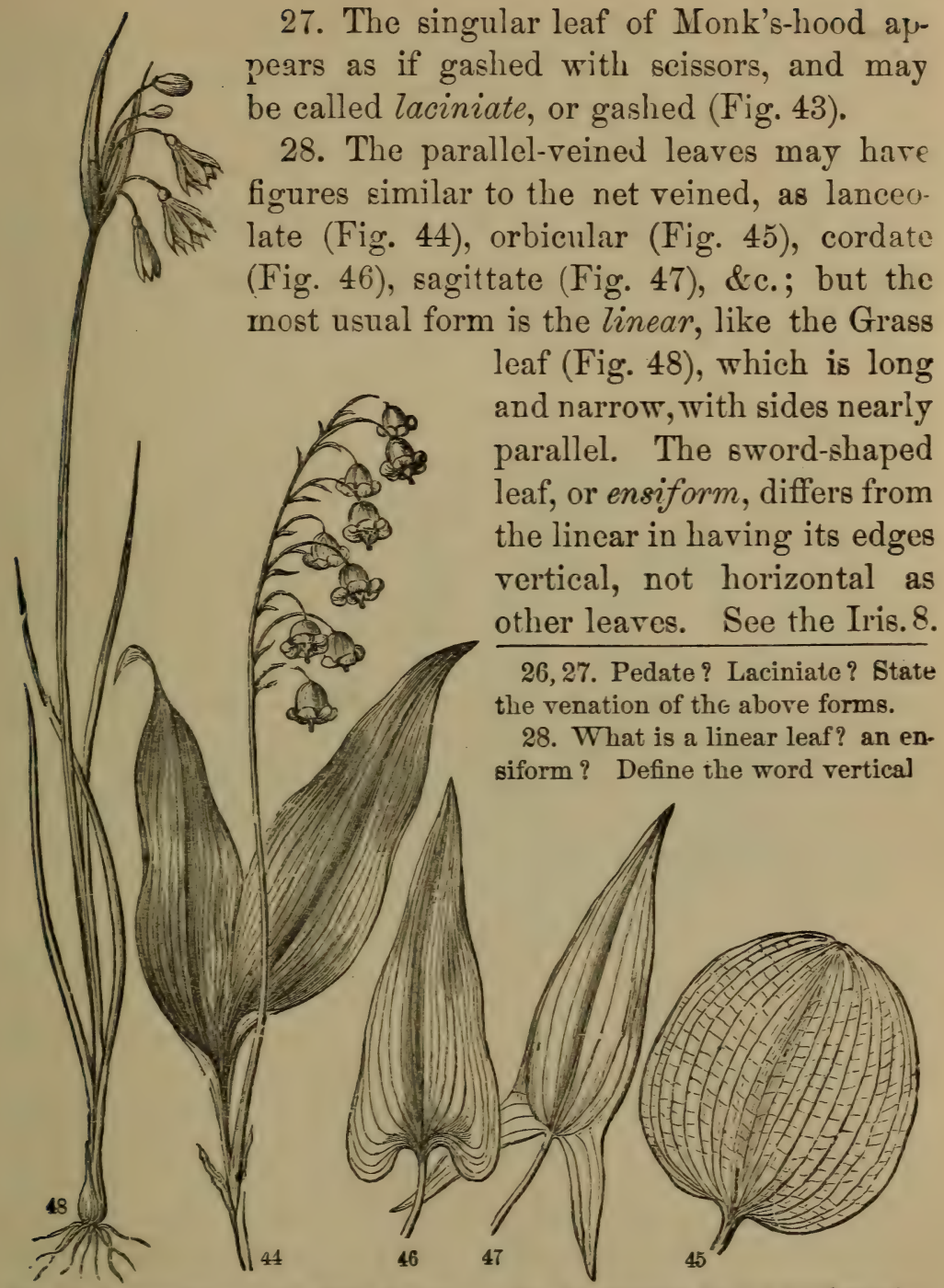

Fig. 44. Lanceolate,-Lilv of the Valley. Fig. 46. Cordate leaf of Pund-weed. Fig. 45. Orbicular,-Round-leaved Orchis. Fig. 47. Sagittate ieaf of Arrow-head Fig. 48. Tinear leaves of Blue-eycd Gruss (Sisyrinchium). 


\section{LESSON VI.}

\section{MARGIN AND APEX.}

29. In describing a leaf we are to consider the patterng of its border, or margin, which are quite various, and often elegant. Some of the leaves heretofore noticed have the

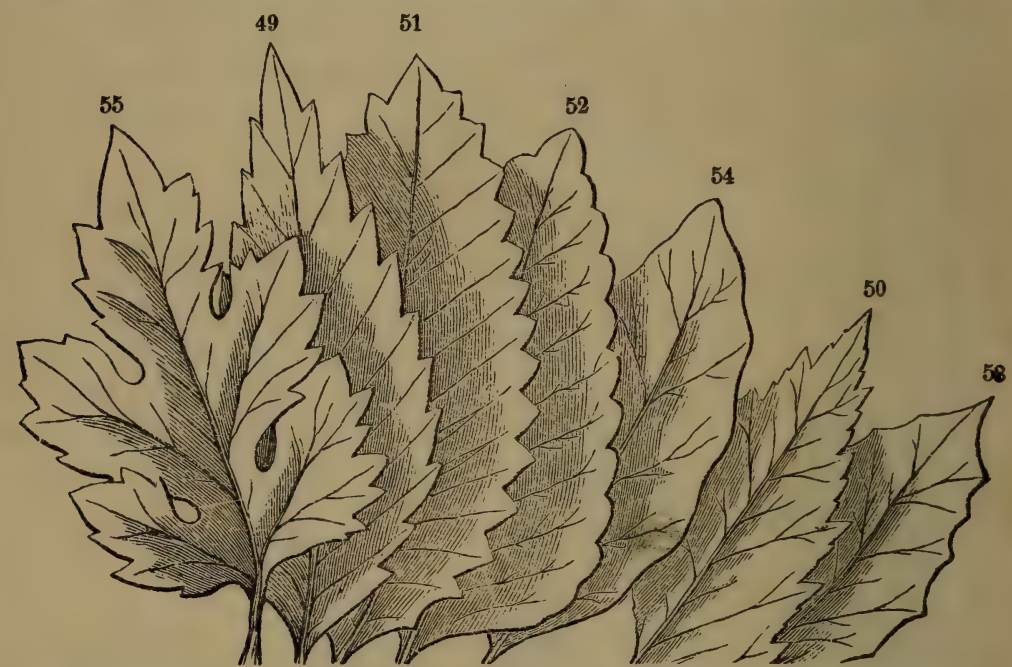

Fig. 49. Scrrate leaf of Chestnut.

Fig. 50. Doubly serrate leaf of Elm.

Fig. 51. Dentate leaf of $\Lambda$ rrow-wood

(Viburnum dentatum).

Fig. 52, Crenato leaf of Catmint.
Fig. 53. Repand leaf of Enchanter'; Night-shade (Circcea Lutetiana).

Fig. 54. Undulate leaf of Shingle Oak (Q. imbricaria).

Fig. 55. Lobed leaf of Chrysanthemum.

Inargins entire and even, as in the Quince leaf, or the Iily. But most leaves are notched in various ways. For exampie, 30. This Willow leaf (Fig. 3) is notched in the margir

29. When is the margin said to be entire? 
like a saw, with the teeth projecting forward. Such a margin is said to be serrate, or, if the teeth are quite small, serrulate. When the teeth point neither forward nor backward, but outward, we call the margin dentate, or toothed; snd if the teeth are quite small, denticulate. See Figs. 49, 50, 51, de.

31. Some leaves are margined with rounded and blunt teeth, and we call them crenate (Fig. 52); or, if such teeth are very small, crenulate.

32. In Figs. 13 and 50, you see that the teeth themselves are again toothed, an arrangement called doubly serrate. So we may find leaves doubly dentate or doubly crenate. Thus we have described seven modes or styles of bordering. Several other modes are found described in the larger botanies.

A P E X.

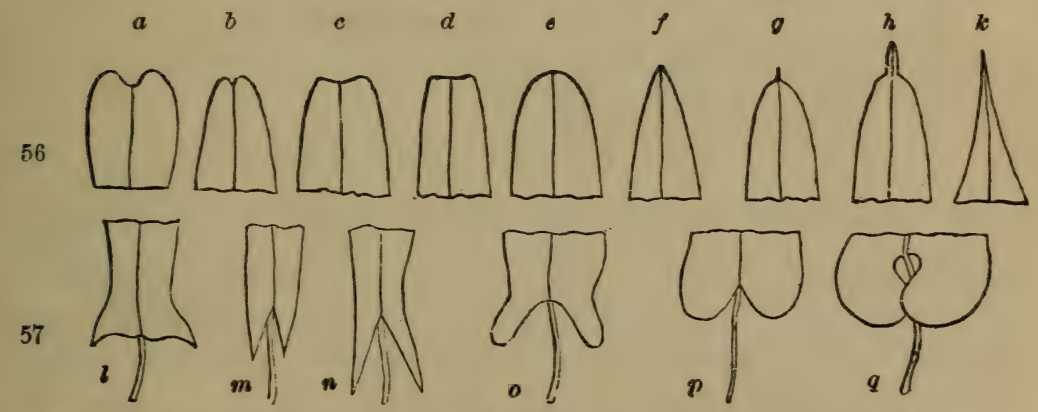

Fig. 56. Apex of lcaves: $a$, obcordate; $b$, emarginate; $c$, retuse; $d$, truncaic: $\theta$, obtuse; $f$, acute; $g$, mucronate; $h$, cuspidate; $k$, acuminate.

Fig. 57. Bases of leaves: $l$, hastate; $m, n$, sagittate; $o$, auriculate; $p$, cordate 7. rer iform.

30 When is the margin serrate? When serrulate? How loes the den tate differ from the serrate?

31. What sort of teeth dres the crenate imply? Crenulate?

32. Explain doubly dentate, \&c 
33. It is also necessary to be acquainted with the vari. ous forms of the apex of leares. This diagran: (Fig. 56) will assist the memory. The apex may be acuminate, ending in a long, tapering point; or cuspidate, suddenly contracted to a sharp, slender point; mucronate, tipped with \& spiny point; acute, simply ending with an angle; obtuse, blunt.

34. Or the leaf may end without a point, being truncate, as if cut square off; retuse, with a rounded and slightly depressed end where the point should be; emarginate, having a small notch at the end; obcordate, having a deep indentation at the end. See also, and explain, the diagram of the bases of leaves (Fig. 57).

\section{LESSON VII.}

\section{O M P O N D LEAVES.}

35. A COMPoUnd leaf consists of several distinct blades borne on one petiole. (See Lesson V., first paragraph.) These separate blades are called leaflets. You notice that in Fig. 39 each of the five leaflets has its own foot-stalk, called petiolule, and its own midvein, \&c.

36. The Rose leaf (Fig. 58) is pinnately compound, or sim-

33. What does the term acuminate imply? What sort of apex is cuspi date? mucronate? acute? obtuse?

34. When may we call the apex truncate? retuse? emarginate? obcor date? Please name these several forms of the bases of leaves.

35. Define a compound leaf. What is a leaflet? What do you call the foot-stalk of the leaflet? 


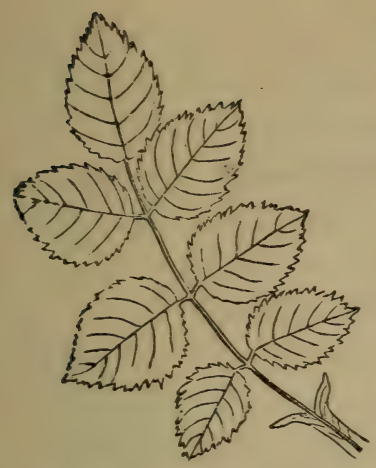

Fig. 58. Leaf of the Rose.

ply pinnate, having several leaflets arranged along both sides of the common stalk. This common stalk, answering to the midvein of a simple leaf, is called the rachis.

37. Among pinnate leaves, there are, at least, three important distinctions. Observe the Figs. 59, 60, and 61. One of them ends with an odd leaflet, and is called odd-pinnate. Another ends with a pair of leaflets, and is equally pinnate. Another still has its alternate leaflets smaller, and is interruptedly pinnate.

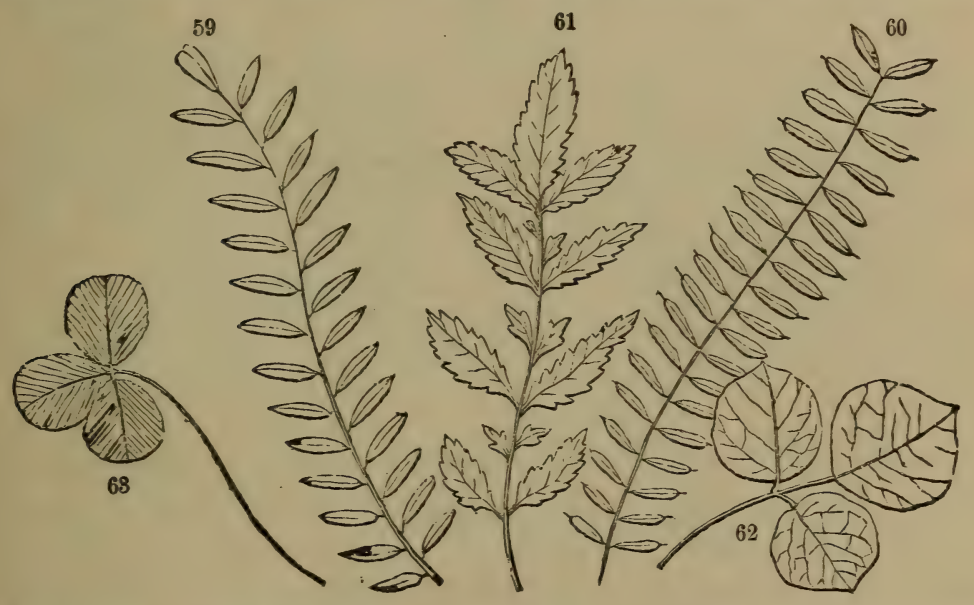

Fig. 59. Odd-pinnate leaf (Tephrosia). Fig. 61. Interruptedly pinnate (Agrimony). Fig. 60. Equally pinnate leaf (Cassia). Fig. 62. Pinnately ternate (Desmodium). Fig. 63. Palmately ternate (Clover).

36. Define the pinnate leaf. What is the rachis?

37. Give the distinction between odd-pinnate and equally pinnate. What leaf is interruotedly pinnate? 
38. Every one knows that the number of leaflets in the Clover is three; also in the Bean, and in this figure (62) of the Desmodium leaf. Such leaves are called ternate. But here the pupil will notice another important distinction. In this Desmodium leaf, the odd leaflet is stalked, and is said to be pinnately ternate; in Clover, the odd leaflet is nearly sessile, like the other leaflets; this is palmately ternate.

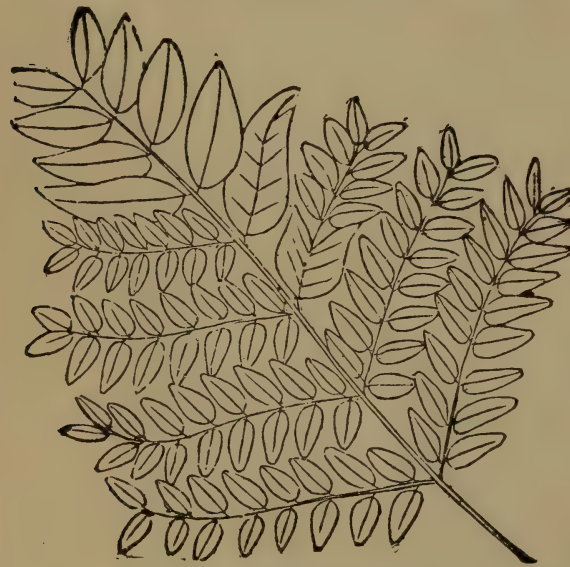

Fig. 64. Honey Locust.

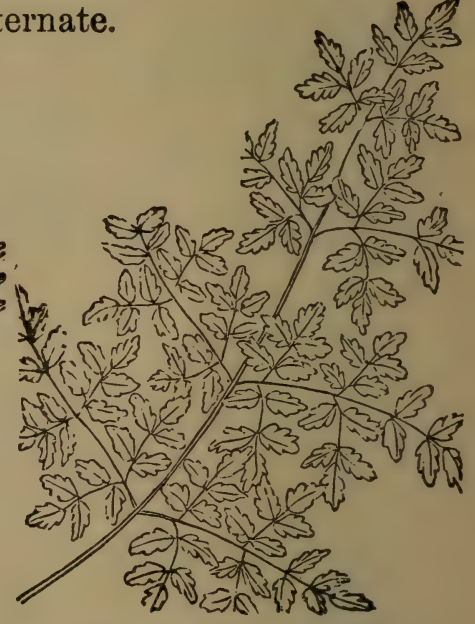

Fig. 65. Poison Hemlock.

39. Fig. 64 represents a bi-pinnate (that is, twice pinnate) ıeaf of Honey Locust. The simple leaflets seem to have each become itself a pinnate leaf. And still more compound is this Poison Hemlock leaf, being tri-pinnate, or thrice pinnate (Fig. 65). In the same manner, we have bi-ternate and tri-ternate.

38. How many leaflets in a ternate leaf? Difference between the pun nately and the palmately ternate?

39. Can you define a bi-pinnate leaf? Tri-pinnate? What is a bi-ternate leaf? A tri-ternate? 
40. All the above forms of compound leares, except the Clover, are founded on the pinnate venation; but the palmate venation gives us the palmately ternate (Clover, already described); the quinate, with five leaflets; the septinate, with seven leaflets, \&c. See the leaves of Horse-chestnut, of Hernp, and of this Lupine (Fig. 66).
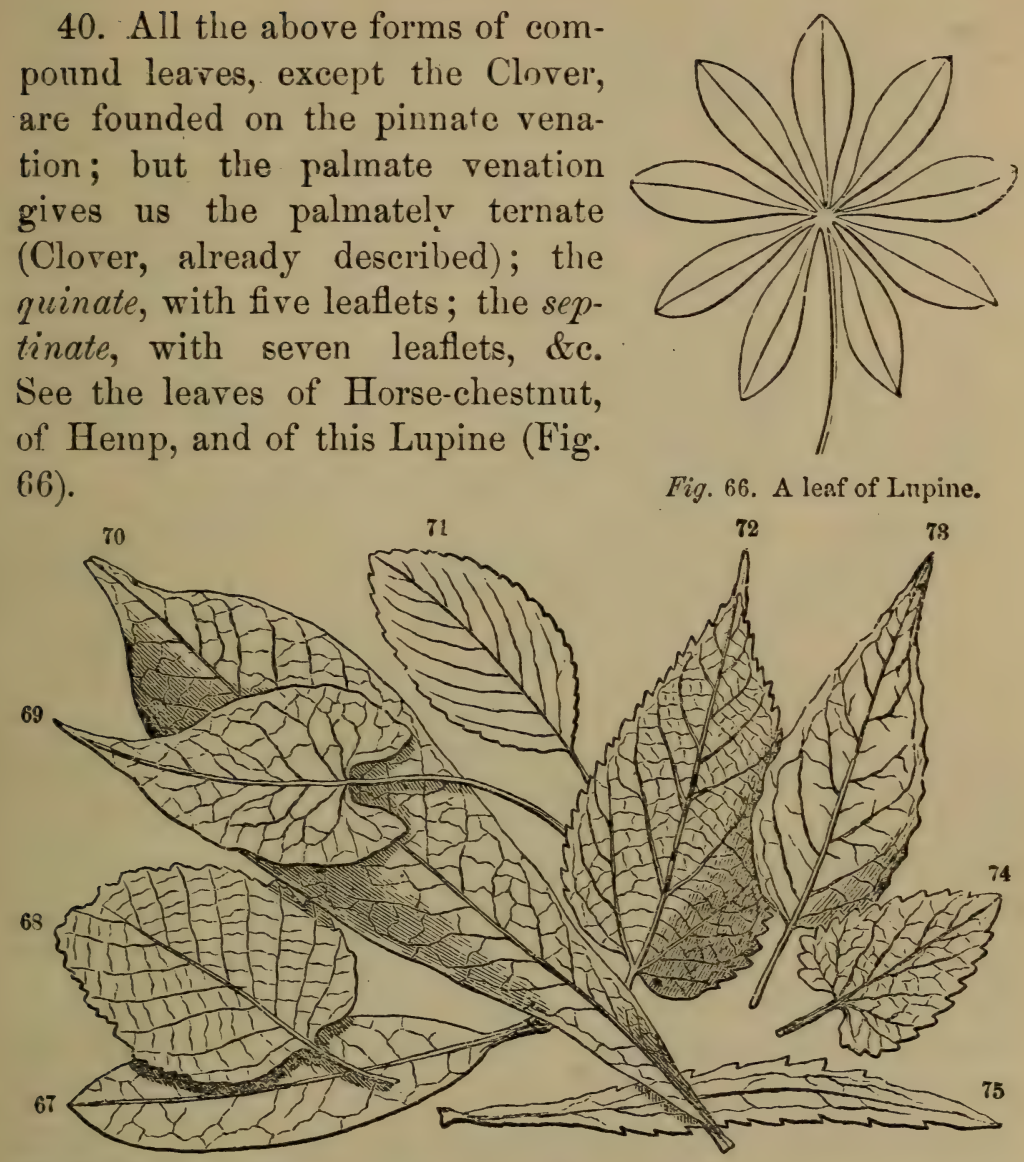

Fig. 67. Rose-bay (Rhododendron).

Fïg. 68. Alder (Alnus glauca).

Fig. 69. Knot-grass (Polygonun sagitta¿̇ $(u m)$.

Fig. 70. Papaw (Asimina triloba).

Fig. 71. Touch-me-not (Impatiens fulva).
Fig. 72. Sugar-berry (Celtis Americana). Fig. 73. Enchanter's Night-shade (Circala lutetiana).

Fig. 74. Catmint (Nepeta Glechoma).

Fïg. 75. Goldenrod (Solidugo Canark-i. sis), a triple-veined leaf.

The pupils should be required to describe the leaves in this cut, as to venation, figure, margin, apex, and base. 


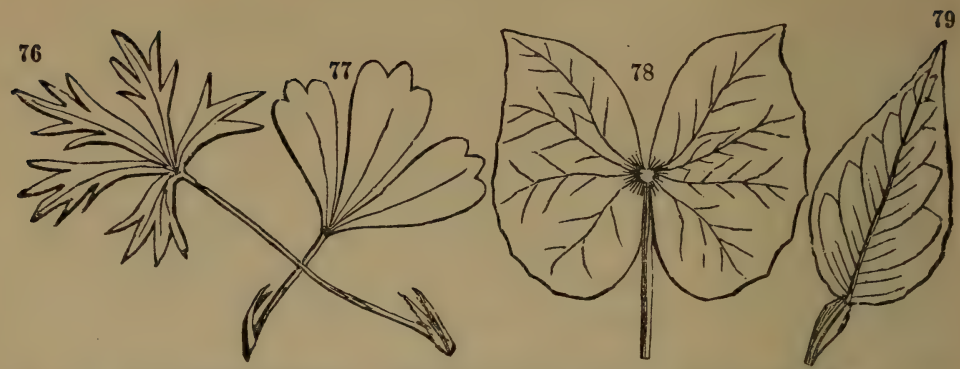

Fig. 76. Potentilla anserina; leaf with five cut lobes, almost quinate.

Fig. 77. Potentilla tridentata ; ternate, with palmate, three-toothed leaflets Fig. 78. Jeffersonia diphylla; a binate leaf.

Fig. 79. Lenon; a simple leaf jointed to the petiole.

\section{LESSON VIII.}

\section{SESSILE LEAVES-FORMS OF STIPULES.}

41. WE have already stated (Lesson I., \& 5) that many -eaves are without petioles (foot-stalks), or, in other words, are sessile. The figures presented on page 33 exhibit some of the modes of attachment peculiar to sessile leaves. In Fig. 80 (an Aster) you see leaves of the form called spatulate-(Lesson III., $\S 5$ ), having large base lobes nearly clasping the stem at the point of attachment. Such leares are said to be $\mathrm{am}$ plexicaul (stem-clasping).

42. In the next figure (81, Bellwort) the leaves are elliptical, parallel-veined, and not only clasp the stem at base, but the lobes there grow together on the opposite side, appearing ss if the stem passed through the leaf; that is, perfoliate.

40. What kind of venation have all these forms? On the palmate vena tion what forms are founded?

41. When are leaves said to be sessile? Define an amplexicacl leaf

42. Can you define a perfoliate leaf? 


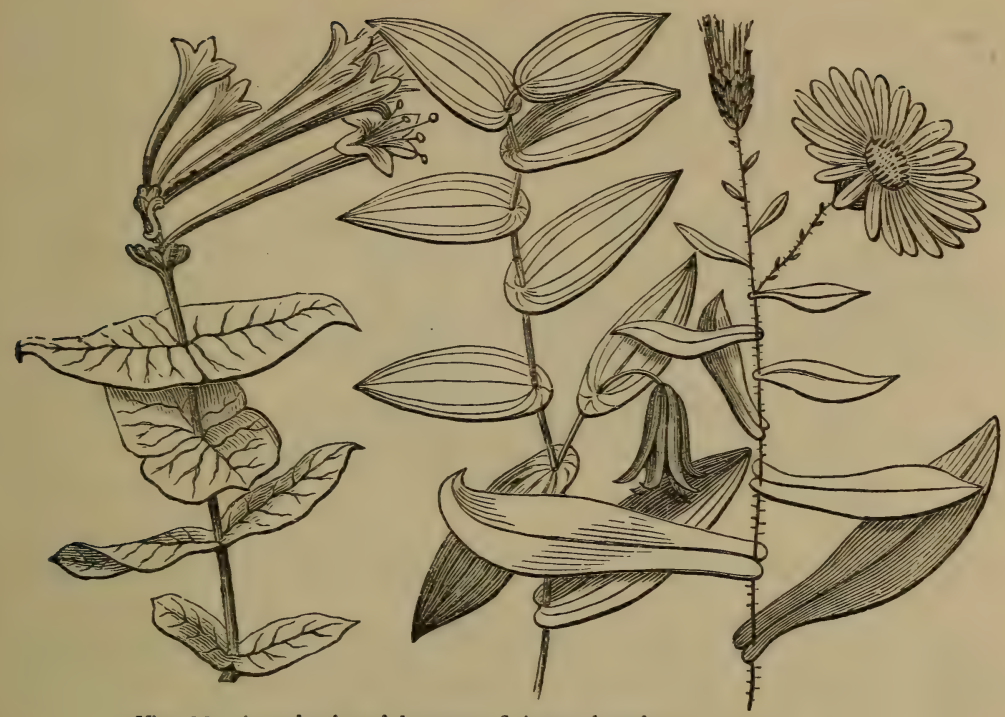

Fig. 80. Amplexicaul leaves of Aster laevis.

Fig. 81. Perfoliate leaves of Bellwort (Uvularia perfoliata).

Fig. 82. Connate leaves of Honeysuckle (Lonicera sempervirens).

43. In Fig. 82 (Trumpet Honeysuckle) the leaves placed opposite are joined together by pairs, base to base. Such are connate leaves.

44. The forms of the petiole, when the petiole exists, are also various. Generally, it is merely a rounded, slender stem, but you will often find it flattened. Have you erer noticed the structure of the Aspen (Poplar) leaf, which su easily flutters in the gentlest breeze? Its petiole is flattened rertically, so that its edges turn sky-ward and earth-ward. Such a form of leaf-stalk is called compressed, and it must be very nicely balanced in order to hold the blade at rest.

43. When are leaves said to be connate?

14. What is the usual form of the petiole? Carefully describe the petiole sf the Aspen. 
45. A winged petiole is flattened horizontally. A sheath. ing potiole embraces the stem with its winged edges like i sheath. You can find plenty of examples of these forms.

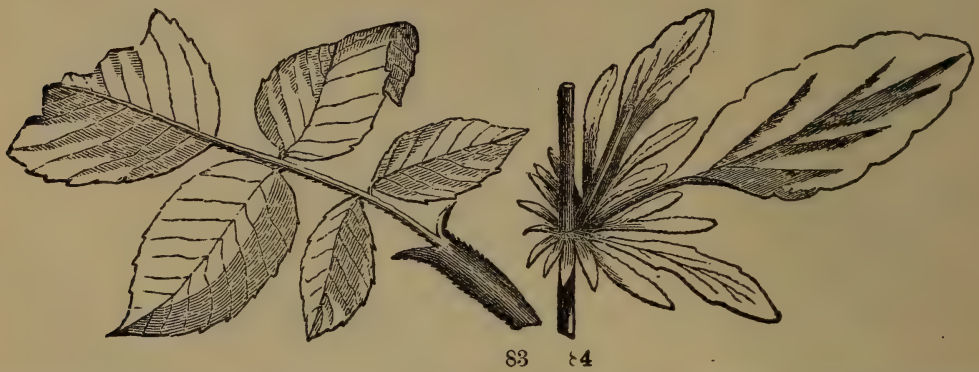

rig. 83. Rose,-stipules adnate. Fig. 84. Violet (V. tricolor),-gashed siipules

46. Let us now study more particularly the varying forms of the stipules. We have already defined them. (See Lesson I., § 4.) Here is seen the leaf of a Rose and of a Pansy (Figs. 83, 84), both with quite showy stipules. The former

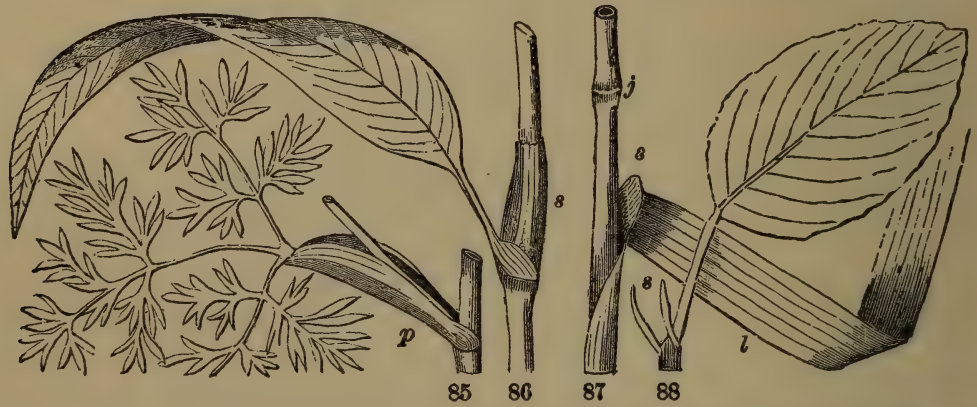

Fig. 85. Leaf of Conioselinum,-tri-pinnate, with sheathing petiole. Fig. 86. Leaf of Polygonum Pennsylvanicum, with its $(s)$ ochrea.

Fig. 87. Stem of Grass, with joint $(j)$, leaf $(l)$, ligule $(s)$.

Fig. 88. Leaf of Pear-tree, with slender stipules.

45. What difference between a winged and compressed petiole? Can you describe a sheathing petiole? Give examples of these three forms. 
has its stipules adnate; that is, growing to the petiole. The Pansy has large stipules deeply cleft into many segments.

47. Figs. $85-88$ are very instructive. Fig. 88 is a Pear leaf, with an ovate blade, a slender, cylindric petiole, and a pair of small, narrow stipules $(s)$. Fig. 86 is a Kunt. grass leaf, with an ochrea $(s)$; that is, a pair of stipules $s$. joined at the edges as to form a sheath around the stem Fig. 87 is a Grass leaf, linear, with a ligule $(s)$ supposed to be the top of a doubled stipule. Fig. 85 is a very compound leaf of Conioselinum, having a broadly winged, sheathing petiole.

\section{LESSON IX.}

\section{ARRANGEMENT OF LEAVES AND BUDS.}

48. If you carefully notice how the leaves are distributed over any plant,- - the Corn plant, for example,-you will soon admire their order and exactness in this respect. At first view, we might suppose their positions all accidental; but it is not so, and much of the peculiar aspect of the plant depends upon this circumstance.

49. In the Corn plant, or in this figure of Lady's-slipper (89), we find the leares alternate, - that is, one on this side, the next one higher and on that side, and so on. So it is in

46. Stipules; can you repeat the definition? Describe the stipules of the Rose. Describe the stipules of the Pansy.

47. Describe the stipules of the Pear. Stipules of Knot-grass-what called? Stipules of Grass-what called?

48. Are the positions of the leaves on the plant accidental ?

49. Can you describe the alternate arrangement? How is this arrange ment more accurately derrribed ? 
the Elm, Cherry, Willow, and many other plants. But it would be more accurate to say that the arrangement, in all these cases, is spiral. (See Class Book, § 224.)

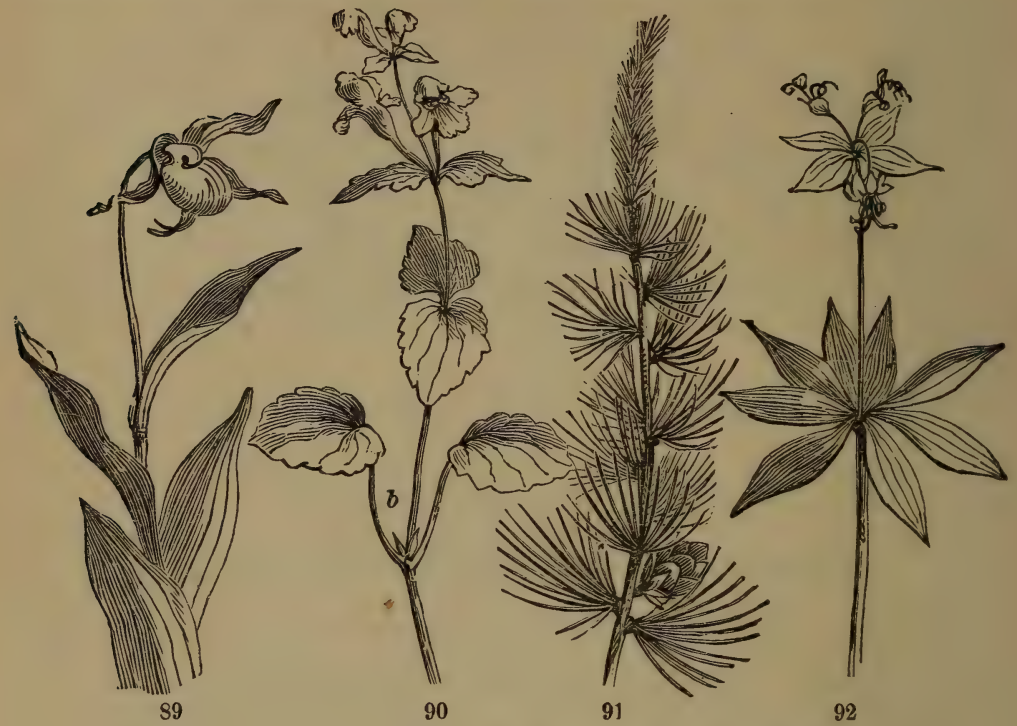

Fig. 89. Jady's-slipper (Cypripedium),-leaves alternate.

Fig. 90. Synandra,-leaves opposite.

Fig. 91. Larch (Larix Americana),-leaves fasciculate.

Fig. 92. Indian Cucumber (Medeola),-leaves whorled.

50. In the Maple, Lilac, Phlox, and in this figure of the Synandra (90), a wild western plant, the leaves are opposite; that is, two opposite ones stand at each joint. The Meadow Lily, and this Medeola (Fig. 92) of the New England woods, have whorled or verticillate leaves; that is, several in a circle at each joint. Again, look at this Larch (Fig. 91), the Pines, \&c., whose leaves, gathered in little tufts or bundles, are fasciculate.

50. Define the opposite arrangement. The whorled ; fasciculate 
51. In early spring, before the leaves are expanded, we find them folded up in the buds. This is called the vernation of the leaves (from the Latin vernus, spring). In this condition the young leaves are closely packed in many curious modes, which are described in the Class look, §§ 209-214.

52. If we dissect and carefully examine a swelling leaf-bud in early spring, we observe in the midst of it a tender point of a growing pith, bearing and covered by many circles of little leaves and scales, packed as close as possible. Fig. 94 shows a twig with two buds as if split through the axis, exhibiting the pith, growing point, young leaves, and scales.

53. According to this figure and the next (94), buds are either terminal $(t)$, situated at the end of the stem or twig, or lateral $(a)$, situated on the side. But we must more care-
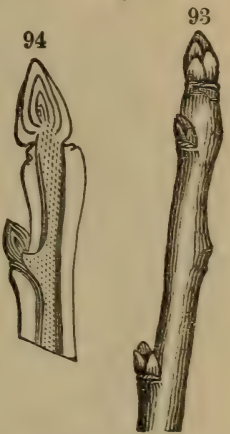

Fig. 93. A twig, with two lateral and one terminal bud.

Fig. 94. Same, split through the two buds. fully define the position of the lateral buds. Should we tell you that they are awillary, or located in the axil of a leaf, you would not understand, until knowing that the axil of a leaf is the upper angle between the leaf-stalk and the stem. (See b, Fig. 90.) Now, remember this rule, which you may soon confirm by your own observation, that there is a bud at the termination of every stem or branch, and in the avil of every leaf.

51. What is the meaning of the term vernation?

52. Give a careful definition of a leaf-bud.

53. What is a terminal bud? What an axillary? Where are bude al ays found? 


\section{LESSON $\mathrm{X}$.}

A P P E D A G E S, E T C.

54. The tendril is a very common appendage. You hare seen it in the Grape-vine, the Pea-vine, the Greenbrier, \&c It is like a stout, green thread, reaching out its curved point like a finger, until it touches some object; then it quickly entwines itself around it, and soon acquires a firm hold. We do not find tendrils on any plants except such as, like vines, are too weak to stand without support.

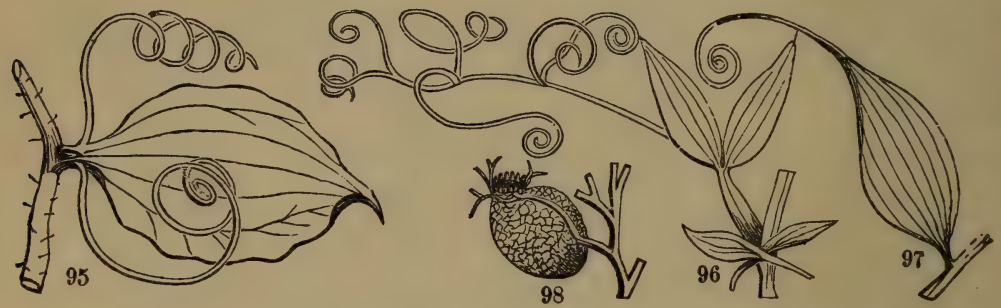

Fig. 95. Leaf of Greenbrier, with tendrils in place of stipules.

Fig. 96. Leaf of Everlasting Pea,-tendrils at end of rachis.

Fig. 97. Leaf of Gloriosa,-apex ends in a tendril.

Fig. 98. Air-bladder of Horn-pondweed.

55. But tendrils are quite various in habit. Those of the Pea (Fig. 96) grow from the extremity of the rachis. Those of the Greenbrier (Fig. 95), from the base of the leaf-stalk, in the place of stipules; those of the Grape-Vines are opposite the leaves, in the place of clusters.

56. Many plants are armed with sharp thorns, spines, or

54. What is the first appendage mentioned? Please describe the form and use of the tendril.

55. State the habit of the tendril of the Pea - Greenbrier; Grape-rine. 
prickles, as if in self defence. See the Thorn-bush (Fig. 99): where the long straight thorns come from the axils of the leaves, and are woody. The terrible thorns of the Honey Locust(Fig. 100)are branched. Those of the common Locust are in the place of stipules. Those last mentioned, and all others which originate with the leaves (as in Berberis, Thistle, \&c.), are more properly called spines.

57. As for the Rose and Bramble, they are armed with prickles, which are horny in substance, connected with the bark only, not with the wood. (See Fig. 101.)

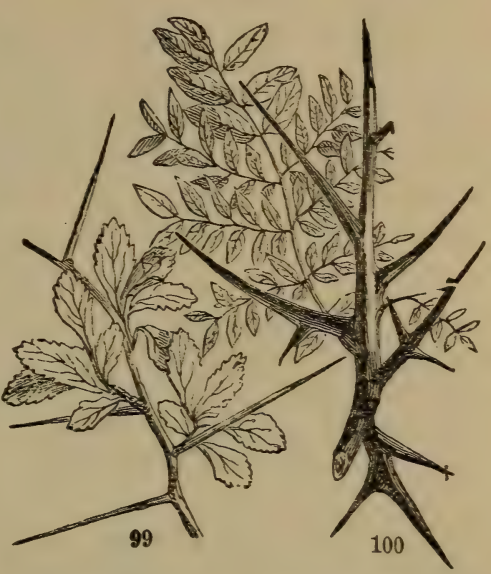

Thorns,-Fig. 99. Cratægus parvifolia (thorny axillary). Fig. 100. Honey Lo. cust (branched thorns).

58. Glands are little wart-like bodies which secrete the peculiar fluids of the plant, sometimes imbedded in the leaf or the rind of the fruit, as in the Lemon, where it is filled with a fragrant volatile oil; sometimes raised on a hair (Figs. 102, 103), as in Sundew, exuding a clammy liquid.

59. Stings are piercing hairs, having a bag at the base filled with an acrid fluid. When touched the tip breaks off, the hair penetrates the skin, and the poison is injected intu the wound. (See Fig. 106.)

56. What is the habit of the thorns of the Thorn-bush? of the Honey Locust? of the common Locust? What of the habit of spines?

57. What of prickles?

58. Describe glands, the two.kinds.

59. What is the structure and action of stings ? 


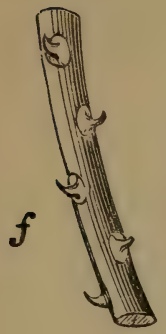

101

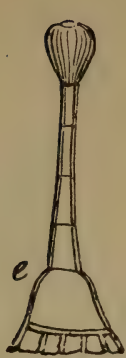

102

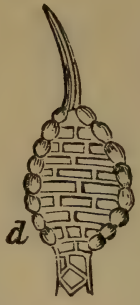

103

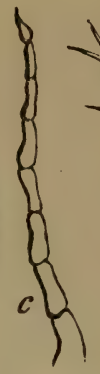

104

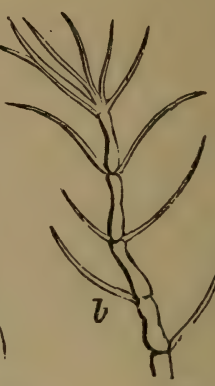

105 $a$

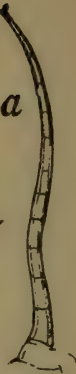

106

What do these figures represent? - Fig. 105 represents a branched hair as it appears under a strong magnifier; Fig. 104, an unbranched or simple hair; Fig. 102 is a hair with a gland on it; Fig. 103, also, is a gland on the top of a hair; Fig. 101 represents the hooked prickles of a Rose-bush, not magnified; Fig. 106 representa a sting of a Nettle, much magnified.

60. Hairs of various kinds (Figs. 104, 105) are found on the leaves and other parts of plants. By this clething peculiar qualities are given to the surface, named and described as follows.

61. A dense coat of hairs will make the surface pubescent when the hairs are short and soft; villous, when rather long and weak; sericious, or silky; tomentous, when matted like felt, \&c.

62. But thinly scattered hairs make the surface hirsute when they are long; pilous, when short and soft; hispid, when short and stiff, \&c.

60. How are plants clothed?

61. Define the term pubescent; villous, \&c.

6i. Define the term hirsute; hispid, \&c. 


\section{LESSON XI.}

ORGANS OF THE FLOWER.

63. TO-Dar we commence the study of the beautiful flower iWe have before us the Meadow Lily (Fig. 107), whose or.

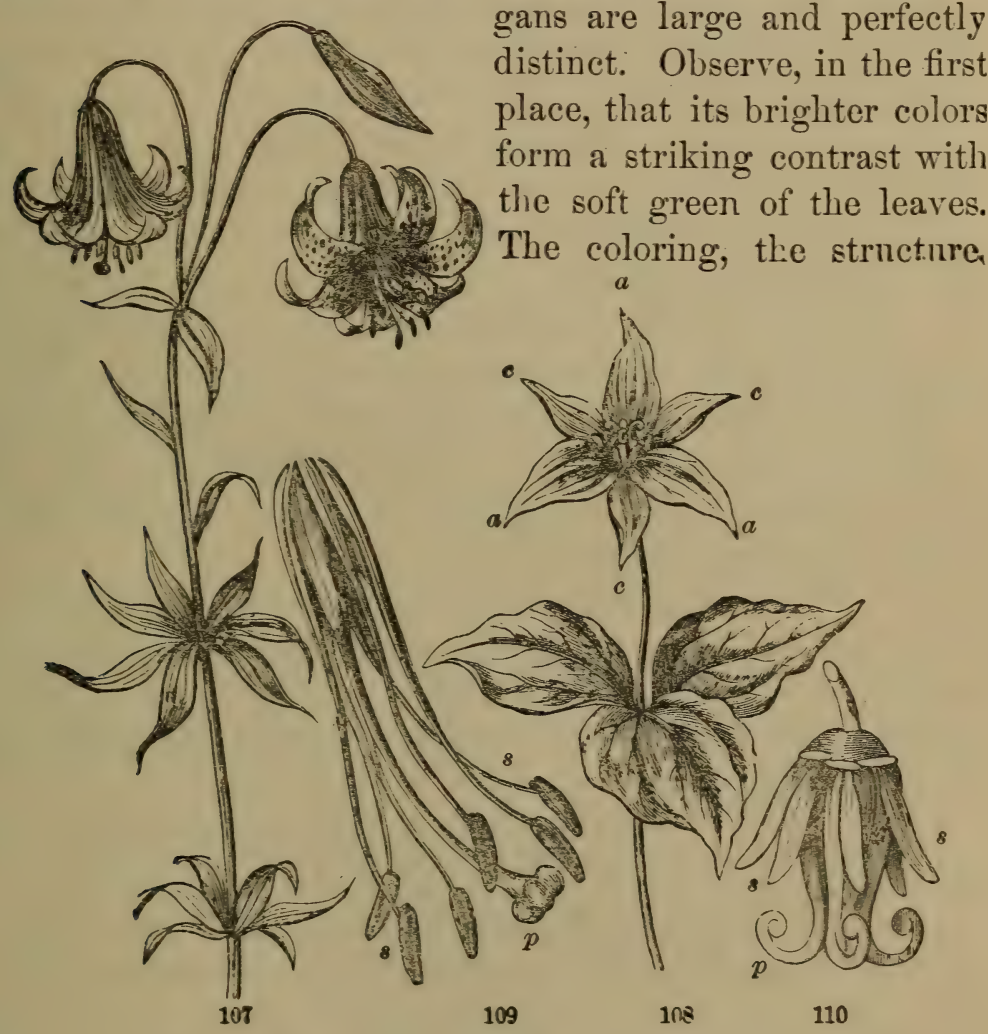

Fig. 107. Meadow Lily (Lilium Canadensis).

Fig. 108. Wake-robin (Trillinm erectum).

Fig. 109. Stamens $(\delta, 8)$ and pistil $(p)$ of the Lily.

Fig. 110. Stamens $(\varepsilon, 3)$ and pistils $(p)$ of the Trillinm. 
and the fragrance of the flower are all worth $y$ of its Infinite Creator, and remind us of his wisdom and goodness.

64. As to the structure of the flower, it is always com. pound, being composed of several or many pieces nicely arlapted to each other. In this Lily, for example, you may count thirteen pieces, or organs, attached in a close order to the summit of the flower-stalk (Fig. 113, a). You may call the flower-stalk the peduncle, and the point of attachment $(r)$ the torus, or receptacle. The former is the better name.

65. Two circles of leaf-like organs form the envelopes of this flower, and each circle consists of three pieces. The onter circle is the calyx, and the three pieces which compose it are called sepals $(s, s, s)$. The inner circle is the corolla, and the three pieces which compose it are called petals $(p, p, p)$. In the Lily and some other flowers the caly $\mathbf{x}$ is colored like the corolla. But it is not so generally. In the - Rose, Strawberry, Pink, and in this Trillium (Fig. 108), the calyx is green, while the corolla is almost always distinguished by some brighter color.

66. Now, taking both calyx and corolla together as a whole, we call them the perianth (a Greek word, meaning around the flower). This name is very convenient when we speak of such flowers as this, where the calyx and corolla are not much different.

63. What is the subject of to-day's lesson? What do you notice as to the color of the flower?

64. What is said of the compound nature of the flower? Of how many pieces is the flower of the Lily composed? What is the peduncle? What is the torus?

65. Will you point out and define the calyx? sepals? Will you point out and define the corolla? petals? What of the colors of these organs?

66. What is the use of the word perianth? Will you point out and define the stamens? What of their uumber? What is the pistil? How many? 
67. Next within the perianth of the Lily we find six long, slender organs of peculiar form and color, called stumens. In the Rose you find a larger number (perhaps one hundred) of stamens, while in the Speedwell you find but two. But the most common number is five. Count them in the Morn. ing-glory, the Bellwort, Primrose, \&c.

68. Lastly, this central, club-shaped body $(p)$, here as long as the stamens, but of totally different structure, is the pistil. Other flowers have more than one pistil, as the P'ink, which has two, the Rose, which has many.

69. Thus, we have learned that the flower-at least this flower-is compounded of four kinds of organs, those of each kind being arranged in a circle by themselves. The onter circle, of sepals, constituting the calyx; the second circle, of petals, constituting the corolla; the third circle, the stamens; the fourth circle, the pistils.

\section{LESSON XII.}

\section{MURE ABOUT THE CALYX AND COROLLA.}

70. Let us examine the flower of the Pink (Fig. 112), the Strawberry (Fig. 111), the Crowfoot, the Single Rose. In either you observe fire green sepals, and the same number of colored petals. Notice also the positions of those orsans, -how the petals stand alternating with the sepals, and that they are all distinct and separate. This is the general rule, but there are many exceptions.

67. Lastly, review the whole arrangement.

70. What is the rule as to the number of petals and sepals? What is the rule as to their relative position, \&c.? 


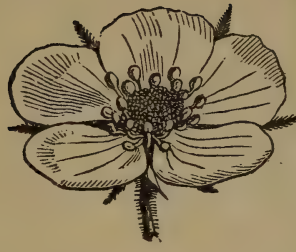

111

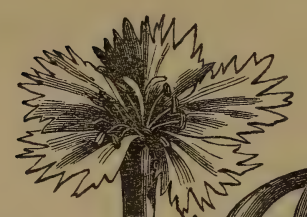

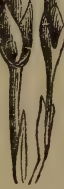

112

Fig. 111. Flower of the Strawberry. Fig. 113. Flower of the Lily.

71. Often in the petal, and sometimes in the sepal, you can distinguish two parts,-namely, the broad, expanded part above, called the lamina, and the narrow part at base by which it is attached to the torus; this is the claw (Fig. $116, c)$. The petal of the Pink has a long claw; of the Rose or Buttercup (Fig. 119), a short one.

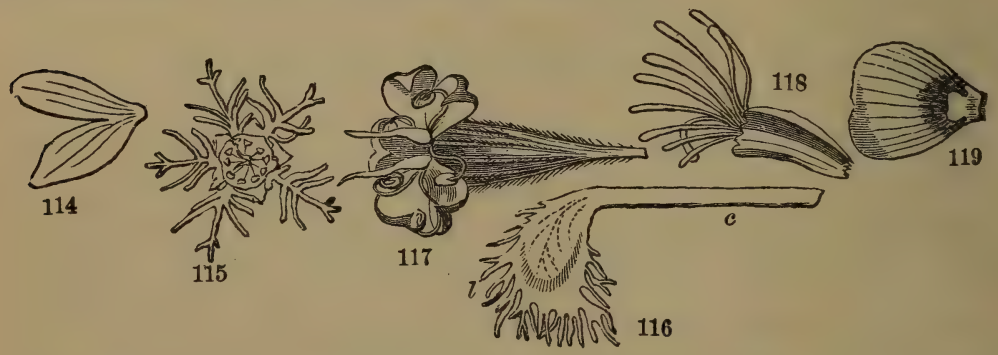

72. The forms of the petal are almost infinite in variety; like the leaf; as ovate, orbicular, oblong, \&c., and some-

71. Will you define the lamina? the claw?

72 Please mention some of the forms of petals. 
times very singular. See these figures. Fig. 114 is the form of the bifid petal of a Cerastium; Fig. 115, the flower of Mitella, with five pinnatifid petals; Fig. 117, the flower of Sweet Cicely, with fire petals inflected at the point; Fig. 116, fringed, long-clawed petal of Silene stellata ; Fig. 118, many-cleft petal of Mignonette; Fig. 119, rounded, short clawed petal of Crowfoot, showing its honey scale, or nectary, at base.

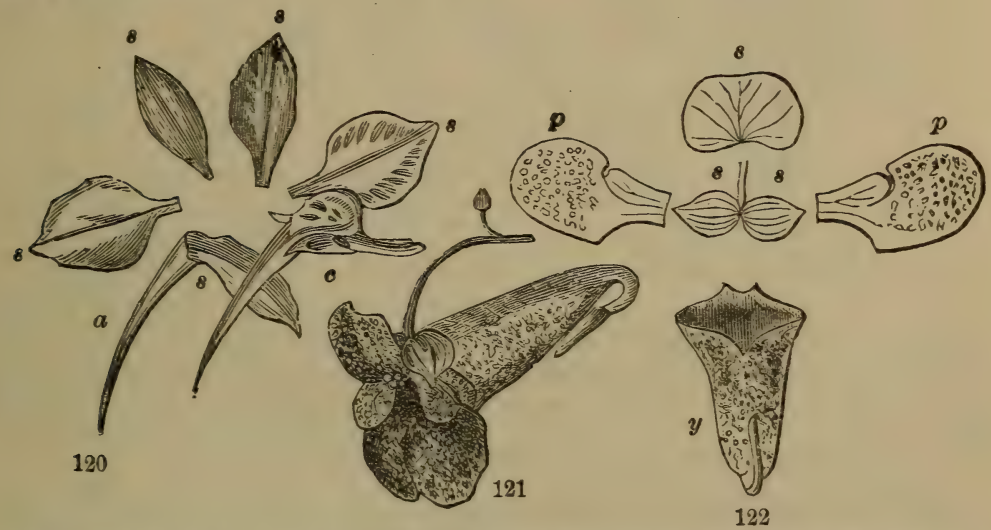

Fig. 120. Larkspur, its petals and sepals separated: $s, s, 8, \delta, 8$, sepals; $a$, tho npper sepal spurred; $c$, the petals all united into one, and produced backwards into a spur which is sheathed in the spur of the calyx.

Fig. 121. Touch-me-not. Fig. 122. Its petals and sepals displayed: $p, p$, the two double petals; $s, \varepsilon, \varepsilon, y$, the four sepals, $y$ being in the form of a sack, with a spur.

73. A nectary is found also in the petals of Columbine (Fig. 361), Larkspur (Fig. 120), Touch-me-not (Fig. 121), \&c., distorting them into grotesque shapes, called spurs.

74. Before us now is the flower of Pink (Fig. 123). The calyx $(c)$ appears as a green tube, with five notches or teeth at the top. It is evident that this is made up of fire sepals

73 What is a nectary? What is a spur? Examples. 
cohering (united) by their edges. The Convolvulus (Figs. 128, 144), the Phlox (Fig. 126), the Pink-root (Fig. 127), \&c., show a similar cohesion (union) of their petals into a ube more or less complete.

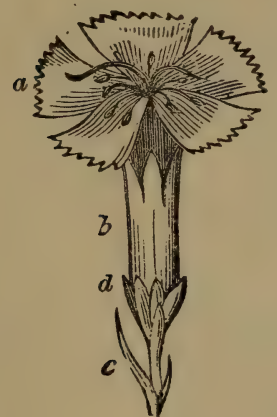

Fig. 123. Pink: $\alpha$, the five petals; $b$, the calyx, composed of five united sepals, $c$, a bract; $d$, several bractlets.

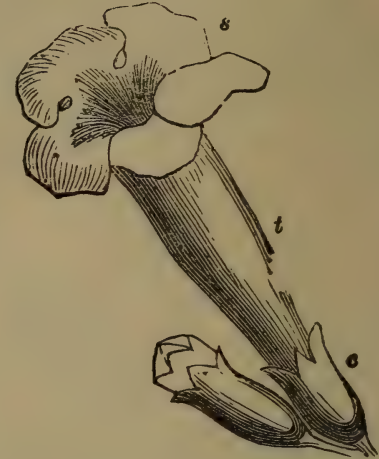

Fig. 124. Flower of Tecuma radicans (the Trumpet-creeper): $c$ is the calyx, composed of five united sepals; $t$, the tube; $s$, the segments of the corolla or the petals, forming the border.

75. The calyx with united sepals is called monosepalous, and the corolla of united petals monopetalous (from the Greek monos, one), from the mistaken idea that this calyx consisted of only one sepal, \&c. Gamopetalous and gamosepalons are similar words, used in the same sense. Opposed to these terms are polysepalous and polypetalous (Greek polys, many).

76. The gamosepalous calyx or gamopetalous corolla, although composed of several pieces, is described as a single organ, and its lower part, formed by the united claws, whether long or short, is the tube (Fig. 124, $t$ ); the upper

74. Describe the calyx of Pink ; corolla of Phlox.

75. Meaning of the terms monopetalous, \&c.?

76. Define the limb of a monopetalous corolla ; the tube ; the throat 
part, composed of the united laminæ, is the limb (Fig. 128, s): the opening of the tube above is the throat.

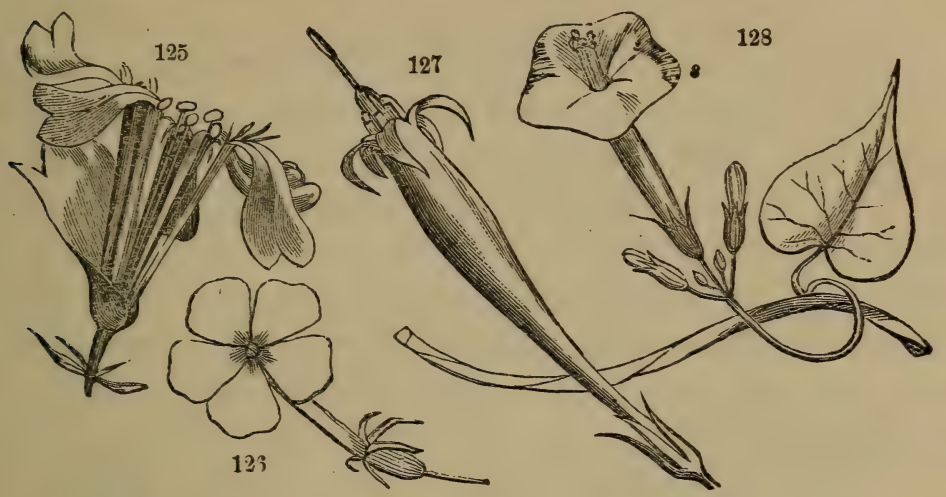

Fig. 125. Flower of Saponaria (Bouncing-Bet); petals and claws quite distinct. Fig. 126. Phlox; claws united, with laminæ distinct.

Fig. 127. Spigelia (Pink-root); petais still further united.

Fig. 128. Quamoclit coccinea; petals united throughout.

77. In the Figs. 125-128, you may see how the petals in different flowers are distinct, or in varions degrees united. In the Bonncing-Bet, the petals, with their long claws, are entirely distinct. In Phlox, the claws unite in a tube, while the laminæ are distinct. In Pink-root, only the narrow tips of the laminæ are distinct; and in Quamoclit, the laminæ also are wholly united.

77. What is the condition of the petals in Pink Soapwort? What their condition in Phlox? What their degree of cohesion in Pink-root? What in Quamoclit? 


\section{LESSON XIII.}

ABOUT ADHESIONS.

78. The pupil will here find discussions more important and intricate. But if he bring to the task eyes determined to see, and a mind determined to understand, the difficulties will soon vanish.

79. Cohesion, as taught in the last lesson, implies the union of organs of the same kind, as sepals with sepals, petals with petals; but adhesion implies the union of one kind of organ with another kind.

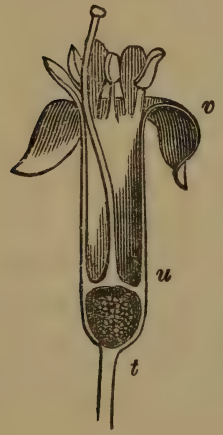

129
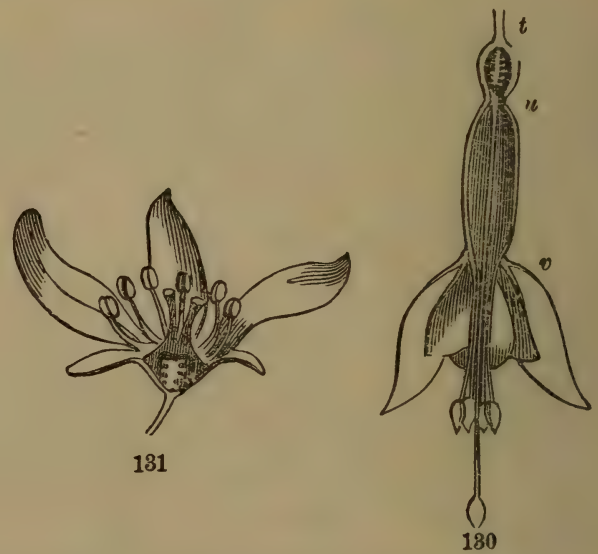

Fig. 129. Section of the flower of the Golden Currant, showing its parts.

Fig. 130. Section of the flower of Fuchsia.

Fig. 131. Of Early Saxifrage.

80. For example, split a flower of Phlox, and you will see the five stamens adhering to the inner side of the corolla tnbe, appearing as if inserted into it.

79. Can you state how adhesion differs from cohesion? 
81. Now we take it for granted that all the organs of the flower have their starting-point or origin at the same one point, namely, at the torus ( $t$, Fig. 129), hence in this figure of the Golden Currant, it is understood that from $t$ to $u$ the calyx, corolla, stamens, and pistil, adhere together; from ? to $v$, the calyx, corolla, and stamens, adhere; and at $v$, a l the organs are separate, that is, free. Observe the samp structure in the Ear-drop (Fig. 130).

82. In this and like cases, the calyx is said to be superior, because it seems to stand upon the pistil (ovary) and fruit, but the more correct term is, calyx adherent.

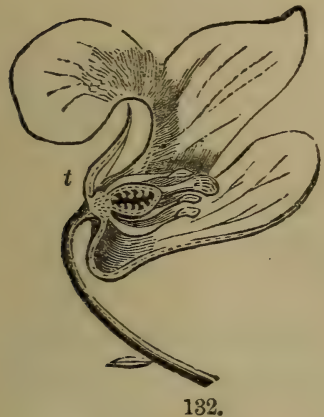

Fig. 132. Section of the flower of Yellow Violet: $t$, the torus. The stamens are bypogynous.

Fig. 133. Section of the flower of Pear: $c, c$, sepals; $p, p$, petals; $s, s$, stamens, - perigynous; 0 , ovary,-inferior or adherent.

83. There are two other terms used in similar cases, which, although hard to pronounce, you may as well become acquainted with now. When the stamens adhere to the calyx

81. What do we take for granted? Please show the adhesions in th Golden Currant.

82. When is the calyx adherent? When superior? 
or corolla they are said to be perigynous, a Greek word, meaning "around the pistil"). Otherwise, when free, they arc said to be hypógynous, meaning " under the pistil."

84. Now study attentively these figures, or rather, the flowers themselves. The figures are sections, $i . e$. , show the lowers as if split. Fig. 132 (the Violet) shows the stamens lyypogynous and the organs all free. Fig. 133 (the Pear; glıws the stamens perigynous, adhering to the calyx. Fig. 131 (the Saxifrage) shows the stamens perigynous and the calyx half adherent. Do not fail to examine many flowers until these troublesome terms become familiar, for these distinctions are very important.

\section{LESSON XIV.}

FORMS OF PERIANTH.

85. WhILE all flowers agree in certain general characteristics, so that you are never at a loss to recognize any one of them as a flower, yet in form and fashion they appear in infinite variety, each form endowed with its own peculiar grace. It is impossible to describe or name every form, but we will endeavor to reduce them to a few classes of forms.

86. Notice first that all forms are either polypetalous or gamopetalous, as already described (§ 75). Again, they are either regular or irregular. Compare the flower of Flas

83 When are the stamens said to be perigynous? When hypogynous?

84. How are they in Saxifrage? in Pear? in the Rose? the Violet?

86. What is the first division of the corolla forms? What is the second division? When is a flower said to be regular irregular? 


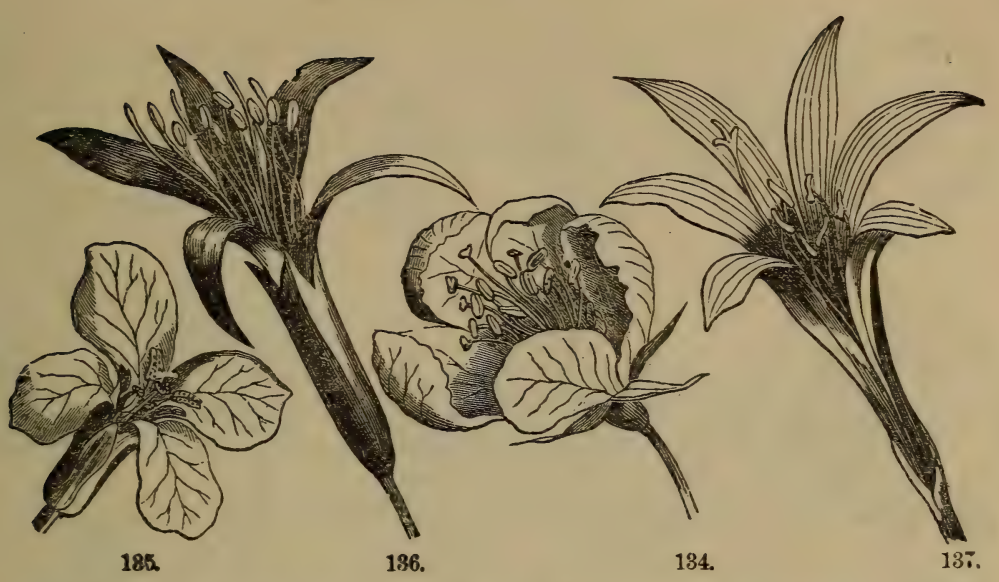

l'olypetalous corollas,-Fig. 134. Wild Apple (Pyrus corvnaria),-rosaceour Fig. 135. Wall-flower,-cruciform. Fig. 136. Scarlet Catchfly,-caryophyllaceous. Fig. 137. Atamasco Lily,-liliaceous.

and Pea. The former is equally and similarly developed all around, and each petal is like all the other petals. It is a regular flower. The Pea flower (Fig. 138) is unequally developed, some of the petals differing in form and size from the others, as shown in Fig. 139 ; therefore it is irregular.

87. The figures at the head of this page represent four different styles of corollas which are polypetalous and regu. lar. Fig. 134 (Wild Apple) is a rosaceous corolla, that is, rose-like, having five short-clawed petals. Fig. 135 (Wallflower) is a cruciform (cross-shaped) corolla, with four long clawed petals.

88. Fig. 136 (Scarlet Catchfly) is a caryophyllaceous corolla,

37. Name the four forms of polypetalous, regular flowers. Can you de suribe the rosaceous corolla? What sort of corolla is the Wall-flower I):scribe it.

88. Please describe the Catchfly or Pink. What sort is it? The Lily please desaribe. What sort of corolla is it? 
pink-like; a form with five long-clawed petals. Fig. 137 (Atamasco Lily) is a liliaceous corolla, having a six-leaved perianth, nade up of three sepals and three petals, all colored alike.

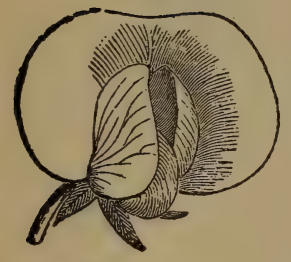

188
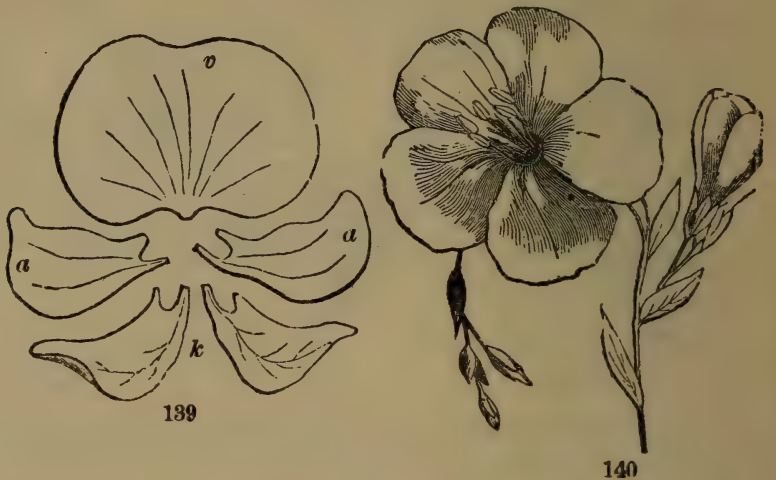

Fig. 138. Pea,-an irregular flower. Fig. 139. Its five petals shown separate, viz., $v$, the banner; $a, a$, the wings; $c, c$, the keel-petals.

Fig. 140. Flax (Linum grandiflorum),-a regular flower.

89. Fig. 138 is the flower of Sweet Pea, an irregular corolla, called papilionaceous, or butterfly-shaped, consisting of five petals, as displayed in Fig. 139, viz., one odd petal above, very large, called the banner, two smaller petals below $(k)$, called the keel, and two lateral petals $(a, a)$, called the wings.

90. We next propose to examine the principal forms of gamopetalous corollas. Here we have a beautiful array of them. Among the regular forms is, first, the Rotate, wheelshaped or star-shaped, having a very short tube, and a flat, epreading border; as Fig. 141 (Campanula Americana).

91. Campanulate, bell-shaped, having a wide tube and

89. Can you describe the papilionaceous corolla?

90. Of monopetalous corollas, describe the rotate.

91. The campan ula: 


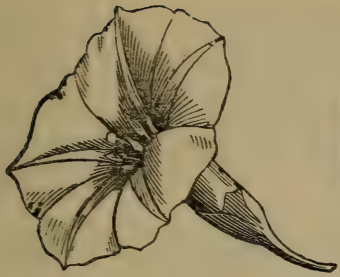

19

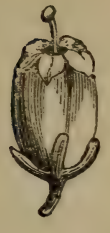

148

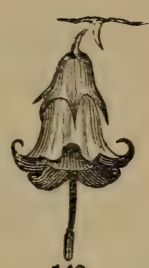

148

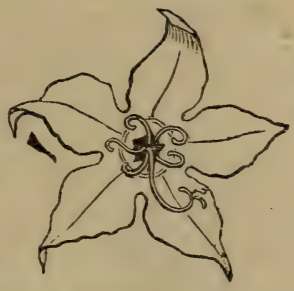

161

Gamoretalous corollas.-Fig. 141. Campanula Americana,-wheel-slaped. Fuy 142. Campannla divaricata,-campanulate, or bell-shaped. Fig. 143. Andromeda,urceolate. Fig. 144. Field Bindweed (Convolvulus), -a funnel-form corolla.

narrow border, as in the Bell-flower (Fig. 142), and in Canter. bury Bells.

92. Urceolate, urn-shaped, an oblong or globular corolla with a narrow opening, as the Whortleberry, Heath (Fig. 143).

93. Funnel-form, narrowly tubular below, gradually en. larging to the border, as Morning-glory (Figs. 22, 144).

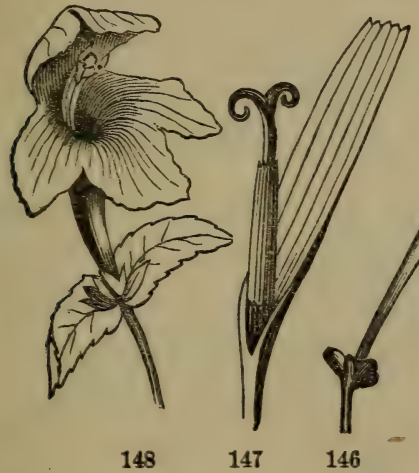

Fig. 145. Petunia,-salver-form.

Fig. 146. Honeysuckle,-tubular.

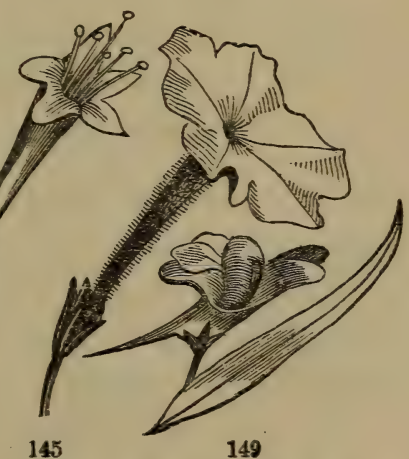

Fig. 147. Dandelion,-liguiato.

Fig. 148. Synandra,-labiate. Fig. 149. Toad-flax,-labiate-personate.

92. The urceolate.

93. The funnel-form. 
94. Salver-form, the tube suddenly spreading out in a horizontal bordes, as in Phlox, Petunia (Figs. 126, 145).

95. Tubular, when the corolla is nearly all a slender tube with a small border or none at all, as in the Trumpet Honey suckle (Fig. 146).

96. Ligulate (from the Latin ligula, tongue), as if formed by splitting the tubular on one side. The notches at the end plainly indicate the number of united petals which compose it, as also do the parallel seams. See the flowers of the Dandelion (Fig. 147), also of Cichory.

97. Labiate (Latin labium, lip), resembles the mouth of an animal. It is a very irregular corolla, having the petals of dissimilar shape and dissimilarly united. See (Fig. 148) a flower of Synandra, or Catmint, or Catalpa. In Fig. 149 (Snap-dragon), the mouth is closed and said to be personate, which means masked.

\section{LESSON X V.}

CONCERNING THE STAMENS.

98. SAFELY infolded within the perianth, we find a number of delicate, thread-shaped organs, quite unlike the sepals and petals. They are arranged in one or more circles, and called the essential organs, because they are absolutely necessary to the perfection of the seed.

94. Describe the salver-form.

95. The tubular. 96. Ligulate.

97. Labiate. Now repeat the regular forms. Repeat the names of th irregular forms.

98. Where do we find the essential organs? How arranged? Why are they so called? 

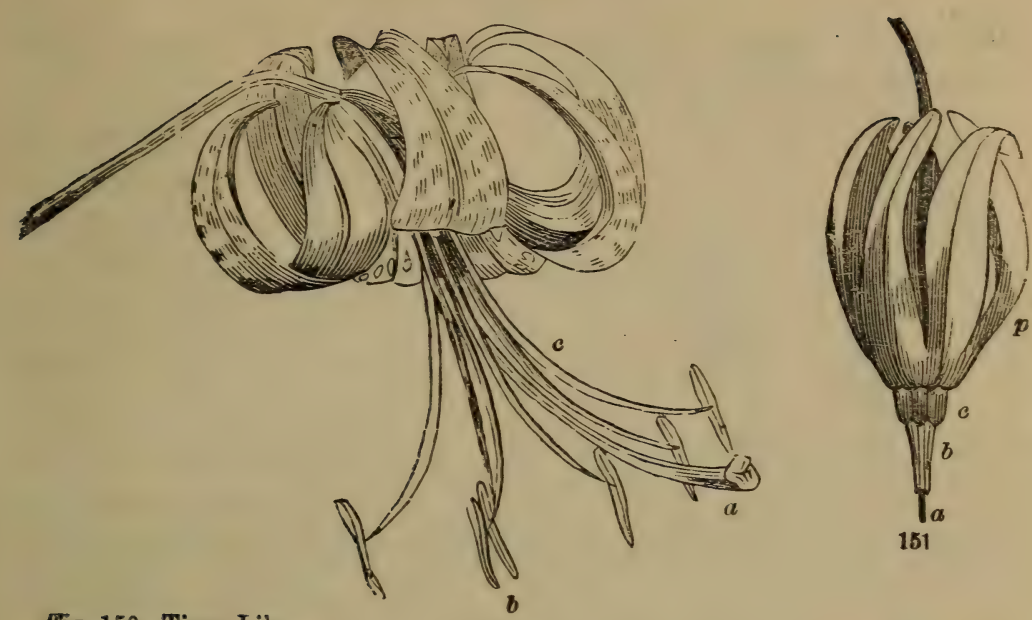

Fig. 150. Tiger Lily.

Fig. 151. Flower (enlarged) of Dodecatheon: $a$, pistil ; $b$, anthers ; $c$, tiaments: p. petals.

99. Let us look at this picture of the Lily (Fig. 150), or at some real flower. The slender organs marked $a, b$, $c$, are the essential organs of which we are speaking; and you see at once that there are two kinds of them. Those which stand in the outer row next to the petals are the stamens.

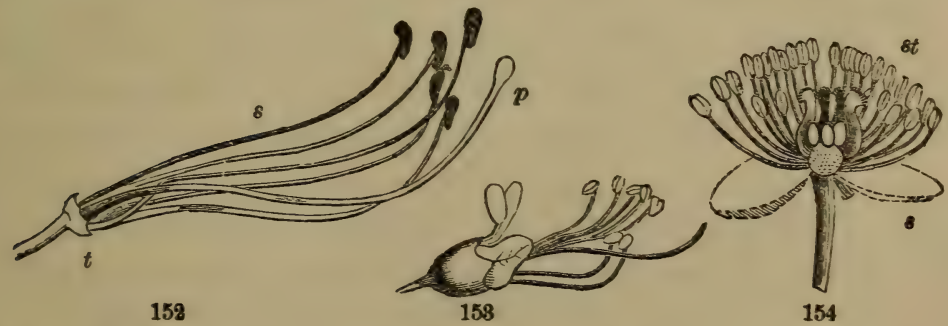

Fig 152. Rhododendron; only the torus $(t)$, the five stamens $(8)$, and the pistil $(p)$. Fig. 153. Buckeye, whole flower; 7 stamens, 1 pistil, 3 petals.

Fig. 154. Hydrastis, split through the centre (a section), showing the torus, 2 pals $(8)$, many hypogynous stamens $(8 t)$, and several pistils in the midst. 
The central urgan (or organs) is the pistil. We now propose to notice the form of the stamens.

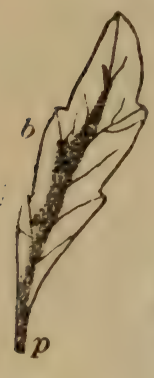

155

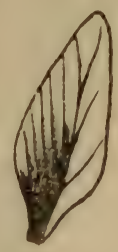

156

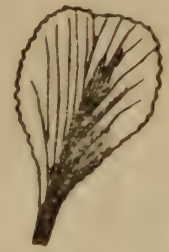

157

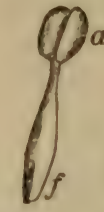

$158 \quad 159$
A leaf (Fig. 155), a sepal (Fig. 156), a petal (Fig. 157), a stamen (Fig. 158), and a pod (pis. til, Fig. 159) of Draba arabizans, placed side by sido for comparison.

100. The stamen may be compared to the leaf. Its slender, thread-like stalk is the filament, answering to the petiole of the leaf $(f, p)$. Its head $(a)$ is the anther, answering to the blade. Moreover, the anther contains within its cclls many dust. like particles called pol. len. When the cells burst the pollen escapes. Thus it appears that the stamen consists of three members. See them illustrated in this figure (161) of a stamen of the MorningGlory.

101. The filament is usually of a thread-like form (as its name, from the Latin filum, a thread, implies). longer than the anther, and more or less elastic. But the filament is no more necessary than the stem of a leaf, and is often wanting.

102. The anther is an oblong body at the top of the filament, consisting of two hollow lobes joined to each other and to the filament by the connectile (c), which answers to the midvein of the leaf. The two lobes are usually marked along their onter edge by a seam, which at length opens into the cells. This opening, however it takes place, is called the dehiscence. If there be no filament, the anther is sessile.

99. How many kinds? Situations of the two kinds respectirely? 100. How does the stamen compare with the leaf? Specify the thre mem bers of the stamen.

101. Describe the filament 102. The anther; the deliscence. 

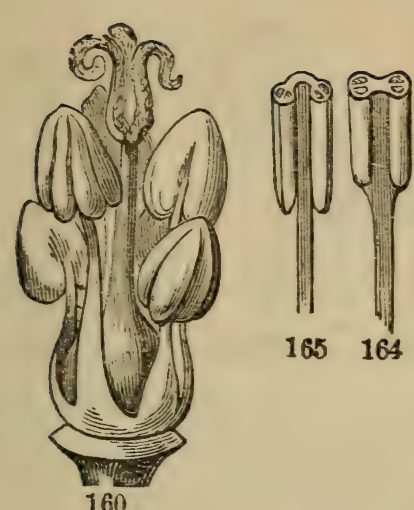

165164
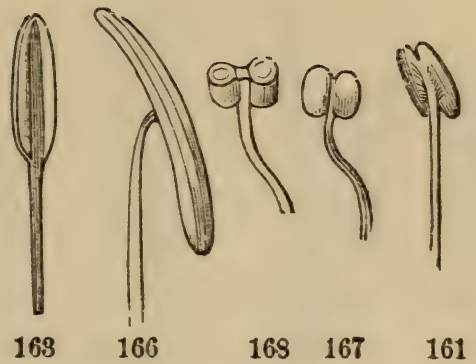

161

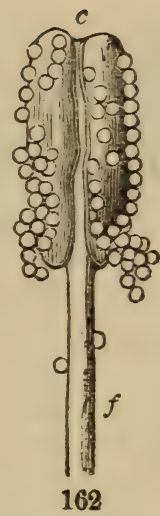

Fig. 160. Frankenia, showing the five stamens (around the one style, which has three stigmas at top).

Fig. 161. Stamen (adnate) of Morning-glory.

Fig. 162. Same, enlarged, with pollen-grains discharged: $f$, filament; $a$, anthor -two-lobed; $c$, top of conuectile.

Fig. 163. Buttercup. Fig. 164. Same, cut across.

Fig. 165. Iris, cut across (extrorse).

Fig. 166. Amaryllis,-versatile. Figs. 167, 168. Larkspur,-innate.

103. But dehiscence takes place very variously. When all regular, it is a chink running lengthwise along the outer edge, as you see in this stamen of a Buttercup (Fig. 163). But here, in this stamen of Iris (Fig. 165), it appears on the back of the anther (looking towards the petals), and we say that the anthers are extrorse, that is, turned outwards. A term of opposite meaning is introrse, denoting that the lines of dehiscence turn inwards towards the pistil, or at least do not turn outwards. For example, the anthers of the Violet (Fig. 173).

104. Moreover, other modes of dehiscence besides chinks are occasionally found. The anthers of Berberis, Sassafras, fc. (see Figs. 171, 172), open by lids hinged at the top. The

103. When is the anther said to be extrorse? introrse? 104. Can you distinguish the opercular and porous dehisence? 


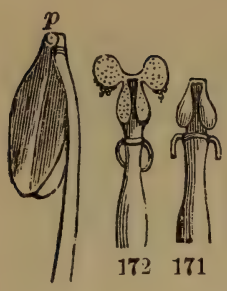

159

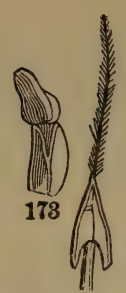

174
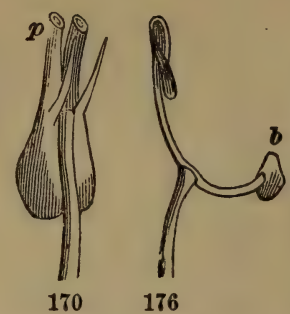

176

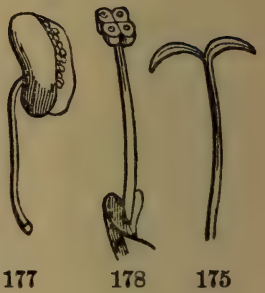

177

teculiar forms of stamens.-Fig. 169. A stamen of Pyrola rotundifolia: $p$, twu spenings (pores) at top where the pollen escapes. Fig. 170. Stamen of Bilberry (Vaccininium uliginosum): $p$, its pores at the top of two horns; it has also two spurs. Fig. 171. Berberis aquifolium, anther closed. Fig. 172. Anther open by two lids upwards. Fig. 173. Anther of Violet with an appendage at top. Fig. 174. Oleander,-an arrow-shaped anther appendaged at top. Fig. 175. Catalpa,-lobes of anther separated. Fig. 176. Sage,-lobes of anther widely separated on stipes; b, barren lobe without pollen. Fig. 177. Mallows,-anther one-celled. Fig. 17S Ephedra,-anther four-celled.

anthers of Huckleberry, Blueberry, Wintergreen, and others of the Heath family, open through two little tubes at the top. The former is opercular dehiscence, the latter porous. (See Figs. 169, 170.)

105. It is also interesting to notice how the anther is attached to the filament in various ways. Generally, it is innate, that is, seeming to stand erect on the top of the filament. Again, it is adnate, which means, attached by its back to the side of the filament, as in Buttercups. And thirdly, it is joined by a single point in its back to the sleuder tip of the filament, as if lightly balanced upon it. This is the versatile anther, common in the Grasses (Figs. 150, 166).

105. What three distinctions in the attachment of the anther? Describe that of the stamens of the Pink ; the stamens of Buttercups ; of the Grasses. 


\section{LESSON X VI.}

\section{MORE ABOUT THE STAMENS.}

106. The careful student will find a great and interesting variety in the number, arrangement, and form of the stamens. In regard to number, as we have already seen, the Lily has six stamens, the Pink has ten, the Speedwell two, the Indian Shot only one. Some flowers have numcrous stamens, as the Rose with forty, fifty, or one hundred, and the Cactus with

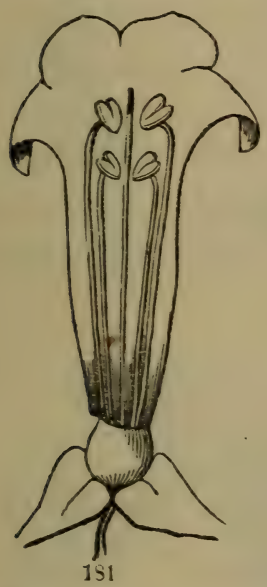

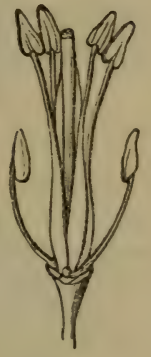

182

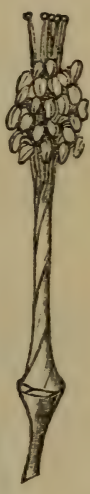

179

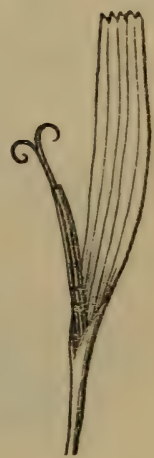

150

Fig. 179. Stamens and pistils of Mallow; the filaments $(f)$ are united into a tube sheathing the styles.

Fig. 180. Floret of Dandelion,- -anthers (a) united into a tube.

Fig. 181. Corolla of Lophospernum, split open to show the four stamens (didye anous) and the one style.

Fig. 1S2. Cardamine,-stamens six, tetradyn'amous.

106. What number of stamens in Pink? Speedwell? Indian Shot? What in the Rose? Cactus? Apple? or in these Howers? Define "staneus definite ;" "stamens indefinite." 
two hundred. I.et us learn how to distinguish between flowers with definite and with indefinite stamens. Definite, when they are not more than ten, indefinite, when more than ten, or not readily counted.

107. The stamens are usually separate and distinct, as in the Lily, Rhododendron, \&c. (Figs. 150, 152), while in the Mallow (Fig. 179), Pea, and other flowers, they grow to yether, forming a tube around the pistil; in other words, they are monadelphous (Greek, monos, one, adelphos, brotherhood). The Pea, or Dielytra, is diadelphous, - the stamens in two sets; and the St. Johnswort, polyadelphous,-in three or more sets. Another mode of cohesion is seen in the floret of Dandelion (Fig. 180), where the anthers cohere while the filaments are distinct, i. e., syngenecious.

108. In two cases we may definitely mark the relative length of the stamens. Didyn'amous stamens (as seen in the Mint tribe, and in the Figworts, Fig. 181) are four in num-
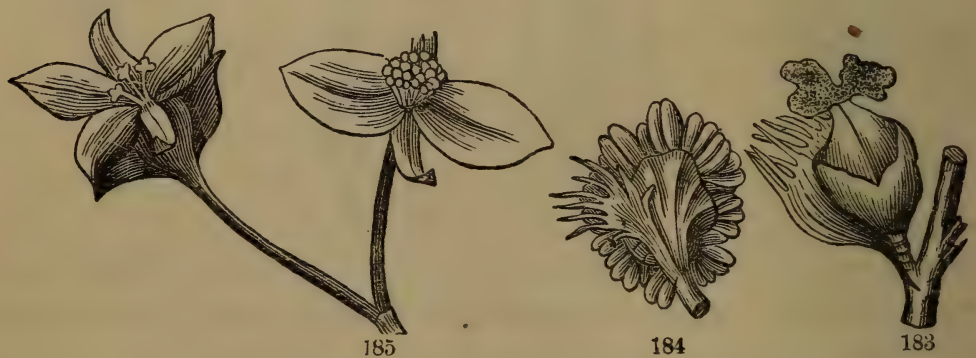

Fig. 183. Pistillate flower of Balm of Gilead.

Fig. 184. Staminate flower of the same.

Fig. 185. Begonı: $a$, staminate flower; $b$, pistillate flower

107. Define "stamens monadelphous." Give examples. Diadelphous Cive examples. Polyadelphous. Example. Define "stamens syngenecious" Mention examples 
ber, two long and two short. Tetradyn'amous stamens are six in number, four long and two short (as in the Mustard tribe, Fig. 182). Again, hypógynous stamens may be seen in the Crowfoot tribe and in Fig. 132; and perígynous sta. mens in the Rose tribe and Fig. 133. What is the differ ence? You need not be told the meaning of these words $(8883,84)$.

109. Some plants have their essential organs separated, so that the stamens are all found in one sort of flowers, the sterile, and the pistils are all in another sort, the fertile. So

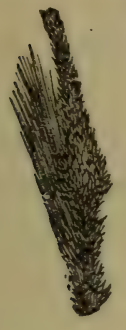

189

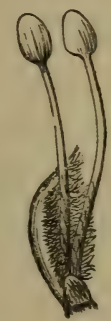

188

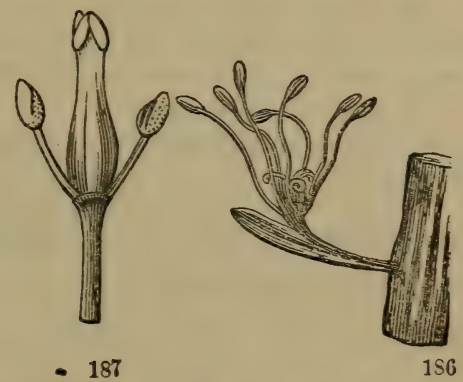

Fig. 186. Flower of Lizard-tail (Saururus); it is perfect, but naked, i. c., with no Horal envelopes; stamens seven, pistils three.

Fig. 187. Flower of Ash (Fraxinus),-naked, with two stamens and one pistil.

Fig. 188. Staminate flower of Willow, - made up of two stamens and a bract.

Fig. 189. Pistillate flower of the same,-merely one pistil and a brict.

it is in the Begonias (Fig. 185), and in the Willows (Figs. 18s, 189). All such flowers are called imperfect, and only the fertile bear fruit

110. A perfect flower is one that has both stamens and

108. In what two cases do we mark the length of stamens? Define "sta nens didynamous ;" “stamens tetradynamous ;" "stamens hypogynous ;

".tamens perigynous."

109. What do you understand by "sterile flowers?" by "fertile flowers?"

110. What is a perfect flower? complete? imperfect? 
pistils. A complete flower has all the organs, viz., sepals, petals, stamens, pistils. A naked flower lacks both the calyx and corolla.

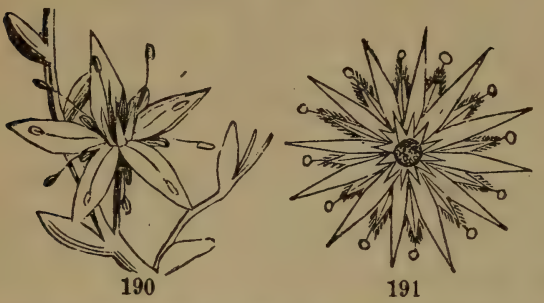

Fig. 190. A symmetrical, regular flower of Iceland Moss (Sedum acre); it has five sepals, five petals, twice five (ten) stamens, and five pistils,-all separate and distinct.

Fig. 191. House-leek (Sedum sempervivum), -twelve-parted. six stamens (in two equal circles), and three pistils (which are sombined in one). cr has each of these several organs in an equal number or, at least, the same number of pieces in each circle of organs. For example, the Flax flower is symmetrical, having sepals five, petals five, stamens five, and pistils five. The Lily is also symmetrical, having three sepals, three petals,

111. A symmetrical flow-

\section{LESSON X VII.}

THE PLAN OF THE FLOWER.

112. It is very instructive and delightful to study the symmetry of flowers in the way mentioned in the last lesson. We are thus led to the discovery of a truth in the science of botany at once beautiful and sublime,-worthy of the wisdom of the Infinite Creator. That truth or principle is, that all flowers, though infinitely various in form and fashion,

111. What a symmetrical flower? How is the Lily symmetrical?

112. Please state the principle learned from studying the symmetry of the flower. 
are built upon one only plan, and that plan founded in the science of numbers.
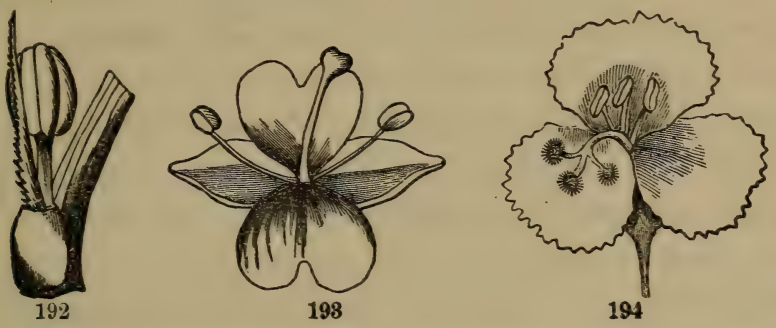

Fig. 192. Flower of Hippuris,-une-parted.

Fig. 193. Circæa Lutetiana; flower two-parted.

Fig. 194. Yellow-eyed Grass (Xyris); flower threc-parted.

113. Let us, then, examine the Flax. Here all the organs are in fives. The Circe has them all in twos; the Iris, in threes. And every plant is distinguished in this way by some number which we call the radical number, according to which its organs are parted. Now in the Mock Orange, or Philadelphus, although the stamens seem to be indefinite, still the radical number is four. The stamens occur in many circles, with four in each circle, so that these are also in fours. As for the pistils, they are evidently four, but so united as to form apparently but one. Examine also the Bloodroot. Its stamens will be found in fours, the radical number, and the stamens of the Apple will be found in fires. So the petals of Bloodroot are twice four (8), and of the Magnolia twice three (6), or three times three (9).

114. It is therefore a general law, that when any organ is

113. Can you define the radical number of the flower? What is it in Circe? Iris? Flax? How is it in Philadelphus? How in Bloodroot?

114. State the lnw of multiplied organs. 
multiplied, its new number is only a repetition of the radical number.

115. Also, when any organ is diminished in number, we find generally that the deficiency is only apparent, and doee not interfere with the law of the radical number. Thus in Philadelphus, the one pistil proves to be four growing to. gether. In the Lady's-slipper, the radical number is three, and the sepals are three, although the two lower ones are united almost to the tip into what seems but one. Thus the true number is often curiously disguised by cohesions.

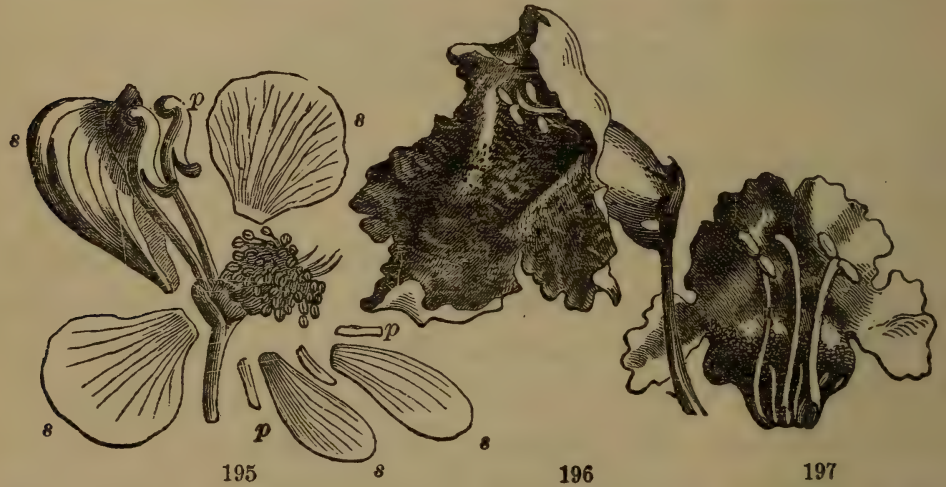

Fig. 195. Flower of Aconitum Napellus displayed; $\delta, \delta, s, \varepsilon, \delta$, the five sepals, the upper one hooded; $p, p, p$, the five petals, of which the two upper are nectaries covered by the hood, and the three lower very minute.

Fig. 196. Flower of Catalpa,-two-lipped, five-lobed.

Fig. 197. Corolla laid open, showing the perfect stamens and rudimentary.

116. Again, the five petals of Monk's-hood (Fig. 195) are apparently but two, while three of them are so very small as to be overlooked. In the Mint tribe, as Peppermint, Cat-

115. How does cohesion interfere with the radical number in Philadelphus חIow in the sepals of the Moccasin flower?

116. How does suppression interfere in Monk's-hood? In the Mint tribe Catalyı? Mustard? What tendency do jou see in all these cases? 
mint, while five-parted, the flowers have generally but four stamens; but on close observation we often find a small rudiment of the fifth stamen in its proper place, as if its growth had been early stopped. And in Monarda and Catalpa, only two stamens grow up to maturity, while three are inere rudiments (Fig. 202). Nevertheless, such flowers are said to be unsymmetrical. So the flowers of the Mustard iribe. The stamens are in two rows of four in each; but of the outer row (or circle) two were checked in growth (or suppressed, as the botanists say) at the outset. (See Fig. 97.) The tendency to symmetry is manifest in all these cases.

117. We must carefully distinguish between the terms unsymmetrical and irregular. The former refers to number only, the latter to form and size

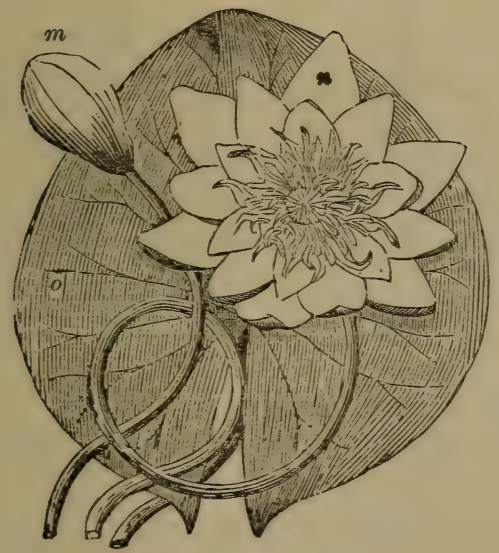

Fig. 198. Nymphæa odorata (Less. XIV.). The Mustard flower is unsymmetrical hut not irregular. The Orchis is irregular, but not unsymmetrical. Snap-dragon is both irregular and unsymmetrical.

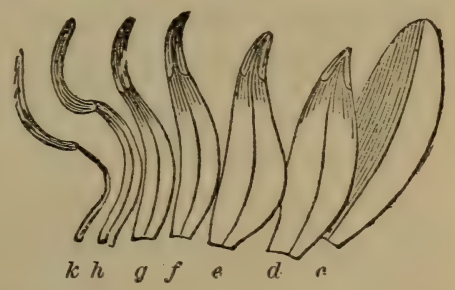

Fig. 199. Petals gradually passing into stamens.

118. Here is a figure of the Water Lily (198), and a separate view of its sepals, petals, and stamens. Observe

117. What difference between unsymmetrical and irregular? Examplea 
how the form of the slender stamen gradually changes to the broad petal. the anther becoming smaller and smal_er. One can scarcely say where it ceases to be a stamen and begins to be a petal. So, also, the petals gradually pass into sepals, and in other plants, Peony for instance, the sepals just as gradually pass into leaves. (See Class Book of Botany, § 113.)

119. This transformation of one sort of organ into another (always from stamen back towards the leaf) is quite common among cultivated plants. It is in this manner that the Rose, Carnation, Peony, \&c., become double, viz., by the stamens, and often the pistils too, becoming petals: for in the wild state these flowers have but five petals.

120. From these examples and others like

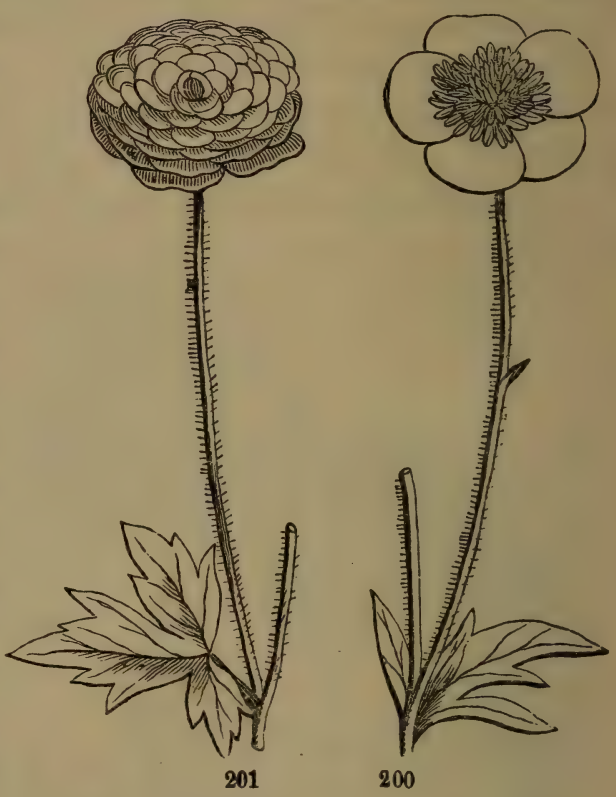

Fig. 200. Flower of Crowfoot.

Fig. 201. Double flower of the same; the stamens and pistils have become petals. them, we conclude that the different organs of the flower, and the lcaf also, although commonly very different, have all one common nature and origin; or, in other words, the organs of the flower may all be considered as transformed leaves.

118. Show the graduation of organs in Water Lily.

119. How do the Rose, Peony, \&c., become double?

120 What great principle is derived from these facts? 


\section{LESSON XVIII.}

\section{OF THE PISTILS.}

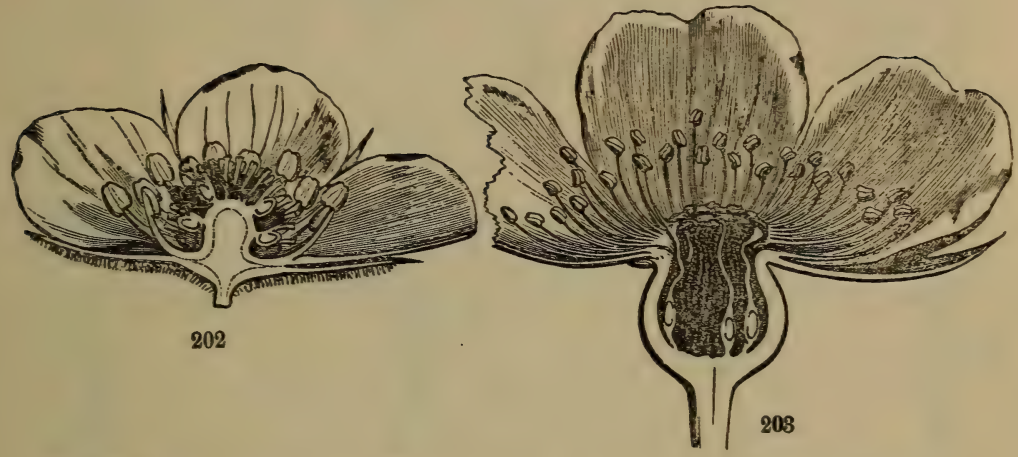

Fig. 202. Section of flower of Strawberry, -ovaries many, on a raised torus.

Fig. 203. Section of a Rose,-ovaries sunk into a hollow torus.

121. The pistils occupy the centre of the flower, at the end or centre of the torus. Their number varies in different plants from one to one hundred, or zore. When they are several they stand arranged in a circle like the other organs. When they are many they are commonly heaped together in a spiral manner, and raised on the conical torus, as in Buttercup, Strawberry, or sunk into the cavity of a hollow one, as in Rose. (See Figs. 202, 203.)

122. The pistil consists, plainly, of three parts, as may be seen in Fig. 204. At the top is the stigma (s), at base is the ovary (o), and between them is the style (sty). The style

121. In what part of the flower are the pistils situated? What is their number? their arrangement? How situated in the Rose?

122. Please describe the pistil and each of its parts. In what case is the stigma sessile? 


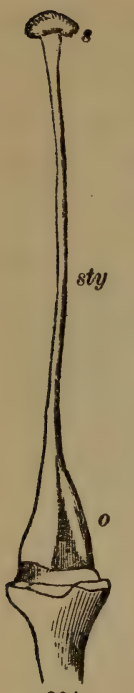

being a merc stalk. like the filament of a stamen or the petiole of a leaf, may, like them also, be wanting, without loss to the pistil. In this case the stigma is sessile (sitting) upon the ovary, as in the pistils of Anemone (Fig. 207), and of Trillium (Fig. 206).

2.04
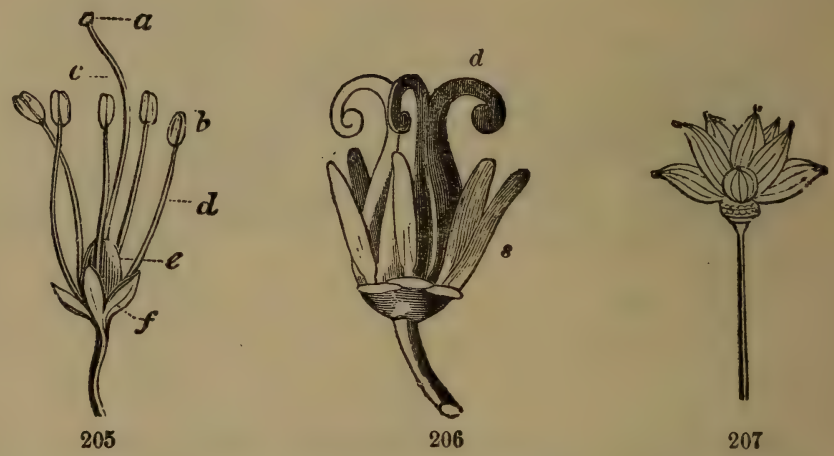

Fig. 204. Pistil of Tobacco.

Fig. 205. Pistil, stamens, and caly $\mathbf{x}$ of Azalea.

Fig. 206. Trillium,-stigmas $(d)$ and anthers $(\delta)$ nearly sessile.

Fig. 207. Pistils of Rue Anemone (A. thalictroides),-stigmas sessile.

123. The ovary is a kind of sac or case, enclosing the ovules (see Fig. 215, where there is but one, or in Fig. 209, where there are five, and Fig. 202, where there are many ovaries.) When full grown, the ovary becomes the fruit, and the ovules the seeds.

124. It is very important to distinguish between the simple and the compound pistil, for when there are several in the same flower they often grow together, forming a single body with members more or less distinct. As the petals grow

123. Describe the ovary and the ovules.

124. Name an important distinction in oraries. When is the orary os pistil compound? 


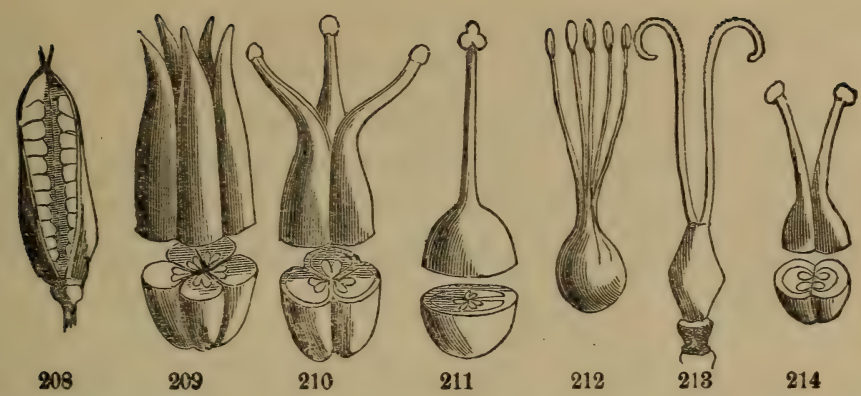

H.g. 208. Simple pistil of Larkspur.

Fig. 209. The five simple pistils of Columbine, all distirict.

Fig. 210. Th. three pistils of a St. Johnswort, -ovaries united but styles distinct.

Fig. 211. Compound pistil of another St. Johnswort, the three pistils entirely anited.

Fig. 212. Flax, - the five ovaries united but the styles distinct.

Fig. 213. Pink, - the two ovaries united, styles distinct.

Fig. 214. Saxifrage,-the two pistils slightly united.

together, forming a monopetalous corolla, so the pistils may combine into a compound pistil. The parts of such a pistil are conveniently called carpels.

125. As to the extent of this union of the pistils, it is found in all possible degrees, always beginning at base and proceeding upwards. For example, in Columbine (Fig. 209), the five carpels (pistils) are entirely distinct; in Early Saxifrage (Fig. 214), the two carpels are united at the base; in Pink (Fig. 213), the two unite to the top of the ovary, leaving the styles distinct; so also in Flax (Fig. 212); in Evening Primrose, the four pistils cohere to the top of the style, leaving the stigmas distinct; and finally, in the Lily, the three carpels are united throughout. (See Figs. 209-214.)

126. We may know the number of carpels in a compound

125. As to the cohesion or union of pistils,-how is it in Columbine? in Pink? in Early Saxifrage? Evening Primrose? Lily? 
pistil by the number of separate styles, or by the separato stigmas, or by the lobes of the stigma or ovary, or by the number of cells in the ovary, or (when only one cell) by the number of seed-rows. Thus the three-lobed stigma or ovary of the Lily indicates a triple pistil, also the three stigmas of the Spring Beanty, and the three seed-rows in the Violet. (See Fig. 229.)
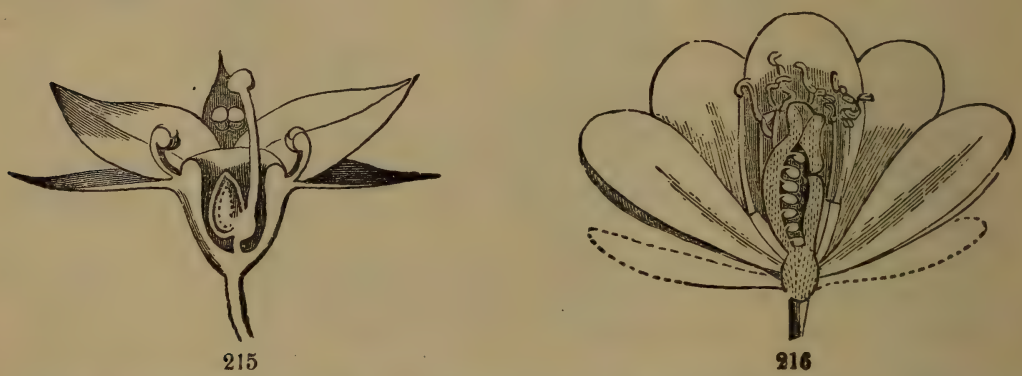

Fig. 215. Section of the flower of Alchemila, showing the stamens perigynous, the style single, simple, and lateral.

Fig. 216. Section of flower of Jeffersonia,-stamens hypogynous, pistil single, simple, with one seed-row.

127. But when the pistils remain separate and distinct we call each one a simple pistil. Thus in Columbine (Fig. 209) there are five simple pistils; in Anemone (Fig. 207), and in Buttercups, many ; while in Cherry, Peach, Bean, Alchemilla, and Jeffersonia, there is just one simple pistil in each flower. Such a pistil is usually of an irregular form, with its style lateral (on one side), and only one seed or seed-row. (See Figs. $215,216$.

126. Please tell us how you detect the number of carpels in the compourd ovary of Spring Beauty; of Lily ; of Violet.

127. What peculiarity in the form of a simple pistil? 


\section{LESSON XIX.}

HOW THE LEAVES ARE FOLDED IN THE BUD

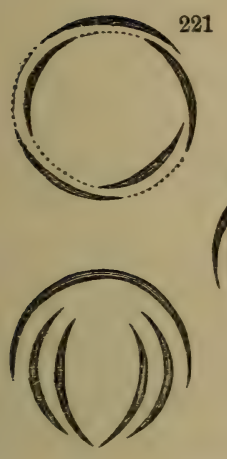

224
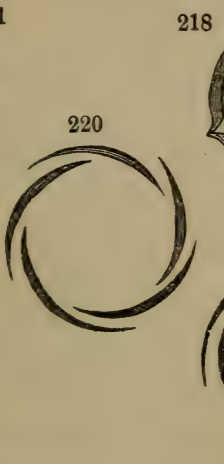

223

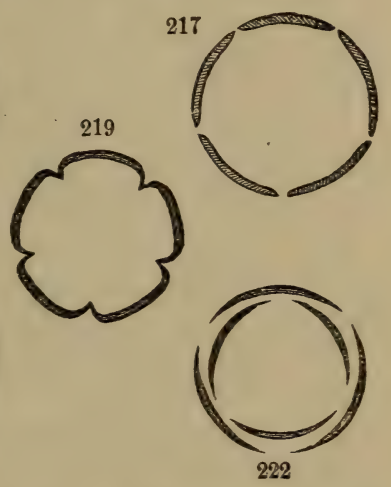

Estivation.-Fig. 217. Valvate calyx, as of Mallow. Fig. 218. Sepals of Holly. hcok,-valvate-reduplicate. Fig. 219. Sepals of Clematis,-valvate-induplicate, Frg. 220. Petals of Flax,-contorted. Fig. 221. Petals of Wild Rose,-quincuntial. Fig. 222. Petals and sepuls of Jily or Tulip. Fig. 223. Petals of Wall-flower,convolute. Fig. 224. Petals of Pea,- vexillary.

128. There is the leaf-bud, consisting of many scales and young leaves, folded up in such a manner as to occupy as little space as possible; and the flcwer-bud, consisting of the organs of the flower in their early state, also closely packed. Now if you study the arrangement of the pieces composing the bud of either sort, you will be surprised and delighted with its variety and elegance. As each species of plant has the same invariable mode of folding in all its buds, this study well becomes a matter of science.

LEss. XIX - What is the subject of this Lesson? 128. Two kinds of buds; please describe each. 
129. With a sharp knife let us make a cross-section (that is, a cut square across) of a flower-bud just ready to open : we may thus obrain some such views as are here drawn. For example, in Fig. 217, we have the valvate arrangement. Hore the pieces composing the circle barely touch each other by the edges, as in the sepals of Mallows, petals of Lilac, valves of a seed-vessel. (See, also, Figs. 218, 219.)

130. In the Phlox, Flax, Oleander, we find a twisted or contorted arrangement of the petals (Fig. 220), where each piece overlaps the next, all in one direction.

131. The bud is said to be imbricated, when some of the pieces are wholly outside, covering by the two edges others which are wholly inside. But this may take place in various ways. See how it is in the petals of the Eglantine, or Apple (Fig. 221). Here two petals are outside, two inside, and one partly both. In the Tulip, one sepal is outside, one inside, and one partly both. And just so with its three petals (Fig. 222).

132. The bud is convolute when each leaf wholly involves all that are within it, as do the petals of Magnolia and Wallflower (Fig. 223); and it is vexillary in the Pea tribe, where only the outside petal, larger than the rest, infolds them all (Fig. 224).

133. The plicate arrangement is found in monopetalous flowers, as in Thornapple, Potato, where the corolla is folded in a manner somewhat like a fan.

129. How do we prepare a bud for examination? What do you under. stand by a cross-section? Define the valvate arrangement, with examples.

130. What æstivation do we find in Flax, Phlox, \&c.?

131. What is the imbricated æstivation? Describe it in the petals of Tulip; Apple; Eglantine.

132. How are the petals arranged in the bud of Wall-flower?

133. How in the flower of Thornapple? or Potato? 
134. The pupil should make himself well acquainted with these seven modes of restivation (so the botanists call it). Other modes are described in larger works. (Class Book of Botany, p. 79.)

135. Also in the leaf-bud we find similar modes of leaf: folding (here called vernation, from the Latin vernus, spring: is astivation is from cestivus, summer). The figures following represent cross-sections of various sorts of leaf-buds. In the bud of Sycamore the infolding scales are imbricate, but the young leaves within are somewhat plicate.

136. In the leaf-bud of Cherry (Fig. 230) we find the convolute vernation, similar to the cestivation of Wall-flower. The leaf-bud of Lilac (Fig. 231) gives us another form of imbricate.

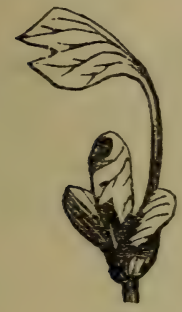

225

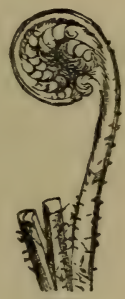

226

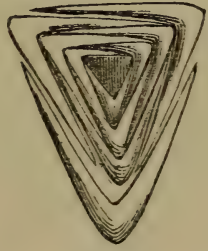

227

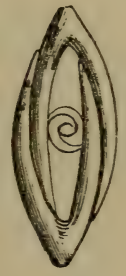

228

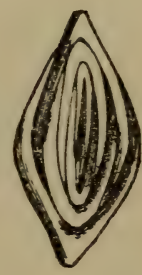

2:29

Vernation.-Fig. 225. Unfolding leaf-bud of Tulip-tree,-reclinate. Fig. 226. Fern leaf-bud,-clrcinate. Fig. 227. Sedge,-equitant. Fig. 228. Sage,-obvolute. Fig. 229. Iris,-equitant.

137. Fig. 229 represents the vernation of Iris, and Fig. 227, of a Sedge-grass. Both are equitant (which means, in Latin,

134. What is the meaning of the word astivation?

135. What is the meaning of the word vernation? Please describe thr vernation in Sycamore leaf-bud.

136. In the leaf-bud of Cherry; Lilac.

137. What of the equitant vernation? 
riding horseback). Each leaf, tirst on this corner, then on that, infolds or overlays all that is within it.

138. Obvolute vernation appears in the leaf-bud of Sage (Fig. 228), where each leaf infolds only half of the blade of its opposite leaf.
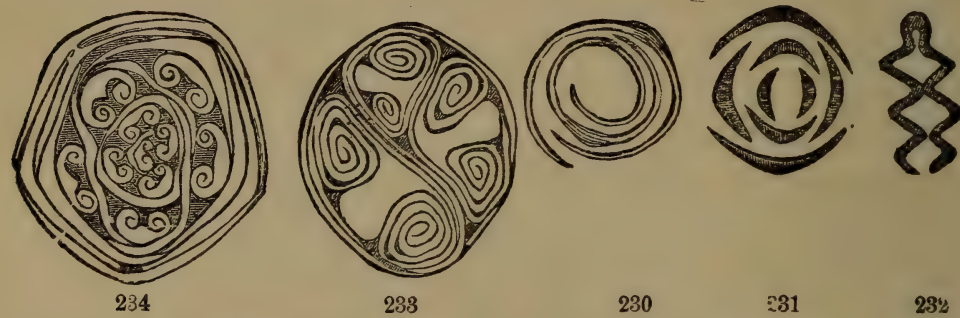

Vernation.-Fig. 230. Cherry leaf-bud,-convolute. Fig. 231. Lilac,-imbricate. Fig. 232. Birch leaf,-plicate. Fig. 233. Dock,-revolute. Fig. 284. Balm-of-Gilead,-involute.

139. In the bud of Dock (Fig. 233) we find the young leaves revolute, or rolled backwards from both edges; but in the bud of Balm-of-Gilead (Fig. 234) they are involute, or rolled inwards from both edges. This is best seen under a mieroscope of one lens, $i$. e., a single microscope.

140. In the bud of Tulip-tree (Fig. 225) each leaf is reclinate, being bent over forward and infolding all within it; and in the Fern (Fig. 226) it is circinate, or coiled from the top downwards, like a watch-spring.

138. The obvolute?

139. What the vernation of Dock? of Balm-of-Gilead ?

140. Please describe the reclinate; the circinate. 


\section{LESSON XX.}

HOW THE FLOWERS ARE ARRANGED ON THE PLANT.

41. WE may now devote one or two lessoris to the arrange ment and position of the flowers upon the plant, a subject to which botanists give the name of inflorescence.

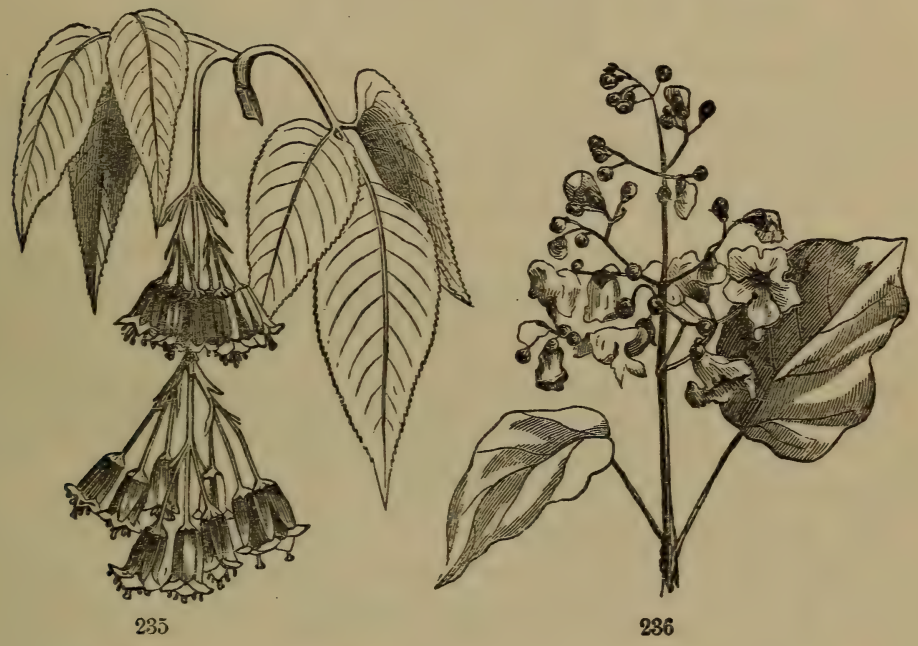

Fig. 235. Staphylea trifolia; a pendulous, paniculate cyme.

Fig. 236. Catalpa; a panicle.

142. Every one has observed such facts as the follow ing, namely, that flowers are sometimes alone, and often in clusters; that they are sometimes raised on stalks, and some

141. What is the meaning of the word inflorescence?

142. What comroon facts in inflorescence does everybody notice? 
times sessile (or without stalks); and that they may arise from terminal buds, or from axillary. With the meaning of the words terminal and axillary you were made acquainted in Lesson IX.

143. The stalk which supports the flower, or the cluster of flowers, we call peduncle. Now the peduncle may be either simple, bearing a single flower, or divided into branches and bearing a cluster of flowers. In the latter case, the branches or branchlets are called pedicels.

144. When the peduncle arises from terminal buds it seems like a continuation of the main stem, as in Foxglove, Horse-chestnut; and when from axillary buds, it comes ont from the side of the stem just above a leaf, as in the Currant. Sometimes it arises from the root or some underground part of the stem, and then we generally call it a scape. Thus the flower-stalk of Tulip is a scape; also of the Dodecatheon.

145. The flower is said to be solitary, not only when alone on the plant, but also when alone in the axil of a leaf, as in Fuchsia, Morning-glory, Petunia.

146. Among clustered flowers, you will often meet with the following twelve varieties of inflorescence, which we must now try to represent and describe. We begin with the spike, such a cluster as we see in the Plantain, Mullen, \&c. We may define it thus: A long peduncle (called rachis), having sessile flowers arranged along its sides. But before we go further with inflorescence, we must examine the bracts which accompany it.

143. Please define peduncle; also pedicel.

144. When are the flowers terminal? axillary? Define scape.

145. Why is the flower called solitary in Fuchsia, Petunia, \&c.?

146. Define a spike. Explain to us the rachis. 


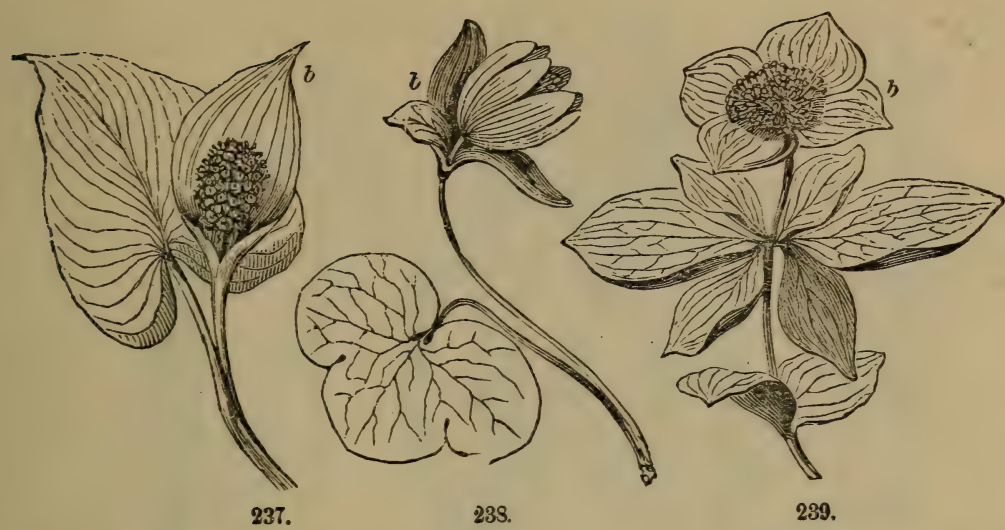

Bracts $(b, b, b)$. Fig. 237. Cornus Canadensis, with an involucre of four colored bracts. Fig. 238. Hepatica triloba, with an involucre of three green bracts. Fig. 239. Calla palustris, with a colored spathe of one bract, inclosing the spadix.

147. Bracts are evidently of the same nature as leaves, differing only in their diminished size, and in their position on the flower-stalks, or near the flowers. They are sometimes colored as brightly as flowers, as in Painted-cup, or in Balm. When several bracts are arranged in a whorl at the base of the clister of flowers, an involucre is formed, such as we find in Carrot, and most of the Umbelworts (Fig. 244). In the Flowering Dogwood the large involncre is colored white.

148. Next in resemblance to the spike is the spadix, an inflorescence seen in the Calla (Fig. 237), Golden-club (Fig. 241), and Cat-tail. It may be defined as a thickened, clubshaped spike, often with a large bract (called spathe) at base, as in Jack-in-the-pulpit, or withont a spathe, as in Fig. 241.

147. What sort of leaves grow on the peduncles, if any? Define bracts What is an involucre? How is it in Cornus? 


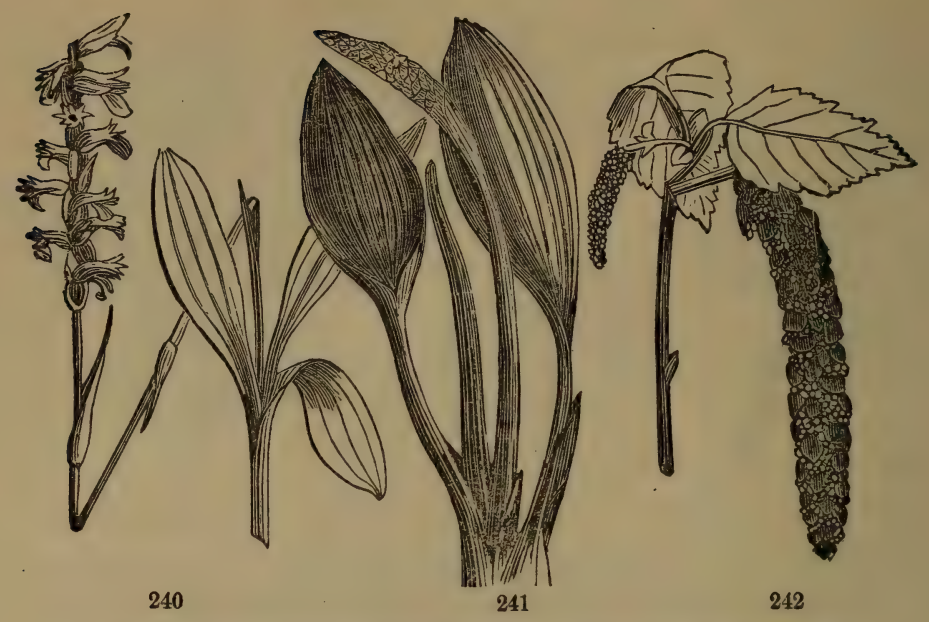

Fig. 240. Lady's-tresses (Spiranthes),-flowers in a twisted spike.

Fig. 241. Golden-club (Orontium),-flowers in a spadix with no spethe. Fig. 242. Birch (Betula), -flowers in aments.

149. An ament, called also catkin, is a more sleuder and delicate spike, filled with colored scales and flowers, and all falling together without separating, such as adorn the Birches (Fig. 242), Willows, and Poplars in early spring. The Hop also bears aments.

\section{LESSON XXI.}

THE INFLORESCENCE, CONTINUED.

150. The flowers of the Black Cherry, Currant, Foxglove Locust, and Moth-mullen are in racemes. The raceme, then, is a rachis bearing its flowers on distinct, simple pedicels

148, 149. Can you define the spike? ament? spadix? and spathe? 150. Please name and describe the inflorescence of Black Cherrv. 
(not sessile, as in the spike). It is often pendnlous, often ereet.
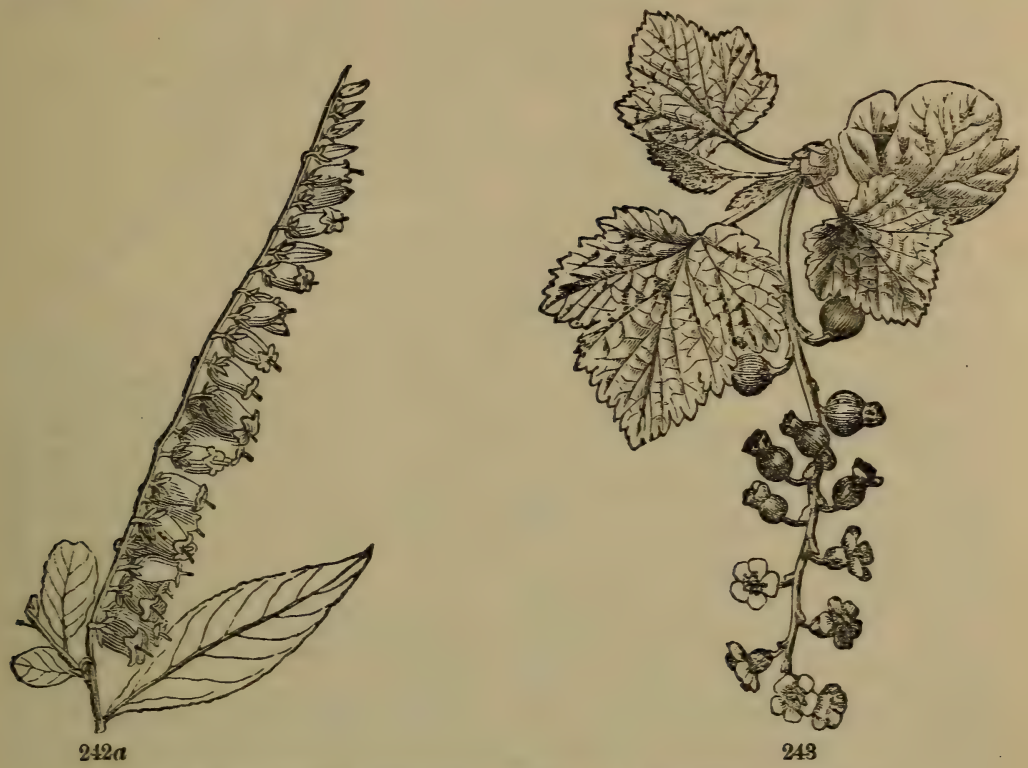

Fïg. 242. Secund (one-sided) raceme of Anáromeda racemosa.

Fig. 243. Pendulous raceme of Currant.

151. The corymb differs from the raceme in having the lower pedicels lengthened so as to elevate all the flowers to about the same level, as in the Yarrow or Wild Thorn.

152. The umbel appears in Milkweed, Onion, Ginseng, \&c. It consists of several pedicels of similar length, all arising from the same point at top of the peduncle. But in Caraway, Carrot, and most of the Umbelworts (Fig. 244), the umbels are compound, as if each of the pedicels had become

151. How does a corymb differ from a raceme?

152. Please name and describe the inflorescence of the Milkweed How 
itself an umbel. These secondary nmbels we call umbellets. At the hase of the umbel there is usually a whorl of bracts forming an involucre $(a)$, and often also at the base of each unbellet (b), when we call it an involucel.

153. The fine tlowers of the Catalpa are in panicles (Fig. 235), also the flowers of Oats. We may describe a panicle as if a raceme should have its pedicels irregularly branched.

154. A cluster resembling a panicle, but more compact, such as you sce in Lilac, is called a thyrse.

155. A head of flowers, such as we see in Clover or the Button-bush,

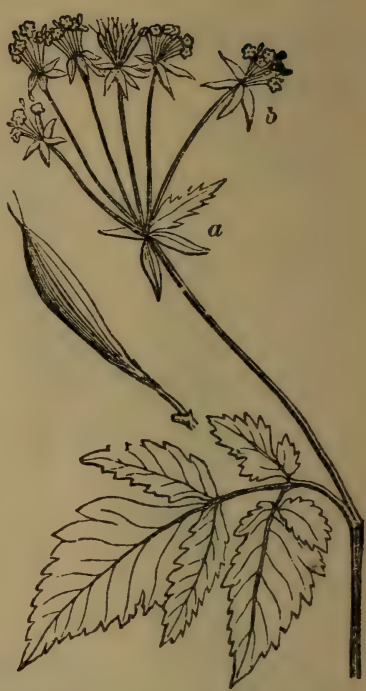

Frig. 244. Compound umbe of Sweet Cicely (Osmorhiza). hardly needs description. We might say that the head is a reduced umbel, having its flowers all sessile at the top of the peduncle.

156. The great family of the Asterworts has all its flowers in lieads, so dense and so nicely arranged as to be easily mistaken for a single flower. But if you carefully examine such a head, say of an Aster, or especially of a Sunflower, you will see that it is composed of many little flowers or florets. The florets of the outer row are enlarged and open, so as to

does that of Carrot differ? What is an umbellet? What the whorl of bracts at the base of the umbellets?

153. Please describe the panicle. 154. The thyrse. 155 . The head.

156. What the inflorescence of the Asterworts? How is the head of Aster made to resemble a single flower? What the florets of the ray? What tho florets of the disk? 
resemble the petals of one corolla, and the involucre, formed of many imbricated scales, resembles a caly $\mathrm{x}$. This head is often called a compound flower. The outer florets are the florets of the ray, the interior are the florets of the disk. See all this illustrated in Figs. 245-250.

157. The forms of inflorescence heretofore described result trom axillary buds; but the three fullowing come from terminal buds. Cyme is the general name given to all the forms of terminal inflorescence. You may recognize them by the order in which the flowers open. Thus, in

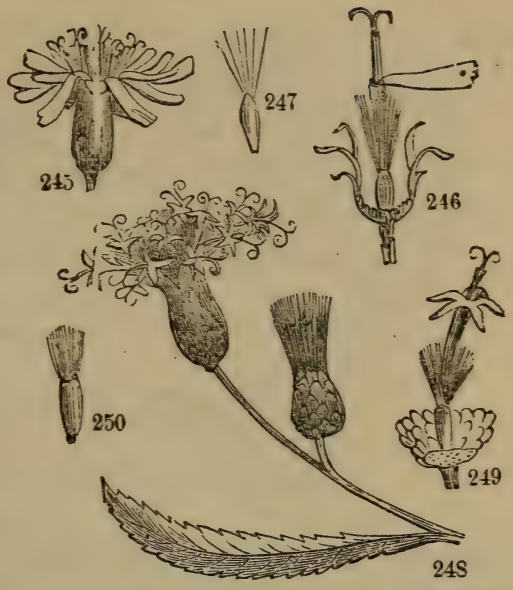

Fig. 245. Head of Blue Milkweed (Mulgtdium); all its florets are ligulate. Fig. 246. A view of one of them remaining on the receptacle. Fig. 247. A fruit crowned with its pappus.

Fig. 248. Heads of Ironweed (Vernonia); all its florets are tubular. Fig. 249. One of them remaining on the receptacle. Fig. 2eั0. Fruit.

the cyme, the terminal and central lowers open first, but in the forms before mentioned, the low 2 r and outer flowers first.

158. When the cyme is spreading and level-topped, we call it a cymous corymb, as in the common Elder; and when not level topped, it may become a cymous panicle, as in Chick. weed (Fig. 25̃1), Spergula, and Staff-tree (Fig. 234).

159. The scorpoid cyme is a very remarkable form of in.

157. Are the forms hitherto described terminal or axillary? Please define the cyme.

158. Cymose corymb ; Cymose panicle.

159. What is a scorpoid cyme? Name and describe the inflorescence of Bunch Pink ; the inflorescence of Catmirt. 

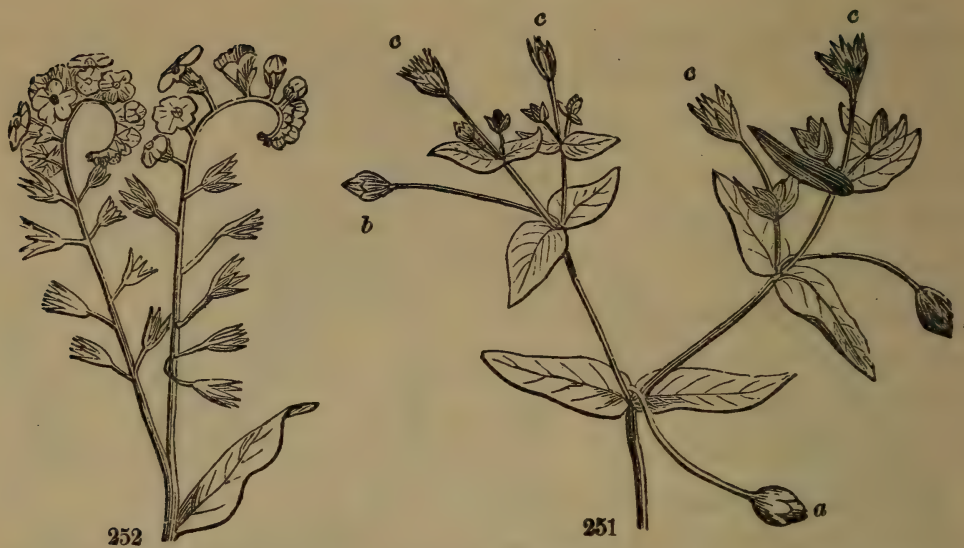

Fig. 251. Cyme of Chickweed (Stellaria media). First, the terminal flower (a! cpened; sesondly, from the axils of its highest leaves arose two branches, and terminated in the flowers $b, b$; thirdly, from their highest axils arose the flowers $c, c$, a, $c$, from whose axils a fourth set is seen to start, and so on.

Fig. 252. Scorpoid cyme of Forget-me-not (Myosotis palustris).

florescence, as shown in Pink-root and Forget-me-not (Fig. 252). Before flowering it is coiled from the tip downwards, and it uncoils as it blossoms. In its nature it is a half-cyme. The fascicle is a densely packed cyme, as seen

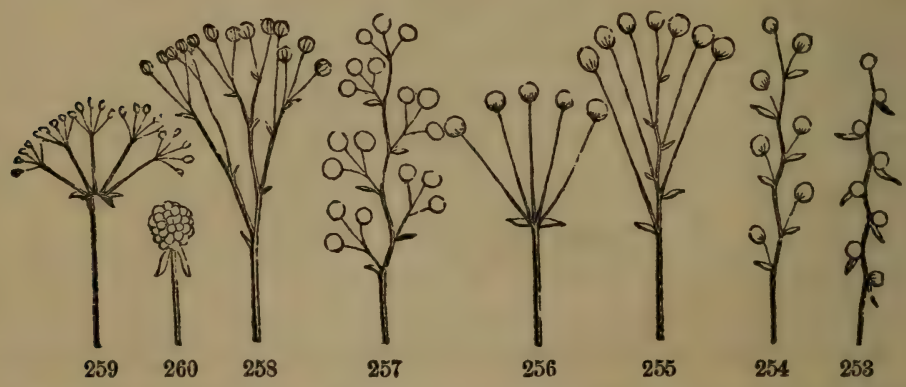

Liagrams of the forms of axillary inflorescence, showing how they gradually pass into each other. Fig. 253. Spike. Fig. 254. Raceme. Fig. 255. Corymb. Fig. 256. Umbel. Fig. 257. Panicle. Fig. 258. Compound corymb. Fug. 260. Head. Fig 2r.9. Comsonnd umbel. 
in Bunch Pink or Pycnanthemum. The glomerule is a small, dense cyme appearing in the axils of the leares, as in Catmint and the Mint tribe ger erally.

160. The preceding diagrams may be carefully studied. They will convey a general idea of all these forms of inflorescence, and how they are related to each other.

\section{LESSON XXII.}

\section{CONCERNING THE FRUIT.}

161. The flower is of short duration. After a few hours or a few days of blooming beauty, it fades and disappears.

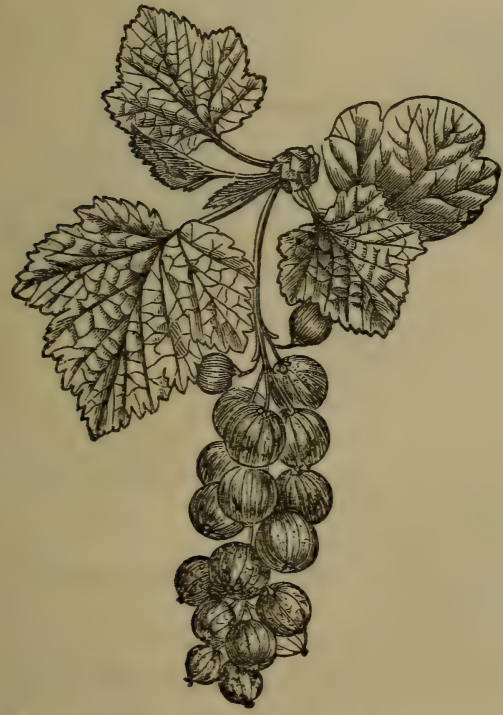

Fig. 201. Fruit of Currant,-a berry.

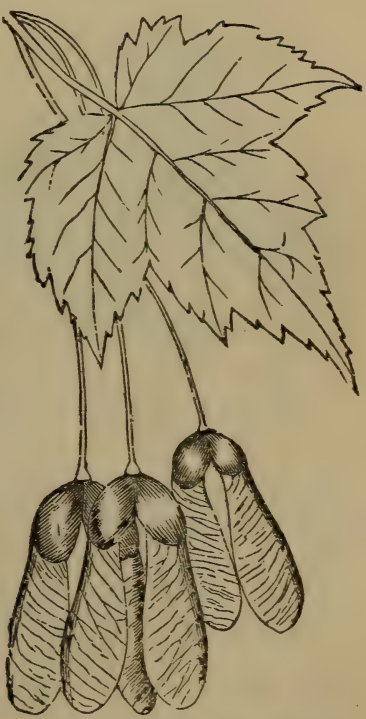

Fig. 262. Fruit of Maple,-samare

160. Please explain the diagrams 253-260. 
The stamens and petals have accomplished their work, and are dead. The sepals also, when colored like petals, are dead. But the pistil, especially the ovary, yet remains in its place, living and growing until the seeds which it contains are perfect.

162. Thus the fruit is the ovary or pistils brought to perfection.

163. During the growth and ripening of the pistil, great and manifold changes occur, so that at last the fruit is very different in form, size, substance, and color. The little pistil in the flower of the Cherry must undergo a great alteration in becoming a plump Ox-heart!
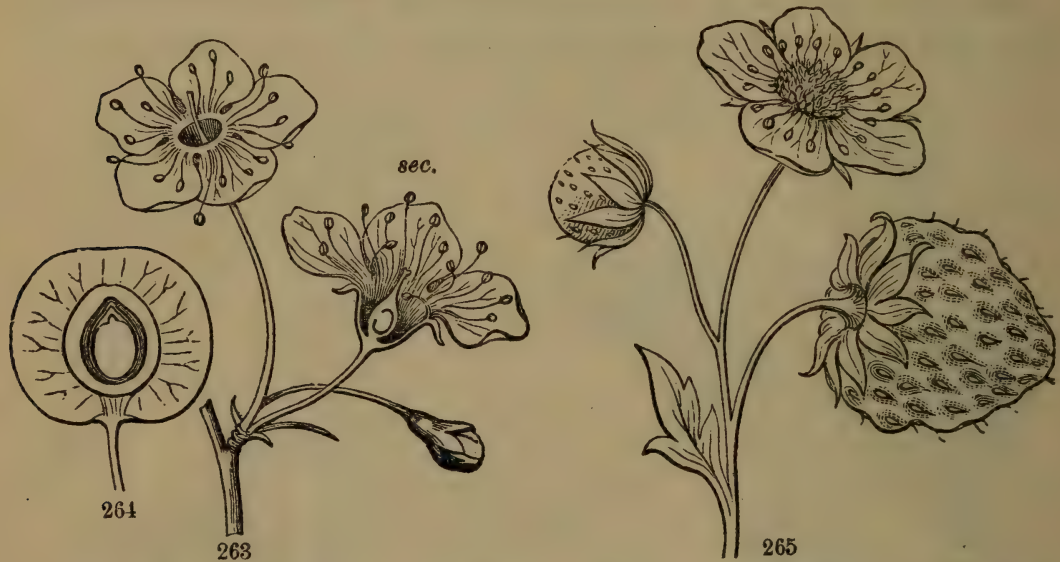

Fig. 263. An umbel of Cherry blossoms, -namely, a bud, an entire flower, and a sciticn showing the one pistil and the perigynous stamens.

Fig. 264. The drupe, eut through to show the stone and one seed.

Fig. 265. 1 corymb of Strawberry,-flower and fruit. The achenia are seen on tie surface of the iruit, which is only the overgrown torus.

161. Can you tell us what parts of the flower perish? What parts remain in place and still grow?

162. How do you define the fruit?

163. Mention some of the changes occurring from ovary to fruit. 
164. In the fruit we see the end and aim of plant-life accomplished, according to the wise and good design of the great Creator. While it serves to reproduce and keep alive the plants upon the earth, it also serves as food for animals and for man.

165. It is curious to observe how different are the parts of the fruit which in different plants become food. In the Appie, we eat the calyx which here

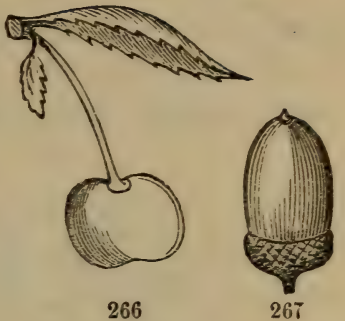

Fig. 266. Drupe,-a ripe Cherry.

Fig. 267. Tryma,-acorn of Red Oak. adheres to the ovary, and in ripening was thickened and enlarged by the nutritious substance. In the Strawberry, we eat the enlarged, pulpy torus, which bears, all over its surface, the little dry, seed-like fruit. In Peach, the luscious morsel is the outer coats of the ovary itself; and in the Orange, it is the inner coat. In the Nut, Pea, Wheat, and most plants, the nourishing

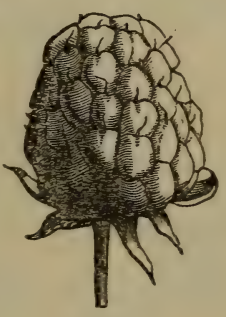

268

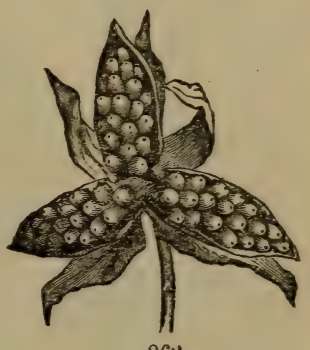

$26 y$

Fig. 268. Etærio,-a Blackberry.

Fig. 269. Capsule of Violet, open. matter is laid up in the seeds, while the carpels ripen into a dry fruit.

166. The fruit consists of the seeds and the seed-vessels The word pericarp means the same as seed-vessel. When

164. Mention some of the uses of the fruit.

165. Can you tell us what part of the Apple is eaten? What part of the Strawberry is the eatable part? What part of the Peach? the Orange? In what part is the nutritious matter deposited in the Pea? Wheat? Almond? 
the pericarp is ripe, it may open in some special manner of itself and discharge the seeds; or it may have no prcvision or opening, and remain closed until it grows or decays

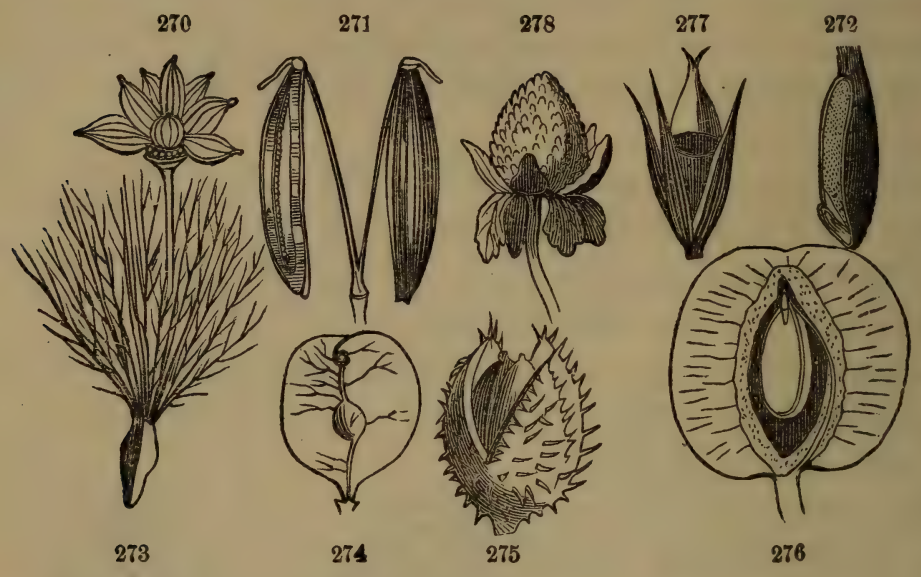

mg. 270. Achenia of Rue Anemone, in a head.

Fig. 271. Fruit of Caraway, consisting of two achenia.

Fig. 272. Kernel of Wheat,-a sort of achenium called cariopsis.

Fig. 273. Fruit of Thistle,-another sort of achenium, crowned with a pappus which serves as wings.

Fig. 274. Fruit of Elm,-a samara, or winged achenium.

Fig. 275. Fruit of Beech,-two nuts, inclosed in the burr.

Fig. 276. The Peach (a drupe),-cut open, showing the seed inclosed in its stone, and the stone in the thick pulp.

Fig. 277. Fruit of Pigweed,-a one-seeded pericarp called utricle.

Fig. 278. Fruit of India Strawberry,-a fleshy torus bearing the achenia outside.

Fruits that open we will call dehiscent fruits, and those which do not open, indehiscent. We will first study some of the forms of indehiscent fruits, arranged as follows :

167. First Division: Fruits indehiscent, one-seeded, dry : namely, Achenium, Samara, Glans.

166. Of what two parts does the fruit consist? What is a dehiscent fruit 1 indehiscent? 
Second Division: Fruits indehiscent, one-seeded, fleshy: namely, Drupe, Tryma, Eterio.

Third Division: Fruits indehiscent, several-seeded; nameIy, Berry, Pepo, Pome.

168. The achenium is such a fruit as we find in Buttercups, Anemone, Sage. Usually there are several produced together from one flower. We must not mistake them for seeds. They are pericarps, each inclosing one seed, as you see in the figures. The grain of Wheat or Corn (called cariopsis) is much the same, but the one seed cannot be separated from the pericarp.

169. The samara is merely an achenium with a wing, as in Ash, Elm, Maple. The latter fruit is a double samara.

170. A glans (or nut) is such a fruit as Acorn, Chestnut, Hazelnut, much like achenium, but larger, and seated in a cup or involucre.

171. A drupe is such a fleshy fruit as the Cherry or Peach. It is well called a stone-fruit. The stone incloses the one seed, and is itself inclosed in a juicy pulp.

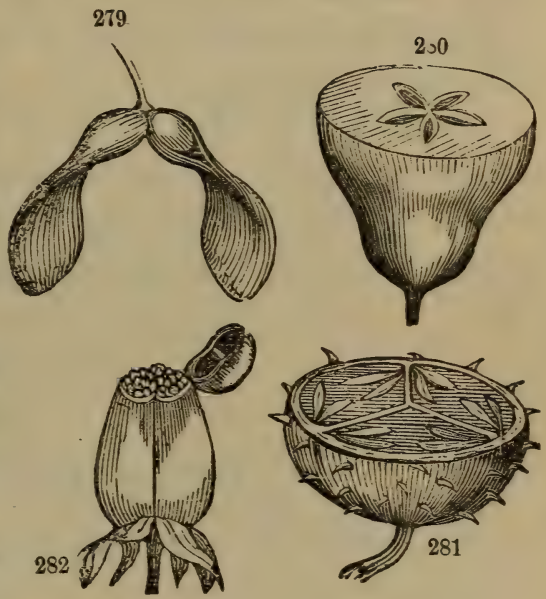

Fig. 279. Maple,-a double samara.

Fig. 280. Pear,-a pepo.

Fig. 281. Gooseberry, cut across; an enlarged view, showing the seeds lying in the pulp.

Fig. 282. Fruit of Henbane, -a pyxik with its lid open.

167. Please define our first division of fruits. What special fruits belong to it ? the second, \&cc.; the third, \&c. 
172. Tryma is the name for such fruits as Walnut, Cocoanut. Like the drupe, it has a stony seed-shell, but its onter coat is rather woody than pulpy.

173. Such fruit as the Raspberry or Blackberry we call etcerio. It consists of inany little fleshy drupes growing fast together or to the torus. In the Blackberry they grow to the torus (Fig. 268).

174. The berry is a thin-skinned, pulpy fruit, holding its several seeds loose in the pulp, as Currant, Grape (Fig. 261). The Orange, \&c., is much like a berry, but on account of its thick rind has been called by another name (hesperidium).

175. Pepo is such a fruit as Squash, many-seeded, with a hard, crusty rind.

176. Pome, the Apple, Pear, Haw, a fleshy fruit with several distinct cells. Here the fleshy calyx grows fast to the ovaries; while in the IIip, or Rose-fruit, the fleshy calyx merely incloses the ovaries, as seen in Fig. 203.

\section{LESSON XXIII.}

FRUITS, CONTINUED.

177. THE dehiscent pericarp, - that is, those which open to discharge the seeds, - are generally dry fruits, known as pods. The various forms have the following names: Pyxis, Follicle, Legume, Silique, Capsule.

168-176. The student will now please define and name the fruit of Butter crps, Corn, Ash, Maple, Oak, Hazel, Plum, Walnut, Raspberry, Grape Orange, Squash, Pear, Haw, and Rose.

177. Please give the names of the dehiscent pericarps. 
178. The pyxis is the most curious and singular of all pods. It opens crosswise by a lid, like a snuft-box. Fig. 284 is the likeness of the pyxis of Rheumatism-root, common in Ohio. It is furmed of one carpel only. Fig. 282 is the pyxis of Henbane, formed of two carpels. So the pyxis

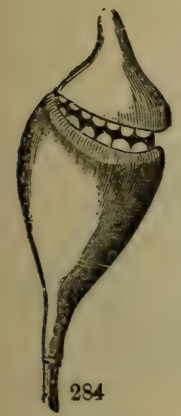
of Poor-man's-weather-glass (Anagallis, Fig. $344)$ is formed of several carpels.

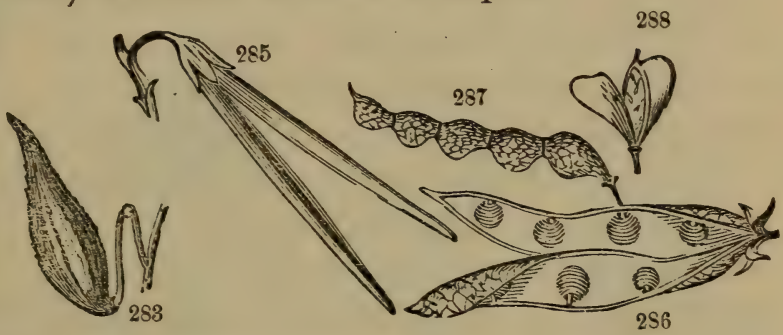

Fig. 283. A follicle of Milkweed (Asclepias).

Fig. 284. A pyxis,-fruit of Jeffersonia, the Rheumatism-root. Fig. 285. A pair of follicles, - the fruit of the Dogbane (Apocynum). Fig. 286. A legume, open, - fruit of the Pea-plant.

Fig. 287. A jointed legume, or loment,-fruit of Desmodium.

Fig. 288. A silicle,-fruit of Shepherd's-purse.

179. Follicle is the name of such pods as those of Colum. bine (Fig. 208), Milkweed (Fig. 283), and of Dogbane (Fig. 285). They are formed of a single carpel, and open lengthwise, on one side only. It is easy to see the resemblance between the follicle and a leaf, the leaf being folded so as to bring its two margins together. (See Fig. 207.)

180. Legume is the proper name of the Pea pod, Bean pod, \&c., of one carpel, one cell, one row of seeds, and commonly

178. Give the character of the pyxis. How does the nyxis of Henbane differ from that of Jeffersonia?

179. Can you describe and name the fruit of Columbine? How is its leafy character seen?

18.0. Describe and name the Pea pod What is a loment? 
opening by twu valves (Fig. 286). Such a pod is sometimes divided crosswise by joints (as in Fig. 287, Desmodium); we then call it a loment.

181. Silique is a two-carpeled pod, such as we find in Mustard. It has two cells, separated by a thin partition, and two rows of seeds (Fig. 291). A short silique, or one not much longer than wide, such as we find in Pepper-grass or Shepherd's-purse (Fig. 288), is called a silicle. (See Fig. 290). 182. Capsule (the word means casket). This name is applied to all

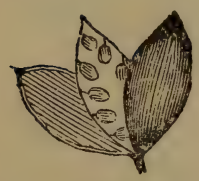

Fig. 290. Silicle of Draba (enlarged). other forms of dry, compound fruits, formed of several united carpels. In opening, they commonly split into several valves, as in Iris; or divide into several parts (carpels) like so many follicles, as in St. Johnswort; or they open by small pores, as in Poppy.

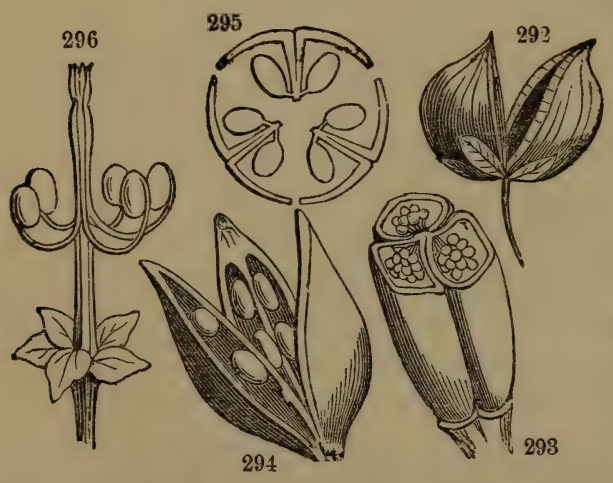

Fig. 292. A capsule,-fruit of Scrophularia ; it is two-celled, two-carpeled, or two-valved.

Fig. 293. A three-celled capsule of Colchicum; it opens be tween the carpels.

Fig. 294. Capsule of Iris, opening into the carpels.

Fig. 295. Cross-section of the same, showing how it opens.

Fig. 296. Fruit of Geranium; its five carpels separate, and are carried up on the curving stvles (called a regma).

181. Mustard pod; describe its structure and name. What is a silicle? 182. What is a capsule? What three modes of opening are mentioned? 
183. We should not omit altogether to notice the aggre gated fruits, such as the Pine-cone (Fig. 300), Pine-apple, $\& c$. These fruits are composed not merely of the pistil, but of the entire flower, or even of the whole inflorescence, bracte and all, grown thick, and consolidated into one fleshy mass. This is evidently the nature of the Pine-apple and of the Mulberry.
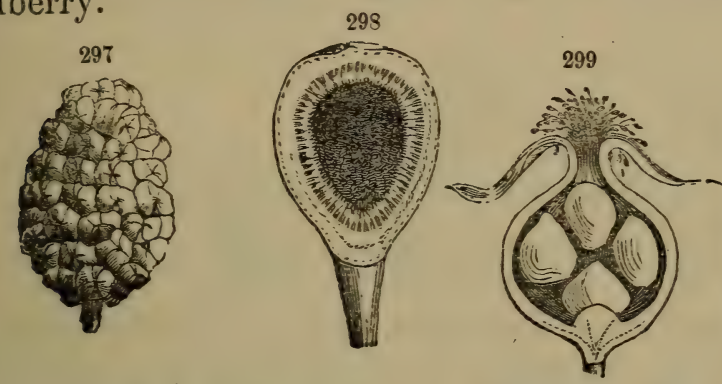

Fig. 297. Black Mulberry,-an aggregated fruit.

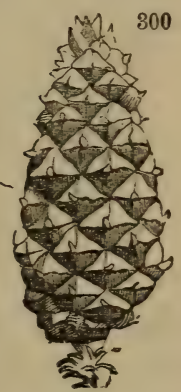

Fig. 298. Fig, cut open, showing the little flowers within.

Fig. 299. Hip of a Rose, cut open, showing the achenia withm.

Fig. 300. Pine-cone, composed of thick scales.

184. As for the Fig, it is a great hollow torus, having its innumerable flowers within the cavity, growing from the walls, and all together become a sweet, pulpy mass.

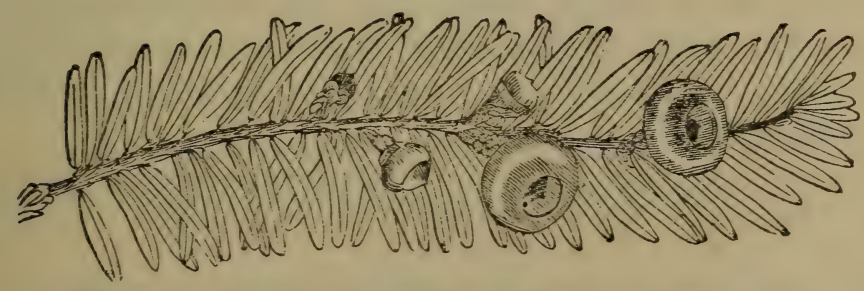

Fig. 301. A branchlet of the Canada Yew, showing the fruit.

183, 184. Mention some examples of aggregated fruits Can you dessribe a Pine-apple? a Fig ? 
185. But there are some kinds of fruit almost or quite destitute of a pericarp, consisting of naked seeds. On the preceding page is a figure (301) of the Canada Yew, a trailing shrub of New England and Canada. The fruit is a singie naked black seed, seated in a fleshy, coralline-red cup. The cone (of Pine, Fir, \&c.) is made up of thick woody bracts, each covering in their axils two or more winged seeds (Fig. 300).

\section{LESSON XXIV.}

CONCERNING THE SEEDS.

186. LAST and most important is the seed, the perfected ovule, containing the germ of a new plant like its parent plant. The seed consists of a kernel and its shell. Place a bean in water, and soon its softened shell or skin is easily separated from the kernel.

187. The shell of a seed may be of any color, as white, black, yellow, red, \&c.; may be polished and shining, or dull and rough; may be of any shape, as round, or oval, or egg. shaped; may be winged, as in Catalpa, or may be clothed with long hairs, called coma. The silk of Silk-grass (Asclepias) is the coma of the seed, and cotton is the coma of Cotton seed. The seed of Poplar (cotton-wood) or Willow is also furnished with coma.

185. What plants have no pericarps? Please describe a cone of l'ine fruit of Yew.

186. What is the seed, and what does it contain? Of what two parts does it consist?

187. What do you remember concerning the color and shape? Describe the coma of a seed 

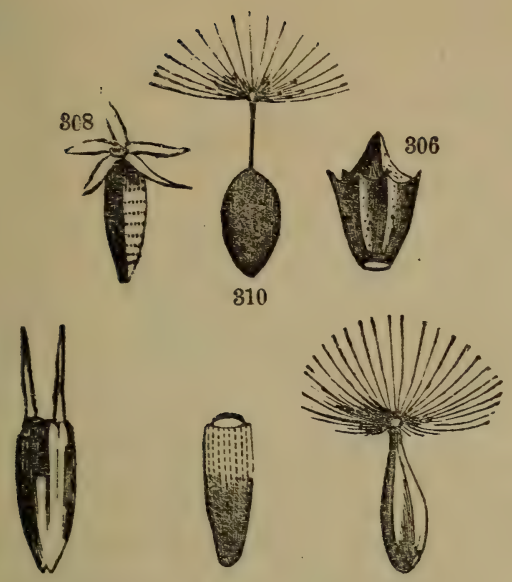

307

3: 5

31.9

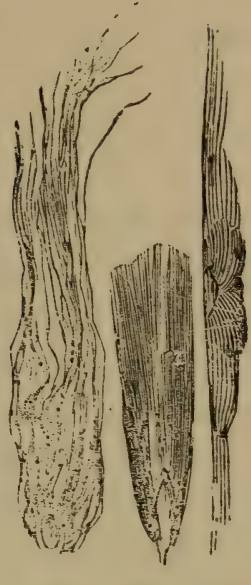

Fig 302. A seed of the Cotton-plant, with its tuft of coma, or cotton.

Fig. 303. A seed of the Cotton-tree (Populus), with its silky coma.

Fig. 304. A winged seed of the Catalpa.

Fig. 305. Achenium of Eclipta; it has no pappus.

Fig. 306. Achenium of Horseweed; scarcely any pappus.

Fig. 3017. Achenium of Sunflower; has two awns for pappus.

Fig. 308. Achenium of Ageratum; has five sepals for pappus.

Fig. 309. Achenium of Bluc Milkweed; has abundant pappus.

Fig. 310. Achenium of Wild Lettuse; with pappus raised on a beak

188. The learner must distinguish between the coma of a seed and the pappus of a fruit. The down of Thistle or Dandelion is pappus, for the little fruit on which it grows is not merely a seed, but a pericarp (achenium), also containing one seed. In a word, the seed may be fledged with a coma, but the fruit is fledged with a pappus, both intended as wings to bear away the seed to distant places. (See Class Bock or Botany, § 485.)

188. What is the distinction between coma and pappus? 
189. As to the seed-kernel, it may concist of two parts, namely, the germ and albumen, or it may be all germ.

190. In the Bean (Fig. 311) 1 is all germ. A better name for the germ is embryo. Now in all seeds, the embryo is, in fact, a miniature plant, consisting of three parts, viz., radicle, plumule, cotyledons. In this Bean, $r$ is the radicle, $p$ is the plumule, $c, c$, are the cotyledons.

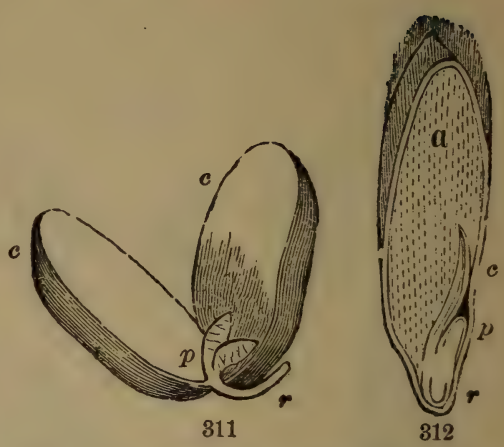

Fig. 311. Seed of Bean, without its shell : $c, c$ are the two cotyledons; $r$, the radicle; $p$, the plumule.

Fig. 312. Seed of Wheat, cut open : $a$ is the albumen; $c$, the one cotyledon; $r$, piumule; $r$, radicle.

814

315

816

317
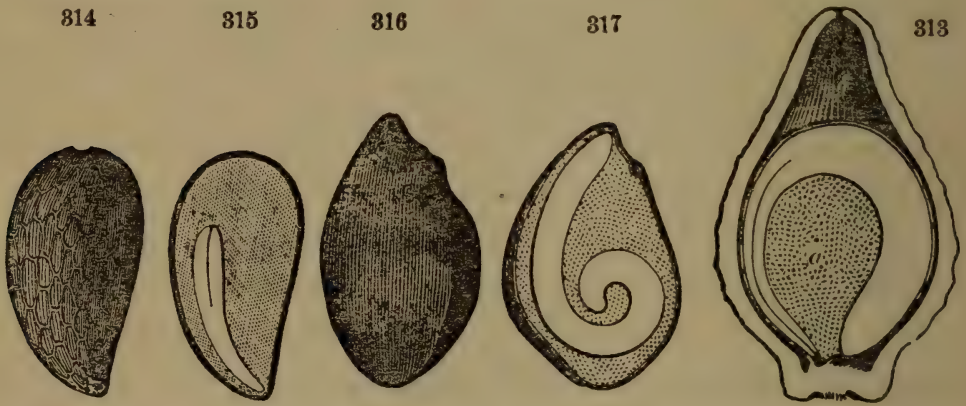

Fig. 313. Seed of Four-o'clock; embryo two-cotyledoned, coiled; $a$, albumen.

Fig. 314. Seed of Heather, Fig. 315. A section of the sane, showing the curved embryo, with two cotyledous, lying in albumen.

Fig. 316. Seed of Onion. Fig. 317. Section of the same, showing the coiled em. bryo, one cotyledon, in albumen.

191 The radicle is the part destined to grow downwards

189. (of what two parts may the seed-kernel consist?

190. Describe the parts of the seed of bean. 
and become root. The plumule is the young bud destiued to expand upwards and become stem and leaves. The cotyledons are two young leaves, thick and bulky, full of starchy matter to feed the embryo when it shall awake and begin to grow.

19.2. In the Wheat-seed (Fig. 312) we find, besides the embryo, a white, mealy mass $(a)$, well known when ground into flour. This mass is evidently intended to answer the same purpose as the starchy cotyledons of the Bean-to nourish the enibryo. The radicle $(r)$, the plumule $(p)$, the cotyledon $(c)$, and the albumen $(a)$, are clearly shown. Fig. 313 (seed of Four-o'clock) also shows albumen; here the embryo is coiled into a ring around the albumen. Thus we see that the food of the young plantlet is laid up somewhere in every seed, either in the bulky cotyledons of the embryo itself, or in the albumen outside the embryo.

193. We have, then, seeds albuminous, and seeds exalbuminous; seeds two-cotyledoned, and seeds one-cotyledoner.

\section{LESSON XXV.}

\section{THE SEED BECOMING A PLANT.}

194. $W_{E}$ have seen that the ripened seed is a miniature plant, living, but sleeping; packed and sealed up for transportation. It may continue to sleep, perhaps, for years, if

191. Describe the nature and destiny of the radicle; of the plumule; of if e cotyledons.

192. Of what does the Wheat-seed consist? What is the intention of the albumen? the position of it in Wheat? in Four-o'clock ?

193. What seeds are albuminous? exalbuminous? What seeds are two cotyledoned? one-cotyledoned? 
kept dry; but if exposed to moisture, it soon awakes and commences its wonderfui course of development.

195. In the Spring of the year the melting snows or the warm rains supply the proper moisture to the seeds which have fallen to the ground, and they may be seen everywhere swelling, bursting, and growing. The young botanist must not fail to watch their development.

196. Beneath some Oak, for example, buried in the old leaves, we find acorns in all stages of growth, showing at one view all the steps in the process of germination. Here is an acorn with its shell softened and its kernel a little swollen. We divide it lengthwise with a sharp knife, and the section (Fig. 318) shows the two thick cotyledons $(c c)$ and the radicle $(r)$.

197. In another acorn (Fig. 319) the cotyledons have absorbed yet more water, and enlarged so much as to burst the shell, and the radicle growing, has come forth, a little root, directing its course downwards.
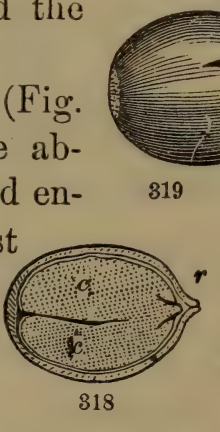

Fig. 313. Acorn, seed of the ()ak, cut open,-showing $c, c_{1}$ the cotyledons ; $r$, the radicle.

Figs $31 \%$, 320, 321. Show the progress of germination: $r$, radicle ; $p$, plumule.

194. Please tell us again what a seed is. In what condition is a secd When will it awake?

195. Condition of the seeds generally in Spring? 
198. In the next stage of growth (Fig. 320 ) the two stalks of the cotyledons ( $s$, petioles, Less. I.), make their appearance, and from between them, at the top of the rootlet, the plumule shoots forth, a little stem with a bud at the top, directing its course upwards. The rootlet, meanwhile, has grown longer, entered the soil, and divided itself into branches and fibres all covered over with fine white hairs. These hairs, called fibrils, may be seen under a microscope, as in Fig. 322 , which represents the end of a fibre of Mrple with its fibrils much magnified.

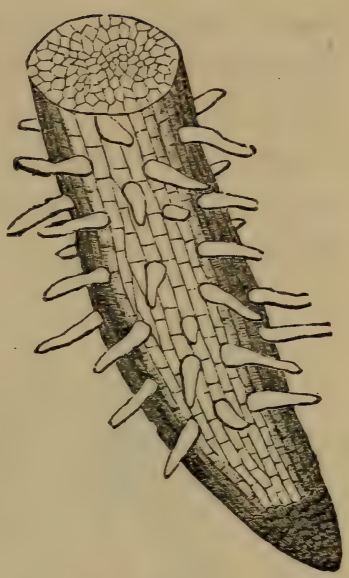

Fig. 322. The extreme end of a rootlet of Maple, greatly magnified under a lens, showing the fibrils.

199. Up to this stage, the growing rootlet and bud have drawn all their nourishment from the store of food laid up beforehand in the thick cotyledons for this rery purpose; but now the rootlet has reached the soil, and by means of its numerous fibrils, which are so many little mouths, it is beginning to draw its nourishment from the earth.

200. Another acorn, or the same one a few days later (Fig. 321), shows root and stem well organized, and the young Oak fairly started on its grand journey of growth and life. The root has descended deeper and spread its branches wider

196. What is the meaning of the word germination? Describe the sectis of an acorn in Fig. 318.

197. Describe that stage of growth seen in Fig. 319.

198. Describe the third stage, as represented in Fig. 320.

199. The first source of food for the embryo? the second?

200. How does the plant appear in Fig. 321? 
in the soil, while the bud has mounted higher, unfolding itself into stem and leaves, and spreading itself in the air and light.

201. The young plant has now become independent of the eeed, which will soon wither and perish. The cotyledons, in this case, are never able to throw off the shell, but perish

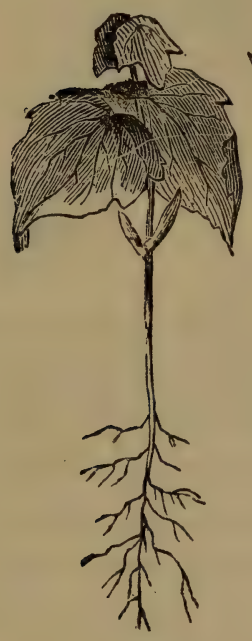

328

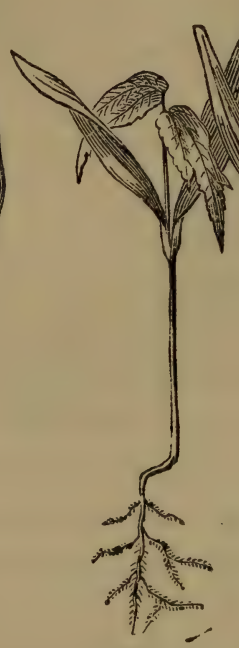

327

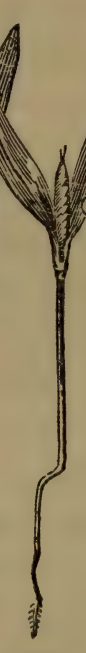

326

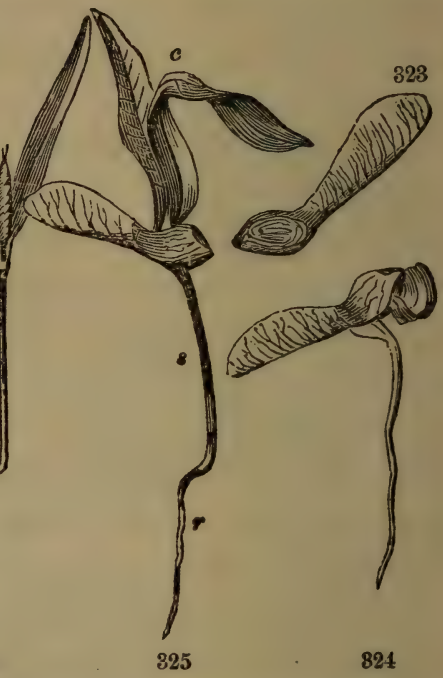

325

Progress of germination in Maple.-Fig. 323. A seed (samara). Fig. 324. Th. same, just beginning to grow; the rootlet descends, the cotyledons have burst the shell. Fig. 325. The leaf-like cotyledons $(c)$ nearly open, the stem $(s)$ and root $(\boldsymbol{r})$ lengthening. Fig. 326. The terninal bud appears. Fig. 32\%. The first pair of true leaves expanded. Fig. 328. The second pair appear, \&c.

together with it. In other plants, however, as in Maple (Fig. 325), the two cotyledons escape from the shell, change culor, and become leaves, - the first pair on the plant $(c)$.

202. The bud, which we called plumule, is still seen at the

201. When does the seed perish? Cotyledons of Oak and Maple--liow differ in development? 
top, arising higher and higher, as it unfolds its axis into the joints (called nodes and internodes) of the stem, its outer scales into leares, and is itself continually renewed from xitbin. Thus the ascending stem, or axis, is always terminated by a bud.

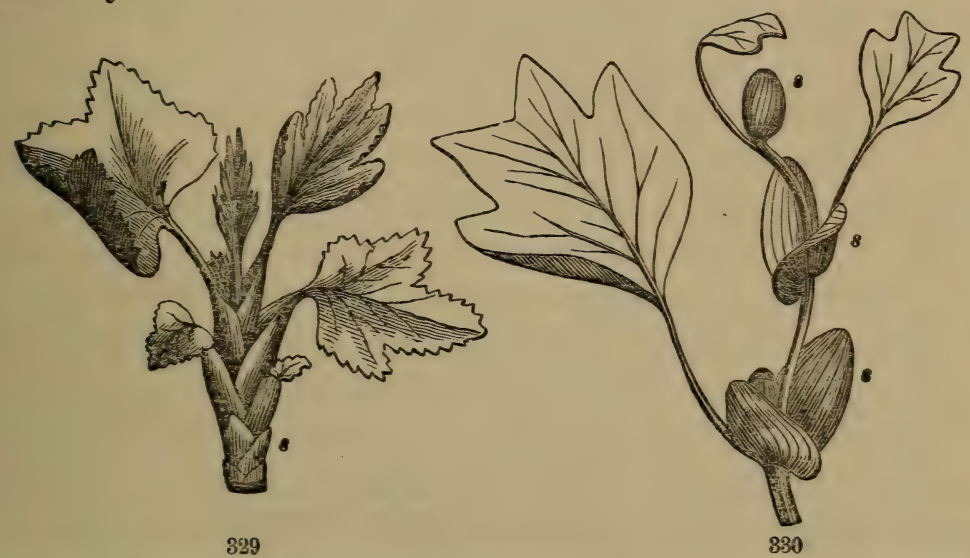

Fig, 329. Bud of Currant unfolding,-the scales $(s)$ gradually becoming leaves. Fig. 330. Bud of Tulip-tree,-the scales unfolding into stipules (s).

203. Soon other buds appear. There is one in the axil of each leaf. So long as the terminal bud only is developrd, the plant grows up a simple stem. But by the growth of these axillary buds, if they grow at all, branches are produced; and these branches, from their axillary buds, proilure branchlets, and so on.

202. What do you understand by the nodes and internodes? How is ubs ris a'ways terminated?

208. In what case will the stem be simple? How are branches pı'sucuor 


\section{LESSON XXVI.}

\section{LIFE OF THE PLANT, OR ITS BIOGRAPHY.}

204. The water which the plant imbibes by its roots be. comes sap in the stem, and circulates in every part as the blood circulates in the animal frame. The leaves, by their broad, thin forms, serve as lungs, to bring all the sap which passes through them into contact with the air and light.

205. By this means the sap is changed into a nourishing food, fitted to sustain the growth of the plant in every part. Thus the leaves are designed, not only as an ornamental robe, but as organs of breathing and digestion.

206. In the second stage of growth, when the plant depends no longer upon the seed for nourishment, it goes on increasing in stature and multiplying its leaves and branches. It now consists of three parts, namely, root, stem, and leaves. These are called the organs of vegetation.

207. The third stage of plant-life is the period of flowering. Before this period, all its activity was devoted to its own nourishment and growth. Now it begins to live and act for the continuance of its own kind after it upon the earth, according to the Divine decree in Genesis, i., 11. Some of its buds undergo a striking change, and open each a flower instead of a leafy branch.

208. A flower is therefore a leafy branch transformed (as

204. What becomes of the water which the roots imbibe? What part de ihe leaves act?

205. What change takes place in the sap?

205. What is the second stage of plant-life?

207. The third stage? Whence come the flowers? 
shown in the Class Book, p. 23), having its axis undevel ped, its leaves in crowded circles, moulded into more delicate forms and tinged with brighter colors, not only to adorn the face of nature, but to prepare the way for fruit.

209. The fourth stage of plant-life is the period of its fruit bearing. The flowers have gradually faded and disappeared, but the pistil, having received the quickening pollen (see Class Book of Botany, p. 148), remains in its place, holds fast alı the nourishing matter which continues to flow into it through the flower-stem, grows, and finally ripens into the perfected fruit and seed.

210. The fifth and last stage in the biography of the plant is its hibernation (winter's sleep), or its death. If the event of flowering and fruit-bearing occur within the first or second year of the life of the plant, it is generally followed by its speedy death. In all other cases it is followed by a state of needful repose, wherein it is commonly stripped of its leaves, and gives few, if any, indications of life, until awaked, with renewed vigor, in the following Spring.

211. Accordıng to their different terms of life, we distinguish plants as annuals, biennials, and perennials. An annual herb completes its whole history in one year. In the Spring it gerrinates; in Summer it grows, blooms, bears fruit; and in Autumn its work and life are ended. The Mustard, Maize, and Morning-glory are such.

212. A biennial herb lives two years. During the first it

208. Please state the nature of the flowe:

209. Please describe the fourth stage of plant-life.

210. The fifth stage.

211. In regard to their term of life, how are plants divided. Describe an annual herb.

212. A biennial herb. 
germinates, grows, and bears leaves only; and in its second year it blossoms, bears fruit, and dies. Such are the Beet and Radish.

213. A perennial plant survives several or many years. There are herbaceous perennials and woody perennials. Tho herbaceous perennials, or perennial herbs, are such as survive the winter only by their roots or their parts which grow underground. These in Spring send up leaves, flowers, and and often stems, all of which perish in Autumn, leaving only the parts underground alive as before. Such are the Hop, Assers, Violets.

214. Woody perennials survire the winter by their stems as well as roots, and usually grow several years before flowering, and thence flower annually during their existence. According to their size, such plants are trees, shrubs, undershrubs. A tree is the largest among plants, having a permanent, woody stem, usually unbranched below, and dividing into branches above. The Oaks, Elms, and Pines are famil iar examples.

215. A shrub is smaller than a tree, usually growing in clusters from one underground mass of roots. The Lilacs, Roses, Alders, are shrubs. Small shrubs, about of our own stature, as the Currants, Brambles, we call bushes. Very low shrubs, as the Blueberries, Box, \&c., are undershrubs.

213. Describe a perennial plant. Of what two sorts? Describe a peren sial herb.

215. A tree, a shrub, bush, undershrub,-how distinguished? To which of the above-mentioned sorts does the Cabbage belong? To wlich the Hol. Iyhock? the Balsamine? Four-o'clock? To which the Tulip? Golden rod? Lily? Pink? Quince? \&c. 


\section{LESSON XXVII.}

CONCERNING THE AXIS OF THE PLANT.

216. The term axis expresses the central eolumn or body of the plant around which the branches and other organs are arranged. As we have already noticed, the axis grows and extends in two directions, - upwards and downwards. The ascending part is the stem, the descending part is the root. The former loves and seeks the air and light, the latter the dark, damp bosom of the earth.

217. The Root serves the twofold purpose of fixing the plant firmly in its place, and of imbibing the necessary food from the soil. The food when thus imbibed is nerer in a solid

Fig. 831. An entire plant (Shepherd's-parse), showing the axis ( $a$ to $r$ ). The part from $c$ to $r$ is the descending axis, or root; from $c$ to $a$ the ascending axis, or stem; $b, b$, branskes, bearing racemes of flower sud fruit.

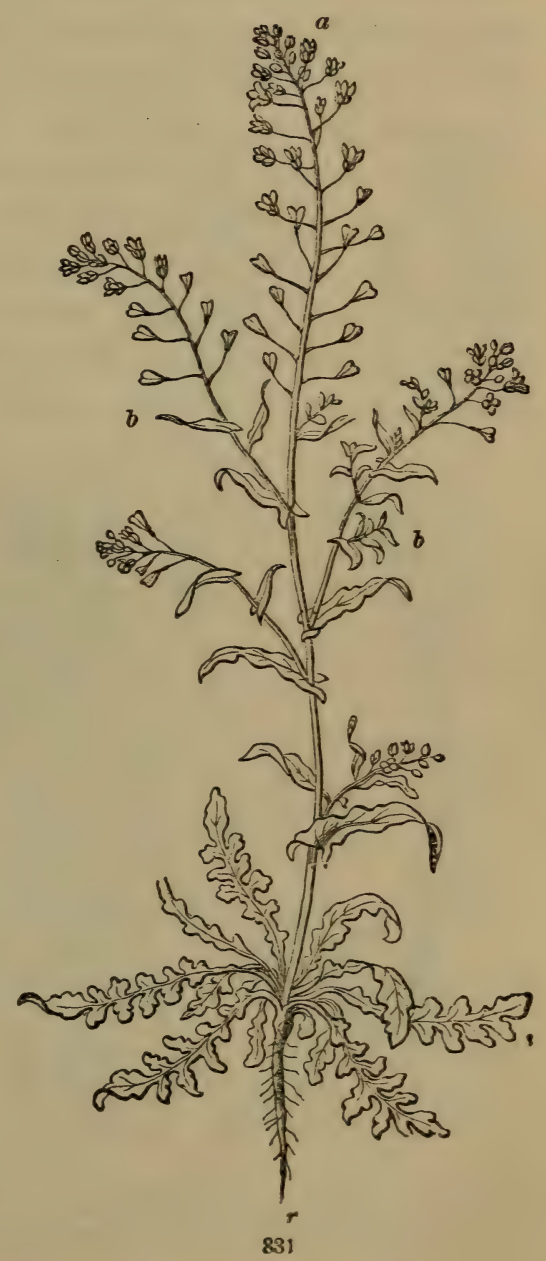


state, but dissolved in water, and consists of certain earths, alkalies, and gases. (See Part II., Chap. 7, Class Book of Botany.)

218. It is the nature of the root to divide itself into branches, and the only organs which properly belong to it are branches, fibres, and fibrils. It puts forth no buds nor leaves unless the plant be in some unnatural state.

219. The roots of woody plants, especially, are branching roots. Year after year they multiply and extend in branches and branchlets beneath the

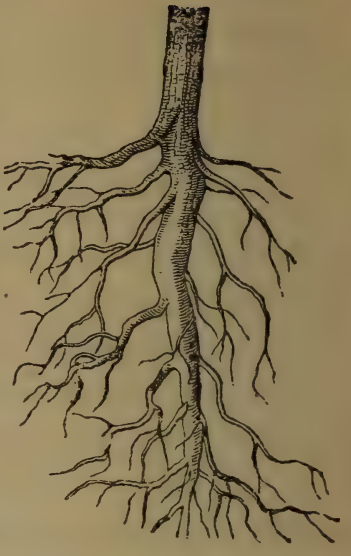

Fig. 332 Branching root of a young tree.

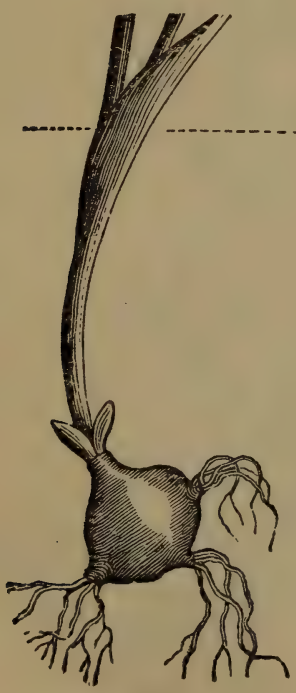

333

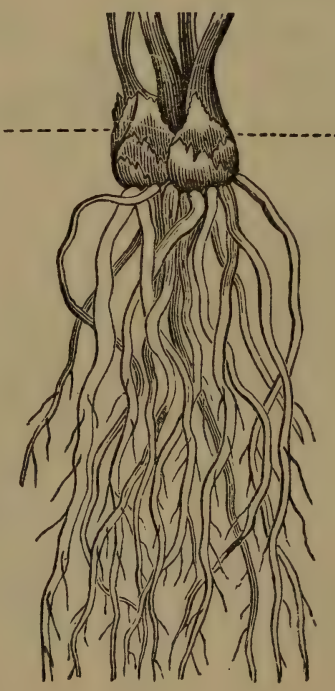

334

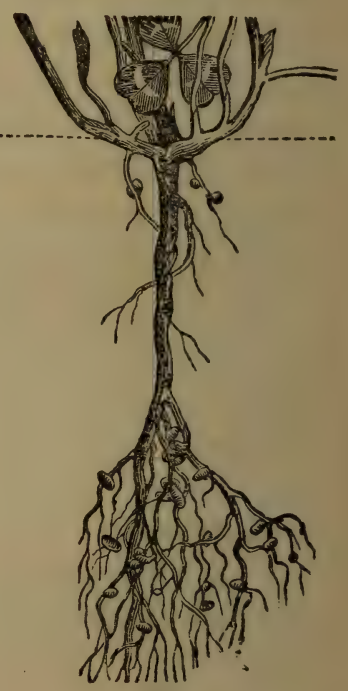

335

Hig. 333. A tuberous root (Erigenia). Fig. 334. Fibrous roots (Buttereurs).

Fig. 335. Branehing root (W nite Clover), with tuberc es. 
ground, in pruportion to the growth of the branches and twigs of the stem above. The axis itself may not descend to any great depth, and after a few years may be found far exceeded in growth by its own branches which extend horizontally in a better soil. The greater the growth of the roots the more firm will be its hold upon the ground, and the greater its capacity fo: drinking in liquid nourishment for the tree.

220. The roots of herbaceous plants take a great variety of forms. Some are tuberous, some fibrous. The tuberous are such as consist of a large axis or body, witn small branches; as in the Beet, Ground-nut, Spring Beauty, and many other biennial plants.

221. The fibrous are such as consist mostly of fibres, with scarcely any axis ; as in Buttercups, Grasses. In such cases the axis ceased to grow immediately after germination, and long thread-like branches supplied its place.

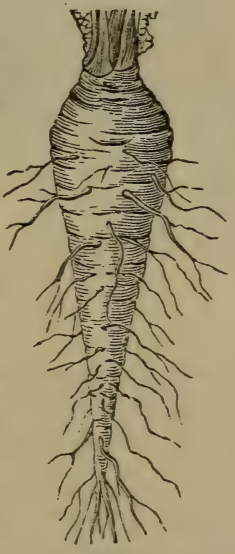

386

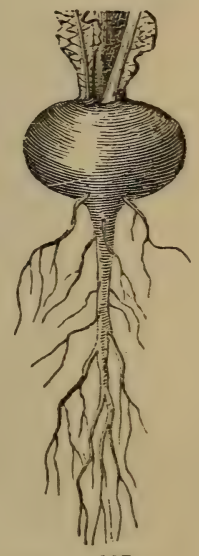

837

Fig. 336. 'I'uberous and fusiform root of Beet.

222. The fibro-tuberous roots Fig. 337. Puberous and napiform are such as have some of their fibres thickened and fleshy, as seen in the Peony, Dahlia,

216. Please explain the meaning of the term axis. In what two directions does it grow?

217. What is the twofold purpose of the root? What does it imbibe? In what state is this food when imbiber?

218. What is said of the nature of the root? What are its only proper organs? What is said of leaves or buds?

219. Describe the roots of woody plants, and their growth.

220-222. Describe tuberous roots; fibrous ; fibro-tuberous ; tubercular. 
Spiræa. If little tubers here and there are attached to the fibres, the root is tubercular, as in Squirrel-corn.
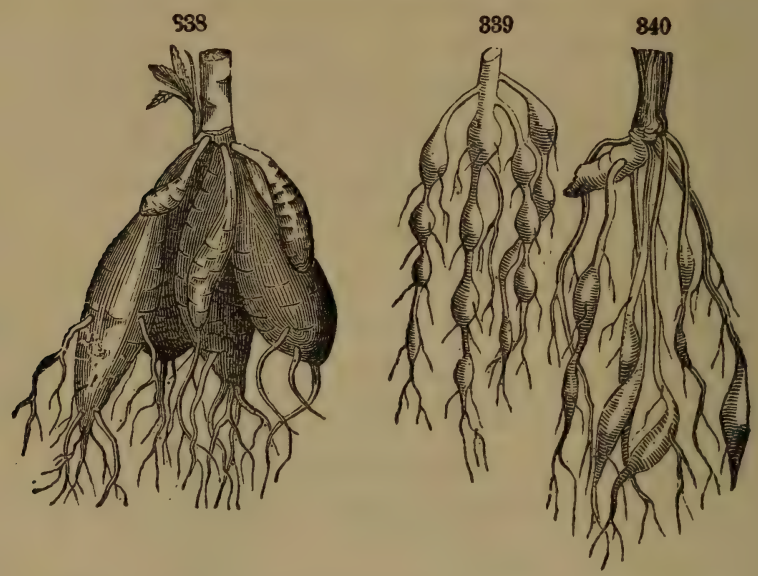

Fig. 338. Fibro-tuberous root of Peony.

Fig. 339. Fibro-tuberous root of Spiræa filipundula.

Fig. 340. Fibro-tuberous root ef Mourning Geranium.

223. All these fleshy forms, whether tuberous or fibro-tuberous, are filled with starch, deposited there in store, for use in the future growth of the plant. Many other forms of roots are described in larger works.

\section{LESSON XXVIII.}

OF THE STEM OR ASCENDING AXIS.

224. The stem tending upward in its growth is often called the ascending axis. It does not in all cases continue to arise

223. What purpose do fleshy roots serve?

LEss. XXVIII. What is the subject of this lesson? 


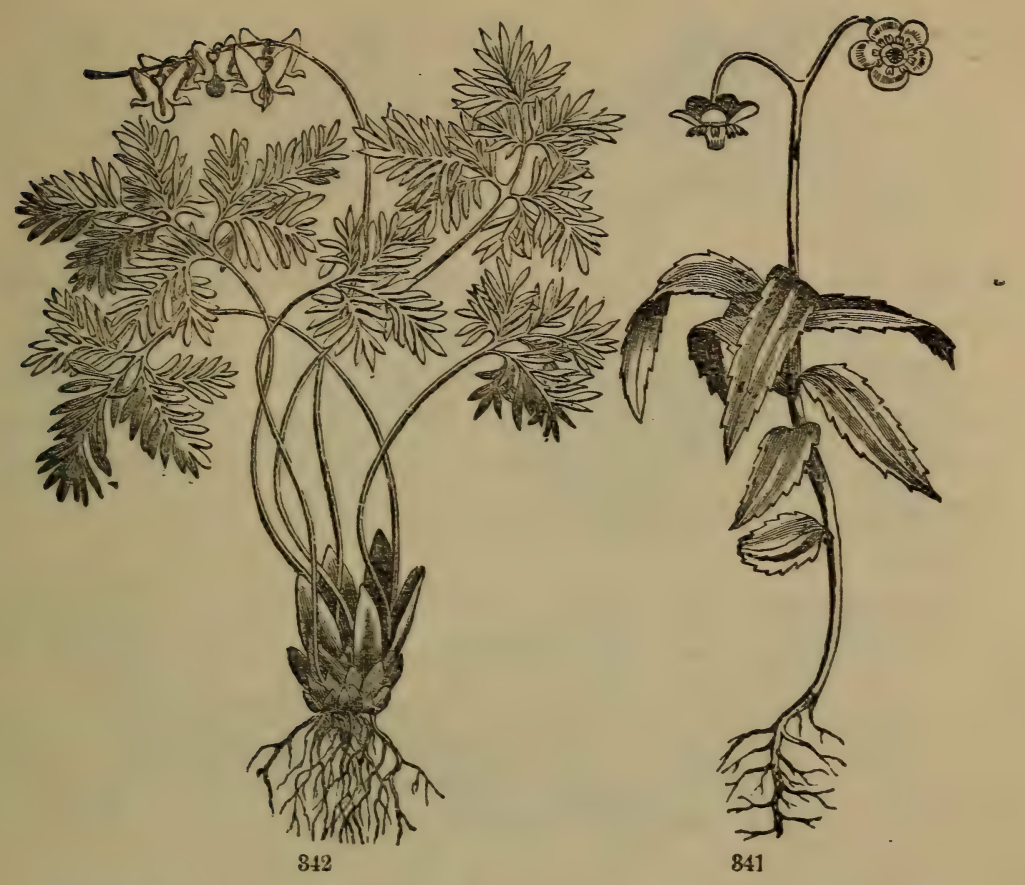

Fig. 341. Spotted Prince's Pine, entire plant: the stem is a "leaf-stem."

Fig. 342. Diclytra (D. cucullaria), whole plant; it has a "scale-stem."

in growing, but often becomes oblique or horizontal. Therefore we have, besides erect stems, stems prostrate, procumbent, trailing, when running along flat on the ground, or over bushes, as the Partridge-berry, White Wintergreen (Fig. 343); and, also, stems decumbent, first arising and afterwards ro clining on the ground, as the Poor-man's-weatlier-glass (Fig. 344).

225. There are, also, subterranean stems, never arising

224. What of the direction of the growth of stems? How does the stem of White IVintergreen grow ? How the stem of Anggallis ? 


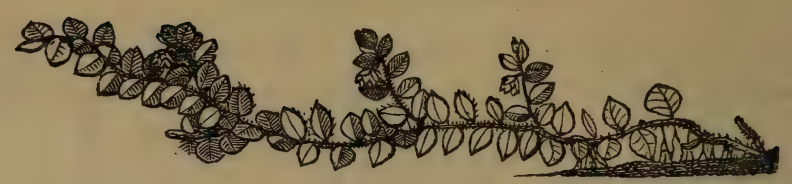

Fig. 343. Tne White Wintergreen (Chiogenes); it has a procumbent stem

above the ground at all, but only sending up leaves and flowers with their stalks, as the Tulip.

226. It is the nature of the stem to produce buds, as it is of the root to produce none. At first the stem is itself a bud, and as it grows it bears this bud always at the summit and produces a new bud in the axil of every new leaf.

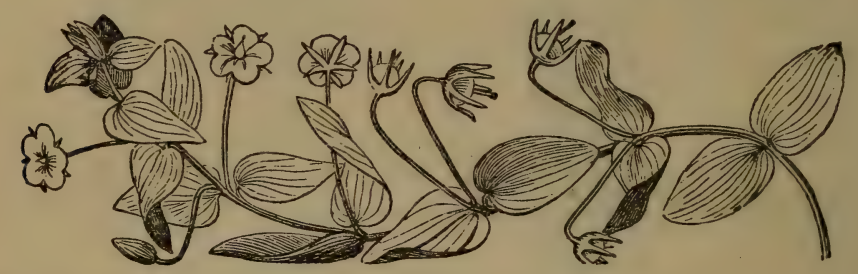

Fiy. 344. Poor-man's-weather-glass (Anagallis); it has a decumbent stem.

227. The stem has nodes and internodes. The joints where the leaves severally come out are the nodes, and the portion of stem between, the internodes. In the bud the internodes are quite undeveloped, and the nodes close together; but as it develops into a regular leaf-stem, the internodes grow, and the nodes with their respective leaves are separated.

228. But in some plants, the nodes only are developed, and the axis never extends itself above ground, and covers itself

225. What of the stem of Tulip?

226. What the nature of the stem with respect to buds?

227. Please tell us what are nodes and internodes. 

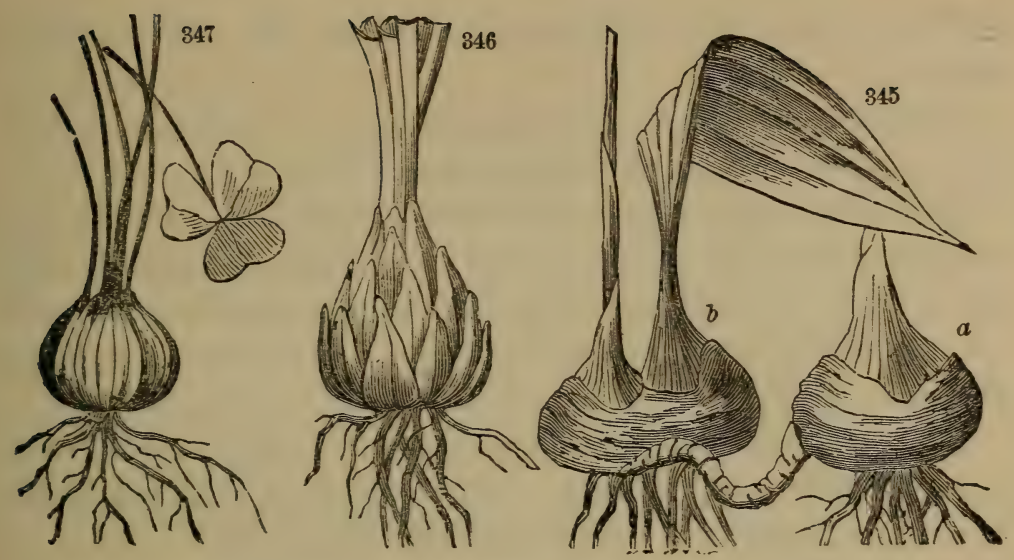

Fig. 345. Corms of Putty-root (Aplectrum): $a$, of last year; $b$, of the present year. Fig. 346. Scale bulb of White Lily.

Fig. 347. Scale bulb of Violet Sorrel (Oxalis violacea).

with scales instead of leaves. Thus we have two classes of stems; namely, leaf-stems and scale-stems. These tigures, one of the delicate Diclytra and the other (Fig. 341) of the

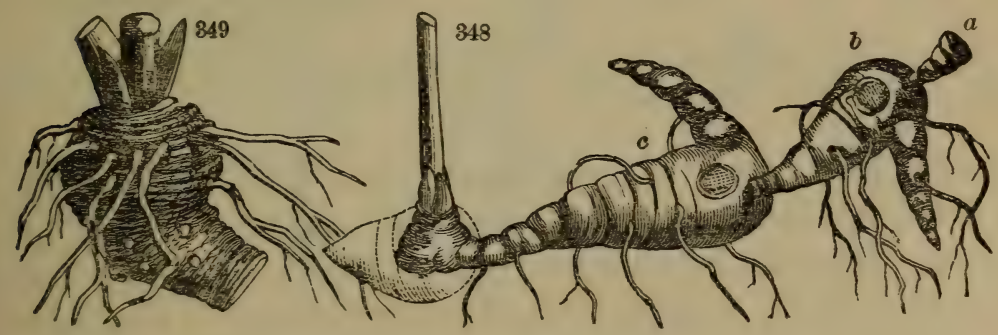

Fig. 348. Rhizome of Solomon's Seal : $a$, fragment of the first year's growth; $b$, the secsud year's growth; $c$, the third year's growth, bearing $d$, the stem of the present year, which will leave a scar (the seal), like that of the others.

Fig. 349. Premorse rhizome of Trillium.

228. What two classes of stems.have we to consider? What is tl e differnce between them? To which class does Diclytra belong? Prince's Pine? 
Prince's Pine, make a fine contrast of the two kinds of stems.

229. Severai varieties of scale-stems must be distinguished: hs, bulb, corm, rhizome, creeper, tuber, \&c.

230 The Tulip, Hyacinth, Onion, Lily, lhave bulbs; you see (Figs. 346, 347), they consist of roundish masses of thick scales with a small axis-in fact, an overgrown bud. The corm is like it in shape, but has a thick axis with thin scales or none. (Fig. 345.)

231. The rhizome, or root-stock, is a fleshy, underground stem, often scaly and marked with scars, as you see in the Bloodroot, Solomon's Seal (Figs. 348, 349).

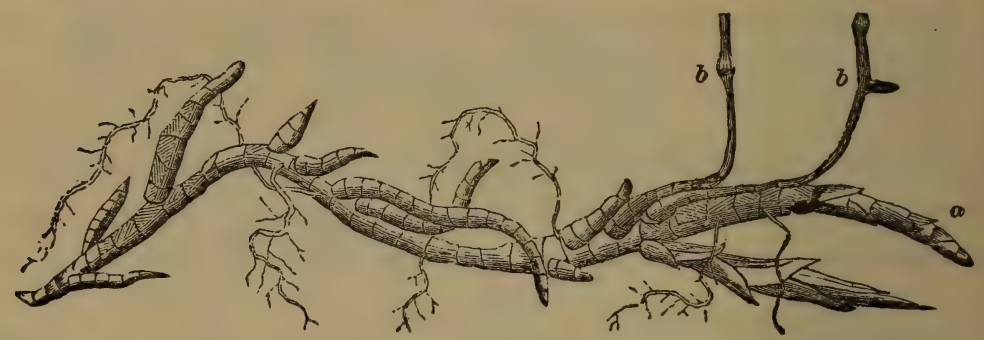

Fig. 350. Creeper of "Nimble Will," or Witch-grass : $a$, bud ; $b, b$, bases of the stems which rise above-ground.

232. The creeper is more slender, much branched, manyjointed and many-scaled, as seen in this figure of the Witchgrass. It sends out rootlets from its joints, and is very tenacious of life, binding the soil into turf wherever it abounds.

233. The tuber, such as grows on the underground steme of the Potato-plant, is evidently a stem (not a root), for it al. ways produces buds.

229. Name five sorts of Ecale-stems.

230. Describe the bulb, the corm. 231. The rhizome.

232. The creeper. 233. The tuber. 
234. Of the leaf-stem class we must describe three kinds, the trunk, caulis, and vine. Trunk is the name given to the stems of woody, erect plants, especially of trees. They are the representatives of loftiness and strength, in poetic phrase, lifting their summits to the skies and doing battle with the storm. There are, indeed, few objects in nature possessed of a truer grandeur than the White Pine's trunks of the North ern forests.

235 Caulis, is the general name given by botanists to the
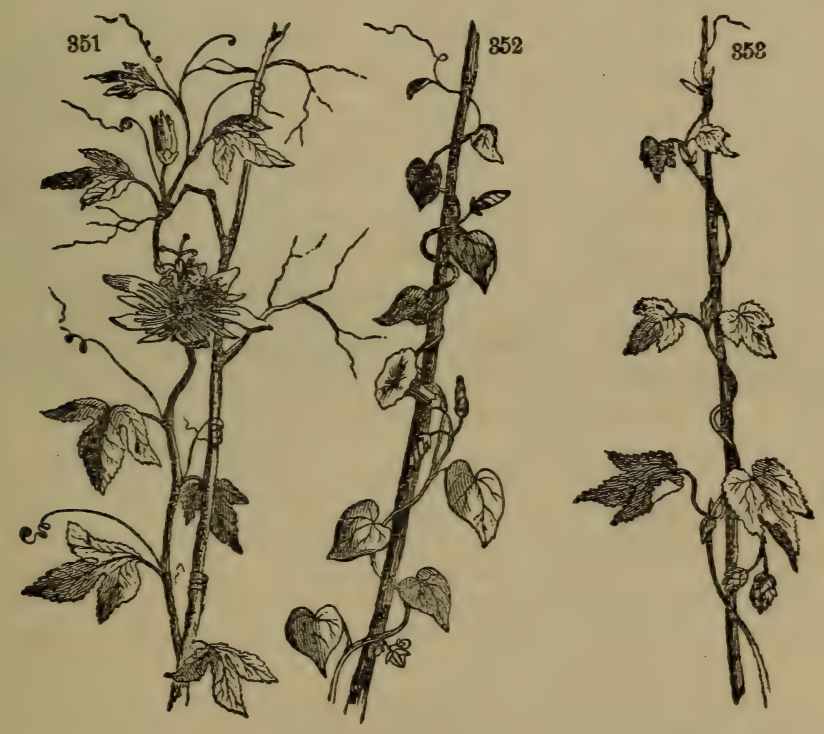

Vines. Fig. 851. Passion-flower (Passiflora lutea), climbing by tendrils. Fig 852. Morning-glory, twining from left to right. Fig. 353. Hop, twining from righ to left.

234. Name, next, three kinds of leaf-stems. Describe the trunk. 235. The caulis. Meaning and use of caulescent? acaulescent? Give ex smples of each. 
stems of herbs. From this word come two adjectives much used and quite convenient, viz., caulescent and acaulescent; the former denoting the presence of stems above-ground, the latter of only underground stems. Thus the Buttercup is caulescent, while the Pitcher-plant is acaulescent; the Garden Violet or Pansy is caulescent, while the wild Blue Violet is acaulescent.

236. Vine, as every one knows, denotes a slender stem, too weak to stand alone, and supporting itself by the aid of other plants or objects. Some vines are woody, some herbaceous, The Hop twines itself around its supporter, turning from right to left, as in Fig. 353. The Morning-glory, also, but it turns from left to right (Fig. 352). Thirdly, the Grape and Passion-flower (Fig. 35̃1) climb by special organs, the tendrits, of wonderful adaptation, showing their Maker's design more truly than if by an audible voice.

236. Describe the vine. What their three varieties? What is the read mirable in the tendril ? 


\section{LES O O XXIX.}

\section{PLANTS TO BE ARRANGED IN CLASSES.}

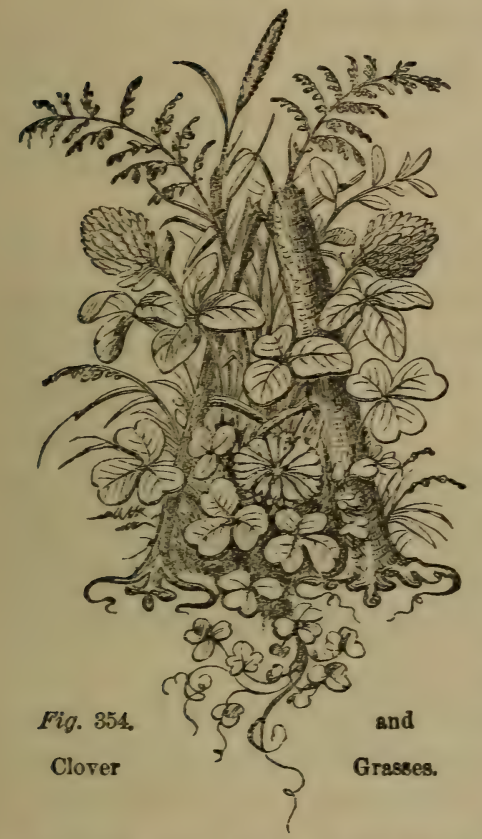

PLANT may be studied by itself, as an individual, separate from other plants or objects: or it may be considered in its relations to other plants, as constituting a part of a system. In this latter view we discover one vast design embracing the inurmerable millions of plants as one kingdom, leading us to adore the wisdom and goodness of him who planned and created the world. For we see that he has not only made each plant with so much loreliness and perfection in itself, but has assigned to each its proper rank in the system, and endowed it with just that nature, habit, and style of beauty, which adapts it to that rank.

238. To study plants as constituting a system, as we now jropose to do, is nseful in two ways: first, it gives us a larger and truer conception of the Vegetable Kingdom; and

237. What two modes of studying the plant are mentioned? In the ser ond mode what discovery is made?

238. In the systematic study of plants what two other advantages? 
secondly, it teaches us how to recognize by name the plante with which we meet, so as to avail ourselves of all that has been recorded concerning the same by botanists before us.

239. Sappose the pupil, in his study, has dropped a single Flax-seed on a lock of cotton floating in water in a bulb. zlass. It grows, filling the clear water with its silvery radisles, while its stem shoots upwards covered with leaves and finally blooming with flowers. This is an individual plant. He studies its organs, colors, portrait, and carefully writes its history.

240. Meanwhile, other Flax-seeds, by thousands, have been sown in the fields, and from each, also, a plant has arisen. The student finds them in flower, tinging all the plain in ocean blue. Now, shall he, as a botanist, repeat his study over each of all these millions? Certainly not. He finds himself already acquainted with them, for each bears an exact resemblance to that which he has already described. His knowledge of one individual Flax-plant, therefore, avails him fur each and all the myriads of Flax-plants growing everywhere.

241. In this manner we obtain the idea of a Species. Thus, a species of plants consists of many individuals of the same kind, having descended from a common stock, and resem. bling each other and their common parent in every feature.

242. The common Blue Flax, of whick linen is made, is $a$ species; the wild Yellow Flax is another; and the Purple Flax of the gardens is another. The White Clover is a spe-

239. Can you give us an idea of an individual plant?

240. Having studied one individual Flax-plant, why do we not need to study the others?

241. Please state your idea of a species.

242. Please illustrate your idea of a species. 
cles with its progeny of millions of plants; the Red Cluver is another; the Yellow Clover another; the Buffalo Clover another. In like manner all the plants of the globe are grouped into species, and this is the first step in classification.

243. The second step carries us to the genus, which we may thus define: A GENus is an assemblage of species which are much alike; especially in their flowers and fruit. Thus, F LAX is a genus made up of the sereral species mentioned above, and other similar species. Clover is a genus composed of 150 species, some of which we have just mentioned. Every one notices the resemblance between White Clover, Red Clover, \&c. Prne is a genus, embracing as species White Pine, Yellow Pine, Pitch Pine, Long leaved Pine, and many others.

244. Individuals of the same species may differ somewhat among themselves, and these differences constitute varieties. Thus Apple-trees differ in their fruit, and there are hundreds of varieties although only one species. Roses differ in their form, color, and fragrance of their flowers, forming many varieties under each species. Probably no two plants of any species were ever exactly alike. Sameness, or monotony, is not a characteristic of Nature.

\section{LESSON XXX.}

THE NATURAL SYSTEM.

245. In attempting to classify and arrange the genera or plants, according to their natural resemblances and differ.

243. Can you now define a genus ? Please illustrate your idea of a genus

244. What is a variety? Illustrate your meaning. 
ences, botanists have formed a system called the Natural Sys. tem. Let us now briefly notice this system of classification. 246 . We have already stated that the plants of the globe are all created in species, and that this is the first step in classification. Then, in the second place, the species are grouped into genera. Now the number of species of plants already known is about 100,000, and the genera 20,000.

247. The third step in our system earries us forward to the Natural Or: krs. These are made up of genera. As we associate similar species to form a genus, so we associate similar genera to form the natural orders. The number of orders described in the Natural System is about three hun. dred. For example, the natural order Crucifiræ, or the Crucifers, embraces such genera as Mustard, Cress, Cabbage, Turnip, Radish, Wall-flower, which every one sees to bear resemblance to each other in many respects.

248. How then shall we define a natural order? It is a group of similar genera; or, a group of genera closely related to each other. Therefore, individuals form species; species form genera; genera form orders. But how shall we classify these three hundred orders?

249. Suppose we take an excursion into the mountains. We walk beneath the forest trees, and among the shrubs. We tread upon the lesser herbs, the matted grasses, and the mosses and lichens which cover the rocks. Everywhere we see plants, and behold the domain of the vegetable kingdom.

245. What is the subject of this Lesson $\mathrm{XXX}$. ?

246,247 . What is the first step in classification? the second ? the third? What number of species known in all the vegetable world? What number of genera? of orders? (Ans. 303.)

248. Define a natural order. Please review these three steps

249. Show how we may divide the vegetable kingdom. 
Now viewing this as one grand whole, we want to divide it into two subkingdoms. How shall we do it?

250. Every attentive observer has noticed that some of these plants produce no flowers; as, e. g., the Ferns and Mosses. Let us then take all such plants and consider them as forming one sub-kingdom, viz., the Flowerless Plants All other plants will of course constitute the other sub.king dom, viz., the Flowering Plants. Botanists call the latter the Phænogamia, and the former, the Cryptogamia (Greek words of the same import).

251. Now these two sub-kingdoms have other

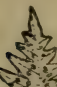
distinctions besides flowering and not-flowering. See the fruit-dots growing on the back of Fern leaves. The microscope shows them to be clusters .

yellow dust. But this dust is not seeds, with

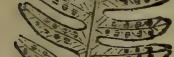
embryo, radicle, \&c. (Less. 2t), but little sacs,

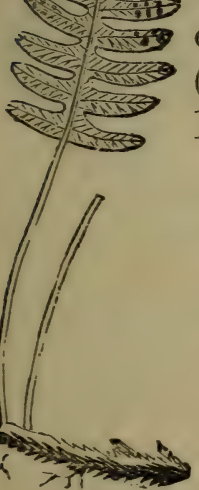

355 containing a fluid, similar to the pollen grains (Less. 15). We call them Sporks. See, also, the Mushrooms haring no leares, and the Lichens
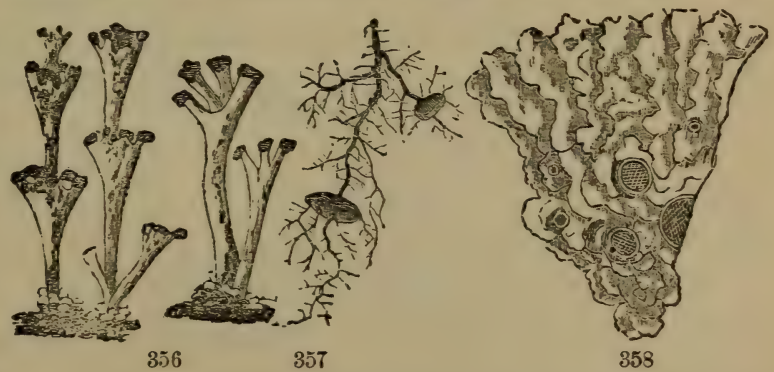

Some of the Cryptogams. - Fig. 355. A Fern, showing the fruit dots. Figs. 356, 357 858, are Lichens, some appearing to have stems, and some with no appearance of any

250. Please distinguish the two subkingdoms. The meaning of Crypto gamia? Phænogamia?

251. What about the Spores of Ferns, \&c. i 
often, also, without stems. Hence we may say of the Cryptogams that they are not only flowerless, but seedless, and often leafless and stemless.

252. We will now dismiss the Cryptogams for the present and consider the Flowering Plants (Phænogams), as one sub kingdom;-how shall this be divided? Every one notices a striking difference between plants with parallel-veined leaves and those with net-veined leaves. The former have their flowers three-parted, while the latter have their flowers two, four, or five-parted, \&c.,-the former have seeds one-lobed (monocotyledoned, Less. 15), the latter, two-lobed (dicotyledoned, Less. 15). Let us, then, divide the Phænogania into two provinces; as Nature has already done.
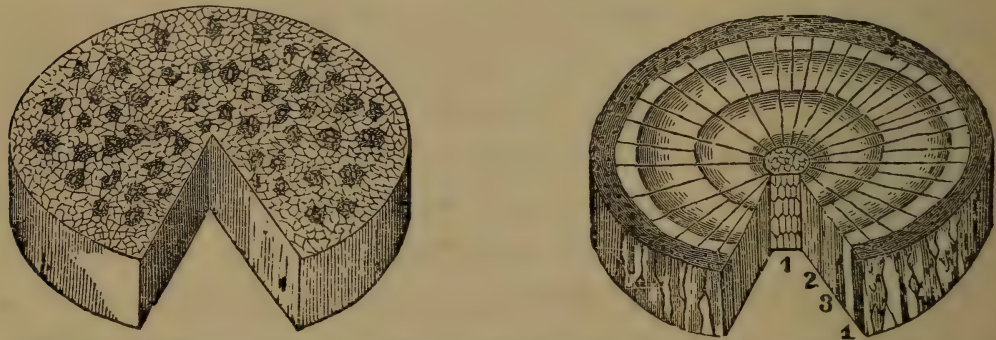

Fig. 359. Cross-section of an exogenous stem (Elm), of two years growth: 1 , the pith; 2, 3, two layers of wood; 4, the bark. Fig. 360. Cross-section of an endogenous stem (Corn), showing no distinction of layers.

253. We may call these two provinces severally, the ExoGeNs and the ENDOGENs:-two Greek words denoting ontside growers, inside-growers, referring to their modes of growth.

254. Now, taking such an Exogen as the Apple-tree, and such an Endogen as the Indian Corn, we may distinguish them thus: 'The Exogen has its wood, if any, arranged in concentric rings, or layers, as seen in Fig. 360 ;-the outer ring

252. Show how the Flowering Plants are divided. 253. Please gire the character of an Exogen; an Fndogen. Mr aning of these two words ? 
being the youngest; the leares net-veined; the flowers sel dom (or never completely) three-parted; and the seeds two lobed. On the contrary:

255. The Endogen has its wood, if any, confused, the inner portions being the newest;-its leaves parallel-veined;--its tlowers three-parted; and its sceds ore-lobed.

\section{LESSON XXXI.}

\section{MORE ABOUT THE NATURAL SYSTEM.}

256. Thus Exogens and Endogens are so clearly defined that you may know them as far off as you can see them. The next step in the analysis is, to subdivide each of these provinces. First, as to the Exogens: We know that they generally have pistils in their flowers, with the young seeds (ovules) inclosed in their ovaries. But there are exceptions to this rule. The Pines, Yews, \&c., have no pistils at all, or, at least, no stigmas, and produce naked seeds, not inclosed in seed-vessels. Hence, we have two classes of Exogens: the naked-seeded and the ressel-see!'ad. The botanists call the latter the Angrosperus (Greek, angios, a ressel; sperma, seed); and the former, the Grmnosperms (Greek, gymnos, naked).

257. Secondly, the Endogens: here consider the peculiar forms and flowers of the Grasses. Their flowers are all enveloped in green, alternate scales, called glumes, instead of

254 Is the Lily an Exogen or Endogen? The Buttercup? The Maple, \&c.? 256. What is the next step in the analysis? State the manner of subdi. villing the Exogens. What is the meaning and etymolngy of the word "Angiosperms?" What of Gymnosperms? Give an example of each. 257. Show the subdivision of the Endogens. What of the Petalifere ? What of the Glumifere? 
the circles of petals common in other flowers. Hence we have a class of Glume-plants and of Glumeless-plants, or, as the botanists say, Glumifere and Phtalifere. Thus we divide all the Flowering Plants into four Classes, viz.:

1. Angiosperms; Exogens bearing stigmas and seed-vessels.

2. Gymnosperms; Exogens with no stigmas, and with naked reeds, as the Pines, Firs, Larches, Cedars, Cypresses, Yews, \&c.

3. Petaliferce; Endogens with no glumes and ordinary flowers.

4. Glumiferce; Endogens with glumes instead of petals, as the Grasses, Sedges, Grains.

258. Agrain, each of these Classes are to be subdivided into Cohorts, as follows: the Angiosperms are divided (not very naturally) into three cohorts, viz. :

1. The Dialypetalce, or Polypetalous Exogens, having flowers with the petals distinct and separate, as in the Buttercup, Rose, Mustard.

2. The Gamopetaloe, having flowers with the petals united into one piece, as in the Phlox, Morning-glory, Foxglove.

3. The Apetalce, having flowers withont petals, either naked, or with only one circle of thoral envelopes (which must then be considered as speals, whatever be the color); as (iinger-root (Asarum), Poke (Phytolacca), and Pig-weed (Chenopodium).

4. Next, the Gymnosperms are regarded as forming one cohort, called the Conoids, having the fruit usually in conce. (Less. XXIII.)

258. After the classes what is the next step in analysis? How are tle Angiosperms subdivided? Please define the Polypetalous Exogens; the Gamopetalous; the Apetalous. What cohort do the Gymnosperms form? Why? What two cohorts do the Petaliferous Endogens form? Define the fifth cohort. Define the sixth cohort. What cohort do the Glumiferous Eudngens constitnte? 
The Endogenous Petaliferæ are divided into two cohorts, viz.:

5. The Spadiciflora, having the flowers on a spadix, as in the Egyptian Calla and Jack-in-the-pulpit.

6. The Floridice, having the flowers separate, not on'a spadix, as in Tulip, Gladiolus.

7. The Class Glumiferæ constitutes the seventh cohort, under the name Gruminoids, i. e., the Grass-like plants.

Six other cohorts are formed from the flowerless plants, but we cannot notice them in this work.

259. Lastly, the cohorts are themselves divided into, or composed of, the Natural Orders, which we defined in Lesson $\mathrm{XXX}$.

260. Table I. Tabular View of the Natural System. Kinqaom. Sub-kinqdoms Provinces. Classes. Cuhorts.

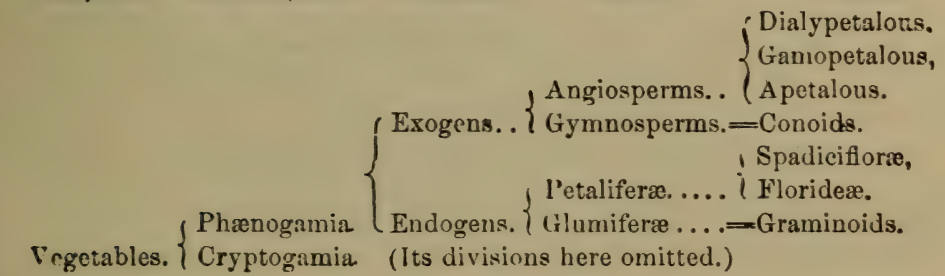

\section{Table II. View of the Natural Srstem.}

1. Flowering Plants. (Next pass to No. 2.1

1. F'owerless Plants. (Pass to No. 9.)

2. Leaves net-veined. Flowers never quite 3-parted....8.

2. Leaves parallel-veined. Flowers 3-parted....4.

3. Stigmas present. Seeds in seed-ressels....5.

3. Stigmas none, seeds naked. Pines. Spruces, \&c.. .6. Gymnosperma
4. Flowers without glumes, naving petals, \&c...7.
4. Flowers witn green, alternate glumes, no petals . . \& Petaliferæ Flumiferæ

PILENOGAMIA. CRY PTUGAMIA EXOGENS. ENDOGENS. Angiosperms

259. Finally, into what are the cohorts themseires divided? Give us e:imples of each of all these cohorts."

260 Explain the nse of Table I 261 of Table II 
5. Petals distinct and separate.

Polytetale

5. Petals united more or less.

Gamophtale.

5. Petals none.

ApkTAL.

6 The cone-bearing plants. Cedars, Larches.

7. Inflorescence a spadix.

Conoros

7. Inflorescence not a spadix.

8. Grass-like plants.

SPADICIFLOR.R

FLoRIDE

GRAMINoIDs.

9. Sucn as Ferns, Mosses, Lichens, Sea-weeds, Mushrooms all onitted in this book. (See Class-Book, Chapter XIV.

262. Table III. A Nother View of the Natural Sistey

VEGETABLE KINGDOM, divided into two sub-kingdoms, viz.:

Sub-kingdom First, PII ENOGAMIA, the Flowering Plants, including

Province 1., the EXOGENS, or Dicotyledons, including two classes

Class 1, the Angiosperms, having three Cohorts, viz.:

Cohort A, Polypetalous Exogens (as Roseworts, \&c.):

Cohort B, Gamopetaloes Exogens (Phloxworts, \&c. !; and

Cohort $C$, Apetalots Exogens (Pokeworts, \&c.).

Class 2, the Gymnosperms, with one Cohort, viz. :

Cohort D, Conorns, or cone-bearing plants (Pineworts, \&c.).

Province 11., the ENDOGENS, or Monncotyledons, two Classes. vir.

Class 3, the Petaliferous Endogens, having two C'ohorts;

Cohort E, Spadiciflore (the Aroids, \&c.);

Cohort $F$, Flonide E (Lilyworts, \&c.).

Class 4, the Glumiferous Endogens, one Cohort, viz.:

Cohort $G$, Graminords (Grasses, Sedges, \&c.).

Sub-kingdom Second, CRY P'TUGAMIA the Flowerless Plants

Province III. \&c, \&c

\section{LESSON XXXII.}

\section{OF THE ANALYSIS OF PLANTS.}

263. To study any subject by the separate examination of the parts of which it is composed, is a process called analysis. For example, in Grammar, we analyze a sentence when wo point out and separately consider the subject, predicate,

962. Of Table III. 203. What is the general meaning of analysis? Illustrate 
object, \&c. In Chemistry, we analyze water when we separate its two elements, oxygen and hydrogen, and examine each by itself.

264. In Botany, however, we use the word analysis in a wider sense. It implies not only the separate study of each carticular organ composing the plant, but doing all this in connection with certain tables, in order to determine its naine and history.

265 This kind of analysis is the constant and delightful pursuit of the active botanist. Without it, the study of books loses half its pleasure and usefulness. The student can acquire a better knowledge of a species by the study of a living specimen, than by memorizing the longest description found in books.

266. During the flowering months, he will often meet with species in blossom which are yet unknown to him. If he is duly interested in his study, he will not fail to seize and analyze each new specimen, and even extend his walk in search of more. In this manner, he may in a few seasons become acquainted with every species in his locality.

267. But we do not expect that all this will be accomplished by our young friends while using as their only text-book this little work. We only aim now to furnish them with the means of making a fair beginning, so that they may be able, in future seasons, to advance rapidly with the "Class Book," or other works of that rank.

268. In the following pages we present the pupil with numerous tables, ajesigned to conduct our inquiries in every process of botanical analysis; also accompanied by a plain, ininiature Flora, or a partial description of all the flowering plants in the United States.

264. What is its signification in botany? 
269. Specimens gathered for analysis should have flowere in full bloom, full-grown leaves, and also, if possible, the mature fruit. If it be an herb, it is well to have the whole of it as the root and lower leaves often afford characters by which the species is known. Suppose you now have good specimens of some one unknown plant, gathered for analysis, -how will you proceed with them?

270 . We first examine the several parts of the plant, beginring with the root and ending with the pistil or ovary, determining the character of each according to the definitions given in the former lessons. After this, we refer to the table commencing on page 121, entitled, "Review of the Natural System," and read, compare, and decide according to the directions contained in Lesson XXXIII., in order to determine the Natural Order to which the specimen belongs. Having determined the Order, we next turn to that Order, and determine the Genus and Species by means of other similar tables.

271. In examining the specimen, previous to the use of the tables, the first inquiries may be somewhat as follows:

As to the plant-whether it be an herb, shrub, or tree. As to the root-whether tuberous, fibrous, or fibro-tuberous. As to the stem-whether a scale-stem or leaf-stem; bulbous, rhizome, or erect, \&c.

As to the leaves-whether alternate or opposite; parallelveined or net-veined; whether the figure be ovate, lanceolate, oblong, \&c.

269. What kinds of specimens are to be preferred for analysis?

270. Please state the first thing to be done with them. After you hav found the Order, what then?

271. What special care should be taken? As to character, what do we inquire concerning plants? What concerning the root? the stem? the leaves? the stipules? What concerning the flowers? the calyx ? the cornl la? stamens? What concerning the pistil or fruit? 
As to stipules-whether present or absent.

As to the flowers- whether symmetrical or unsymmetrical; regular or irregular; whether the calyx be free or adherent; the petals, whether distinct or united; the stamens, whether hypogynous or perigynous, whether opposite to the petals or . alternate with them.

As to the pistil and fruit,-whether the carpels be more than one, and whether distinct or united. (See Lesson XVIII.)

\section{LESSON XXXIII.}

\section{HOW TO ANALYZE A PLANT BY THE TABLES.}

272. Oun readers are already informed that the Flora which accompanies these instructions is not intended to make them acquainted with the plants of the country, but simply to teach the pupil how to analyze. Hence they will not expect to find in it any thing like a full account of all our flora, but a few plain exercises by which they may trace every flowering plant in the country to its Natural Order, about one in every two to its Genus, and about one in every five to its Species. In conducting an exercise in this Flora with a class of pupils who have well studied the former part of the work, some method like the following would be interesting and profitable.

273. Suppose the class present, and each furnished with a specimen of some one unknown species, both in flower and fruit.

Teacher. Are you all ready? Turn to the Flora and let us find out together the family relations and the names of this fine plant. We will commence at the "Analysis of the Natural Orders" (page 132), and read the first pair of lines, which we will call a couplet. 
John (reads). "Plants bearing flowers (Phænogamia). "Plants not bearing flowers (Cryptogamia)."

Teacher. To which of these sub-kingdoms does your specimen belong I John. To the flowering plants, for it has both flowers and fruit.

Teacher. Now tell us to which couplet we shall next pass.

John. To the second.

Teacher. Very well. Edward, you may read and determine the second couplet in the same manner.

Edward. "Leaves net-veined. Flowers never completely three-parted.

"Leaves parallel-veined (rarely net-veined). Flowers three-parted." This specimen seems to answer to the first line, having net-veined leaves and five-parted flowers. It is, then, an Exogen. Pass to No. 3.

Teacher. Now let it pass along, and if a wrong decision is made, let the observer signify it by raising his hand.

Sarah. "Stigmas present. Seeds inclosed in seed-vessels.

"Stigmas none. Seeds naked." These flowers have pistils and stigmas. I think it is an Angiosperm. Pass to No. 5.

Eliza. "Corolla with distinct petals.

"Corolla with united petals.

"Corolla none; sepals sometimes none." My specimen has five distinct petals, and five sepals. It is therefore Polypetalous. Pass over to $\mathbf{A}$.

Jane. "Herbs.

"Shrubs, trees, or undershrubs." This plant is an herb. Pass on to No. 2.

Mary. "Leares alternate or all radical.

"Leaves opposite, on the stem." The leaves of the stem are alternate, but many are radical. Pass to No. 15.

Louisa. "Flowers regular or nearly so. Fruit never a legume.

"Flowers irregular," \&c. I do not remember the legume. (Several hands are raised.)

Teacher. Edward will define a legume.

Edward. A legume, sir, is a fruit like a pea-pod.

Teacher. Can Mary improve this definition?

Mary. The legume is a simple, or one-carpeled fruit, with two valres acd one cell.

Louisa. But this plant has regular flowers, in any case. See No. 17.

Nancy. "Stamens numerous." \&c. I count more than twenty stamens here. Turn to No. 21. 
Lucy. "Stamens on the torus," \&c. I think they are on the torus, and not on the calyx. Next to No. 22.

Emily. "Pistils few or many, distinct (at least as to the styles).

"Pistils (styles, also, if any), completely united." I see many litt'e green pistils, quite distinct, in the centre of the flower. Go to No. 23.

Caroline. "Petals five or more, deciduous. Leaves not peltate," \&c This flower has five petals, but I do not know whether they are deciduous or not.

Teacher. Will some of yuu relieve Caroline's doubts?

Emily. I think they are deciduous, for they have already fallen off from several of my flowers.

Teacher. True. Then what is Caroline's decision?

Caroline. I suppose, then, that the plant belongs to the "Order of the Crowfoots," which is the first natural order.

Teacher. Well done. This brings us to the order of which our plant seems to be a member. Let us now turn to that order and learn the genus of the plant. But before we look into the "Aualysis of the Genera," we should carefully compare our plant with the characters of the order, so that we may be sure that we have not erred in our conclusion. John will read aloud these characters, and the class will consider whether their specimens answer to each.

John (reads). "Herbs, rarely shrubs, with a colorless, acrid juice" (\&c., to the end).

Teacher. Since we are now confident that we have a plant belonging to the order of the Crowfoots, let us commence the "Analysis of the Genera." Edward, the first couplet.

Edwoard. "Sepals four, valvate in the bud. Achenia tailed.

"Sepals imbricate in the bud." The sepals are imbricate. No. 2.

Sarah. "Ovaries one-seeded, achenia in fruit.

"Ovaries with two or more seeds." I find one seed in each ovary, indeed, the ovary is itself like a little seed. Pass to No. 3.

Eliza (after reading the couplet). The greenish sepals are quite differ ent from the yellow petals. Go to the triplet marked $d$.

Jane (after reading the three lines). As this plant has leaves on the stem, and a little scale with honey at the base of each petal, I must pro nounce it a Crowfoot, genus No. 4.

Teacher. We now turn to that genus (page 147), and read its character fur the sake of confirmation and a better knowledge. 
Mary (rearls the character of the genus Ranunculus aloud).

Teacher. We are now ready for the analysis of the species. Mary is next.

Mary. "Petals yellow. Seeds (carpels) rough with prickles. Flowerm sinall. South.....

"Petals yellow, seeds smooth and even.....

"Petals white (claws yellow). Seeds wrinkled crosswise." This spe cimen has smooth seeds and yellow petals. Pass to $a$.

Louisa. "Leaves more or less divided," \&c. This second line of the triplet describes the plant. Pass on to $b$.

Nancy. "Root leaves neither divided nor cleft, inerely crenate.

"Lower leaves three-cleft, but not divided to the base.

"Leaves all ternately divided and much cleft." Pass to $c$.

Lucy. "Sepals reflexed in flower. Plants erect.

"Sepals spreading in flower, shorter than the petals." The sepals are reflexed. Read Nos. 14,15 .

Emily, after reading both descriptions, finally concludes that she bolde in her haud a specimen of the Bulbous Crowfoot, or Ranunculus bulbosus, in which conclusion all concur.

\section{LESSON XXXIV}

\section{VARIOUS SUGGES'IIONS AND CAUTIONS.}

274. 'THE work of analysis is often attended with diflicul ties which severely try the skill and perseverance of the young botanist. So it often is in the study of Algebra, or of Logic; indeed, in nearly every valnable branch of learning His decisions may be wrong through a want of a thorough acquaintance with botanical terms, or through his ignorance of the real characters of his specimens. Of course his success will always be in proportion to the accuracy of his knowl edge,-here, as well as in all other pursuits.

274. Mention two sources of error in the analysis of plants 
275. But the minuteness of the organs or parts to be studied is often discouraging even to the accurate student, Inuch more to the careless one. To overcome this, skill in dissection and a dauntless courage in observation are indis pensable. Moreover, there is often much ambiguity in the vature of the subject. For example, whether the Geraniums are herbs or shrubs; whether the flower's of Petunia are regular or irregular; whether the Pear leaf is ovate or oval, \&c. Experience will at length diminish this difficulty.

276. The exact limits between the classes, the cohorts, \&c., are not always easily defined. For example, is Trillium an Exogen or an Endogen? Its netted leaves indicate the former, but its flowers being three-parted throughout, and its seeds with one cotyledon, prove it to be an Endogen. Again, is Spring Beauty an Exogen or an Endogen? Its leaves seem, at first, parallel-veined, but as its flowers are five-parted it is an Exogen.

277. Angiosperms will be readily distinguished from Gymnosperms, if we remember that almost all the latter are evergreen trees, like the Pines, Cedars, Larches, \&c.

278. The industrious student will very soon find himself so well acquainted with the different characters of the cohorts that he will in analysis refer lis plant at once to its right cohort, without consulting the previous parts of the table. This is desirable; and a thorough acquaintance with the

275. What of the minuteness of the organs of some plants? What of the ambiguity of the plants themselves? What will soon diminish this diff. culty? Mention examples of this ambiguity.

276. Are the limits of the classes, cohorts, genera, \&c., always clear? How do we know that the Trillium is an Endogen? that Spring Beauty if an Exogen?

277. How may the Gymnosperms be quickly distinguished? 
characters of the five great orders following will prove a great saving of time and trouble.

279. The Crucifers are herbs with alternate leaves, cruciform flowers ( $\$ 87)$, two staniens shorter than the other four, and two-celled pods. Example, Mustard.

280. The Peaworts are plants with one-celled pods, mostly papilionaceous flowers and compound leaves. Examples, Pea, Bean.

281. The Umbellifers have alternate leaves, small, regular, five-parted flowers, in umbels, and two-seeded fruit. Caraway

282. The Asterworts are herbs with compound flowers, that is, with heads composed of many little five-parted flowers appearing together like a single flower. Asters, Sunflower.

283. The Labiates are herbs with square stems, opposite leaves, labiate flowers, and fruit deeply cleft into four parts Peppermint.

Among Endogens we select two or three orders.

284. The Orchids. Herbs with very irregular and grotesque flowers, and stamens united to the style. Orchis.

285. The SEDGEs. Herbs with solid stems; linear, grasslike leaves (if any), on entire sheaths; and with green glumes and flowers.

286. The Grasses. Herbs with hollow stems, linear leaves on split sheaths, and with green glumes and flowers.

279. Define the Crucifers

281. The Umbellifers.

283. The Labiates.

285. The Sedges.
280. The Peaworts

282. The Asterworti.

284. Define also the Orchıds.

286 The Grasses. 


\section{ABBREVIATIONS AND SIGNS,}

\section{Often used in Descriptive Botany.}

ach., acneurs.

cost., æstivation. aiver., alternate. anth., anther. a.rill., axillary. c., commou. cal., calyx. cusps., capsule. con., corolla. decid., deciduous. diam., diameter. emarg., emarginate. $f$. or ft., feet.

fil., filament.
fl., flower ; fls., flowers.
fr., fruit.
hd., head; hds., heads.
hyp., hypoyynous.
imbr., imbricate.
inf., inferior.
invol., involucre.
irreg., irregular.
leg., legume.
lf., leaf; lvs., leaves,
lfts., leatlets.
ova., ovary.

pet., petals. $r$, rare, uncommon. recp., receptacle.

reg., regular. rhiz., rhizomo $r t$, root. sds., seeds. seg., segments. sep., sepals. st., stem. sta., stamens. stig., stigmas. sty., styles.

Apr., April. Aug., August. Dec., December. Feo., February. Jan., January. Ji., July. Jn., June. Mar., March. Noo., November. Oct., October. Sept., September.

$N$, Northern, that is, the northern portions of the Dnited States.

$N$ - $E$., New England, or the Northeastern States.

$N$. $W$., the Northwestern States.

$E$., the Eastern, or the Atlantic States.

$W$., the Western, or the States bordering on the Mississippi and Obio rivers.

$M$., the Middle States or portions of the United States.

$S$. , the Southern States.

$S_{.}-E_{\text {. }}$ the Southeastern States, and S:- $W$., the Southwestern States.

N. $\boldsymbol{Y}$., New York. Mass., Massachusetts. Pa., Pennsylvania, \&c.

f. (with or without the period), a foot.

(a single accent) denotes an inch (a twelfth of 1 foot).

"(a double accent) a second, a line (a twelfth of an inch).

(1) An snnual plant.

(2) A biennial plant.

2f A perennial plant.

ל A plant with a woody stem.

o A pistillate flower or plant.

$\Varangle$ A perfect flower, or a plant bearng perfect flowers.

\& (placed after), a naturalized plant.

$\dagger$ (placed after), cultivated for ornament

$\ddagger$ (placed after), cultivated for use.

$\infty$ Indefinite or numerous.

8 Monceious, or a plant bearing staminate and pistillate flowers.

of Diœcious ; fistillate and staminate flowers on separate plants.

\& ซf of Polrgamors; the sance species, with pistillate, perfect, and staminatr fis

0 (a cipher , siguifes wanting or none, as, "Petals 0." 


\section{ANALYSIS OF THE NATURAL ORDERS,}

Being a Key for the ready determination of the Natural Order of any plant native or cultivated, growing within any State east of the Mississippi river, or bordering on its western shore.

Noтk.-A star (*) prefixed to the name of the Orier, aenotes that that Order, with its genera and species, is described in its place in the Flora. The Orders not thus marked are uot noticed in the Flora beyond this Tal,le. The Orders are here numbered to correspond with the "Class Book of Botany."

\section{C1.ASSES ANI COHORTS}

1 Flowerung Plants... 2.

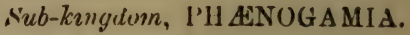

1 Flowerless Planty.... Ferns, Mosses, Lichens, Mushrooms,

Sen-weeds, \&c. (not further noticed here). sub-kingdom, (KY PTOGAMIA.

2. Leaves net-veined. Flowers never completely 3-parted ...3. EXOGENS:

2. Leaves parallel-veined (rarely net veined). Flowers 3-parted....4. ENDOGENS.

3. Stigmas present. Seeds inclosed in a seed-ressel....5. Angiosperms.

3. Stigmas none. Seeds naked (Pines, Spruces, \&c.).. . *. Gymnosperms.

4 Flowers without glumes, colored or green....7.

Petaliferæ

4. $\mathbf{P}$ "swers with green, alternate glumes, no perianth ....8.

Glumiferæ

5. Corolla with distinct petals....A.

Cohort 1. Polypetalous.

5. Corolla with united petals.... $\mathbf{B}$.

Cohort 2. GaMopetalous.

5. Corolla none. Sepals sometimes none .C. Cohort 3.

6. The cone-fruited piants (same as Gymnosperms)..D. Cohort 4.

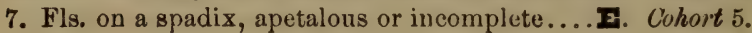

7. Fls. complete, perianth double. No spadix...

8 The grass-like plants (same as Glumiferæ). G. Cohort 7.

Apetalous.

Conords.

SPADICIFLORE.

FLORIDE

Graminoide

\section{A Orders of the Polypetalous Exogens}

1. Herbs....2.

1. Shrubs, trees, or undershrubs. .3 .

2. Leaves alternate or all rudical....15.

2. Leaves opposite on the stem....11.

3. Flowers regular or nearly so ...4.

3. Flowers irregular (or fruit a legume, $\$ 180$ ) $\ldots .57$

4 Stamens 3 times as many as the petals, or more... 5 .

Stamens 1 or 2 times as many as the petals, or fewer.. 7 .

5. l.eares opposite....60.

5. L.eares alternate. . 6. 
6. Stamens on the torus or on the hypogynous ( $\$ 83)$ petals... 63 .

6. Stamens and petals on the calyx tube (perigynous, $\S 83$ ).. .68.

7. Ovaries simple, distinct or one only. Vines or erect shrubs...69.

7. Ovary compound....8.

8. Ovary inferior, - wholly adhereut to the calyx ....70.

8. Ovary superior,-free from the calyx, or nearly free....9.

9. Stamens opposite to the petals, and of the same number....72.

. Stamens alternate with the petals, or of a different number....10

10. Leaves opposite on the stem....73.

10. Leaves alternate, compound....76.

10. Leaves alternate, simple ....78.

11. Stamens 3 times as many as the petals, or more....47.

11. Stamens 1 or 2 times as many as the petals, or fower....12

12. Pistils distinct and simple, few or one only ...48.

12. Pistils united into a compound ovary....18.

13. Ovary free from the calyx. ..14.

13. Ovary adherent to the calyx. ..49.

14. Stamens opposite to the petals, and of the same number....51.

14. Stamens alternate with the petals, or of a greater number....52.

15. Flowers regular or nearly so. Fruit never a legume....17.

15. Flowers irregular (rarely regular), or the fruit a legume.. 16

16. Stamens 3 or more times as many as the petals....42.

16. Stamens few and definite, $5-12 \ldots .43$.

17. Stamens uumerous, 3 or more times as many as the petals....21.

17. Stamens few and definite....18.

18. Ovary free from the calyx, - superior... 19.

18. Ovary adherent to the calyx, -inferior....39.

19. Pistils one or indefinite (1-15), distinct, simple.. .30.

19. Pistils definite in number, as follows, viz....20.

20. Carpels (or pistils) 2, united, the short styles cambined into 1 ....s?

20. Carpels 3 or 4 , united, the styles or stigmas 3 , or 4 , or $6 \ldots 32$.

20. Carpels 5 , distinct or unitel, with 5 distinct styles....37.

20. Carpels 5, united, and the styles combined into 1. .38.

21. Stamens on the torus (hypogynous) $\ldots .22$.

21. Stamens situated on the corolla at base....27.

21. Stamens situated on the caly $\mathrm{x}$ at the base...28.

22. Pistils few or many, distinct (at least as to the styıes)... 23.

22. Pistils (and styles also, if any) completely united...24.

23. Petals 5 or more, deciduous. Leaves not peltate. Order of the * Cronofoots. I

23. Petals 3, persistent and withering. Floating leaves peltate. W'uter-shields.

23. Petals many, deciduous. Leaves all peltate.

* Water-bans. $\varepsilon$

24. Sepals 2 only $\ldots 26$.

24. Sepals 4,5 , or 6, mostis $5 . \ldots 25$ 
25. Petals numerous, imbricate in the bud.

* Water Lilies. 9

25. Petals 5 , imbricate in bud. Leaves tubuiar.

* Wuter-pitchers. 10

25. Petals 5, convolute in bud. Flowers of 2 sorts.

* Rock-roses. 17

26. Petals 5 , imbricate in bud.

26. Petals 4, usually crumpled in bud.

27. Filaments united into a tube. Anthers 1-celled.

* Purselanes. 22

* Puppyworts. 11

* Mallows. 24

28. Sepals 2, persistent. Fruit a pyxis ( $\$ 178)$.

* Purselanes. 22

28. Sepals 3 to $5 \ldots 29$.

29. Petals imbricate in hud. Fruit a long pod. South.

* Landenblooms. 26

29. Petals imbricate in bud. Fruit not a pod.

29. Petals convolute in bud. Fruit compound.

80. Stamens opposite to the imbricated petals. Pistil one.

80. Stamens alternate with the petals, or more numerous.

31. Stamens 6 (tetradynamous, § 108). Pods 2-celled.

31. Stamens 4, or 8-12. Pod 1-celled.

32. Sepals and petals in 3 's. Stamens 6 . Small herbs.

32. Sepals and petals in 4's. Stamens 8 . Climbing.

32. Sepads and petals in 5 's....83.

33. Stamens definitely $5 \ldots .34$.

33. Stamens indefinite, $8-30 \ldots . .36$

34. Stamens monadelphous. Stems climbing. * Passionravts. 60

34. Stamens distinct....35.

* Roservorts. 47

Loasads. 53

- Berberids. 6

* Cronofonts. 1

- Crucifers. 13

Capparids. 14

Limnanths. 36

- Indian Soapworts. 41

35. Stem climbing. Flowers greemsh. * (Mexican vine.) Order 105

35. Stem erect. Flowers yellow.

Turnerworts. $5 €$

85. Stem erect. Flowers cyanic.

* Sundews. 19

36. Flowers perfect, very many and small. * Rock-roses. 17

36. Fls. monœcious. Plants woolly, scurfy, or downy. Order 112

37. Stamens 5, alternate with the 5 petals. Seeds inany. * Flaxworts. 30

87. Stamens 5, opposite to the 5 petals. Seed 1. (Leadworts.) *Order 80

87. Stamens 10 (twice as many as the petals), united at base. ${ }^{*}$ Wood-8orrels. 32

87. Stamens 6-24 (twice as many as the petals), distinct. * Houseleeks. 56

38. Ovary 1-celled. Leaves radical, spinous. S. $\quad *$ Sundews. 19

38. Ovary 3-5-celled. Leaves mostly radical, dotless. * Order 73

38. Ovary 3-5-celled. Leaves cauline, dotted, pinnate. Rucworts. 37

89. Style 1, but the carpels $(\$ 124)$ as many as the petals $(2-6)$. Onagrads. 52

89. Styles 2, carpels 2 , fewer than the (5) petals....40.

39. Styles $3-5 \ldots .41$.

40. Seeds several.

10. Seeds two only.

41. Sepals 2 , with 5 petals.

41. Sepals as many as the petals.

42. Ovaries many or few, rarely 1 , always simple.

42. Ovary compound, 8-carpeled, open before ripo.
* Saxifrages. $\quad 57$

* Umbelurorts. 63

* Purselanes. 22

* Araliads. 65

* Crowfoots. 1
Mignoneties. 15 
43. Sepuls fewer or more in number than the petals....44.

43. Sepals and petals each of the same number....45.

44. Sepals 2 (or vanished); petals 4 (2 pairs), with 1 or 2 spurs *Fumeworts. 12

44. Sepals 4, petals 2; the largest sepal spurred behind. * Jewelweeds. 34

44. Sepals 5, petals 3. No spur.

* Milkworts. 45

45. Flowers 4-parted, not very irregular. No spur. Cappurids. 14

45. Flowers 5-parted....46.

46. Stamens 8. Spur slender.

Trophyworts. 35

46. Stamens 5. Spur blunt, or nume.

* Violets. 16

46. Stamens 10 (or more). Fruit a legume. No spur. * Peaworts. 46

47. Pistils many, entirely distiuct, simpie.

* Crowfoots. 1

47. Pistils 3 to 5 , united more or less completely.

* St. Johnsworts. 18

47. Pistils 5 to 10 , united, with sessile stigmas and many petals.

48. Pistil only 1, simple. Petals 6-9. Stamens 12-18.

Ice-plants. 28

43. Pistils 3 or more, distinct, simple. Flowers all symmetrical. * Houseleeks. 56

48. Pistils 2, covered up by the stamens Juice milky. * Order 97

49. Carpels as many as the sepals....49:

49. Carpels fewer than the sepals. ...50.

49? Anthers opening at the top.

49.' Anthers opening along the side

50. Seeds numerous. Styles 2.

50. Seed 1 in each cell. Styles 2 or 3.

50. Seed 1 in each cell. Style 1 (double).

51. Style 3-cleft at the summit.

51 Style and stigma 1, undivided.

32. Leaves pinnate, with stipules between the petioles.

52. Leaves simple, toothed or lobed....53.

52. Leaves simple, entire....54.

53. Flowers cruciform, with 6 stamens.

Crucifers. 13

53. Flowers 5-parted, with 10 stamens

* Geraniums. 31

54. Petals and stamens on the throat of the calyx.

* Loosestrifes. 51

54. Petals on the torus (hypogynous) ....55.

55. Flowers irregular, unsymmetrical (\$110). * Milkur.r's. 45

55. Flowers regular, 2 (or 3 )-parted throughout. Water-pepper's. 20

55. Flowers regular, 5-parted.....56.

56. Leaves dotted with pellucid or black dots. * St. Johnsucorts. 18

56. Leaves not dotted.

* Pinkwoorts. 21

b7. Pistıl a simple carpel, becoming a legume. Stamens 10-100. * Peavorts. 4e

57. Pistil compound, 3-carpeled....58.

57 Pistil compound, 5-carpeled....59.

58. Flowers perfect. Leaves digitate.

* Buckeyes. 41

58 Flowers monœcious $(\S 10 \ni)$. Leaves 1-sided. Cultivated. Begoniads. 59

59. Stipules present. Mlants half-shrubby. Cultivated. * Geraniums. 31

59. Stipules none. Shrubs or half-shrubs. Native. * Order 73 
60. Stamens on the torus, in several sets. Leaves dotted.

* St. Johnswoorts. $1 \varepsilon$

60. Stamens on the calyx (perigynous, $\$ 83$ )....61.

61. Ovaries many, free, but inclosed.

* Calycanths. 3

61. Ovary compound, free in the bell-shaped calyx.

* Loose-strifes. 51

61. Ovary compound, adherent to the calyx...62.

62. Leaves with a marginal vein.

62. Leaves with no marginal vein.

Myrtlebloons. 49

* Saxifrages. 57

6). Petals imbricate or vasvate in the bud....65.

63 Petas convolute in the bud....64.

64. Anthers 1-celled, turned inwards.

64. Anthers 2-celled, turned outwards. South.

* Mallows. 24

65. Ovaries distirct, many or few....66.

65. Ovary compound....67.

66. Petals 6, valvate $(\S 129)$. Erect shrubs. *Papaws. 4

66. Petals $3-9$, imbricate. Trees or erect shrubs. * Magnoliads. 2

66. Petals 6-9, imbricate. Climbing shrubs. Moonseeds. 5

67. Leaves dotted with pellucid dots. _. Orangeworts. 28

67. Leaves dotless. Sepals valvate. Fls. small.*Lindenblooms. 26

67. Leaves dotless. Sepals imbricate. Fls. large. *Teaworts. 27

68. Style 1, with many stigmas. Green, fleshy shrubs Cacti).*Indian Figs. 58

B8. Styles several, or 1 with 1 stigma. Woody trees or shrubs. * Lioscworts. 47

69. Pistils many, spicate on the slender torus. Climbers. Schizanths. 4

69. Pistils 2-6, capitate on the short torus. Climbers. Moonseeds. 5

69. Pistil 1 only. Stamens opposite the petals. $\quad$ * Berberids. 6

70. Flowers 4-parted, with 8 stamens.

70. Flowers 4-parted, with 4 stamens.

* Onugrads. 52

* Cornels. 65

70. Flowers 5 -parted, with 5,10 , or many stamens....71.

71. Ovary 5-carpeled, 5-styled.

*Araliads. $\quad$ is

71. Ovary 2-carpeled. Leaves palmate-veined.

* Currants. 5́อ̃

71. Ovary 2-carpeled. Leaves pinnate-veined.

* Sasifíages. 57

72. Leaves opposite. Stem climbing by tendrils. *Vineworts. 44

72. Leaves alternate. Erect, or vine without tendrils. *Buckthorns. 43

78. Carpuls $8-5 \ldots 74$.

78. Carpels 1 or $2 \ldots .75$.

74. Styles short. Leaves simple.

74. Styles long and slender. Leaves pinnate, serrate.

75. Styles 2, slender. Samara double.

75. Style 1, short. (Drupe, or single samara.)

$\begin{array}{rr}\text { * Staff-trees. } & 42 \\ \text { * Soapworts. } & 41 \\ \text { * Mapleworts. } & 40 \\ \text { * Order } & 99 \\ \text { Pride-of-India. } & 29 \\ & \\ \text { Rueworts. } & 37 \\ \text { * Sumacs. } & 39 \\ \text { * Soapworts. } & 41\end{array}$

76. Filaments 10, united into a tube. Leaves bi-pinnate. Pride-of-India. 29 i6. Filaments 5, distinct....77.

77. Leaves pellucid-punctate.

77. Leaves not dotted. Ovary 3-carpeled, 1-seeded.

77. Leaves not dotted. Ovary 3 -carpeled, 3 seeded.

* Soapworts. 4 1 
78. Petals 4, yellow.

78. Petals 4-7, cyanic....79.

79. Fruit becoming fleshy drupes....80.

79. Fruit becoming dry capsules....81.

80. Stigmas 3, but the drupe is 1-seeded.

* Sumacs. 38

80. Stigmas 4-6, and the drupe 4-6-seeded. *(Hollyworts.) Order 74

81. Capsule 3-seeded. Seed with a scarlet aril. *Staff-trtes 42

81. Capsule 2 or 3 -seeded, seed not ariled. \& 3. * Order 73

81. Capsule many-seeded. § 2. * Ord. 73, and Pittospores. 39

\section{B. Gamopetalie, or Monopetalous Exogens}

1. Stamens (6-100) more numerous than the lobes of the corolia....s.

1. Stamens (2-12) fewer than the corolla lobes, or of the same number...2.

2. Ovary adherent to the calyx tube, that is, inferior....3.

2. Ovary free from the calyx tube, that is, superior ....4

3. Stameis cohering by their anthers.....11.

3. Stamens entirely distinct....12.

4. Flowers regular....5.

4. Flowers irregular....28.

5. Stamens as many as the petals....6.

5. Stamens 2, fewer than the petas...26.

6. Stamens opposite to the lobes of the corolla (and free).. .14.

6. Stamens alternate with the lobes of the corolla (rarely comnnte)....7.

7. Shrubs, trees, with the stigmas or carpels 3 to $6 \ldots 15$.

7. Herbs 1-10-carpeled, or shrubs 2-carpeled....16.

8. Stamens 6, united below into 2 equal sets. Herbs. * Order 12

8. Stamens 10 , united into a split tube around the 1 style. $\quad$ * Order 46

8. Stamens many, united into an entire tube around the styles. * Order 24

8. Stamens many, united only at the base into 1 or 5 sets....9.

8. Stamens entirely distinct....10.

9. Calyx of 5 leafy, imbricated sepals. Shrubs, trees.*(Teanorts.) Order 27

9. Calyx tubular, 5 -toothed, or truncate. Shrubs, trees. * Styracacece. 75

10. Stamens 8 or 10. Flowers all perfect. * Heathworts 73

10. Stamens 8 or 16. Fls. not ali perfect (diœcions). Persimmons. 76

11. Flowers in a compact head surrounded by an involucre. * Asterworts. 70

11. Flowers separate, irregular, perfect. Plants erect. * Lobeliads. 71

11. Flowers separate, regular, imperfect. Weak vines. (Cucurbits.) Order 58

12. Leaves alternate. Flowers 5-parted, regular, separate. * Fiellioorts. 72

2. Lenves opposite, with stipules between, or verticillate. * Madderworts. 67

12. Jeaves opposite. Stipules none....13

18. Stamens 4 or 5 . Ovary 2-5-celled.

13. Stamens 2 or 3 . Ovary 1 -celled, 1 -seeded.

* Honeysuckles. 66

13. Stamens 4. Ovary 1-celled, 1-seeded.

Valerians. 68

Teazelworts. $6 \varsigma$ 
14. Herbs. Ovary with 5 styles and but 1 seed.

* Leaduorts. 80

14. Herbs. Ovary with 1 style and many seeds.

* Primworts. 78

14. Shrubs, trecs. Ovary 1-styled, 5-celled, 1-seeded. Soapworts. 77

15 Style none. Drupe 4-6-seeded

*Hollyworts. 74

1E. Style one. Drupe 4-seeded.

Vervains. 88

15. Style one. Capsule 3-5-cel!ed, many-seeded.

* Heathworts. 73

16 Ovary 1, deeply 4-parted or 4-partible, forming 4 achenia.

* Borragezoorts. $9 \mathrm{c}$

16. Ovaries 2, distinct, often covered by the stamens....18.

26. Ovary 1 , compound....17.

17. Ovary 1-celled....20.

17. Ovary 2-6-celled....22.

18. Stigmas united or connate. ...19.

18. Stigmas distinct. Flowers minute, yellow

19. Flower-bud with convolute pieces.

* Bindweeds. 98

19. Flower-bud with valvate pieces.

* Dogbanes. 96

20. Seeds several....21.

20. Seed one. Corolla limb entire.

21. Leaves cleft and lobed.

* Order 101

21. Lvs. or lfts. entire. Fls. not spicatc. ${ }^{*}$ Gentianworts. 95

21. Leaves entire. Flowers spicate.

Ribworts. 79

22. Leaves opposite....23.

22. Leaves alternate...24.

23. Ovary 2 -celled.

* Logariads. 85

23. Ovary 8-celled. Plants not twining. ....

24. Ovary 8-celled. Plants not twining.

24. Ovary 2-celled, 2-6-seeded. Twining

24. Ovary 2-celled, 4-seeded. Stem erect.

24. Ovary 2-celled, many-seeded....25.

25. Styles 2.

25. Style one.
* Phloxworts. 92

* Bindweeds. 98

* Borrageworts. 90

* Hydrophylls. \$1

* Nightshades. 94 Ribroorts. 79

26. Herbs Corolla 4-parted, dry, scarious.

26. Shrubs....27.

27. Corolla 5-parted, imbricate in bud.

27. Corolla 4-parted, valvate or none.

Jasminewoorts. 98

* Oliveivorts. 99

28. Ovary deeply 4-parted, forming 4 (or fewer) achenı....29.

28. Ovary entire, of one piece....30

29. Leaves opposite. Stems square

* Labiates. 89

29. Leaves alternate Stems round.

Borrageworts. 80

30. Ovary with 4 or fewer seeds. Leaves opposite. Vervains. 87

30 . Ovary with many seeds, or more than $4 \ldots . .31$.

31. Trees or climbing shrubs. Seeds winged. * Bignoniads. 83

31. Trees. Seeds wingless. Paulowonia, in Order 86

81. Erect shrubs. Seeds wingless. Heathworls. 73

81. Herbs....82. 
82. Leatless and without verdure.

* Broomrapes. $8 \varepsilon$

32. Leaves only at base. Fls. spurred. *Butterworts. 81

32. Leafy ....33. Fruit 4 or 5-celled.

Pedaliads. 84

33. Fruit 2-celled....34.

34. Corolla convolute in bud.

dcanths. 87

84. Corolla imbricate in bud.

* Figworts. 86

34. Corolla plicate in bud.

- Nighitshudes. 94

\section{Orders of the Apetalous Exogens.}

1 Plantw her Daceous, the flowers not in aments (except in the Hop, 115) ...2.

1 Plauts woody,-shrubs or trees....22.

2. Flowers with a regular calyx or calyx-like involucre....8.

2. Flowers naked, having neither calyx nor corolla....20.

3. Calyx tube adherent to the ovary, limb lobed, toothed, or entire....8.

3. Calyx free from the ovary, sometimes inclosing it....4.

4. Ovaries several, entirely distinct, each 1-styled, 1-seeded.

* Order 1

4. Ovary one only, simple or compound....5.

5. Style or stigma one only....6.

5. Styles or stigmas $2-12 \ldots .7$.

6. Ovary 1-ovuled, bearing but one seed....11.

6. Orary many-ovuled, bearing many seeds....12.

7. Ovary 1-3-ovuled, 1-3-seeded....13.

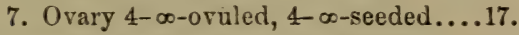

8. Stamens $1-12$, as many or twice as many as the stigmas....9.

8. Stamens $2-10$, not symmetrical with the 1 or 2 stigmas....10.

9. Stigmas and cells of the ovary 1-4.

9. Stigmas and cells of the ovary 6 .

10. Ovary many-seeded. Styles 2.

10. Ovary 1 or 2 -seeded. Style 1.

11. Flowers perfect. Calyx 4-lobed. Stamens 1-4.

* Order 52

* Birthworts. 100

* Order 57

11. Flowers perfect. Calyx entire, funnel-shaped, colored.

11. Flowers imperfect. Calyx lobed, green.

12. Stamens 4, opposite the sepals.

12. Stamens 5 , alternate with the sepals.

18. Fruit 3-6-seeded, with 3 (often cleft) stigmas.

13. Fruit 1-seeded....14.

14. Stipules sheathing the stems.

14 Stipules none....15.

15. Calyx with searious bracts outside.

15. Caly $x$ double. Climbing.

Sandalworts. 108

* Order 47

15. Calyx naked.....16.

16. Leaves alternate.

16. Leaves opposite.

* (Loosestrifes.) Order 51

* Order 78

Spurgeworts. $11 \%$

* Knot-grasses. 102

* Amarant/lis. 108

* Mexican Vine. 105

* Goosefoots. $10 \mathrm{~s}$

83. * Order 21 
17. Leaves opposite....18.

17. Leaves alternate....19.

18. Fruit a pyxis, opening by a lid.

18. Fruit a capsule, opening by 4 or 5 valves.

* Order 25

* Order 21

19. Fruit a capsule, 5-celled, 5-horned.

* Order 56

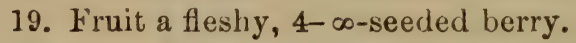

19. Fruit dry, 1-seeded, opening by a lid.

20. Flowers on a spadix with a spathe.

- I'okeweed8. 103

* Ainaranths. 160

* Order 131

20. Flowers in a long, naked spike. Stamens 6 or 7 .

Lizard-tails. 123

20. Flowers solitary, axillary, minute. Water-plants...21.

21. Stamen 1. Leaves opposite.

Starworts. 121

21. Stamens 2. Leaves alternate, dissected.

Threadfoots. 125

21. Stamens 12-24. Leaves whorled, dissected.

Hornworts. 126

22. Flowers, none of them in aments....23.

22. Flowers (imperfect), the sterile only in aments....24.

22. Flowers (imperfect), both the sterile and the fertile in aments. ..35.

23. Leaves opposite...24.

23. Leaves alternate....27.

24. Stamens 2.

24. Stamens 3. Parasites.

24. Stamens 4-9 9.25 .

25. Fruit a double, 2-winged samara.

25. Fruit not winged...26.

26. Seeds 6. Low shrubs. Box.

26. Seed 1. Shrubs.

* Order 99

Mistletoe-Loranths. 108

* Order 40

Spurgeworts. 112

Oleasters. 111

27. Style or stigma 1. Seed 1....28.

27. Styles or stigmas $2 \ldots . .31$.

27. Styles or stigmas $3-9 \ldots .32$.

28. Calyx free from the ovary....29.

28. Calyx adherent to the ovary....30

29. Anthers opening by valves.

29. Anthers opening by slits.

30. Seeds 2-4. Shrubs.

30. Seed 1. Trees.

31. Stamens numerous.

31. Stamens as many as the calyx lobes.

Laurels. 118

* Daphnads. 107

Sandalworts. 109

* Order 65

* Order 62

E'lmworts. 118

32. Leaves pinnate. I'istils 5 .

82. Leaves simple, linear, evergreen.

(Prickly Ash.) Order 37

C'rowberries. 116

82. Leaves simple, not linear....33.

33. Flowers 3-parted. Fruit dry.

(Stillingia.) Spurgewoorts. i18

33. Flowers 4 or 5 -parted. Fruit fleshy.

*(Buckthorns.) Order 48

34. Nut or nuts in a cup or involucre. Leaves simple.

* Mastwort8. 119

84. Nut naked, a tryma (§ 172). Leaves pinnate. *Walnuts; Hickoryworte. 117 
85. Fruit fleshy, compound. Juice (sap) milky. Artocarps 114

85. Fruit dry (except in Myrica, 121). Sap watery....36.

36. Aments glubular, racemed. Nutlets 2-celled. (Liquidambar.) Order 69

36. Ainents globular, solitary. Nutlets 1-celled. Sycamores 116

36. Aments cylindrical or oblong.....87.

37. Uvary 1-celled, 1-seeded. Fruit dry or fleshy. Galeworts. 12] 37. Ovary 2-celled, 2-ovuled, 1-seeded.

37. Ovary many-ovuled, many-seeded.

* Birchworts. 121

* Willowworts. 12

\section{Orners of the Conoids.}

\&eaves simple. The fertile flowers in cones. Sterns branched. * Pincworts. $12 \%$ Leaves simple. The fertile flowers solitary. Stems branched.

* Yews. 128

Leaves pinnate. Stems not branched, palm-like.

Cycaus. 129

\section{E. Orders of the Spadiciflore.}

1. Trees or shrubs with palmately-cleft leaves all from one terminal bud, and

a branching spadix arising from a spathe.

Falms. 130

1. Herbs with simple (rarely ternate) leaves. Spadix simple....2.

2. Plants minute, floating loose on the water.

Duckmeats. 132

2. Plants with stem and leaves rooting in the soil....3.

3. Spadix evident, in a spathe or on a scape.

* Aroids. 1.31

3. Spadix obscure or spike-like. Stems leafy....4.

4. Flowers with no perianth, densely packed.

*Typhads. 182

4. Flowers with a perianth or not. In water.

* Naiads. 183

\section{$\boldsymbol{F}$ Orders of the Florider.}

1. Flowers (not on a spadix) in a small, dense, involucrate head.. .17

1. Flowers (not on a spadix) solitary, racemed, spicate, \&c....2.

2. Perianth tube adherent to the ovary....4.

2. Perianth free from the ovary ....3

3. Petals and sepals differently colored (except in Medeola, 147)....9

3. Petals and sepals similarly colored....12.

4. Flowers imperfect....5.

4. Flowers perfect...6

5. Low herbs, in water

5. Woody clinbers.

6. Stamens 1 or 2, growing to the pistil (gynandrous).

6. Stanen only 1 , with half an anther.

* Frogbits. $1 \varepsilon 4$

Iamroots. 144

* Orchids. 188

6. Stamens 3 to 6 , distinct....7.

Arrowworts. 139

7. Perianth woolly or mealy outside. Ovary half-free. Bloodworts. 142

7. Perianth glabrons outside....8. 
8. Stamens 3. Anthers turned inwards.

Burmaniads. 137

8. Stamens 3. Anthers turned outwards.

* Irids. 143

8. Stamens 6.

* Amaryllids. 140

9. Pistils many, distinct, achenia in fruit.

* Water-plantains. 187

9. Pistils 3 , more or less united....10.

10. Leaves verticillate, in 1 or 2 whorls. Stigmas 3 . * Trilliads. 147

10. Leaves alternate....11.

11. Stigmas 3. Plants growing on other plants. Bromeliads. 141

11. Stigmas united into one.

* Spiderworts. $1 \mathrm{~L}_{2}$

12. Leaves net-reined, broad.....13.

12. Leaves parallel-veined....14.

13. Flowers perfect, 4-parted.

Jroomia-Roxburgs. 146

13. Flowers dicecious, 6-parted.

* Greenbriers. 136

14. Styles, and often the stigmas also, united into $1 \ldots 1$...

14. Styles and stigmas 3 , distinct....16.

15. Flowers colored, regular. Stamens 6 ( 4 in one species). ${ }^{*}$ Lilyworts. 148

15. Flowers colored, irregular, or else \$-stamcned. * Pontederiads. 135

15. Flowers greenish, glume-iike, or scarious.

*Rushes. 151

16. Leaves rush-like. Ovary of three 1-seeded carpels. * Arrow-grasses. 137

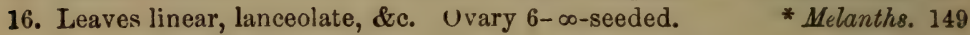

17. Petals yellow, small, but sluowy. Leaves radical. Xyrids. 153

17. Petals white, munute, fringed. Leaves radical. Pipeworts. 154

\section{G. Orders of the Graminoids.}

Flower with a singie oract (gıume). Stem solid. Sheaths entire.

Flower with several bracts (glumes and pales). Stem hollow. Sheaths split on one side.

Arassen 156 


\title{
THE FLORA:
}

OR,

\begin{abstract}
SELECTIONS FROM THE NATIVE AND CULTIVATED PIAANTS
\end{abstract} OF THE UNITED STATES.

Designed as first exercises in Analytical Botany.

Explanationo. - The Tables in this work are designed to be complete, that is, each Ordinal Table includes all the genera belonging to that order known within the lunits of the Flora $\left(i . e_{\text {., the }}\right.$ Strtes east of the Rocky Mountains); and esch Generic Table includes, in like manner, all its known species. The numbers annexed to the genera in the Ordinal Tables, refer to the descriptions immediately following. If no number be annexed, the pupil will understand that that genus is not further noticed.

\section{COHORT I. \\ THE POLYPETALOUS EXOGENS.}

tissential Character.-Flowering Plants (Рнжnogamia), with their stems growing by additions to their outside in layers (ExogENs), their seeds inclosed in a sced-vessel or pericarp (ANGIOsperms), their flowers with a double perianth and their petals distinct (Polr Petales). (But to this last condition there are many exceptions.)

\section{Order I. RANUNCULACE $A$. The Crowfoots}

Herbs, rarely shrubs, with a colorless, acrid juice, with leaves mostly alternate and much divided, without stipules; sepals 3-15, deciduous, distinct, and colored when apetalous; vetals $3-15$, distinct, often deformed or contracted or wanting;

strmens $x$, distinct, hypogynous ; pistils $\infty$ (rarely 1 or few), distinct, becoming in fruit either achenia, follicles, or berries. 


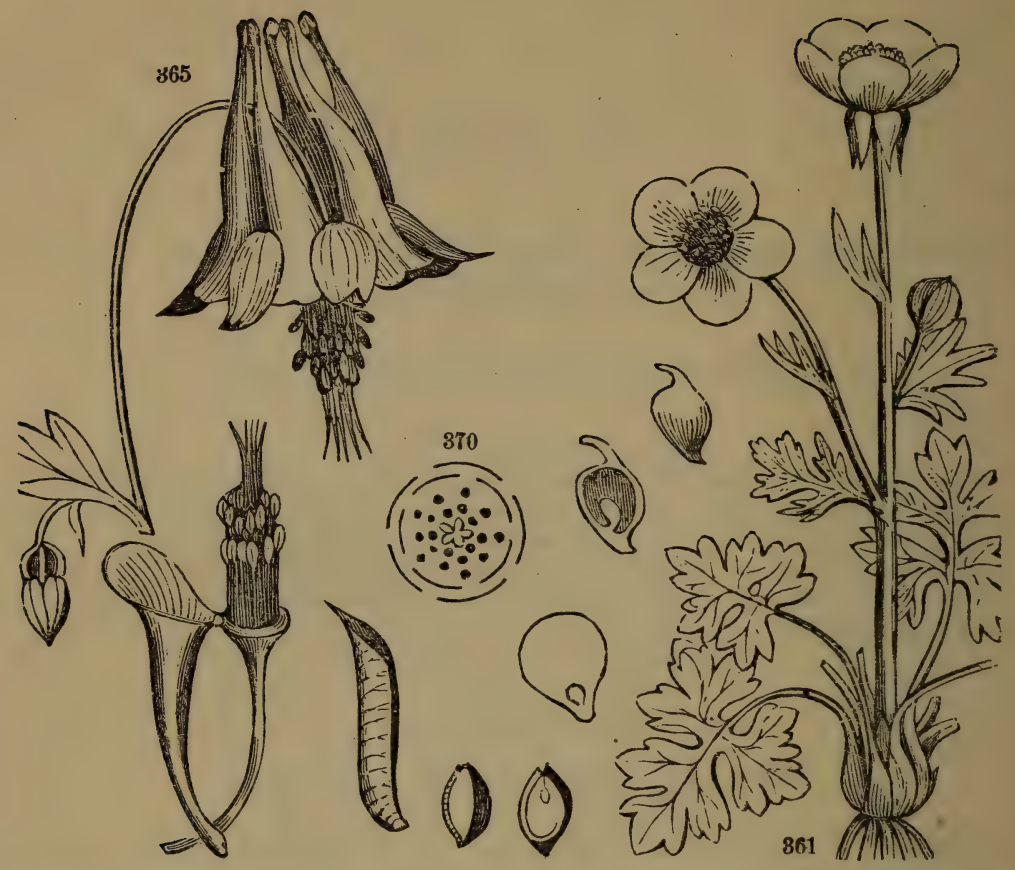

Fig. 361. Bulbous Crow foot; 2, a petal, showing the honey-scale at base; 3 , a single ovary 4 section of 1 , showing the ovule.

Fig. 365. Wild Columbine; 6 , one of the hollow petals atteched to the receptacle witu the stamens and styles; 7 , a ripe follicle; 8 , a seed; 9 , section of it, showing the embryo.

Fig 370. Plan of the flower.

\section{Analysis of the Genera.}

$\$$ Sepals 4, valvate in the bud. Achenia tailed.... a

8 Sepals imbricate in the bud ...2.

2 Ovaries 1-seeded, achenia in fruit....3

\& Uvaries with, 2 or more seeds....4

2 Corolla 0 , or undistinguishable from the colored calyx ....5

3 Corolla and calyx distinct either in color or form....d

4 Septls as permunent as the stamens. Fruit dry...6

4 Sepals falling $\mathrm{cff}$ sooner than the stamens....

4 Serals persisteut with the fruit. Petals very large....m

5 Sepals persistent with the stamens....b

5 Sepals caducous (falling) sooner than the stamens.... 
6 Flowers regular....7

C Flowers irregular....h

7 Petals none....e

7 Petals smaller than the sepals....f

7 Petals larger than the sepals....g

a Petals none or stamen-like. Leaves all opposite. Virgin's Bover. Clem atıs. I

b Stem leaves opposite, remote from the Hower. Anem'one. Anemòne. 2

b Leaves all radical. 3 bracts close to the flower. Liverleaf. Hepat'ica.

- Flowers mostly imperfect. Leaves compound. Meadino Rue. Thalic'trum. 12

c Flws, perfect. Lvs. simple, palmately lobed. Prairie Rue. Trautvettéria.

d Leaves all radical, linear. Torus linear. Small plant.

Mousetail. Mrosu'res.

d Lvs. cauline. Petals with a honey-scale at base. Crowfoot. Ranon'colus.

d Leaves cauline. No hor ey-scale. Petals red or yellow.

Pheasant's-eye. Ado'nis. 5

p Sepals white, 5 in number. Leaves compound.

Fulse Rue. Isopy'rum.

- Sepals yellow, $6-9$.

f Petals tubular at apex. Roots yellow.

$f$ Petals tubular at base, 1-lipped.

f Petals tubular, 2-lipped. Sepals persistent.

$f$ Petals concave, 2-lobed. Flowers racemed.

g Petals larger than the colored sepals, 3-lobed.

$\mathrm{g}$ Petals larger than the colored sepals, spurred alike. Marsh Marigold. CAL'тHA. 6 Gold-thread. Cop'Trs. 7 Globe-flower. TroL'Lius. 8

Hellebore. HeLLeB'ores. Yelloiv-root. ZANTHORH'zA. Fennel-flower. NIGEL'LA.

h Upper sepal ssurred, inclosing spurred petals. Larkspur. DeLphin'itм. 10

h U pper sepal hooded, covering 2 deformed petals. Monk's-hood. Aconi'tum. 11

\& Flowers numerous, in long, slender racemes.

Bugbaive. Cimicif'tea.

1 Flowers mauy, in short racemez. Berries simple.

Buneherry. Аст $\boldsymbol{E}^{\prime} \mathbf{A} .13$

k Elower one only. Leaves 2. Berry compound. in Disk sheathing the ovarics. Very Showy.

Turmeric-ront. HynRas'ris. 14 Peony. P'énia.

\section{CLEM'ATIS. Virgin's Bower.}

Calyx of 4 colored sepals, valvate-induplicate in the bud. Petals none, or small and stamen-like. Stamens many, shorter than the sepals. Ovaries many, styles becoming long and feathery upon the seed-like achenia. $-2 f$ Mostly climbing vines, with twisted petioles for tendrils, and with opposite, compound leaves.

\& Leaves verticillate. Outer stamens petal-like. Vine.... No. 1

Leaves opposite. Petals norie. Calyx colored....a

a Erect herbs near 1 foot high. Flowers solitary....10, 11, 12

a Vines climbing... b 
b Flıwers clustered in panicles....2, 3, 4, 5

b Flowers solitary, large, showy....6, 7, 8, 9

1 Clem'atis verticilla'ris. Purple Virgin's Bower. Leaves ternate, 4 at each nodo Flowers purple, 2 at each node. Hills. N. W.

2 C. Virginia'na. Virginian $V$. Leaves ternate. Leafiets smooth, lobed, and tocthed

$2 \mathrm{C}$ holoseric'ea. Silky $V$. Leaves ternate, leaflets downy or silky, entire. S. C Catesbya'na. Cutesby's V. Lvs. bi-ternate, lfts. 3-lobed. Clusters axillary. S. ( C. Flam'mula. Sweet $\Gamma$. Lvs. pinnate. Lfts. entire, pointed. Fls. terminal. † 6 C. cylin'drica. Crisped V. Lfts. acute, thin, 3-15. Sepals wavy at edge, b-p. S. 7 C. reticula'ta. Veiny $\nabla$. Lfts. obtuse at each end, thickish. Sep. wavy. h-p. s

8 C. Vior'na. Leather-flower. Lfts. ovate, acute, pinnate. Sep. not wavy. P.

9 C. Viticella. Vine-Bower. Lfts. oval, 3-15. Sepals not wavy, obovate. P. 1 10 C. ochroleu'ca. Ground V. Lrs. undivided, ovate, entire, silky beneath. p-y. 11 C. ova'ta. Egg-leaved V. Lvs. undivided, broad-ovate, smooth, glaucous. p. S. 12 C. Baldwin'ii. Buldwin's $V$. Lvs. 3-cleft, the upper lance-ovate, entire. p. S.

\section{ANEMO'NE. Anem'one, or Wind-Flower.}

Calyx regular, of 5-15 colored sepals resembling petals. Petals properly none. Stamens many, much shorter than the sepals. Pistils many, collected into an oblong or roundish head. Achenia generally without tails. Leaves mostly radical, palmately lobed, those of the stem opposite, forming a sort of involucre.

\$ Carpels with long, feathery tails in fruit. Flower large....1

$\S$ Carpels without tails....a

a Stem leaves (involucre) sessile....2, 3

a Stem leaves petiolate.... b

b Flower-stalk 1 or several, all leafless $\ldots . .4,5,6$

b Flower-stalks $2-5$, all but the first 2-leaved in the middle....7, 8

I A. Nuttal'lii. Pasque-flower. Lvs. cleft into linear lobes, vary hairy. Apr. N.-W.

2 A. Carolinia'na. Carolina A. Flower only one, with 15 sepals. S. W.

3 A. Pennsylvan'ica. Pennsylvanian A. Flowers 1-5, with 5 obovate, purc white sepals. Height $12-20^{\prime}$. N. W.

4 A. nemoro'sa. Wood $A$. Flower 1 , stalk 2 or $3^{\prime}$ long. Sepale rose-white. Apr.

5 A. cylin'drica. Gray's A. Flowers mostly several, whitish, stalks 6-12' long. Fruit heads oblong or cyliudrical. May. N. W.

A. th ilictroi'des. Rue A. Flowers several or many, rosy or white, on short (1-2') stalks. Leaves of the invol. 2, twice ternate. Apr. Common.

7 A. Virginia'na. Virginia A. Leaf-lobes, lance-ovate. Flowers greenish. white. Height 2-3 feet. Common.

8 A. mul:f'id3. Red A. Leaf-lobes linear. Flowers red. Height 6-12'. r. N 


\section{HEPAT'ICA. Noble Liverwort.}

Calyx (generally called an involucre) of 3 entire, ovate, green sepals (or bracts), situated a very little below the corolla. Corolla of 5-9 petals, arranged in 2 or three rows. Achenia without tails. - 2f Pretty little plants blossoming in early spring. Leaves all radical, thick, 3-lobed, green through the winter. Flowers numerous, one on each scape, blue, roseate, or white.

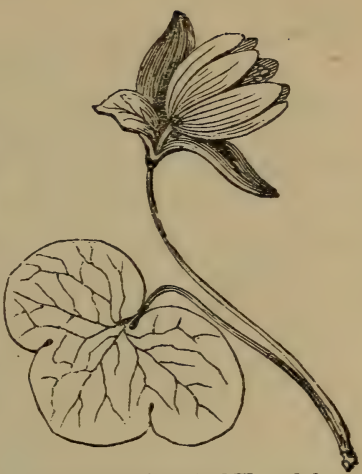

Fig. 371. Flower and leaf of H. triloba.

$1 \mathrm{H}$. tril'oba. Leaf-lobes and sepals obtuse. Scapes hairy, several inches high 2 H. acutil'oba. Leaf-lobes and sepals acute. Fls. and scapes like the other.

\section{RANUN'CULUS. Crowfoot. Buttercups.}

Calyx of 5 ovate sepals. Corolla of 5 roundish, shining petals, each with a honeyed scale or pore at the base inside. Stamens 00. Achenia numerous, flattened, crowded in a roundish or oblong head.-A large genus of herbs mostly perennial ( 2 ) and with yellow flowers. Leares divided or entire. Juice very acrid.

\& Petals yellow. Seeds (carpels) rough with prickles. Fls. small. S ...1, 2

$\left.\begin{array}{l}\$ \text { Petals yellow. Seeds smooth and even ....................... Seeds wrinkled crosswire .... } \\ \S \text { Petals white (claws yellow). }\end{array}\right\}$

a Leaves all undivided. Plants growing in wet places....5-s

a Leaves more or less divided, not growing under water....v

a Leaves in fine, thread-like divisions, growing under water....3, 4

b Ront leaves neither divided nor cleft, merely crenate....9, 10

b Lower leaves 3-cleft but not divided to the base. Height 1-2f....11-13

b Leaves all ternately divided and much cleft....c

c Sepals reflexed in flower. Plants erect....14, 15

c Sepals spreading in flower, shorter than the petals....16-18

1 R. murica'tus. Rough-jruited C. Plant smonth. Seeds with large, stout, honked heaks. Seprals spreading. Leaves 3 -lobed and cleft. South.

z parviflo'rus. Small-flouered C. Plant hairy. Seeds with a very short beak. Sepals finally reflexed. Leaves 3-lobed and cleft. South.

$8 \mathbf{R}$ aquat'ilis. Water Crowfoot. In ponds and rivers. The white petals with a cavity at base. Only the flowers above water. Summer.

4 R. Pursh'ii. Pursh's Crowfoot. In stagnant water. The yellow petals witt a seale at base. Florting leaves, 3-5-parted. Spring. 
5 R. Flam mula. Spear-lexved C. Stems ascending (1-2f). Leaves all lanceo'ata narrow, entire, on sheathing stalks. Sum.

6 R. pusi1'lus. Tiny $C$. Stems nearly erect. Leaves ovate and lanceolate. Petale mostly but 3, with about 10 stamens. May.

7 R. rep'tans. Creepiny C. Stems creeping and rooting (4-8'). Leaves lance-lirear, and linear. Flower 1 at a node. July.

I R. Cymbala'ria. Boat $C$. Stems creeping and rooting (1 foot). Leaves all $\mathbf{r}$ suml cordate, crenate. Salt-marshes. June.

9 R. aborti'vus. Abortive $C$. Plant glabrous, 1-2f. high. Root leaves, roundcordate. Petals smaller than the sepals. Spring. c.

10 R. rhomboi'deus. Rhombic C. Plant hairy, bushy, 4-10' high. Root leaves rhombic-ovate. Sepals spreading. N. W.

11 R. palma'tus. Palm $C$. Stem hairy. Seeds with a straight beak in a round head. Leaves palmately 3-5-cleft, with sinus closed. South.

12 R. recurva'tus. Hook-seea! $C$. Stem hairy. Seeds with a recurved beak in a r(יוnd head. Leaves all similarly 3-parted. Flowers small. Spring.

13 R. scelera'tus. Villuinous $C_{\text {. }}$. Stem glabrons. Seeds not beaked, in an oblung head. Flowers small. Leaves palmately 3-5-parted. June, July.

14 R. bulbo'sus. Bulbous C. Erect $\left(6-12^{\prime}\right)$ from a solid bulı. Petals large Head of fruit round. Root leaves ternate. Spring.

15 R. Pennsylvan'icus. Bristly $C$. Erect (1-3f.), very hairy. IIead of fruit oblong. Leaves ternate. Summer.

16 R. repens. Large creeping C. Stems first ascending, then creeping. Flowerstalks furrowed. Petals obovate, large. Wet places. June.

17 R. fascicula'ris. Early C. Stem erect. Root fibres thickened. Flower-stalks terete. Petals narrow. Leaves appear pinnate. May.

18 R. acris. Tall Buttercup. Stem erect $(2-3 \mathrm{f}$.). Leaves palmately divided, and cleft. Petals roundish. Flower-stalk terete, calyx spreading. Summer. B. In the gardens, it becomes double-flowered.

\section{ADO'NIS. Pheasant's-eye.}

Sepals 5, colored. Petals 5-15, with no scale on the claws. Achenia in a spike, egg-shaped, and pointed with the hardened, persistent style. Leaves numerously cleft into linear and very narrow segments. Flowers terminal, solitary, red or yellow.

1 A. autumna'lis. Late $P h$. A fine, hard annual, from Europe, cultivated in gardens and naturalized in some places. Stem rather thick for its height, brancised Leaves pinnately parted, with very numerous segments. Petals 5-8, of a bright crimson color, $1 \frac{1}{2}$ ' across.

A verna'lis. Early Ph. Petals 10-12, oblong, yellow, d'sntate. Upper leaves sessile, all much divided. Flowers large. Spring. $\uparrow$ 


\section{CAL'THA. Marsh Marigold.}

Calyx colored, of 5 roundish sepals resembling petals. Corolla 0 . Stamens 00. Follicles 5-10, oblong, compressed, erect, many-seeded.-2f Smooth marsh plants.

C palus'tris. Cowslips. Marsh Marigold. In wet meadows. Root large, think. Stem about 1f. high, hollow, round, branched. Leaves large (4-6' wide), roundish, cordate, crenate-lower on long, half-round petioles, upper sessileall of a dark, shining green, and very smooth. Flowers of a golden yellow in all their parts, $1 \frac{1}{1}$ broad. Outer row of stamens club-shaped, long. Spring.

\section{COP'TIS. Gold-thread.}

Calyx of 5 or 6 oblong, colored sepals. Corolla of 5 or 6 small club shaped sepals, hollow and 1-lipped at top. Stamens 20-25. Follicles 510, stalked, beaked, spreading, 4-6-seeded.-2f Herbs with radical leaves, and long, creeping root-stocks.

C. trifo'lia. Gold-thread. Leaves 3-foliate, all radical, the divisions broad, 4-8" long, crenate, smooth shining, sessile. Petiole 1-2' long. Stems 'underground, creeping extensively, bright yellow, and very bitter. Peduncles $3-4^{\prime}$ high, each 1-flowered. Calyx white. Petals yellow, much smaller than the sepals, barely distinguishable among the stamens by their color. May.

\section{TROL'LIUS. Globe-flower.}

Calyx of 5,10 , or 15 concave sepals colored like petals. Corolla of 5-25 small, linear petals, which are tubular at base. Stamens many, much shorter than the sepals. Pods many, each many-seeded.-2f smontb, with palmately-parted leaves.

' T. laxus. American $G$. Sepals 5. Petals 15-25, shorter than the stamens. Grows in swamps, M. $r$. Calyx yellow, greenish outside. June.

2 T. Europæ'us. European G. Sepals 10-15. Petals 5-10. as long as the stamens. Flowers globular, bright yellow. †

3 r. Asiat'icus. Asiatic G. Sepals 10, orange-colored Petals 10, longer than stamens. $\dagger$

\section{AQUILE'GIA. Columbine.}

Sepals 5, ovate, colored, spreading. Petals 5, tubular with a wide mouth, the outer margin erect, the inner attached to the receptacle, and behind extended into a long, spurred nectary. Stamens $30-40$, the inner 
ones longer and sterile. Styles 5. Follicles 5, many-seeded.-24 Leares twice and thrice ternate. Flowers nodding.

1 A. Canaden'sis. American C. Spurs straight, longer than limb. Stamens exserted. Flowers scarlet.

A. vulga'ris. European C. Spurs ineurred, shorter than limb. Stamer.s inclrder'. Flowers purple. $\dagger$
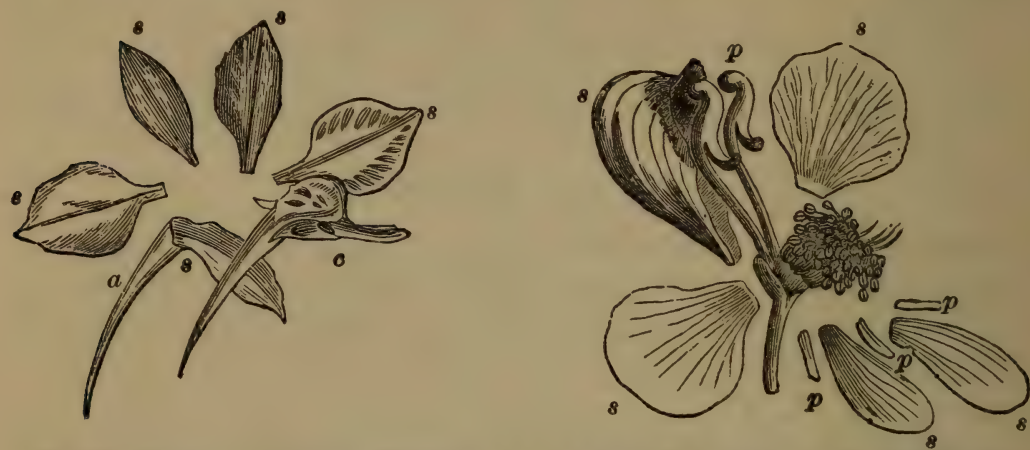

Fig. 372. Flower of Larkspur, displayed : $8, s, s, 8, s$, the five petals; $a$, the spurred sepal; c, the two petals, spurred, which spur was sheathed in the spurred sepal.

Fig. 373. Flower of Garden Aconite, displayed : $8, s, s, s, 8$, the five sepals; $p, p, p, p, r$, the Ave petsis.

\section{DELPHIN'IUM. Larkspur.}

Sepals 5, colored, the upper one spurred. Petals very irregular, the two npper ones extended behind into a tubular, honeyed spur, sheathed in the spur of the calyx. Styles 1-5. Follicles 1-5. - Showy herbs with the leaves much divided. Flowers blue, red, or purple, never yellow.

$\$$ Petals united into 1 piece. Pistil and pod $1 \ldots . .1,2$

$\S$ Petals 4, distinct. Pistils and pods $2-5 \ldots$ (a)

a Leaves many-parted into linear segments....8

a Leaves divided into 3-7 wedge-shaped lobes....(b)

b T'all $(2-5 f$. $)$, with slender, many-flowered racemes ....4, 5

b low $\left(6-18^{\prime}\right)$, with few $(6-12)$ flowered racemes....6-8

D. consol'ida. Field L. Fls. loosely scattered. Ovary smooth. Lvs. finely crit. (1)

D. Aja'cis. Rocket $L$. Flowers covering the branches. Ovary pubescent. Leave finely cut. (1) $t$

8 D. azu'reum. Azure L. Fls. in strict, slender racemes. Ovaries 3-5. 2 W. . D. exalta'tum. Tall Wild L. Leaf-lobes 3-5, curvate. Spur straight. M. Summer. 1 5 D. elatum. Bec L. Leaf-lobes 3-7, curvate. Spur curved downwards † 
6 D. tric'orne. Low Wild L. Leaf-lobes linear. Pods recurved. Height 6-12'. M. W.

7 D. vires'cens. Green-flowered $L$. Leaf-lobes lanceolate. Fls. greenishwhite. S. W.

S D. grandiflorum. Great-flowered L. Leaf-lobes $5-7$, linear. Fls. large, b. 1. 1

\section{ACONI'TUM. Monk's-hood. A'conite.}

Sepals 5, irregular, colored, upper one vaulted or hooded. Petals 5 uf 5 , the two uprer on long claws, concealed beneath the upper sepal, resurved and honeyed at top; the other 3 or 4 very small. Styles 3-5. Follicles $8-5 .-2$ Leaves palmately cleft or divided. Flowers odd and showy, in terminal spikes.

1 A. uncina'tum. Wild M. Stem reclining, widely branched. Helmet conical. M. S. 2 A. Napel'us. Garden $A$. Stem erect, nearly simple. Helmet semicircular. †

\section{THALIC'TRUM. Meadow Rue.}

Petals none. Sepals 4 or 5, petal-like, caducous, shorter than the stamens. Ovaries 4-15. Achenia either ribbed or inflated, short-beaked. if Leaves ternately compound, with stalked and lobed leaflets. Flowers in loose clusters, often imperfect, homely.

\$ Flowers diœcious, paniculate. Achenium subsessile.... Nos. 1-3.

$\S$ Flowers perfect, corymbous. Achenia long-stiped.... No. 4.

1 T. Cornu'ti. Common M. Stem tall (3-4f.), its leaves sessile (no common petiole) ; leafiets 3 -lobed, resembling those of Columbine; flowers white, in large panicles ; stamens clarate, erect. Meadows. June-August.

2 T. purpuras'cens. Purplish $M$. Leaves as in No. 1, but the leaflets are thick, firm, with rolled edges; flowers purplish-green; stamens drooping. Stems tall (3-6f.), purplish. Rocky woods and hills. May, June.

3 T. dioi'cum. Early $\mathbf{H}$. Leaves all petiolate, leaflets thin, glaucous, 5-7-lobed; flowers purplish-green, stamens drooping, capillary, none in the fertile fls. 1-2f. Hilly woodi. April, May.

T. clava'tum. Southern $\boldsymbol{M}$. Leaves all petiolate, biternate. Flowers white, fewer; stamens clavate; achenia 5-10, curved. Mountains, South.

\section{ACT 无'A. Baneberry.}

Sepals 4 or 6 , caducous. Petals 4-8, spatulate, long-clawed. Filaments slender. Ovary 1, with a sessile, 2-lobed stigma. Berry with a lateral furrow, many-seeded. 2f Leaves ternately divided, leaflets ovate, cutlobed and toothed. Flowers white, in a short raceme. 
1 A. spica'ta. Red B. Common in rocky woods, Can. to Penn. and W. Plant smooth 1-2f., bearing 2 or 3 large bi- or triternate leaves and a short terminal raceme. Petioles 4- $7^{\prime}$ long. Stems hollow. Pedicels slender, $9^{\prime \prime}$ long. Berries cherry-red, oval, 6". May.

2 A. alba. White $B$. Foliage the same as in No. 1. Stem solid. Raceme oblong, petain very slender. Pedicels in fruit as thick as the peduncle, red. Berries smaller :4-6”n milk-white, May.

\section{HYDRAS'TIS. Turmeric-root.}

Petals none. Sepals 3, petal-like, soon falling. Ovaries 12 or more, becoming a fleshy fruit resembling a raspberry. Acines 1- or 2-seeded. if Roots a tangled mass, yellow, sending up in spring a single radical leaf, and a stem which is 2-leaved and 1-flowered.

H. Canaden'sis. In damp woods, Can. to Car. and Ky., rare eastward. Leaves palmately 3-5-lobed. Flower terminal, reddish-white. Fruit crimson. May, June.

\section{Order II. MAGNOLIA'CEA. The Magnoliads.}

Trees and shrubs with membranous stipules sheathing the buds, with leaves alternate, leathery, simple entire, or lobed, never serrate; flowers solitary, large and showy, mostly odorous and perfect; sepals $3-6$, colored Jike the $6-12$ hypogynous imbricated petals; stamens numerous, hypogynous, distinct, and many ovaries; fruit compound, composed of the united carpels.

\section{Analysis of the Genera.}

$\$$ Pistils arranged in a cone....2

$\S$ Pistils whorled in a single row. Shrub. South.

2 Anthers opening inwards.

2 Anthers opening outwards.

Star Anise. Illio rum. MagNo'LIA. 1 LIRIODEN'DRON. 2

\section{MAGNO'LIA.}

Sepals 3. Petals 6-9. Anthers longer than the filaments, opening inwards. Carpels 2-valved, 1-2-seeded, imbricated into a hard, cone-like fruit. Seeds berry-like, suspended when ripe by a long seed-stalk.-A nuble genus of trees or shrubs, with large, fragrant flowers.

\& Native Magnolias, flowering with the leaves....a

8 Exotic Magnoliss, flowering before the leaves expand....8 
n Leaves acute at the base (not cordate)....b

a Leaves cordate or auriculate at the base. Trees $8^{n}-40$. high ....5-7

b Leaves shining above, white or rust-colored beneath. Putals $9-12 \ldots .1,2$

b Leaves dull green both sides, thin, deciduous. Petals $6-9 \ldots .3,4$

, M. grandiflo'ra. Big Luurel. 'Tree evergreen, 60-70f. high. Leaves thick, rust downy beneath. Flowers 8 or $9^{\prime}$ broad, white. S.

M. glauca. White Bay. Shrub deciduous, 6-25f. high. Leaves very smooth glaucous beneath. Flowers $2-3^{\prime}$ broad, cream-color. Swamps. †

3 M. acumina'ta. Cucumber-tree. Tree large. Leaves oval, acuminate, scat tered. Flowers small ( $3-4^{\prime}$ broad), petals obovate. M. S.

4 M. umbrel'la. Umbrella-tree. Tree small (20-30f.). Leaves wedge-lanceo late, whorled, very large, as well as the flowers. M. S.

5 M. corda'ta. Yellow Cucumber-tree. Petals 6-9, yellow, with reddish lines. Lvs. broad-orate, slightly cordate. Flowers $4^{\prime}$ broad. S.

6 M. Fra'seri. Ear-leaved M. Petals 6, pure white. Leaves ear-shaped at basc, cbovate-spatulate, near 1f. long. Spring. S.

7 M. macrophyl'la. Great-leaved M. Petals 6, white, each 6-8' in length. Leaves 2-3f. long, obovate-spatulate, cordate. Tree 30-50f. high. S. W. †

8 M. conspic'ua. Yulan. Flowers in Spring, large, rose-colored or white, with 6-9 petals or sepals, nearly erect. Japan.

\section{LIRIODEN'DRON. Tulip-tree.}

Sepals 3. Petals 6, in two rows. Anthers opening outwards. Carpels 1-2-seeded, imbricated into a cone, indehiscent, separating from each other in fruit.-Trees with large and fragrant flowers.

L. tulipif'era. Tulip-tree. Whitewood. Poplar. This is one of the finest and largest trees of our forests. The trunk is generally straight and cylindric, dividing at the top rather abruptly in a few coarse and crooked branches. Leaves dark

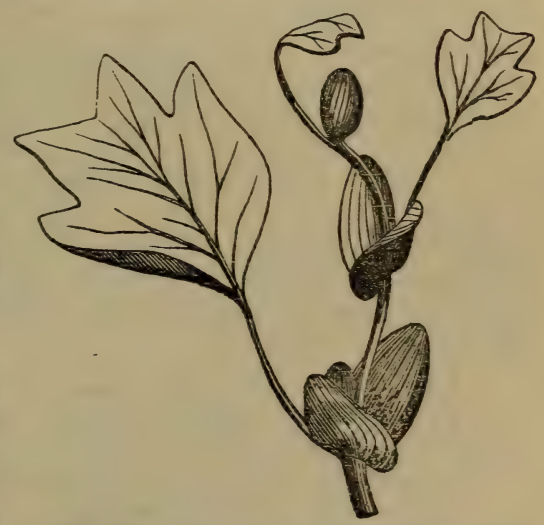

Fig. 374. Young branch of Tulip-tree, unfold. ing from the bud: 8,8 , stipules. green, smonth, square at the end, with 2 lobes each sid?, 3-5' in length and breadth. Flowers large and elegant, grecnish-yellow, orange within, 4-6* broad. May, June. 


\section{ORDER III. CALYCANTHACEE. Calycanths.}

Shrubs with opposite leaves, destitute of stipules. Flowers axillary, solitary, all the organs $\infty$ and arranged as in the following genus.

\section{CALYCANTHUS. Sweet-scented Shrub.}

Sepals and petals similar, imbricated on the tubular torus, which bears the short stamens on its top, the distinct achenia within, and becomes fleshy but green in fruit. Leaves entire. Flowers brown-purple, with the fragrance of strawberries. The species are native South. AprilJune.

1 C. flor'ida. Garden Shmub. Leaves oval-elliptic, some pointed, downy beneath: scpals and petals about 20 , near $1^{\prime}$ long. Shrub 4-8f.

$2 \mathrm{C}$ læviga'tus. Smooth $S$. Leaves thin, oval, smooth and green both sides.

3 C. glaucus. Glaucous $S$. Leaves ovate, acuminate, glaucous beneath.

\section{ORDER IV. ANONACEA. Anonads.}

Trees or shrubs with entire alternate leaves and no stipules;

flowers, green or brown, axillary, polyandrous, hypogynous, valvate;

8epals 3, petals 6 , in two circles; pistils several or many;

fruit fleshy or pulpy, of separate or united carpels, $\infty$ - seeded.

\section{ASIM'INA. Papaw. Custard Apple.}

Outer row of petals larger. Stamens densely packed in a round mass. Pistils several, distinct, but few ripening and becoming large, oblong, pulpy fruits, with many flat seeds. Fls. solitary, brownish. We have only one species at the North.

* Flowers appearing before the leaves. Petals purple..... Nos. 1, 2.

* Flowers appearing with the leaves. Outer petals yellowish.... Nos. 3, 4.

1 A. tril'oba. Common Papaw. Leaves obovate-oblong, acuminate ; petals dark-purple the outer roundish, 3 or 4 times as long as the sepals.-A small handsome tree 10-30f. high, along streams, Middle, Western and Southern States. Leaves 8 to $12^{\prime}$ long, very smooth, on short stalks. Flowers $1^{\prime}$ broad. Fruit about $3^{\prime}$ long, and $1^{\prime}$ thick, yellowish, fragrant, eatable, ripe in October. (Fig. 70.)

8. parviflo'ra. Small-flowered $P$. Leaves obovate-oval, abruptly pointed; petals oval, green-purple, the outer hardly twice longer than the sepals. Dry soils. South. Shrub 2-3f. Leaves about $6^{\prime}$, flowers half an inch wide.

A. grandiflo'ra. Large-flowered $P$. Leaves obovate-oblong, obtuse, grayish-tomentouf ; outer petals very large (2' long), yellowish-white. Ga., Fla. 2-3f. March-April.

- A. pigmæ'a. Pigmy P. Leaves thick, evergreen, narrow, obtuse, smooth ; outer petald many times longer than the sepals, pale yellow. Shrub, 6-12'. S. 


\section{URDER VI.-BERBERIDACE E. The Berberids.}

Herbs and shrubs, with alternate leaves and perfect flowers, with sepals imbricated in the bud in 2 or more rows;

vetals opposite the sepals, also imbricated in two or more rows; stamens opposite to the petals, the anthers usually opening by two lids; coary 1-celled, solitary and simple, forming a capsule or berry.

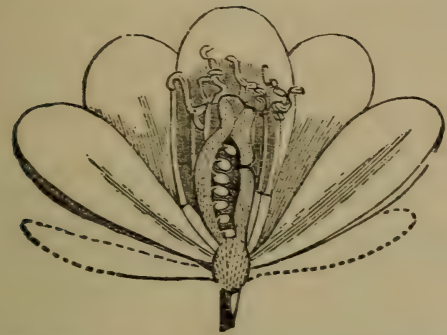

Fig. 375. Section of the flower of Jeffersonia.

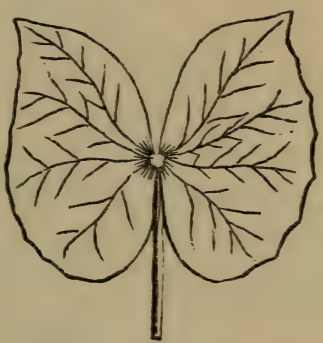

Fig. 376. A leaf of the same.

\section{Analysis of the Genera.}

$\S$ Herbs, anthers opening by two valves hinged at top..... a

$\S$ Herbs, anthers opening by 2 slits lengthwise....b

$\S$ Shruhs, with yellow flowers and acid berries.

a Stamens 6. Fruit 2, drupe-like, soon-naked seeds.

BER'BERIS. 1

a Stamens 6. Fruit a 2-4-seeded berry.

a Stamens 8. Fruit a capsule opening by a lid.

Umbrella-leaf. Diphyllei'a.

b Stamens 9-18. Flower 1, with 2 leaves.

Twin-leaf. JeFFERSO'NIA. 2 May Apple. Podopart'suצ. 3

1. BER'BERIS. Barberry.

Sepals 6, obovate, colored, the 3 onter ones smaller. Petals 6 , round1sh, with two glands at the base of each, inside. Stamens 6 . Stigma sessile, disk-like, on the top of the ovary. Berry oblong, sour, 1-celled, 2-3-seeded.-Fine, hardy shrubs, with the wood, inncr bark, and flowers yellow.

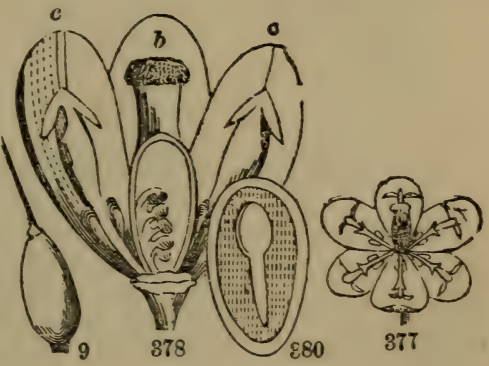

Fig. 377. $a$, Flower of Berberia vulgaris; $\iota$, the pistil (magnified), with the ovary cut opes c, c, petals with ktamens opposite; 0 , s berry ; 380 , a seed cut open, showing the emil.ryi. 
I B vulga'ris. Common Barberry-bush. A well-known, bushy, handsome shrub, in hard soils. Grows 3-8f. high. Leaves oval, near $2^{\prime}$ long, rounded-ohtuse at spex, tapering to a petiole, with bristly serratures on the margin Flowers yellow, a dozen or more in each hanging raceme, with entire petals. Stamen irritable, springing against the stigma when touched. Berries red, very June.

B. Aquifo'lium. Holly-leaved $B$. Leaves pinnate, of 7-13 thick, spiny-tootl ed leaflets. Shrub $3-5 f$. high. Cal. $\dagger$

\section{JEFFERSO'NIA. Twin-leaf.}

Sepals 4, colored, caducous. Petals 8 , spreading. Stamens 8 , with (inear anthers. Pod on a short stipe, opening by a lid. $-2 f$ Flowers and eaves from the root. Scape 1-flowered. (Figs. 375, 376.)

i. diphyl'la. Twin-leaf. A very curious plant, acanlescent. Leaves each with two hlades, about 1f. high. Flowers same height, white. Root-stock black, with a thick mass of fibres, supposed good in rheumatism. M. W.

\section{PODOPHYL'LUM. Mandrake.}

Sepals caducous. Petals $6-9$, obovate, concave. Stamens 12-18, with inear anthers, the lids scarcely opening. Berry large, egg-shaped, 1-celled, crowned with the solitary stigma.-Low, somewhat poisonous herbs, with one ur two leaves and one flower.

P. pelta'tum. May Apple. Wild Mandrake. A singular and interesting plant, in woods and fields. Height about 1f. The barren plants bear but a single leaf, which is $5-8^{\prime}$ broad, $5-7$-lobed, and centrally peltate. The flowering plants have a pair of leaves, with the flower at the fork of the two petioles-the leaves not peltate, but with a deeply-hollowed base, about 7-lobed. Flower drooping, white, about $2^{\prime}$ across. Fruit yellowish, witk the flavor of the Strawberrv. Mxy.

\section{Order VIII.-NELUMBIACEA. The Water-beans.}

Herbs aquatic, prostrate root-stock, and radical, peltate leaves, with flowers large, solitary, on long, upright scapes, 4 or 5 -sepaled; petals numerous, arranged in many rows, as are also the many stamens; ovaries separate, each with a simple style and stigma, becoming in fruit 1-seeded nuts, half sunk in the hollows of the very large torus, the seeds with a very large embryo and no albumen. 


\section{NELUM'BIUM. Nelumbo.}

The character of the genus the same as that of the order.

v luteum. Yellow Nelumbo. A magnificent flowering plant, frequent in the stag nant waters of the South and West, rare in N. Y. and Conn. The leaves are 1-2f. broad, round, entire, peltate in the centre, which is concave, and elevated above the water more or less on the long petioles. Flowers several times larger than the White Water Lily, but without fragrance. Petals concave, of s brilliant white at edge, becoming yellow towards the base. Nuts (called Water-beans) about as large as acorns, eatable. June, July.

\section{Order IX.-NYMPHAACE. Th. The Water Lilies.}

Her3s aquatic, with roundish leaves from a prostrate rhizoma; flowers large and showy, the sepals, petals, and stamens gradually passing

into each other, imbricated and arranged in many rows ; sepals few, colored inside, persistent; stigmas radiating and crowning the ovary, which in fruit becomes a capsule compound and 5-celled; seeds minute, numerous, with the embryo at the end of the albumen.

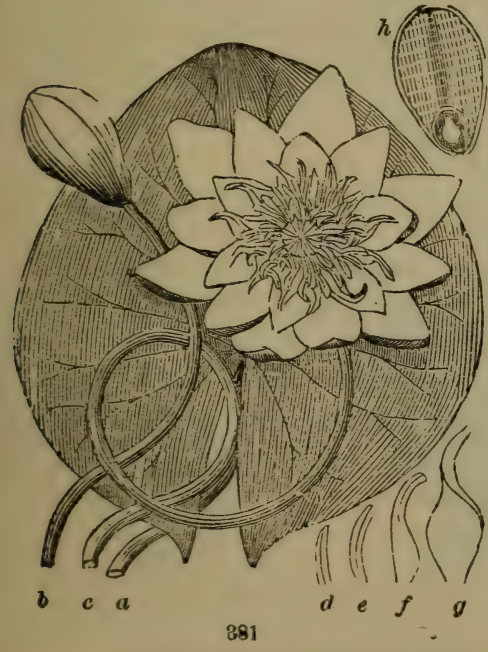

\section{Analysis of the Genera.}

Petals large as the sepals, white, red, or blue.

NYMPHEA, 1

Petals smaller than the sepals, stamenlike, yellow. Frog Lily. Nuphar.
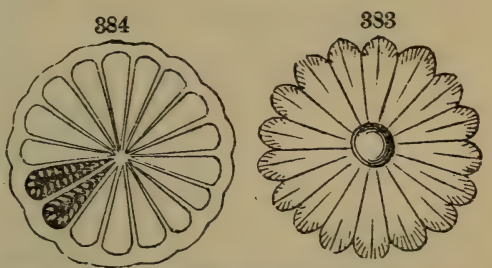

Fig. 381. Nymphæa odorsta: $a$, the leaf; o the flower: $b$, the bud; $d, e, f, g$, stamens grad ually changing into petals; $h$, a seed cut open. showing the embryo in a little sac. Fig. 383 , the many-rayed stigma ; 384 , cross-section of t/u many-celled ovary 


\section{NYMPH $E^{\prime} A$. Water Lily.}

Sepals 4 or 5 , green outside. Petals in many rows inserted on the receptacle beneath the ovary. Stamens inserted above the petals. Anthers slender, opening inwards, the outer filaments gradually widening and pass. big into petals. Capsule ripening under water.

W odora'ta. Whit Water Lily. One of the loveliest of flowers, frequent in pond and sluggish streams. The root-stock is long and thick, running in the mui where the water is from 3-10f. deep, sending up leaves and Howers to the surface. Leaves $5-6^{\prime}$ long, roundish, cleft at the base to the centre, where the lons retiole is inserted, margin entire. Petals lanceolate, $1 \frac{1}{2}-2^{\prime}$ long, of the most delicate texture and whiteness, often tinged with purple. Filaments yellow. July.

\section{ORDER X. SARRACENIACEA The Water-pitohers}
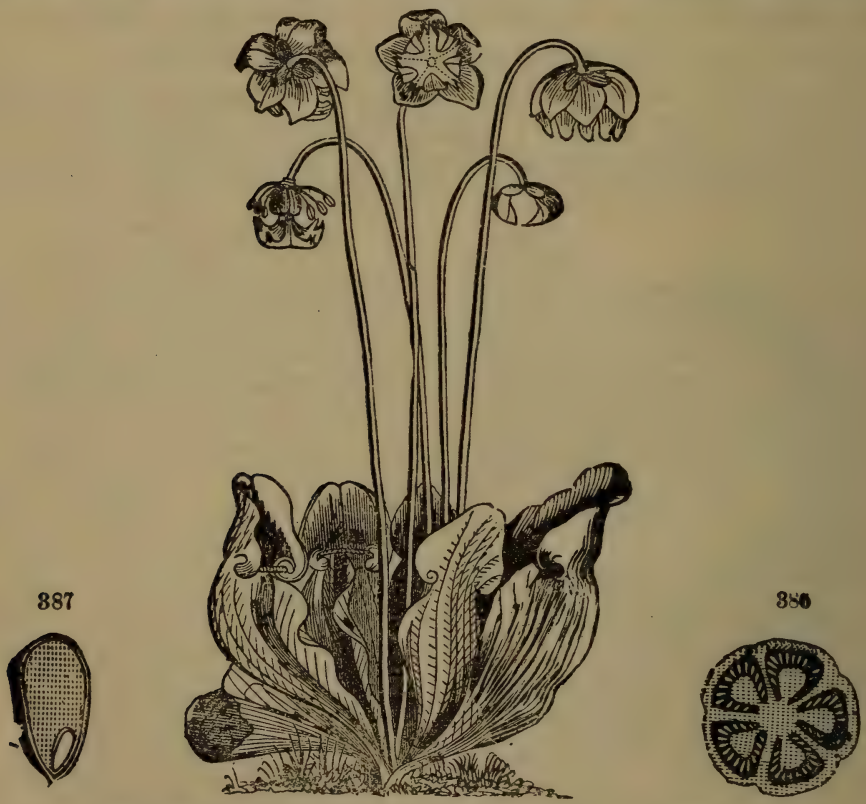

Fig. 385. Sarracenia purpurea, with bud, flower, and fruit.

Pig. 386. Section of the 5-celled ovary.

Fig. 337. A seed (mag nifled), with small smbryo and large albumen 
Horbs aquatic, in bogs, with fibrous roots, and with the 'eaves all radical, urn-shaped, hollow, and large flowers on scapes; repals 5, with 3 little bracts at base; petals 5, clawed, incurved; stamens hypogynous; ovary 5-celled, with a single style, the stigma very broad, peltate, and 5-angled, crowning, in fruit, the capsule, which is 5-celled and full of minute, albuminous seeds.

\section{SARRACE'NIA. Pitcher-plant. Trumpet-leaf.}

Character essentially as expressed in the order. Nos. 2, 3, 5, 6, are vrobably varieties, not species.

Leaf-blade inflected over the throat of the tube...7, 8

I Leaf-blade erect, cr nearly erect; throat of the tube open... $z$

a Leaf-tube pitcher-shaped, with a broad wing....1-3

a Leaf-tube trumpet-shaped, with a narrow wing....4-6

- s. purpu'rea. Purple Pitcher-plant. Flowers purple. Leaves all inflated alike, dark green with purple veins, $6-9^{\prime}$ long. Scapes 1-flowered, 1-2f. high, June.

2 S. Leterophyl'la. Yellow Pitcher-plant. Fls. yellow. Lvs. pale, the outer slendi- Jn.r.

S. ala'ta. Narrow-roinged $P$. Fls. yellow. Lrs, all more sleuder than in No. 1. S.-W.

4 S. (Grono'vii) flava. Yellow Trumpet-leaf. Flowers yellow. Leaves 18-36' high, all yellowish green, veins not purple.

5 S. rubra. Red Trumpet-leaf. Fls. reddish purple. Lvs. (1-2f.) purple-veined. S.

6 S. Drummondii. Drummond's T. Fls. purple. Lvs. $\left(18-36^{\prime}\right)$ mottled with colors. S. 7 S. psittacina. Parrot's Pitcher-plant. Fls. purple. Lvs. $\left(3-5^{\prime}\right)$ spotless, hooded. S. 8 S. variolaris. Mottled $P$. Flowers yellow. Lvs. $\left(12-18^{\prime}\right)$ spotter with white. S

\section{Order XI. PAPAVERACEE. The Poppyworts.}

Herbs, generally with a colored juice, with alternate leaves;

flowers on long peduncles, solitary, never blue;

sepals 2 or 3 , falling off when the flower expands;

petals generally 4 , sometimes 8 ; stamens $4,8,12,16$, or 20 , \&c. ;

stigmas 2, or if more, star-like on the flat apex of the compound ovary ;

Pruit a pod-shaped or roundish capsule; seeds numerous and minute.

\section{Analysis of the Genera.}

q Plants with a yellow juice. Petals yellow, crumpled in bud....a

a Stigmas and placentæ 3,4 , or 6 . Capsule ovoid....c

a Stigmas and placentæ 2 only. Capsule long, pod shaped.... 
I Plants with an orange-red juice.

Bloodroot. Sanguina'ria. 1

I Plants with a milk-white juice.

Poppy. Papa'ver. \&

I Plants with a colorless juice. Calyx a cap, falling off whole.

Petals 4, orange-yellow. Lvs. dissected. California Poppy. Esouscnolt'zis

b Pjd 1-celled, smooth. Leaves pinnately divided. Fls. yellow.

Stamens 24-32, shorter than the 4 petals. Celandine. Crelino'nium

3 Pod 2-celled; rough. Leaves palmate. Stig. 2-horned. Horn Poppy. Glau'cium

c Style present, stigmas 3 or 4. Stem lvs. 2, opposite. Yellow Poppy. Meconor'sis

e Style none, stigmas 4 or 6 . Stem lvs. alternate. Prickly Poppy. A RakMo'ng

\section{SANGUINA'RIA. Bloodroot.}

Sepals 2, caducous. Petals 8-12, the outer longer. Stamens about 24. Stigma sessile, 1 or 2-lobed. Capsule pod-like, oblong, 1-celled, 2-valved, acute at each end, and many-seeded.- 2 A low, acaulescent plant, with white flowers, and full of a red or orange-colored juice.

S. Canadensis. Bloodroot. An interesting plant, in shady, rich soils, flowering in early spring. Rhizoma thick, fleshy, and when broken or wounded exudes a blood-colored juice, as does every other part. From each joint of the root-stock springs a single large glaucous leaf, and a scape about $6^{\prime}$ high, bearing a single flower. Leaf kidney-shaped, with lobes separated by rounded sinuses between. Flower of a square outline, white, scentless, and of short duration.

Fig. 388. Sanguinaria Canadensis: $b$, the pod; $c$, cross-scction of it; d, seed sut open, showing the embryo.

\section{PAPA'VER. Poppy}

Sepals 2, caducous. Petals 4. Stamens 00. Stigmas many, united into a star-like crown, sessile upon the thick ovary. Capsule 1-celled, opening by pores beneath the edges of the stigma. Exotic herbs, mostly $\odot$, with

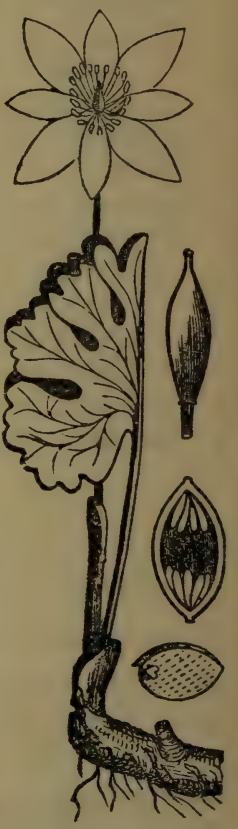

388 s milk-white juice abounding in opium.

* Bristly or hairy. Leaves pinnatifid. Flowers scarlet...2, 3

- Smontl, glancous. Leaves cut-trothed, clasping. Flowers white .1 
1. P. somnif'erum. Opirm P. Fls. large, often double. $\dagger$ Summer.

2 P. droium. Simall Red P. Pod club-shaped, smooth. Leaves coaretly divided. Flowers light red, smaller than in No. 1. M. S. Summer.

2 P. Rheas. Corn P. Pod globular, smooth. Leaves more finely divided Flowers large and brilliant, deep scarlet, often double. $†$ Sum

\section{Ordar XII. FUMARIACEA. The Fumeworts.}

Herbs smooth and delicate, with brittle stems and watery juice; leaces usuaily alternate, many cleft or compound;

floucers irregular, purple, white or yellow; sepals 2, very small;

petals 4, more or less cohering, one or both of the outer saccate, the two

inner inclosing the anthers in their coherent tips;

stamens 6 , in 2 sets of 3 in each; pistil 1 ; pod 1-celled.

\section{Analysis of the Genera.}

* Corolla equally 2-spurred or 2-saceate at base....a

- Corolla unequal, only 1 of the petals spurred....b

a Petals slightly united or distinct, deciduous. Not climbing. DrCEN'tra. 1

a Petals firmly united, persistent. Plants climbing. Mountain Fringe. AdL'MIA.

b Ovary with several seeds, forming a slender pod. Corydal. Coryd'alis. 2

b Ovary with 1 seed, beconing a globular nut.

Fumitory. FUMA'RIA.

\section{DICEN'TRA. Ear-drop.}

Sepals 2, very small, sometimes disappearing. The 2 outer petals alike, saccate at base, with spreading tips; the 2 inner alike, spoon-shaped. meeting face to face over the stamens and pistils. Filaments flat, separate or not. Middle anther of each set 2-celled, the outer 1-celled. Pod many-seeded. $-2 f$

$\S$ Low herbs $\left(6^{\prime}\right)$, with white flowers in simple racemes.... 1, 2

¿ Taller (1-2f.), with purple flowers racemed or panicled $\ldots .3,4$

I D. enculla'ria. White Ear-drop. Root bulb-like. Spurs of the flowers divergent acute, straight. Flower nearly as broad as long. Spring.

: D Canaden'sis. Squrrel-corn. Root bearing yellow tubers as large as peas. Fls much longer than broad, spurs rounded, incurved. May, Jn.

s D. exim'ia. Wild Purple Ear-drop. Racemes paricled. Flowers obloug with very short blunt spurs. Sepals manifest. M. S. $\dagger$

8 D. spectab'ilis. Chinese $E$. Raceme simple. Flowers nearly as broad as long $\left(1^{\prime}\right)$, very fine and showy; sepals nbsolete. + 


\section{CORYD'ALIS. Corydal.}

Sepals 2, very small. Petals 4 , one of which is spurred at base. Fila ments with broad bases united into 2 sets, sheathing the ovary. Pod 2 . valved, slender, many-seeded. Leaves twice ternate, on the stem. In rocky places. Spring.

C. glau'ca. Pink C. Erect. Fls. pink-yellow, panicled. Leaf-lobes obtuse. (3)

c. au'rea. Golden C. Diffuse. Fls. yellow, racemed. Leaf-lobes acute. (D)
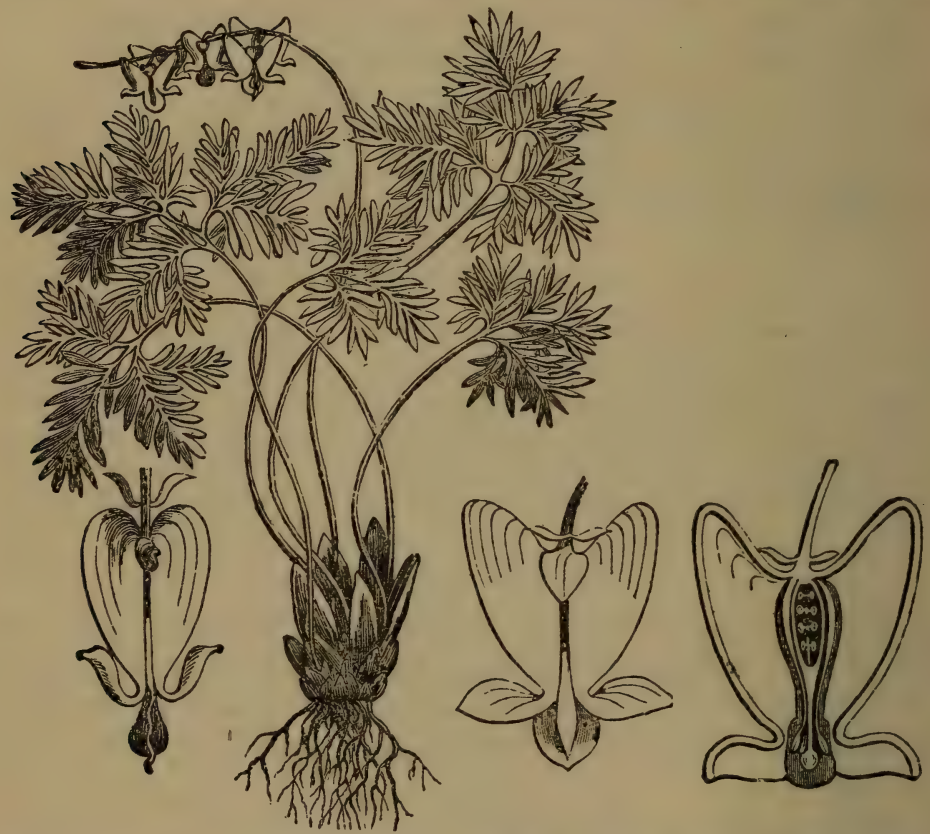

Fig. 359. Dicentra cucullaria, entire plant. Fig. 390. Enlarged view of a flower. Fig. 391. A antion of the same. Fig. 392. A flower (enlarged) of D. Cansdensis.

\section{ORDER XIII. CRUCIFERA. The Crucifers, or Mustardworts.}

Zerbs with alternate leaves and no stipules, and regular flowers, with sepals 4 and petals 4 , spreading in the form of a cross; 
stamens 6, 2 of them on opposite sides shorter than the rest; an ovary of 2 united carpels, forming in fruit a silique or silicle, with 2 cells and few or many seeds ; seeds without albumen, the large embryo variously bent and folded.

Nоте.-Under this large Order, as under others, we present to our young readers a complete snalysis, by which they may trace to its genus any Mustardwort growing in the United States. But as the genera are so nearly alike, great care and close observation will be needful in avoiding mistakes. The piants for examination must bs in fruit as well as in flower.

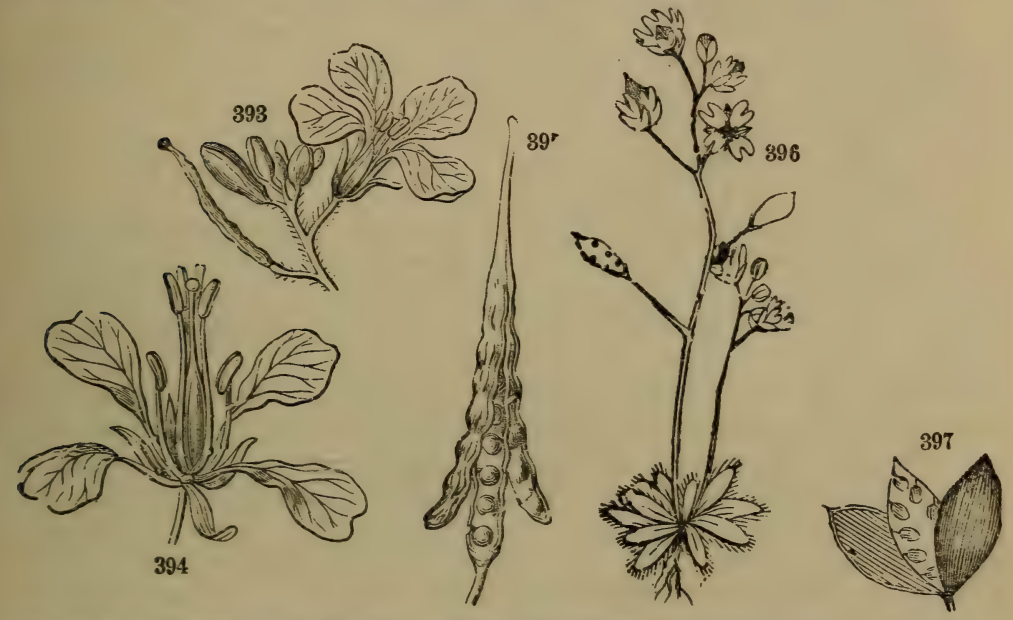

Fig. 393. Flower of White Mustard. Fig. 394 Same, with its parts separated. Fig. 395. A silique, ripe and open. Fig. 396. Iraba verna. Fig. 397. A pod open.

\section{Analysis of the Genera. \\ * Garden plants cultivated for ornament or art}

1 Fruit a silique or long pod $(\S 363) \ldots, .5$

1 Fruit a silicle or short pod $(\$ 364) \ldots .2$

2 Silicle 2-celled, with 2 or more seeds....3

2 silicle 1-celled, with one seed only.

8 Petals all equal....4

3 Petals unequal, the 2 outside ones larger.

4 Son:e of the stamens toothed. Gardens.

Woad. Isa'ris.

- Stamens all toothless. Silicles very large and thin.

Candy-tuft. IBE'RTs. 1

Madwort. Alys'sum.

5 Seeds flat. Stigmas 2-horned, spreadiug. Satin-flower. LUNA'RIA.

5 Seeds egg-shaped. Stigma with 2 converging lobes.

Stock. Matthi'ola.

Rocket. Hes'PERIs 


\section{** Plants growing vild, or cultivated for fuod}

1 Fruit a silique, 2-celled lengthwise, $\left\{\begin{array}{l}\text { flowers yellow ....8 } \\ \text { flowers white, purple, \&c.... } 6\end{array}\right.$

1 Fruit a silicle, 2-celled lengthwise, $\left\{\begin{array}{l}\text { flowers yellow ....5 } \\ \text { flowers white, purple, \&c....2 }\end{array}\right.$

1 Fruit a jointed pod, with the partitions crosswise....11

3 Silicle flattened or turgid, with a broad partition....4

2 Silicle flattened contrary to the narrow partition.....3

3 Silicle triang., seeds several in each cell. Shepherd's-purse ('APsel'́n.

3 Silicle roundish, with one seed in each cell. Pepper-grass. LePID'IUM. 1

3 Silicle double, with one seed in each lobe. S. Swine Cress. SEnebie'ra. 5

4 Silicle flattened. Leaves cauline or radical. Whitlow-grass. Draba. 6

4 Silicle turgid. Leaves cauline.

4 Silicle turgid. Leaves all raäical.
Horse Radish. ARMORA' CIA

r. Awlwort. SUbUla'ria.

5 Silicle obovoid, i.e., inversely egg-shaped, turgid. False Flax. Cameli'na.

5 Sil. globose, turgid, membranous. Style long. Bladder-pod. Vesica'RIA.

5 Silicle oblong, turgid, and somewhat terete. Cress. NAstur'tium.

6 Seeds arranged in two rows in each cell, not winged. Cress. Nastur'tium.

6 Seeds in two rows in each cell, wing margin. Tover-mustard. TUR'RITIS.

6 Seeds arranged in a single row in each cell....7

7 Sil. linear, flattish, each valve with 1 central vein.

7 Silique lanceolate, flat, the valves veinless.

7 Siliques linear, veinless, terete. Flws. purple.

7 Siliques linear, veinless, flat. Fls. whitish. Cuckoo-flower. C'ARDAMI'NE. 9

8 Sceds ovate or oblong....9

8 Seeds globose....10

8 Seeds flat, with a broad, winged margin. S.

LEAVENWORTH'IA.

9 Calyx $\frac{1}{2}$-open. Lvs. runcinate, or finely dissect. Hedge-musturd. Sisyu' вriom.

9 Calyx closed. Leaves lyrate-pinnatifid. Winter Cress. Barba'rka. 10

9 Calyx closed. Leaves lanceolate. False Wall-flower. ERrs'ruUm. 11

10 Calyx spreading. Valves of the pod 1-3-veined. Mustard. Sina'PIs. 12 .0 Caly $x$ mostly erect. Valves of the pod 1-veined. Cabbage, dec. Bras'sica.

11 Pods short, 2-jointed, with 1 seed in each joint. Sea-rocket. Cani'́ris.

11 Pods with several transverse joints and cells. Radish. RaPH'AnUs.

\section{IBE'RIS. Candy-tuft.}

The two outside petals larger than the two irside ones. Pods flattened truncate, emarginate, the cells one-seeded.--Foreign, ornamental plants.

1 Flowers white. Plain abont 1f. high....2-4

1 I. umbella'ta. Purple C. Fls. purple, in umbels. Lvs. serrate, upper entire. 2 I ama'ra. Bitter $C$. Corymbs lengthening into racemes. Lvs. sligatly tooth sd. 5 I. pinna'ta. Wing-leaved $C$. Corymbs scarcely lengthening. Leaves pinnatifid.

I I. saxat'ilis. Rock C. Corymbs not lengthening. Shrubby. Lvs. linear, entire. 


\section{LUNA'RIA. Satin-flower.}

Sepals somewhat 2-lobed at base of the flower. Petals nearly entire. Staniens without teeth. Silicle oval or lanceolate, flat, usually very large, with a stalk. Seed-stalk adhering to the partition.-Foreign, ornamental plants.

L. redivi'va. Perennial S. Pods lanceolate, narrowed to each end. Lrs. sharp toothed. 2 .

I bien'nis. Biennial S. Pods broad-oval, rounded at each end. Lvs. blunttoothed. (2)

\section{CAPSEL'LA. Shepherd's-purse.}

Calyx equal at base. Silicles triangular, wedge-shaped at base, notched at top, compressed laterally, that is, contrary to the narrow partition. Valves boat-shaped. Style short. Seeds 00, oblong, small.-A common weed, with white flowers.

C. Bursa-Pasto'ris, Shepherd's-purse. Found everywhere, in fields, pastures, and road-sides. Stem growing to a foot in height, hairy below, branching. Root leaves many (when the plant has room), half a foot long, deeply-lobed and toothed. Stem leaves much shorter, with two ear-shaped stem-clasping lobes at base. Flowers very mall, in racemes which become very long, and are suc. ceeded by the little purse-shaped pods. Apr.-Sept. (See Fig. 331.)

\section{LEPID'IUM. Pepper-grass.}

Sepals ovate. Petals ovate, entire. Silicles roundish or oval, notched at the enil, flattened contrary to the very narrow partition. Cells 1 -seeded. Valves boat-shaped, dehiscent. Flowers white, racemed, numerous.

1 Stem leaves undivided. Flowers from June to Sept...2

1 I sativum. Leaves all divided and lobed. Pods round. Gardens. July. 2 L Virginicum. Tongue-grass. Pods round, wingless. Stem leaves toothed. 8 I rudera'le. Pods roundish-oval, wingless. Petals 0 . Stem leaves entire. W. I I campes'tre. Pods orate, winged, rongh-scaly. Leaves arrow-shaped. W

\section{SENEBIE'RA, Swine Cress.}

Silicle 2-lobed, appearing double. Valve somewhat turgid and inde hiscent. Cells each with 1 roundish and 3-cornered seed. Flowers white, in short racemes which stand opposite to the leares. 
S. pinnatif'ida. A prostrate, weed-like plant, common at the South, in fields and so river-banks. Leaves divided in a pinnate manner, into oblong, toothed lobes. Flowers obscure, with scarcely any petals. Silicles flattened, notched at apex, wrinkled on the surface. Feb.-July.

\section{DRA'RA. Whitlow-grass.}

Calyx equal at base. Petals equal. Filaments without teeth. Silicle val-oblong, entire, flattened parallel to the broad partition. Cells 2, many-seeded. Seeds not margined.-Low herbs, with small white or yoliow flowers in racemes. (See Fig. 396.)

$\S$ Petals 2-cleft, white. Leaves all radical....1

$\&$ Petals entire or merely notched. Stems more or less leafy..... a

a Style present. Plants perennial....2, 3

a Style none. Plants annual or biennial....b

b Pedicels as long or longer than the pod....4, 5

b Pedicels shorter than their pods....

1 D. verna. Spring $W$. Leaves oblong, hairy. Scape $1-5^{\prime}$ high. (1) (See Fig. 396.) 2 D. arabi'sans. Rock $W$. Leaves minutely toothed. Silicle twisted, longer than the pedicel, ohlong-lanceolate, 4-6" long. Lake shores. (Figs. 155-159.)

8 D. ramosis'sima. Bushy $W$. Leaves with remote and slender teeth. Silicle as long as its pedicel, style half as long. Flowers white. Kocks.

4 D. nemora'lis. Wood $W$. Petals notehed at end. Pod half as long as ita pedicel. Seeds near 30. Flowers yellowish-white. N-W.

4 D. brachycar'pa. Short-fruited $W$. Petals entire. Pod as Jong as pedicel, 10-12-seeded. Leaves round-ovate. S. W. March, April.

5 D. Carolinia'na. Leaves round-ovate, entire. Pods linear, in a عort of corymb. Flowers white. Plant hispid, 1-3' high. E. S. April-June.

G D. cuneifo'lia. Wedye-leaved $W$. Leaves wedge-oblong. P'ods lance-oblong, 2030 -seeded, racemed. Plant $3-8^{\prime}$ high. S-W.

\section{AR'ABIS. Rock Cress. Sickle-pod.}

Sepals erect. Petals clawed, entire. Silique linear, flattened, valves one-veined in the middle. Seeds in a single row in each cell. Flower white. April-June.

$\S$ Leaves all (or at least the radical) pinnatifid....1, 2

Leaves all undivided; toothed or entire, often clasping ..... a

- Siliques short (6-12") and straight. Seeds not winged....3, 4

a Siliques longer $\left(1-2^{\prime}\right)$, straight or curved. Seeds not winged....5, 6

a Siliques long $\left(3^{\prime}\right)$, curved, hanging. Seeds winged....7, 8 
1 A Indovicia'na. Lonisiana $R$. All the leaves feather-cleft. Seeds bordered. Plant slender, 6-10' high. S. Mar., Apr.

2 A. lyra'ta. Lyre-leaved $R$. Only the root leaves feather-cleft. Seeds not bordered. Plant 6-12' kigh. Pods $1+2^{\prime}$ long.

8 A. Thalia'na. Mouse-ear $R$. Stems erect. Leaves nearly entire. Petals twice longer than the sepals. Pods erect. Plant downy. May.

1 A denta'ta. Toothed $R$. Stems diffuse. Leaves sharply toothed. Petals scarce loliper tha: sepals. Pods spreading. Rough. M. W.

5 A. patens. Patent $R$. Downy. Pods spreading and curved upwards, beaked with a distinct style. $w$. W. S.

6 A. hirsu'ta. Hairy R. Plant hairy. Siliques straight, erect. Style uvne. Leaves arrow-shaped. Fls. g.

7 A. læviga'ta. Smooth Sickle-pod. Stem leaves arrow-shaped, clasping, narrow. Pod spreading. Plant glabrous, 2f. high.

8 A. Canaden'sis. True Sickle-pod. Stem leaves pointed at both ends, sessile. Por eurved, pendulons. Tall, downy.

\section{DENTA'RIA. Tooth-root. Pepper-root.}

Sepals converging or closed. Silique lanceolate, with flat, veinless valves opening elastically. Seeds in a single row in each cell, ovate, not bordered.-Plants 2 . Rhizoma prostrate, jointed. Stem leaves but 2 or 3. Flowers white or purplish.

Tा Stem leaves almost opposite or whorled... 1, 2, 3

I Stem leares alternate or scattered. Root-stock moniliform....4, 5

1 D. diphyl'la. Two-leaved $P$. Stem leaves 2 only, leaflets 3 , ovate, toothed.

2 D. lacinia'ta. Cut-leaved $P$. Stem leaves 3, leaflets 3-5, linear, eleft.

3 D. multif'ida. Stem leaves $2-3$, numeronsly divided into linear leaflets. S.

4 D. max'ima. Leaflets 3, ovate, cut and cleft. Lrs. 3-7. Fls. purple. M.

5 D. heterophyl'la. Lflts. 3 , nearly entire; of the rt. lvs. round-ovate, toothed

\section{CARDAMI'NE. Bitter Cress.}

Calyx a little spreading. Silique linear, with flat, veinless valves which are narrower than the partition. Stigma entire. Seeds not margined. with a slender seed-stalk. Flowers white or purple.

* Leaves pinnate with many leaflets. April-June....1, 2

* Leaves simple or partly ternate. Mostly perennials.....

a Style slender. In low, wet grounds....

a Style none. In high mountains....

I C. husu'ta. Pennsylvanian C. Smooth, about 1f. erect. Leaves 5-11-fuliate, th terminal lobe largest, 3-lobed. Stigma sessile. Wet. (3) $c$.

2 C praten'sis. Cuckoo-flower. Stẹm simple, ascending, 1f. Leaves 7-15-foliate. with stalked, roundish leaflets Style present. Flowers large. Wet. «s 
8 C. rhomboid'ia. Rhombic C. Stems upright, bearing tubers at base. Poila linear-lanceolate. Leaves roundish and rhomboidal. $w$. or $p$. c.

$4 \mathrm{C}$ rotundifo'lia. Round-leaved $C$. Stems decumbent, branched. Pods l.near subulate. Leave roundish, lower 3-lobed. $w$. By streams.

$5 \cup$ vilidifo'lia. Daisy-leaved C. Leaves smooth, roundish. Pods erect. Heigh 13 . N. I.

3. spattra'ta. Spath-leaved $C$. Leaves hairy, spatulate. Pocss spreading. 6'. $\mathrm{S}$

\section{BARBA'REA. Winter Cress.}

Sepals ercit, nearly equal at base. Silique columnar, 2-4-cornered. $\nabla$ alves concave or keel-shaped by means of a strong central vein. Seeds in a single row. Leaves lyrate-pinnatifid. Flowers yellow.

B. vulga'ris. Winter Cress. Common in old fields, also brook-sides. Whole plant glabrous. Stem 1-2f. high, branching above. Leaves lyrate with the terminal lobe roundish, upper leaves obovate, pinnatifid at base, crenate, or repanddentate-all dark green, shining. Flowers showy, in racemes. Pods obscurely 4-cornered, slender, $\frac{3}{4}$ ' 1) : co. curved upwards. May, June. थै

\section{ERYS'TMUM. False Wall-flower.}

Calyx closed. Silique linear, 4-sided. Stigma capitate. Seeds un a single row in each cell. Mostly (อ. Flowers yellow.

1 E. cheiranthoi'des. Stem ascending. Fls. small. Pods spreading, $1^{\prime}$ in length. M.

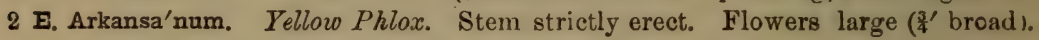
Pods 2-8' long. River bluffs. A fine plant.

W.

\section{SINA'PIS, Mustard.}

Sepals spreading. Petals ovate, with straight claws. Silique nearly terete, valves 3-veined. Style short. Seeds in a single row, globular.(1) or (2) with yellow flowers. (Figs. 393, 394.)

1 s. nigra. Black $M$. Upper leaves lance-linear, entire. Pod 4-cornered, smooth. 2 s. arven'sis. Field $\boldsymbol{M}$. Leaves all repand-toothed. Pods torose, smooth.

8 S. alba. White $M$. Leaves all lyrate-pinnatifid. Pods bristly, shorter than beak

\section{ORder XVI. VIOLA'CEA. Violets.}

Herbs with simple (often cleft), alternate leaves with stipules; flowers irregular, spurred, with the sepals, petals, and stamens in 5's; corolla spurred at base; anthers united: 2 of the filaments appendaged: 
style 1, witl a one-sided stigma; capsule 1-celled, 3-ral red; seeds many, with the embryo nearly as long as the albumen.

\section{Analysis of the Genera.}

Sepals unequal, with ear-shaped lobes at base. Eepals nearly equal, not appendaged at base.

Viola. Green Violet. So'LR.

\section{VI'OLA. Violet.}

Sepals 5, prolonged at base into two auriculate lobes. Petals more or less unequal, the largest one spurred at base, the 2 cpposite ones at the sides equal, the 2 upper ones all equal. Stamens cohering by their anthers, 2 of them spurred at base. Seeds attached to the valves of the capsule. -24 Low herbs, caulescent or acaulescent. Peduncles angular, solitary, 1-flowered, nodding at the top.

* Acaulescent: leaves and flowers all radical....a

* Canlescent : stems leafy....d

a Flowers blue....b

a Flowers white.... Nos. 2-4.

a Flowers yellow..... No. 1.

b Petals beardless....5-7

b Petals bearded....c

c Leaves divided....8, 9

[otic 22.

c Leaves undivided....10-12, and the Ex-

d Pet. yellow. Stems leafy at the top only....13-15

d Petals not yellow, or but partly yellow....

e Stipules entire. Summer....16

e Stipules fringe-toothed. May, June....17-19

e Stipules lyrate-pinnatifid, very large ...20-21

1 V. rotundifo'lia. Early Yellow Violet. Lvs. round-ovate,

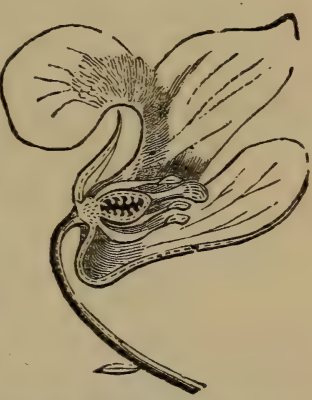

Fig. 398. Violet No. 1: section

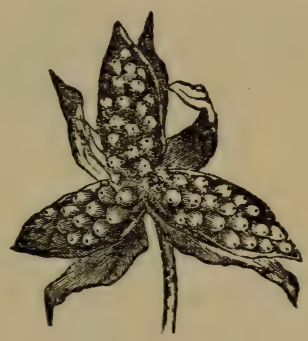

Fig. 399. Ripe, open eap sule of Violet. cordate, smooth. Sepals blunt. April.

$2 \nabla$. lanceola'ta. Lance-leavell $V$. Lvs. lanceolate, tapering to the base. Some bearded $8 \mathrm{~V}$ primulæfo'lia. PrimroseV. Lvs. lance-ovate, abrupt at base. Fls. beardless $4 \nabla$. blanda. Sweet $W i l d V$. Leares round-cordate. Fls. beardless, fragrant. Muy I $\nabla$. palus'tris $B o g V$. Lvs. reniform-cordate. Spur very short. Stips, orate. White IIts

6 V. Selkir'kii. Selkirk's $V$. Lrs, round-cor. Spur near as long as petals, blunt. Mary.

$7 \nabla$. peda'ta. Foot-leaved $V$.Lvs. pedate, 5-9-part., segm. narrow, entire. Root premorit. 8 V. delphinifo'lia. Larkspur $V$. Leaves in 7-9 linear, 3-clefl segments. W. Aprih 9 V. palma'ta. Palm-leaved I. Leares hastate-lobed. cordate. Fariety of No. 10 
$10 \nabla$. cuculla'ta Hood-leaved $V$. Leaves reniform-cordate, base lobes involute. com. 11 V. villo'sa. Woolly $V$. Leaves round-ovate, cordate, obtuse, flat, downy. M. s $12 \mathrm{~V}$ sagitta'ta. Arrow-lvd. V. Lrs. lance-oblong, some sagittate or cut-toothed at base. 13 V. hasta'ta. Hulberd-leaved $V$. Smooth. Lvs. hastate. Stip. ovate, minute. S. 14 V. tripar'tita, Three-cleft V. Hairy. Lvs. deeply 3-parted. Stip.lancen!ate. 3 15 V. pubes'cens. Downy $V$. Downy. Lvs. broad-cordate. Stip. ovate, large. a $16 \nabla$. Canaden'sis. Canada $V$. Plant 1 f. high. Leares cordate, pointed, smooth. $17 \mathrm{~V}$. stria'ta. Cream-colored $V$. Spur 4 the length of the corolla. Stip. large, oblong $18 \mathrm{~V}$. Muhlenber'gii. Muhlenberg's $V$. Spur $\frac{1}{2}$ the length of corolla. Stip. lanceolate. 19 V. rostra'ta. Long-spurred $V$. Spur longer than corolla. Stipules lanceolate. 21) V. tric'olor. Pansy. Heartsease. Stipules as large as the lesves. Fls. three-collored. 21 V. grandiflo'ra. Great-flowered $V$. Stip. much smaller than the leaves. Purple. $\uparrow$ 22 V. odora'ta. Sweet English $\Gamma$. Stolons creeping. Lvs. cordate. Fragrant. $\uparrow$

\section{ORder XVII. CISTACEA. Rock Roses.}

Herbs or Iow shrubs; leaves simple, entire, mostly alternate;

flowers perfect, regular, hypogynous, lasting but a day ;

sepals 5, unequal, the 3 inner contorted, all persistent; petals 5 , rarely 3 , or 0 , twisted contrary to the sepals ; ovaries 3 , united, forming a 1-celled, 3 -valved capsule; seeds many, on the parietal placentæ. (See the Glossary.)

* Petals 5, yellow, larger than the sepals. Low shrublets.

* Petals 3, narrow, brown-purple, as short as the sepals.

* Petals 5, yeliow, large and showy, sometimes 0 .

HUDSONIA. 1

LECHEA. 2

HELIANTHEMUM. 3

\section{HUDSO'NIA. Hudsonia.}

Little heath-like, very leafy and branching shrublets, growing in sands. 1 H. tomento'sa. Hoary-tomentous; leaves oval, appressed ; flowers subsessile.

2 H. ericoi'des. Downy; leaves subulate, loose; flowers pedicelled.

\section{LECH'EA. Pinweed.}

Perennial herbs, often woody at base, much branched, bearing the small obscure flowers in axillary clusters. Pods as large as a pin's head, thcir 3 partial cells each 1-2-seeded. Summer.

$\$$ Pedicels longer than the oval pod..... Nos. 1, 2.

$\S$ Pedicels shorter than the globular pod ....Nos. 3, 4.

1 L. minor. Lesser $P$. Leaves linear; 2 outer sepals minute. $5^{\prime}-15^{\prime}$ high.

2 L. Novæ-Cæsare'æ. New Jersey $P$. Leaves elliptical; 2 outer sepals slendex, oftey longer than the otbers. About if. $\mathrm{N}$ Y and N J. 
3 I. major. Larger $P$. Hairy ; leaves elliptical; pods angular. 1-2f.

I L. thymifo'lia. oary-pubernlent ; leaves narrowly oblanceolate : pods quite rounded, larger (near 1"), polished. 10-20' high.

\section{HELIAN'THEMUI. Rock Rose.}

Petals 5 (when present), crumpled in bud, fugacious. Stamens few or many. Stigma 3-lobed. Capsule triangular, 3-valved, opening at the top.

* Flowers of two sorts, the later ones apetalous. Stamens 3-10.... Nos. 1, 2.

* Flowers all alike, 5-petalled. Stamens $\infty$.....Nos. 3, 4.

1 H. Canaden'se. Flowers solitary, terminal, the apetalous flowers in axillary clusters; sepals acute; leaves lanceolate, acute, with rolled edges. In dry soil. Can. to Va. Stems 8-12' high. Plant hoary-pubescent. July-August.

2 H. corymbo'sum. Flowers all terminal, crowded; sepals obtuse, woolly. N. J. and S.

3 H. Carolinia'num. Flowers subterminal, large; sepals acuminate. Solith.

1 H. arenic'ola. White-tomentous; leaves and sepals obtuse. 3-6'. In sand. S.

\section{Order XVIII. HYPERICACEA. St. Johnsworts.}

Herbs or shrubs with opposite, entire, dotted leaves, and no stipules; flowers mostly yellow, in cymes ; sepals unequal, 4-5, dotted; petals 4-5, twisted in the bud, dotted, and with the veins oblique; stamens hypogynous, in 3 or more parcels ; ovary superior; style 1 ; fruit a capsule or berry, many-seeded.

\section{Analysis of the Genera.}

Petals and sepals 5....2

Petals and sepals 4. Flowers yellow.

St. Peterswort. As'crrom.

2 Fls. yellow. St. Johnswort. HYPER'ICCAr. 1 2 Flowers purplish. ELODE'A.

Fiz̆. 400. Hypericum perforatum (Common St. J.hnswort): stem, leaves, and flowers, Fig. 4)।. The stamens in 3 sets surrounding the ovary with 3 atyles, Fig 402. Cross-section of the orary

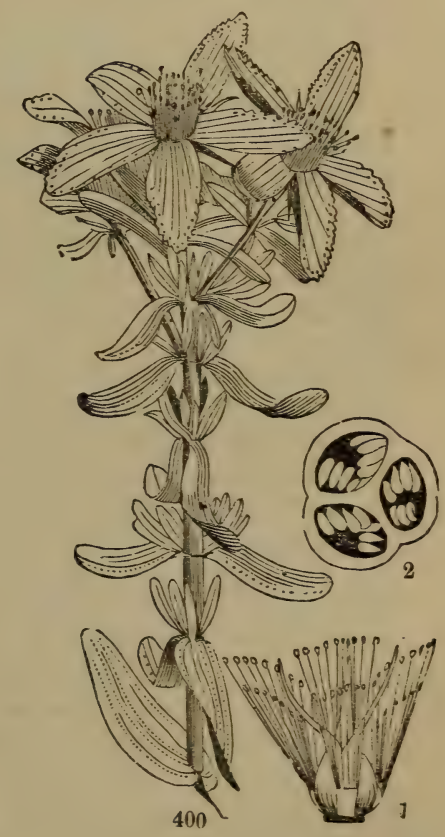




\section{HYPER'ICUM. St. Johnswort.}

Sepals 5, connected at base, nearly equal, leaf-like. Petals 5, oblique. Stamens many (sometimes few and distinct), united into 3-5 parcels with no glands between them. Styles 3-5, either distinct or united at base. Capsule 1-celled, or 3-5-celled.-Herbs or shrubs, with branching stems, opposite, entire leaves, and yellow flowers. (Figs. 210, 211, 400-402.)

$\$$ Stamens 25 to 100 , more or less united into sets....a

$\$$ Stamens 5 to 15 , not at all united....

a Carpels (pistils) and styles 5 or more. Capsule 5-celled.....Nos. 1, 2

a Carpels 3. Capsule 3 -celled (the partitions meeting).... b

a Carpels 3. Capsule 1-celled (the partitions not quite meeting)....

b Shrubby. Petals not dotted. Leaves lanceolate or oblanceolate....s-b

b Shrubby. Petals not dotted. Leaves linear....6, 7

b Herbaceous. Petals sprinkled with black dots....8-10

c Shrubs. Styles united into $1 \ldots$. d

c Half-shrubby. Styles united into $1 \ldots .$. e

c Herbaceous. Styles distinct, at least at the top....f

d Flowers solitary or in 3 's, axillary. Stems 2-edged....11, 12

d Flowers clustered in a compound, terminal cyme....13, 14

- Flowers in a leafless, stalked cyme. Lcaves obtuse $\ldots . .15,16$

- Flowers in a leafy (few-leaved) cyme. Leaves acute....17, 18

f Stem or branches 4-cornered or square....19, 20

f Stem and branches terete, not angular....21, 22

g Flowers in corymbous cymes....23, 24

g Flowers racemed on the slender branches....25, 26

1 H. pyramida'tum. Giant $S$. Herb 3-4f., flowers $2^{\prime}$ broad. Leaves lance-oblong.

2 ‥ Kalmia'num. Kalm's $S$. Shrub 1-2f., flowers 1' broad. Leaves lance-linear.

3 H. Buckle'yi. Buckley's S. Leaves obovate. Flowers terminal, solitary. \$

4 H. prolif'icum. Prolific S. Lvs. lance-oblong. Cymes componnd. W.

5 H. galeoi'des. Bedstraw S. Lvs. lance-linear. Clusters axillary. S.

6 H. rosmarinifo'lium. Rosemary S. Lvs. petioled, shorter than internodes. S.

7 H. fascicula'tum. Clustered S. Lvs. sessile, longer than the internodes. S.

8 H. perfora'tum. Punctured S. Stem 2-edged. Lvs. small, light-dotted. o.

9 H. corymbo'sum. Corymbed S. Stem terete. Lrs. large, black-dotted. c.

10 H. macula'tum. Spotted S. St. terete. All over black-dotted. Sty. long.

$11 \mathrm{H}$. au'reum. Golden $S$. Lvs. thick, obtuse, sessile. Fls. large (1 $\left.\mathbf{z}^{\prime}\right)$. Stam. 500 ! S

12 H. ambig'uum. Dubious $S$. Lvs. thin, acute, sessile. Fls. $8^{\prime \prime}$ broad. Pet. toothed. S

$13 \mathrm{H}$. myrtifo'lium. Myrtle S. Branches terete. Lvs, clasping. Cyme leafy. S.

11 ㅍ. cistifo'lium. Rockrose S. Branches 2-edged. Lrs. sessile. Cyme leaflese s

15 且 nudiflo'rum. Naked-flowered S. Lvs. lance-ovate. Pod ovoid-conic. M. S,

16 ㅍ. sphæ̋̀rocar'pon. Round-fruited S. Lvs. linear-oblong. Porl globular. W. 
17 H. adpres'sum. Closed $S$. Lrs. half-erect. Petals obovate, longer thaz sep

18 H. dolabrifor'me. Hatchet $S$. Lvs. spreading. Pet. dola'riform, long as sep. 19 H. angulo'sum. Angled S. Lrs. ovate, acute. Style thrice longer than ovary.

$20 \mathrm{H}$ ellip'ticum. Eiliptic $S$. Lvs, elliptic, obtuse. Style as long as ovary. N. M. 21 H. grave'olens. Strong-scented S. Smooth. Lrs. oblong-ovate, clasping. \& 22 H. pilo'sum. Hairy S. Hairy. Lvs. lance-ovate, appressed. S.

2: H. mu'ticum. Dwarf $S$. Lvs, ovate, clasping, 5-veined. Cymes leafy. c.

2 H. Canaden'se. Canada S. Lvs. linear, black-dotted. Cymes leafless. c. 25 H. Saro'thra. Pine-weed S. Lvs, awl-shaped, minute. Fls. sessile. 26 H. Drummon'dii. Drummond's $S$. Lvs. linear. Fls. stalked. W.

\section{Order XIX. DROSERACEA. The Sundews.}

Herbs growing in bogs, often covered with glands, with leaves alternate, circinate (rolled from top to base) in the bud; flowers regular, of 5 persistent sepals and 5 withering petals: stamens 5, distinct, and a single, compound ovary; styles 1-5, and fruit a 1-3-celled many-seeded capsule, and with seeds having a small embryo at the base of the albumen.

\section{Analysis of the Genera.}
f coiled (circinate) in the bud. $\left\{\begin{array}{l}\text { Stamens 10-15. } \\ \text { Stame }\end{array}\right.$
Leaves $\{$ nct coiled in the bud. Sterile stamens many.
Stamens 5.
Dros' ERA. 1 Parnas'sia. 3 Dion $\boldsymbol{A}^{\prime}$ A. 8

\section{DROS'ERA. Sundew.}

Sepals 5, united at base, persistent. Petals 5. Stamens 5. Styles 8-5, ench deeply 2-parted, so that there seems to be 6-10. Capsule 3-5-valved, 1-celled, many-seeded.- 2f Small aquatic herbs. Leaves (all radical in the Ameriean species) clothed with long, reddish, gland-bearing hairs, exuding a clear, sticky fluid. Flowers in a raceme on a slender scape, which is at first coiled downward, but uncoils as the flowers open.

* Scape 4-6 times longer than the spreading leaves.... 1-3

* Scape 1-2 times longer than the ascending leaves....4-6

3 D. rotundifo'lia. Round-leaved $S$. Leaves round, on long hairy stalks. Fls $w$ bite, small (about $3^{\prime \prime}$ broad). Scapes $5-8^{\prime}$ high. $c$.

2 D. minor. Lesser $S$. Lvs. wedge-obovate, on sm roth stalks. Scape 3-6'. p. $\mathcal{S}_{\text {, }}$ 8 D. brevifo'lia. Tiny S. Lrs. spatulate, on short, hairy stalks. Scape 2-3'. p. S 
4 D longifolia. Lông-leaved $S$. Lvs. spatulate, on long, smooth stalks. 4-7'. White. (Fig. 20, 21.)

5. I linearis. Linear-leaved $S$. Lvs. linear, obtuse; stalks smooth. $8-6^{\prime}$. White.

B D. filiformis. Thread-leaved S. Lrs. filiform, long. Ssape 1f. Purple.

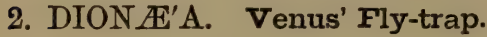

Supals 5, spreading. Petals 5, obovate, with pellucid veins. Stamens 10-15. Style 1. Stigmas 5, many-cleft. Capsule breaking irregularly in opening, 1-celled, many-seeded.-2f Glabrous herbs. Leaves all radical, sensitive, closing convulsively when touched. Scape umbelled.

D Muscip'ula. A very remarkable plant, in sandy bogs, at the South, sometimes cultivated. Leal'es spreading, the petiole broadly winged, ending in a roundish blade which is fringed with spines, instantly closing upon insects which alight upon it. Scape 6-12' high, bearing an umbel of 8-10 white, handsome flowers.' Apr., May. †

Fig. 403. Venus' Fly-trap. Fig. 404. Ovary and style. Fig. 405. Section of ovary.

\section{PARNAS'SIA. Grass-of-Parnassus.}

Sepals 5. Petals 5, inserted on the calyx (perigynous). Stamens also perigynous, in 2 rows, the outer row of numerous sterile filaments, united

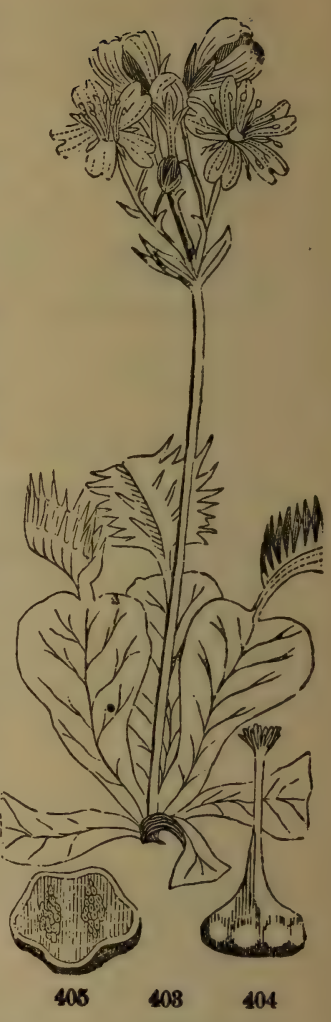
in 5 sets, the inner row of 5 perfect stamens. Stigmas 4, sessile. Capsule 4-celled. Seeds very numerous. 24 Elegant herbs, with radical leaves and 1-flowered scapes.

1 P. Carolinia'na. Meadow $G$. Sterile filaments, 3 in each set. Leaves about 7-veined, broadly oval or ovate, radical ones on long stalks, cauline few, near the ground, sessile, clasping. Scape about If. high, bearing one flower at top, which is about $1^{\prime}$ across. Petals marked with green veins. July, Aug.

P asarifolia. Broad-leaved G. Sterile filaments, 3 in each set. Lvs. reniform. S. 8 palus'tris. Swamp G. Sterile filaments, $9-15$ in each set. Lvs. cordate. N. W 


\section{Order XXI. CARYOPHYLLACEÆ. Pinkworts.}
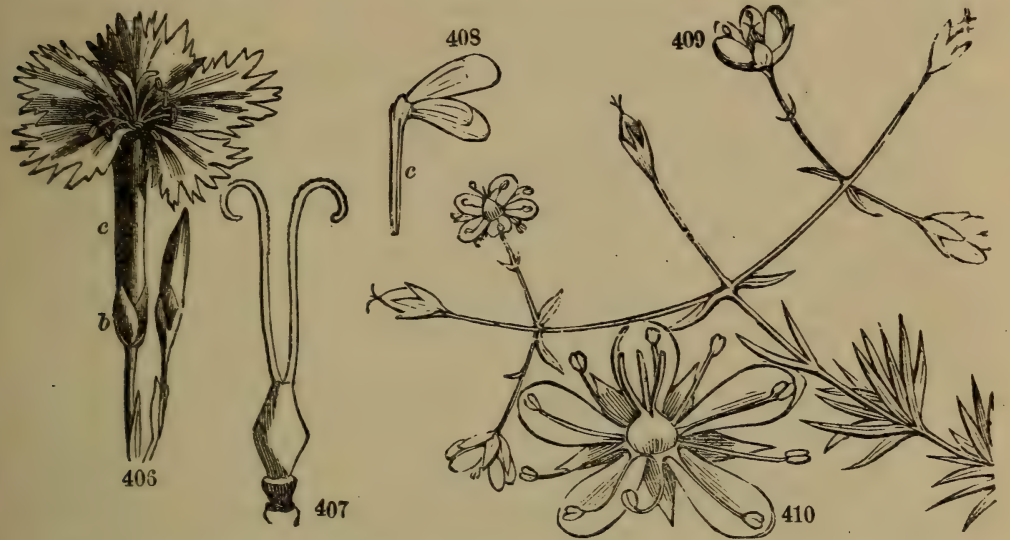

Fig. 406. Pink (Pheasant's-eye): $b$, the bracts; $c$, the tubular calyx. Fig. 407. The orarg with its 2 styles, Fig. 408. A petal of the Diurnal Lychnis, 2-cleft: c, the claw. Fig. 403 Arenaria stricta, showing the spreading eyme. Fig. 410. A flower enlarged, calyx not tubular

Herbs with the stems swelling at the nodes; opposite, entire leaves; sepals 4 or 5 , sometimes distinct and sometimes united into a tube; petals 4 or 5 (sometimes 0 ), with or without claws, hypogynous ; stamens generally twice as many as the petals; styles $2-5$; fruit a 1-celled (rarely 2-5-celled) capsule with numerous seeds, and an embryo coiled around fleshy albumen.

\section{Analysis of the Genera.}

$\S$ Stıpules dry, scale-like, between the leaves at base ....6

s Stipnles none....2

2 Sepals united into a tube. Petals with long claws....3

2 Sepals distinct or nearly so. Petals sessile or none....4

3 Calyx with 2 or more bractlets at base.... a

8 Calyx naked, $i . e$., with no bractlets.... b

4 Pod 1-celled and with several seeds. Petals generally present....

4 Pod 1-celled, with 1 seed. Petals none, calyx green....g

4 Pod completely 3 -celled. Petals none, caly $x$ white.... 4

5 Petals 2-parted or 2-lobed....c

5 Petals undivided and entire....d 
6 Styles or stigmas 3 or 5 . Pod 1-celled, many-seeded....e

6 Styles or stigmas 2 or united into 1 . Pod 1-seeded....f

Styles 2. Petals varicusly notched or fringed.

Pink. Dian'tnite. 1

b Styles 2. Capsule 4-toothed when open. Soapwort. SAPONA'RLA.

b Styles 3. Capsule 6-toothed when open. Silene. Silene. \&

b Styles 5. Calyx 5-toothed, teeth short or long. Rnse Campion. Lychiss. 8 Styles 5. Pod opening at top by 10 teeth.

Styles 3. Pod splitting into 6 valies. Chickweed. Starwort. Stella'ria. d Styles 3. Valves of the ripe pod 3, each 2-toothed. Sandwort. Arevi'ria. d Styles 3. Valves of the pod 3, entire.

d Styles 4 or 5, always as many as the sepals.

Grove Sandwort. A IsI'NE.

d Styles 3 and 5. Plant fleshy. Disk 10-lobed. Sea Sandwort. Honken'ya. e Styles 5. Leave linear, whorled. Flowers white. Spurry. SPER'GULA. e Styles 3 and 5. Lrs. linear, opposite. Fls. red. Sand Spurry. Spergula'ria. e Styles 3 in all the fls. Leaves in 4's. Stipules ovate. All-seed. I'olycar'ron. e Styles 3 in all the fls. Leaves opposite. Stipules many- cleft. STipulio'ida.

f Sepals green, distinct or nearly so....

f Sepals white above, united into a tube below.
Nailwort. ParoNYCh'ia. SYPHONYCH'IA.

8 Styles 2. Utricle inclosed in the hardened calyx tube. Fnavell. Scleran'tuis.

b Styles 3. Stamens 3 or 5 . Herb flat on the ground. Carpet-werd. Mollu'ao. 5

\section{DIAN'THUS. Pink. Carnation.}

Calyx tubular, cylindrical, striate, with 2 or more pairs of opposite, un. bricated scales at base. Petals 5, with long claws, limb unequally notched. Stamens 10. Styles 2, with revolute stigmas. Capsule cylindrical, one celled.

I Bracts as long as the calyx tube....1, 2, 3

If Bracts much shorter than the calyx....4, 5, 6

1 D. Arme'ria. Wild Pink. Bracts erect. Leaves linear. Flowers small, pink-red in cymes of about 3. Stem 18-24' high. In sandy fields. July. E.

2 D. barbatus. Sweet William, or Bunch Pink. Bracts erect. Leaves lanceolate, cymes large, many-flowered. Red or variegated with white. May-July. I

D. Chinen'sis. China Pink. Bracts spreading. Jeaves lance-linear. Flowere solitary, red, large. Plant evergreen, not glaucous. †

4 D. caryophyl'lus. Carnation Pink. Bracts rounded. Petals crenate, beard. less. Whole plant glancous. Many beautiful varieties. +

5 D. pluma'rius. Pheasant's-eye. Bracts orate. Petals fringe-toothed, Leardud Plant glaucous. Flowers solitary, white and purple. †

6. D. super'bus. Superb $P$. Bracts mucronate, ovate. Petals pinnatifid fringes. bearded, cymes level-topped. White. + 


\section{SILE'NE. Catch-fly. Campion.}

Calyx tubular, swelling, without scales at base, 5-toothed. Petals 5. 2 cleft, the claws often crowned with a stiff scale. Stamens 10. Styles

3. Capsule partly 3 -celled, opening by 6 teeth at top. (Fig. 116.)

* Petals many-cleft and fringed. Fls. white or roseate, large. Perennial....1-8

* Petals bifid or entire, not fringed....a

a Calyx inflated and netted with veins. Perennial ....4, 5

a Calyx close upon the pod, not inflated....b

b Flowers spicate, alternate. Annual....6, 7

b Flowers not spicate....c

- Petals white, elosed in sunshine....8, 9

c Petals red, purple, \&c.,-(d) bifid....10,11

-(d) entire....12-15

1 S. stella'ta. Whorled C. Lrs. in 4's. Calyx inflated. Fls. white, many. July.

2 S. ova'ta. Ovate $C$. Leaves opposite. Calyx not inflated. Flowers white. S.

8 S. Baldwin'ii. Baldwin's C. Lvs. opposite, obovate. Fls. very large, roseate. S $4 \mathrm{~S}$. infla'ta. Bladder $C$. Petals not crowned. Flowers few, white.

5 S. nivea. Snowy $C$. Petals with a little crown. Flowers many, white.

$6 \mathrm{~S}$. quinquevul'nera. Variegated $C$. Woolly. Petals entire, red, white-edged. s

7 S. noctur'na. Spiked C. Downy. Petals narrow, 2-parted, greenish-white.

8 S. Antirrhi'na. Snapdragon C. Sticky in spots. Calyx egg-shaped.

9 S. noctifo'ra. Night $C$. Viscid-downy. Calyx cylindrie. Petals 2-parted.

$10 \mathrm{~S}$. Virgin'ica. Virginian C. Leaves spatulate. Fls. large (2'), crimson. M. S.

i) S. rotundifo'lia. Round-leaved $C$. Leaves round, large. Fls. large, scarlet. W

12 S. Pennsylvan'ica. Perennial. Petals rose-purple, toothed at end.

13 S. re'gia. Royal C. Perennial. Petals scarlet, entire, oblanceolate.

14 S. Arme'ria, Garden C. Annual. Stem sticky in spots. Flowers rose-p. 1 $15 \mathrm{~S}$. acau'lis. Stemless $C$. Annual. Scape $2^{\prime}$ high, 1-flowered. Mountains

\section{LYCH'NIS. Cockle. Rose Campion.}

Ualyx tubular, 5-toothed, without scales at base. Petals 5, clawed. Stamens 10. Styles 5. Capsule 1-celled, or 5-celled at the base, opening at the top by 5 or 10 teeth. Petals sometimes crowned.

* Petals broad, entire. Plants very hairy....1, 2

* Petals 2-cleft, crowued with 2 scales at top of claw $\ldots . .8,4$

* Petals gashed or 4-cleft. Plants nearly smooth....5, 6

L. Githa'go. Cuckle. Sepals longer than the crownless, purple petals.

L. Corona'ria. Mullein Pink. Sepals shorter than the stiff-crowne I petals. †

3 L. Chalcedon'ica. Sweet William. Fls. scarlet, in a crowded, conpound cyme. $\uparrow$

4 I. diu'rna. Diurnal L. Fowers light purple, in an open, loose cyıne. + (Sce Fig. 406.) 
5 I corona'ta. Chinese $L$. Petals very broad, friaged with numerous teeth

B L. Floscu'culi. Ragged Robin. Petals divided into 4 long teeth, crowned. †

\section{CERAS'TIUM. Mouse-ear. Chickweed.}

Sepals 5, ovate, acute. Petals 5, bifid or 2-cleft. Stamens 10, some times 5 or 4 . Styles 5. Capsule cylindrical or roundish, opening at top by 10 tooth-like valves. Seeds numerous. Fls. white, in cymes. (Fig. 114.

Petals about as long as the calyx. Plants hairy....1, 2

Petals much longer than the ealyx. Plants hairy or downy....3, 4, 5

1 C. vulga'tum. Common M. Lvs, obovate. Sepals acute. Fls. at first crowded. 2 C. visco'sum. Sticky $M$. Hairs sticky. Leaves lance-ovate. Sepals obtuse.

3 C. arven'se. Field $M$. Lvs. linear. Ripe pods as long as the calyx. N. E.

4 C. oblongifolium. Leaves lance-obl. Pods longer than calyx. M.

8 o. nu'tans. Nodding M. Ripe pods curved, thrice longer than calyx. N W

\section{MOLLU'GO. Carpet-weed.}

Sepals 5. Petals 0. Stamens 3-5, opposite to the sepals. Styles 3 . Capsule 3-celled, 3-valved, many-seeded.-(1) Low or prostrate herbs, with the leaves appearing whorled.

M. verticilla'ta. Stems slender, jointed, much branched, lying flat on the ground. At each joint stands a whorl of wedge-shaped or spatulate leaves of unequal size, usually about 5 in number, and a few flowers, each solitary on its stalk, which is shorter than the petioles. Flowers small, sepals white inside. In ery plices. July-Sept.

\section{Order XXII. PORTULACACEA. The Purselanes.}

Herbs with thick, entire leaves, no stipules, and regular flowers; flowers with 2 sepals, 5 petals, open only in the sunshine; stamens opposite to the petals when of the same number, often more; pistils several, with their ovaries united, free, or half-free, forming in fruit a pyxis ( $\$ 178)$ or a capsule.

\section{Analysis of the Genera.}

ๆ Sepals five, Petals none. Fruit a pyxis. Stamens $\infty$. Sea Purselane. Seso'vion. I Sepals 2. Petals 5....a

a Stamens 5 , opposite the pets.ls.

a Stamens 8-30, on the torus. Pod 3-valved.

Spring Beauty. Clayto'nia. !

a Stamens $8-30$, on the ca.yx Pyxis opening by a lid. TAli'nUm.

PORTULA'C4. 2 


\section{CLAYTO'NIA. Spring Beauty.}

Sepals 2, ovate. Petals 5, emarginate or obtuse. Stamens 5, inserted on the claws of the petals. Stigmas 3, on 1 long style. Capsule 3-valved, $2-5$ seeded.-They are small, fleshy, 2 , early-flowering herbs, arising from a small tuber.

1 C. Carolinia'na. Leaves ovate-lanceolate. Sepals and petals obtuse.

2 C. Virgin'ica Leaves linear or lance-linear. Sepals acute, petals obovate.

\section{PORTULA'CA. Purselanes.}

Sepals 2. Petals 5, equal. Stamens 8-20. Styles 3-6. Pyxis lid opening off near the middle.-Low and fleshy herbs.

1 P. olera'cea. Common P. Leaves thick, wedge-shaped. Stem fleshy, reddish, prostrate. Flowers sessile, small, yellow. A common weed. Summer.

2 P. grandifo'ra. Great $P$. Leaves cylindric and fleshy. Stems ascending. Fls larg $\rightarrow$ red or scarlet. Cultivated. June.

\section{Order XXIV. MALVACEA. The Mallows.}

Herbs, shrubs, or trees, with alternate, stipulate, divided leaves, with the flowers showy, axillary, regular, often with an involucel at the base; 5 sepals valvate and the 5 petals convolute in the bud, hypogynous; stamens indefinite and monadelphous, the anthers splitting across; carpels several, united into a ring or forming a several-celled capsule; seeds with a curved embryo in a little albumen.

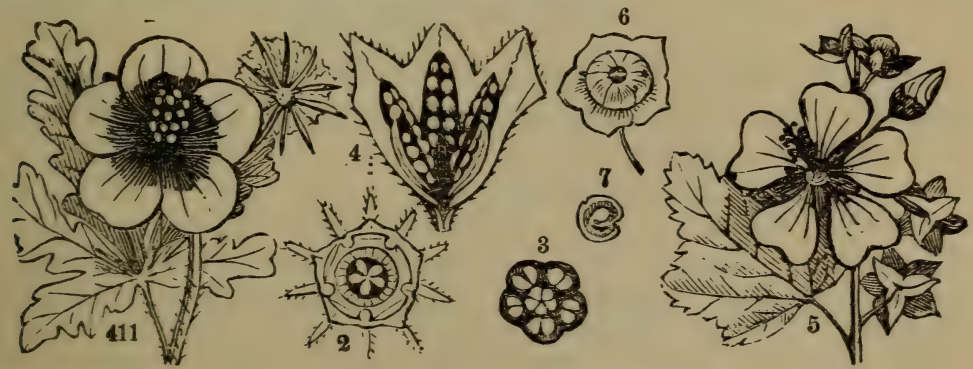

Fig. 411. Hibiscus Trionum (Flower-of-sn-hour); 2, cross-section of the flower, showirg the arrangement of its parts; 3 , cross-section of the 5-celled capsule; 4, capsule open by its f ro valres; 5 , Malva sylvestris; 6 , its fruit, consisting of 10 earpels arranged in a cirele; 7 , section of ove of the carpels, showing the curved embryo. 


\section{Analysis of the Genera.}

Calyx naked, $i$. e., having no involucel....b

\& Calyx furnished with an involucel as if a second calyx....2

2 Pistils and carpels more than $5 . .$. a

2 Pistils and carpels 5 only, each 1 -seeded....c

2 Pistils and carpels 5 or 3 , each $3-\infty$-seeded....d

a Involucel of 6-9 bractlets. Carpels 1-seeded.

a Involucel of 3 united bractlets. Carpeis 1-seeded.

a Involucel of 3 distinct bractlets. Carpels 1-seeded.

a Involucel of 3 distinct bractlets. Carpels 2-seeded.

b Flowers diœcious. Stigmas 10, linear.

b Flowers perfect. Carpels 5 or more, 1 -seeded.

b Flowers perfect. Carpels 5 or many, 3-9-seeded.

c Stigmas 10. Carpels 5, baccate, united.

c Stigmas 10. Carpels 5, dry, distinet.

c Stigmas 5. Carpels 5, dry, united into a pod.

d Involucel of many bractlets. Calyx regulur.

Marsh M. A Lth R' A. Tree M. Lavate'ra. Maliozo. Mativa. 2

d Involucel of many bractlets. Calyx split on one side. Okra. A вelmos'cuus. d Involucel of 3 incisely-toothed bractlets. Cotton. Gossyp'IUM.

\section{ALTH $\mathbb{E}^{\prime} \mathrm{A}$. Hollyhock, \&c.}

Calyx surrounded at base by a 6-9-cleft involucel. Carpels $\infty, 1$-seed. ed, not opening, arranged circularly around the axis.

1 A officina'lis. Marsh M. Lrs. downy, entire or 3-lobed. Fls. rose-col., stalked.

2 A. rosea. Hollyhock. Leaves rough-hairy, roundish, 5-7-lobed. Flowers sessile. 3 A. ficifo'lia. Fig-leaved Hol. Lvs. hairy, deeply 7-parted. Fls. orange colored.

\section{MAL'VA. Mallows.}

Calyx 5-cleft, with a 3-leaved involucel at its base. Carpels and styles numerous. Fruit cheese-form, separating when ripe into many 1 -seeded pieces, arranged circularly.

* Flowers white or rose-colored....1, 2,3

* Flowers deep red or purple....4, 5, 6

1 M. rotundifo'lia. Cheese $M$. Stem prostrate. Lvs. round-cordate. Fls. small. $2 \mathrm{M}$. crispa. Crisp M. Stem erect, tall. Lvs. abundantly crisped and curled. $\uparrow$ M. moscha'ta. Musk M. Sts. ascend. Lrs. deeply 5-part. Fls. large, showy. 4 M. sylves'tris. Wood M. Lvs. roundish, lobed. Petals obcordate.

5 M. triangula'ta. Lrs. triangular-ovate. Petals wedge-obcivate. N.-W.

6 M. papaver. Prppy M. Lvs. palmately parted. Petals erase. Stalks rery long. S.-W. 


\section{HIBIS'CDS. Hibiscus.}

Calyx 5-cleft, surrounded by a many-leared involncel. Styles united, stigmas 5, distinct. Fruit a 5-celled, 5-many-seeded capsule. Flowers large, often nearly a foot broad.

Is!yx, \&c., hispid. Leares palmately divided....1, 2

3aiyx, \&c., velvet-ılowny. Leaves undivided, angularly lobed....3, 4

I Calyx, \&c., glabrous, i. e., smooth ..... a

a Leaves deeply lobed or parted....5, 6

a Leares undivided or slightly lobed....7, 8

1 H. aculea'tus. Prickly $H$. Bractlets of involucel forked. Fls. sulph-yellow. S.

2 H. Trio'num. Flower-of-an-hour. Bractlets entire. Fls. chlorine-yellow. c. †

3 H. Moscheu'tos. Marsh H. Lvs. ovate, toothed. Sepals abruptly pointed. Rose-red. $c$.

4 H. grandiflo'rus. Giant II. Leares cordate, lower 3-lobed. Sepals gradually pointed. $p$-r. S.

5 E. milita'ris. Sicord $H$. Lrs. hastately 3-lobed. Flowers tubular-bell-shaped, flesh-color. W.

6 H. cocci'mus. Scarlet II. Lvs. paimately 5-parted. Cor. expanding, carmine-red. S

7 H. Carolinia'nus. Lost $H$. Herb. Lvis. cordate. Fls. purple. Very rars. S.

8 H. Syri'acus. Tree $H$. Tree 8-15f high. Lrs. wedge-orate. $v . p . \dagger$

\section{ORDER XXVI. TILIACF无. Lindenblooms.}

Trees or shrubs with simple, stipulate, alternate, toothed leaves ;

flowers perfect, axillary, with 4 or 5 sepals and petals;

stamens many, hypogynous, commonly united in sets;

pistils 3-10 united into 1 , forming a dry or flesny fruit.

\section{TIL'IA. Linden. Basswood.}

Sepals 5, valvate in bud, deciduous. Petals 5, oblong, obtuse. Stamens $\infty$ in 5 sets. Ovary 5-celled, but in fruit becoming 1-celled, 1-2-seeded. Large haudsome trees with a tough bark, and soft wood. Flowers in small cymes, with the peduncle attached part way to the midveiu of a large bract.

I T. Europæ'a. Linden or Lime-tree. Stamens slightly united and having no scales or staminodia (as in the next); leaves roundish, smooth. A fine shade-tree. 40f.

I Americana. Bassuvod. Stamens having a petal-like scale, with each of their : sets opposite to the petals; leaves broad-cordate, pointed, green both sides, often downy beneath ; style as long as the blunt petals. A fine tall forest-tree. Therw is another species West. 


\section{ORDER XXVII. CAMELLIACE $Æ$. Teaworts.}

I'rees or shrubs with alternate, simple, feather-veined exstipulate leaves : flowers regular, showy, with sepals and petals imbricated; stumens very $\infty$, hypogynous, more or less united at their bases ; fruit a woody pod, 3-6-celled, few-seeded.

- Exotics. Some of the inner stamens distinct and free.... Genus 1, 2

* Natives of the South. Stamens all conjoined at base.... Genus 3. 4

1 CAMEL'LIA Japonica. Japan Rose. The free stamens numerous (or transformed into petals). Leaves oval, pointed, serrate, thick, evergreen and shining. Flowers white varying to red, single or double. Beautiful shrubs of the greenhouse. Native of Japan.

2 THEA. Tca. The free stamens only 5 or 6 . Sepals scarcely bracted at base. Petals 5 or 6, very concave, white. Shrubs 4-8f.; native of China. Leaves oblong to lanceolate, serrate, smooth and shining, and when cured or dried they form the various kinds of tea.

3 STUAR'TIA. These are beautiful shrubs, with large deciduous leaves, large showy fragrant flowers (2-8' broad), axillary, and nearly sessile. Stamens ull united at hase into 1 set. Styles 5, united or separate. 2 species.

4 GORDO'NIA. Loblolly Bay. Trees with large, white, axillary, stalked flowers. Leaves evergreen and shining (in $G$. Lasianthus) or deciduous (in G. pubescens), oblong. Stamens united below into 5 gets. Va. to Fla. May-Aug.

\section{Order XXX. LINACE A. The Flaxworts.}
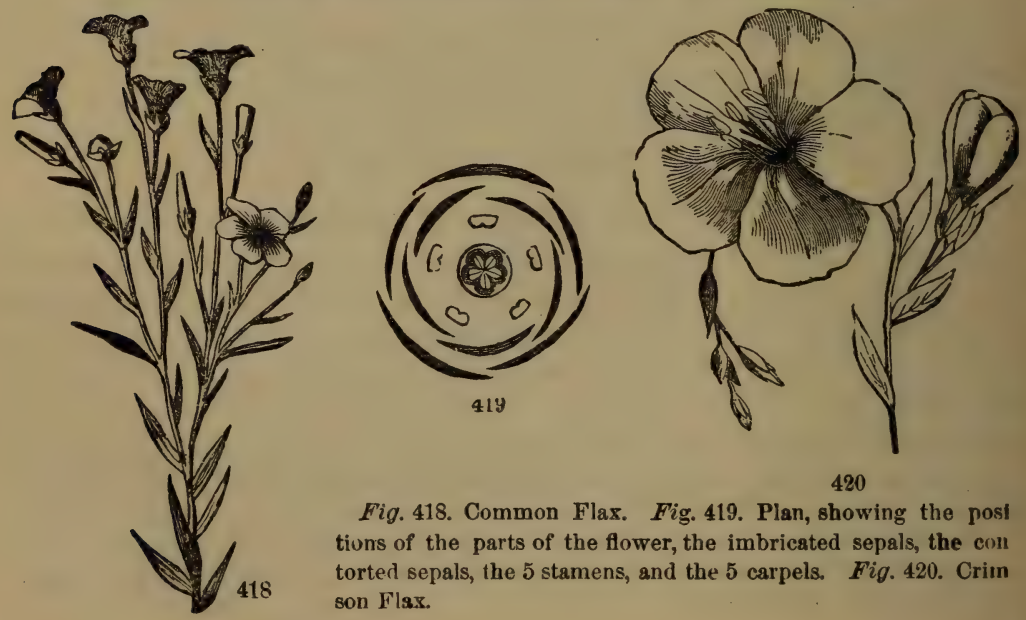

420

Fig. 418. Common Flax. Fig. 419. Plan, showing the posi tions of the parts of the flower, the imbricated sepals, the con torted sepals, the 5 stamens, and the 5 carpels. Fig. 420 . Crim son Flsx. 
Herbs with entire, simple leaves and no stipules; with

flowers regular, symmetrical, perfect, and 5-parted;

calyx imbricate, and corolla convolute in the bud;

stamons and styles each 5; capsule with 5 double-cells, 10 -seeded.

Our culy genus is

\section{LI'NUM. Flax.}

The character is sufficiently indicated in the Order. The long, tough fibres of the bark constitute the linen of commerce.

\& Flowers blue or red, large ( 1 ' broad),.... Nos. 1-3

$\S$ Flowers yellow. Leaves linear. Sepals ciliate....4,5

\$ Flowers yellow, Leaves lanceolate. Sepals entire...6-8

$1 \mathrm{~L}$, usitatis'simum. Common $F$. Flowers blue, in a sort of corymb. Leaver lance-linear, acuts. The seed yields linseed oil. Fields.

2 I. peren'ne. Perennial F. Flowers blue, axillary and terminal. Leaves linear, acute, scattered. Gardens.

3 L. grandifo'rum. Crimson F. Flowers crimson, axillary. Leaves lance-elliptic, acute, sessile. Gardens.

$4 \mathrm{~L}$. rig'idum. Rigid F. Sepals longer than the globular pod. Styles united at hase. 5 L. simplex. Simple F. Sepals shorter than ovate pod. Styles distinct. S.-W.

6 L. virginia'num. Stems and branches erect. Flowers 6" broad. c.

$7 \mathrm{~L}$. diffu'sum. Stems, branches, leaves diffuse. Flowers $2^{\prime \prime}$ broad. W.

8 L. trig'ynum. Three-styled $F$. Flowers large (1') with 3 styles. †

\section{ORder XXXI. GERANIA'CEA. Gerania.}

Herbs or shrubby plants with the lower leaves opposite; with the flowers regular or irregular, terminal or opposite the leaves; with the sepals 5, persistent, and petals 5, clawed, twisted in the bud; the stamens 10, monadelphous, and pistils 5, united; the carpels in fruit separating and bending upwards on the elastic style, each with one seed. Albumen 0.

\section{Analysis of the Genera}

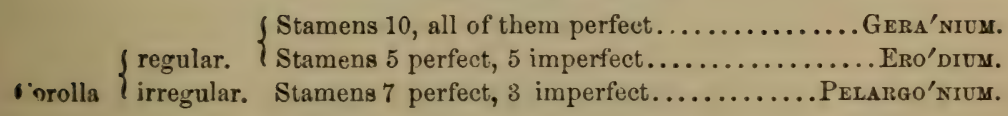

\section{GERA'NIUM.}

Sepals and petals 5, regular: Stamens 10, all perfect. Fruit besked. 
at last separating into 5, long-styled, 1 -seeded carpels. Styles smooth inside, finally curling from the base upward, but still adhering at top to the axis.-Herbs with forked stems, much divided lenves. Flowers nostly purple.

Petals entire, twice as long as the awned sepals....1, 2

Petals notched or 2-lobed, short. Leaves palmately 5-7-lobed. Pods hairy (3.....3, 4

1 G. macula'tum. Spotted G. Erect. Lvs. palmately 3-5-parted. Flowers large ( $1^{\prime}$ broad), showy. Sepals mucronate. spring. $c$.

2 G. Robertia'num. Herb Rohert. Difuse, weak. Lvs. primately 3-parted to the base. Flowers small ( $7^{\prime \prime}$ broad). Sepals mucronate. June.

3 G. pusil'lum. Dwarf $G$. Diffuse. Sepals veinless. Leaves parted into 5-7 linear lobes, lobes 3-cleft. Fields and hills. July.

4 G. Carol:nia'num. Stems diffuse. Sepals with an awn. Lvs. parted into 5 wedge-oblong, many-cleft lobes. Fields. July.

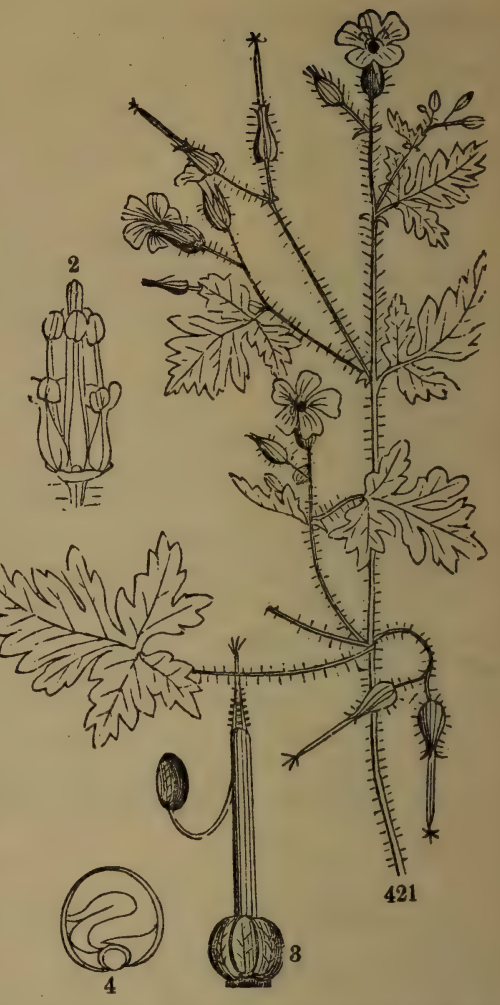

Fig. 421. Herb Robert, leaves, flowers, and fruit; 3, fruit enlarged, showing one carpel on its elastic style; 4, cross-section of a seed, showing the large embryo flling the whole space; 2 , the 10 stamens.

Observation.-The pupil will pereeive by the table above, that the parlor "gern niums" belong to the genus Pelargo'nium.

\section{ORder XXXII. OXALIDACE F. WoOd Sorrels.} Low herbs with a sour juice, and alternate, compound leaves; with Powoers regular and symmetrical, 5-sepaled and 5-petaled; 
tamens 10, monadelphous, hypogynous, the alternate ones longest; carpels 5, united and forming in fruit a 5-celled pod; setds albuminous.

\section{OX'ALIS. Wood Sorrel.}

Sepals 5, distinct or united at base, persistent. Petals wuch longer than the sepals. Stamens united at the base. Styles 5. Capsule roundish or pod-shaped, cells several-seeded. Herbs mostly 2 , with trifoliate leaves.

1 o. Acetosel'la, Wood Sorrel. Fls. white, with purple veins. Plant acaulescent, arising from a creeping root-stock. c. N. Ju.

20 . viola'cea. Violet $W$. Flowers violet-purple. Plant acaulescent, arising from a scaly bulb. Scape with an umbel. May.

8 O. stricta. Yellow $W$. Flowers yellow. Plant with leafy stems, weak, branched. Flowers umbelled. Grows everywhere.

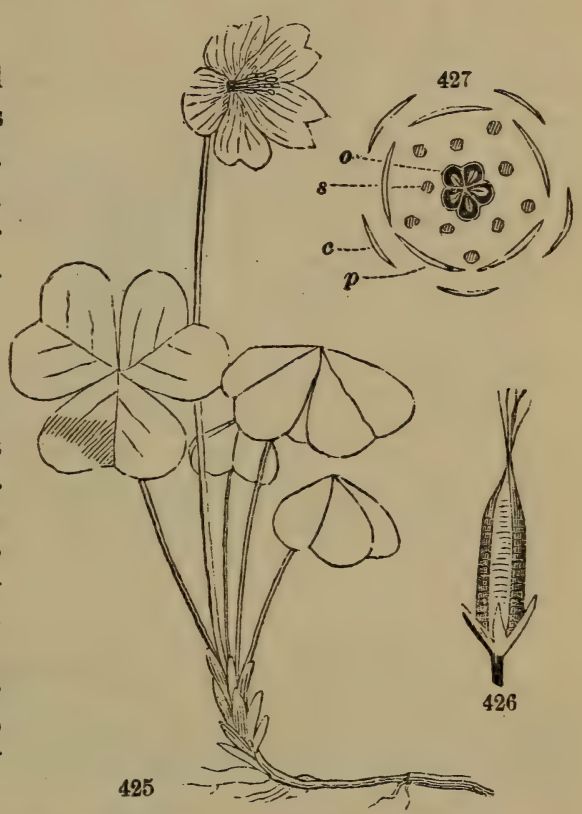

Mig. 425. Oxalis Acetosella. In the plan of the flower, 0 , the 5 carpels in the centre $s$, the 10 stamens in two rows; $p$, the 5 petals; $c$, the 5 sepals. Fig. 426 . The ripe pod.

\section{Order XXXIV. BALSAMTNACE.E. The Jewel-weeds.}

Mlerbs annual, with a fleshy stem, watery juice, and simple leaves;

flewers very irregular and unsymmetrical; calyx spurred; stamens 5 , on the torus; pod bursting by 5 elastic valves.

\section{IMPA'TIENS. Touch-me-not.}

Sepals colored, apparently but 4 (the 2 upper being united), the lowest (y) enlarged into a sac tipped with a bent spur. Petals 4, united into 2 double ones $(p, p)$. Stamens $5^{\circ}$ short, the anthers united over the pistil. 
Fruit a pod of 5 strong elastic ralves which break and coil at the slightest touch when ripe, scattering the seeds. Stem tender, thickened at the nodes. Leaves alternate.

: I. pal'lida. Pale Jewel-weed. Lvs. oblong-ovate. Fls. pale fellow, sparingly dotted, with a very short, recurved spur.

2 I. fulva. Tawny Jewel-rveed. leares rhombic-ovate.

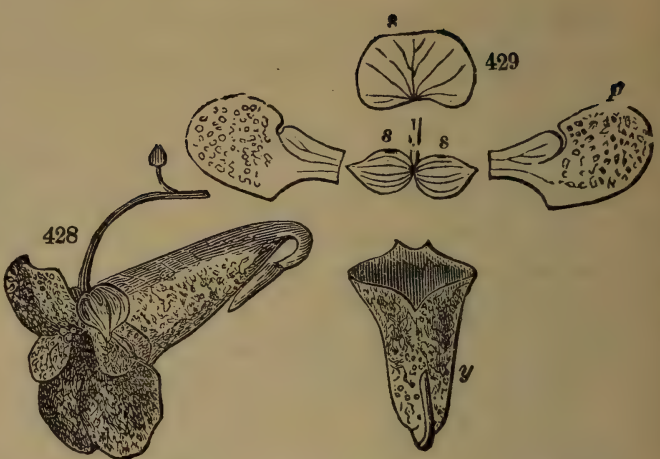

Fig. 428. Flower of the Pale Jewel-weed. Fig. 429. Itz parts displayed: $\delta, \alpha, 8, y$, the four sepals, the latter spurred; $p, p$, the 2 petais, each double.

Flowers deep orange, thickly spotted, with a long ciose-reflexed spur.

3 I. Balsami'na. Balsamine. Leaves lanceolate. Flowers very large and showy. white, crimson, scarlet, flesh-colored, \&c. †

\section{ORDER XXXVIII. ANACARDIACEA. Stimacs.}

Shrubs or trees, with a resinous or milky caustic juice ;

leaves alternate, without stipules or pellucid dots ;

flocers small, regular, pentandrous, commonly imperfect.

\section{RHUS. Sumac. Poison Oak.}

Sepals, petals, and stamens each 5. Styles 3 Fruit a smal; 1-seeded, roundish, dry drupe. Flowers greenish.

6 Leaves simple. Flowers perfect (or all abortive by cultivation).....Nos. $1,2$.

I Leaves compound. Flowers poiygamons.... (a)

a Flowers in clustered spikes preceding the 3-foliate leaves........ 3.

a Flowers in axillary panicles with the 3-13-fo. liate leaves. Poisonous....4-6.

a flowers in terminal thyrses with the 9-31-foliate leaves....(b)

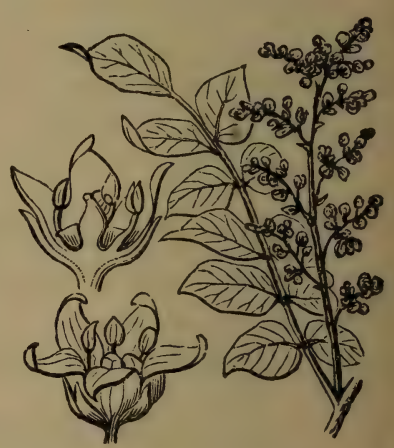

Fig. 429', Rhus venenata, leal and panicle. 2. A staminate flower. 3. Section of a fertile flower. 
b Common petiule winged between the leaflets..... No. 7.

b Common petiole not winged..... Nos. 8-10.

I $\mathbf{R}$ Cot'inus. Venetian Sumac. Smoke Tree. Leaves obovate, entire, thick. Flower mostly abortive, pedicels diffusely branched, hairy. Italy.

? R. cotinoi'des. Leaves oval, obtuse, acnte at base. Flowers minute. Mts. S.

3 R. aromat'ica. Sveet $S$. A small aromatic shrub, 2-6f. Leaflets sessile, ovare Flowers yellowish. Drupes globular, woolly, red, sour. May. Not poison.

1 R. venena'ta. Pi ison S. Dog-wood. Very smooth; leaflets 7-13, oval, pointed, ver; entire. Drupes greenish yellow, smooth. A small tree, 10-15f. high, in swamps June. The most venomous of the species. (Fig. 429'.)

5 R. toxicoden'dron. Poison Oak. Poison Ivy. Erect or declining, 2-3f. Leaflets 3, variously toothed or cut-lobed, downy. Drupes smooth. June.

6 R. radi'cans. Climbing $7 x y$. Stems climbing trees, etc.; by innumerable radiating tendrils. Leaflets ovate, smooth, entire. Reputed poisonous. June.

7 R. copalli'na. Mountain Sumac. Shrub, 1-6f. Leaflets 9-21. July.

8 R. pu'mila. Creeping S. Leaflets 9-17, coarsely toothed. Poisonous. Carolina.

9 R. typh'ina. Stag-horn S. Branches and petioles woolly. Leaflets 11-31, lance-oblong, downy beneath. Drupes red, acid; wood yellow. June. Shrub 10-20f.

10 R. glabra. Smooth S. Smooth ; leaflets lanceolate, whitened beneath. Shrub 6-15f. high. Flowers in terminal, dense panicles, greenish red. Fruit clothed with crim. son fur which is excessively sour to the taste. Bark used in tanning.

\title{
Order XL. ACERACEA. The Maples.
}

Trees or shrubs with opposite, usually simple palmate-veined leaves; the flowers often imperfect, with the 5 sepals imbricated in the bud, and the petals 5 , hypogynous, sometimes 0 ; the stamens mostly 8 , and the fruit a double samara, with two opposite wings, 2 -seeded.

$$
\text { Analysis of the Genera. }
$$

Leaves simple, palmate-veined. Very common.

Leaves compound, odd-pinnate. Leaflets 3-5, toothed. Box-Elder. NEGundo.

\author{
Maple. ACER. 1
}

1. ACER. Maple.

Calyx of 5 united sepals, 5-lobed. Petals 5 or 0. Styles 2. Stamens 6-8. Leaves simple, palmate-lobed. Flowers mostly polygamous.

\& Pedicels short, in side clusters, flowering before the leaves. Trees....1, 2

\& Pedicels long, slender, drooping, flowering with the lvs. Large trees....3,

\$ Pedicels in racemes, flowering after the leaves....5-7

$1 \mathrm{~A}$ dasycar'pum. White $\boldsymbol{M}$. Leaves deeply lobed, square at base, silver-white beneath. Ovaries downy. Frúit very large, Petals 0 . Tree 50f. 

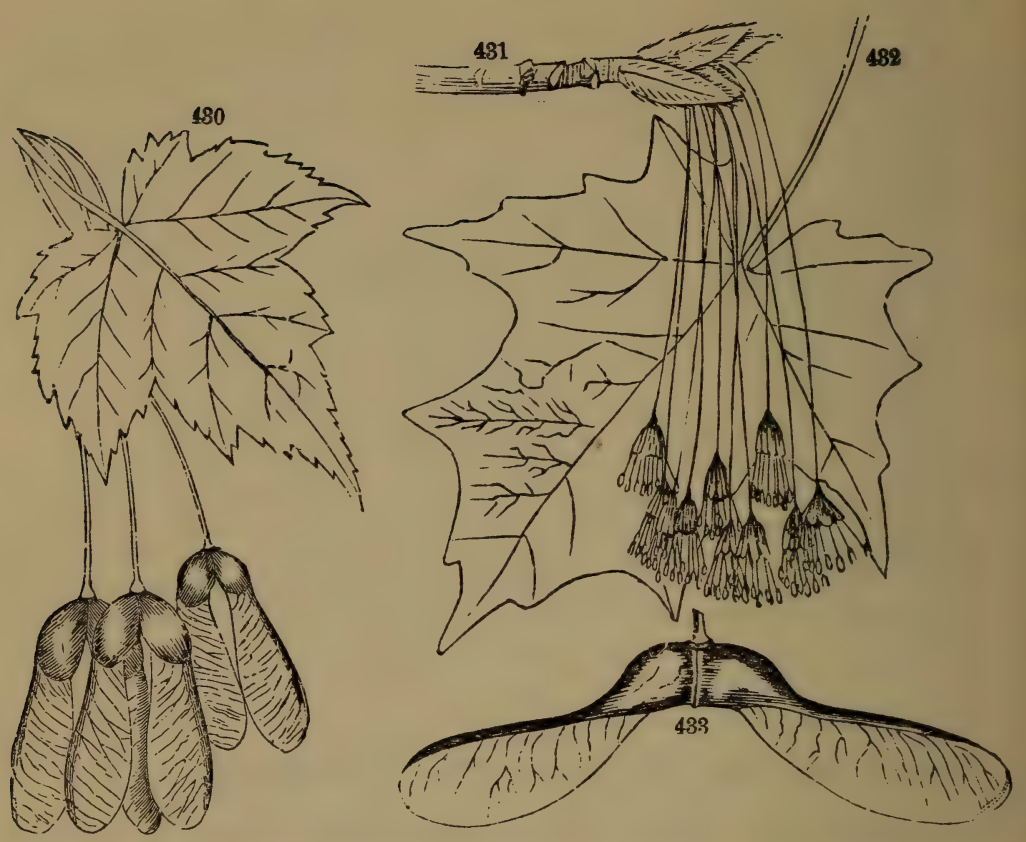

Fig. 430. Red Maple (Acer rubrum), a leaf and several samara. Fig. 431. Sugar Maple (Acer saccharinum), leaf, flowers, and fruit.

2 A. rubrum. Red $M$. Swamp $M$. Leaves lobed, cordate at base, paler beneatn Petals linear-oblong. Ovaries and fruit smooth. 40 to $100 \mathrm{f}$. Flowers red.

3 A. sacchari'num. Rock $\boldsymbol{M}$. Sugar $\boldsymbol{M}$. Leaves cordate, 5-lobed, with deep, rounded openings between. Bark light gray. $g-y$.

4 A. ni'grum. Black $M$. Sugar-tree. Leaves cordate, with the sinus closed. roundish, with 3 broad, shallow lobes. Bark dark gray. $y$.

5 A. spicatam. Mountain-Bush $M$. Racemes erect, thyrse-like. Shrub 10-15f. high, in clumps. Bark gray. Leaves 3-5-lobed. $g$.

6 A. Pennsylvan'icum. Striped $M$. Whistle-wood. Racemes drooping. Tree suas. with striped bark (green and black). Leaves 3-lobed. $g$.

A. Pseudo-Plar'anus. Sycamore $M$. Racemes long, drooping. A large tree in parks. Leaves 5-lobed, broad, rounded. Flowers green. 


\section{ORDER XLI. SAPINDACEA. Indian Soapworts.}

Plants of various habit, mostly with unsymmetrical flowers; sepals and petals both imbricated in the bud; stamens 5 to 10 , inserted on a thick disk under the ovary ; fruit usually colored and showy, lobed, 1 or few-seeded.

The Order includes the following three Tribes.

\section{Analysis of the Genera.}

8 1. The Buckere Tribe. Leaves opposite, carpels 2-oraled....a
a Petals unequal. Stamens 7 . Leaves digitate.
Buckeye. Es'cusus. 1

§ 2. The Soapberri Tribe. Leaves alternate. Carpels 1-ovuled....b

b Trees, with pinnate-leaves and fruit with soapy pulp, covering a large seed. Stamens 8-10. South. Soapwort. SAPIN'DER.

b Herbs climbing with tendrils. Leaves biternate. Fruit a large, inflated, 3-carpeled pod. Balloon-vine. CARDIOSPER'MUM.

\$ 3. The Bladder-ntt Tribe. Leaves opposite, pinnate. STAPHYLE'A. S
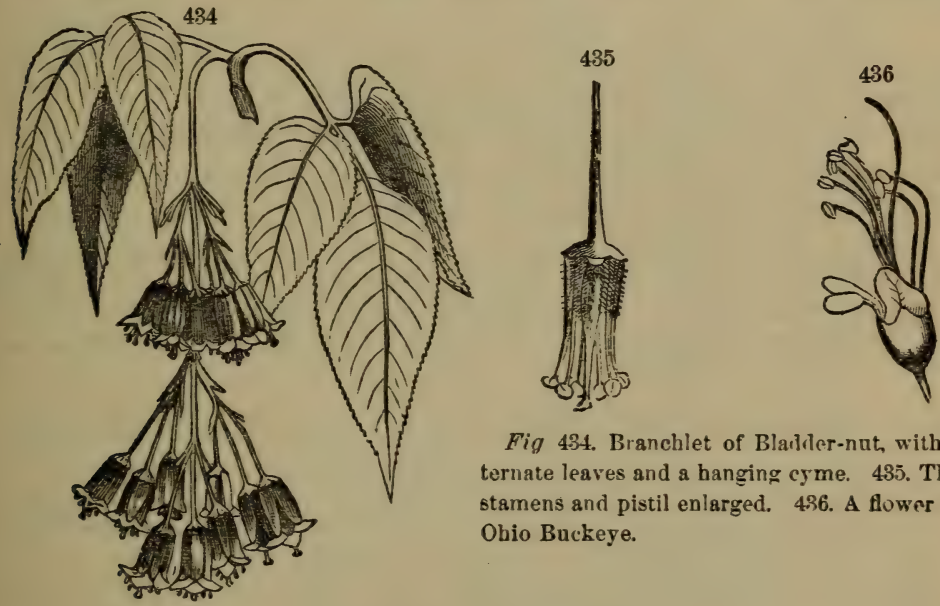

Fig 434. Branchlet of Blaliler-nut, with 2 ternate leaves and a hanging cyme. 435. The stamens and pistil enlarged. 436. A flower of Ohio Buckeye.

\section{AS'CULCS. Buckeye.}

Calyx 5-toothed. Corolla of 4 or 5 unequal petais. Stamens 7, distunet, inequal. Style filiform. Orary 3-celled, with 2 ovules in each cell, but only 1 of the 6 ovules grows, becoming a large seed. Flowers in terminal prnicles. 
$\S$ Fruit covered with prickles. Petals 4 or 5 , spreading....1, 2

$\$$ Fruit sinooth. Petals 4, erect, 2 of them clawed.... $3-5$

1 E. Hippocasta'neum. Horse Chestnut. Leaves of 7, obovate leaflets Petals 5 Fruit prickly. Panicles large, handsome. $\dagger$

2 IE. glabra. Oliio Buckeye. Leaflets 5, oval cr oblong. Petals 4. Tree ill scented. Flowers yellowish. Seed mahogany-color. W.

3 IE. fla'va. Lig Buckeye. A large tree, with pale-yellow flowers. Leaflets 5-7 Petals very unequal, longer than stamens. W.

$\leq \mathbb{E}$ Pa'via. Red-flinered $B$. Shrub 3-10f. Fls. large, red, in thyrse-lire racemes, Very handsome. S. +

5 E. parviflo'ra. White $B$. Shrub 2-3f. Petals 4, somewhat alike, spreading, thrice shorter than the stamens. $\mathrm{S}$.

\section{STAPHYLE'A. Bladder-nut.}

Flowers perfect. Sepals 5, colored like the 5 petals. Stamens 5 . Styles 3. Capsules 2 or 3 , with thin, inflated walls.-Shrubs.

I. S. trifo'lia. Ternate B. A handsome shrub, 6 sf. high. Leaves ternate, leaflets ovate. Racemes pendulous. Petals ciliate below. Fruit very large, 8 -celied, inflated like a bladder.

\section{Order XLII. CELASTRACEA. Staff-trees.}

Shrubs or small trees, with simple leaves; flowers small, 4 or 5 -parted, with imbricated sepals and petals; stamens perigynous, alternate with the petals. Style 1; fruit 2-5-celled. Seeds enclosed in a fleshy aril.

1 Staff-tree. Shrubs climbing and twining. Leaves alternate, oblong, acuminate, serrate. Capsule 3-valved. Seeds with a scarlet aril.

2 Burning Bush. Erect or trailing. Leaves opposite, serrate. Flowers perfect, greenish or purplish. Pods lobed, red; arils scarlet. Econ'ryus.

\section{Order XLIII. RHAMNACEA. Buckthorns.}

Shrubs or small trees, with simple mostly alternate leaves; calyx valvate. Stamens opposite to the small petals, both perigynous. fruit 2-5-celled, cells each 1-sceded.-We have 4 genera.

Buckthorn. Leaves alternate. Petals shorter than the calyx or none. Flowers axillary. Fruit blackish, drupe-like, seeds $2-4$.

RHAMsur.

2 Jersey Tea. Leaves alternate. Petals longer than the calyx, clawed, white in our species. Flowers in dense terminal clusters.

8 Supple Jack. Leaves alternate. Petals not clawed. Flowers in small terminal panicles. Drupe purple. Shrub climbing, twining. BFrcis MrA. $4 \Lambda$ sleuder trailing shrub with opposite leaves and spiked fls. South. SAGKrik'tis. 


\section{ORder XIIV. VITACEA. Grapevines.}

Shrubs climbing by tendrils ; flowers sinall, regular, clustered; calyx minute, with scarcely any limb ; petals valvate, caducous ; stamens opposite to the petals, ovary 2-celled, berry 4-seeded.

\section{VITIS. Grapevines.}

Fig. 436'.

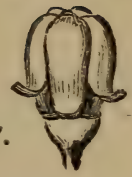

§ True Vitrs. Petals cohering at top and falling off without expanding. (Fig. 436'.) (a) 1 Cresus. Petals free, expanding before falling. Tendrils coiling....Nos. 6, 7,8 5 Aurkiopsis. Petals free, rxpanding. Tendrils with an adhesive foot.... No. 9

a Leaves beneath clothed with a whitish or rusty wool.....Nos. 1, 2, 3

a Leaves glabrous except the veins, and green both sides.... Nos. 4, 5, 10

$1 \nabla$. labrus'ca. Fox G., Catawbx, lsabella. Berries large, pa!e-green, or amber.

$2 \nabla$. æstiva'lis. Summer G., Clinton G. Berries small. deep-blne. Clusters slender.

3 v. Caribæa. Caribean $G$. Berries medium size (1/ $\mathrm{inch}$ ). Downy all over. Florida.

4 V. cordifo'lia. Frost G. Clusters large, loose; berries small, blackish, in Nov.

5 V. vulpi'na. Muscadine. Clusters small; berries large. Leaves shining. s.

$6 \mathrm{~V}$. indivi'sa. Leaves simple, angular or entire; berry small ( $\left.\boldsymbol{2}^{\prime \prime}\right)$. Swamps. S.

$7 \nabla$. bipinna'ta. Leaves bipinnate, cut-serrate. Tendrils none, or few. Berries black.

$8 \mathrm{~V}$. inci'sa. Leaves 3-foliate, thick, lobed; herry 1-sceded. Florida to La.

$9 \mathrm{~V}$. quinquifo'lia. Tirqinia Creeper. Leaves digitate, with 5 leaflets.

10 V. vinife'ra. European Wine-grape. Leaves not shining. Berries large, variable in form, size, and coior.

ORDER XLV. POLYGALACEA. The Milkworts.

Plants without stipules, bearing very irregular flowers ;

stamens 4-8, diadelphous;

anthers opening at the top, 1-celled; fruit a flattened, 2-celled, 2-seeded

capsule, free from the calyx.

Fig. 437. Polygala polygama: $a$, the radical flowers; 8 , P. paucifolia; $f$, the crest on the lower petal; 9 , the stamens in 2 sets, and the style seen beneath the houded lower petal.

Fig. 440. The ovary and the style: 1 , seed of P. sanguinea, with its 2-lobed caruncle; 2 , seed of P. Nuttallii.

\section{POLYG'ALA. Milkwort.}

Sepals 5, persistent, 2 of them in ings) wing-shaped and coilored.

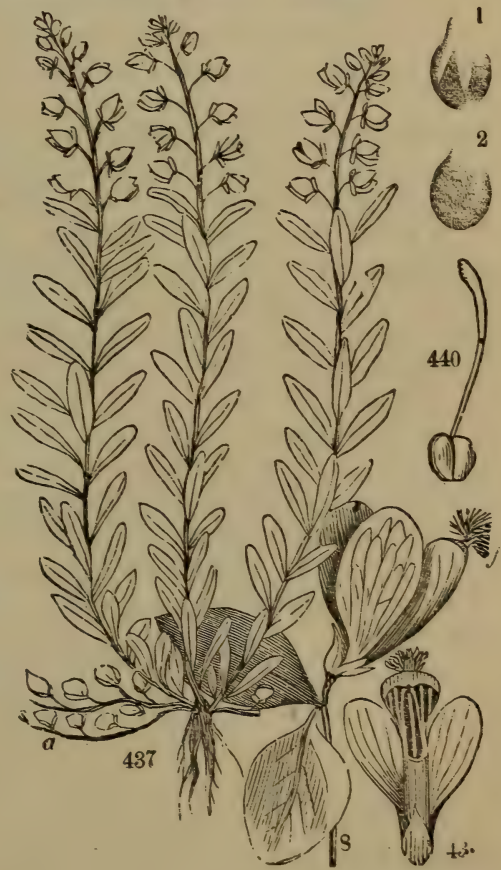


Petals 3 , the lower onc hoat-shaped, and often tipped with a crest. Sta mens united by the filaments into a split sheath, or into 2 sets, cohering more or less with the claws of the petals. Fruit a small 2-celled, 2-seederl capsule, flattened on the sides and notched on the top. Seeds with an appendage at one end.-Low, bitter herbs (sometimes shrubs), with simple entire leaves, sometimes bearing underground flowers. 'Fig. 437, a.)

* Leaves al. alternate and scattered....a

* Leaves whorled, at least the lower ones....e

a Flowers purple, or reddish, or white....b

a Flowers yellow or yellowish green....d

b Flowers solitary or in racemes, purple.....Nos. 1-3

b Flowers in spikes which are oblong or slender....

- Leaves lanceolate, large, pointed at each end....4

c Leaves linear, 1 to $2^{\prime \prime}$ wide....5-7

c Leaves awl-shaped or bristle-shaped....8-10

d Spikes solitary, large, thick. Biennial....11, 12

d Spikes numerous, corymbous, small. Biennial....18, 14

e Spikes acute, slender....15, 16

e Spikes obtuse, thick....17, 18

1 P. paucifo'lia Showy M. Fls. 2 or 3, large (root Hs. small). Lvs. ovate. (Fig. 438.1

2 P. grandiflo'ra. Fls. racemed, crestless. Lrs. lance-ovate. S.

3 P. polyg'ama. Flowers racemed, crested. Lvs. linear-oblong. (Fig. 487.)

4 P. Sen'ega. Seneca Snake-root. Fls. white, in slender spikes. Stem 1f. ligh

5 P. sanguin'ea. Bloody 1 . Spikes oblong, obtuse, dense. Wings sessile.

6 P. fastigia'ta. Roofed M. Spikes roundish, loose-flowered. Wings clawed.

7 P. Nuttal'lii. Nuttall's M. Spikes rotndish, acute, dense. Wings elliptic.

8 P. incarna'ta. Flesh-colored $1 /$. Lrs. few, subulate. Pet. much longer than calyx.

9 P. seta'cea. Naked $\boldsymbol{M}$. Leaves very minute. Petals longer than calyx. \&.

10 P. Chapman'ii. Chapman's M. Lvs. subulate. Calyx long as petals. S.

1 $\mathrm{P}$. lu'tez. Yellowo M. Tall (8-12'), with orange-yellow flowers. M. S.

12 P. na'na. Dwarf $M$. Low $\left(3-5^{\prime}\right)$, with greenish-yellow flowers. S.

13 P. cymo'sa. Cyme-flowered M. Lvs. mostly cauline. Seed not bracted. S

14 P. ramo'sa. Branching $M$. Lvs. mostly radical. Seed bracted. S.

15 P. verticilla'ta Whorled M. Lvs. linear. Wings roundish. Fls. greenish. W

t6 P. Boykin'i., Brykin's M. Lis. lance-obovate. Wings round-obovate. S.

17 P. crucia'ta. Cross $M$. Spikes obt'se, thick, sessile. Wings pointed.

18 F. brevifo'lia. Sh.rt leaved $M$. Spikes obtuse, loose, stalked. Wings acuta

\section{Order XLVI. LEgUMinos A. Leguminous Plants.}

Plants with alternate, mostly compound stipulate leaves, with t-5 sepals; 5 petals, more or less papilionaceous, sometimes regular 
about 10 stamens, monadelphous, diadelphous, or distinct; a single, simple pistil, producing a legume in fruit, and with no albumen in the seeds.

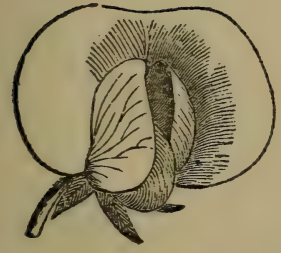

443

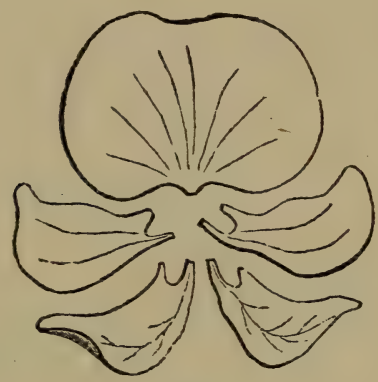

444

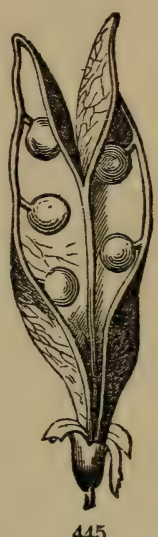

445

Fig. 443. Flower of the Pea. Fig. 444. Its petals displayed; $v$, the banner; $a, a$, the winus a, c, the 2 keel petals. Fig. 445. A leguine (pea-pod).

\section{Analysis of the Genera.}

§ Flowers papilionaceous (\$ 89). Upper petal (banner) covering the rest in bud....2

$\$$ Flowers nearly regular, or upper petal covered by the rest in bud....*

\& Flowers regular, in dense heads. Petals valvate in bud. Leaves bipeunate ...

2 Stamens 10, all distinct....s

2 Stamens 10 , all or 9 united....3

3 Leaves cirrhous (Fig. 96), the rachis ending with a tencril....r

3 Leaves not cirrhous....4

4 Pod a loment ( $\$ 180), i$. e., jointed between the seeds ....

4 Pou a legume, 1, 2, or $\infty$ seeded, not in joints....5

5 Erect (or if prostrate, with palmately 3 -foliate lenves)....7

5 Trailing or twining vines, leaves pinnately compound....9

6 Flowers yellow....q

6 Flowers cyanic (not yellow)....p

7 Leaves simple, with yellow flowers....o

7 Leaves palmately 5 -15-foliate (rurely simple) . .

7 Leaves palmately 3 -foliate....m

7 Leaves pinnately 3 -foliate....k

7 Leaves pinnate with no odd leaflet, 15-25 pairs. ..b

7 Leaves pinnate with an odd leaflet....8 
8 Leafiets dotted with dark glands....6

8 Leaflets not dotted. Herbs....f

$\delta$ Leaflets not dotted. Shrubs or trees....

9 Leaves pinnately $5-15$-foliate....d

9 Leaves pinnately 3-(rarely 1-) foliate. Flowers yellow....

9 Leaves pinnately 3 -foliate. Flowers cyanic....10

10 Calyx 4-toothed or entire....b

10 Calyx 5 -toothed or 5 -cleft..... a

a Keel with the stamens and style spirally coiled.

Beun. Phase'olis. I

a Keel obtuse, on short elaws. Fls. very large, blue. S. Blue Banner. Centrose'ma.

a Keel acute, on long claws. Fls. very large, roseate. Butterfly Pea. Clito'ria.

b Calyx 4-eleft, supported by 2 bractlets. Fls. purple. Milk-vine. Galad'tia.

b Calyx 4-toothed, with 2 bractlets. Fls. purple. Sds. flattened. DuL'Iсноs.

b Calyx 4-toothed, without bractlets. Fls. pale p. Hig-Peanut. A MPHicarp $\mathbb{E}^{\prime}$ A.

b Calyx entire. Flowers and seeds scurlet. S. Red Bean. Erythri'na. c Legumes 5-seeded. S.

c Legumes 1-2-seeded. S.

VIG'NA. Rhynco'sia.

d Herbs. Keel (straight in Galactia, 2) spirally twisted.

d Shrubs. Keel curved. Fls. blue, in hanging racemes. †

e Flowers white or red, in racemes.

Pea-vine. Apius. 2

W' ISTA'RIA.

- Flowers yellow, few in a cluster. Pods intlated. Bladder Senna. Colo'tra.

t Pod 2-celled lengthwise, turgid.

: Pod half-2-celled lengthwise.

$f$ Pod 1-celled. Style hairy outer side.

f Pod 1-celled. Style not hairy at all. S.
Milk Vetch. Astraq'alus.

Bastard Vetch. Pнаса. Goat's Rue. 'T'врнио'sis.

Indigo. INDIGo' FERA.

g Shrubs. Fls. spicate, only 1 petal (the banner). W.S. Lead Plant. A моR' '́

g Herbs. Flowers with 10 stamens, bluish, spicate. W. DA'LEA.

g Herbs. Flowers with 5 stamens, white or red, capitate. W. Petaloste'mon.

h Pod 1-2-seeded, valves double. Tall, with yellow flowers. S. GLorid'icm.

b Pod many-seeded, very long. Tall, with yellowish flowers. S. SksBa'NIA.

k Pod few-seeded. Flowers scarlet in ErtThri'na.

k Pod few-seeded. Flowers white or yellow.

Melilot. Melilo'rus, 4

Is Pod 1-seeded. Flowers yellow. Leaves resinous-dotted in RHyncosia.

r Pod 1-seeded. Flowers cyanic. Leaves dark-dotted.

P'SOIRA'LEA.

s Pod 1-seeded. Flowers cyanic. Leaves not dotted. Mililot. Melilo'rus. 4

m Herbs with curved or spiral pods.

m Herbs with small 1-4-seeded pods not coiled.

m Tree with yellow flowers in hanging racemes. +

n Stamens all united. Calyx 2-lipped.

n Stamens all but 1 united. Calyx bill-shaped.

- Shrubby. Keel oblong, straight.

- Herbs. Keel curved, acuminate.

p Leaves pinnate, 5 -21-foliate.

D Leaves pinnate, 5-21-foliate. Racemes stalked. Vt

Medic. Medica'go. 11

Clover. Trifo'Liom

Golden Chain. LABUR' ${ }^{\prime} \cup M$

Lupine. LUPI'NES 6

Psora'lea.

Seotch Broom. Genis'rA. Rattle Pod. Crotala'ria. Coronil'la. HEDTS'AREM 
p Lvs. pinn'ly 3-fol., stipellate. Pod 3-7-jointed. Tick Tiefual. Desso'dium.

p Lrs. pinn'ly 3-fol. Stipels none. Pod 1-jointed. Bush Trefoil. Lespene'za, 7

q Leares palmately 4-foliate. Stamens all united.

q Leaves pinnate, $7-49$-foliate. Stamens 9 united.

q leaves pinnately 3 -foliate. Pod slender at base.

9 Leares pinnately 4 -foliate. Rod gibbous at base.

$r$ Leaflets serrate. Pods 2 -seeded.

$\boldsymbol{r}$ Leaflets entire. Style grooved outside, hairy inside.

ZOR'NIA.

ESCHYNOM'ENE.

Strlosan'thes.

Peanut. AR'schis.

Chick Pea. Cicer.

Pea. Pisum. 8

I Leaflets entire. Style flattened, hairy most inside. Sweet Pea. Latu'rros. 12

I Isaflets entire. Style filiform, hairy most outside.

Vetch. VIC'IL. 13

- Pod legume flat and thin, short-stiped. Lrs. pinnate. Tree. S. W. Cladas'turs.

s Pod inflated, stipitate (stalked at kase). Lvs. 1-3-foliate. Baptis'ia. 9

t Fls. perfect, purple, papilionaceous. Tree. Lvs. simple. Judas-tree. Cercis.

t Fls. perfect, yellow. Lrs. equally pinnate. Senna. Cassia. 10

t Fls, imperfect, green. Sta. 5. Trees thorny. Honey Locust. Glenits'chia.

t Fls. imp., greenish. St. 10. Trees unarmed. Ky. Coffee-tree. Grunoc'ladrs. n Pods flat, jointell between the seeds. Shrubby. Sensitive Plant. Mrmo'sa. u Pods prickly, 4-sided, 4-valved. Sensitive Brier. Schran'kia. u Pods smooth, turgid, filled with pulp. Tree. S. Sponge-tree. Vacher'Lia. a Pods smooth, flat, dry. Petals distinet. Stam. 5-10. Herbs. Desman'rhus. a Pods smooth, flat, dry. Petals united. Stam, 8-200. S. Julibrassin. Aca'cra.

\section{PHASE'OLUS. Bean, \&c.}

Calyx 5-toathed or cleft, the 2 upper teeth half united. Keel including the stamens and style, and with them spirally coiled or twisted. I.egume straight or curved, manyseeded. Seeds oblong, kidneyshaped.-Herbs twining or trailing. Leaves pinnately trifoliate, stipellate. June-Oct.

- Natire species, growing in fields and woods.... a

- Frotic species, growing only by culti-

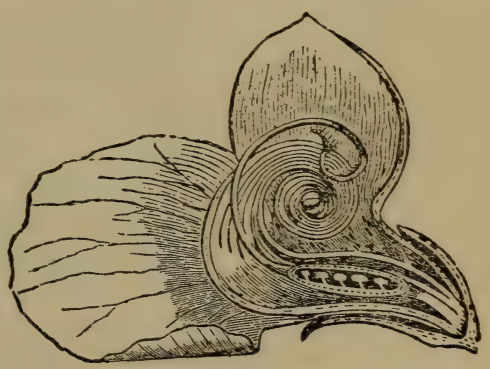

Fig. 446. Section of flower of the Bonn showing the spirally coiled stamens and stylo the simple orary, sc. vation ....b

a Flowers racemed. Pods curved....1

a Elowers 1 or few in a head. P ds straight. . 2-4

b Stenıs climbing....5-7

b Stems erect, bushy $\ldots .8$ 
1 P. peren'nis. Perennial Wild-bean. Leaflets ovate, pointed. Racemes in pairs. 4-7f. $p$ 2 P. diversifo'lius. Trailing $W$. Leaflets angular, 2-3-lobed. Peduncle longel than leaf. $c$.

8 F. hel'volus. Long-stalked W. Leaflets lance-ovate, not lobed. Peiluncle 34 times longer than the leaf. M. S.

4 F. paucifo'rus. Fetw-flowered $W$. Leaflets linear-oblong, hairy. Peduncle longer than the leaf. W.

of vulga'ris. Common Garden-bean. Leaflcts ovate, pointed. Racemes solitary, shorter than leaves.

S P. multiflo'rus. Scarlet Pole-beań. Fls. scarlet, showy. Root tuberous. Pedicels opp. $\uparrow$ 7 P. luna'tus. Lima B. Flowers white. Lfts. ovate-deltoid, acute. Pods broad, large. 8 P.na'nus, Bush-bean. Erect, bushy. Leaves broad-ovate, acute. †

\section{A'PIOS. Ground-nut.}

Calyx bell-shaped, somewhat 2-lipped, the 2 side teeth nearly obsolete, the lower tooth longest. Keel incurved and at length coiled against the very broad, reflexed banner. Ovary sheathed at base.-Twining, smooth herbs. If Root bearing eatable tubers. Leaves pinnately 5-7-foliate.

A. tubero'sa. Stem round, twining about other plants, 2-4f. in length. Leaflets mostly 7, narrow-ovate, more or less acuminate, on short stalks. Racemes axillary, solitary, dense-flowered, shorter than the leaves. Flowers dark purple. The tubers on the root are oval, thick, and very nutritious. In thickets and shady woods. July, Aug.

\section{ROBIN'IA, Locust.}

Calyx short, bell-shaped, 5-cleft, the 2 npper divisions more or less anited. Banner large, wings obtuse. Stamens diadelphous $(9 \& 1)$. Style bearded inside. Legume flattened, long, many-seeded.-Trees and shrubs with stipular spines. Leaves unequally pinnate. Flowers showy, in axillary racemes. April, May.

R. visco'sa. Clammy Locust-tree. Racemes rather compact, rose-white, erect. Branchlets and stalks sticky. Leaflets ovate. In parks. Native South.

R Pseudaca'cia. Common Locust-tree. Racemes rather loose, drooping, white, fragrant. Leaflets oblong-ovate, smooth, as well as the branchlets.

R. his'pida. Rose Acacia. Shrub 4-9f. high, hispid, with clusters of large, pu pl flowers. Leaflets 5 or 6 pairs, broadly oval.

\section{MELILO'TUS. Melilot. Sweet Clover.}

Calyx tubular, 5-toothed. Keel petals completely united, shorter than the thers. Of the 10 stamens 9 are united, one separate. Pod 1 or few. 
zeeded, longer than the permanent calyx. Leaves pinnate.y trifoliate Flowers in racemes.

I M. officina'lis. Yellow $M$. Leaflets obovate-oblong, obtuse, dentate. Calyx half as long as the yellow corolla. Pod 2-seeded. Stem $3 f$.

$2 \mathrm{M}$. alba. White $\boldsymbol{M}$. Leaflets ovate-oblong, square at end. Calyx not half as long as the white corolla. P'od 2-seeded. Height 4-6f. Very fragrant.

\section{TPIFO'LIUM. Clover. Trefoil.}

Calyx 5-cleft, with bristly teeth, persistent. Petals more or less united at the base, persister $\mathrm{L}_{\mathrm{t}}$ and withering. Banner longer than the wings, which are also longer than the keel. Stamens 10, diadelphous (9\& 1). Legume short, membranous, often included in the calyx, 1-6-seeded, mostly indehiscent. - Herbs with palmately trifoliate leaves. Leaflets straight-veined. Flowers in heads or spikes. Apr.-Sept.

* Flowers yellow, in sniall, dense, oval heads. Pod 1-seeded.....1, 2

- Flowers cyanic (not yellow)....a

a Flowers on little stalks (pedicels) and finally deflexed....b

a Flowers nearly or quite sessile, never de-

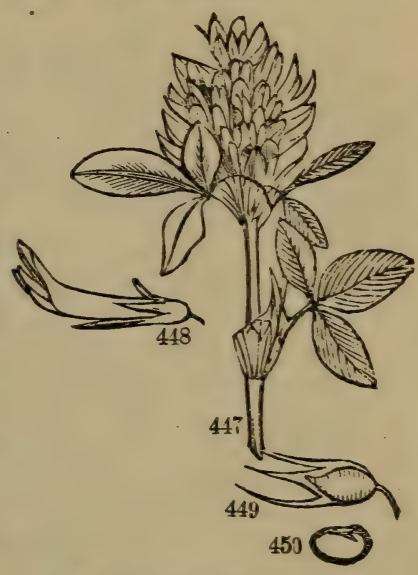

Fig, 44i. Red Clover,-a head of flowers. Fig. 448. A single flower. Fig. 449. A pod, with a part of the calyx. Fig. 450. A seed, cut open. Eee also Fig. 37. flexed....c

b Heads small, on stalks some ten times longer....3, 4

b Heads large, on stalks two or three times longer...5, 6

c Calyx teeth feathery, longer than the whitish corolla....7

c Calyx teeth shorter than the purple or roseate corolla....8-10.

- T. procum'bens. Yellow C. Stipules much shorter than the petioles. Style 3 or 4 times shorter than the pod. Heads orate, $\frac{1}{4}$ in. thick. Stems prostrate. May.

8 T. agra'rium. Larger Yellow C. Stipules longer than the petiole. Style about, as long as the pod. Heads oblong, $\frac{1}{2}$ in. thick. Stems ascending. June, July.

3 T. Carolinia'num. Southern C. Stipules leaf-like. Calyx teeth thrice lungez than its tube. Legume 4-seeded. Scarcely forms a turf. W. S.

4 T. repens. White C. Shamrock. Stipules narrow, scale-like. Calyx teeth shorter than its tube. Pod 4-seeded. Forms a dense turf. Fls. white. c. T. reflexum. Buffalo $C$. Lfits. obovate. Calyx nearly as long as the red ecrolla.

6 T. stoloni'ferum. Prairie C. Leaflets obcordate. Calyx not half as long as the white corolla. W. 
7 T. anven'se. Rablit-foot $\boldsymbol{C}$. Heads cylindrical, very hairy. Lfts. narrow obovate 8 T. praten'se. Red $C$. Leaflets spotted, oval. Heads roundish, sessile. Flower rose-red, or white. c. † (Figs. 447-456.)

9 T. me'dium. Zigzag C. Lifts. oblong. Heads roundish, stalked. Fls. deep purple. $r$ 10 T incarna'tum. Rose Trefoil. Lfts. round-ovate. Heads oblong. Fls. rose-red. ^

\section{LUPI'NUS. Lupine.}

Calyx deeply 2-lipped, upper lip 2-cleft, lower entire or 3-toothed. Wings united towards the top, keel acuminate. Stamens monadelphous, the filaments forming an entire sheath. Anthers alternately oblong and globose. Pod leathery and knotted.-Herbs, with leaves palmately 5-15foliate, rarely simple.

1 L. peren'ais. Common L. Root creeping, perennial. Stem erect, 1-2f. high,

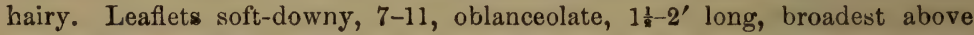
the middle. Flowers alternate, in an erect, terminal raceme, blue, varying to white. It is often called Sun-dial, from the fact of its leaves turning to face the sun from morning till night.-Several other species are cultivated in gardens. May, June. (Fig. 66.)

2 L. villo'sus, Mullein $L$. Stem erect, 1-2f., terminating in a showy raceme. Leaves simple, clothed in a dense coat of silky wool as well as the stem. S.

\section{LESPEDE'ZA. Bush Clover.}

Calyx 5-parted, with 2 bractlets at base, the sepals nearly equal. Keel very obtuse, on slender claws. Stamens diadelphous (9\& 1). Legume .ens-shaped, small, flattened, unarmed, one-seeded, not opening. -2 Leave rinnately trifoliate. Flowering in Aug., Sept.

If Flowers in dense spikes, whitish, with a purple spot on the banner....1, 2

I Fls. racemed, \&c., violet or purple. Some of the fls. with no corolla.... a

a Stem prostrate, trailing, diffuse. Leaflets oval....8

a Stem erect and mostly branched, 1-3f. high....4, 5

1 L. capita'ta. Head B. Leaflets elliptical, silky. Spikes shorter than leaves. Stem nearly simple, 2-4f.

2 L. hirta. Hairy $B$. Leaflets roundish-oval. Spikes longer than leaves Stem branching, very hairy.

3 L. repens, Creeping B. Downy more or less, except the upper side of the leaves whinh is always smooth. Stems slender, many.

1 . violn'cer Violet $B$. Smoothish. Leaflets oval, varying tc sblong and lireat obtr.se, tcronate. Corolla $3-4^{\prime \prime}$ long. Varies greatly.

5 L. Steu'vi. 'lant velvety or downy. Lfts. round:sh-obovate. Variable. 


\section{PI'SUM. Pea.}

Calyx divisions leaf-like, 2 upper shortest. Banner large, reflexed. Stamens 10, diadelphous ( $9 \& 1$ ). Style flattened, keel-shaped, bearded on the upper side. Legume oblong; tumid. Seeds globose-Climbing herbs. Leaves pinnate, ending with a branching tendril.

P sati'vum. Common Garden Pea. Leaflets usually 4. ovate, entire. Stipules rather larger than the leaflets (2-3' long), ovate, half-cordate at base. Flowers 2 or more on axillary peduncles, large, white. Pods 2 or 's' long, 5-9-seeded. A very valuable leguminon plant, all over smooth and glaucous. There are many varieties. June. (Also, Fig. 443.)

\section{BAPTIS'IA. Wiid Indigo.}

Calyx 4-5-cleft half way. Petals of about equal length, somewhat united. Banner roundish, notched at the end. Stamens 10, distinct, deciduous. Pod inflated, many-seeded, raised on a stalk in the persistent calyx. $-2 f$ Large herbs

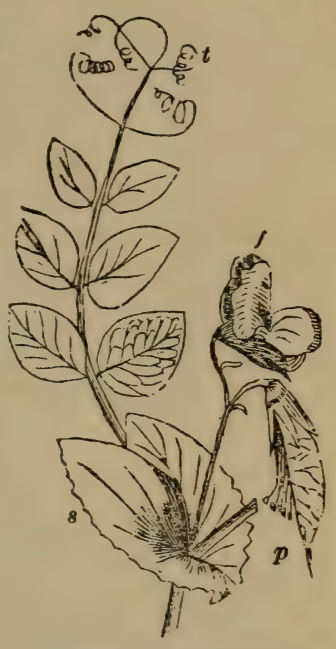

Fig. 451 Common Per: 8 , the large stipules; $p$, the pod: $f$, the flower; $t$, the tendrils on the end of the leaf. with leaves palmately 3 -foliate or simple. Flowers in racemes. Leafit ts mustly oblong, broadest above. Apr.-Sept.

\& Leaves simple. Flowers yellow. (3 species fur South, orritted.)

$\$$ Leaves 3 -foliate.... a Flowers blue, in a few long racemes....1

a Flowers white, in a few long racemes....b

a Flowers yellow, solitary, or in short racemes....c

b Stipules leaf-like, longer than the petioles....2, 8

b Stipules much shorter, or not longer than the petioles...4, 5

c Flower-stalks not longer than the calyx...6, 7

c Flower-stalks much longer than the calyx. S. Omitted.

1 B. anstra'lis. Austral $W$. Smooth. Lfts. obovate or oblong. Fls. large. W. S. $\uparrow$ 2 B. leucophæ'a, Whitish W. Stipules large, ovate. Racemes nodding. II.

3 B. villo'sa. Woolly $W$. Stipules small, lance-linear. Racemes erect. $\mathbf{S}$.

B. leucantha. Stipules lance-linear, about as long as petioles. W. S. †

B. alba. Stipules and bracts minute, early falling off. S.

6 B. lanceola'ta, Leaflets narrow-elliptic. Flowers axillary. S.

7 B tincto'ria. Leaflets small, round-oborate. Racemes tcrminal. Common. 


\section{CAS'SIA. Senna.}

Sepals 5, scarcely united at base, nearly equal. Petals 5, unequal, but not papilionaceous. Stamens 10, distinct, 3 upper anthers often sterile, 3 lower ones beaked. Legume long, many-seeded.-Leaves simply and abruptly pinnate, mostly with a gland on the petiole. Flowers yellow. July, Aug.

T Racemes axillary. 3 of the anthers imperfect, 7 of them perfect....1, 3

I $R$ acemes above the axils. Anthers all perfect. Stem 1-2f. high....4, 5

1 C. obtusifo'lia. Blunt S. Leaflets 4-6, obtuse. Stem 1-3f. high. S.

2 C. occidenta'lis. Western S. Leuflets 6-12, acute. Stem 4-6f. high. S.

8 C. Marilan'dica. American $S$. Leaflets 12-18, mucronate. Stems 5f. high.

4 C. Chamæcris'ta. Sensitive Pea. Anthers 10, unlike. Fls. large. Lfts. 16-24.

5 C. nic'titans. Sensitive S. Anthers 5, alike. Fls, small. Leaflets 12-30.

\section{MEDICA'GO. Medick.}

Calyx 5-cleft. Corolla deciduous. Banner free and remote from the keel. Legume variously curved, coiled or twisted. Leaves pinnately 3-foliate, denticulate. From Europe. May-July.

* Pods smooth, not spiny.... Nos. 1, 2, 3.

* Pods spiny, spiral ; spines in a double row. Fls. yellow.....Nos, 4, 5, 6.

1 M. sati'va. Lucerne. Smooth, erect. Fis. purple, large. Pods sliral.

2 M. lupuli'na. None-such. Downy, prostrate. Fls. yellow. Pod reniform.

3 M. scutella'ta. Snails. Fls. yellow. Pod coilcd like a snail-shell.

4 M. denticula'ta. Leaflets obovate. Stip. bristly, gashed. Pod loose-coiled.

5 M. macula'ta. Leaflets obcordate, with a purple spot. Pod close-coiled.

6 M. intertexta. Hedge-hog. Leaflets rhombic. Stipules gashed. Spines close.

\section{LATH'YRUS. Vetchling.}

Calyx lobes short. Style flat, bent, widened laterally above, bearded along the inner side (next the free stamen). Pod oblong, several-seeded. Trailing or climbing. Leaves equally pinnate, produced into tendrils. Peduncles axillary.

* Leaflets a single pair. Garden species, from Europe.... Nos. 1, 2.

* Leaflets commonly 3-pairs.....Nos. 3, 4, 5.

* Leaflets commonly 5-pairs. Peduncle many-fiowered.....Nos. 6, 7.

1 L. latifolius. Everlasting Pea. Stem winged. Flowers large, pink, many an eack long peduncle. A variety has white flowers. 24

2 L odora'tus. Sweet Pea. Peduucle 2-flowered, flowers red and white.

3 L. ochroleu'cus. Flower cream-white, 7-10. Stipules half-cordate.

4 L. palus'tris. Flowers blue-purple, 2 or 3. Stipules half-sagittate.

5 I. myrtifo'lius. Flowers pale-purple, 5 together. Stipules ovate, entire. 
6 L. mari'timus. Beach Pea. Stipules large, half-has'ate. Shores.

7 L. veno'sus. Stipules small, half-sagittate. Purple. Shady banks.

\section{VIC'IA. Vetch.}

Style filiform, bent, bearded all around at the upper end beneath tho

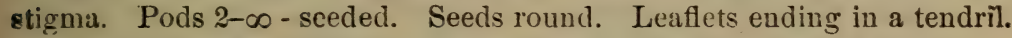

* Peduncle 1-2 flowered, shorter (in flower) than the leaves.... Nos. 1, 2.

* Peduncle 4-8-flowered. Stipules deeply toothed. Leaflets 10-14. . . No. 3.

* Peduncle 3-20-flowered. Stipules entire, small. Flowers bluish.....Nos. 4, 5, 6.

i $\nabla$. sati'va. Vetch, T'ares. Leaflets 10-14, notched at end. Flowers purple, large

2 V. tetrasper'ma. Four-seeded $V$. Leaflets 8-12, obtuse. Fls. whitish. Pod 4-seeded

3 V. America'na. Leaflets very obtuse. Flowers purplish, 8 or $9^{\prime \prime}$ long.

4 V. Oarolinia'na, Leaflets 12-16, linear-oblong, obtuse. Flowers small, scattered.

5 V. Cracca. Downy. Leaflets 20-24, acute, mucronate. Flowers small, close

(i) $\nabla$. hirsu'ta. Hairy. Leaflets 12-16, truncate. Pods hairy, 2-seeded.

\section{Orner XLVII. ROSACEA. Roseworts.}

Trees, shrubs, or herbs with stipules mostly, and alternate leaves; with flowers regular, commonly showy, perfect, and polyandrous; with 5 sepals united at base, often supported by as many bractlets outside; 5 petals (rarely 0), which are perigynous as well as the stamens; $1-\infty$ pistils, which are distinct, or sometimes united and adhering to the calyx tube; fruit various; seeds with no albumen.

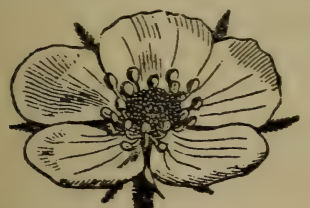

455

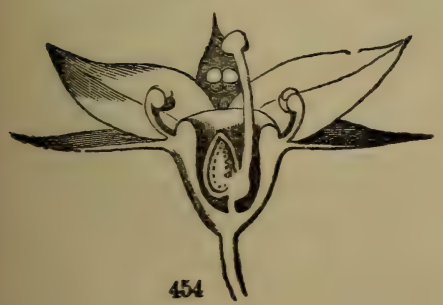

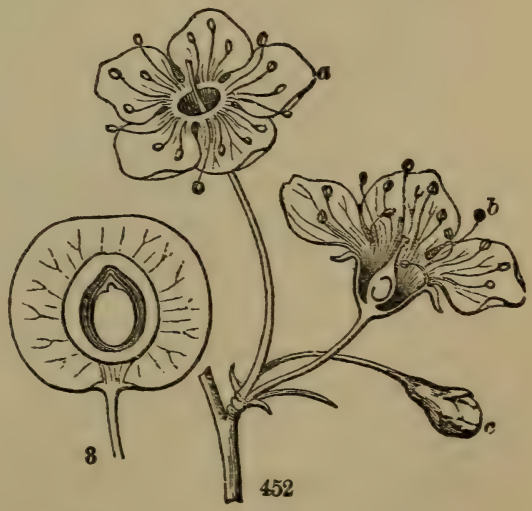




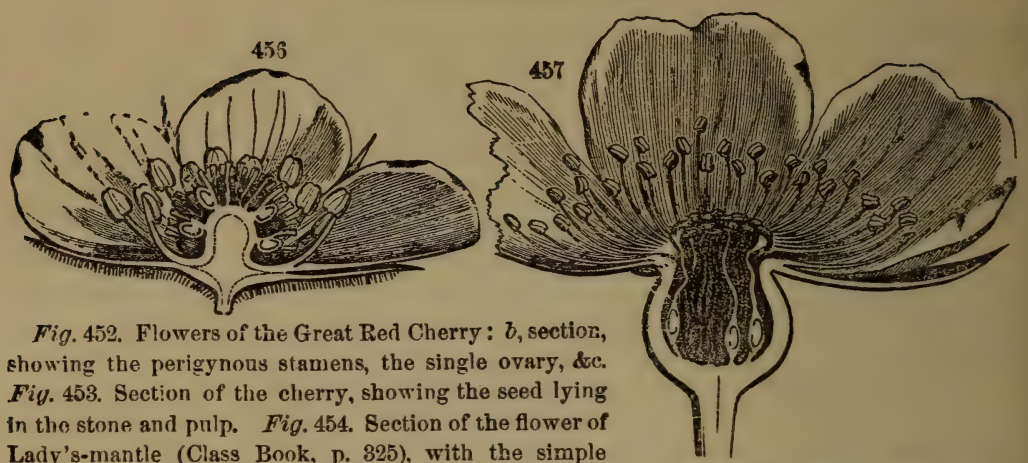
Lady's-mantle (Class Book, p. 325), with the simple ovary, lateral style, \&c. Fig. 455. A flower of Strawberry. Fig. 456. A section of the same showing the perigynous stamens, the many simple pistils on the large torus. Fig. 457. Section of a Rose, showing the many simple pistils sunk in the hollow torus, \&c.

\section{Analysis of the Genera.}

₹ Flowers with 1 pistil and no petals. Herbs....a

$\$$ Flowers with 1 pistil and 5 petals. Shrubs or trees....2

\& Flowers with $2-\infty$ pistils....3

2 Style lateral, $i . e_{\text {. }}$, arising from the side of the ovary....

2 Style terminal, i.e., arising from the top of the ovary....c

8 Pistils (carpels) 2-5, all consolidated with the calyx. Fruit a pome....d

3 Pistils (carpels) 2-50, free, in an open or closed calyx....4

4 Carpels 1 -seeded, achenia inclosed in the calyx tube....e

4 Carpels 1-seeded, achenia dry or pulpy in an open calyx....5

4 Carpels several-seeded, pods in an open calyx....

5 Styles persistent on the dry achenia....

5 Styles falling off with the rest of the flower....6

b Calyx entirely bractless. Flowers never yellow....g

6 Calyx with bractlets beneath it as if donble....h

a Stamens 1-4. Style lateral. Fls. scattered. Lady's-mantle. Archemir'is. a Stamens 4. Style terminal. Fls. in dense spikes. Burnet. SANGUIsor'BA. a Stamens $\infty$. Style terminal. Flowers in spikes. Burnet. Pote'ricu. b Stamens about 20. Drupe 1-seeded. S. Cocoa Plum. Chrrsubala'sus.

c Stone globular, smooth. Fruit not glancous.

c Stone flattened, smooth. Fruit glaucous or downy. Cherry. Cer'asts. 1

- Stone roughened with pits and furrows. Fruit pulpy.

- Stone roughened with pits and furrows. Fruit dry. Plum. Pro'nus. Peach. PER'SIOA.

d Petals spat.-oblong. Pome with 5 dble.-cells. Shad-bush. Amedan'chier. 2

d Petals roundish. Pome with bony, 1-seeded cells. Thorn. Craterégs.

d Petals roundish. Pome with thin, 2-seeded cells.

d Petals roundish. Pome with 5, many-sceded cells. Apple. Prrus. \& Quince. Croo' nus. 4 
- Carpels inany, in the fleshy calyx. Flowers often double.

Rose. Rosa. 5

e Carpels 2 only, in the dry, fluted, prickly calyx. Agrimony. Agraro'nia.

$f$ Petals and sepals 8 or 9 . A small, rare plant on mountains DrFas.

$f$ Petals and sepals 5. Achenia numerous. Avene. Gecr. 6

g Sepals equal. Fruit a heap of pulpy achenia. Fls. cyanic. Bramble. Rebes. 7 B Sepals unequal. Stems creeping. Flowers white. Fulse Violet. Dalibar'da. 3

b Torus small, dry. Flowers yellow. Bractlets minute or 0. Waldstei'nia. 9

h Torus small, dry. Fls. mostly yellow. Bractlets large.

h Torus becoming very large and juicy in fruit. Strawberry. Fraga'ria. 11

h Torus becoming large and spongy. Fls. purple. Lvs. pinuate. Con'ArUM.

k Petals obovate, not yellow. Stamens very long.

Steeple-bush. SPIr. $\mathbf{s}^{\prime} \mathbf{A}, 12$

k Petais lance-linear, not yellow. Stamens very short. Indian Pliysic. Gille'nia.

r Petals multiplied, orange-jellow. Pods 1-seeded. Shrubs.

Guelder Rose. KER'RIA.

\section{CER'ASUS. Cherry.}

Calyx 5-cleft, regular, deciduous. Petals 5, much spreading. Stamens 15-30. Ovary with 2 ovules. Drupe globular, very smooth, destitute of a glaucous bloom. Stone also globular and smooth.-Trees or shrubs. leaves folded in the bud. Flowers early, white. May. (Fig. 452.)

$\S$ Leaves evergreen, leathery, entire....1

$\S$ Leaves deciduous, thin ....a

a Flowers in umbel-like clusters from side buds. Drupes red....b

a Flowers in racemes leafy at base. Cherries black or blackish....2, 3

b Shrubs or trees growing wild, native....4, 5

b Trees cultivated, not native....6, 7

I C. Carolinia'na. Cherry Laurel. Flowers in dense, short racemes. Fruit black, poisonous. Splendid in cultivation.

2 C. sero'tina. Wild Black $C$. Trees with lance-oblong, blunt-toothed leaves.

3 C. Virginia'na. Choke C. Shrubs with oval-obovate, slender-toothed leaves. 4 C. pum'ila. Sand C. Shrubs trailing, with lance-obovate, acutelrs. Fr. ogg-shaped. 5 C. Pennsylvan'ica, Wiild Red C. Trees. Lvs. oblong-ovate, acuminate. Fr. roundish.

6 C. A'vium. Oxheart C. Leaves oblong-ovate, acuminate, hairy beneath.

7 C. vulga'ris. Great Red C. Leaves lance-ovate, acute, narrowed to base.

\section{AMELAN'OHIER. June-berry.}

Calyx 5-cleft. Petals 5, oblong-ovate and oblanceolate. Stamens shinrt. Styles 5, somewhat united at base. Pome 5-celled, cells cartilaginous, each nearly divided into two 1-seeded divisions. - Small trees or shrubs with simple, serrate leaves, and white early flowers in racemes. 
A. Canaden'sis. Shad-berry. June-berry. A small tree or shrub found in woods, with a dark-grayish bark. Flowers large white, in racemes at the ends of the branches, appearing in April and May, while the forests are yet naked. Fruit round, purplish, well-flavored, ripe in June. The plant is very variable in size, and in the leaves, \&.c.

\section{PY'RUS. Pear. Apple.}

Calyx urn-shaped, limb 5-cieft. Petals 5, roundish. Stamens 00. Styles ? 5. Pome fleshy or berry-like, containing 2-5 cartilaginous (thin and elastic) carpels, each with 2 seeds.-Trees or shrubs. Leaves simple or pinnate. Flowers showy, white or rose-colored, in cyme-like umbels. May, June.

$\S$ Leaves pinnate. Fruit as large as peas, scarlet when ripe...6, 7

\& Leaves simple....a

a Wild shrubs, 5-8f. high. Flowers small, in compound clusters....5

a Trees wild or cultivated. Flowers large, in simple clusters....b

b Flowers white. Pome bell-shaped, acute at base....1

b Flowers rose-white. Pome with a pit at base....2-4

1 P. commu'nis. Pear. Leaves ovate-lanceolate. Styles 5, distinet. † (Fig. 280.)

2 P. malus. Apple. Leaves ovate, not lobed, the veinlets incurved. (Fig. 138.'

3 P. corona'ria. American Crab. Leaves ovate, often lobed, cut-serrate, straight veined. (Fig. 454.)

4 P. angustifo'lia. Narrow-leaved $C$. Leaves lanceolate, scarcely veiny.

5 P. arbutifo'lia. Choke-berry. Leaves obovate or oval, with glands on mid-vein.

6 P. America'na. Mountain-Ash. Leaflets 13-15, lanceolate, pointed.

7 P. Aucupa'ria. English $M$. Leafiets lance-ovate, acute. Fruit larger.

\section{CYDO'NIA. Quince.}

Calyx urn-shaped, 5-cleft. Petals 5. Styles 5. Stamens many. Pome with 5 parchment-like cells, each with several seeds.-Shrubs. Leaves simple. Flowers solitary or few in a cluster.

1 C. vulga'ris. Common Quince. Leaves downy beneath, broadly ovate, acute, entire, with small, half-ovate stipules. Flowers roseate, solitary terminal. Fruit large, obovate, highly esteemed in preserves, \&c. (Fig. 1)

o. Japon'ica. Japan Quinc.. Leaves glabrous, ovate-lanceolate, acute at eacb end, serrulate. Stipules reniform. Flowers red, side clusters, opening early.

\section{RO'SA. Rose.}

Calyx tube urn-shaped, fleshy, contracted at the throat, limb 5-cleft t.je sepals generally with a little leaf at tip Petals 5 (greatly multiplied 
by culture); achenia $\infty$, bony, hispid, included in and attached to the in side of the fleshy calyx-tube.-Shrubby and prickly plants. Leaves ansyually pinnate. Stipules attached to the petiole, or often free.

In the table, the first ten species are found growing wild in this country, and scmetimes also cultivated. The other species never grow wild here.

Styles growing together into an inserted column. Climbers....h

istyles not cohering into a column....a

a Stipules nearly free from the petiole and falling off....g

a Stipules adhering to the petiole.... b

b Plant armed with curved or hooked prickles, erect....d

b Plant armed with straight prickles....c

c Wild, native Rnses, 1-3 f., erect....5-7

c Cultivated exoties climbing (No. 20) or erect....21-28

d Lexflets glandular and fragrant beneath....f

d Leaflets not at all glandular. Shrubs erect....e

e Wild, native Rose, flowers single....8

- Cultivated exotics, mostly double-flowered....13, 14

f Flowers single. Wild....9, 10

f Flowers double. Exotic, cultivated....15-17

g I.eatlets 5-9. Flower-stalk enveloped in bracts....4

g Leaflets $3-5$. Flower-stalk bractless, very smooth....2, 19

h Leaflets $3-5$, mostly 3 . Native and cultivated....1

h Leaflets $5-9 \ldots$. Stipules and sepals mostly entire....11, 12

k Stipules fringed, sepals entire....3

k Stipules entire, sepals pinnatifid....18

1 R. setig'era. Michigan $R$. Flowers in corymbs, rose-colored, changeable. W. † 2 R. læviga'ta. Cherokee $R$. Lfts. very smooth, ellip. Fls. solit., white. S. 1 8 R. multiflo'ra. Japan $R$. Lfts. soft, wrinkled. Fls. corymbed, ciolible. S. $†$ 4 R. bractea'ta. Macartney $R$. Fls. solitary, with large bracts beneath it. S.-W. +

5 R. lu'cida. Shining $R$. Lfts. 5-9, elliptic, shining. Prickles few. Calyx hispid.

6 R. nit'ida. Wild $R$. Leaflets $5-9$, narrow-lance, shining. Prickles numerous.

7 R. blanda. Bland $R$. Lfts 5-7, oblong, dull. Prickles very tew. Calyx smooth 8 R. Caroli'na. Swamp R. Stems 4-7f. high. Flowers in ecrymbs. Dull green. 9 R. rubigino'sa. Sweet Brier. Sepals persistent. Some of the prickles awl-shaped. 10 R. micran'tha. Eglantine. Sepals deciduous. All the prickles hookeri alike. Fls. small.

11 R. sempervi'rens. Evergreen $R$. Prickles alike. Lfts. evergreen, leathery.

12 R. arven'sis. Ayrshire R. Prickles unlike. Ltts. soft, decidnous. †

18 R. cinnamo'mea. Cinnamon $R$. Stipules broad, pointed, involute, wavy. $\dagger$

14 R cani'na. Dog $R$. Stipules broad, serrulate. Sepais fail off after flowering. $\uparrow$ IE R. centifo'lia. Cabbage $R$. Moss $R$. Sepals splezd in flower, often very glandular. + 
16 R. damasce'na. Damosk $R$. Monthly $R$. Sepals reflexed in flower. Fowers very double. $\dagger$

17 R. alba. White $R$. Sepals pinnatifid, spreading. Fls. corymbed, large. † 18 R. moscha'ta. Musk R. Leaflets lanceolate, pointed. Fls. panicled, large, white. $\uparrow$ 19 R. In'dica. Chinese Monthly. Bengal R. Tea Rose, dec. Lfts. ovate, pointed. 1 90 R Alpi'na. Boursault $R$. Lfts. 5-11, obovate, sharp-serrate. Stipules narrow. 21 R. eglante'ria. Yellow Rose. Lfts. broad-oval. Petals obcordate, fugacious. 1

22 R. Gal'lica. French $R$. Leaflets elliptical. Petals large, spreading. †

28 R. Pimpinellifo'lia. Burnet R. Lfts. small, roundish. Flowers small. †

\section{GE'UM. Avens.}

Calyx 5-cleft, usually with 5 alternate bractlets outside. Petals 5 . Stamens many, collected on a dry receptacle, and bearing the long, per. sistent style. $-2 f$ Leaves pinnate or lyrate.

$\S$ Style bent and jointed near the middle....a

\$ Style straight and not jointed, wholly persistent. Rare plants....6, 7

a Head of fruits quite sessile, with the styles finally hooked....b, 1

a Head of fruits stalked in the calyx more or less....4, 5

b Petals yellow, longer than the calyx....2, 8

1 G. Virginia'num. Petals white, as long as the calyx. Receptacle hairy.

2 G. macrophyl'lum. Mountain A. Lvs, ending with a very large roundish leafler 8 G. stric'tum. Yellow A. The end leaflet but little larger than the rest. Height 3-5f

4 G. vernum. Head-stalk A. Petals yellow, small. Stalk as long as head. W.

5 G. riva'le. Water $A$. Whole flower dark purple, large, nodding.

6 G. trifo'rum. Bractlets longer than the calyx or purplish petals. Fls. 3 . W.

7 G. Peck'ii. Peck's A. Bractlets minute. Pet. yellow. Stem almost leafless. Mts.

\section{RU'BUS. Bramble. Blackberries and Raspberries.}

Calyx 5-parted, without bractlets. Petals 5, deciduous. Stamens $\infty$. Ovaries many, kecoming many pulpy, drupe-like achenia (grains) united into a compound fruit.-Half-shrubby plants with 4 roots and (2) stems, armed with prickles. Flowers mostly white. In the Blackberries the pulpy receptacle constitutes a part of the fruit, but in the Raspberries it does not.

* Leaves simple, 3-5-lobed. Flowers large....1-8

* Leaves compound, of 3-7 leaflets....a

- Stems stout, upright, often recurved at top....b

- Stems weak, trailing or prostrate....7

b The side leaflets stalked. Prickles strong, recurved....s

b The side leaflets sessile. Prickles weak, nearly straight....4 


\section{Raspberrics.}

I R. odora'tns. Rose Flowering. Petals round, purple. Stalks hairy-clammy.

2 R. Nutka'nus. White-flnwering. Petals broad-oval, white. Fls. several. N.-W.

3 R. Chamæmo'rus. Cloud-berry. Petals obovate, white. Flower only one. Mts.

4 Petals as long or longer than the calyx ....5, 6

4 R. Idæus. Garden Raspberry. Petals shorter than the calyx.

5 R strigo'sus. Wild Red Raspberry. Corolla cup-shaped, single.

6 $\mathrm{R}$ rosæfo'lius Bridal Rose. Corolla spreading, double. Cultivated.

7 Stems prickly, shrutby, biennial. Fruit of many grains....11

7 R. trifo'rus. Stems entirely unarmed, green, $\odot$ Fruit of few grains.

8 R. occidenta'lis. Thimble-berry. Pl. glaucons. Petals shorter than sepals. Fr. dark

8 Plants not glaucous. Petals much longer than the sepals....9, 10

\section{Blackberries.}

9 R. villo'sus. High Blackberry. Flowers in racemes. Leaflets ovate.

10 R. cuneifo'lius. Sand Bl. Fls. 1-3 together. Lfts. wedge-obovate. M. S.

11 Prickles many. Flower-stalks without leaves or bracts....12, 13

11 R. Canaden'sis. Dewberry. Prickles few. Flower-stalks with leafy bracts.

12 R. his'pidus. Hispid, Bunning Bl. Flowers small, with spreading sepals.

13 R. trivia'lis. Low Bush Bl. F'owers large, with reflexed sepals. S.

\section{DALIBAR'DA. False Violet.}

Ualyx deeply 5 or 6 -parted, 3 of the segments larger. Petals 5. Stamens many. Styles 5-8, long, deciduous. Fruit 5-8 dryish, drupe-like achenia. 2 2f Low herbs with creeping stems, simple leaves and 1-2 white flowers on each stalk. North.

n. re'pens, Creeping $F$. Found in damp woods. Creeping stems a few inches to a foot in length. Leaves roundish-cordate, crenate. Stipules very narrow-linear. Petioles 1-3' long. Scapes 1-flowered, about as long as the petioles. June.

\section{WALDSTEI'NIA. Dry Strawberry.}

Calyx 5-cleft, with 5 alternate, sometimes minute and deciduous bractlets. Petals 5 or more, sessile. Stamens many. Styles 2-6. Achenia few, dry, on a dry receptacle.-2f Acaulescent herbs with lobed or divided radical leaves and yellow flowers on scapes.

W. fragario:'des. A pretty plant, in hilly woods, bearing some resemblance to the strawberry. Root-stock thick, scaly, blackish. Leaves trifoliate, on pet'oles 8-6' long; leaflets broad-wedge-shaped, cut-toothed, of a shining green alove. Scapes about as high as the leaves, bearing 2-6 flowers, which are $\frac{1}{2}$ 'across. June.

W. loba'ta. Lobed $D$. Along rivers, \&c. Leaves simple, roundish-cordate, gener ally 3-5-lohed, \&c. April, June. S. 


\section{POTENTIL'LA. Cinquefoil.}

Calyx deeply 4-5-cleft, with an equal number of alternate bractlets outside. Petals $4-5$, obcordate. Stamens $\infty$. Achenia $\infty$, collected in a head on a small, dry receptacle.-Herbs or shrubs with compound leave aud (mostly) yellow flowers. (Figs. 76, 77.)

* Leaves palmately compound... a

* Leaves pinnately compound....6-8

a Leaflets 3 only in each leaf....1

a Leaflets 5. Stems prostrate or inclining....4,5

1 Flowers yellow. Stems herbaceous....2, 3

1 P. tridenta'ta. Trident C. Fls. white. Lfts. wedge-obov., 3-toothed at end. N. 2 P. Norve'gica. Norway C. Erect, many-flowered. Petals short. N. M.

3 P. min'ima. Tiny C. Low. Stems 1-flowered. Pet. longer than sepals. Mts

4 P. Canaden'sis. Canada C. Leaflets green both sides, serrate, oblong.

5 P. argen'tea. Silver $C$. Leaflets silvery-white beneath, pinnatifid. 6 P. frutico'sa. Shrubby C. Erect, shrubs with yellow flowers. :teight 1-2f. N. 7 P. Anseri'na. Goose-grass. Stemless herbs. Leaves and peduucles radical. 8 Herbs with leafy stems. (3 rare species omitted.)

\section{FRAGA'RIA. Strawberry.}

Calyx deeply 5-cleft, with an equal number of alternate bractlets outside. Petals 5, obcordate. Stamens $\infty$. Achenia many, fixed to the surface of the large, conical, pulpy, scarlet or white receptacle.-Low 24 plants with trifoliate leaves. (Figs. 265, 455, 456.)

1 F. Virginia'na. Common S. Bractlets under the calyx entire. Flowers white, on scapes. Root-stock sending out runners which take root and form new plants.

2 F. In'dica. Indian Strawberry. Bractlets under the calyx 3 -lobed. Petals yellow. Stems trailing on the ground. Fruit roundish, bright red, tasteless. S. $†$ (272.)

12. SPIR $\mathbb{E}^{\prime} A$. Meadow-sweet. Hard-hack.

Calyx 5-cleft, persistent. Petals 5, roundish. Stamens 10-50, exserted. Carpels distinct, 3-12, forming little 1-celled, several-seeded pods. Styles terminal. - 2f Beantiful, unarmed herbs or shrubs with alternate leaves and branches, and small white or rose-colored flowers. May, Aug.

* Shrubs 4-9 f. high ....a

* Herbs with the leaves once cr thrice pinnate....7

- Stipules present....1, 2

a Stipules none. Leaves simple and undivided ...b 
- Flowers in panicles. Leares lance-ovate....3, 4

b Flowers in corymbs or little umbels. Leares oval or ovate....5, 6

1 s. opulifo'lia. Nine-bark. Leaves simple, 3-lobed. Corymbs unbeliate. N.

จ S. sorbifo'lia. Sorb-leaved M. Leares odd-pinnate. Flowers in panicles.

$3 \mathrm{~S}$. tomento'sa. Hard-hack. Lvs, with a rusty white deuse wool beneath.

4 S. salicifo'lia. Willozo-leaved. Lrs. nearly smooth. Shrub 3 or 4 f. higil.

o s corymbo'sa. Corymb very large, terminal, flat-topped. Height 1-2f. S.

i S. h hpericefo'lia. St. Peter's Wreuth. Little umbels many, lateral. Cultivated.

7 Leaves once-pinnate. Inflorescence terminal, on a long stalk....8, 9, 10

7 S. Arun'cus. Goat's Beard. Lis. thrice-pinnate. Fls. in slender spikes. M 9 S. loba'ta. Queen of the Prairie. Flowers purple. Side leaflets 3-lobed. W. 9 S. filipen'dula. Dropwort. Fls. white. Lfts. pinnatifid-serrate. Gardens. 10 S Ulma'ria. Meaduzo-sweet. Flowers white. Lfts. doubly-serrate. Gardcns.

\section{URder L. MELASTOMACEA. IMelastomes.}

Plants with square branches, and opposite, simple, 3-r-veined leaves; flowers with adherent calyx tube, $t$ wisted petals, and definite stamens. anthers opening by terminal pores. Fruit a capsule or herry.

\section{RHEX'IA. Deer-grass.}

Perennial herbs, with showy flowers. Leaves 3-5-veined. Calyx tube prolonged and narrowed above the ovary, 4-cleft. Petals 4 . Anthers b; 1-celled. Style declined. Capsule 4-celled, $\infty$ - seeded.

* Anthers curved, Jinear, appendaged at base. Flowers purple.... (a)

* Anthers straight, oblong, not appendaged. Maryland to Fla..... Nos. 5-7.

a Stem square, winged. Lrs. orate to lanceolate, bristly-serrate.... Nos. 1, 2.

a Stem terete or teretish. Leaves lanceolate to linear.... Nos. 3, 4.

I R. Virgin'ica. Meadow Deauty. Plant 12-18' high, with scattered hairs, sessile leaves and a large cyme of bright purple flowers. Wet grounds.

2 R. stricta. Plant $3-4$ f. high, smooth, calyx smooth. tube very short. S.

3 R. Maria'na. Hairy. Leaves on short petioles, bristly-serrate. 1-2f.

4 R. glabel'la. Glabrous. Leares sessile. Calyx hispid. Damp woods. S. 5 R. cilio'sa. Leaves broad ova:e, bristly ciliate. Petals purple. Sowin.

b R. serrula'ta. Leaves small, round-oval, serrulate-ciliate. Flowers purple. S.

i K. lu'tea. Leaves oblong-linear. Flowers panicled, jellow. Woods. S.

\section{ORDER LI. LYTHRACEA. Loosestrifes.}

Plants with entire, exstipulate, mostly opposite leaves;

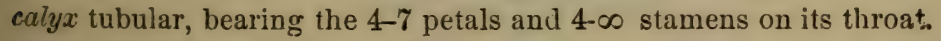
ovary and style compound. Fruit a capsule, or fleshy; many-seeded 
5 Shrube, with alternate leaves, $\infty$ stamens, and 6 purple, crisped petals on claws. Lvs.round-ovate, smooth. E. India. Crape Myrtle. Lagerstroz'mia $\S$ Shrubs, with opposite, oblong, shining leaves, $\infty$ stamens, and an adherent calyx tube. Flowers scarlet. Fruit crimson. Pomegranate. $\$ \pi$ rbs growing wild. Stamens $4-14 \ldots$ (a)

a Flowers irregular. Calyx inflated, gibbous at the base. Stam. 12 .

a Flowers regular. Calyx cylindrical, striate, with 5 minute horns.

PU'NICA

a Flowers regular. Calyx bell-form, with 5 teeth and 5 long horns.

Stam. 10. Petals 5, rose-purple. Fls. showy, slustered. Com.

Cu'PIIFA.

LYTHRUM. 1

1 LYTHRUM. Loosestrife.

$\S$ Stamens as many as the petals. Flowers axillary, solitary.... Nos. 1-3.

$\S$ Stamens twice as many as the petals. Flowers spicate, or racemed.... No. 4.

I L. hysopifo'lium. Grass Poly. Petals 5 or 6, pale purple. Lrs. obtuse. 6-12'.

2 L. linea're. Petals 6, whitish. Leaves linear, obtuse. Swamps, N. J. and S.

3 L. ala'tum. Petals 6, crisped, deep purple. Lvs. acute. Stem winged. 24. 1-2f. W.

4 L. Salica'ria. Tall (2-5f.), with lanceolate cordate leaves and terminal long spiker (or racemes ?) of purple or rose-purple fls. N. E. and N. Y., and cult.

\section{Order LII. ONAGRA'CEAs. Evening Primroses.}

Herbs with alternate or opposite leaves; and with the parts of the flowers generally in 4's, sometimes in 3 's, 2's, or 1's; with the sepals united below into a tube, valvate in the bud; the petals and stamens inserted into the throat of the calyx; ovary coherent with the tube of the calyx; becoming in the fruit a 2-4-celled capsule or berry with many seeds.

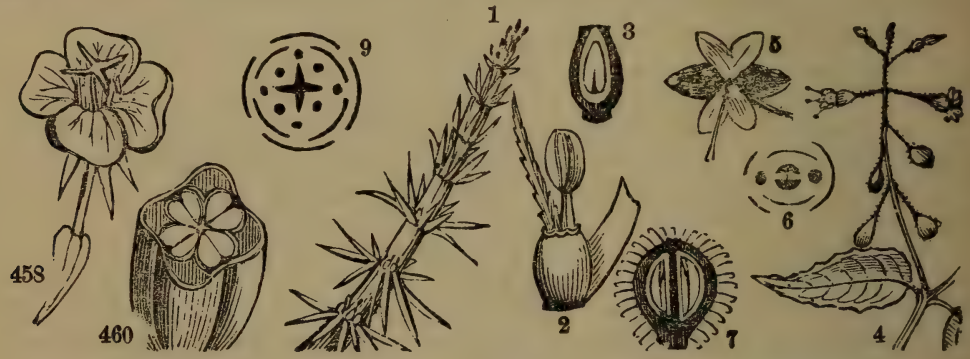

Fig. 458. Flower of Enothera fruticosa. 9. Plan of the flower. Fig. 460. Section of the 4.celled capsule of $\mathrm{OE}$. biennis. 1. Hippuris vulgaris. 2. Its flower, with 1 stamen, 1 ovary. 2 style. 3. Vertical section of its 1-seeded fruit. 4. Circæa Lutetiana. 5. The flower en larged. 6. Plan of the flower. 7. Vertical section of the 2-celled and 2-seeded fruit.

\section{Analysis of the Genera.}

- Flowers 4 or 5 -parted (that is, with 4 or 5 petals, sepals, \&c.) $\ldots 2$

* Elowers 8 -parted, i. e., with 3 sepals, 3 stamens, \&c. (no petals)....8 
* Huwers 2 purted, with 2 sepals, 2 petals, de.....

* Flowers 1-parted, with 1 stamen, 1 pistil, 1 seed (no petal)....h

2 Flowers perfect (that is, having both stamens and pistils)....3

2 Flowers monœcious (some with stamens, some with pistils)....

3 Stame is 8 , twice as many as the sepals....4

3 Stameos 4, same number as the sepals....d

4 Calyx tube much prolonged above the ovary....5

4 ( aly $x$ tube not prolonged above the ovary ....a

5 Garden exotics, with showy purple flowers....

5 Wild, native herbs, rarely cultivated.... b

a Seed comous nith a tuft of silky hairs. Fls. purplish. Willno Herb. Epilo'вrтs. 1

a Seed not eomous, \&c. Fls. large, yellow. Southern. Yellow Jessie. Jussiz' A.

b Petals equal, not clawed, yellow. Pods $\infty$-seeded.

Evening Primrose. ENothe'RA. 2

b Petals hardly equal, clawed, red. Pods 1-4-seeded. Gaura. Gaura.

- Herbs from California. Calyx tube short. Petals clawed. Clarkia. Clar'kia.

c Shrubs from Chili. Cal. tube long, enlarged. Fls. hanging. Eur-drop. Fuch'sia.

d Petals yellow, sometimes minute or 0 . Lvs. entire. Seed Box. Ludwig'LA

- Petals greenish or none. Leaves many-cleft. Water-plants.

Water Milfuil. Mrriophý'LUM.

f Delicate herbs with small, jale flowers. Enchanter's Nightshade. CIRc I'A. \& $^{\prime}$ g Small herbs in wet places, with pinnatifid lis. Mermaid Weed. Prosenpina'ca.

h In water, rare. Leaves linear, whorled. Mare's Tail. HrPpe'ris.

\section{EPILO'BIUM. Willow-herb}

Calyx tube not prolonged above the ovary. Limb deeply 4-parted, deciduous. Petals 4. Stamens 8. Stigma often with 4 spreading lobes. Orary and capsule linear, 4-cornered, 4-celled, 4-valved. Seeds crowned with a tuft of long hairs. -2 Flowers purplish or white.

E. angustifo'lium. Narrovo-leaved Willow-herb. Rose-buy. A tall, showy herb (46f. high), common at the North. Leaves narrow-lanceolate, nearly entire, with a vein running along the margin. Flowers large, all parts pale purple or white, in a long, terminal spike. Style and stamens declines. Stigma with 4 long lobes. July, Aug. Our four other species, with small flowers, and a clurshaped, undivided pistil, we omit.

\section{EENOTHE'RA. Evening Primrose.}

Calyx tube prolonged beyond the crary, deciluons: segments 4, reflexed. Petals 4, equal, obcordate or obovate, inserted into the top of the calys tube. Stamens 8. Capsule 4-celled, 4-valved. Stigma 4-lobed. Seeds not tufted.-Herbs with alternate leaves, and yellow flowers (in all the following species). May, Aug. 
$\S$ Flowers opening by night. Pods rounded at the corrers, sessile....1,2

$\S$ Flowers opening by day. Pods club-shaped, sharply 4-cornered.....

a Stems erect, $1-3$ feet high. Flowers large $\left(1-2^{\prime}\right.$ across $) \ldots . .3$

a Stems half-erect, $6-16^{\prime}$ long. Flowers small $\left(5-8^{\prime \prime}\right.$ across $) \ldots . .6,7$

1 E. bien'nis. J,vs. slightly toothed. Pods oblong. Fls. 1' or more wide

2 CE. sinua'ta. Leaves sinuate-toothed or pinnatifid. Flowers $\mathbf{f}$ wide. $\mathbf{S}$.

5 Pods scarcely winged on the 4 sharp angles. Leaves narrow....4, 5

3 G. frutico'sa. Pods with the 4 angles distinctly winged. Leaves lanceolate.

$4 \mathrm{CE}$. ripa'ria. Leaves linear-lanceolate. Flowers finally racemed. \$. M.

5 CE. linea'ris. Leaves linear. Flowers on the ends of the branches. S. M. 6 GE. pum'ila. Flowers straw-yellow. Pods almost sessile. Common. N M. 7 E. chrysan'tha. Fls. orange-yellow. Pods distinctly stalked. Kare N.H.

\section{CIRC $E^{\prime} A$. Enchanter's Nightshade.}

Calyx tube a little prolonged above the ovary, lobes 2. Petals 2, ob cordate. Stamens 2, opposite the sepals. Fruit reflexed, inversely egg. shaped, with hooked hairs, 2-celled, 2-seeded.-2 S Small, tender herbs, with opposite leaves and terminal racemes of small, reddish-white fluwers.

C. Lutetia'na. (See the figure.) Stem 1-2f. high, sparingly branched, pubsscent Leaves dark green, ovate, subcordate, acuminate, coarsely toothed. Padicel : without bracts, bent down after flowering. Fruit clothed with bristly hooks June, July.

C. alpi'na. Stem $5-10^{\prime}$ high, very smooth. Leaves pale green, broad corda.e, thin slightly dentate. Common in rocky woods at the North. July.

\section{ORDER LV.-GROSSULACA. Currants.}

Small shrubs, often prickly, with alternate, lobed, plaited leaves;

flowers in axillary racemes, regular, 4 or 5parted, small;

petals inserted into the throat of the calyx, small, distinct, and the fruit a 1-celled, many-seeded, 2-carpeled berry.

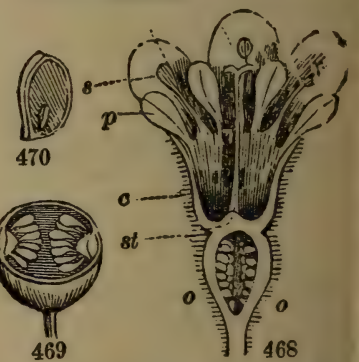

Fig. 463. A flower of the Red Currant cut open; $o$, th 3 ovary and ovules; st, the style e, the calyx tube; $p$, the petals; 8 , the stamens. Fig. 469. A berry cut open, showing the two placenter and seeds. Frig. 470. A seed cut open, showing the little embryo. 


\section{RI'BES. Currants and Gooseberries.}

The character of the genus is about the same as of the Order.

8 Currants. Stems without prickles or thorns ....a

Gonseberries. Stems armed with prickles or spines....c

a Leaves rolled in the bud (convolute). Fls. bright jel....1

a Lvs. plaited (plicate) in the bud. Fls. not yellow....b

b Fruit hairy ....2, 3

b Fruit smooth....4-6.

c Fruit hispid....7, 8

c Fruit smooth....d

d Stalks of the flower or fruit long....11, 12

d Stalks very short....9, 10

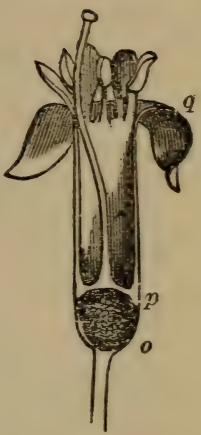

1 R. an'reum. Missouri Currant. Shrub 6-8f., with smooth, 3-lobed leaves (Fig. 471). W. †

Fig. 471. Missourt Currant,-flower divided.

2 R. sanguin'eum. Oregon $C$. Flowers bright red, showy.

Leaves 3-5-lohed. †

3 R. prostra'tum. Skunk C. Fls. striped with red. Lvis. 5-7-lobed. Mts. N. M. 4 R. ru'brum. Common Red C. Leares not dotted, downy beneath. Berries globular, red or white, in pendulous racemes as well as the fls. (Figs. 243, 261.) 5 R. flor'idum. Flowering C. Leaves yellow-dotted. Berries obovate, black.

6 R. nigrum. Black $C$. Leaves yellow-dotted. Berries roundish, black. Petiole shorter than the blade. Racemes loose, partly nodding, Gardens.

7 R. Cynos'bati. Prickly Goosebrry. Racemes 2 or 3-flowered. Styles united. (Fig. 281.)

8 R. lacus'tre. Sxamp G. Racemes 5-8-flowered. Style 2-cleft. Berry small. I R. hirtil'lum. Smoothish G. Stems not prickly. Calyx tube bell-shaped. North. 10 R. oxycanthoi'des. Hawthorn G. Stems very prickly. Calyx tube cylindric. North.

11 R. rotundifo'lium. Round-leaved $G$. Calyx cylindric. Stalk 1-3-flowered.

12 R. Uva Cais'pa. Garden G. Calyx bell-shaped. Stalk hairy, 1-flowered. 1

\section{Order LVI. CRASSULACEA. The Houseleeks.}

Thick. juicy plants, with simple, mostly entire leaves; with flowers perfectly symmetrical and regular; the petals, sepals. and pistils being of the same number (3-20); and the stamens either the same or twice as many; the follicles (as many as the oraries) distinct or somewhat united. 


\section{Analysis of the Genera.}

Sistils (follicles) entirely distinct and separate....2

$\$$ Pistils 4 or 5 , united into a 4 or 5 -celled capsule....4

2 Stamens twice as many as the pistils, petals, or sepals....3

2 Stamens as many ( 3 or 4 ) a the pistils, \&c. Herb $1-3^{\prime}$ high $r$. Trus $x^{\prime}$

Flowers 5 (rarely 4 )-parted. Stamens 10 or 8.

Flowers 12 (or 6-20)-parted. Stamens 12-40.

Stone-crop. SF'dum. 1

$4 \odot$ Herb 2-4' high, fleshy, with 4-parted flowers. S. Diamor'PHA.

4 4 Herb 10-16' high, not fleshy, with 5-parted flowers. c. Pentho'rex.

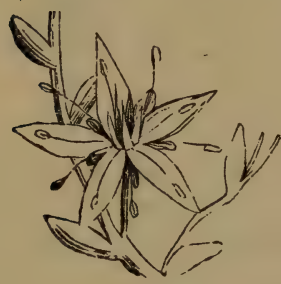

478

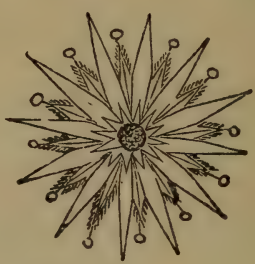

474

Fig. 472. A flowering branch of Sedum acre. Fig. 473. A flower of $\mathrm{S}$. acre, natural size. Frig. 474. A flower (12-parted, symmetrical, regular) of Sempervioum (Houseleek).

\section{SE'DUM. Stone-crop. Orpine.}

Sepals and petals 5, sometimes 4, distinct. Stamens 10 or 8. Pods 5, sometimes 4, distinct, many-seeded, with an entire scale at the base of each.-Mostly $2 f$ herbs, with 5-parted flowers in cymes, or in one-sided clusters.

1 Flowers white, or pinrplish, or rose-colored....2

1 S. a'cre. Iceland Mosis. Fls. yellow. Plant in low tnfts. Gardens.

2 Leaves scattered, 1-3' long....3-5. (Figs. 472, 473.)

2 S. terna'tum. Stone-crop. Leaves in whorls of 3's. Flowers white, in a 3-spiked cyme.

3 S. telephioi'des. Faise $O$. Leaves lanceolate or obovate, nearly entire. M. S.

4 s. Tele'phium. Common $O$. Leaves oval, serrate, obtuse. Flowers purplish.

5 S. pulchel'lum. Handsome $O$. Ivs. linear. Fls. in an umbel of spikes, purp. s

\section{ORder LVII. SAXIFRAGACEA. Saxifrages.}

Herbs or shrubs with the pistils fewer than the sepals of the flower; the petals as many as the calyx sepals (4 or 5), and together with the 
$5-10$ stamens inserted on the calyx; the styles 2, distinct, with their 2 oxaries more or less united below, and either free or adhering to calyx; nods capsular, many-seeded; embryo slender, in albumen.
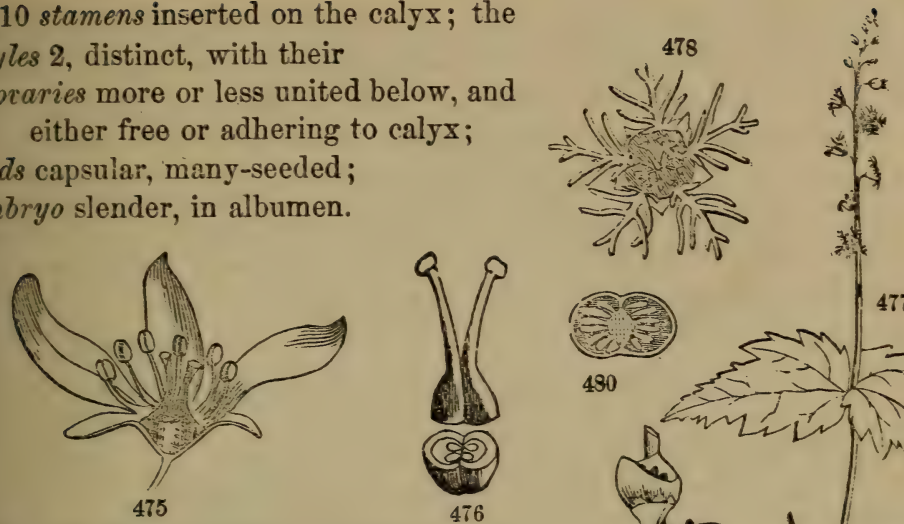

Fig. 475. Section of flower of Early Saxifrage (Cless Book, page 371). Fig.476. Ovary and pistils, cut across to show the two cells. Fig. 477. Mitella diphylla; 8, a flower, magnifed; 9 , the fruit pods open. showing the black seels. Fig. 480. Cross-section of the ovary; 1 , seed cut open, showing the long embryo.

\section{Analysis of the Genera.}

\& Ilerbs. Petals imbricated in the bud....a

Shrubs. Petals valvate or convolute (twisted) in bud....e

a Flowers with 10 stamens.... b

a Flowers with 5 stamens....d

b Petals 4-6, usually 5 , entire....

b Petals 5, all pinnatifid. Stamens 10.

Mitrewort. Miten'LA. ]

b Petals 0 . Low, prostrate, in wet places. Water Carpet. Chrs sosple'Nidu.

c Pods 2-celled. Leaves simple, mostly radical. Saxifrage. SAXIF'RAGA. 5

c Pods 2-celled. Leaves bi-ternately compound, cauline. S Astí'Be.

c Pods 1-celled. Leaves palmately lobed. Fulse Mitrewoort. Trarfíla. 2 d Styles 2, pod 2-celled. Seape reclined, 8-12' long. W. Sullivan'tia. d Styles 2, pod 1-celled. Scape erect, a foot or more. M. W. a Styles 3, pod 1-celled. Herb in tufts $\mathbf{z}^{\prime}$ high. S.

HEU'CHERA.

e Leaves opposite, simple....f

e Leaves alternate. Shrub 4-Sf. erect. Racemes white. M. S. ITz'A. 1 Slurub climbing trees, \&c. Flowers white, fragrant. S. DectMánta. Shruls erect. Cymes not radiate-all the flowers perfect. Shrubs erect. Cymes radiate. Stamens 8-10. Puiladel'phes. ? HYDRAN'GEA. 1

\section{MITEL'LA. Mitrewort.}

Calyx E-cleft, bell-shaped. Pefals 5, pinnatifid with linear divisionk, 
inserted on the throat of the calyx. Stamens 5 or 10 , included. Styles 2, very short. Capsule short, 2-beaked, 1-celled, 2-valved.-2 Small, slender herbs, with roundish, lobed, and cordate leaves, mostly from the root. Flowers small, in a slender raceme. $N$.

1 M. diphyl'la. Scape $12-20^{\prime}$ high, with 2 opposite leaves nearly sessile, and many white flowers above with curionsly cleft petals. May, June. (See Fig. 4i7.)

Q M. nu'da. Seape leafless, thread-like, $5-7^{\prime}$ high, few-flowered. May, June.

Both species send out runners from the base.

\section{TIAREL'LA. False Mitrewort. Gem-fruit.}

Ualyx 5-parted, lobes obtusePetals 5, entire, the claws inserted on the calyx. Stamens 10, exserted. Styles 2. Capsule 1-celled, 2-valved, 1 valve much larger.-2f Fls. white. N. M.

T. cordifo'lia. Scape about $10^{\prime}$ high, sometimes bearing a leaf, the flowers white in all their parts, forming a cylindrical raceme. In rocky woods, with the Mitrewort, very common at the North. May, ofune.

\section{PHILADEL'PHUS. False Syringa.}

Caiyx 4-5-parted, tube adherent to the ovary, persistent. Corolla 4-5-petaled. Styles 4, more or less united. Stamens $20-40$, shorter than the petals. Oapsule 4-celled, 4-valved, many-seeded. - Handsome flowering shrubs, with opposite leaves. Petals convolute in the bud.

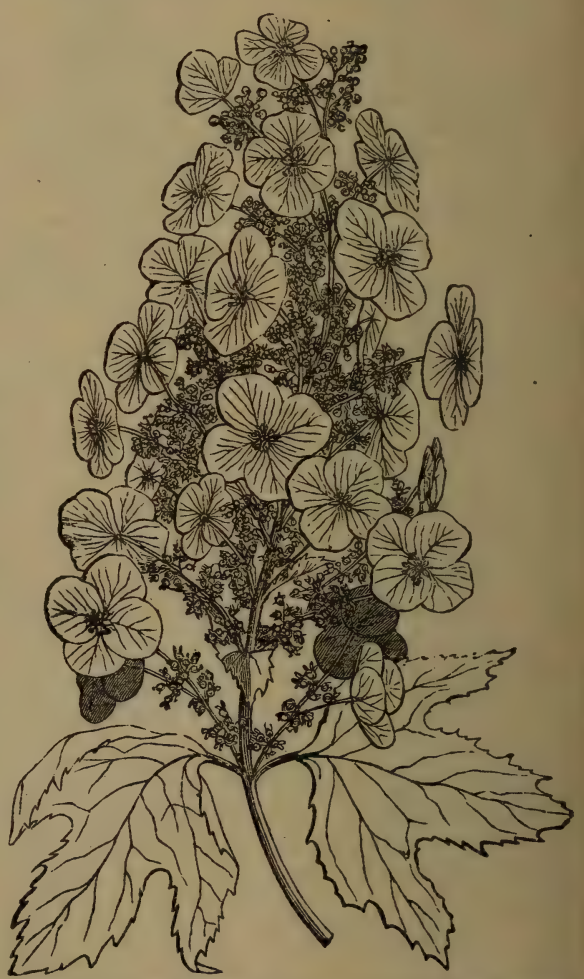

Fig. 4S2. "Radiant" panicle of Oak-leaved Hydras gea; the larger flowers neutral. 
P. grandifo'rus. Large-flowered Syringa. A very showy shm?k, 6f. nigh. Leaves ovate, acuminate, 3 -reined. Stigmas 4, styles united into 1 . Flowers large, in umbels of 2-7, white nearly inudorous. Cultivated, but wild at the South. June. P. eorona'rius. Mock Orange. Stems 5-8f. high. Leares oral aud orate, shortpointed, feather-veined. Styles and stigmas 4, distinct. Flowers numero 1.3, white, handsome, very fragrant. Cultivated. June.

\section{ч. IIYDRAN'GEA. Hydrangea.}

Flowers in cymes, the marginal ones generally barren, with the sepals much enlarged (that is, the cymes are radiant). The fertile flowers are small, calyx about 4-toothed, petals 4 , stamens 8 or 10 ; capsule 2 -beaked. many-seeded.

$1 \mathrm{H}$. arbores'cens. Big Will H. Leaves ovate, obtuse or cordate at base, nearly smooth. Cymes flat. Shrub 4 to 6 feet high. M. W. Cultirated.

2 F. quercifo'lia. Oak-leaved $H$. Leaves deeply sinnate-lobed. Cymes in the form of a panicle. South. Cultivated. (See Fig. 482.)

$3 \mathrm{H}$. radia'ta. Silver-leaved $H$. Leaves ovate, clothed with a silvery-white down beneath. Cymes flat. Shrub 6-8f. high. S. †

4 E. horten'sis. Changeable H. Leaves elliptical, narrowed at each end, smooth. Cymes mostly all barren, changing from green to white, pink, blue, \&c.

\section{SAXIF'RAGA. Saxifrage.}

Calyx 5-cleft, either free, or adherent to the base of the ovary. Petals 5, entire. Stamens 10. Styles 2. Pod 2-celled, 2-beaked, opening between the beaks, many-seeded.

\& Leaves opposite (small) on the prostrate stem. F:owers purplish.... No. 1.

$\$$ Leares alternate on the ascending etem. Flowers yellow or white.....Nos. 2-4.

$\$$ Leares rosulate at the base of the mostly leafless scape.... (a)

a Calyx entirely free from the ovary (inferior).... Nos. 5-7.

a Calyx adherent to the base of the ovary (half superior).... Nos. 8-10.

1 S. oppositifo'lia. A small plant with large fls. C'liffs, Willoughby L., Vt. and N.

2 S. aizoi'des. Petals yellow, spotted. Lvs. narrow. With No. 1, and West.

3 S. rivula'ris. Petals white. Root leares reniform. White Mits. and North.

4 S. tricuspida'ta. Petals yellow, dotted. Lvs. 3-cusped at apex. L. Superior.

$5 \mathrm{~S}$. erosa, and two other species, on Mts. Penn. and S. (See Botanist and Flor.)

8 S. Aizo'on. Leaves evergreen, thick, spatulate, bordered with white teeth. Petals obovate, cream-white. Rocks, Willonghby Mt., and W.

9 S. Virginien'sis. Early Saxifrage. Lrs. oval-spatulate with a broad petiole. Scape par.icled, 4-12' high. Petals white, oblong, much longer than the calyx. Flowers many, in April and Mray. Grows on rocks, common.

10 S. Pennsylva'nica. Swamp S. Leaves lance-oblong, acutish, narrowed to a short stalk. Scape 1-2f., branching into a diffuse panicle of small, greentsh homely flowers. Petals narrow, scarce longer than the reflexed sepals. Swamps. 


\section{ORDER LVIII. CAC'TACEA. Indian Figs.}

Plants with green, fleshy, angular or jointed, nearly leafless stems, armed with numerous prickles and terrible spines. Flowers often showy. We have at the North only one native species. Many are cultivated.

\section{OPUN'TIA. Indian Fig.}

Caiyx tube not produced above the ovary. Stock composed of fleshy, inostly flattened joints. Sepals, petals, and stamens indefinite, at the top of the ovary. Style 1, with 4-10 stigmas. Leaves minute, alternate, with tufts of prickles in their axils.

O. vulga'ris. Grows or dry rocks. Joints several, 4-6', obovate. Flowers large (3-4' broad). Petals ;-10, yellow. Fruit egg-shaped, crimson, eatable

\section{Order LX. PASSIFLOPACEA. Passionworts.}

Plants often woody, climbing by tendrils, with alternate leaves anc leafy stipules. Flowers perfect, of wonderful structure, as seen in

\section{PASSIFLO'RA. Passion-flower.}

Calyx colorea within, deeply 5-parted, bearing a complex crown of colored filaments on the throat, and the 5 petals above them. Ovary raised on a stipe, with the 3 stigmas and 5 anthers. Fruit a pulpy berry.

\section{Order LXIII. UMBELLIFER E. The Umbelworts.}

Herbs with hollow, furrowed stems, simple or componnd leaves; no stipules, but with a broad sheathing base to the petioles; the small flowers in umbels, and the caly $x$ wholly adherent to the ovary, the petals and stamens 5, standing on the top of the ovary; the styles 2, and the fruit dry, its 2 carpels seed-like and separating marked outside by ribs and furrows running lengthwise.

\section{Analysis of the Genera.}

* Plants growing wild, some of them cultivated for the eatable root....2

* Plants never wild, but cultivated for their fruit, \&c..... q

2 Flowers white, rarely rose-colored or cream-colored....3

2 Flowers yellow, or (in one instanse) dark purple....4

3 Umbels simple, leaves simple. Little creeping wet plants.... a

3 Umbels regularly compound, the flowers not sessile....c

3 Umbels irregular, flowers in crowded heads, sessile... b

4 Fruit lecidedly flattened on the back....p

4 Fruit flattened on the sides or not at all.... 
a Fruit flattened. Leaves roundish. Pennywort. IIrdroco'trle.

a Fruit globular. Lvs, linear. Fis. pedicelled. Ileight 1-2'. $r$. Crant'zia.

b Fruit clothed with hooked prickles. Heads small, 2-4. c. Sanicle. SANIc'Cra, 1

b Fruit clothed with seales. Heads often near 1' thick. W. S. c. ERrs'gicm.

c Umbels not radiate ( $\S 255, a$, outer flowers not larger than the rest)....d

c Unub. rad. very large. Huge heros, 4-8f. high. c. Cono Pursnip. Herac'lets.

d Leaves simple linear petioles without blades. $S$.

TiedMan'Nis.

3) Leaves only once divided, pinuately or ternately ....e

c Leaves twice or thrice compounded....g

e Fruit flattened or contracted, more or less, on the sides....f

e Fruit much flattened on the back. M. S. Archemore. Archemo'ra.

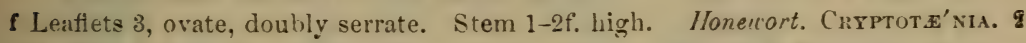

f Leaflets 3, long, linear, grass-like. Rare. S. Nerveleaf. Necrophru'LcM.

f Leaflets 5-11, lanceolate or lance-linear. 2-6f. Water Parsnip. Si'cs.

f Leaflets 5-9, oblong. Stem nrocumbent. S. Marsh Einuel. Helosciad'il

g Bracts of the involitere (not involucel) entire....h

$\mathrm{g}$ Bracts of the involucre eleft and divided.....

$\mathrm{g}$ Bracts of the involucre none or almost none....m

h Fruits bristly, club-shaped, few. Stem 1-2f. high.

Cicely. Osmorhi'za. 3

h Fruits smooth, flattened on the sides, ribs wavy. Poison Hemlock. Coxi'us. 4

h Fruits smooth, flattened on the back, ribs winged, straight. $r$. CoNiosen's[M.

h Fruit smooth, terete, not flattened, ribs straight. Lovage. Ligrs'ricrm.

k Fruits bristly, short, numerous. Often cultivated. Carrot. DAv'ccs.

k Fruits smocth. Stems and leaflets thread-like. Rare. Discopleu'ra.

k Fruits smooth. Stem 3-6' erect, bulbous. W. Pepper-ard-Salt. Erigeni'a. 5

m Fruit flattened on the back. Stems large. c. Angelica. Archangel'ica.

m Fruit flattened on the sides....n

m Fruit terete, not flattened. Poison. N. Rare. Forl's Parsley. Ethu'sa.

n Calyx 5-toothed. Stems diffuse, slender. W. Chervil. Ch.

n Cal. 5-toothed. Umbels stalked. Sts. ereet, very slender. S. Leptocat'Lrs.

n Calyx teeth none, fruit strongly ribbed. Poison. Water Hemlack. Cicu'ta. 6

n Calyx teeth none, fruit scarcely ribbed. W. Rare. Crest Umbel. Eu'Lophus.

- Involucels leafy. Leares perfoliate, simple, entire. Modesty. Bcplec'ror.

- Involucels minute. Seed with 5 winged ribs. Golden Alexanders. Thas'piUy. 7

- Involucels minute. Seed with 5 ribs not winged. Alexanders. Ziz'ra. 8

p Involucels minute. Fruit corky. Leaves bi-pinnatifid. Poltre'sta.

p Involucels none. Fruit thin. Leaves pinnate. Parsnip. Pastixa'ca.

$q$ Flowers white. Involucre 0 or of 1 entire bract....r

3 Flowers white. Involuere of a few eleft bracts. Parsley. Petroserinex. Flowers yellow. Leaf segments very narrow and many. Fennel. Fenic'clox.

$r$ Umbellets radiate. Fruit round. Lvs. finely eut. Coriander. Corian'drom.

r Umbellets not radiate (the flowers all similar)....s

s Fruit flattened on the sides, roundish. Lf, segin. Tedge-form. Celery. A'picx.

s Fruit flattened on the sides, oval. Leaf segments linear. Caravay. $\mathrm{CA}^{\prime} \mathbf{R}$. Eruit egg-shaped, not flattened. Loaf segments linear. Anise. P'; MPINEL'LA 


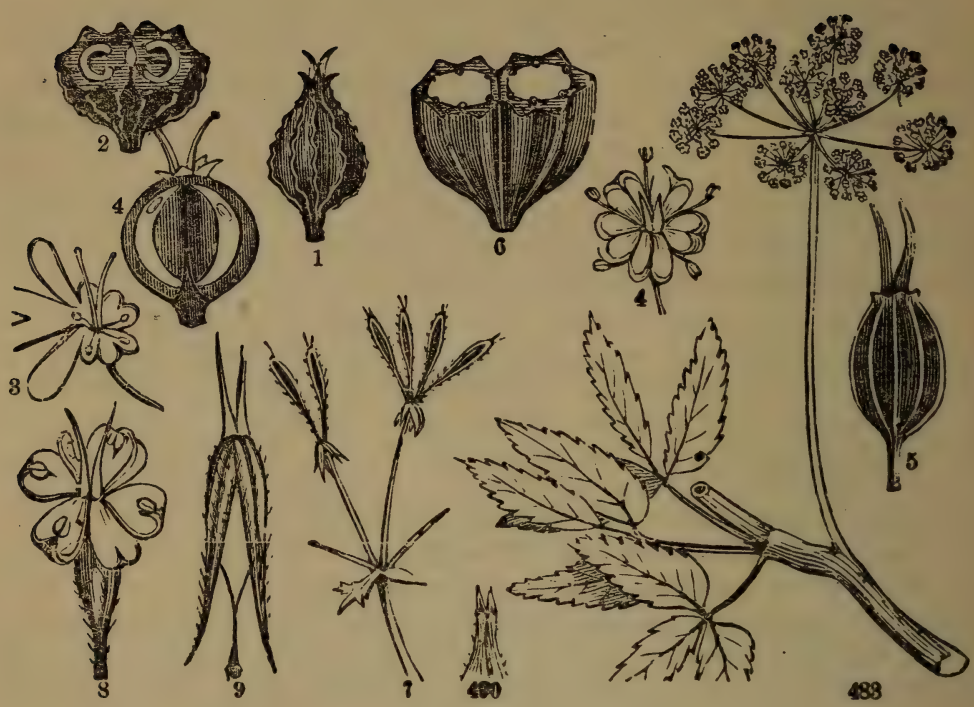

Fig. 4S3. Golden Alexanders, with its compound, naked umbel, \&c. 4. A flower enlarged o. The fruit with its thread-shaped ribs anil two persistent styles. 6. Cross-section, showing the two carpels with the oil-tubes and flat inner face. 7. Umbel of sweet Cicely, in fruit. 8. A flower enlarged. 9. The fruit with the two carpels separating from the base and supported by a two-cleft stalk. Fig. 49\%. Summit of the fruit of Bitter Cicely. 1. Fruit of Poison Hemlock, with the undulate-crenulate ribs. 2. Cross-section, showing the grooved inner face and involute albumen. 3. Radiate flower of Coriandrum. 4. Vertical section of the globose fruit, showing the minute embryo.

\section{SANIC'CLA. Sanicle.}

Flowers polygamous. Calyx teeth leafy, tube bristly. Petals obovate, orect, with the point inflected. Fruit roundish, armed with hooked prickles. Carpels without ribs. - 2f Plants 1-2f. high. Umbel with a few capitate umbellets. Involucre of few cleft bracts, inrolucel of several, entire. June-Aug.

I s. Marylan'dica. Long-styled $S$. Sterile flowers many, pedicellate; fertile flower sessile. Styles slender, conspicions, recurved. Leaves 5-7-parted. Common.

8 S. Canaden'sis. Short-styled $S$. Sterile flowers few, much shorter than the fertile. Styles shorter than the prickles. Leaves 5-parted, upper 3-parted. Umbels (or heads) small. Woods. Common 


\section{CRYPTOT $E^{\prime}$ NIA. Hone-wort.}

Calyx teeth obsolete. Petals with an inflexed point. Fruit linear-ob long or ovate-oblong. Seeds with 5 obtuse ribs, contracted at the sides -2f A smooth herb with 3-parted leares. Umbels compound, with rery unequal rays, white flowers, no involucre, and few-leaved involucels.

C Canaden'sis. St. 1-2f. high, erect. Leaflets large, the side ones often 2-parte 1 or lobed. Common in moist woods. July.

\section{OSMORHI'ZA. Cicely.}

Calyx teeth obsolete. Fruit linear-oblong, clnb-shaped, tapering to the base, crowned with the conical styles; carpels each with 5 equal, acute, bristly ribs, and a deep groove on the face.- $2 f$ Leaves bi-ternately divided, with the umbels opposite. Involucre few-leaved; involucel 4-7. leaved. Flowers white. Fruit an inch in length. Height about $2 \mathrm{f}$. May, June. (Figs. 244, 487-9.)

O. Longis'tylis. Sweet $C$. Styles thread-like, nearly as long as ovary. Plant downy The root has an agreeable spicy flavor.

o. brevis'tylis. Bitter C. Styles conical, 5 times shor -yr than ovary. Plant hairv. Less interesting than No. 1. (See Fig. 490.)

\section{CONI'UM. Poison Henlock.}

Calyx teeth obsolete. Fruit ovate, flattened on the sides, each carpe. with 5 wavy-crenulate ribs on the back, and a deep narrow groove on the inner face.-C (2) Herbs with large, decompound leaves, with very many eaflets. Involucre and involucels of $3-5$ leaves, the latter one-sided. Flowers white. (Figs. 65, 491, 492.)

C. macula'tum. Stem spotted with purple, glaucous, about 4 f. high. Leaves bright green, leaflets small, lanceolate, pinnatifid. Umbels terminal, the involucels with the inner half wanting. June, July.

\section{ERIGENI'A. Pepper-and-salt.}

Ualyx limb wanting. Petals flat, entire. Carpels (half-fruits), 3-ribbed, contracted on the face, forming together a fruit much broader than long. - 2 Root tuberous. See Fig. 333. 
2 bu'bo'sa. A small, early-flowering herb, Western N. Y. to Mo. Stem arises from a roundish tuber deep in the ground. The root leaf is thrice ternate. The involucrate leaf twice ternate. The dark-brown stamens with the little white petals suggest its common name.

\section{CICU'TA. Water Hemlock.}

Calys 5-toothed. Petals with the point inflected. Fruit roundish, uttle contracted on the sides so as to appear somewhat double. Seeds with 5 , flattish, equal ribs, 2 of them on the margin.- 2 Poisonous herbs with compound leaves and perfect umbels of white flowers. Involucre few-leaved or 1 . Involucels many-leaved.

3 C. macula'ta. Spotted Water-Hemlock. Stem streaked with purple, 3-6f. high, smooth, striate, hollow. Lower leaves triternate and tripinnate, segments lanceolate, serrate. Umbels $2-4^{\prime}$ broad. Fruit 10-ribbed. Involucels of 5 or 6 short, slender, acute bracts. Common in wet meadows. July, Aug.

2 C. bulbi'fera. Narrow-leaved Wuter-Hemlock. Stem green, striate, slender, with little bulblets in the axils of the branches. Leaves bi-ternately divided. Leaflets linear or lance-linear, $2-4^{\prime}$ long, with distant teeth. In wet meadows and swamps. Aug.

\section{THAS'PIUM. Alezanders.}

Calyx minutely 5-toothed. Fruit elliptical, roundish across, not flattened either way, seeds each with 5 winged ribs. $-2 f$ Leaves divided. Involucre none, involucels few-leaved. The species resemble the Zizias except in their fruit. May, June. (Figs. 483-6.)

1 Root leaves simple, cordate, stem leaves once-ternately divided....2

$1 \mathrm{~T}$. barbino'de. Leaves bi- or tri-ternate, lfts. cut-serrate. St. hairy at joints. 2 T. au'reum. Golden A. Fruit oval. Flowers yellow. Stem 2-3f. high.

8 T. atropurpu'reum. Purple A. Fruit roundish. Flowers dark purple. Stem 2-3f. high. S. M.

\section{ZIZ'TA. Alexanders.}

Calyx minutely 5-toothed. Fruit oval or ovate, flattened at the sides so as to appear somewhat double. Seeds each with 5 ribs which are not winged, but thread-like.- 2 Smooth, with divided leaves and yellow flowers. Umbels compound, with no involucre or involucels.

7. integer'rima. Entire-leaved $A$. Root and stem leaves bi- and tri-ternate, leatle ${ }^{+}$ oatire. Plant 1-2f. high, in rocky woods. May-Juby. 


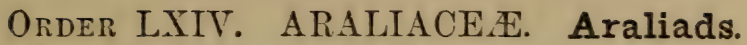

Plants much like the Lmbelworts in their lvs., fls., and inflorescence; pistils 2-5, united below into 1 ovary with $2-5$ cells; fruit a capsule or berry, with $2-5$ seeds. Petals not inflected.

\section{Analysis of the Genera.}

- Styles 5. Umbels many. Leaves alternate, pinnately componnd.

* Styles 2 or 3. Umbel 1. Leaves whorled, palmately compound.

ARAILA. I

- Style 1. Climbing vine. Leaves simple, alternate. European Iry. Hedera.

\section{ARA'LIA. Wild Sarsaparilla.}

Calyx superior, 5-toothed. Petals 5, ovate, spreading. Stamens 5 on the ovary with the $\mathbf{5}$ styles. Fruit a berry. Herbs or shrubs with alternate pinnately compound leares. Lmbels white or greenish. Summer.

* Plauts low (1-2f.), with few (3-i) umbels corymbously arranged.... Nos. 1, 2

* Plants taller (3-12f.), with numerous umbels in racemes.... Nos. 3, 4

1 A. nudicau'lis. 'Stem underground, sending up 1 long-stalked leaf and a scape a foot high, bearing 3 umbels. Plant smooth. 24 Rocky woods. E. and $W$.

2 A. his'pida. Mild Elder. Stem shrubby and prickly at base. herbaceous abore. Leaflets ovate, cut-serrate. Umbels about 3. Berries blue-black. Fields.

3 A. racemo'sa. Pettymorrel. Herbaceous, smooth, branched, 3-5f. Leaves large, deecmpound: leuflets orate, serrate. Umbels small, very many, in a panicle of racemes. Root highly aromatic. Woods.

4. A. spino'sa. Angelica Tree. Hercules' Club. Snrub or tree prickly, stem simple, bearing all the leares and panicles at the top. Leaves bi- or tripinnate.

\section{GINSENG. Ginseng.}

Diœcious and polygamous. Calyx-tube adherent, limb obsolete. Petals 5, ovate, obtuse. Stamens 5. Styles 2 or 3 , erect (none in the $f$ flowers). Fruit berry-like, 2 or 3 -seeded. 24 Root tuberous. Sten simple, bearing 3 leaves in a whorl, and 1 umbel. Fls. white.

! G. trifo'lium. Ground-nut. Root a ronnd tuber deep in the ground, connected with the stem by a short screw-like ligament. The stem arises 3-6 qhove the surface, smooth, slender, simple At the top is a whorl of 3 compound leares, and a central peduncle bearing a little umbel of pure white flowers. Leaflets generally 3. Barren and fertile flowers on separate plants, the latter with 3 styles and 0 slamens, the former with but one style. Damp woods. MFay.

2 3. quinquifolium. True Ginseng. Root fusiform, fleshy. Stem round, smooth, $1 \mathrm{t}$ high, with a terminal whorl of 3 compound leaves and a central stalk bearing a simple nmbel of vellowish-white flowers. The fertile flowers have 2 stylur, and are usually separated from the barren, on different plants. Berries bright scarlet. In rocky or Lilly woods. June-August. 


\section{Order LXV. CORNACE.E. Cornels.}

Trees and shrubs, seldom herbs, with simple, mostly opposite leaves; with fowers 4-parted, arranged in cymes; the 4 petals valvate in the bud; and with the 4 stamens stauting on the top of the 2 celled

ovary, which is adherent to the calyxtube; styles united;

fruit a 1 or 2 -seeded drupe.

Fig. 495. Low Cornel; $b$, the 4-leaved involucre surrounding the head of flowers.

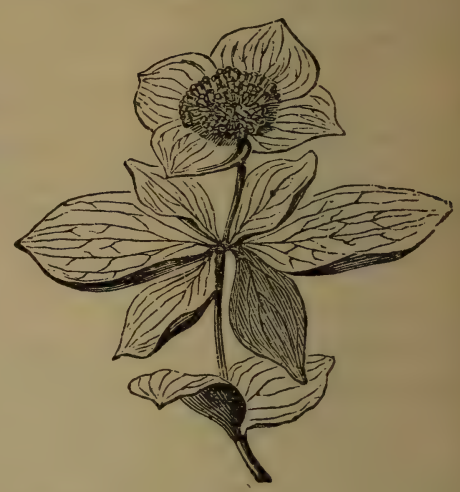

Analysis of the Genera.

$\S$ Flowers perfect, 4-parted. Petals 4. Drupe 2-celled. C'orneil. Cornt'e. J \$ Flowers imperfect, 5-parted. Petals often 0. Drupe 1-celled. Trees with small, green flowers in side clusters. Fruit plum-like. Tupelo. N rssa.

\section{CORNUS. Cornel, Dogwood.}

Trees, shrubs, or perennial herbs. Flowers in cymes. Sepais, petals, and stamens each 4 , with a double pistil.

$\S$ Cymes with a 4-leaved white involucre. Drupes red.....Nos. 1, 2

$\$$ Cymes naked (no involucre). Leaves mostly alternate, oval..... No. 3

\& Cymes naked (no involucre). Leaves all opposite. Flowers white (a)

a Twigs and cymes pubescent. Fruit light blue. Shrubs 5-9f. ...Nos. 4, b

a Twigs and cymes glabrous. Leaves white-downy bencath.... Nos. 6, 7

a Twigs and cymes glabrous. Leaves smootb, taper-pointed.... Nos. 8, 9 .

10. Canaden'sis. Low Cornel. A low herb in damp woods, with a simple stem bearing 2 opposite, and 4 or 6 whorled ovate leaves. May, June.

C. flor'ida. Flowering Dogwood. A small tree with opposite ovate leaves. Cymes compact, leaves of the involucre obcordate, large, showy. May.

3 C. alternifo'lia. Shrub or tree 8-20f., flat-topped. Drupes blne-purple.

10. seric'ea. Leaves ovate-oblong, silky-downy beneath. Sepals lanceolate. Common.

O. asperifo'lia. Leaves lance-oval, scabrous above. Sepals minute. W. and S.

6 C. circina'ta. Leaves round-oval, large. Drupes light blue. 6-10f. June.

7 C. stolonif'era. Red Osier. Shoots red and straight. Leaves broad ovate, acuta

Drupes lead-white. Shrub in clump, 6-10f. E. and W. May.

C C. stricta. Branches erect, brown. Cyme loose. Anthers and fruit blu ish. S.

8 O. panicula'ta. Branches gray. Cymes somewhat panicled. Fruit white. June. 


\section{COHORT II.}

\section{THE GAMOPETALOUS EXOGENS.}

Essenticl Character. - Flowering plants (Рнжnogamia) with their stems growing by additions to the outside in layere (Exogens), their seeds inclosed in a seed-vessel or pericar $\mu$ (ANGIOSPERMS), their flowers with a double perianth and their petals united (Monopetal ).

\section{ORder LXVI. CAPRIFOLIACE A. Honeysuckles.}

Shrubs and herbs, often twining, with opposite leaves ; with flowers clustered and often fragrant, 5-parted and uften irregular; corolla monopetalous, tubular or rotate; stamens on the tube of the corolla, often one less than its lobes; ovary adherent to the calyx; style 1 ; fruit a herry, drupe, or capsule ; embryo small, in fleshy albumen.

\section{Analysis of the Genera.}

1 Corolla tubular. Stigma capitate, on a slender style....2

1 Corolla rotate, deeply 5 -lobed. Stigmas 8 , rarely 5 , sessile. Shrubs....

2 Herbs....a

2 Shrubs....b

- Stamens 4, capsule 3-celled. A trailing evergreen. Twin-flower. LinN $\boldsymbol{E}^{\prime} \mathbf{A} \mid$

ata. 5, drupe bony, 3-5-celled. Erect, unbranched. Fever-root. Trios'тeuy

b Cor. bell-shaped, reg'r. Berry glob., 4-celled, 2-seeded. SyMrнoriuar'rus. 2

b Cor. tubular, lobes unequal. Berry 2-3-celled, few seeded. c. LonicE'RA. 3

b Corolla funnel-shaped. Capsule 2-celled, many-seeded. c. Diervil'́la 4

- Leaves pinnate. Berry globose, pulpy, 3-seeded.

Elder. SAмBU'ctis 5

- Leaves simple. Drupe flattish, 1-seeded. Handsome shrubs VibUR'NUM 6

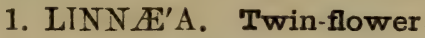

Calyx tube ovate, limb 5-parted, deciduous, with 2 bractlets at base. Yorol a bell-shaped, limb a little irregular, 5 -lobed. Stamens 4, 2 longer han the other 2. Capsule 3-celled, but only 1-seeded, 2 of the cells being empty.--A trailing evergreen herb, dedicated to Linnæus, the first and greatest of botanists. 
L. borea'lis. The unly species, a fine little plant, found in mcist woods in cool ely. mates. It has long, thread like, creeping stems, rooting at the joints, the upright branches about $3^{\prime}$ high. Leaves small, roundish. Flowers in pairs, rosecolored, nodding, at the top of the slender stalk. June.

\section{SYMPHORICAR'PCS. Snow berry.}

Calyx tube globose, limb 4-5-toothed. Corolla bell-shapcd, 4-5-lobed regular. Stamens 4-5, short. Fruit a globose berry, 4-celled but only 2-seeded, 2 cells being empty.-Small erect shrubs with oval, entire leaves, zose-white flowers in short clusters.

* Stamens and style included (i.e., not longer than the corolla)....1, 2

* Stamens and bearded style exserted (extending out of the corolla)....3

1 s. racemo'sus. Cult. Fls. in loose, leafy racemes. Berries snow-white, large.

2 S. occidenta'lis. Wolf-berry. Fls. in dense, nodding spikes. Berries white. N.-W 3 S. vulga'ris, Coral-berry Fls, in axillary heads. Berries red. M. S. W.

\section{LONIOE'RA. Honeysuckle.}

Calyx tube globular, limb 5-toothed, very short. Corolla tubular or funnel-form, iimb 5-cleft, irregular or almost regular. Stamens 5. Ovary 2 or 3-celled. Berry jew-seeded.-Climbing or erect shrubs, with opposite and often connate leaves (that is, their bases growing together around the stem), entire on the margins.

\$ Sıem climbing, flowers sessile, whorled (in pairs in one species)..... a

Stem mostly erect, leaves never connate, flowers in pairs...2

- Upper pair or pairs of leaves nnited (consate) at base....b

a Leuves all distinct, corolla ringent, (In gardens only.)....7, 8

- Corolla tube gibbous (swelled out on one side) at base, limb ringent....5, 6

b Corolla tube equal and slender (not gibbous)

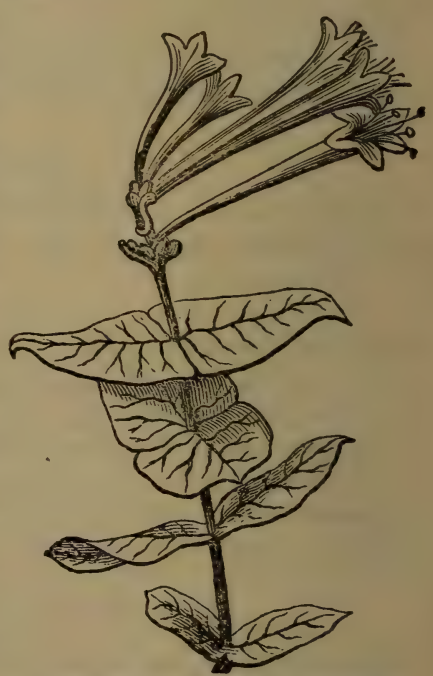

Fig. 496. Trumpet Honeysuckl. at the base....1

1 Corolla ringent, lower lip linear, upper 4-lobed....2-4

1 L. sempervi'rens. Trumpet $H$. Cor. trumpet-shaped, nearly regular, scarlet 
2 L. flava. Wi ${ }^{2} d$-yellow $H$. Flowers in a terminal, 2 (or more)-whoried spike, pale yellow. Leares glancous. W. S.

3 L. grata. Wild-sucet $H$. Fls. in terminal and axillary whorls, reddish white.

1 L. Caprifo'lium. Italian $H$. Fls. in a single, terminal whorl, red, yel., and white. 5 L. parvifo'ra. Small-fl. $H$. Leares oblong, smooth and giaucous beneath. Flowers 1' long, yellowish and purplish, or crimson.

6 L. hirsu'ta. Hairy H. Leaves broad-oval, hairy and downy, green inot glaucous). Flowers sulphur-yellow. N.

7 L. Periclym'enum. Waodline H. Fls. whorled, capitate, red and yellow, sweet scented. Leaves deciduous. Berries red. $†$

8 L. Japon'icum. Japan H. Flowers in pairs, axillary, sweet-scented, deeply two-lipped, reddish. Leaves evergreen. $\dagger$

9 Corolla gibbous at base, lobes more or less irregular. Wild...10-12

9 L. Tartar'icum. Tartarian $H$. Corolla scarcely gibbous, lobes spreading, equal, rose-color, handsome. Leaves cordate, obtuse. +

10 L. cilia'ta. Fly $H$. Corolla lobes short, erect, nearly equal. Berries red.

11 L. oblongifo'lia. Sroamp Fly H. Corolla deeply ringent. Pedicels long. Berries double, purple. Shrub 3-4f. high, swamps. N.

12 L. cœru'lea. Blueberried $H$. Corolla lobes short, subequal, yellow. Pedicels very short. Berries double, blue. N.

\section{DIERVIL'LA. Bush Honeysuckle.}

Calyx tube oblong, limb 5-cleft. Corolla twice as long, limb 5-cleft and nearly regular. Stamens 5. Capsular fruit 2-celled, many-seeded.Small erect shrubs with opposite leaves and axillary flowers.

D. trif'ida. Stem about 2 f. high, branching. Leaves ovate, serrate, ending in a loug, narrow point. Peduneles 1-3-fiowered, the ovaries sleuder, about half as long as the greenish-yellow corolla. Hedges and woods. June.

\section{SAMBU'CUS, Elder.}

Calyx small, 5-parted. Corolla regular, rotate, 5 -cleft into obtuse labes. Stamens 5. Stigmas sessile. Rerry globose, pulpy, 3-seeded.-Shruhd (5-6f. high) or perennial herbs with pinnate or bi-pinnate leaves. Flowere (white) in cymes.

s. Canaden'sis. Siveet $E$. Leaflets 7-11. Cymes flat. Berries dark-purple. run S. pu'beas. Red E'. Leaflets 5-7. Cymes oblong, panicled. Berries red. May. 


\section{VIBUR'NUM. Viburnum.}

Calyx superior, small, persistent. Corolla rotate, limb 5-lobed, lubes obtuse. Stamens 5. Stigmas 1-3, sessile. Fruit a stony nut covered with soft pulp, that is, a drupe. Shrubs and trees with simple leaves Flowers white, in compound fiat cymes.

$\$$ Cymes radiant,-the outer flowers sterile and showy. Lvs. stipuled....Nos. 1, 2 $\$$ Cymes not radiant, - the flowers all alike perfect.... (a).

a Leaves 3-lobed, palmately $3-5$-veined, with setaceous stipules.... Nos. 3,4

a Leaves not lobed,--coarsely toothed, straight-veined. Cyme stalked...Nos. 5-7 -finely and sharply serrate. Cymes sessile.....Nos. 8, 9 . -entire or nearly so.....Nos. 10, 11. Exotic,.... No. 12.

1 V. lantanoi'des. Hobble Bush. A handsome shrub some 3f. high, in rocky woods. Shoots often reclined and rooting again. Leaves round-corlate, serrate, downy on the veins ana petioles. Cyme sessile. Drupes ovate. May.

2 v. Op'ulus. High Cranberry. Shrub 8-12f., in borders of woods, all smooth. Leaves 3-lobed, 3-veined, rounded at base, lobes pointed. Cymes peduncled. Fruit bright red, very acid, often used in sauce. June.

Variety, ro'seum. Snow-ball. Flowers all neutral, in globular cymes. Cult.

$8 \mathrm{~V}$. acerifo'lium. Dockmackie. Leaves subcordate, 3-veined, lobes pointed, acutely dentate, downy beneath. Stamens exserted. Drupes purple. 4-6f. Woods.

4 V. pauciflo'rum. Lvs. 5-veined at base. Stamens included. Drupes red. Mts. Rare.

$5 \mathrm{~V}$. denta'tum. Arrow-ucood. Shrub 8-12f., with straight shoots and branches, all smooth. Leaves round-ovate, acutely toothed, on slender petioles. Fruit blne, with a concave-convex nut. Damp woods. June.

$6 \mathrm{~V}$. pubes'cens. Leaves ovate, broad-dentate, hairy beneath. Shrub 2-3f.

7 V. molle. Poison Haw. Towny thronghout. Leaves broad-oval. acute, crenatedentate. Fruit blue, nut grooved. In woods, Ky. to Fla. 10f. May.

$8 \mathrm{~V}$. Lenta'go. Sweet Viburnum. Tree 10-20f., in rocky woods. Leaves ovate and long-pointed, serrate ; petiole long, with wavy margins. Fruit at last glaucousblack, oval, eatable when ripe, in Autumn. Flowers in June.

$9 \mathrm{~V}$. prunifo'lium. Black Haw. Sloe. 'Tree 10-20f., common in herlges and woods. Leaves shining, ova!, obtuse or barely acute, finely serrulate; petioles short, scarcely margined. Fruit oval, green, then scarlet, then blue-black, sweet. Mlay.

Variety: ferrugin'eum, Possum Haw, has tasteless dripes. Leaves rusty beneath. Southern.

10 V. nudum. Leaves oval varying to oblong and lance-oval, not shining: petioles not winged. Cymes on short stalks. Drupes blue, eatable. 10-20f. A pril-June.

11 V. obova'tum. Leaves small ( $1^{\prime}$ or less), obovate, obtuse, subsessile, dotted. Cymas many, small, Eessile. Fruit black. 12f. River banks. S April.

12 V. Tinus. Lauristine. Leaves lance-ovate, entire, thick and shining. Chire 


\section{Orner LXVII. RUBIACE E. The IMadderworts.}

Plants with opposite, sometimes whorled, entire leaves; the slipules between the petioles; the caly $x$ adherent to the ovary; :orolla regular, inserted on the calyx tube;

lımens inserted on the corolla and as many as its lobes;

arics 2, united; with the 2 styles more or ,ess united.

\section{Analysis of the Genera.}

\& Leaves whorled. Herbs with square stems....a

\& Leaves opposite, with small stipules between the petioles....2

2 Ilerbs, with the flowers habitually 4-parted....3

2 Shrubs or trees....d

3 Fls. twin (always in pairs)....b

3 Flowers single (not twin)....c

a Flowers 5-parted. Fruit twin, fleshy, berry-like. Madder. Rv'BIA.

a Flowers 4-parted. Fruit twin, dry, separable nuts. Bedstraw. GA'Lium.

b Two fls. on one ovary. Creeping stemis. Partridge-berry. Mitchel'La. 1

c Carpels 2, 1-seeded, both never opening. Fls. axillary, solitary. Dio'dia.

c Carp. 2, 1-seeded, one never opening.

Fls. axillary, clustered. Spermaco'ce.

c Carpels 2, few-seeded. Corolla much exserted. Bluets. Housto' NIA. 2 - Carpels 2, many-seeded. Cor. scarce exserted. Greenhead. Or.Denlan'dia.

d Flowers 4-parted, in globular

hds. Button-hush. Cephalan'thus.

d Fls. 5-parted, cymes radiant

with scarlet sepals. S. PINckne'YA

\section{MITCHEL'LA. Partridge-berry}

Flowers 2 on each double ovary. CaJyx 4-parted. Corolla funnel-shaped, hairy within. Stamens 4, short, inserted on the corolla. Stigmas 4. Berries composed of the 2 united ovaries. $J n$.

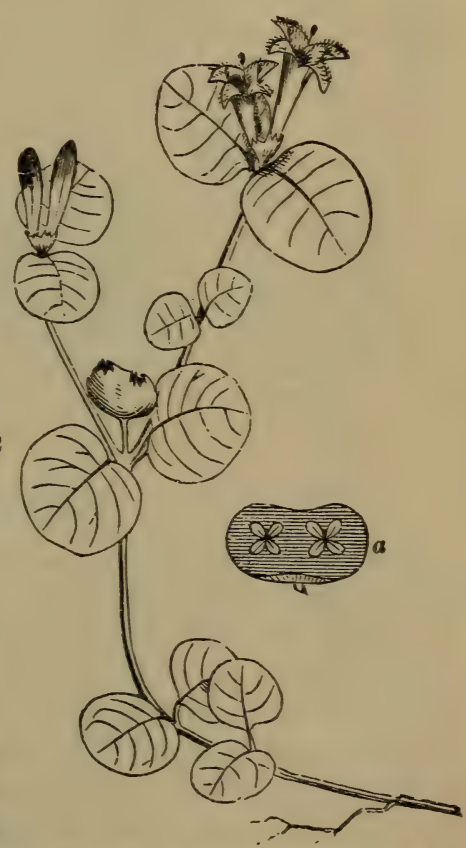

Fig. 497. Mitchella repens, whole plant, with flowers and fruit. $a$, crosssection of the dcuble fruit, showing the two ovaries. 
M. re'pens. Common in woods. Leares round-ovate. Flowers white or pinkish Berries red, remaining through the winter.

\section{HOUSTO'NIA. Bluets.}

Calyx tube round egg-shaped, 4-cleft, persistent. Corolla tubular, mucn exceeding the calyx, limb 4-lobed, spreading, filaments 4 , on the corolla Style 1. Capsule 2-lobed, half-free.-Herbs. Stipules connected to the petiole. Flowers never yellow.

Corolla salver-form, glabrous. Peduncles 1-flowered....a

8 Corolla funnel-form. Peduncles many-flowered, cymous....b

a Flowers terminal. Small, delicate herbs....1, 2

a Flowers axillary. Small, delicate herbs....3, 4

b Leaves lance-orate. Cymes terminal....5

b Leaves lance-linear. Cymes terminal....6, 7 .

1 H. cœru'lea. Duarf Pink. Stems very numerous, upright, 3-6'. Root leaves ovate-spatulate. Flowers pale blue. May, June.

2 H. serpyllifo'lia. Thyme-leaved B. Stems thread-form, decumbert, 6-12'. Leaves round-ovate, petiolate, fringed. Flowers on long stalks, pale. S.

3 H. min'ima. Tiry B. Leaves linear-spatulate. Stems $1-3^{\prime}$ high. Prairies.

4 H. rotundifo'lia. Round-leaved $B$. Lvs. roundish. Stems 2-5'. S. Mts.

Б 甘. purpu'rea. Prairie Innocence. Stems upright, much branched, 1f., with numerous clusters of roseate or white, very delicate flowers. W. S.

$6 \mathrm{H}$. longifo'lia. Long-leaved I. Stems 4-10', erect. Leaves oval-elliptic, narrowed to end.

7 H. angustifo'lia. Narrow-leaved I. Stems 1-2f. erect. Lvs. linear. Flowers numerous. W.S.

\section{ORDER LXX.-COMPOS'IT A. Asterworts.}

An immense family of herbs or shrubby plants, with compound flowers, that is, the flowers (or florets) collected into close heads upon a common receptacle, and surrounded by an involucre of many bracts (called scales), with 5 stamens which have their anthers united into a tube around the style, with the calyx tube closely adhering to the 1-celled orary (an achenium in fruit), and the calyx limb crowning the ovary in the form of a roppus consisting of scales, awns, bristles, or hairs, or else entirely wanting; the corolla consisting of 5 united petals, either strap-shaped (ligulate or tubular, and the style 2-cleft at the top.

In this Order the pupil will remember that the heads are called radiate, when the outer flurets only have rays or are ligulate (see Fig. 498); radi. 
ant, when all the florets are ligulate (Fig. 504); discoid, when ali the florets are tubular, there being no rays (Fig. 509). The receptacle is the broad top of the stalk on which the florets sit (Fig. 499). It is chaffy when there are scales or bracts growing among the florets, and naked when none.

The tubular florets constitute the $d i s k$, and the ligulate, if any, the ray; the disk is generally yellow, while the ray is about as often cyanic (that i, blue, red, white, or any color except yellow) as yellow.

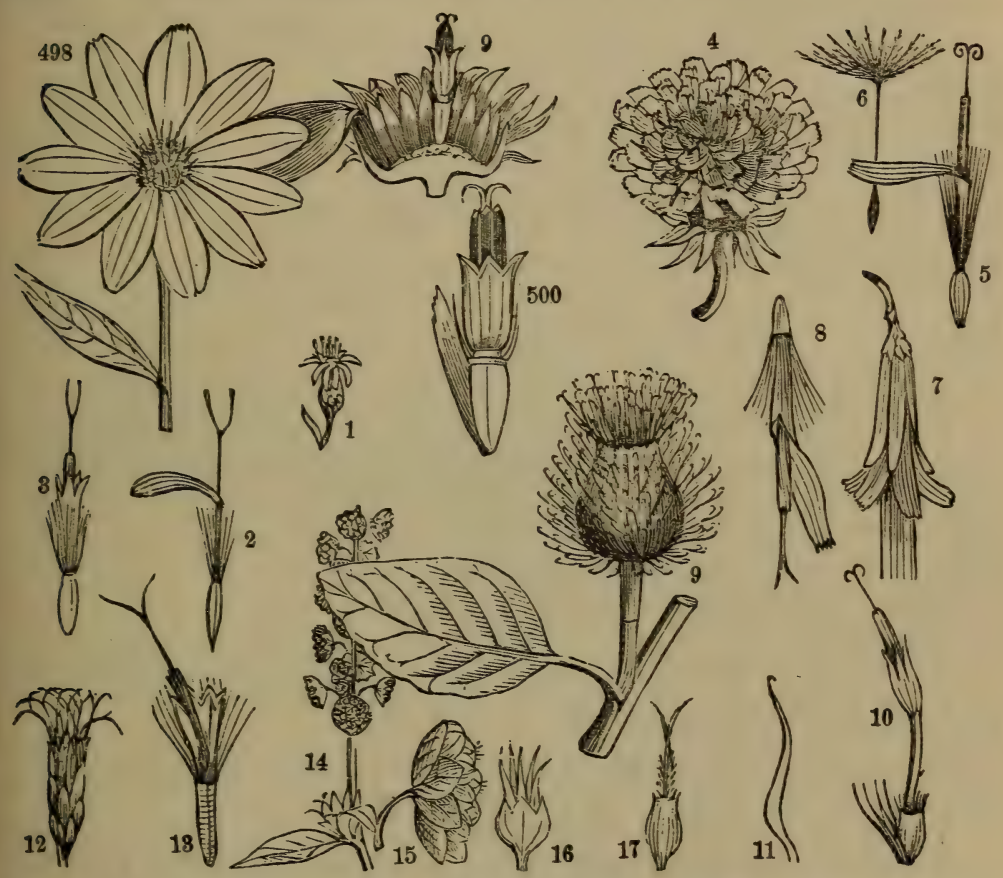

Fig 498. A Sunflower,-heal radiate. 9. Vertical secition of the head, showing the seales of the involucre, and a single disk-flower remaining upon the convex receptacle. Fig. 500. A perfect disk-fluwer magnifed, showing the acheninm, the 2 awns of the pappus, the 5-toothed tu bular corolla, the 5 stamens united around the brancherl style, and the chaff-scale at base. 1 . Hea (rariate) of Solidago casia. 2. A pistillate, lignlate flower of the ray. 3. A perfect disk-flower 1 A (radiant) head of Dandelion. 5. A perfect, ligulate flower. 6. Achenium, with its long beak and feathery pappus. 7. A (radiant) head of Nabalus altissimus. 8. A flower. 9. L (Burd ck), bear discoid. 10. A flower. 11. One of the hooked scales. 12. A (discoid) head of Eupaturium purpureum. 13. A flower. 14. Ambrosia (Pigweed). 15. Staminate head enlarged. 16. Pistillat - involucra enlarged. 17. The fertile flower. 


\section{Analysis of the Genera.}

\section{Sub-order First, TUBULIFLOR}

høving all the perfect flowers tubular $(\S 95)$, the ligulate flc vers, if any, impertest

Heads of flowers radiate, with yellow rays....2

$\S$ Heads of flowers radiate, the rays not yellow....

Heads of flowers discoid (no rays). These genera, about 50 in number, sucl $s$ the Tansy, Wormwood, Boneset, Ironweed (Figs. 248-250), Everlasting, Burdock (Fig. 509), Thistle, Hogweed (Fig. 514), and even Bachelor's-button, are all, fJr want of room, omitted. (See Class Book of Botany, p. 410, \&c.)

2 Leaves alternate or scattered on the leafy stems....4

2 Leaves opposite or whorled on the steins, or all radical...6

3 Leaves alternate or scattered on the leafy stem....7

3 Leaves opposite or whorled on the leafy stem....

3 Leaves all radical and the flowers on a scape....

4 Receptacle chaffy (with bracts growing among the florets)....5

4 Receptacle with deep, horny ceiis, like a honeycomb....

4 Receptacle not chaffy, flat or merely convex....a

4 Receptacle not chaffy, conical or globular....f

5 Rays sterile, disk fertile. Receptacle conical or columnar....g

5 Rays sterile, disk fertile. Receptacle flattish. Fruit flattencd on the sides....h

5 Rays fertile, disk sterile. Receptacle flat. Fruit flattened same way as scales....

6 Receptacle chaffy. Rays sterile, disk fertile....o

6 Receptacle chaffy. Rays fertile, disk sterile....p

6 Receptacle chaffy. Rays fertile, disk perfect....q

6 Receptacle naked or destitute of chaffy scales....m

7 Receptacle not chaffy, naked of scales....8

7 Receptacle chaffy with scales among the florets. Lrs. finely divided....

7 Receptacle chaffy with scales, \&c. Lvs. undivided, merely toothed....w

8 Pappus of numerous bristly hairs....9

8 Pappus of 2 or 3 awns and minute hairs. Glabrous plants....t

8 Pappus wholly wanting, or only a membranous margin....u

9 Involucre of unequal scales, imbricated in several rows....10

9 Involucre scales nearly equal, narrow, and almost in one row....

10 Pappus simple, the bristly hairs abundant and about equal....r

10 Pappus double, the outer row of hairs extremely short....s

a Involucre scales imbricated in several rows....b

a Involucre not imbricated, the outer scales very short or none SenE'dro.

a Invol. not imbr., outer scales equal to the inner. Marigold. CaLEN'DULA.

a Involucre not imbricated, outer scales longer than inner. S. GaILLAR'dIA

b Pappus simple, the bristles all equal and of one kind....

b Pappus donble, the outer very short and chaffy. Lvs. entire. W. S. Currsor'sis

b Prppus double in the disk, none in the rays. Lvs. tcothed. S. HFтеRothe'cs 
- Heads small, rays few (2-15)....d

c Heads quite large, rays narrow, about 30. Tall. c. Elecampane. IN'0la. त l'appus scaly, very short. Root lvs. cordate. Rays 4 or 5. S. BRACHYche'ta. d Pappus abundant bristly hairs. Root lvs. not cordate. Go'denrod. Solida'Go. 1 d l'ap. of a single row of equal bristly hairs. P'ed. long, slender. S. Isopap'pcs.

e Involucre about 4-rowed. Rays 20-80. Head solitary. S. Baldwin'ia.

e Inro_icre about 2-rowed, Rays 8-10. Heads corymbed. S. Av'TrNosper'MCM. IR.y florets pistillate. Leaves decurrent.

I Ray florets neutral.

Snezzewort. HeLe'NiUM.

g Fruit (achenia) 4-angled. Meads large, showy. Cone-flower. Rudbeck'ta.

g Fruit flattened, winged. Heads showy. Rays dronp. W. S. Lep'Achys.

a $\Delta$ chenia wingless. Pappus of 2 deciduous seales. Sunflower. Helian'tuos. 2

h Aclinnia winged. Pappus of 2 persistent awns. Lvs. often decurrent. W

Rag-Sunflower. Actinom'Eris.

k Achenia wingless, in more than 1 row. Coarse herbs with large heads.

M. W. Lcaf-cup. Sil'PhiuM.

k Ach. winged, in only 1 row. Small, with middling hds. S. BerLandik'Ra.

r. Stems leafy, crect, about, 2 f. (or 1-3f.) high ....n

m Stemless plants, leaves radical, appearing after heads. Colt's-foot. TussiLa'Go.

n Scales 5, united in 1 row. Leaves pinnate. French Mrarigrill. TaGE'Tes.

n Scal. in 2 rows, the ont. nnited. Lrs. pinn. W. S. False Dug fennel. Drso'nia.

$\mathrm{n}$ Scales in 1 or 2 rows, all distinet. W. S. Arnica. AR'NicA.

- Involucre imbricated in 3 or more rows of scales. Sunfunver. Helian'thes. 2

- Invol. 2-rowed. Pappus of downwardly hispid awns. Burr Marigold. Bi'dexs. 3

- Invol. 2-rowed. Pappus upwardly hispid if at all. Tick Sunflower. Coneop'sis. 4

p Achenia wingless. Rays 5-12. Herbs viscid, 2-10f. high. S. Polra'nia.

p Achenia wingless. Rays 5. Herbs $2-10^{\prime}$ high, at first stemless. Flowers early in Spring. W. S.

Chrisog'oncm.

p Achenia broadly winged. Rays 12-25. Coarse, tall herbs. M. S. W. Resin Treed, Polar Plant. Sil'phicM.

q Herbs 3-6f. high. Rays 1-5. Recept. flat. S.-W. Croun Bearl. Verbesi'na. q Herbs 2-3f. high. Rays 6-9. Receptacle convex. S.-IV. Tetragonothe'ca. q Herbs 2-6f. high. Pays 10-15. Recept. conical. False Sunflower. HeLiop'sis. q Shrubs 3-10f. high, with solitary heads. S. BORRIOH'IA. r Ach. very silky, biggest at top. Rays about 5. False Aster. Sericorar'pus. r A chenia smooth or smoothish, flattened. Rass 6-100. Sturwort. Aster. s Wild plants 1-4f. high, with middle-sized heads (about 1' broad). Diplopap'pus. s Garden plants 1-2f. high, with very large heads. China Aster. Callis'tersous.

i Herbs 2-3f. high, very smooth. Leares lanceolate, entire. W. Bolio'nia.

t Her bs $\frac{1}{2}-9$ f. high, hairy or rough. Rays 20-200. White-weed. Enig eron. a Involucre brcad and flattish. Pappus 0 . Rays white. Ox-eye. Levcan'themcr. u Involucre hemispherical. Pappus a memoranous margin. Cult. PYre'thrum. a Involucre hemispherical. Pappus 0..Lrs. lobed. Cultivated. Chrssan'themom. u Inv. bell-shaped. Pappas 0. Lvs. entire. Rays violet-purp. W. + Laisy. BeL'us. 
v Disk florets yellow, perfect. Rays pistillate.

$\checkmark$ Disk florets yellow, perfect. Rays nentral.

$\checkmark$ Disk florets white, perfect. Rays pistillate.

* Rays short, white, 3 or 4 . W. S.

w Rays very short, white, 5 , ear-shaped. W. M.

Camomile. A NTHEM'ro. May-weed. MARU'TA. Yarrow. ACHIL'LEA, 7 Ci'OWn-beard. VERBESI'NA. Parthe'nidm.

- Rass very large, purple, pendulous.

I'urple C'one-flower. Echina'cea.

$\therefore$ Leaves pinnately divided. Inner irvoluce of 8 united scales. $+D_{A A^{\prime} L I A .}$

$x$ Leaves simple. Receptacle conical with large chaff. + ZrN'NIA.

s Leaves simple. Receptacle flat. Rays rose-color. Tick-seed. Coreop'sis.

x Leaves simple. Receptacle flat. Rays white, short. W. EcLip'TA.

v Heacis in corymbs. Disk florets regularly 5-toothed. $r$ NARDos'mia.

y Heads solitary. Disk florets regularly 5-toothed. S. Daisy. BEL'LIs.

y Hds. solitary. Disk flts. 2-lipped, outer lip 3-toothed, inner 2. S. Chapta'LiA

$S u b$-order Second, LIGULIFLOR $E$,

having all the florets ligulate $(\$ \Omega 6)$ and perfect, $i . e$. , the heads radiant.

2 Flowers bright yellow....8

2 Flowers cream-color or purplish....5

2 Flowers blue. Stems leafy, erect....e

3 Pappus none. Involucre of about 8 equal scales....a

3 Pappus double, the outer of scales, inner of bristles....b

3 Pappus wholly of feathery bristles....f

3 Pappus wholly of hair-like bristles, generally abundant...4

4 Fruit bearing the pappus on its slender beak....c

4 Fruit not lengthened into a beak, pappus sessile....d

5 Pappus consisting of equal, feather-like bristles....f

5 Pappus of simple, hair-like bristles, abundant....g

a Leaves all alternate. Heads panicled. $r$.

Nipplewort. LAMPSA'NA.

a Leaves partly opposite. Heads solitary or umbeled. Pappus 0. S. APo'oon.

b Leaves all radical, pinnatifid-toothed. Pappus scales 5, with 5 bristles. $c$. Dwarf Dandelion. Krig'IA.

b Lvs. all or mostly rad., seldom pinn. Pap. scal. and brist. many. CyN'thiA.

c Stemless leaves runcinate. Pappus white. Dandelion. TARAX'ACUM. 8

c Stems leafy or not. Pappus reddish or tawny. S. PyRRhopap'PU.

c Stems leafy, leaves runcinate. Pappus silky-white. c. Lettuce. LACTU'Js.

d Pappus brownish Stems mostly leafy. with many heads. $c$.

Huwkweed. HIERA'CIUM. s

d Pap. silky white. Stemless; scapes each with one head. W. Trox'rmos.

d Pappus silky white. Stems bear prickly leaves. $c$ Sow Thistle. Son'oncs.

- Pappus of many small scales. Branched stems 2f. high. Heads axillary,

large. Common. Eastward.

e Pappus of many hair-like bristles. 3-8f.
Succory. Сicho' RIUx.

Blue Lettuce. MuLaE'Didr.

f Leaves on the stem linear, entire. Purpl. + Vegetable Oyster. Tragopo'eon.

$f$ Leaves all radical, toothed. Flowers yellow. Fruit taper-beaked. 
B Ach. with a long beak, pap. silk-white. Heads erect. c. Till Lettuce. LAcro'cA g Achenia not beaked, pappus dull-white. Hds. nod. c. Drop-flower. NaB'ales 10 5 Achenia not beaked, pap. dull-white. IIds. erect, purrle. S. $r$. Lrgodes'mi
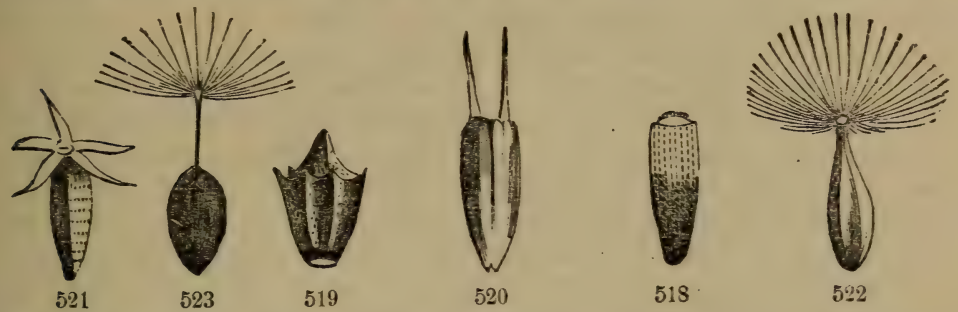

Achenia of Asterworts, showing the rarying pappus. Fig. 518. Achenium of Eclipta, no pappus. Fig. 519. Horseweed (Ambrosia trifida). Fig. 520. Sunflower; pappus 2 teeth Fig. 521. Ageratum,-5 scales. Fig. 522. Blue Lettuce,-many hair-like bristles. Fig. 523. Wild Lettuce, pappus raised on a beak.

\section{SOLIDA'GO. Goldenrod.}

Heads few-flowered, the rass 1-15, pistillate, disk florets perfect. Involucre oblong, imbricate, with close-pressed scales. Receptacle alveolate, narrow. Pappus simple, of equal, hair-like, rough bristles.-Herbs, verv abundant in the United States. Stem erect, branching near the top. Leaves alternate. Heads small, florets all yellow (in $\mathbf{S}$. bicolor, whitish), opening from August to October. (See Figs. 501-503.)

T Shrub woody, 1-3f. high. Heads with 1-3 rays. S....1

T Herbs. Heads without rays (discoid). S ...2, 3

IHerbs. Heads with rays (1-15, generally small)....a

a Scales of the involucre with recurved, leafy, green tips....4, 5

a Scales of the involucre erect, tips scarcely at all green....b

b Heads (white or yellow) in axillary, close clusters or short racemes...6-9

b Heads in terminal racemes forming a close or a spreading panicle....c

b Heads in terminal compound corymbs....n

c Racemes erect, not one-sided. Leaves feather-veined....d

c Racemes spreading or recurved, the flowers all on one side....t

d Alpine species (growing only on mountains). Hears quite large....10-12

d Not alpine-growing in plains or low grounds. Heads not large....

e Plants very smooth, at least the stem and leaves. Rays $4-7 \ldots \ldots 13-15$

e Plants downy or hoary with very close sof hairs. Rays $9-12 \ldots 16,17$

f Leares 3 or 1-veined. Very smooth salt-marsh Lerbs....18, 19

I Leaves evidently 3 -veined. Herbs inland, \&c....g

f Leaves not veiny, thick, subcutive ....27-29

( Ireares evidently feather-veined, mostly serrate ... 
g Leaves entire or very nearly so....20, 21

g Leaves serrate. Stem smooth and glabrous....22-24

g Leaves serrate. Stem roughish-pubescent....25, 26

k. Stem downy or hairy. Leaves rough or not....30-32

$x$ Stem smooth and glabrous. Leaves smooth or rough....m

$m$ Rays 6-12. Racemes close, forming a compact panisle....38-40

m Rays 6-12. Racemes distant, loosely or scarcely panicled....36, 37

m Rays 2-5. Racmes, or the panicle, long and slender....33-35

n Leaves lanceolate, large. Stem smooth....44-46

n Leaves lanceolate, large. Stem rongh-downy....41-43

n Leaves linear, entire. Stems much branched, smoothish ...47, 49

1 S. pauciflosculo'sa. Shrubby Goldenrod. Bush $2 \mathrm{f}$. high, very smooth, with lanceolate leaves and the 5 -flowered beads in erect, panicled racemes. $\mathbf{S}$.

2 S. discoi'dea. Rayless $G$. Disk florets 10-15. Racemes erect, panicle slender. S.

B S. brachyphyl'la. Chapman's $G$. Florets 5-7. Racemes spreading, one-sided. S. 4 S. squarro'sa. Ragged $S$. Rays 10-15. Scales stiff, with spreading, green tips. Heads large. N.

5 S. squarrulo'sa. Rough S. Rays 6-10. Scales awl-shaped, with slender, loose tips. S.

6 S. bi'color. Creamy S. Rays about 8, creamy-white. Plant hairy. Lvs. elliptic.

7 S. Buck'lyi. Buckly's S. Rays 4-6, yellow. Plant woolly. Leaves oblong. S.

8 S. Latifo'lia. Broad-leaved S. Ravs yellow. Plant smoothish. Leaves broad lanceolate, coarse-toothed. Seed downy. $c$.

9 S. cæ'sia. Polished $S$. Rays yellow. Plant smooth and glaucous. Lvs. lin.-lance. olate. Stem flexuous, tall, slender. A beautiful Goldenrod. Woods. $c$.

10 S. thyrsoi'dea. Thyrse G. Leaves ovate, long-stalked. Tall, 1-3f. high. Heads large. Coarse, showy. In mountain woods.

11 S. Virgau'rea. True G. Leaves oval, short-stalked. Low, $2-3^{\prime}$ high. Heads about 30 -flowered, few, often only one.

12 S. hum'ilis. Mountain G. Lvs. oblanceolate. IIigh 6-12'. Heads about 12 -fl wd. $13 \mathbf{S}$. virga'ta. Virgate $G$. Heads all in one raceme at top.

14 S. stric'ta. Cpright G. Heads in a panicle, which is narrow and erect.

$15 \mathrm{~S}$. specio'sa. Shovoy $G$. Ileads in a thyrse-like panicle, large and very showy.

Pedicels shorter than the involucre, pubescent. Leaves very broad.

16 S. verna. Early S. Whitish-downy. Lower leaves ovate. May, June. \$. 17 s. puber'ula. Dusty $S$. Dusty-puberulent. Lower leaves oblanceolate Panicle long, compound, dense. Scales acute. Aug. N.

18 S. sempervi'rens. Evergreen $S$. Lus. lanceolate, thick, obscurely 3. veined E 19 S. angustifo'lia. Narrow-lv. S. Lvs. lance-lin. 1-veined, thick. Hds. small. s 20 S. nemora'lis. Wood S. Plant dusty, roughish. Lvs. acute. Rays showy. c 21 S. rupes'tris. Rock $S$. Plant smooth. Lvs. acuminate. Rays very short. W 22 S. Missourien'sis. Missourie G. St. 1-2f. All glabrous. Panicle dense. W 23 S. sero'tina. Late $G$. Stem 3-6f. Leaf veins hairy beneath. Paniclo loose.

21 S. gigan'tea. Giant G. Stem 3-8f. Branchlets hairy, Leaves lanceolate 
25. S. Canaden'sls. Canada G. Leaves pointed, rough. Panicle broad. c.

26 S. Short'ii. Short's $G$. Leaves acute, very smooth. Panicle long, narrow. W. 27 S. pilo'sa. Hairy S. Hairy, 4-7f, high. Leaves remotely serrulate. N.-J. S. 28 S. odo'ra. Sweet S. Stem downy in lines, slender, 2-8f. high. Leaves very entire, smooth, punctate with pellucid dots. Fragrant. $c$.

S. Iortifo'lia. Twist-lv. S. Stem rough. Lvs. often twisted, not punctate. S.

30 S. altis'sima. Tall S. Stem hairy, 4-6f. Lvs, veiny, rough. Scales acute. 6 31 S. Drummon'dii. Drummond's $S$. Stem 1-2f. Lvs. velvety. Scales obtuse. W

32 S. rad'ula. Rasp-lv. S. Stem rough-downy. Lvs.oblong-spatulate. W.

83 S. ulmifo'lia. Elm S. Branchlets hairy. Scales acnte. Rays 3 or 4 , disk flowers 3 or 4 . N. W.

84 S. Boot'ii. Boott's $S$. Branchlets hairy. Scales obtuse. Rays 2-ñ, disk flower: 8-12. S.

B5 S. linoi'des. Flux S. Smooth all over. Scales obtuse. Rays 1-4. 12-20', N, 36 S. Muhlenber'gii. Muhlenberg's S. Lvs. large, thin, notched, smooth botl sides. Heads 15 -flowered. N.

37 S. pat'ula. Spreading S. Lvs, large, thick, very rough on the upper side. Stem 2-4f, branches leafy. Heads 20 -flowered. N.

88 S. ellip'tica. Marsh S. Very leafy. Lvs. elliptic. Panicle dense, pyramidal.

B9 S. argu'ta. Saw-lv. S. Leaves few, elliptic, sharply serrate. Panicle spreading.

6 S. neglec'ta. Neglected $S$. Leaves few, serrate, lin.-lanceolate. Panicle narrow. $41 \mathrm{~S}$. Ohien'sis. Ohio $S$. Smooth all over. Lvs, obtuse, flat. Corymbed. W. 42 S. Riddel'lii. Riddell's $S$. Branches, \&c., dust-downy. Lvs. acute, concave. Heads corymbed. W.

43 S. corymbo'sa. Corymbed $S$. Branches corymbed, hirsute. Outer secund. 4 S. Houghto'nii. Houghton's $S$. Hds. few, very large. Otherwise like No. 41. N.-W. t5 S. rig'ida. Stiff $S$. L rs. rigid. Heads very large. Scales obtuse. Height 3-5f. 6 6 S. Spithamæ'a. Dwarf $S$. Leaves thin, sharp-serrate. Scales acute. Height 6-12'. Mountains. S.

$47 \mathrm{~S}$. lanceola'ta. Lance-lv. S. Leaves linear-lanceolate, 3-5-veined. Rays minute, about 17 . Corymbs crowded, fragrant. $c$.

48 S. tenuifo'lia. Linear-lv. S. Leaves narrow-linear, one-veined. Rays short, about 10. More slender, with thinner clusters. $c$.

\section{HELIAN'THUS. Sunflower.}

Heads many-flowered, rays neutral, disk-florets perfect. Scales of the involucre in several rows, more or less imbricated. Torus flat or convex, the chaff persistent, embracing the 4-sided, flattened achenia. Pappus of 2 chaffy awns, deciduous.-Herbs, mostly 2 , rough. Leaves opposite, the apper often alternate, mostly 3-veined. Heads mostly large, the disk from half an inch to 1 . broad. Rays yellow, disk yellow or purple. July. Oct. (Figs. 498, \&c.) 
Disk with its corolıas and paies dark purple....a

$\S$ Disk with its corollas and pales yellow....c

a Herbs annual. Leaves chiefly alternate....1, 2

a Herbs perennial. Leaves opposite....b

b Scales of the involucre acuminate....3-5

b Scales of the involucre obtuse....6, 7

c Leaves chiefly alternate and feather-reined....8-11

c Leaves chiefly opposite and 3-veined or triple-veined ...d

d Scales of involucre erect, closely imbrieated....e

d Scales loosely spreading. Heads large, 9-15-rayed....f

d Scales loosely spreading. Heads small, 5-8-rayed....22. 25

e Plants green, rough....12, 13

e Plants whitish, downy ....14, 15

$f$ Scales lance-linear, longer than disk. Leaves thin....16,17

f Scales lance-ovate, as long as the disk. Leaves thick....18-21

1 H. an'nuus. Crmmon $S$. Stont and tall (3-10f.). Heads large 6-10 across, nodding. Achenia (seeds) glabrous. A variety has all the flowers ligulate.

2 H. deb'ilis. Slender $S$. Slender, decumbent. Ileads small. Seeds downy. S.

$3 \mathrm{H}$. Rad'ula. Rusp-lv. S. Leaves roundish, rongh, obtuse. Rays 7-10 or none. S.

4 H. heterophyl'lus. Leaves oval, lanceolate, \&c. Rays 12-18. Pales acute. S.

$5 \mathrm{HI}$. angustifo'lius. Leaves lance-linear, pointed. Pales 3-toothed. N.-J. S.

6 H. rigidus. Rigid S. Lvs. lanceolate, pointed. Scales ovate, acute. Rs. 12-20. W.

$7 \mathrm{H}$. atrorubens. Livid $S$. Leaves ovate, obtusish. Scales oblong, obtuse. S.

8 H. gigan'teus. Tall S. Hairy, rough. Lvs. lanceclate, pointed, serrate. $c$.

9 H. tomento'sus. Velvet $S$. Very downy. Lowerlvs. ovate, nearly entire. W. S.

$10 \mathrm{H}$. grosse-serra'tus. Coarse-toothed $S$. Stem smooth. Leaves lance-pointed, sharp-serrate. Rays 15-20. W.

$11 \mathrm{H}$. tubero'sus. Artichoke. Cultiv. Lvs. 3-veined, lower cordate-orate.

12 H. lætiflo'rus. Laughing $S$. Branched. Leaves lance-oval, short petioled.

18 H. occidenta'lis. Western $S$. Stem slender, simple, rearly leafless above.

$14 \mathrm{H}$. mol'lis. Sift $S$. Leaves ovate, cordate, sessile. Plant woolly. W.

$15 \mathrm{H}$. cine'reus. Aslyy $S$. Lvs, ovate-oblong, tapering to base. Ashy-downy. O.

16 H decapet'alous. Ten-rayed S. Rays 9-12. Leaves all opposite. Stem 3-4f. N. M.

17 H. tracheliifo'lius. Trach-leaved S. Rays 12-15. Branch lvs. alternate. 4-8f. W.

$18 \mathrm{H}$. doronicoi'des. Fulse Tiger-bane. Leaves petiolate, ovate, and lanceovate, upper alternate. Scales longer than disk. Rays 12-15. W. S.

19 H. strumo'sus. Warty S. Leaves short-petioled, lance-ovate, all alike. Scales equaling the disk. c. A double-flowered variety is cultivated.

$20 \mathrm{H}$. hirsu'tus. Hairy $S$. Leaves petiolate, hairy beneath. Scales hairy. W.

$21 \mathrm{H}$. divarica'tus. Forked S. Leaves sessile, very rough, opposite or ternate. $c$. 22 H. microceph'alus. Small S. Stem smooth, much branched. Lvs. narrow. W. 23 H Schweinit'zii. Schweinitz's $S$. Stem downy, rough. Leaves white, downy. Car. 24 H. læviga'tus. Polished S. Stem and leaves very smooth. Not branched. S. Mts. 25 E. longifo'lius. Long-lod. S. Leaves lance-linear, acnte, smoth. Rays 8-10. Ga 


\section{BI'DENS. Burr-Marigold.}

Involucre scales nearly equal, double, the outer generally large and leafy. Rays few (3-8, or sometimes none), neutral, clisk perfect. Recep. sacle rhaffy, flat. Achenia flattened or 4-sided, crowned with 2-1 awns sich are hispid backwards.-Leares opposite. July-Oct.

Rays inconspicuous or none.....

- Rays quite showy, yellow....4, 5

a Achenia filttened, hroadest at top....1-3

a Achenia slencier, 4 -sided....6, 7

: B. frondo'sa. Leafy $B$. Leaves pinnately 3-5-fol., divisions distinct. Rays 0.

2 B. conna'ta. Leaves simple, lower ones sometimes 3-parted. Kays 0.

3 B. cer'nua. Vodding $B$. Leaves simple, scarcely connate. Rays few or 0 .

4 B. chrysanthemoi'des. M $u d B$. Lvs. narrow-lance., equally serrate, connate.

5 B. Beck'ii. Beck's $B$. Lvs. mostly under water and very finely divided. M.

6 B. leucan'tha. White $B$. Heads small, with white rays. Lrs. pinnate. S.

7 B. bipinna'ta. Spanish Teedles. Ray's very short, yellow. Lus. bi-pinnate

\section{COREOP'SIS. Tick-seed.}

Involucre many-flowered, double, each of 8-13 scales, the outer leaty, the inner membranuus. Receptacle flat, the chaff falling with the fruit. Achenia flattened, often winged, emarginate, each commonly with 2 teeth or awns which are not hispid downwardly as in Bidexs.-Leargs generally opposite. Heads showy (rarely without rays).

* Headis discoid (without rays)....1, 2

* Heads radiate, rays showy....2

a Disk yellow, rays also yellow, mostly entire.... b

a Disk yellow, rays rose-colored, 3-5-toothed at the end....20, 21

a Disk purple, rays yellow with a purple base, toothed....18, 19

a Disk purple, rays wholly yellow, toothed at the end....14-17

b Leaves petiolate, compound, with Ianceolate, tcothed divisions....3-5

b Leaves petiolate, compound, with linear, entire divisions...6, 7

b Leaves peiiolate, simple, or some of them eared at base....8-10

Leaves sessile, 3-parted, divisions entire or not often, seeming whorled... 11-is

1 C. discoi'dea. Rayless $T$. Leaves on long petioles, ternstely divided. W.

2 C. bidentoi'des. Leaves on short petioles, toothed, lance-linear. Penu. F.

$\mathrm{C}$ au'rea. Golden T. Leaflets 3-5. Onter scales about 8. Achenia 2-4-touthed. S

C. trichosper'ma. Leaflets 5-7. Outer scales about 8. Ach. slender, 2-'oothed

5 f. aristo'sa. Leaflets 5-7. Outer scales 10-13. Achenia 2 or 4 awned. W.

6 C. trip'teris. Stem 4-8f. high. Hds. on short stalks. Rays $\frac{1}{2}$ ' long, entire. W. 8

7 C. grandifo'ra. St. 1-2f. high. Heads on long stalks. Rays 1' long, 4-5-cleft. A 
8 C. latifo'lia. Stem 4-6f. high. Rays entire. Leaves ovate, serrate. S. 9 C auricula'ta. Stem 1-3f. high. Rays 2-5-toothed. LVs. often eared at base. $\mathbf{S}$ $10 \mathrm{C}$ lanceola'ta. Stem 2-8f. high. Rays 4-5-toothed. Lvs. lanceolate, entire. S.

$11 \mathrm{C}$ senifo'lia. Leaf divisions all entire, appearing in 6-leaved whorls. S.

12 C. vesticilla'ta. Leaf divisions all again divided into narrow-linear lobes. W.

13 C. pralma'ta. Lvs. deeply 3-cleft, wedge-shaped, lobes linear, not whorled. W. $11 \mathrm{C}$ delphinifo'lia. Leaves sessile, 3-parted, the divisions often lobed. S. 15 C gladia'ta. Shoord-lv. C. Leaves petioled, lanceolate, sometimes divided. Stein round. S.

16 C. angustifo'lia. Narrow-lv. C. Leaves petioled, narrow-spatulate, entire. Stem square. $\mathrm{S}$.

17 C. CEm'leri. EEnler's C. Leaves petioled, lanceovate, entire. Stem round below. $\mathbf{S}$.

18 C. Drummon'dii. Drummond's C. Lvs. pinnately 3 -5-foliate, divisions oblong oval, entire. $t$

12 C. tincto'ria. Dyer's C. Leaves pinnately much divided, divisions linear, entire. $†$

20 C. ro'sea. Rose C. Stem leafy, leaves narrowlinear, entire. Rays rose-white. E.

21 C. nuda'ta. Leafless C'. Stem few-leaved, leaves awl-shaped, entire. Rays rose-red. S.

\section{ASTER. Starwort.}

Ileads many-flowered. Scales of the involucre generally imbricated in two or more rows, and with green tips. Disk florets tubular, perfect, rays fertile, in one row, oblong, revolute when old. Receptacle flat, marked with pits. Pappus simple, hair-like, rongh. Achenium usually flattened. -A large genus of $2 f$ herbs, very abundant in the United States, flowering in late summer and autumn. Leaves alternate; disk florets yellow, changing to purple; rays blue, purple, or white, never yellow.-The spe cies are very variable, and many of them are hard to distinguish.

* Radical and lower leaves cordate and petiolate....a

* Radical leaves never cordate....

a Heads in lous 8 corymbs. Rays white or whitish ....1, 2

a Heads in racemes or panicles, ilue or bluish....b

Ieaves evidently serrate; rays light blue, abont 12 , spreading $\frac{1^{\prime}}{2^{\prime}} \ldots 3,4$

b Leaves entire or nearly so; rays bright blne, spreading near $1^{\prime} \ldots .5-7$

c Involucre scales tipped with green, or the outer ones wholly grcen....d

c Involucre scales with scarious margins or wholly scarious....f 
d Stem leares c.asping, with a cordate or auricled base....e

d Stem leares sessile, rarely clasping, never cordate or auricled....19

e Involucre scales close, in several rows, outer ones gradually shorter....8, 9

e Involucre scales loose, nearly equal, outer ones often wholly greer....10-12

f leaves lanceolate and linear-lanceolate, more or less rough ....13-15

I Leaves linear, fleshy, very smooth, entire. Salt-marsh herbs....16-18

1 A. corymbo'sus. Corymbed $S$. Slender, with thin, serrate leaves.

2 A. macrophyl'lus. Big-lvd. S. Stout, with large, thick, ser., rough lrs. 18-rayed, 8 A. cordifo'lius. Heart-leuved $S$. Involucre scales close, obtuse. Ivs, sharp-serrate.

1 A. sagittifo'lius. Arrow-leaved $S$. Scales awl-shaped, long, loose. Lvs. blunt-serrate.

5 A. azu'reus. Azure $S$. Stem leaves sessile, rough, lanceolate, and linear.

6 A. undula'tus. Stem lvs. on winged stalks, with rounded clasping bases, wavy.

7 A. Shor'tii. Short's $S$. Stem leaves on naked stalks, all cordate, pointed, entire.

\& A. patens. Patent S. Plant rough-downy. Leaves entire. Scales pointed.

2 A. lævis. Polished $S$. Plant smooth and glawcous. Scales broad, acute.

10 A. prenanthoi'des. Lvs. sharply cut-serrate, with a long, slender, entire base.

11 A. punic'eus. Red-st. S. Lvs. sparingly serrate, lance. Stem hairy, often red.

12 A. Novæ-Angliæ. New-England $S$. Leaves entire, rough, numerous. Rays nearly 100, $\frac{3}{4}$ long. Stems 4-6f. high. A fine species, often cultirated.

13 A acumina'tus. Dell $S$. Leaves coarsely-toothed, broad-lanceolate, long-pointed, often clustered. Rays white. In dark woods. N.

14 A. nemora'tis. Wood $S$. Leaves narrow-lanceolate, nearly entire, acute, with edges revolute. Heads 1-3. In damp woods. N. M.

15 A. ptarmicoi'des. Sneezeroort $S$. Leaves entire, stiff, acute. Heads corymbed.

16 A. flexuo'sus. Zigzag S. Heads large, with showy rays. Stem flexuous.

17 A. linifo'lius. Flax $S$. Heads numerous, with very short rays in 2 rows.

$18 \mathrm{~A}$. subula'tus. Heads with showy blue rays. Scales in 2 or 3 rows. $\mathbf{S}$

19 Ma:y species, very variable, here omitted. (See p. 420, Class Book.)

\section{ERIG'ERON. Fleabane. Whiteweed.}

Heads many-flowered, mostly hemispherical, rays very numerous (20-200), narrow, linear, pistillate ; disk flowers perfect. Receptacle flat, naked (no chaff or pits). Scales of the involucre nearly equal and in one row. Pappus generally simple.-Herbs with alternate leaves. Rays white, blue, or reddish. Flnwering from May to September.

Rays showy, longer than the involucre. Heads large $\left(\frac{1}{2}-1^{\prime}\right.$ broad)....a Rays obscure, shorter than the involucre, whitish. Heads very small....1, 2

a Rays parple, very numerous. Heads loosely corymbed.... 3-5

a Rays white or whitish. Heads loosely panicled....6-8

1 E. Canaden'se. Canada F. Erect, hairy. Leaves lanceolate. Heads paniclel

8 E. divarica'tum Prostrate $F$. Low, diffuse. Lrs. linear. Heads corymbed. W 
3 ¿. bellidifo'lium. Daisy 7. Leaves nearly entire. Rays $5 n-80$, bluish-p.

4 E. Fhiladel'phicum. Leaves nearly entire. Rays 150-200, reddish-purple.

5 E. quercifo'lium. Oak-lv. F. Lvs. sinuate-pinnatifid-toothed. Rays 100-200. \& 6 E. an'nuum. Annual $F$. Stem leafy, 3-5f'. high. Leaves coarse-toothed.

7 E. strigo'sum. Rough $F$. Stem leafy, 2-3f. high. Leares nearly entire.

S E. nudicau'le. Naked $\boldsymbol{F}$. Sten leafless, 1-2f. high. Rays about 30. S.

\section{ACHILLE'A. Yarrow. Millfoil.}

Heads many-flowered, rays few, fertile; receptacle flat, chaffy; achenia Hlattened, margined, without a pappus.- If European herbs with small, 4-12-rayed heads in corymbs. Juno-Sept.

1 A. millefo'lium. Leaves twice pinnatifid with fine segments. Rays 4 or 5 . c.

2 A. Ptar'mica. Sneezewort. Leaves undivided, lance-linear, serrate. Rays 8-12. r.

\section{TARAX'ACUM. Dan'delion.}

Involucre many-flowered, double, the outer of small scales much shorter than the close, erect row of the inner. Receptacle naked. Achenia produced into a long beak crowned with copious white, hair-like bristles of the pappus.-Acaulescent herbs with runcinate leaves. (Figs. 504-506.)

T Dons-leo'nis. Dan'delion. Outer scales of the involucre reflexed. Leaves ruu cinate, smooth, dentate.-In all open situations, blossoming at all seasons except winter. Scape round, hollow, lengthening after flowering, and bearing a globular head of seeds and seed-down, whose light and airy form is \& very famil iar sight to all.

\section{HIERA'CIUM. Hawkweed.}

Involucre more or less imbricated, egg-shaped, many-flowered. Ache. nia not prolonged into a beak, striate. Pappus of rough, brittle, numerous tawny bristles in a single row.- 24 Leaves alternate, entire, or toothed Florets yellow. July-Sept.

* Involucre and stalks smooth or nearly so....a

- Involucre, stalks, \&c., rough with glandular hairs....b

a IIeads with 50 to 60 florets.... 1

a Ileads with 10 to 20 florets....2, 8

b Ileads with 40 to 50 florets....4

b Heads with 20 to 30 florets....5, 6

1 H. Canaden'se. Canada $H$. Stem leafy, corymbed at top. Leaves sharptoothed. N. 
2 F. panicula'tum. Panicled $H$. Stem leafy, widely panicled. Leares fine-toothed. 8 H. veno'sum. Rubin's Plantain. Stem almost leafless, corymbed. Lvs. entire.

4 H. scabrum. Rough $H$. Heads corymbed. Plant stiff, rongh-hairy.

5 H. longip'ilum. Long-haired $H$. Plant clothed with straight bristles $1^{\prime}$ long. W

; $甘$. Grono'vii. Gronovins' $H$. Plant slender, quite hairy below.

\section{NAB'ALUS. Lion's-foot.}

Involucre cylindrical, double, the inner of many linear scales in one row, the outer of a few short scales at base. Receptacle naked. Achenia sinooth, striate, not beaked, crowned with a copions, straw-colored or brownish hair-like pappus.-Erect herbs, with a thick, tuberous, bitter root. Heads 5-18-flowered, white or straw-colored, often purplish. Aug.-Oct.

- Heads glabrous, pendulous. Leaves multiform in the same plant....a

- Heads hairy, erect or nodding. Leaves reniform, undivided....7-9

a Tall (2-4f. high). Heads (8-12-flowered) in a corymb-like panicle....1, 2

a Tall (2-6f. high). Heads in a long, raceme-like panicle....3, 4

a Low (5-10' high). Heads racemed. Found only on high mountains....5, o

$1 \mathrm{~N}$. al'ba. White L. Pappus cinnamon-color. Leaves hastate, often lobed.

2 N. Fra'seri. Fraser's L. Pappus straw-color. Leaves deltoid, often cleft.

$3 \mathrm{~N}$. altis'simus. Tull $L$. Heads 5 -flowered. Leaves divided, or cleft, or entire.

4 N. virga'tus. Rod L. Heads 8-12-flowered. Lowest leaves pinnatifid

$5 \mathrm{~N}$. na'nus. Dwarf $L$. Outer involucre of short-ovate, close scales.

$6 \mathrm{~N}$. Boot'tii. Boo't's $L$ Outer involucre of linear, loose scales.

7 N. racemo'sus. Racemed L. Heads nodding, 9-12-flowered. W. M.

$8 \mathrm{~N}$. crepidin'eus. Crepis $L$. Heads nodding, 25-35-flowered. W. S.

9 N. as'per. Rough L. Heads erect, 11-14-flowered. Panicle racemed. W.

\section{ORder LXXI. LOBELIACEA. Lobeliads.}

Herbs with alternate leaves, scattered flowers, and often milky juice; caly $x$ superior; corolla irregular, 5-lobed, tube split down to the base ; stamens 5, united into a tube both by the filaments and anthers; orary adherent to the calyx tube; styles united into one; 'igma fringed ; fruit a 2-3-celled, many-seeded capsule.

LOBE'LIA. Cardinal-flower. Indian Tobacco.

The two npper lobes of the irregular corolla are smaller than the three 
lower. Stamens united into a curved tube. Stigma 2-lobed. Capsule opening at top. Seeds very small.-Flowers axillary, generally forming leafy or bracted raceines. July-Sept.

8 Stems leafy ....a

Stems leafless, leaves nedrly all crowded at the root, under water....11, 12

a Flowers bright red or scarlet, large and showy ....1, 2

a Flowers blue, varying to bluish-white....b

b Stem stout, 2-3 or 4f. high. Flowers large, about $1^{\prime}$ long.... 3-5

b Stem slender, $6^{\prime}-2 \mathrm{f}$. high. Flowers small $\left(\frac{1}{4}-\frac{1}{8}{ }^{\prime}\right.$ long $) \ldots .$. c

c Stem branched, racemes several, ioose, or flowers scattered....6, 7

c Stem generally simple, bearing a single raceme... 8-10

1 L. cardina'lis. Cardinal-flwr. Stem smooth. Leaves oblong-lanceolate, acute.

2 L. ful'gens. Mexicun. Stem downy. Leaves linear-lanceolate, long-pointed. † 3 L. puber'ula. Leaves obtuse, denticulate. Raceme one-sided. Plant downy. 4 L. syphilit'ica. Blue $C$. Lvs. acute, slightly toothed. Racemes equal, hairy.

5 L. amæ'na. Pretty C. Leaves acuminate, toothed. Racemes one-sidei, smoothish. S.

6 I. infla'ta. Indian Tobacco. Hairy. Lus. ovate-lancenlate, toothed. Pod inflated.

7 L. Kal'mii. Kalm's C. Smonth. Leaves linear-spatulate, entire. Fls. blue-white.

$8 \mathrm{~L}$. Nuttal'lii. Nuttall's L. + Pedicels twice as long as the flowers. Leaver linear, extremely slender. S. M.

9 L. spica'ta. Spiked L. Pedicels as long as the flowers. Racemes dense. Leaves oblong.

10 L. leptostach'ya. Slender-spiked L. Pedi. none. Lvs. lance-oval, smooth. W

11 L. Dortman'na. Water L. Root leaves linear, terete, hoilow, fleshy. Scape long.

.12 L. paludo'sa. Marsh L. Root leaves linear-oblong, flat. Stem tall. S.

\section{Order LXXII. CAMPANULACEA. Bellworts.}

Herbs with a milky juice, alternate leaves;

flowers mostly blue and showy, with a superior

calyx; a regular and mostly campanulate 5-lobed corolla; with the 5

stamens usually separate, and ovary adherent to the calyx tube; and with the 2-5-celied pod crowned with the remains of the calyx.

Analysis of the Genera.

Calyx tube very short (below the flower).

Colyx tube long and three-angled.

CAMPAN'ULA. 1

SPECULA'RIA 


\section{UAMPAN'ULA. Bell-flower. Harebell.}

Calyx 5-cleft. Corolla bell-shaped, funnel-shaped, or wheel-shaped, its 5 lubes valvate in the bud, closed at the base inside by the valve-like bases of the 5 stamens. Pod opening on the sides. $-2 f$ Herbs with axillary or terminal flowers. JuneOctober.
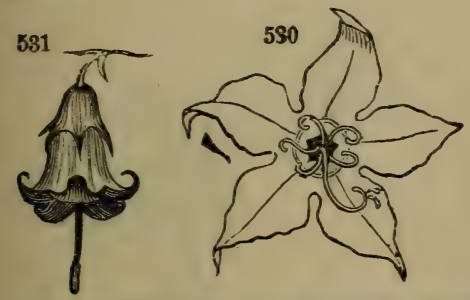

Fig. 526. The Harebell, the whole plant. 7. Ovary of Canterbury Bells, with $f$, a broad filament, $s$, an anther, and $p$, the hairy style. S. A cross-section of the curious 5-celled seedvessel, 2 placentæ in each cell. 9. Seed cut open, showing the large embryo. Fig. 530. Flower of American Bellwort. Fig. 531. Flower of Patent Bellwort.

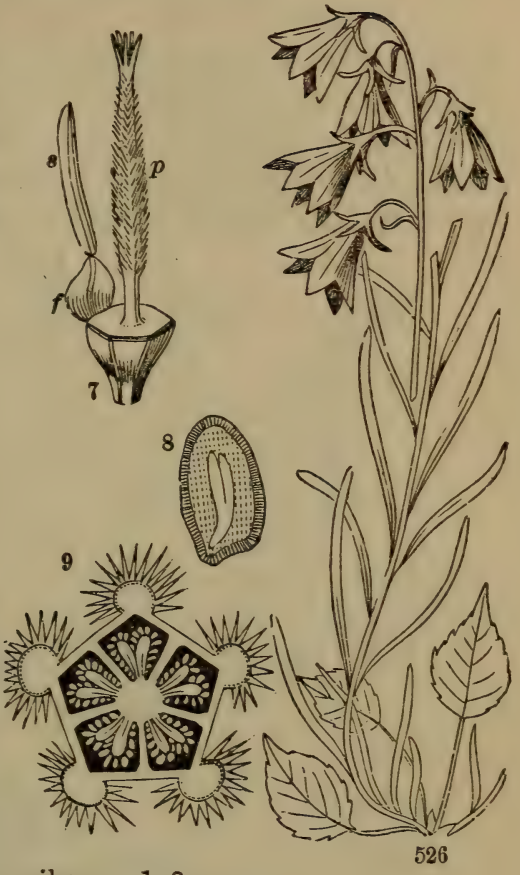

$\S$ Corolla wheel-shaped, flat, in leafy spikes....1, 2 .

\& Corolla bell-shaped, \&c., broadly or narrowly....a

a Flowers on slender pedicels, solitary or panicled....b

a Flowers sessile or nearly so. Stem erect. Gardens....7-9

b Flowers large $\left(6-12^{\prime \prime}\right.$ broad). Root leaves unlike the stem leaves....3, 4

b Flowers small $\left(2-5^{\prime \prime}\right.$ broad). Leaves all similar in form ....5, 6

1 C. America'na. American B. Stem tall (2-4f.). Leaves pointed at ends, smooth.

2 C. planiflo'ra. Stem low $\left(i-12^{\prime}\right)$, simple. Lvs. thick, shining, obtuse, or acute. $\dagger$

3 C. rotundifo'lia. Harebell. Stem weak. Root lrs, roundish, stem lvs. linear.

4 C. persicifo'lia. Peach $B$. Stem erect. Leaves lance-linear. Flowers very broad. $†$

C. aparinoi'des. Bedstraw B. Stem reclining, rough backwards. Flowers white.

6 O. divarica'ta. Patent $B$. Erect. Panicle wide. Leaves toothed. Fls. blue. S.

7 C. glomera'ta. Flowers crowded above, funnel-shaped. Plant smooth. †

8 C. me'dium. Canterbury $B$. Flowers distant, very large, obtuse at base. $†$

9 C. lanugino'sa. Woolly B. Flowers scattered, rather large, acute at base. I 


\section{Orner LXXIII. ERICACE A. Heathworts.}

Herbs, or more generally $s h r u b s$, with simple, often evergreen leaves; flowers regular or nearly so, 4 or 5-parted; ${ }_{p}^{2}$ etals rarely almost distinct; stamens as many or twice as many as the lobes of the corolla, and the anthers oddly appendaged and generally opening by two terminal pores; the style 1, and the ovary 4-10-celled, with albuminous seeds.

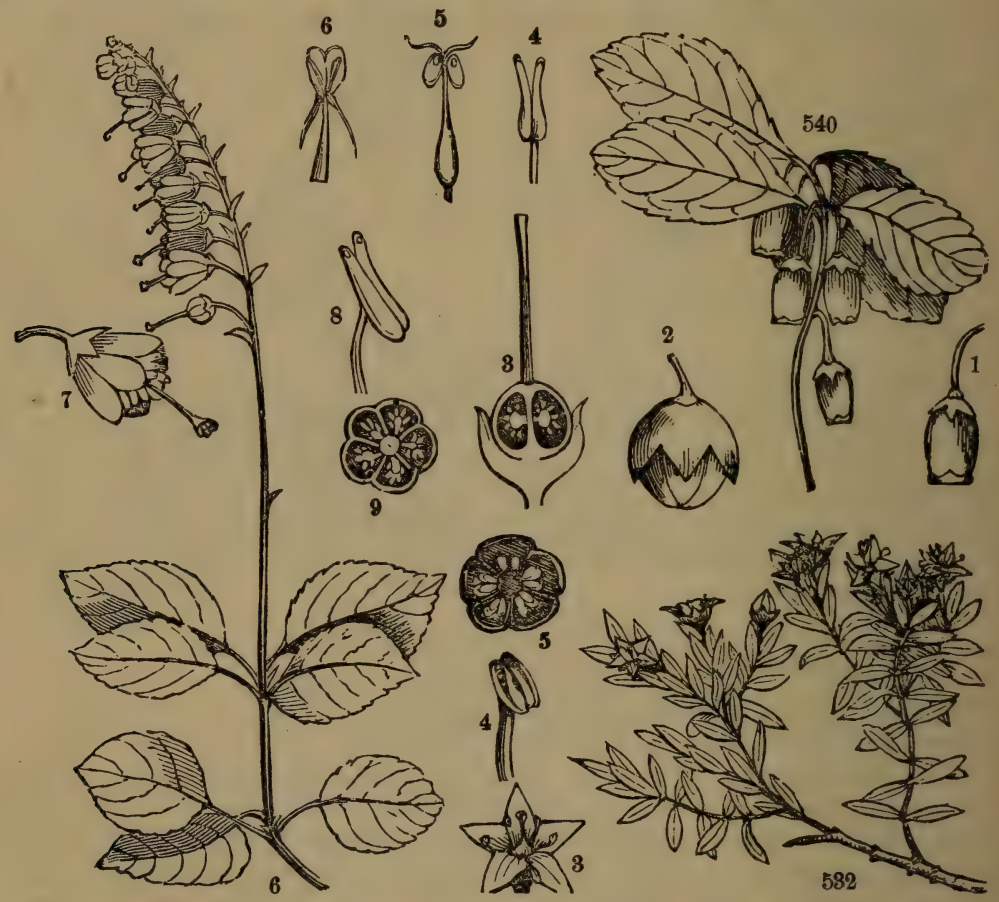

Fig. 532. Azalea procumbens. 3. A flower enlarged. 4. A stamen, much enlarged, showing the lengthwise opening of each of the cells. 5. Cross-section of a 5-celled capsule of Rhododendron, showing the inflexed margins of the valves. 6. Pyrola secunda. 7. A flower enlarged. 8. A stamen enlarged, showing the terminal tubes and pores. 9. Cross-section of a 5-celler, many-sceded capsule. Fig. 541). Checkerberry (Gaultheria). 1. A flower enlarged. 2. A berry. 8. Vertical section of the ovary, showing the free, fleshy calyx. 4. Anther of the Vacciniuu Vitis-Ideæ. 5. Stamen of Bearberry (Arctostaphylos). 6. A wned stamen of a Blucberry (Jancinium). 


\section{Analysis of the Genera}

Shrubs or trees, or shrublets....2

$\$$ Herbs evergreen, with green herbage and leaves....m

\$ Herbs leafless, without verdure. Bracts scale-like....n

2 Calyx adherent, crowning the berry in fruit....a

2 Calyx free from the ovary, or inferior....3

8 Petals united into a gamopetalous corolla....4

8 Petals entirely or very nearly separate and distinet ...5

4 Flowers 4-parted. Stamens $8 \ldots . . \mathrm{b}$

4 Flowers 5-parted. Stamens 5 or $10 \ldots$.

5 Pods 2 or 3 -celled, cells only 1 -seeded. Southern....k

5 Pods 3-celled, cells many-secded....g

5 Pods 5 or 7 -celled, cells many-seeded....h

6 Corolla urn-shaped (oval or globular), lobes small....c

6 Corolla not urn-shaped, open or spreading....e

a Erect shrubs with 5-parted Howers and 10-seeded berries.

a Erect shrubs with 5-parted flowers and $\infty$-seeded berries.

Huckleberries. Gaylussa'́da.

Blueberies. VAcCrN'ICM.

a T'railing shrublets. Corolla 4-cleft, reflexed. Fr. red. Cranberry. Oxrcoc'cus. 1

a Trailing shrublets. Corolla 4-cleft, spreading. Fruit white.

Boxberry. СhIOG'zNES. 2

- Leaves linear-acerose, whorled or crowded. Cultivated. Heath. ER'ICA.

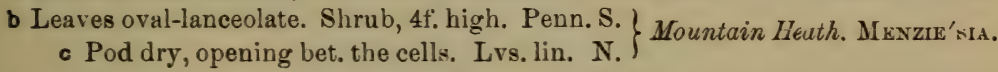

c Pod dry, opening into the cells....d

c Drupe fleshy, 5-seeded. Shrubs trailing. Bearberry. Arctostaph'rlos.

c Berry fleshy, many-seeded. Little shrublets. Checkerberry. Gaulthe'Ria. 3

a Shrublet moss-like, on high Mts. Leaves linear. Moss Andromede. Cassi'ops.

d Shrubs with ample leaves. Pod-valves entire. Andromede. Androm'eda.

d Tree with ample leaves and slender racemes. Sorrel-tree. OXYDEN'DRUM.

e Corolla saucer-form, holding the anthers in 10 pits. Laurel. KaL'MiA. 4

- Corolla salver-form, very fragrant. Trailing. May-flower. EPig-s's. 5

- Corolla funnel or bell-form, with spreading lobes....f

1 Stamens 5, included. Plant and leaves very small. Míts. N. H. Leioseleo'ria.

f Stamens 5 (rarely more), long-exserted. Corolla funnel-form.

AzA'LFA. 6

f Stamens 10 (rarely fewer), exserted. Corolla bell-form. Bay. Rhododen'dron.

g Leaves alternate, deciduous, serrate. Flowers racemed. CLE'THRA

g Leaves mostly opposite, evergreen, entire. Flowers umbeled.

h Flowers 5-parted. Corolla regular.

Sand Myrtle. Leiophý LUM.

h Flowers 5-parted. Corolla irregular.

Labrador Tea. LE'DiM.

h Flowess 7-parted, regular. Stamens 14. 8.

Кноро'RA.

BEFA' rLA. 
k Flowers 4-parted, with 8 stamens and a 3-seeded pord. S. ELLrot'Tia. k klowers 5 parted, with 5 stamens. Leaves lanceolate, entire. S. CYrý'́l. k Flowers 5-parted, with 10 stamens. Lvs. lanceul., ertire. S. MIrLOCA'RYcm. m Elowers racemed, many. Perennial, low, smonth, erect. P'YR'OLA. m Flower solitary, one only. l'erennial, small. N. $r$. MONE'sEs.

« Flowers corymbed, few. Leaves evergreen, thick. Pipsissiwa. Chimaph'ı A. 9 n Corolla polypetalous. Plant white, reddish, \&c. Indian Pipe. Monot'ropa.16 n Corolla gamopetalous, bell-shaped, in a short spike. S. Scrwernir'zia. n Corolla gamop., egg-shaped, in a loose rac. Albany Beechdrops. Preros'pora.

\section{OXYCOC'CUS. Cranberry.}

Calyx superior, 3-cleft. Corolla 4-parted, with lance-linear, reflexed segments. Stamens 8, anthers tubular, 2-parted, opening by oblique pores. Berry globular, 4-celled, many-seeded.-Trailing and very slender, with woody stems, alternate, thick, narrow, entire leaves, and acid. eatable fruit. Flowers purplish. June.

10 . palus'tris. Bng C. Stems thread-form, trailing. Leaves ovate, $2-4^{\prime \prime}$ long. Pedicels terminal, 1-flowered.

20 . macrocar'pus. Market $C$. Stems thread-form, trailing. Leaves oblong, 4-6" long. Pedicels axillary, 1-flowered.

3 O. erythocar'pus. Bush C. Stems 1-3f. high, erect. Leaves oval, pointed, ser. rulate. Petals not reflexed at first. S. Mountains.

\section{CHIOG'ENES. Boxberry.}

1 C. hispid'ula. Running $B$. A little woody creeper, 4 to $6^{\prime}$ long, in old woods, northward. Leaves many, small, oval. Flowers white, 4-parted. Berry white. Plant tastes like Checkerberry. (Fig. 547.)

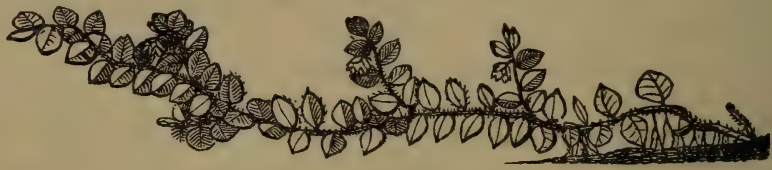

Fig. 547. Boxberry, the entire plant.

\section{GAULTHE'RIA. Checkerberry.}

Calyx 5-cleft, with 2 bractlets at base. Corolla urn-shaped, the limb of 5 short, revolute lobes. Stamens 10. Capsule 5-celled, invested by the calyx, which becomes a pulpy berry.-Little shrubby or half-shrulby plants, with alternate, evergreen leaves. (Figs. 540-543.) 
a. procum'bens. Common Checkerberry, or Wintergreen. Branches ascending 3' from the prostrate, slender root-stock, which is usually concealed. Leaves obovate, and few nodding flowers, all clustered at top of the stem, and spicy in flavor. Berries scarlet. Flowers in Summer, white.

\section{KAL'MIA. Calico-bush. Mountain Laurel.}

Calys 5-parted. Corolla with 10 prominences beneath, and 10 corresponding pits within, holding the 10 anthers. Filaments recurved. Border with 5 shallow lobes. Capsule 5-celled, many-seeded.-Beautifu, shrubs, with entire, evergreen, leathery leaves. Flowers white and red, in racemed corymbs. May-June.

1 Flowers in terminal corymbs. Leaves smooth, thick....2, 3

1 Flowers in lateral corymbs. Leaves rusty or downy beneath ...4, 5

1 K. hirsu'ta. Hairy L. Flowers axillary, solitary, stalked, red. Plant hairy. Leaves mostly scattered, acute, sessile. 1-2f. S.

2 K. latifo'lia. Gleat $L$. Leaves scattered, green both sides. Corymbs large, rosewhite, numerous and very showy. 3-20f.

8 K. glau'ca. Polished L. Leaves opposite, glaucous-white beneath, revolute ou the margin. Corymbs small, lilac. 2-3f.

4 K. cunea'ta. Wedge-leaved $L$. Leaves scattered, wedge-oblong. Corymbs small, roseate, each of 4-6 flowers. Plant 3-5f. S.

5 K. angustifo'lia. Sheep-poison. Leaves opposite and in 3's, blunt at each end. Corymbs small, deep purple. $3-4$.

\section{EPIG $\bar{E}^{\prime} A$. May-flower.}

Calyx large, 5-parted, with 3 bracts at base. Corolla salver-form, tuhe hairy within, limb of 5 spreading lobes. Stamens 10 . Anthers open by slits. Capsule 5-celled, 5-valved.-Little trailing shrubs.

E. repens Trailing Arbutus. Leaves cordate-ovate, entire. Corolla tube cylindrical. Stems slender, flat on the ground, 10-15' long. Leaves evergreen, rounded at the end, $2^{\prime}$ or more long. Flowers tinged with red, very fragrant. April, May.

\section{AZA'LEA. Azalea.}

Calyx small, 5-parted. Corolla funnel-form, somewhat irregular, with 5 spreading lobes. Stamens 5, and, with the 1 style, long exserted, curved toward the lower side, Anthers open by pores. Capsule 5-celled, 5-valved.-Erect shrubs. Leaves alternate, deciduous, entire. Flower: large, showy, fragrant, clustered. April-July. 
Lobes of the calyx all (rarely 1 excepted) very short or miate....1, 2

8 Lobes of the calyx all oblong, and of conspicuous length ....3-5

1 A. visco'sa. Clammy Swamp Pink. Flowers very viscid, appearing with the full-grown leaves, the tube much longer than the segments. Shrul 4-7f White or roseate.

2 A. nudiflo'ra. Pinxter Bloom. Clusters naked, appearing with or before the young leaves. Corolla tube downy, scareely longer than the segments. Branches often whorled. Colors pink, purple, white, buff, \&c. †

B A calendula'cea. Flaming Pinxter. Young branchlets downy, corymbs nearly or quite leafless. Tube of the corolla hairy, shorter than the ample lobes. Common. Penn. S. \& W. Flowers very many, flame-color, bright red, saffronyellow, \&c. $\dagger$

4. A. arbores'cens. Tiee Azalea. Branches smooth. Leaves glaucous beneath. Corymbs leafy with full-grown leaves. Corolla tube longer than the lobes, not viscid. Height 10-20f. Mountains. S.

5 A. Pon'tica. Asiatic A. Flowers viscid, with full-grown leaves. Tube widzmouthed, as long as segments. All colors. †

\section{RHODODEN'DRON. Rose Bay.}

Calyx 5-parted. Corolla broad, campanulate, regular or slightly irreg. ular, 5-lobed. Stamens 10, mostly declined, anthers opening by pores. Capsule 5-celled, 5-valved.-Shrubs with alternate, entire, evergreen leaves. Flowers umbeled, splendid.

$\S$ Calyx lobes large, leaf-like. Exotic....7

$\$$ Calyx lobes small, scale-like....a

a Leaves small, obtuse at each end. Mountains....1, 2

a Leaves large, acute, rusty or silvery beneath ....5, 6

a Leaves large, acute, glabrous beneath....3, 4

1 R. Lappon'icum. Lapland $R$. Shrub $5-10^{\prime}$ high. Lvs. scaly, elliptic. N.

2 R. Catawbien'se. Catawba R. Shrub 3-5f. high. Leaves smooth, oval. S.

3 R. max'imum. Great $R$. Leaves oblanceolate, acute, paler beneath. Flowers in large umbels, white, with yellow dots. Rocky woods.

4 R. Pon'ticum. Asiatic $R$. Leaves lanceolate, acuminate, not paler beneath. Flowers large, purple, variegated.

B R. puncta'tum. Dotted-lf. $R$. Lvs. with rusty, resinous dots beneath. Mts. S. $\checkmark \mathbf{R}$ arbo'reum. Tree $R$. Leaves with silvery spots beneath. Asia. $\dagger$

7 R. In'dicum. Indian $R$. Leaves rough, wedge-lance. Fls. few together. †

\section{PYR'OLA. False Wintergreen.}

Calyx 5-parted. Petals 5, equal. Stamens 10, anthers large, turned outwards, opening by 2 pores at the obtuse top. Style thick. long; stig. 
mas 5, often projecting like rays. Pod 5-celled, 5-valved, opening into the cells, many-seeded- -2 Low, evergreen herbs, almost woody, with the leares generally radical, and the scape bearing a raceme of nodding flowors. Mostly northern. June, July.

Stamens ascending, style declined and curved....a

Stamens and style straight and erect....5, 6

a Leaves thick and shining. Flowers white or :ose-colored....1, 2

a Leaves green, not shining. Flowers greenish-white....3, 4

1 P. rotundifo'lia. Round-leaved P. Lrs. orbicular. Mostly white petals. (Fig. 14.,

2 P. asarifo'lia. Heart-leaved $P$. Leares round-cordate. Rose-colored petals.

8 P. ellip'tica. Pear-leaved $P$. Leaves large, thin, elliptical, on short petioles.

4 P. chloran'tha. Gicen-fl. P. Lvs. small, thick, roundish, shorter than petioles.

5 P. secun'da. One-sided $P$. Raceme with the green-white flowers all on one sidu.

6 P. minor. Lesser P. Raceme spike-form, with small, globular, white fls. Mts.

\section{CHIMAPH'Lla. Pipsissiwa.}

Calyx 5-parted. Petals 5, spreading, round. Stamens 10. Anther cells lengthened above into tubes. Style very short, thick. Capsule 5-celled.-Small evergreens, with oblong, serrate, clustered leaves, and terminal flowers. June, July.

1 C. umbella'ta. Prince's Pine. Leaves wedge-lanceolate, in 4's-6's. Umbel 4-7-flowered, on an erect stalk. July.

2 C. macula'ta. Spotted P. Leaves lanceolate, acuminate, marked with rhitish streaks along the midvein. Flowers 2 ur 3. (See Fig. 548.)

\section{MONOT'ROPA. Pine Sap.}

Ualyx of 1-5 bract-like sepals. Petals 4 or 5 , connivent in a bell-shaped corolla. Stamens 8-10, Capsule 4-5-celled, 4-5-valved.-Low herbs growing on the juices of other plants, all white or tawny, with scales instead of leaves.

1 M uniflo'ra Irdiar. Pipe. Sepals 1-3. Flower solitary, scentless. Stem $6^{\prime}$ high, common in woods. Whole plant white. Summer.

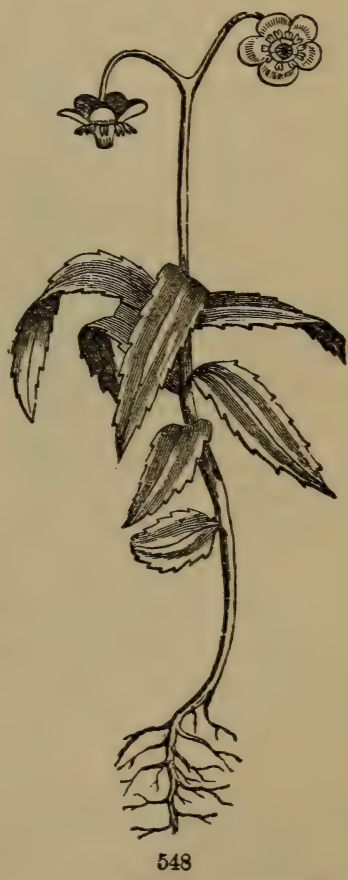

2 M. Hypop'itis. Pine Sap. Downy, tawny. Sepals 4, 5. Flowers racemed, fra graut. Stem i-S' high. Root a tangled ball of fibres. Aug. 


\section{ORDER LXXIV. AQUIFOLIACEAE. Hollyworts.}

Shrubs or trees with alternate, simple leaves without stipules; flovers small, axillary, sometimes polygamous, with a minute free calyx; corolla 4-6-parted, hyposynous, imbricate in the bud; stamens on the very short tube of the corolla alternate with its petals; ovary free, becoming a drupe-like fruit with 2-6 stones or nutlets.

\section{Analysis of the Genera.}

Flowers habitually 4-parted. Drupe with 4 bony, sulcate nutlets. ILEX. $\mathbf{3}$

f Flowers habitually 4-parted. Drupe with 4 horny smooth nutlets. Shrub 46f., with oblong entire leaves. Pedicels slender. Drupes red. Nemopastres. \$ Flowers habitually 6-parted. Berry with $6(7,8)$ smooth cartilaginous seeds. Pkinos. 2

\section{ILEX. Holly.}

Flowers 4-(rarely 5-) parted, mostly perfect but many abortive. Calyx 4-toothed, persistent. Petals 4, slightly united at base. Stamens 4. Stigmas 4 or united into 1 . Drupe red, the 4 bony nutlets ribbed and furrowed on the back. Flowers white, single or clustered in the axils.

I. opa'ca. American Holly. A handsome evergreen tree, 15-30f. high, in woods, Masw. to Florida. It has thick, smooth, oval, toothed leaves, spinescent at apex and margin. Flowers clustered, June. Drupes ripe in late autumn.

The other species, 6 in number, are very rarely found growing N. of Maryland.

\section{PRINOS. Winter-berry.}

Flowers perfect but often fruitless. Stamens 6 (rarely fewer in the barren, rarely more in the fertile flowers). Berry 6 -seeded, seeds witl a smooth cartilaginous testa. Shrubs with small white flowers.

1 P. verticilla'tus. Black Alder. A shrub 7-12f., very ornamental in fruit, found in wet places. The bark is nearly black. Leaves small, elliptical, pointed, pubescent beneath. Berries scarlet, in close bunches as if verticillate, all winter.

2 P. glaber. Ink-berry. Shrub 3-4r., with thick, shining, wedge-lanceolate, evergreen leaves tonthed at the end. Berries black. The other (4) species are less common.

\section{ORDER LXXV. STYRACACEA. Storaxworts.}

Trees and shrubs with alternate simple leaves, perfect flowers, 4-8-parted; stımens 2-5 times as many as the petals and inserted on their united bases style 1. Ovary adherent. Fruit 1-5-seeded. Mostly Southern plants.

\section{Analysis of the Genera.}

1 STYRAX. Storax. Shrubs in wet grounds (Va. to Fla.), with drooping racemes of $w h$ te shuwy flowers. Stamens twice as many as the petals. April-May.

2 HALE'SIA. Snow-drop Tree. Trees 10-50f., in wonds, Va. to Fla., often cult. Fls peo. dulous, white, showy, earlier than the abruptly pointed leaves. Two kinds.

3 SYM'PLOCOS. Small tree. 10-20r. Fls. yellow. Stamens $\infty$. Fruit 1-seeded. S. 


\section{Order LXXFIII. PRIMULACEA. Primworts.}
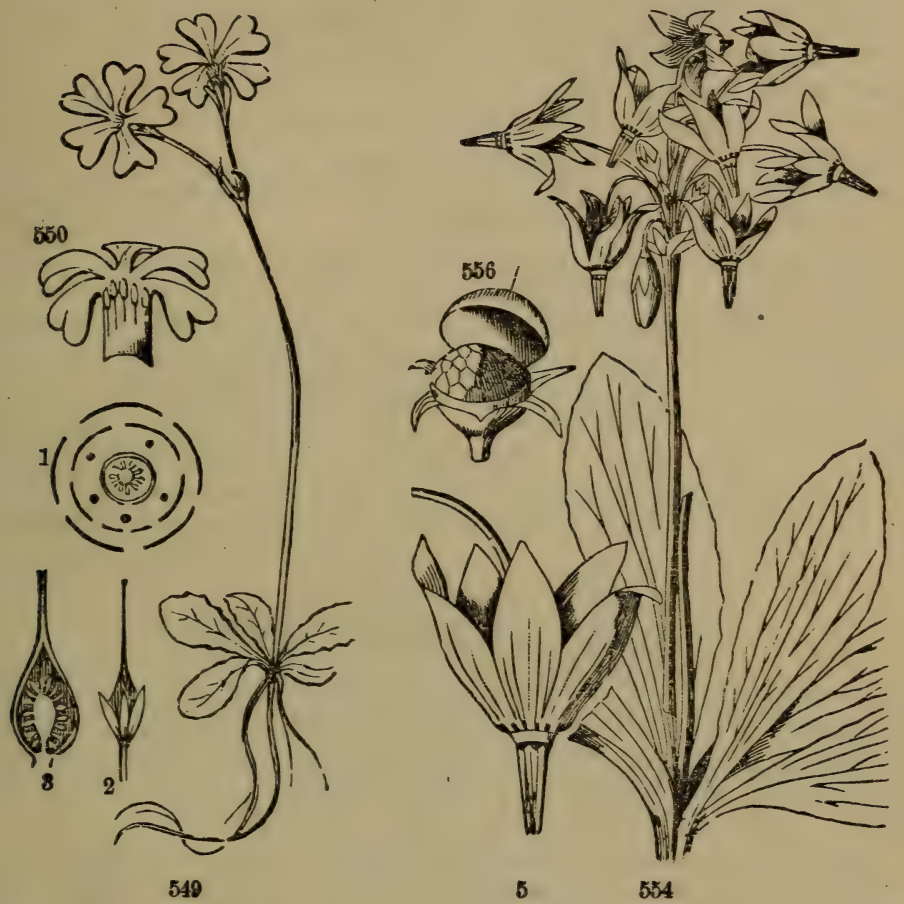

Fig. 549. Primuı Mistassinica, the whole plant. Fig. 550. The corolla cnt open, showlig the stamens on the tube. 1. The plan of the flower, showing the stamens opposite the petals, 2. The calyx and ovary. 3. The fruit cut open, showing the seeds on the central placenta Fig. 554. Dodecatheon Meadia, whole plant. 5. A single flower, natural size. Fig. 556. Fruit (ij $x$ ls) of Anagallis, with its lid open, showing the seeds

Herbs low, with the leaves either radical or mostly opposite; with the flwoers 5 (rarely 4 or 6)-parted; the corolla monopetalous, regular; the stumens inserted on the corolla-tube and opposite to its lobes; the ovary 1-celled, with a free, central placenta; style 1 ; stigma 1 ; the capsule 1-celled, many-seeded; seeds with fleshy albumen. 


\section{Analysis of the Genera.}

- Stemless. Leaves all radical, scape bearing an umbel.... a

- Stems leafy. Flowers yellow, corolla wheel-form (tube none)....b

* Stems leafy. Flowers whits, red, \&c., never yellow....2

2 Leaves whorled, at least those near the flowers. Corolla white....c

Leaves opposite, entire. Flowers axillary, solitary....d

2 Leaves alternate, entire. Flowers white....e

a Cor. tube egg-shaped, lobes short, spread. Dwarf Primrose. Androsa'or.

a Corolla tube cylindrical, lobes spreading. Primrose. Prim'ula. 1

a Corolla tube cylindrical, lobes reflexed. American Cowslip. Dodecath'zon. 2 b Corolla 5-parted, withont intermediate teeth. Loose-strife. Lysmach'ia. 8 b Corolla 6-parted, with 6 intermediate teeth. Racemes axillary. NaUmber'ara.

c Fls. 7-part. Lws. entire, in a single whorl. Chick Wintergreen. Trienta'Lis, 1

- Fls. 5-parted. Leaves finely pinnatikd, in water. Feather-foil. Hoтto'nia.

d Plant prostrate, with scarlet corollas.

d Plant erect, with no corolla, but white calyxes.

Pimpernel. Anagal'Lis. 5

e Fls. 5-parted, panicled. Plant $8-15^{\prime}$ high.

Black Saltwort. Glaux.

e Fls. 4-parted, axillary. Plant 1-2' high. Dwarf Pimpernel. Centun'cucus.

\section{PRIM'ULA. Primrose. Auricula.}

Calyx angular, 5-cleft. Corolla salver-shaped, or often rather funnelshaped, with 5 entire, or notched, or bifid lobes. Stamens 5, included. Pod opening at the top, many-seeded. -2 Herbs with the leaves all rad. ical, and the flowers showy, in an umbel on a scape.

* Corolla salver-form, limb abruptly spreading. Plants wild, rare....1, 2

* Corolla salver-form, limb abruptly spreading. Plants cultivated....3, 4

* Corolla funnel-form, limb gradually spreading. Cultivated....a

a Leaves hairy, rugose, toothed, or crenate, or wavy at edge....5, 6

a Leaves smooth, plane, entire, or sometimes crenate....7, 8

1 P. Mistassin'ica, Mistassins P. Smooth, green, 3-8' high. Flowers 1-8, flesh-colored. On lake shores. N. First seen on L. Mistassins.

2 P. farino'sa. Bird's-eye P. Mealy, 3-10' high. Flowers 3-20, lilac-yellow Shores of the great lakes. N.

P grandiflo'ra. Common P. Petals obcordate, notched, yellow, purple, \&c.

I purpu'rea. Purple $P$. Petals obtuse, entire, dark-riolet, never yellow. †

5 P. officina'lis. Cowslip P. Lvs. hairy. Outer fls. nodding, border concare.

6 P. eia'tior. Oxlip P. Leaves smooth above. All fls. noddıng, border flat. 1 I P Auric'ula. Auricula. Lvs. and calyx mealy-glaucous. Bracts very short. + 8 P. calvci'na. Cup P. Lvs. white-edged, calyx inflated. Bracts long. Purpl. + 


\section{DODECATH'EON. American Cowslip.}

Calyx 5-parted, reflexed. Corolla tube very short, limb rotate, 5-parted, with the limb reflexed. Stamens 5, inserted into the throat of the corolla, filaments short, anthers long, acute connivent at apex, but shorter than the style.- 4 Leaves all radical, oblong, scape erect, bearing an umbel of nodding rose or white flowers. May, June. (Fig. 554.)

D Mea'dia. Pride of Ohio. A striking and elegant plant, in prairies throughout the Western States. Scape 1-2f. high. Petals white or pink. Stamens yellow. †

\section{LYSIMACH'IA. Loose-strife.}

Calyx 5-parted. Corolla tube rery short, limb 5-parted, spreading. Stamens 5, on the base of the corolla, filaments often united. Pods 5-10valved. Seeds several or many. $-2 f$ Leaves opposite or whorled, entire. Flowers mostly yellow. June, July.

\& Erect Peduncles several-flowered, or flowers panicled....a

Erect. Pedicels 1-flowered, flowers racemed....8, 9

\& Erect. Pedicels 1-flowered, flowers axillary....1

§ Prostrate, creeping. Pedicels (or umbels) axillary....10, 11

a Leaves thick, rather obtuse, with the edges rolled back....4, 5

a Leaves thin, acuminate, with the edges not rolled....6, 7

1 Leaves mostly opposite, on petioles fringed with hairs....2, s

1 L. quadrifo'lia. Whorled $L$. Leaves whorled in 3 's, 4 's, and 5 's, sessile.

2 L. cilia'ta. Fringe-lf. $L$. Leaves ovate, often cordate. Stems mostly branched.

8 L. hib'rida. Hybrid L. Lvs. lance-oblong, opposite or whorled. Stems branched $4 \mathrm{I}$. asperifo'lia. Rough-lf. L. Leaves oblong-lanceolate. Panicle bracted. S.

5 L. longifo'lia. Lang-lf. L. Lvs. lance-linear. Fls. large, scarcely pan. W. 6 L. lanceola'ta. Lance-lf. L. Lvs. whorled in 4's, lance. Upper fls. racemed. S. 7 L. Fra'seri. Fraser's L. Leaves opposite, ovate, often cordate. Panicle large. S. $8 \mathrm{~L}$. stric'ta. Strict $L$. Leaves nearly opposite, narrow-lance., with bulblets.

9 L. Herbemon'ti. Herbemont's L. Lvs. whorled, in 4's or 5's, lance., acuminate. S. 10 L. rad'icans. Rooting $L$. Branches rooting at the end. Leaves lanceolate. 11 L. Nummula'ria. Moneywort. Stem simple. Leaves roundish, very obtuse

\section{TRIENTA'LIS. Chick-wintergreen.}

Calyx and corolla 7-parted. Stamens 7. Pod many-seeded.-2f Stern low, simple. Pedicels 1-flowered.

T. America'na. American C. A pretty little plant, common in woods northward. Stem $3-5^{\prime}$ high, hearing several lanceolate teares in a sort of whorl at tcp. and from their midst, 1 or more white, starlike flowers. May, Ju 


\section{ANAGAL'LIS. Pimpernel.}

Calyx and corolla 5-parted, wheel-shaped. Stamens 5. Pod globular opening by a lid all around ( $i$. e., a pyxis).-Herbs with square stems and opposite leaves. (Fig. 556.)

A arven'sis. Ssarlet P. Poor-man's-weather-glass. A small, trailing plant, in fiel.ls, roadsides, \&c. Leaves sessile, broad-ovate. Pedicels 1-flowered, axillary. Flower red, rarely blue. Opening at 8 A. M., closing at 2 P. M., and in damp weather not opening at all. (See the figure, 557.)

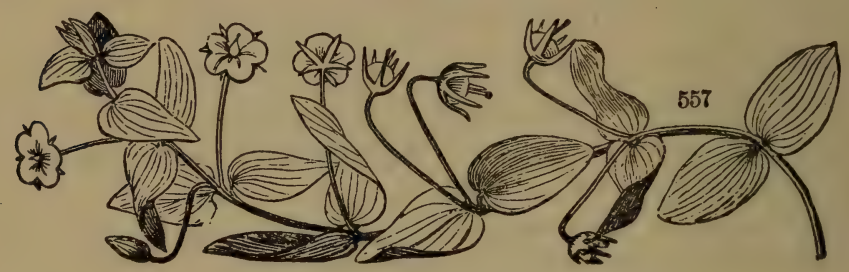

ORdER LXXX. PLUMBAGINACE A. Leadworts.

Herbs or undershrubs. Leaves alternate or all clustered at the root ; flowers regular, 5-parted, with a plaited, persistent calyx ; stamens hypogynous, opposite to the petals or inserted on their claws , styles 5, ovary free from the calyx. Fruit 1-celled, 1-seeded.

\section{Analysis of the Genera.}

Style 1 , with 5 stigmas. Pod opening by valves. Leaves cauline. \& Styles distinct, at least above. Utricle not valvate. Leaves radical....(a)

a Styles glabrous, with slender stigmas. Scape branching.

Plumbago. 8

a Styles plumous, with slender stigmas. Scape simple, capitate.

STATICE. 1

1. STAT'IĆE. Marsh Rosemary.

Calyx funnel-form, limb scarious, 5-nerved and 5-parted. Petals almost distinct. Ovary crowned with the 5 smooth slender styles. Utricle opening crosswise. $2 f$ Herb with the scape branching, the flowers each 3-bracted.

1 8. Limo'nium. Plant 8.15' high, in salt marshes. Leaves all radical, oblong to oblan ceolate, acute, tipped with a bristle, long-stalked. Scape paniculate, flowers bluo. purple, separate or in pairs, on the upper side of the branchlets. July-Oct. 
ARME'RIA vulga'ris, Thrift, is another sea-coast plant, sometimes cultivated, har. ing a tuft of linear leaves at base, and a bunch of rose-colored flowers at top of the scape.

FLUMBA'GO Capen'is, Leadwoort, has pale blue fls. resembling Phlox. Cultivated.

\section{ORDER LXXXI. LENTIBULACE $\nexists$. Butterworts.}

Uerbs growing in water or wet places with bilabiate flowers on scapes; caly $x$ of 2 or 3 sepals. Corolla with a spur behind, throat bearded; stumens 2 , included. Styles, 2, ovary free, capsule many-seeded.

\section{Analysis of the Genera.}

$\delta$ Leaves broad, entire. Corolla throat open. Calyx 5-parted. Growing in wet rocky places, chiefly South. Butterwort, PrNGuicula. S Leaves nely dissected, sumetimes 0 . Corolla throat closed. UtricULARIA. 1

\section{UTRICULA'RIA. Bladderwort.}

Calyx 2-parted. Corolla irregularly bilabiate, spurred. Stamens 2. Stigma 2-lipped. Pod round, 1-celled. Plauts loosely floating or fixed in the mud. Leaves mostly present, furnished with little sacks (utricles) filled with air which floats them. Scape erect. Summer. (Fig. 98.)

- Elowers purple.....Nos. 1, 2

- Flowers yellow.....(a)

a Plants rooting in the mud....Nos, 3-5

a Plants floating in the water....(b)

b Plants buoyed by a whorl of inflated petioles....No. 6

b Plants buoyed by air-bladders on special branchlets.....Nos, 7, 8

b Plants buoyed by air-bladders on the leaves.... (c)

c Flowers of 2 kinds, the lipless down on the stems.... No. 9

c Flowers all alike and borne on the scapes....(d)

d Flower-stalks 2-12, nodding in fruit, on each scape.... Nos. 10, 11

d Flower-stalks 1-5, erect in fruit on each scape.... Nos. 12-15

1 U. purpu'rea. Leaves whorled, on the long floating stems. Fls. 6" broad. Ponds.

2 U. resupina'ta. Leaves scattved on the creeping stems. Flowers 4". Muddy shores

3 U. cornu'ta. Scape tall (8-12'), scaly, 2-5-flowered. Fls. large, spur decurved.

4 U. subula'ta. Scape $2-5^{\prime}$ high, very slender, flowers few, small. Spur inflexed.

5 U. biparti'ta. Scape $2-3^{\prime}$, flowers 1-3, on slender pedicels. Lower lip of the cor olla entire. South.

b) $\mathrm{U}$. infla'ta. Floating stem long. Scape 6-10' high, flowers 4 or $5,8^{\prime \prime}$ broad.

7 U. interme'dia. Leares crowded, in 2 rows, rigid. Fls. 2 or 3, spur conical.

8 U. Robbin'sii. Leaves alternate, thread-like. Fls. 4-7, spur fusiform.

- U. clandesti'na. Stem-flowers solitary, bud-like. Scape with 2 or 3 fls. seldom seen.

10 U. valga'ris. Scape with 5-12 fls. Corolla throat closed. Spur conical.

11 U. minor. Scape with 3-6 fls. Corolla throat open. Spur blunt, very short 
12 U. stria'ta. Scape 1f., with 2-6 fls. Cor. upper lip striate with red ; lvs. forked.

13 U. biflo'ra. Scape 5', with 2 fls. Lvs. root-like, capillary, with many bladders.

(4 U. gibba. Scape 2-3', with 1-2 fls. Lvs. hair-like, with few bladders. Spur gibbous.

\section{ORDER LXXXII OROBANCHACE $A$. Broom-rapes.}

Herbs without green foliage, growing on the roots of other plants ; flowers irregular, monopetalous, with 4 (didynamous) stamens ; vary free from the calyx, 1-celled, with 2 or 4 parietal placentæ ; capsule enclosed within the withered corolla, with very many seeds.

\section{Genera.}

1 EPIPHE'GUS Virginia'na. Beech-drops. A smooth, dull red, leafless plant, 1f., with sessile flowers all along the branches. Upper fls. sterile. Grows in Beech woods.

2 CONOPH'OLIS America'na. Squaw-root. A simple, thick, short stem covered with scales, the flowers in the axils of the upper. Calyx split down in front. Yellowial. 8 PHELIP压'A Ludovicia'na. A branched, thick. scaly, downy stem 6-12', with the fls. all perfect, in crowded spikes. Calyx 5-toothed. Corolla lips subequal. Illinois. 4 APHYL'LON. Broom-rape. Stems underground, sending up peduncles or scrpes 5'. each bearing a nodding purplish flower, with a curved tube and spread limb.

\section{Order LXXXIII. BIGNONIACEA. Trumpets.}

Plants with opposite leaves, destitute of stipules, often climbing;

flowers gamopetalous, irregular, 5-parted, showy;

stamens 5, but only 2 or 4 of them perfect, and didynamous; ovary 2-celled, with 1 style, forming a dry pod with winged seeds.

\section{Analysis of the Genera.}

Stamens 4. Pod valves and partition contrary. Leaves pinnate. Troo'mi. 1 Stamens 4. Pod valves and partitina parallel. Leaves binate Bigno'NIA. Stamens 2. Pod straight, cylindric. Trees Leaves simple. Catal'PA. 2

\section{TECO'MA. Trumpet flower.}

Calyx bell-shaped, 5-toothed. Corolla trumpet-shaped, with a 5-lobed, nearly regular limb. Stamens didynamous, 4 , with the 5th a small rudi. ment. Pod with the partition contrary to the valves.-Trees or shruis, often climbing. Leaves digitate or pinnate. Flowers red. 


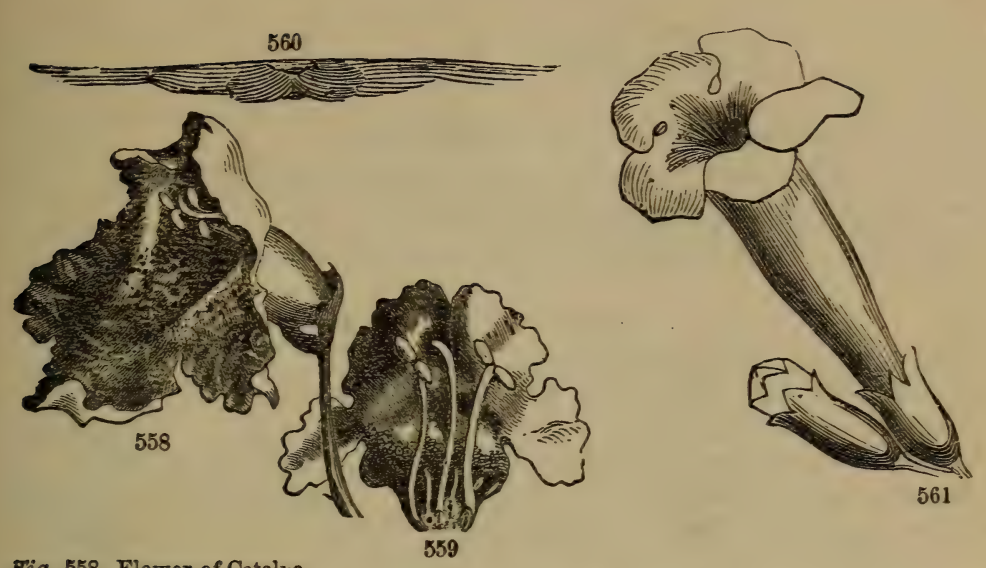

Fig. 55\%. Flower of Catalys.

Fig. 559. The Corolla cut open. showing the 2 perfect stamens and the 3 rudiments of stamens Fig. 560. A 2-winged seed of Catalpa.

Fig. 561. Flower of the Trumpet Creeper.

1 T. radicans. Trumpet Creeper. Climbing by radicating tendrils. Leaflets 9-11, ovate, acuminate, toothed. Corolla tube thrice longer than the calyx. Stamens included. A well-known, splendid climbing vine. S:Immer.

2 r. Capen'sis. Cape T. Climbing. Leaflets 7-9, round-ovate, serrate. Stamens and style exerted. Corolla tube curved. + S. A frica.

8 T. grandiflo'ra. Chinese T. Climbing. Leaflets 9-11, pointed, ovate, toothed. Two glauds on the nodding pedicels. Corolla tube scarce longer than calyx. 1

\section{CATAL'PA. Catalpa.}

Corolla unequally bell-shaped, 4 or 5-lobed. Stamens 2 perfect, with $\mathbf{3}$ rudiments. Capsule long, cylindric, with q thick partition.

c. bignnnioi'des. Trees with large, broadovate, cordate, velvety leaves, and terminal panicles of showy, white, variegatcd flowers. Common.

Fig. 562. A panicle (size much diminished) of Catalpa.

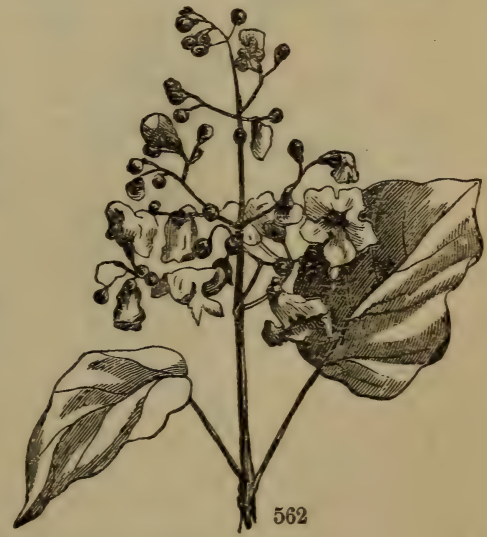




\section{ORDER LXXXV. LOGANIACEA.}

Herbs or shrubs with opposite leaves, with the stipules small or mere ridges connecting the base of the petioles; flowers 4 or 5-parted, gamopetalous, regular; soary free; fruit 2-celled, many-seeded, or few-seeded

\section{Analysis of the Genera.}

$\$$ Corolla tubular, lobes 5 , valvate in the bud....a

$\S$ Corolla bell-shaped, lobes 4 or 5 , imbricate in the bud....b

a Styles wholly united into 1 . Corolla tube long. W. S.

SFIGE'LIA.

a Styles distinct, with the stigmas united. Fls. small, white. S. Mrtre'old.

b Flowers 4-parted. Diffuse, low herbs. M. S.

b Flowers 5-parted. Slender climbing shrubs. S.

Pulyprenum. POLYPRE'MUM.

GeLsem'inUM. 2

\section{SPIGE'LIA. Pink-root.}

Calyx segments linear-subulate. Corolla narrowly funnel-form. Stamens 5. Capsule 2-celled, few seeded.-Herbs with the flowers sessile in a terminal one-sided coiled spike.

s. Maryland'ica. Maryland $P$. Stem square, erect. Leaves sessile, ovate-lanceolate. Corolla 4 or 5 times longer than the calyx, scarlet June.
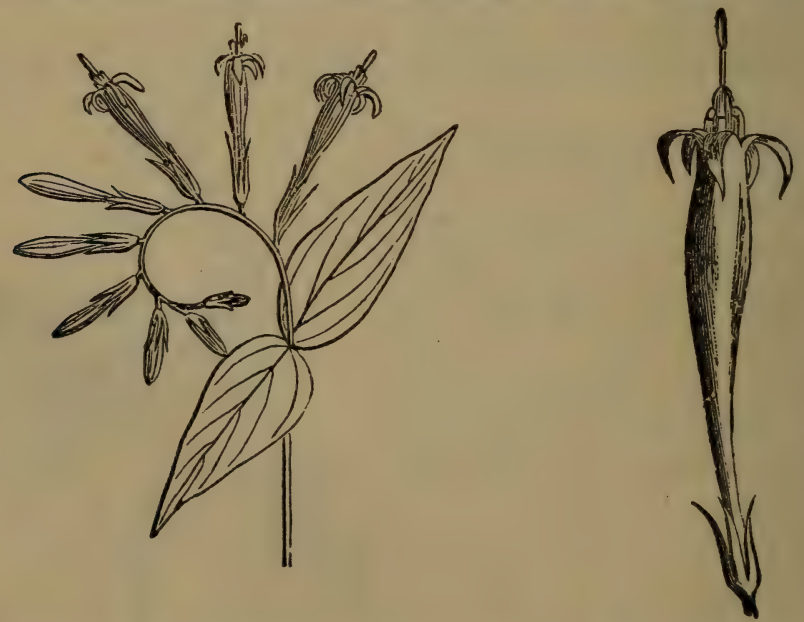

Fig. 563. Spigelia; the spike uncoils as the flowers open. Fig. 564. A fluwer, natural alza 


\section{GELSEMI'NUM. Yellow Jessamine.}

Calyx lobes oblong. Corolla funnel-bell-form, with 5 short, roundish lribes. Filaments 5, on the corolla. Stvle thread-form with 2 double stigmas.

G. sempervi'rens. A shrub very common, South; with long, wiry, twining stems, ascending bushes and hedges. Leaves evergreen, shining, lanceolate. Corolla tube 1 inch long, golden-yellow.

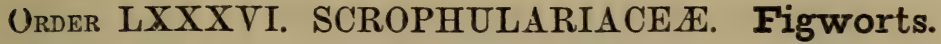

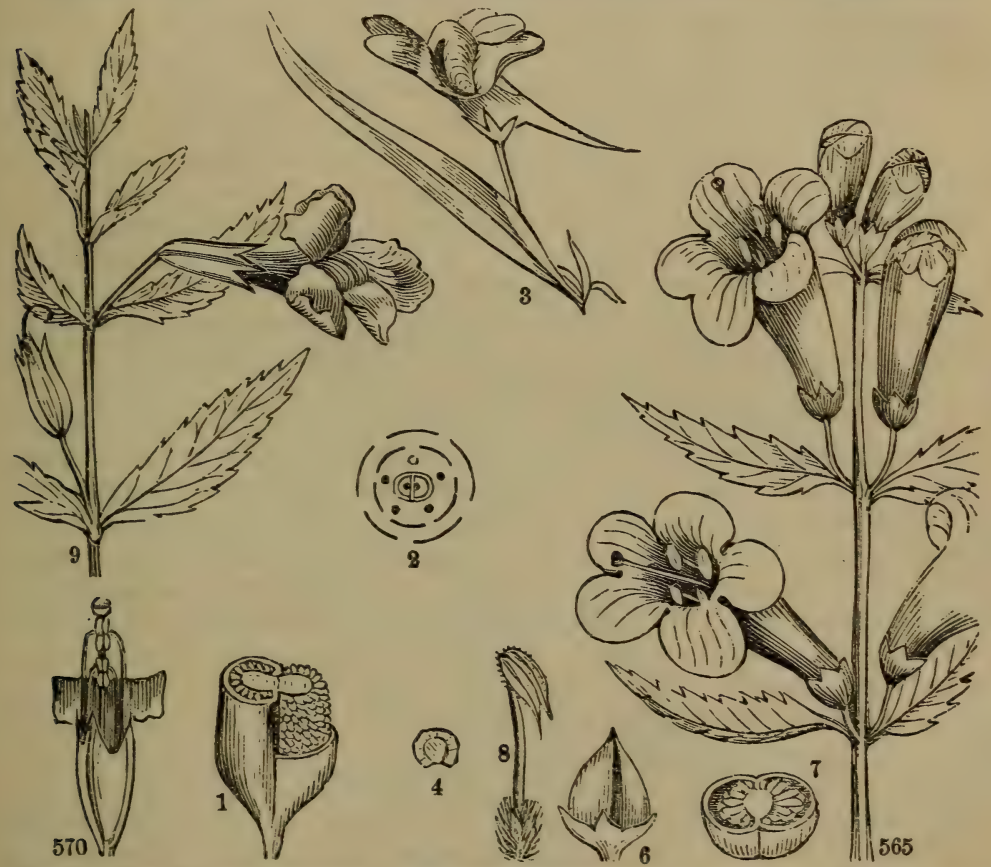

Fig. 565. The Yellow Foxglove (Dasystoma pubescens). 6. Mature fruit. 7. Cross-section of the 2-celled capsule. 8. A stamen enlarged. 9. Monkey-flower (Mimulus ringens). Fig. 5711. Calyx with the corolla partly removed, showing the didy nomous stamens in puirs, with the stigm: above the highest pair. 1. Sections of the 2-celled, many-seeded capsule. 2. Plan of the fluwer, showing the position of the fifth rudimentary fllament. 3. Linaria vulgaris, leaf, auil persınat a bl-lsbiate, spurred flower. 4. A wingerl seed. 
Plants mostly herbaceous, with unsymmetrical flovers, without fragrance caly $x$ mostly 5-parted, free from the ovary, persistent; corolla bi-labiate or otherwise irregular, lobes imbricated in the bud; strmens on the corolla tnbe, 1 or 3 of the 5 usually imperfect or minute; mary 2-celled; style 1; stigma 2-lobed; capsule 2-celled, many-seeded.

\section{Analysis of the Genera.}

* Herbs with the leaves alternate or all radical....2

* Herbs with the leaves opposite or sometimes whorled....4

* Trees with large cordate leaves and large blue panicles.... a

2 Flowers diandrons, having but 2 perfect stamens....c

2 Flowers didynamous, having 4 stamens, 2 of them longer ....3

2 Flowers pentandrons, having the 5 stamens all perfect.... b

3 Corolla bi-labiate, with the throat closed (personate)....d

3 Corolla bi-labiate, throat open, upper lip arched....e

3 Corolla rather bell-shaped, with 5 nearly equal lobes....f

4 Flowers with only 2 perfect stamens....g

4 Flowers with 4 perfect stamens, the 5 th scarcely appearing....5

4 Flowers with 4 perfect stamens and a 5 th sterile distinct filament....n

5 Corolla 2-lipped, the limb quite irregular...6

5 Corolla limb nearly regular, with 4 or 5 plain, spreading lobes....

6 Stamens included in the tube of corolla, generally in pairs... k

6 Stamens ascending beneath the arched upper lip....m

6 Stamens descending into the sack-shaped lower lip....h

a Corolla trumpet-shaped, stamens arched downwards. Fragrant. + P'allow'N1a.

b Corolla wheel-shaped, stamens declinate. Scentless. Mullein.VERBas'cum. 1

c Curolla 4-lobed, minute, white. Plant small. Lvs. radical. S. Amphine'tuus.

c Corolla 4-lobed. Fls. spiked. Lvs. mostly radical. Scape 1f. N.-W. SYnTHI'RIs.

c Corolla deeply many-cleft, variously colored. Lvs. cleft. $\dagger$ Scinzan'тнus.

d Corolla protracted into a spur behind. Racemes leafy. Toad-flax. LINA'RIA. ₹

d Cor. swollen into a sack behind. Rac. leafy. † Snap-dragon. Antirkhi'num.

e Bracts lobed, generally colored. Anth.-cells unequal. Painted-cup. Castille'sa.

e Bracts and leaves entire, green. Flowers purplish. Chaff-seed. SoHwal'Bea.

e Bracts and leaves serrate, green. Flowers yellow. Lousewort. Pedicula'ris.

$f$ Tall, erect, with large, nodding flowers. Gardens. Foxglove. Diarra'lis.

f Low and minute. Corolla equally 5-eleft. In mud. Mudwort. LrMosé'LA.

$f$ Climbing, slender. Corolla large, gibbous at base. † Mexico. MaUran'dia.

f Climbing, slender. Corolla large, equal at base. $\dagger$ Mexico. Loprosper'MOM.

g Corolla labiate. Calyx 5-parted. Sterile filaments minute or $0 . \quad$ Grati'or.A. 3

g Corolla labiate. Calyx 5-parted. Sterile filam. forked. Mud-flower. Ilysan'thris.

g Corolla labiate. Calyx 4-parted. Flowers very small. Semi-fliwer. Hemian'th cs.

g Corolla rotate, with 4 nearly equal lcbes, lower smallest. Speodwell. Veron're. 4 
h Handsome herbs, 1-2f. high, with flowers blue and white.

Innocence. CoLLIN'sIA, E

k Leaves serr. Sts. square. Palate of lower lip prominent. Monkey-fl. Mrn'clus. P k Leaves many-cleft into fine divisions. W.

Conohea. Cono'BEA.

k Leaves entire. Corolla protracted into a spur behind. Toad-flax. LiNa'ria. 2 Leaves entire. Cor. not spurred. Small, obscure weeds. W. MI. S. Herpes'tis. m Fls, yellow, in a terminal, one-sided spike. Yellozo-rattle. Rhinan'тнсs. m Fls. white, small, in a term. one-sided spike. Mts. Eyc-bright. Euphra'sia. m Fls. yellowish, axil., or in a leafy, equal spike. Cow wheat. Menan'pyrcm.

a Sterile filament shorter than the rest, smooth.

n Sterile filament long, projecting, bearded.

n Sterile filament a scale on the brown corolla.

- Corolla purple, in a long, slender spike.

sriake-head. Сннцо'кк. 7 Beard-tongue. Pentste'mon. Figwort. SCROPHULA'Rín Leaves lance-ovate.

Biue-hearts. BuCHNE'RA.

- Cor. purp. or rose-white, axillary. Lvs. narrow-lin., entire. GERAR'dia. 8

- Corolla yellow, and 5-lobed as well as the calyx....p

p Stamens searcely longer than the tube of the corolla....q

p Stamens long-projecting, with very large anthers. S.

MaCRANThE'ra

q Stamens quite unequal in length. Sepals very short.

DasYs'ToMa. 9

q Stamens about equal in length, anths. all perfect. Sep. long. W. SEYME'RIA.

\section{VERBAS'CUM. Mullein.}

Calyx 5-parted. Corolla rotate, 5-lobed, slightly irregular. Stanens 5, all perfect, filaments woolly, at least the three upper ones. Pod roundish egg-shaped, 2-valved, many-seeded.-Mostly (2) herbs. Flowers in spikes, or panicles, or racemes. Leaves alternate. June-August.

1 V. Thap'sus. Common M. Tall, woolly. Leares decurrent. Flowers spiked, 2 filaments smooth.

2 V. Blatta'ria. Moth M. Branched, sinooth. Leaves serrate. Flowers rucemed. Filaments violet-woolly.

3 v. Lych'nitis. White $M$. White-downy, branched. Leaves crenate. Flowers panicled. Filaments white-woolly.

\section{LINA'RIA. Toad-flax.}

Calyx 5-parted. Corolla personate with the throat closed by the prominent palate, upper lip reflexed, lower 3-cleft, tube inflated and spurred behind. Pod 2-celled, bursting below the top.-Herbs with the lower leaves generally opposite, the upper alternate. Flowers solitary, axillary, often forming leafy racemes. June-September.

1 L. vulga'ris. Butter and Eggs. Leaves lance-linear. Flowers large, yellow and or:unge, in a close raceme. Erect. 
2. Canaden'se. Canada T. Leaves linear, obtuse. Flowers small, blue, loosely racemed. Stem erect.

8 L. Elat'ine. Puinted T. Leaves ovate-hastate. Flowers small, yellow, and par. ple. Stem prostrate.

\section{GRATI'OLA. Hedge-hyssop.}

Calyx nearly equally 5-parted. Corolla upper lip entire or slightly 8-cleft, lower 3-cleft. Fertile stamens 2, mostly with 3 sterile filaments. Pod 2-celled, 4-valved, many-seeded.-Low herbs with opposite leaves. Peduncles axillary, 1-flowered, usually with 2 bracts near the calyx June-August.

$\S$ Flowers on peduncles. Plants weak, smonth, or viscid....a

\& Flowers sessile or nearly so. Plants rigid, bristly-hairy. S...8, 9

a Sterile filaments thread-like, tipped with a small head....b

a Sterile filaments none, or very minute and pointed....5-7

b Leaves entire or nearly so. Plants smooth....1, 2

b Leaves tonthed. Plants generally viscid-downy. Flowers white....3, 4 1 G. officina'lis. Officinal $H$. Stem erect. Leaves clasping. Fls. whitish. S.

2 G. au'rea. Golden $H$. Stem ascending, branched. Leaves sessile. Flowers yellow, showy.

3 G. visco'sa. Viscid H. Leaves ovate-lanceolate. Sepals and bracts lanceolate. S 1 G. ramo'sa. Branching H. Lrs. linear-lance. Bracts minute. Sepals lineur. S.

5 G. sphærocar'pa. Round-fruited $H$. Peduncles not longer than calyx. I'od globular. W.

[calyx. S.

6 G. Florida'na. Flırida H. Peduncles long. Corolla four times longer than the

7 G. Virginia'na. Virginiun H. Peduncles long. Cor. twice longer than calyx. 3 G. pilo'sa. Hairy $H$. Leaves ovate, toothed. Corolla scarce longer than calyx. S. э G. snbula'ta. Awl-lv. H. Leaves narrow, entire. Cor. thrice longer than calyx. S.

\section{VERON'ICA. Speedwell.}

Ualyx 4-parted. Corolla with a wheel-shaped, spreading, 4-cleft burder, the lower segment smallest. Stamens 2, inserted into the tube, rrojecting. Sterile filaments 0 . Pod flattened, mostly obtuse or notehed at the apex, 2-celled, few or many-seeded.-Mostly herbs, with opposite leaves. Flowers small, solitary, axillary, or racemed, blue, flesh-color, or white. March-September.

Erect, tall (1 $\$-4$ f.). Flowers in dense terminal spikes....1, 2

- Low, weak $\left(3-12^{\prime}\right)$. Leaves opposite. Corolla tube very short....a

a Racames mostly opposite, from the axils of the leaves, sky-blue ...3,4

a Racemes mostly alternate, from the axils of the leaves, light-colored....5, 6

a Racemes terminal, or the flowers axillary and not racemed....b 
b Floral leaves like the rest, not longer than the recurved peduncles....7-9

b Floral leaves bract-like, longer than the erect flower-stalks....c

- Perennial. Flower-stalks equalling or exceeding the calyx....10, 11 .

- Annual. Flower-stalks shorter than the calyx, or none....12, 13

1 v. Virginia'na. Culver's Physic. Leaves whorled. Corolla tube longer than limb.

2 V. spica'ta. Spike-flowered S. Leaves opposite. Corolla limb longer than tube. +

3 V. Anagal'lis. Water $S$. Leaves sessile, cordate-clasping, ovate-lance.

4 V. America'na. Brooklime. Leaves petiolate, oblong-ovate, base roundish or cordate.

5 V. scutella'ta. Marsh S. Leaves linear. hucemes very slender, few-flowered.

6 V. officina'lis. Common S. Lvs, obovateelliptical, finely serrate. Racemes dense.

7 V. Buxbaum'ii. Buxbaum's S. Lvs. roundish-ovate. Pod triangular-obcordate. Fields. E.

8 V. agres'tis. Neckweed. Lvs. cordateovate. Pod roundish, r.cutely notch-

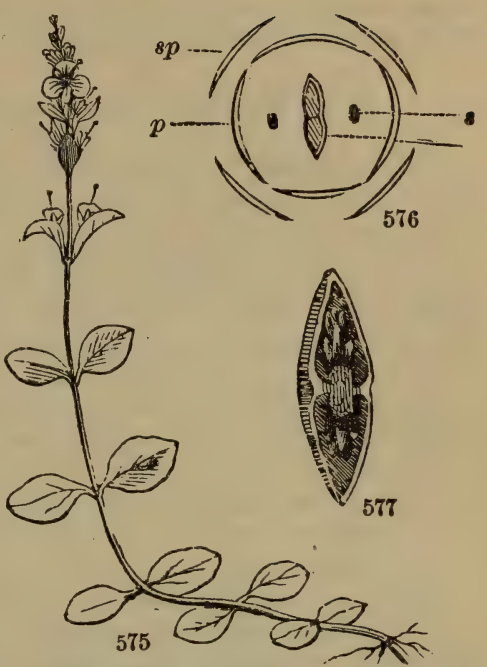

Fig. 575. Speedwell ( Veronica serpyllifolia), whole plant. Fig. 576. Plan of the flower: $o$, is the 2-celled ovary; $s$, the 2 stamens; $p$, the 4 petals; $s p$, the 4 sepals. Fig. 577. Cross-section of the pod, show ing its 2 cells, \& $c$. ed. Fields. E.

9 V. hederæfo'lia. Ivy-leaved $S$. Leaves cordate, roundish, 3-5-lobed. Capsu!o 4-seeded. M. Rare. [than long. $c$. 10 V. serpyllifo'lia. Thyme-leaved S. Flower-stalks longer than calyx. Pod broader 11 V. alpi'na. dlpine S. Fl.-stalks as long as the calyx. Pod obov. Hlairy. White Mts. 12 V. peregri'na. Purslane $S$. Smoothish. Leaves petiolate, oblong, fewtoothed, fleshy. $c$.

13 V. arven'sis. Corn S. Hairy. Lower leaves ovate, crenate, petiolate; urper lanceolate, sessile, entire. Stem 2-6' high. In fields. Cornmon.

\section{COLLIN'SIA. Innocence.}

Calyx 5-cleft. Corolla 2-lipped, throat closed, upper lip bifid, lower Iıp trifid, with the middle segment keel-like, holding the style and 4 stanens in a kind of sack. Capsule roundish.-Annual herbs.

1 C. verna. Early Collinsia, or Innocence. Corolla 2 or 3 times longer than the calyx Plant $S$ to $18^{\prime}$ high, tender and delicate. Leaves lance-ovate, dentate, opposite Flowers variegated witb blue and white, singular and pretty. M. W. 
20. parvifo'ra. Small-flowered I. ('orolla scarcely longer than the calyx, blue. Plant small. N.-W.

\section{MIM'ULUS. Monkey-flower.}

Calyx prismatic, 5-angled and 5-toothed. Cor lla tubular, upper lip reflexed or erect, 2-lobed, lower lip spreading, with a prominent palate, 3-loberd. Pod 2-celled, many-seeded.-Herbs prostrate or erect, with square stems, opposite leaves, and axillary solitary flowers. July.

* Species from California, cultivated in gardens ....3, 4

- Species growing wild, in fields, road-sides, \&c. Fls. blue....1, 2

1 M. rin'gens. Ringent $M$. Stem not at all winged. Leaves sessile. Peduncles longer than the flower. $c$.

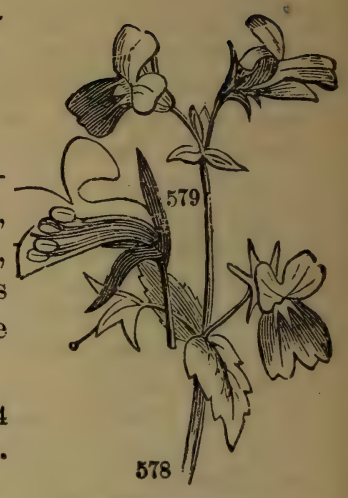

Fig. 578. Collinsia verna

Fig. 579. Section of a flower, full size.

2 M. ala'tus. Wing-stem 3 . Stem slightly winged. Leaves petiolate. Peduncles shorter than the calyx.

$8 \mathrm{M}$. lu'tea. Yellow M. Flowers yellow, often spotted. Leaves round-ovate. $\uparrow$

- M. cardina'lis. Cardinal M. Fls. scarlet, large and brilliant. Leaves ovate. $\uparrow$

\section{CHELO'NE. Turtle-head.}

Calyx deeply 5-parted, or the sepals distinct. Corolla inflated, upper lip broad, concave, lower 3-lobed, bearded in the throat. Stamens 4, woolly, with a 5 th sterile filament shorter than the others. Seeds many, broadly wing-margined. -2 Plants about $2 \mathrm{f}$. erect, with opposite serrate leaves. Auq.-Sept.

1 C purpu'rea. Purple T. Leaves lanceolate, petiolate. Flowers purple. Probably a variety of the next. W. M.

2 C. gla'kra. White $T$. Leaves lanceolate, sessile or nearly so. Flowers white purplish. By brooks and wet places.

\& O. Igo'ni. Lyon's $T$. Lvs. ovate, petiolate, rarely cordate. Fls, purple or vhite. 8.

\section{GERAR'DIA. Purple Gerardia.}

Calyx bell-shaped, 5-toothed, valvate in the bud. Corolla tnbular, swelling above, with 5 unequal, spreading lobes, which are shorter than the tube. Stamens 4, quite unequal by pairs, included, hairy. Pod ovate, pointed, many-seeded.- (1) Erect and branching herbs, with opposite, aleuder leaves, and large, showy, porple or rose coiored How ers. July-Sert 
\& Calyx segments longer than its tube. Two anthers very smali. W. (Onitted.)

s Calyx segments short, equal. Anthers all equal....a

a Corolla bi-labiate, upper lip very short, erect. S. (Omitted.)

a Corolla lobes subequal, all spreading; throat usually hairy....b

b Leaves almost none; opposite scales instead. S. (Onitted.) ...

b Leaves all alternate, filiform. S. (Omitted.)

b Leaves opposite....c

c Peduncles not louger than the calyx. Leaves linear....1, 2

c Peduncles much longer than the calyx. Leaves linear, long....d

d Flowers large, about $9^{\prime \prime}$ long.... 3,4

d Flowers small, about $6^{\prime \prime}$ long....5, 6

1 G. mariti'ma. Sea-side G. Leaves linear, fleshy. Fls. small, their stalks scarce as long as the truncate calyx. Cor, upper lobes fringed. Salt marshes. E.

2 G. purpu'rea. Purple G. Leares linear. Peduncles shorter than the calys, which is a truncate tube with setaceously acute teeth. Flowers 1' long. Common. 3 G. as'pera. Rough-lv. G. Pedunc. twice longer than calyx, which has teeth. W.

4 G. linifo'lia. Flax G. Peduncles many times longer than the toothless salyx. S. 5 G. tenuifo'lia. Slender $G$. Leaves linear, $1^{\prime}$ long. Peduncle 1', longer than the corolla, which is purple, with spots inside. Slender, brarıched, 6-12' high. $c$.

6 G. seta'cea. Bristlc-lv. G. Leaves linear-setaceous, the floral ones much shorter than the very long peduncles. Plant 12-18' high. Flowers rose-color. W.

\section{DASYS'TOMA. Woolmouth.}

The characters are the same as in Gerardia, except that the calyx is 5-cleft, and imbricated in the early bud; the corolla yellow, with tube longer than the lobes, and woolly inside; the leaves rather large, and mostly pinnatifid, and the root 2 . Flowers very showy. Plants 2-4f. high. July-Sept. (Figs. 565-568.)

$\$$ Sepals finely toothed. Leaves all pinnatifid, with toothed lobes....4, 5

$\$$ Sepals entire. Leaves entire or mostly once pinnatifid-toothed....1

1 Glabrous. Leaves acute at apex, lanceolate in outline $\ldots . .2,3$

1 D. flava. Downy $W$. Downy. Leaves nbtuse, entire, except the lower. Sepals obtuse. Common in woods.

\&. n. quercifo'lia. Oak-leaved $W$. Glancous. Leaves mostly pinnatifid. Corolla $2^{\prime}$ ir length. Calyx segments lance-acuminate, longer than its tube.

B D. integrifo'lia. Entire-leaved W. Green. Leaves lanceolate, entire. Stalks shorter than calyx. Flowers 1'long. In woods. Ohio, W.

4 D. pedicula'ria. Lousewort $W$. Smoothish or downy, branched. Flowerstalks longer than calyx. Leaves lance-ovate, twice pinnatifid.

5 D. pectina'ta. Combed W. Very hairy. Leaves lanceolate, pectinate-pinnatifid. Stalks shorter than calyx. 


\section{Order LXXXIX. LABIATA. Labiate Plants.}

Herbs with square stems, and opposite, aromatic leaves; flowers axillary, in verticils, sometimes as if in spikes or heads; ovrolla labiate (rarely regular), the upper lip 2-cleft or entire, G verlappirg in the bud the lower 3-cleft lip; stamens 4, didynamous, or 2; ousry deeply 4-lobed, forming in fruit 4 hard nuts or achenia.

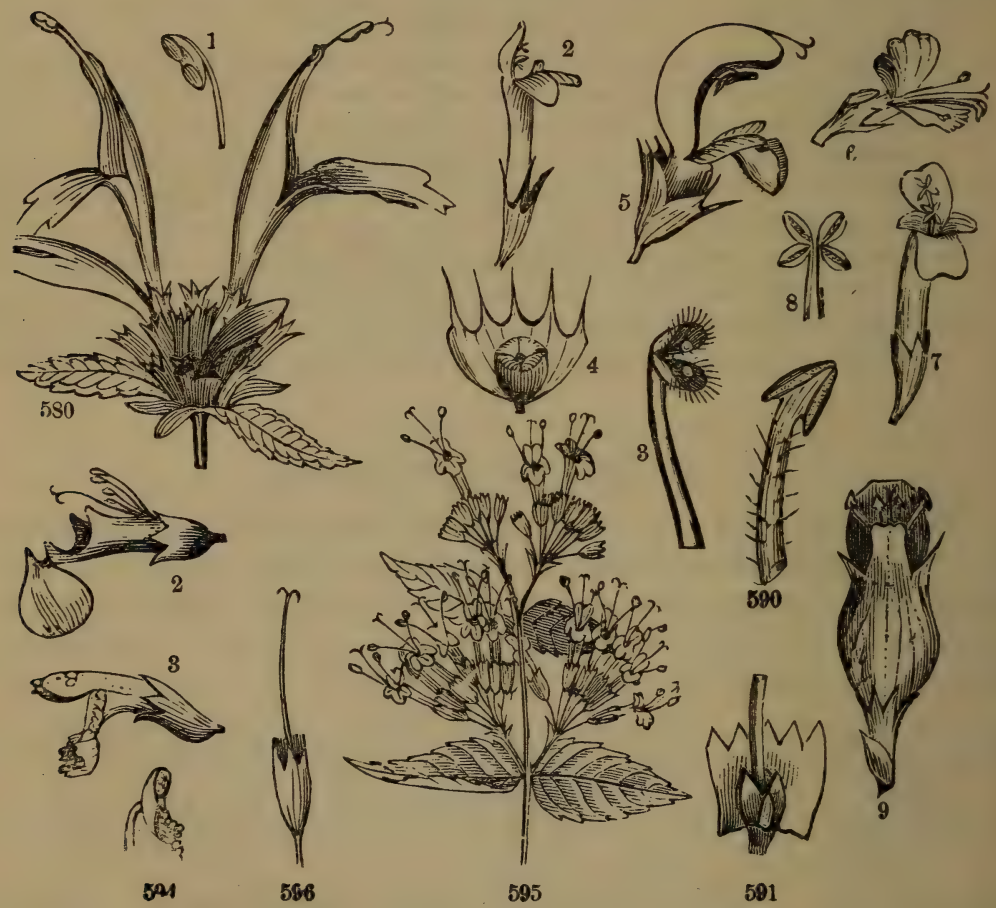

Fig. 580. Monarda didyma. 1. An anther enlarged. 2 Flower of Hemp Nettle (Galeop ais). S. One of its stamens much enlarged. 4. The calyx opened, showing the 4 achenia 5. Flower of Sage (Salvia). 6. Flower of Ocimum basilicum. 7. Flower of Nepeta Glechoma 8. A pair of the anthers forming a cross. 9. Flower of Physostegia Virginica seen from beneatri. Fig. 590. One of its stamens. 1. Its ovaries with the rudimentary filament. 2. Flower of Ten crium Canadense. 3. Flower of Catnep (Nepeta Cataria). 4. One of its anthers. 5. Dittany (Cunila Mariana). 6. A ealyx and style. 


\section{Analysis of the Genera.}

Siowers w:th only 2 perfect stamens....7

$\S$ Flowers with the 4 perfect stamens all declining to the lower lip....a

$\$$ Flowers with the 4 perfect stamens erect or ascending to the upper lip....2

2 Stamens of equal length. Corolla almost regular, 4 or 5 -lobed....c

2 Sta., the upper pair longer than the lower (outer). Calyx 13-15-veined....k

2 Stamens, the lower pair longer than the upper (interior) pair....3

3 Stamens diverging apart, mostly straight and exserted....6

3 Stamens parallel, ascending and long-exserted from the upper side...b

8 Stamens parallel, ascending in pairs beneath the upper lip....4

4 Calyx 13-reined, 5-toothed, and somewhat 2-lipped ....g

4 Calyx 5-10-veined or irregularly netted....

5 Calyx strongly 2-lipped, upper lip truncate, closed in fruit....m

5 Calyx not labiate, 3 or 4 -lobed, open in fruit....n

5 Calyx subequally 5-toothed, teeth not spinescent....

5 Calyx subequally 5 -toothed, teeth ending in sharp spines....q

5 Calyx nnequally 8-10-toothed....s

6 Calyx hairy in the throat, mostly labiate....f

6 Caly $x$ naked in the throat, mostly equal, 5-toothed....e

7 Stamens ascending beneath the galea (upper lip). Anthers 1-celled.....

7 Stamens exserted, distant. Anthers 2-celled....d

a Corolla upper lip 4-lobed, lower entire, flattish. $+\quad$ Siveet Basil. O'crmux.

a Corolla upper lip 4-lobed, lower saccate, deflexed. S. Hyptis. Hrpris.

a Corolla upper lip 2-lobed, lower 3-lobed, long, lilac. † Lamender. Lavan'DUda.

b Stamens exserted throngh a fissure in the tube. Blue Curls. Trichos'tema.

b Stamens very long, involute, arehing the corolla. Germander. TEU'CRIUM.

* Corolla limb equally 5-lobed. Stameus short. Blue-false-Gentian. Isax'тнrs.

c Corolla limb 4-lobed, the broadest lobe notched. Peppernint, \&c. Mentha. 1

d Cor. nearly reg., 4-cleft. Calyx naked in throat. Water Hoarhound. Lro'opcs. 2

d Corolla labiate, cyanic, throat naked. Stam. straight. Dittuny. ConI'LA. I

d Cor. labiate, esanie, throat naked. Stam. ascend. Pennyroyal. Hede'ona.

d Corolla labiate, yellow, throat hairy. Stamens

long-exserted.

- Fls. yel. Coarse herbs not fragrant, with large lvs.

Horse-balm. Collinso'nis.

e Fle. bright blue. Handsome herbs. Calyx 15-veined. † Hyssop. Hrs'sopus.

e F.s. pale blue, in dense hds. Calyx 10 or 13-striate. Wild Basil. Pronan'themur. Fis. pink-colored, axillary. Lvs, linear, small. $\dagger$ Summer Savory. SATuRE'da. f Corolla exserted, pink-color, racemed. Leaves linear, smooth. Stem 1f. S.

f Corolla short as calyx, pale-purple. Bracts roundish, colored.

DIFERAN'DRA.

Marjotam. ORIG'ANUM.

f Corolla short as calyx, bl ne-purp. Bracts minute, grcen. Thyme. TnYacs. 
Cor. tube straight. Lvs. small, subcrenate or entire. Calaminth. CaLAMrN'тHA. q g Corolla tube curved upwards. Leaves large, coarse-crenate. Balm. Melis'sa.

b Anthers halved, the halves widely separated, each 1-celled. Sage. SaL'via. 5

h Anthers halved, one half present, 1 celled. Filaments toothed. Slurub. +

h Anthers whole, 2-celled. Calyx subsequally 5-toothed.

Rosemary. RosMari'nUs.

Mountain Mint. Monar'da.

h Anthers whole, 2-celled. Calyx labiate, teeth bristle-shaped. BLEPHIL'IA. * Leaves serrate. Stamens diverging. Fls. spiked. Tull Hyssop. Lophan'tuUs. L Lvs. serrate. Stam. all ascend. Fls, capitate. Dragonliead. Dracocepu'alum. k Lvs. crenate, cordate or reniform. Corolla smonth inside. Calmint. NeP'ETA. " k Leaves crenate, cordate. Corolla tube very broad, hairy inside. CedronkL'LA. m Calyx lips toothed. Filam. forked. Fls. spiked. Self-heal. Bruné'ta. 8 m Calyx lips entire, the upper appendaged on back. Skullccp. Scutella'ria. 9 n Calyx 3-lobed. Anthers all distinct. Corolla large, purplish. S. Macbrídea.

n Calyx 4-lobed. Anthers, upper pair, connate. White. W. Sxnan'dra.10 - Cor. tube inflated in the midst, whitish. Tall. Lion's-heart. Physoste'gra.11 - Cor. tube inflated at the throat, purple. Lvs. roundish. Henbit. Lam'ium. - Corolla infiated in the broad concave upper lip. Jerusalem Sage. PhLomis. - Corolla not inflated, short....p

p Calyx salver-form, 10-veined. Black Hoarhound. BaLlo'ta.

p Calyx broad-campanulate, netted. Molucca Balm. Molluccen'́s. q Lvs, serrate. Anth. open crosswise. Nuts truncate. Hemp Néttle. Galeop'sis. q Leaves serrate. Anth. open lengthwise. Nuts obtuse. Hedge Nettle. Stacrys. Leaves lobed. Nuts truncate at top, 3-angled. Motherwort. LEONU'RUs. s Cor. white, upper lip flattish. Style equally bifid. Hoarhound. Marru'Brum. s Corolla white, upper lip concave. Style unequally bifid. S. Leucas. - Corolla scarlet, exserted. Calyx upper tooth longest. Lion's-ears. Leono'Tis.

\section{MEN'THA. Mint.}

Calyx equally 5-toothed. Corolla nearly regular, tube included in the calyx, border 6-cleft, the upper lobe mostly notched. Stamens 4, equal, straight, erect, distant.-Aromatic herbs, with the pale purple or white flowers in close axillary clusters, or forming spikes.

* Whorls of flowers remote, axillary, not in spikes. Leaves petiolate....1, 2

* Whorls of flowers approximate, forming terminal spikes....3, 4

1 M. Canaden'sis. Wild Mint. Plant grayish, fragrant. Lvs. acute at each end.

2 M. arven'sis. Fivid M. Plant green, ill-scented. Lvs. frequently obtuse at base.

3 M. piperi'ta. Peppermint. Leaves petiolate, ovate, serrate, smooth. Spikes few, thick, short. Stems 2-3f. high.

4 M. vir'idis. Spearmint. Leaves sessile, lance-oblong, acute, serrate. Spikes many, slender, long. Stems 1-2f. high. 


\section{LYC'OPUS. Water Hoarhound.}

Calyx tubular, 4-5-cleft. Corolla nearly regular, 4-cleft, tube as long as the calyx, stamens 2 , distant, diverging the length of the straight styke. - 2f Low herbs, with deeply toothed or pinnatifid leaves, and remot axillary whorls of small, whitish flowers. July, Aug.

L. Virgin'icus. Stem obtuse-angled. Leaves sharp-toothed. Calyx 4-clurt, blunt.

L. Europæ'us. Stem sharp-angled. Leaves sinuate-toothed. Calyx 5-cleft, spiny.

\section{CUNI'LA. Dittany. (Figs. 595, 596.)}

C. Maria'na. Maryland D. Stem branched, 1-2f. high. Leaves ovate, serrate, nearly sessile. Cymes axillary and terminal, corymbous, stalked. Corolla nearly twice as long as the calyx, pale-red. In rocky woods. N. Y. to Gia. Summer.

\section{CALAMIN'THA. Calaminth.}

('al gx 13-veined, tubular, throat mostly hairy, upper lip 3-cleft, lowor 2-clejt. Corolla tube straight, exserted, throat enlarged, upper lip erect, sub'jutive, lower lip spreading, its middle lobe largest. Stamens 4, lower pair longer. -24

1 C rlinopo'dium. Wild Basil. Herb hairy, 1-2f. high. Leaves ovate, subserrate. Flowers many, in dense, axillary whorls, with subulate bracts. Caly $\mathrm{x}$ bent.

2 c. Nep'eta. False Catmint. Herb hairy, 2f., much branched below. Lvs. broad . ovate, petiolate. Whorls few-flowered above. Calyx straight. Hills. Va.

8 C. glabel'la. False Pennyroyal. Herb smooth, half erect, $6-12^{\prime}$, branched. Lv's. oblong, those of the runners ovate. Cor. pale-violet. Fragrant. June. M.

4 C. canes'cens. Hoary C. Shrub $10^{\prime}$ high. Lrs. linear. Fls. op posite, roseate. s.

5 C. coccin'ea. Scarlet $C$. Shrub with narrow obovate leaves, large scarlet fls. S.

6 C. Carolinia'na. Carolina C. Shrub 1f. Leaves ovate, serrate-erenate. Flowers rose-purple. $\mathbf{S}$.

\section{SAL'VIA. Sage.}

Calyx striate, labiate, throat not hairy. Corolla ringent, upper lip straight or falcate, lower spreading, 3-lobed. Stamens 2. The connectile is placed transversely on the filament like the letter $\mathrm{T}$, bearing at each end 1 lobe of the halved anther. (See Figs. 585, 176.)

$\S$ Herbs native, in woods, \&c....a

$\S$ Herbs or shrubs in gardens, with blue flowers....7, 8

Shrubs from Mexicr, cultivated, with large scarlet flowers....8, 10 
a Calyx slight:y 2-lipped, obscurely 3-toothed, equal. South....1-8

a Calyx deeply 2-lipped, 5-toothed, lower lip longer....4-6

1 S. azu'rea. Azure S. Leaves linear-oblong. Fls. downy, azure-bluc. Summer

2 S. urticifo'lia. Nettle-lv. S. Lvs. rhombic-ovate. Coroila smooth, blue. May.

8 S. coccin'ea. Scarlet $S$. Lvs. ovate, cordate, hoary. Corolla red, smooth. July 4 S. Clayto'ni. Clayton's S. Lvs. lanceolate, pinnatifid, cauline. Fls. small. S.

5 S. obova'ta. 'Obovate $S$. Lvs. broadly obovate, entire. Flowers blue. S.

6 S. lyra'ta. Lyrate $S$. Leaves all radical, oblong, lyrate, erose-dentate, 1 or 8 on the scape, bract-like. Fls. $1^{\prime}$ long, violet-purple. M. S. Spring.

i s Scla'rea. Clarry S. Lvs. ample, broad-ovate. Corolla upper lip large, higharched. + (Fig. 585.)

8 S. officina'lis. Common S. Lvs. not large, lance-oblong, rugous. Corolla uppez lip scarce longer than the lower, some vaulted. Shrubby.

9 S. ful'gens. Stem weak. Lvs. lance-ovate, long-stalked. Caly $\mathrm{x}$ scarcely colored.

10 S. splen'dens. Stem erect. Leaves broad-ovate, staıked. Calyx scarlet also.

\section{MONAR'DA. Mountain-mint.}

Calyx tubular, lengthened, 15̌-ribbed, nearly equally 5-toothed. Corolla tubular, long, the lips linear or oblong, lower reflexed, 3-lobed, upper erect, entire, involving the filaments. Stamens 2, with rudiments of more. -Erect, fragrant herbs, with rather large flowers in bracted whorls or heads, the bracts generally tinged with the color of the flowers JulySept. (Figs. 580, 581.)

$\S$ Calyx densely hairy in the throat. Corolla purple or whitish....1, 2

$\S$ Calyx naked in the throat. Corolla scarlet or yellow....3, 4

1 M. fistulo'sa. Wild Bergamot. Stem acutely angular, 2-4f. Leaves laneuovate, petiolate. Heads of flowers large, dense, terminal. b. p. w. M. W.

2 M. Bradburia'na. Bradbury's M. Stem simple, 3f. Leaves lance-oblong, subsessile, hairy both sides. Heads few, large, purple. W.

8 M. puncta'ta. Horsemint. Stem branched, 2-3f. high. Leaves lance-oblong, tapering to a petiole. Bracts longer than the pale yellow flowers. M. W. S.

4 M. did'yma. Mountain Balm. Stem branched, 2-3f. Leaves broad-ovate, acuminate. Heads large, with long crimson flowers and bracts. +

\section{NEP'ETA. Catmint.}

Calyx striate, obliquely 5-toothed. Upper lip of the corolla nutched or 2-cleft, lower 3-lobed, middle lobe largest, throat naked and widened. Stamens ascending beneath the upper lip.— 4 Lvs. crenate.(Figs. 587, 588.)

$1 \mathrm{~N}$. Cata'ria. C'atnep. Tall. Cymes dense, terminal spikes. Ieaves cordate. 2 N. Glecho'ma. Gill. Trailing. Cymes loose, axillary. Leaves round-reniform 


\section{BRUNELTA. Blue-curls.}

B. valga'ris. Common $B$. Stem simple, ascending 8-18'. Leaves oblong-ovate, stalked, toothed. Whorls close together, forming an oblong, dense spike. Coroila blue, upper lip truncate, with 3 awns.

\section{SCUTELLA'RIA. Skullcap.}

Calyx campanulate, lips entire, with an appendage on the back and closed after flowering. Corolla with a long, ascending tube, the upper lip vaulted, nearly entire, middle lobe of the lower lip wide, spreading. Stamens approximate in pairs, ascending beneath upper lip.-Bitter herbs, not aromatic. Flowers generally blue. May-August.

§ Flowers large (7-13" long), racemed above, with bracts....a

$\$$ Flowers large or small, opposite, solitary in the axils of the leaves....8-10

\$ Flowers small ( $3^{\prime \prime}$ long), in slender, axillary, 1-sided racemes....11

a Bracts ovate, abrupt at base. Lips of the corolla short....1, 2

a Bracts lance-ohlong, acute at base. Leaves notched, petiolate....b

a Bracts leaf-like, longer than the calyx. Leaves entire, subsessiie....7

b Helmet (upper lip) of the corolla longer than the lower....3, 4

b Helmet of the corolla not longer than the lip....5, 6

I S. versic'olor. Vurieguted $S$. Floral leaves sessile, broad-ovate, not cordate Corolla lower lip scarcely longer than the upper, blue above. M. W.

I S. saxati'lis. Rock $S$. Weak, branched, ascending. Upper leaves oval, obtuse. Corolla lower lip twice longer than the upper, blue above, tube pale. Rocks. W. S.

3 S. canes'cens. Hoary S. Tall, downy. Leaves petiolate, oblong or ovate Flowers canescent, tube gradually enlarged. M. W. $c$.

4 S. villo'sa Woolly $S$. Stem woolly. Corolla tube slender, enlarged only at the throat. Helmet much larger than the lip. S.

5 S. serra'ta. Saur-lf. S. Nearly smooth. Leaves acuminate, both ends. W. S.

6 S. pilo'sa. Hairy S. Plant hairy. Leaves rhomb.-ovate, obtuse. M. S.

7 S. integrifo'lia. Entire-leaved $S$. Erect. Leaves ovate-lance., entire, subsessile. M.

\& S. nervo'sa. Nerve-lf \&. Lvs. broad-ovate, 3-5-veined. Stem 8-15'. M. W

9 S. par'vula. Pigmy S. Lvs. oblong, ovate, obtuse, entire, sessile. Stem 3-6'. M. W.

C S. galericula'ta. Common $S$. Leaves lance-cordate, crenate-serrate. Flowers 1' long. $c$.

I1 S. lateriflo'ra. Mad-dog S. Branching, smoothish. Lvs. ovate-lancec late, acuminate, serrate, petiolate. Racemes lateral, leafy. o. 


\section{SYNAN'DRA. Synandra.}

Oalyx 4-cleft. Upper lips of corolla entire, vaulted, the lower in 3 unequal, obtuse lobes. Throat widened. Stamens ascending beneath the upper lip, the two upper anthers cohering. (Figs. 597, 90.)

1 s grandiflo'ra Great-flowered $S$. Grows in woods, West. 6-8' high. Leaves opposite, ovate, cordate, toothed. Fls. few, $1^{\prime}$ long, upper lip very large. Juns.

\section{PHYSOSTE'GIA. Lion's-heart.}

F Virginia'nii. Virginian L. Stem square, erect 2-3f., with very smooth, sessile leaves in four rows, and a terminal, 4-rowed spike of large, showy, purplish-white flowers.

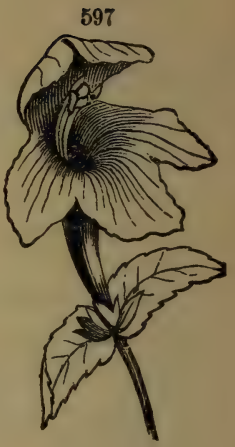
Aug., Sept. (Figs. 589-591.)

Order XC. BORRAGINACE AE. Borrageworts.
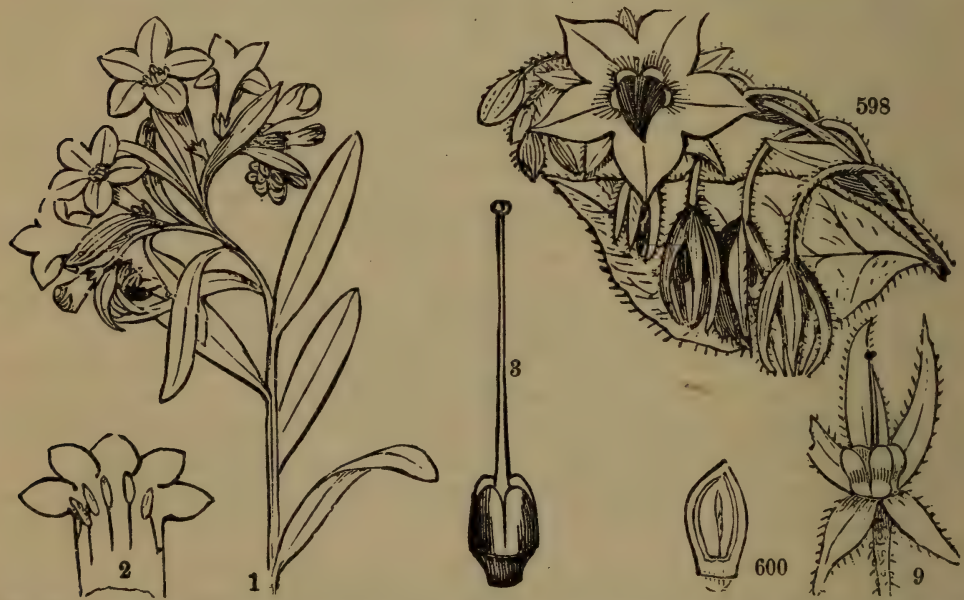

Fig. 598. Borrage (Borrago officinalis). 9. The four nuts with the style and calyx. Fig. 600 Une of the nuts cut open, showing the seed, embryo, \&c. 1. Puccoon (Lithospermum canes cens). 2. Corolla laid open, showing the stamens. 3. Pistil of Comfrey, consisting of the deeply 1-lobed ovary with the slender style arising from between the lobes and near their base.

Herbs, shrubs, or trees, with round stems and branches; leaves alternate, generally rongh with stiff hairs; stipules none; 
flowers seldom yellow, generally in a coiled (circinate) inflorescence ${ }^{*}$ sepals 5 ; petals 5 , united below, almost always regular;

stamens 5; ovary deeply 4-lobed, forming in fruit 4 separate, 1 -seeded nuts or nutlets, generally without albumen.

\section{Analysis of the Genera.}

$\$$ Ovary not 4-luked, but separating when ripe ir to several achenia.....

S Ovary 4-lobed or parter, becoming 4 achenia around the style....2

2 Corolla irregular, with unequal lobes or a bent tube.... b

2 Corolla perfectly regular....3

3 Achenia or ovary prickly. Corolla throat closed with 5 scales.... \&

8 Achenia and ovary not prickly....4

4 Corolla throat closed by 5 scales....

4 Corolla throat open, no scales, sometimes 5 ridges....d

a Corolla tube with open thruat. Achenia 4. Heliotrope. Turnsol. HeLrotro'pidr. 1

a Corolla tube with constricted throat. Achenia 2. False Helio. HeLrotroph'rтux.

b Corolla irregularly 5-lobed. Throat open. Blue. Viper's Bugloss. Есн'тuм.

b Corolla with the slender tube bent, closed. Blue. Bugloss. Lrcop'sis.

c Corolla wheel-form, anthers exserted. Blue. Borrage. BorRa' Go.

c Corolla tubular bell-form. Style exserted. White. Comfrey. Sra' Phytum.

a Vor. tubular, with erect, acute lobes. White. False Gromwell. Onosmo' Dius.

d Corolla lobes rounded, spreading,....e

e and imbricated in the bud. White or yellow. Gromwell. Lithosper'merr. 2

e and imbricated in the bud. Purple or blue, large.

- and convolute in the bud. Blue or white, small. Merten'sta. 3 Mroso'trs. 4

f Corolla salver-form. Ach. priekly on the edge. Burr-seed. Echinosper'MuM.

i Corolla funnel-form. Achenia prickly all over. Hound's-tongue. Crnoglos'sux. 5

\section{HELIOTRO'PIUM. Turnsol. Heliotrope.}

Corolla salver-form, lobes shorter than the tube. Anthers sessile. Style short, terminal. Ovary entire, splitting at length into 4 achenia.-Herbs or shrubs. Flowers in one-sided, coiled spikes.

1 н. Europæ'um. Wild H. Herb downy. Leaves oval, obtuse. Spikes single or forked. White. S.

[o',tuse. Blue. W.

2 ㅍ. curassav'icum. Glaucons H. Herb smooth, glaucous. Lvs. linear-lanceolate,

8 н. Peruvia'num. Common H. Shrubby, whitish-downy. Spikes many, clustered. $w \cdot \cdot p \cdot+$

\section{LITHOSPER'MUM. Gromwell or Grammell.}

Calyx 5-parted. Corolla funnel-form or salver-form, the limb 5-lobed, shroat open, naked or with 5 projections. Stamens included. Achenia 
bony, ovate, smooth or wrinkled, fixed by a flat base-Herbs generally with thick, reddish roots. Flowers spiked or racemed, with leafy bracts. May-July.

$\S$ Flowers white, small....a

Flowers yellow, showy. Achenia smooth, polished....5-7

a Achenia roughened with wrinkles....1

a Achenia smooth and polished....2-4

L. arven'se. Wheat-thief. Root (1), red. Leares lancs-linear. Plant 12-18' high, hairy. $c$.

[tube. N. M.

2 L. officina'le. Gromwell. Root 2 . Lrs. lanceolate. Calyx equal to corolla

8 L. latifo'lium. Broad-leaved G. Root 2 . Leaves lance-ovate, sharply acuminate. Sepals longer than the corolla, spreading in fruit. Stem 1-2f.

4 L. angustifo'lium. Narrow-lv. G. \& Lvs. linear, stiff, edges some revolute. M.W. 5 L. canes'cens. Puccoon. Soft-velvety, canescent. Lvs. oblong-linear. Tube of the corolla thrice as long as the very short calyx. Plant $8-12^{\prime}$ erect. W. \&c.

6 L. hirtum. Hairy P. Rongh-hairy. Lvs. lance-linear. Cor. long as calyx. W. s.

7 L. longiflo'rum. Long-flowered $P$. Rough-ashy. Lvs. lance-linear. Corolla tube four times as long as the calyx, lobes crenulate, wavy. W. S.

\section{MERTEN'SIA. Lungwort.}

A short, 5-cleft calyx; a tubular corolla, slender below, suddenly enlarged above, limb 5-cleft; the 5 stamens inserted at top of the tube, and with smooth achenia. - 2 Plants usually smooth, with terminal racemes.

1 M. Virgin'ica. Virginian L. Very smooth, 12-18' high. Root lvs. large, stalked; stem Ivs. sessile. Fls. somewhat trumpet-shaped, blue-lilac, very fine. May. W.

2 M. marit'ima. Sea $L$. Smooth, diffuse. Leaves ovate, fleshy. Corolla limb longer than the tube, which shows 5 folds in throat, blne-purple. E.

8 M. panicula'ta. Punicled $L$. Rough. Leaves cordate, acuminate, veiny. Caly $x$ hispid, thrice shorter than the tube, bel. ferm, blue-white corolla. N.-W.

\section{MYOSO'TIS. Forget-me-not. Scorpion-grass.}

Calyx 5-cleft. Corolla salver-form, the 5 lobes slightly notched at the end, throat closed with 5 short, concave scales. Nuts smooth, orate, with a small cavity at base.-Little herbs slightly woolly. Racemes finally becoming long. May-Aug.

M. palus'tris. True $F$. Flowers in one-sided racemes. Plant smoothish, 6-12' high. Leaves linear-cilong, obtuse. Flowers blue with a yellow centre.

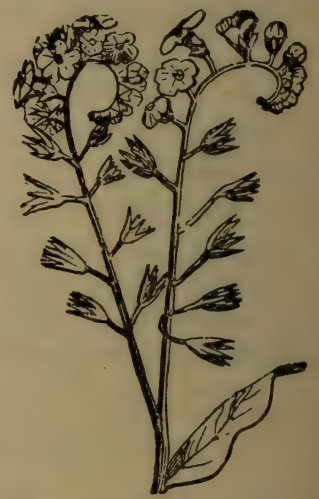

Fig. 604. Forget-me-not, s pair of scorpoid cymea 
2 M. arven'sis. Field F. Fls, in 2-sided, leafless racemes. Plant hairy. Pedicels twice as long as the open, equal calyx. Lvs. oblong-lance., acute. Rare. $w$.

3 M. stric'ta. Rough F: Flowers in 2-sided racemes, which are leafy at their base. Pedicels as long as the closed, 2-lipped calyx. Leaves oblong. $w$.

\section{CYNOGLOS'SUM. Hound's-tongue.}

Calyx 5-parted. Corolla short, funnel-form, the throat closed with 5 obtuse scales, lobes rounded. Nuts depressed, covered with short, hooked prickles, fixed laterally to the base of the style.-Coarse herbs, strongscented, with the flowers in leafless, panicled racemes. June, July.

C. officina'le. Common $H$. Velvety. Stem leafy (1-2f.). Flowers reddish purple. C. virgin'icum. Stalked $H$. Hairy. Stem leafless above (2f.). Flowers pale blue. C. Morriso'ni. Morrison's H. Hairy, leafy (2-3f.), wide-spread. Flowers whitish.

\section{ORDER XCI. HYDROPHYLLACEA. The Hydrophylls.}

Mostly herbs with alternate lobed leaves, and regular bluish flowers; calyx 5-cleft, usually with appendages at the clefts, persistent; corolla 5-lobed, often with 10 honey scales or furrows near the base; stamens 5, inserted into the corolla, with a single bifid style; ovary simple, free, 1-celled, with 2 usually projecting several-seeded placentæ.

\section{Analysis of the Genera.}

1 Corolla with 10 honey scales inside, extending lengthwise....2

1 Corolla destitute of honey scales. Stamens equalling corolla. Cosman'thus. 2 2 Fls. in coiled cymes, withont bracts. Placentæ large, fleshy. IIy drophý'́lum. 1 2 Flowers in one-sided racemes, bractless. Placentæ linear. Phace'Lia. 2 Flowers (mostly) solitary. Calyx very large. Leaves pinnatifid. Ellis'is.

\section{HYDROPHYL'LUM. Water-leaf.}

Sepals slightly united at base. Corolla campanulate, with 10 linear honey scales running lengthwise, folded inward so as to form 5 grooves. Stamens exserted. Pod globular, 2-celled, 1-4-seeded, with large, fleshy placentæ.-Handsome herbs, with the root leaves on long petioles, and the flowers in clustered cymes, bluish or white.

\$ Calyx not appendaged. Stamens much exserted....1-3

$\S \mathrm{H}$. appendicula'tum. Appendaged $\dot{W}$. Calyx appendaged at the clefts. Stamen not exsarted. W. S. 
1 H. macrophyl'lum. Great-leaved W. Lvs. pinnately-veined and lobed, rough hairy. Peduncles long. W. S.

2 H. Virgin'icum. Virginia $W$. Leaves pinnately-veined and lobed, smocth Peduncles long. $c$.

3 H. Canaden'se. Canada W. Leaves palmately-veined and lobed, smooth Peduncles shortes than petals. $r$.
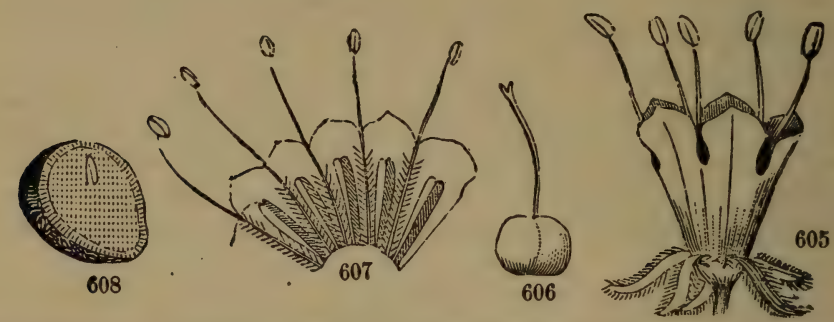

Fig. 605. A flower of Virginian Water-leaf. Fig. 606. The Ovary and Style. Fig. 607. Corolla cut open, showing the honey grooves. Fig. 608. A seed, cut, showing the embryo.

\section{COSMAN'THUS. Miami Mist.}

Corolla broad-campanulate, soon falling off, throat not appendaged, limb of 5-fringed lobes. Ovary 1-celled, the two projecting placentæ each 2-seeded.- (1) Delicate herbs with alternate leaves, long, bractless racemes, and small, white or pale-blue flowers.

1 C. Pur'shii. Pursh's M. Nearly smooth. Leaves pectinately pinnatifid, lobes oblong-acute. Sepals lance-linear. Height 8-12'. Penn., S. and W. Pale blue. 2 c. fimbria'tus. Fringed $C$. Downy. Leaves pinnate, segments rounded cr oblong, obtuse. Sepals obtuse, oblong-spatulate. Mts. Tenn. S.

\section{Order XCII. POLEMONIACEA. Phloxworts.}

Herbs with alternate or opposite leaves, and regular, showy, 5-parted flowers; calyx free from the ovary;

corolla of 5 united petals, twisted and imbricate in the bud;

stumens 5 , inserted into the midst of the corolla tube and alternate with its lobes ;

ovary 3 celled; styles united into 1 ; stigma 3 -cleft; capsule 3-celled, 3-valved, with few or many albuminous seeds. 
Analysis of the Genera.

Corolla salver-form. Filaments unequal. Leaves simple.

Corolla funnel-form. Filaments equal. Leaves dissected.

Phlox. PhLox. 1

Corolla bell-form. Filaments equal. Leaves pinnate. Polemony. Por.exo'nrum. a

\section{PHLOX. Lychnidea}

Calyx angular, deeply 5-cleft, corolla sa.ver-10"ms. the talie more or less curved. Stamens quie unequa. inserted in the tabe of the corolla abore the middle. Capsule 3-celled, cells 1-seeded. - Very beantiful North American herbs. Leaves generally opposite, sessile, simple, entire. Flowers varying from nur ple to white. April-July.

* Lobes of the corolla rounded and entire at the end....10-12

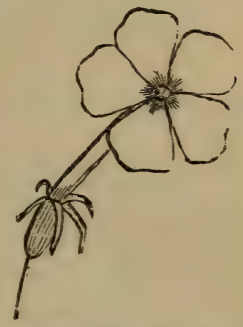

Fig. 600. Flower of of a Phlox.

- Lokes of the corolla notched or bifid at the end.... a

a Panicle of cymes oblong or pyramidal, many-flowered....1, 2

a Panicle of cymes corymbed, level-topped, flowers fewer....b

- Plants glabrous. Calyx teeth shorter than its tube....3, 4

- Plants hairy. Calyx teeth very slender, larger than its tube....

c Leaves narrow, linear or nearly so....5, 6

c Leaves broad, ovate, lanceolate, \&c...7-9

1 P. panicula'ta. Panicled L. Garden P. Tall. Leaves lance-ovate, acuminate at each end. Calyx-teeth bristle-pointed, nearly as long as the tube. W. S. †

2 P. macula'ta. Spotted L. Stem purple-spotted. Leaves lance-ovate, upper cordate. Calyx-teeth lanceolate, acute, half as long as its tube. Fields. W. S. +

s P. Caroli'na. Carolina $L$. Stem ascending. Leaves lance-ovate. W. S.

4 P. glaber'rima, Polished L. Stem erect, simple. Leaves lance-linear. W. S. 5 P. pilo'sa Hairy L. Leaves lance-linear, acute. Calyx seyments bristle-subulate, much longer than its tube. Stem slender, 1-2f. W. S. p.-vo.

6 P. involucra'ta. Cup-fl. L. Hoary-downy. Lvs. linear oblong, obtusish at eack end, the floral crowded beneath the dense cymes. $p .-r$. S.

7 P. rep'tans. Creeping L. Stolons creeping. Stem oblique. Lvs. obovate, couse. W. S.

8 P Laphamii. Lapham's $P$. Slender, erect. Lrs. ovate, acute, thin. W.

- P. Drummondii. Drummond's $P$. Annual, branched, hairy. Leares mostly alternate. Calyx segments revolute. Corolla purple, with a star. S. †

10 P. divarica'ta. $W^{\top} i l d L$. Low, diffuse, downy. Lvs. lance-ovate, acute. Par icle corymbed, loose. Corolla grayish-blue. c. (No. 8, may be the same.)

11 P. bi'fida. Beck' $L$. Low, diffusely hranched. Lvs. lanceolate, stem-claspinq. 12 P. subula'ta. Mass Pink. Prostrate, much branched. Lvs. linear-subulate. !t grows in deuse tufts, covered over with rose-colored flowers in May. 


\section{POLEMO'NIOM. Polemony.}

1 P. cœru'leum. Blue $F$. ltreek Valerian. Stem erect, 1-2f. high. Lrs. pinnate with 11-17 leaflots. Capsule 12-20-seeded. Sometimes wild. +

P. rep'tans. Creeping $P$. Stem weak, diffuse. Leaves pinnate, with 7-11 lestlets Capsinie 4-6-seeded. Woods, common. Light blu s.

\section{Order XCII. CONVOT.VULACE. 左. Bindweeds.}

Herbs twining or training, with alternate leaves : flowers showr:

caiyx with 5 much imbricated sepris, persistent:

corolla regular, 5-iobed or entire, pıartec anc sisted in the. oud:

stamens 5, and style singie ; ovary free, becoming in

fruit a pod which is 2-4-celled and 2-6-seeded;

embryo large and leafy, with thin mucilaginous albumen.

The suborder, Cusoutine $\approx$, consists of small orange-colored, leafless. plants, living on other plants (parasites), with small flowers, and no cotyledons (Ousouta, the Dodder).

\section{Analysis of the Genera.}

$\S$ Ovaries 2, distinct, with 2 distinct styles.... \& $\S$ Ovary 1 , open, when ripe by $2-4$ valves....2

2 Ovary 2-celled, 2-valved, 4-seeded....3

2 Ovary 8-celled, 3 -valved, 6 -seeded.... b

2 Ovary 4 -celled, 4 -valved, 4 -seeded....a

8 Styles 2, distinct....e

8 Styles united into $1 \ldots . .4$

4 Calyx enveloped in 2 large bracts....d

4 Calyx naked....c

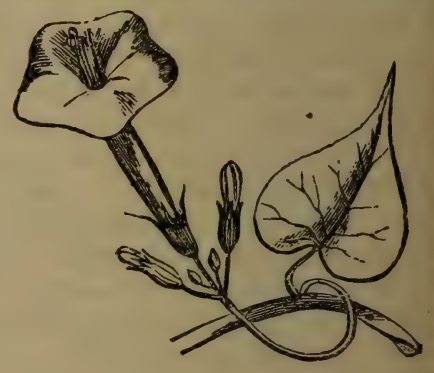

Fig. 610. Entire-leaved Cypress-vine (Quamoclit coccinea.)

- Stamens exserted. Cor. small (scarce $1^{\prime}$ broad). † Cypress I'ine. QUaM'ocLIT. 1 a Stamens included. Corolla large ( $2^{\prime}$ broad). $+\quad$ Sweet Potato. Bata'tas. 2 b Beautiful twining vines. Cor. bell-funnel. † Morning-glory. Рнав'вітіs. 3 - Stamens included. Stigma capitate.

c Stamens included. Stigmas 2, linear.

- Stamens exserted. Corolla tube slender. $\dagger$ False Bindweed. Iтом A' A. 4 Bindweed. Convol'velcs. E Good-night. CALYNYo'TION. d Stigmas 2, obtuse. Corolla bell-form. + Rutland Beauty. Car YsTe'gra. 6 - Peduncles longer than the leaves. Soft-downy.

Stylisma. Struis'ma

f Capsules 2, each 1-seeded. Plant very small, prostrate. S. Dichon'nra. 


\section{QUAM'OCLIT. Cypress Vine.}

1 Q vuiga'ris True C. Leaves pectinate-pinnatifid. Fls. scarlet, crimson, \& c. S. I Q coccinea Entire-lv. C. Lvs. undivided, cordate, acuminate. Crimson W S.

\section{BATA'TAS. Sweet Potato.}

( B. litlora'lis. Sea-side B. Peduncle 1-flowered, as long as the sinuate, cordate leaf. $\mathbf{S}$.

B. macrorhi'za. Wild Potato. Peduncle 1-5-f'nwered, shorter than the lobed or entire leaf, which is downy beneath. Flowers purplish-white. S.

B ed'ulis. Sicceet Potato. Peduncle 3-5-flowered, shorter than the palmate or pedate-lobed leaf. Flowers showy, rose-purple. $†$

3. PHAR'BITIS. Morning-glory. (Fig. 22.)

1 P. purpu'rea. Common M. Leaves entire, cordate. Peduncle 2-5-flowered. †

2 P. Nil. Indigo M. Lvs. 3-lobed, cordate. Ped. 1-3-flwd. Sepals long. M. S. †

\section{IPOM $E^{\prime} A . \quad$ False Bindweed.}

A large genus. Some of its tropical species are shrubs and trees; and are all trailing or climbing herbs, chiefly at the South. We mention but one species.

.. pan'durata. Wild Potato. Leaves broadly cordate, often fiddle-shaped (panduriform). Corolla large (near $3^{\prime}$ long), 4 times longer than the calyx, white, witk. a purple centre. Root very large. Sandy fields, West and South.

\section{CONVOL'VULUS. Bindweed.}

1 C. arver'sis. Field $B$. Leaves sagittate. Fls. white, with a tinge of red, small.

2 C. tri'color. Tri-colored B. Leaves lance-obovate. Fls. yellow, white, blue. $†$

\section{CALYSTE'GIA. Bracted Bindweed.}

1 C. spithamæ'us. Erect $B$. Stem ascending, 8-10' (a span). Leaves lance-oblong Peduncle as long as the leaves, bearing 1 large, white flower. Fields.

2 C. Sepium. Rutland Beauty. Stem twining, long. Leaves cordate-sagittate Flowers numerous, large, white, sometimes double in cultivation.

e r Catesbeia'nus. Catesby's $B$. Plant downy, twining. Flowers purple. 8. 


\section{Order XCIV. SOLANACEA. Nightshades.}
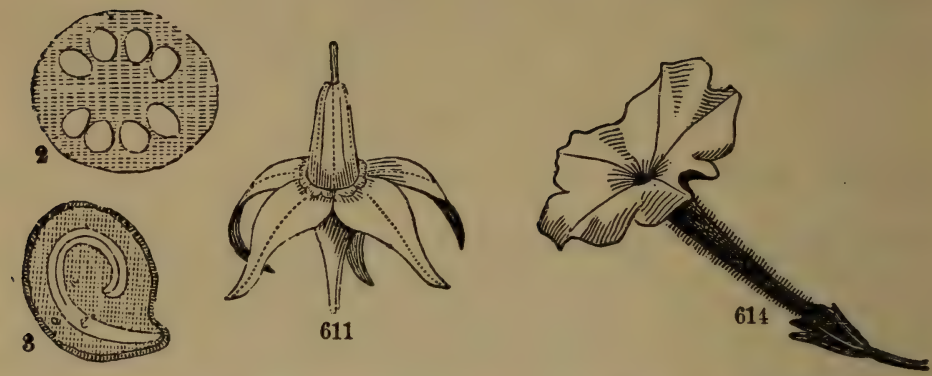

Fig, 611. A flower of Bitter-sweet (Solanum Dulcamara). 2. Cross-section of the berry. 3. A seed cut open, showing the long, curved embryo. Fig. 614. Flower of Petunis

Plants herbaceous or shrubby, with alternate leaves; and with flower-stalks often opposite to the leaves; and the pedicels without bracts; caly $x$ generally persistent, 5 -lobed; corolla 5-lobed, mostly regular, valvate and plaited in the bud; ovary free, 2-celled (rarely 3 or 4-celled), many-seeded; style and stigma single; fruit a capsule or berry, with many seeds ; embryo curved, lying in fleshy albumen.

\section{Analysis of the Genera.}

$\$$ Corolla wheel-shaped, the tube very short. Anthers convergent....a

$\$$ Corolla bell-shaped, the broad tube includir.g the erect anthers....b

\& Corolla funnel-form, tube long, and-(2)

2 The limb somewhat irregular....c

2 The limb perfectly regular....3

3 Stamens exserted....d

3 Stamens included....e

a Anthers connate, opening by slits Berry lobed a Anthers connivent, opening by pores. Berry rouna.

a Anthers connivent, opening by pores. Pod angular.

Tomato. LYcosper'sIoUM. Potato. Sola'num.

b Corolla bluish. Berry dry, enveloped in the calyx. Apple Peru. Nrosn'DHe

b Corolla yellowish. Berry fleshy, inclosed in the calyx.

Ground Cherry. PhYs'ALts.

b Corolla purplish. Berry black, in the open calyx. Belladonna. Ат'RopA. - Stamens exserted, declining. Capsule opening by a lid. Henbane. Hroscr'asros. c Stamens included, unequal. Capsule opening by valves. Petunia. Pexu'nia. 
d Stamens growing to the summit of the tube. Neircmberg. Nerrember'Gia.

d Stamens growing to the bottom of the tuve. Matrimony. Lro'rum

- Calyx 5-angled. Capsule spiny or smooth.

e Calyx terete. Stigma capitate. Herbs coarse.

- Calyx terete. Stigma 2-lobed. Delicate shrubs. + False Tamarisk. FABIA NL
Thorn Apple. Datu'ra

Tobacco. Nicotia'Na.

\section{SOLA'NUM. Nightshade.}

Calyx 5-parted. Corolla rotate, limb spreading, tube very short, limt plaited in the bud, 5-lobed. Anthers erect, slightly united or converging, each opening at top by 2 pores. Berry globular or depressed, 2-celled. - Herbs or shrubs unarmed or prickly. Leaves often 2 together, a large and a small one. Flowers generally lateral. May-July.

§ Plants not prickly: Anthers short, blunt....a

Plants prickly. Arthers long, linear, and pointed....b

a Herbs with pinnatifid leaves, shorter than the racemes....1

a Herbs with undivided leaves, longer than the racemes....2-4

a Shrubby plants, erect or climbing. Berries red....5-7

b Peduncles exceeding the leaves, many-flowered....8, 9

b Peduncles shorter than the leares, few-flowered....10, 11

I s. tubero'sum. Potato. Segments of the leaves unequal, some very small. Corolla limb 5-angled. Tubers on the undergronnd branches.

2 s. nig'rum. Black Nightshude. Smoothish. Leaves ovate, toothed, and wary. Flowers small, white, in lateral umbels. Berries black.

8 s. nodiflo'rum Knot-flowered $N$. Quite smooth. Leaves ovate, entire. Flowers minute, white, the stalk arising from a knot in the stem. S.

4 S. pycnan'thum. Stem hispid. Leaves ovate-acuminate, wavy. Peduncle 2 or 3 -flowered. 8 .

5 S. Dulcama'ra. Bitter-sweet. Stem flexuous, climbing. Leaves ovate, cordate, upper ones lobed or gashed. Flowers purple, in lateral cymes, drooping. (Fig. 611.)

6 s. Pseudo-cap'sicum. Jerusalem Cherry. A small, handsome, erect shrub, 2-4f. †

Is. sempervi'rens. Evergreen $N$. Climbing. Leaves thick, cordate, elliptic, oh. tuse, with a blunt cusp, very smooth and shining. Panicles termisaal. T

8 S. Carolinen'se. Horse Nettle. Leaves angular-lobed. Racemes leafless. $\boldsymbol{w}$.

9 s Virginia'num. Virginia $N$. Leaves pinnatifid. Racemes leafy. Pale. S.

10 S. mammo'sum. Apple of Sodom. Woolly and prickly. Leaves roundish-ovate, lobed. Fruit inversely pear-shaped. Flowers violet-colored.

11 s esculen'tum. Egg-plant. Leaves ovate, somewhat sinuate, downy. Flower: 6-9-parted. Fruit egg-shared, from the size of an egg to a water-n.elon. † 


\section{Orner XCV.-GENTIAN.ACE E. The Gentianworts.}

IJerbs with opposite, entire, smosth leaves, and showy regular flowers ;

corolla usually twisted in the

bud, with as many lobes as stamens, and alternate with

them, mostly persistent and withering;

stigmas 1 or 2 ;

ovary 1 -celled, superior, becoming a 2-valved pod with many seeds.

\section{Analysis of the Genera.}

$\S$ Leaves opposite or whorled, sometimes minute. Corolla mostly twisted in bud....2

\& Leaves alternate or radical. Corolla valvate in the bud ....d

2 Corolla with a glandular spot on each lobe, sometimes with spurs....c

2 Corolla without glandular

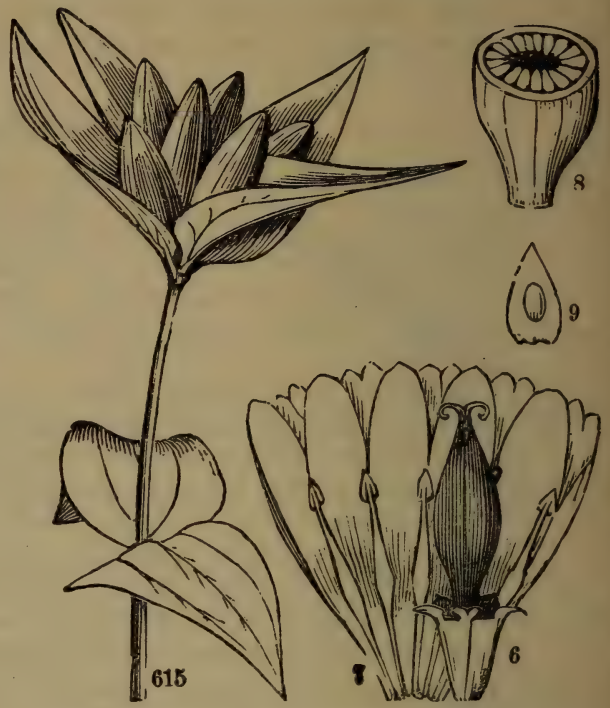

Fig. 615. Gentiana Andrewsii, 6. The calyx and capsule. 7. The corolla laid open, showing the folde (2-lobed) between the proper petals, and the stameng attached at base. 8. Capsule cut across. 9. Seed magnified, with its large, loose testa. spots or spurs....3

3 Corolla tubular, the tube longer than the limb.... a

3 Corolla deeply cleft, mostly wheel-shaped, tuhe very short....b

a Sepals 4 or 5 . Corolla fringed, or with folds between lobes. Anthers straight.

\section{Gentia'na.}

a Sepals 4 or 5 . Anthers spiraily twisted.

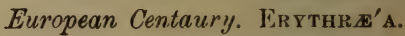
a Sepals 2, leaf-like. Cor. 4-cleft, white or purplish. Pennywort. UвоцA'RIA.

b Leaves very small or mere bracts. Fls. 4-parted. Screw-stem. BaRto'Nia.

b Leafy. Fls. 5-12-parted. Anthers curved. American Centaury. SARBA'TIA. c Corolla 4-parted, with 4 spurs beneath at base. Spurred Gentian. HaLE'NIA. c Cor. 4-parted, without spurs. Tall, with whorled leaves. Columbo. Fra'sera.

d Corolla bearded inside. Leaves 3 -foliate, on long stalks.

Buck-bean. MenYan'thes.

a Corolla smooth inside. Leaves simple, floating. 


\section{GENTIA'NA. Gentian.}

Calyx 4-5-cleft. Corolla 4-5-lobed, regular, usually with plaited folds between the lobes. Stigmas 2, style short or none. Pod oblong, 2-ralved, many-seeded.-Leaves opposite. Flowers solitary or in eymes. Aug.-Oct.

Corolla with folded appendages between the 5 lobes. Anthers cohering....b

Coroila with no appendages between the lobes. Anthers separate....a

a degments ot tue corolla entire, pale-blue, 5 in number....1

a segments or tne corolla fringed, mostly but 4, bright blue....2, 3

- f'lowers solitary, terminal, blue or white....4

b Mlowers cizstered, yellowish or cream-white $\ldots . .5,6$

3 Finwars clasiered, blue....7-9

- G. quinqueflo'ra. Five-Leaved G. Clusters about 5 -flowered. Corolla lobes bristleponteri.

2 G. crini'ta. Fringed $G$. Leaves lanceolate. Corolla conspicuously fringed. Height 1f.

z G. det'onsa. Shorn 7. Lvs. linear. Corolla lobes crenate-ciliate. Height if 4 G. angustifo'lia. Sand $G$. Slender, 1f. erect. Lrs. linear. Flower large. b. or $p$. 5 G. ochroleu'ca. Pile G. Lvs. lance-oval, narrowed to the sessile base. Corolla greenish-white, a third longer than the sepals. S. M.

6 G. alba. Whitish G. Lvs. lance-ovate, clasping with the broad base. Coroila cream-white, 4 times longer than sepals. W. M.

7 G. Andrew'sii. Closed Blue G. Leaves ovate-lanceolate, 3-veined. C'orolla never opening, the lobes equalling the 5 fringed folds. (Figs. 615-619.)

8 G. Sapona'ria. Soapwort G. Plant smooth. Leaves rough-edged, linear-lanceolate. Corolla open, the lobes twice longer than the cleft folds.

9 G. puber'ula. Rough G. Plant scabrous. Lvs. lance-ovate, very rough at edge. Corolla somewhat bell-shaped, folds very short. W. S.

\section{SABBA'TIA. American Centaury.}

Ualyx 5-12-parted. Corolla rotate, limb 5-12-parted. Stamens 5-12. Style 2-parted. Capsule 1-celled.-Beautiful biennials, with mostly ro. seate flowers.

8 Corolla mostly 9 (rarely 7-12)-parted....1, 2

Corolla 5 (ra-ely 6)-parted....a

a Branches alternate or forked....b

a Branches opposite. Flowers with a central star.. .c

b Flowers white or nearly white....3, 4

b Flowers rose-red, with a central star....5, o

c Flowers white, cory mbed....7, 8

- Flowers rose red, panionlate....9. 10 
1 s. gentianoi'des. Gentian $C$. Leaves linear, rigid, longer than the internodns Flowers 8-10-parted, bright flesh-color, clustered. S.

2 s. chloroi'des. Chlora C. Leaves lanceolate. Branches few, alternate, eack bearing at top a solitary, 7-12-parted, bright purple flower. E.

$3 \mathrm{~S}$. calyco'sa. Cup C. Calyx leafy, as large as the 5-6-parted corolla. S.

4 S. panicula'ta. Panicled C. Sepals linear, half as long as 5-p arted eor. S.

$s$ gra'cilis, Slender $C$. Leaves ovate to linear. Sepals bristle-form, as long the corolla. M. S.

13. stclla'ris. Starry $C$. Leaves lance-obovate. Sepals linear, much sliorter thas corolla. d.

7 S. corymbo'sa. Crrymbed C. Leaves lanceolate, 3-veined. Calyx segmente linear, thrice longer than its tuhe, half as long as the corolla. N.-J. S.

8 S. macrophyl'1a. Leaves 5-veined, cusp-pointed. Sepals shorter than calyx tube. $\mathrm{S}$.

9 s. angularis. Angled C. Stem square, with winged angles. Leaves ovate, clasping, 5-veined. Flowers many, rose-red, the star greenish. Wet. c.

10 S. brachia'ta. Prairie C. Stem square, slender, joints 2-4 times longer than the sessile, lance-linear leaves. Panicle oblong. Corolla 6-parted, the star vellow. W. S.

\section{Order XCVI. APOCYNACEA. Dogbanes.}

Plants with a milky juice, entire and mostly opposite leaves;

flowers 5-parted and regular, with the corolla twisted in the bud; stamens 5, with distinct filaments, anthers sometimes slightly united; ovaries 2 , distinct, but with their stigmas united at top of the styles: fruit 2 follicles containing several or many albuminous seeds.

\section{Analysis of the Genera.}

* Herbs erect, 2-4f. high, the flowers in cymes....a

* Shrubs twining or trailing, with opposite leaves....

* Shrubs erect, 3-6f. high, with the leaves in whorls of $3 \ldots . . . c$

a Cor. bell-shaped, whitish. Style none. Sds. silky. Dog's-bane. APoc'YNum. 1

a Corolla funtel-form, bluish. Style 1. Lvs. scattered. Amson. Amso'ria. Fls. solitary, blue. Throat 5-angled. Lvs. evergreen. $\dagger$ Periwinkle. VIN'OA. Flowers in cymes, jellow, small. Lvs. petiolate. Wet. South. Forstero' c Leaves thick, evergreen. Flowers large, rose-colored. Olear der. NE'RICM.

\section{APOC'YNUM. Dog's-bane.}

Stamens shorter than the corolla, arising from its base, and alternate with 5 glandular teeth. Anthers arrow-shaped, cohering to the stigmes 
by the middle. Follicles long, slender, separate. Seeds with a tuft of long, silky down. June-August.

$1 \mathrm{~A}$. androsæmifo'lium. Tutsan-leaved $D$. Corolla rose-white, much longer than the calyx. Leaves ovate. Plant smooth, elegant, about 3f. high.

A. cannabi'num. Hemp D. Cor. greenish-white, scarce longer than the calyx. Leaves oblong. Bark tough as hemp.

Fig. 620. Common Dog's-bane. 1. A flower of the natural size. 2. The flower cut open, showing the peculiar stamens. 3. The 2 styles and stigmas. 4. The plan of the flower. 5. The 2 follicles. 6. A seed with its tuft of silk.

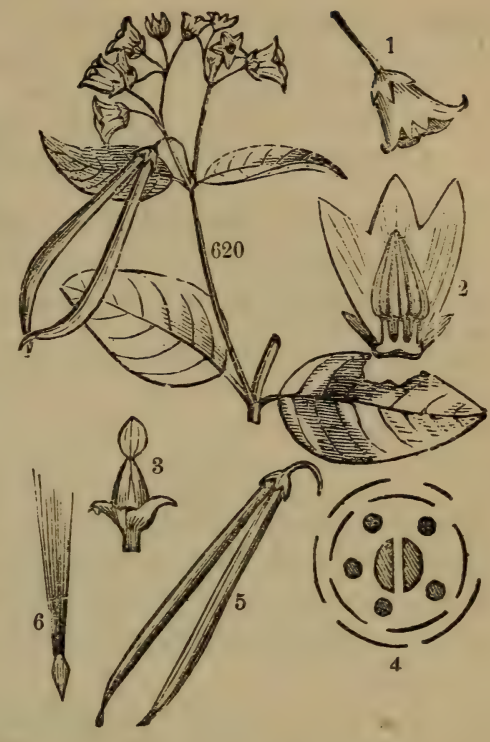

\section{Order XCVII. ASCLEPIADACE E. Asclepiads.}

Plants (chiefly herbs in the United States) with a milky juice; leaces opposite (rarely whorled or scattered), entire, without stipules; flocers generally umbeled, 5-parted, regular; sepals and also the petals united at base, both commonly valvate in the bud; stamens united into a fleshy mass with the two stigmas; pollen cohering in masses; ovaries 2 , forming follicles in fruit

\section{Analysis of the Genera.}

8 Plants erect. Stamen-mass crowned with 5 little hoods....2

8 Plants twining or prostrate....8

2 Iloods each with a little projecting horn....a

2 Iloods destitute of horns.... b

3 Flowers dark purple....c

3 Flowers whitish or flesh-colored....

- Petals reflexed. Hoods erect, horns incurved. Silkgrass. Milkweed. AscLe fI ss. I

b Petals reflexed. Hoods erect, adnate to the anthers. Acera'tes.

v Petals spreading, green. Hoods free from the authers. S. Anan'therix. D P'stals erect, yellowixh. Mass of anthers stalked. S. Podostio'ma 
c The 5 filuments distinct. Pollen masses 5. N.-Y. Perislócio.

e Filaments united as well as the stigmas. Pollinia 10.

d P'etals spreading. Hoods erect. Leaves linear. Coast, S. SEnte'rA.

d Petals spreading. Hoods tlat, spreading. † Wax-plant. Hor'A.

d Petals erect, white. Hoods erect, 2-awned. S.-W. Common. EnsLe'nia.

\section{ASCLE'PIAS. Silk-grass. Milkweed.}

(We have many species of this genus, blooming in the Summer months. Begin mons will find them difficult to distinguish. We omit them here, referring the reade to the Class Book.)

\section{ORDER XCIX. OLEACEA. Oliveworts.}

Trees and shrubs with opposite leares, with flowers 4-parted, regular, sometimes without petals; corolla (when present) valvate in the bud; stamens 2 , rarely 4; mary 2-celled, with 2 ovules in each cell; fruit fleshy or dry.

\section{- Analysis of the Genera.}

$\S$ Leaves pinnate. Fruit a dry, winged samara....a

$\S$ Leaves simple. Fruit a dry, 2-celled pod (capsule)....b

$\S$ Leaves simple. Fruit a fleshy drupe or berry ....2

2 Corolla present. Stamens included. White....

2 Corolla present. Stamens exserted....d

2 Corolla none. Fruit an oblong drupe....e

1 Trees with imperfect flowers and odd-pinnate leaves. Ash. Frax'intis.

b Corolla salver-form, with short, white or purple lobes. + Liluc. Srrin'aA. 1

b Corolla bell-form, with long, yellow lobes. † Forsythia. Forsx'тнг. c Corolla with long, linear, pendulous lobes. Virginia Fringe-tree. Chionan'тнus. c Cor. with short lobes. Panicle dense. Berries black. Privet. Prim. Liqus'trum. d Style 2-parted. Leaves serrate. Shrubs. + Osmanth. Osman'thus.

d Style simple. Panicles axillary. S.

d Style simple. Panicles terminal. Trees. $\dagger$

- Flowers very imperfect, diøecious. Shrubs. Wet. W. S. Adelia. Forestíera.

\section{SYRIN'GA. Lilac.}

Is ruga ris. Common L. Leaves cordate-ovate, entire. Flowers lilac-purple.

$2 \mathbf{S} . \mathrm{al}^{\prime} \mathrm{ba}$. White Lilac. Flowers pure white. Shrub taller. (Variety of No.1.)

8 S. Per'sica. Persian L. Leaves lanceolate, entire or cleft. Flowers in looses panieles, lilac-blue. Apr. May. 


\section{COHORT III.}

\section{THE APETALOUS EXOGENS.}

Essential Character.-Flowering plants (Рнenogamia), with their stems growing by additions to the outside and the wood in circular layers (Exogens), with the seeds inclosed in seed-vessels (ANGIOsperms), and the flowers destitute of petals (APETALE).

\section{ORder C.-ARISTOLOCHIACE $\approx$. Birthworts}

Low herbs or climbing shrubs with alternate leaves, large flowers; calyx adhering to the ovary, valvate in bud, brown or dull colored; stamens 6-12, at top of the 6-celled, many-seeded oxary.

Analysis of the Genera.

Calys bell-form, regular, 3-cleft. Stamens 12. Herbs with creeping,

underground stems.

Wild Ginger. Ass'ruy, 1

Calyx tubular, bent, irregular. Anthers 6. Shrubby, erect or climbing, with very odd flowers.

Birthwort. ARIstolo'chia.

\section{ASARUM. Wild Ginger.}

I A Canadense. Canada $W$. Leaves in pairs, broad-reniform, with the single flower between the petioles scarcely above-ground. May-July. $c$.

2 A. Virginicum. Virginia $W$. Leaf solitary, round-ovate, cordate, the single flower much shorter than the petiole. Sepals obtuse. Mts. Va. S. April.

S A. arifol'ium. Arum-lv. W. Leaf solitary, broadly hastate, with long, angular lobes at base. Calyx throat contracted, lobes very short. Va. S. April.

\section{ORder CI.-NYCTAGINACE E. Marvelworts.}

Herbs (ehrubs or trees) with swelling joints; entire, opposite leares ; fencers surrounded by an involucre (which is, of course, calyx-like when the flower is solitary):

ailyx often colored like a corolla, tubular or funnel-form, breaking off alove the 1-celied, 1-seeded orary. 


\section{Analysis of the Genera.}

Involucre just like a calyx, involving a single, large flower. Calyx funnel-form corolla-like, the limb entire.

Invclucre involving 2-5 small, rose-red flowers. W. S. Four-o-clock. MIrAB' ILIs. . nvolucre none, or minute bractlets. Flowers minute. S.

OXYB'APHUS. BOERHAA'via.

\section{MIRAB'ILIS. Marvel-of-Peru. Four-o-clook.}

1 M. Jala'pa. Peruvian F. Leaves ovate, subcordate. Fls. stalked, with a ıarge border, infinite in variety of color, opening about 4 o'clock, P. $4 .+$

2 M. dichotoma. Mexican F. Erect, smouth. Calyx with a small norder. +

8 M. longiflo'ra. Long-fl. $F$. Diffuse, viscid. Calyx tube downy, ve.y long. I Mex.

\section{ORDER CII.-POLYGONACEA. Knotweeds.}

Herbs with alternate leaves, swollen joints, and with stipules sheathing the stem above the joints; flowers racemed, perfect; calyx persistent; sepals 4-6, imbricated, distinct or united at base; stamens 4-12; ovary 2 or 3-styled, 1-celled, 1-seeded in fruit.

\section{Analysis of the Genera.}

* Calyx 4-parted, regular. Stamens 6. Styles 2. Mountain Sorrel. OxYR'1A.

* Calyx 6-parted. Stamens 9. Sepals all similar. Kinubarb. Rheum.

* Calyx 6-parted. Stamens 6. Inner sepals larg\%. Dock. Sorrel. Rrunx.

* Calyx 5-parted (irregularly 4-parted in one species)....a

a Sep., the 3 inner fringed. Fls. solitary. S. Fringe Knotweed. ThYsaner'LA.

a Sepals not fringed, entire or nearly so....b

- Pedicels solitary. Sep. all open or 3 closed on the fruit. M. S. PolygonkL'La. b Pedicels usually clustered. Sepals all closed on the fruit. PoLYG'onum. i b Pedicels clustered in the bract. Sepals all opur. Buckwheat. FAGOPY'RUM.

\section{POLYG'ONUM. Enotweed.}

Calyx 5- (rarely 4-) parted, colored or corolla-like, the sepals all crect and inclosing the fruit. Stamens 4-9. Styles 2 or 3 . Nut lens-shaped or 3-cornered.-Herbs with swollen, sheathed joints. Flowers small, white, red, or greenish. May-Aug.

\$ Stems climbing, with reversed prickles. Leaves cordate-sagittate....19, 20

$\$$ Stems unarmed, twining. Leaves cordate-hastate....17, 18

Stems erect or decumbeat, unarmed. Leares hardly ever cordate.... a 
a Calyx unequally 4-cleft. Styles 2, long, deflexed....16

a Calyx equally 5-parted. Styles erect....b

b Sheaths with a spreading border. Stamens 7. Plant tall....15

- Sheaths not bordered. Stamens 5,6 , or $8 \ldots$ c

- Flowers in leafless, terminal, spike-like racemes....d

c Flowers axillary, or rarely forning a leafy raceme....f

d Raceme one, dense. Stems decumbent at base....18, 14

d Racemes several. Sheaths naked, not fringed....11, 12

d Racemes several. Sheaths bristly fringe-ciliate....e

e Style 2 (or 3)-cleft. Achenia flat or lens-shaped....8-10

e Style 3-cleft. Achenia sharply 3-cornered. Wet....5-7

$f$ Achenium protruding beyond the ealyx, 3-angled....3, 4

f Achenium included in the calyx, 3 -angled ....1, 2

$1 \boldsymbol{P}$. avicula're. Bird $\boldsymbol{K}$. Prostrate or erect. Leaves elliptic-lanceolate, acutish at each end. Achenia striate, dull. Very common.

2 P. ten'ue. Slender $K$. Slender, rigidly erect. Leaves lance-linear, erect, acute.

3 P. marit'imum. Sea $K$. Prostrate, diffuse, glaucous, close-jointed. Leaves linear-oblong, fleshy. Achenia smooth, shining. E.

4 P. ramosis'simum. Lake $K$. Erect, much branched, 2-8f. high. Leaves lance-oblong or linear. Achenia smooth, dull. W.

5 P. hirsu'tum. Hairy $K$. Hairy-tawny. Leaves lanceolate from a blunt base. S. C P. hydropiperoi'des. Mild Water-pepper. Stem smooth. Leaves linear-lanceolate, not acrid, tapering at both ends. Spikes slender. Calyx dotless.

7 P. aere. Sharp $W$. Stem smooth. Leaves biting, dotted as well as the calyx, lanceolate, pointed. Spikes very slender, thread-form.

8 P. hydropi'per. Water-pepper. Smooth. Leaves very biting, dotted. Spikes short, nodding. Calyx dotted. Achenia roughened.

9 P. Car'eyi. Carey's $K$. Plant hairy. Spikes nodding, on very long stalks.

10 P. Persica'ria. Lady's-thumb. Leaves marked with a brown spot. Spikes short, dense, erect. Achenia shining, flattened.

11 P. Pennsylvan'icum. Pennsylvanic $K$. Spikes oblong, dense, with glandularhispid stalks and pedicels. Achenia with flat sides. $c$.

12 P. incarna'tum. Flesh-red $K$. Spikes linear, nodding, the stalks and branches glandular-dotted. W. S.

18 P. amphib'ium. Water $K$. Stem ascending from a prostrate, rooting baso. Leaves lance-oblong. Stamens 5. Spikes large, dense, rose-red.

14 P. vivip'arum. Alpine Bistort. Creeping at base. Lvs, lance-linear. Mts. N.

15 P. orienta'le. Prince's Feather. Stem stout, tall, with large, drooping spikes. †

16 P. Virginia'num. Lip-fl. $K$. Leaves large. Racemes slender, flowers remote.

17 P. convol'vulus. Knot-Bindweed. Roughish. Ricemes axillary. Fruit dull.

18 P. cilino'de. Bearded $B$. Sheaths with a hairy ring. Panicles axil. and termir a!

19 P. dumito'rum. Hedge $B$. Calyx with the 3 outer sepals acutely wing-keeled.

20 P. sagitta'tum. Scratch-grass. Lvs. lance-sagittate. Stamens 8. Styles 5.

91 P. arifo'lium. Arum-lv. S. Lvs. pointed, with pointed lobes. Stam. 6. Sty. in 


\section{Order CIII. PHY'TOLACCACEA. Polreweeds.}

Herbs or shrubs with alternate leaves, no stipules, and flowers racemed; sepals colored, 4 or 5 ; petals none; stamens few or many;

ovary of one or several carpels, which are united into a ring, forming a berry in fruit; cells as many as the carpels, each 1-seeded; mbryo curved around the fleshy albumen.

\section{Analysis of the Genera.}

Sepals 5, roundish. Sta. 5-20. Ovary 5-12-carpeled and seeded. Phrtolao'oa. 1 Sepals 4, persistent. Stamens 4-12. Ovary 1-carpeled and 1-seeded. S. Rivi'Na.

\section{PHYTOLAC'CA. Poke.}

Character expressed in the Analysis.-Tall and stout perennials, with greenish fluwers and purple berries.

P. decan'dra, Plant 5-8f. high, very smooth, bushy. Leaves large, ovate, acute at each end, petioled. Racemes at first terminal, finally opposite to the leaves. Berries oblate, of a rich dark purple. July-Sept.

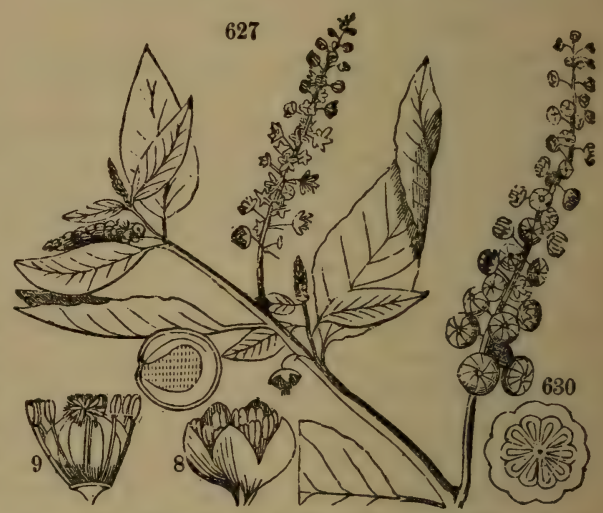

Fig. 627. Phytolaces decandria, leaves, flowers, and fruit. 8. A flower, natural size. 9. It stumens and ovary. Fig. 630. Cross-section of the ovary. 1. A seed cut open, showing the em. bryo coiled around the albumen.

\section{Order CV. CHENOPODIACE $\nexists$. Goose-foots.}

IIerbs, mostly homely weeds, more or less fleshy, with alternate leaves ; stipules none, scarious bracts none. Flowers apetalons, small, greenish ; stamens opposite the sep.ls or fewer in number than they ; ovary 2 -styled, forming a 1 -seeded utricle or caryopsis. Embryo coiled or spiral in the seed.

\section{Analysis of the Genera.}

Stem wining and climbing. Flowers in many racemes, white....(d)

Stems erect. Leaves none, or fleshy and terete, often spinescent....(a)

i stems erect. Leares flat, neither fleshy nor spinescent. Flowers greenish... 
2 Flowers all perfect and alike....(b)

2 Flowers of two sorts, monœcious or diœcions.....(c)

a Leaves ovate, corlate, petiolate, thick. 24 S. Am. Mexican Vine. Boussingaul'tia

b Pericarp rough and cor.iy. Root fusiform, fleshy. Lvs. large. (2) Beet. BEтA.

b Pericarp smooth, thin. Calyx bractless, not appendaged, 5-cleft, enclosing the utricle which is lens-shaped and horizontal. Fls. minute, in panicled spikes. (1) $2 f$

Pigweed, Oak-of-Jerusalem, etc. CHENopo'duM

b Pericarp smooth, thin. Calyx of 5 distinct sepals, often becoming berry-

like in fruit. Fls.glomerate. (1)

Strawberry Blite. BuItux.

c Fruit enclosed in a hardened calyx without bracts. Styles 4. Leaves hastate-lanceolate, to sagittate, petiolate. Fls. axillary.

Spinage. SPINA'cra.

c Fruit naked (no calyx) between 2 bracts. Styles 2. Herbs (sometimes shrubby) often mealy or scurfy. Lvs. sometimes opposite, triangular, etc.

At'RIPLEX.

d Stems jointed, leafless, having the flowers at the joints. Stamens 1 or 2. Fleshy, herbs with opposite branches. Seaside.

Samphire. SaLICOR'NIA.

d Stems with leaves linear fleshy, and profusely branched. Flowers minute, sessile, clustered. Stamena 5. (1) In salt marshes. Glasswort. Chenopodína.

d Stems with terete awl-shaped leaves tipped with a spine. Calyx-winged on the back, wings persistent and purplish in fruit. Saltwort. SaL'sola Kali.

\section{Order CVI. AMARANTACEAE. Amaranths.}

Herbs very similar to the Goose foots, but with an imbricated involucre of 3 dry scarious bracts added to the flowers. Style 1. Fruit a 1-seeded utricle, caryopsis o: berry. Flowers very small and numerous.

\section{Analysis of the Genera.}

$\$$ Anthers 2-celled. Orary with $\infty$ ovnles, utricle $\infty$-seeded. Cockscomb. CALo'sIA. $\S$ Anthers 2-celled. Ovary 1-ovuled, ntricle 1-seeded. Leaves alternate....(b)

$\S$ Anthers 1-celled. Ovary 1-ovuled, ntricle 1-seeded. Leaves opposite.....(a)

* Flowers monœcious or polygamous, all with a calyx and stamens. Amaran'Tus. 1

* Fls. diccious, the pistillate with neither ca!yx nor stam. Water IIemp. ACNI'DA.

a Sterile stamens 5 , the 5 fertile joined into a tube. Heads axillary. South. Telanthe ra. a Sterile stam. 5 , the 5 fertile in a tube. Spikes terminal and axillary. W. Froelicn'ia. a sterile stamens none.-b Flowers paniculate, white. River banks. W. IREsi'Ne. -b Fls. capitate, crimson, \&c. Glebe Amaranth. GoMPHRE'NA.

\section{AMARAN'TUS. Amaranth.}

Calyx of 5 or 3 sepals, with 3 bracts at base. Stamens $3-5$. Stigmas 2 or 3. Fruit a 1-seeded utricle which is regularly circumscissile, or tears open, or does nnt open at all.-We find 11 species (see Botanist and Florist, p. 283), among which are the White Pignceed and other weeds of the gar den, and a few showy herbs like the following : 
A hypochondri'acus. Prince's Feather. Smoothish. Leaves lance-oblong, gome red dened. Spikes very obtuse, the terminal one much the longest. Flowers deep pur. ple, 5-parted. Fields and gardens. 3-6f. From Mexico.

A. panicula'tus. Pubescent, pale green or purplish. Leaves lance-ovate. Spikes slender, acutish, numerous, all subequal, reddish green, or in the variety sanguineu, crimson. Bracts awn-pointed. Calyx 5-parted. Fields and garfens. 2-3f.

\section{Order CVII. THYMELACE A. Daphnads.}

Shrubs with a very tough bark, entire leaves and perfect flowers; caly $x$ colored, tubular, regular, 4-parted, bearing the 4-8 stamens ; ovary free, forming a 1-celled, 1-seeded drupe in fruit.

\section{DIRCA. Leatherwood.}

Calyx colored like a corolla, its limb obscurely 4-toothed. Stamens 8, exserted. Style 1. Flowers opening before the leaves, 3 from each bud.

D. palus'tris. Shrub 3-5f. high, along streams, with pendent, yellowish flowers in April and May. Drupes small, oval, red. Lvs. oblong-obovate.

\section{DAPHNE. Daphne.}

Calyx colored, funnel-form, limb spreading, 4-parted. Stamens 8, not exserted. Berry fleshy, 1-seeded. Exotics.

$1 \mathrm{D} . \mathbf{M e z e}$ 'reum is a shrub, 2-3f., with very smooth lanceolate leaves appearing later than the side clusters of rose-purple, sweet-scented flowers.-Two or three other species are found in the greenhouse. Europe.

\section{ORDER CXVII. JUGLANDACEÆ. Walnuts.}

Trees with alternate, pinnate exstipulate los. and monœcious flowers; sterile flowers in aments with an irregular perianth ; fertile, solitary, \&c.; \& calyx regular, 3-5-lobed. Fruit a tryma $(\S 172)$ with a fibrous epicarp (shuck) and a bony endocarp (shell); seen large, with lobed, often sinuous, oily cotyledous.

\section{Analysis of the Genera.}

Sterile aments solitary, simple. Epicarp persistent on the tryma.

Jugrang 1

Sterile aments ed, lates $\mathrm{xl}$. Epicarp 4-valved, separating. 


\section{JUGLANS. Walnut.}

f Calyx scale-like, 5 or 6-parted, with about 20 stamens. \& Calyx terminal, 4-parted, with 4 greenish petals and 2 fringed stigmas.

$1 \mathrm{~J}$. cine'rea. Butternut. White $\mathrm{W}$. Tree 40-50f., with wide-spread branches. Leatlets 15-17, lanceolate. Fruit oblong-ovoid. Kernel with two great lobes, rich snd sweet. The wood is used in ornamental work.

8. nigra. Black $W$. Tree 60-s0 ., with a tall straight trunk. Leaflets 15-21, lance ovate, subcordate. Fruit globular. Wood dark purple, used in cabinet-work, very valuable. Seed rich in oil.

\section{CAR'YA. Hickory.}

\& Calyx scale-like, 3-parted, with 4 or 5 stamens. $\&$ Calyx 4-cleft; no petals. Shell smooth and even. Timber very strong.

* Leaflets 13-15, scythe-shaped. Nut oblong, thin-shelled, very sweet....No. 1

* Leaflets 7-11. Nut with a tender shell and very bitter kernel.... Nos. 2, 3

* Leaflets 5-9. Nut roundish, hard-8helled, sweet and eatable....(a)

a Valves of the epicarp distinct to the base. Bark with loose plates... Nos. 4, ?

a Valves of the epicarp united below. Bark solid, firm... Nos. 6-8

1 C. olivæfor'mis. Pecan Nut. Tree 60-90f., in river bottoms, W. and S.W.

2 C. ama'ra. Bitter Nut. Tree 20-40f. Leaflets sharply serrate. Nut white.

3 C. aquat'ica. Tree 30-40f. Leaflets subentire. Nut reddish. Swamps, S.

4 C. alba. Shagbark. Tree 40-50f. Leaflets 5 , the 2 lower smaller. Common.

5 C. sulca'ta. Thick Shellbark. Tree 40-80f. Leaflets 9-11, the odd one subsessile.

Fruit large, oval, 4-furrowed; nut pointed at both ends, shell thick.

6 C. tomento'sa. Mocker Nut. Tree 40-60f. Lfts. 7-9, rough-downy. Little meat

7 C. porci'na. Pignut. Tree 60-100f. Leaflets 5-7, smoothish. Fruit somewha pear-shaped.

8 C. microcar'pa. Tree 60-80f. Leaflets 5-7, glabrous. Nut small as a nutmeg.

\section{ORder CXVIII. LAURACEA. Laurels.}

Trees and $s h r u b s$ aromatic, with alternate, simple, dotted leaves;

sepals colored, 4-6, slightly united, strongly imbricated; anthers 2 or 4-celled, opening upwards by as many valves; cxary 1-ovuled, becoming a drupe in fruit; no albumen.

\section{Analysis of the Genera.}

Flowers perfect, the calyx persistent. Leaves evergreen.....

Flowers imperfect. Calyx deciduous. Leaves deciduous..... b

a Trees. Lvs, thick, lance-oblong. Fls. umbeled. S. Bay Galls. Per'sea. 
b Involucre none. Anthers 4-valved. Leaves lobed. Sassafras. SAA'EAFRAs. ] b Involnere 4-leaved. Anthers 2-valved. Shrubs. Spice-bush. Ben'zoIN.

b Involucre 4-leaved. Anthers 4-valved. Shrubs. S. Pond-spice. Tetranthe Ra.

\section{SASSAFRAS. Sassafras.}

Flowers diœcious, 6-parted, regular. Stamens 9. Trees with decidu ous leaves, expanding after the clusters of yellow flowers.

S. officina'le. Common $S$. Leaves of two forms, ovate and entire, or \&-lobed anid scute at base. Tree aromatic, 10-30f. high.

\section{OrDER CXIX. CUPULIFERA. The Mastworts.}

Trees or shrubs, with alternate, simple leaves, and deciduous stipules, flowers monœcious, the sterile in aments, which are racemed or head-like; stamens in the sterile flowers, 6 to 20 , on the base of the calyx; ovary in the fertile flowers with several cells and ovules, but becoming is: fruit a 1-seeded nut surrounded by an involucre (cup, burr, or sac).

\section{Analysis of the Genera.}

$\$$ Sterile flowers in aments, fertile flowers solitary or 2 or 3 tngether $\ldots .2$

\& Sterile flowers and fertile also in aments, the latter loose and large.....

2 Involucre 1-flowered, cup-like, composed of many little scales..... a

2 Involucre 2 or 3 -flowered, composed of few large valves....b

a Sterile aments slender, calyx 5-eleft, stamens 5 or 10 . Fertile flowers, cousisting of an ovary sitting in a scaly cup, becoming, in fruit, an acorn, 1celled, 1-seeded. A noble genus of trees (rarely shrubs), always known by their peculiar fruit, called acorns. The timber is of great value, especially in ship-building. In the Class Book of Botany, 23 species are described. (See Figs. 82-34, 267.)

Oak. QueRcus. 1

b Involucre of the fruit and fertile flowers a burr with 4 valves. Sterile aments slender, each flower with 5-15 stamens ; 3 fertile flowers in each involucre, which is beset with slender prickles. We have two species, one a tree, the other a shrub. Timber excellent. The fruit is sweet and nutritious. (See Fig. 277.)

Chestnut. CASTA'sisa

b Involucre of the fruit a burr with 4 valves. Sterile aments head-like, suspended by a slender stalk. Calyx 6 -cleft. Two flowers in each burr, which is covered by weak spines. Nuts sharply 3 -angled. They are tall, valuatble forest-trees.

Beech. FaGU

b Involuere a sac, longer than the nuts, torn at the top. Sterile flowers in a slender ament. Shrubs. Usually but one flower or nut in each involuere. 
c Involuere a closed, inflated sac, one-flowered, many together in the pendillons, hop-like cluster. Small trees, with very comract, strong timber, called Hop Hornbeam. Iron-zcooll. Lever-wood. Us'TRYA.

c Involuere an open, 3-lnbed leaf, 1-flowered, Small trees, with a strung, heavy timber. Hornbeam. C'ARPI'nes.

\section{QUERCUS. Oak.}

1 Leaves mostly entire, the ends subequal. petioles very short.... Nos. 1-4

I Leaves 3-lobed and dilated above, awnless when full-grown. Fruit (2)... Nos. 5, 6

8 Leaves 3-9-lobed or pinnatifid, broad; the lobes bristle-pointed. Fruit (2)....(a)

\& Leaves 5-9-lobed, lobes obtuse, never bristle-puinted. Fruit (1), sessile....13-15

\& Leaves 9-25-toothed, obovate, downy beneath, awnless. A corn (1), sweet....16-17

a Leaves at base cuneate, short-petioled. 3-5-lobed. Sbrubs or small trees....7, $\varepsilon$

a Leaves at base abrupt or truncate, mostly long-petioled, 7-9-lobed....(b)

b Nnt one-third immersed in the saucer-shaped, fine-scaled cup...9, 10

b Nut near half immersed in the hemisnherical, coarse-scaled cup....11-12

1 Q. virens. Live Oak. Tree 40-50f., often smaller. Lvs, elliptic-oblong, obtuse, rarely with a few teeth. Peduncle longer than acorn. Timber excellent. Va. and $\mathrm{S}$.

2 Q. cine'rea. Upland Willow O. Shrub 4-20r. Lvs, as in No. 1. Peduncle short. Va. and S.

3 Q. imbrica'ria. Shingle O. Laurel 0 . (Fig. 33.) A handsome tree 40-50f., with dark. shining, lance-oblong, wavy leaves. Nut ruundish, on a short peduncle. W. and S.

4 Q. Phellos. Will ow O. Tree 38-60f. Lvs. linear-lanceolate. often some teeth. N. J. and S. 5 Q. aquat'ica. Water 0 . Tree 20-40, handsome. Leaves glabrous, acute at base. $S$. 6 Q. nigra. Black Jack. Barren 0. Tree small (8-25f.), gnarled. Leaves rustdowny beneath. Lobes obtnse. or in var. triloba with a few awned teeth. M. W. S. 7 Q. Catesbæ'i. Turkey 0 . Tree 20-25f Leaves large, narrowly and irregnlarly lohed. S. 8 Q. illicifo'lia. Scrub 0 . Shrub 4-if. Lvs. regularly 5-lobed, white-downy beneath.

9 Q. rubra. Red O. (Fig. 267.) Tree 50-70f. Lv8. (not deeply) 7-9-lobed, dark-red in autumn. Cup 9-12" broad, nut 1', oblong-ovoid.

10 Q. palus'tris. Pin 0 . Tree 60-80f. Lvs. deeply 5-7-lobed, russet-brown in antumn. Cup 5-7" broad. nut ronnd-oval, 9" long. (Fig. 318, etc.)

11 Q. falca'ta. Spanish $O$. Tree 60-70f. Lvs. ashy-pubescent beneath, lobes falcate. $\mathrm{S}$. 12 Q. cocci'nia. Scarlet $O$. Tree very large (80f.). Lvs. much like No. 9, but turn bright. red in autumn, glabrous, often widening above. Nut half covered by the cup.

13 Q. alba. White 0 . (Fig. 32.) Tree 30-60f. or more, with light-colored bark. Lrs. sinuate-pinnatifid, lobes subequal. Nut immersed. Timber excellent.

14 Q. obtusi'loba. Post $O$. Three upper lobes broader, 2-lobed. Nut immersed. 15 Q. macrocar'pa. Moss-cup 0 . (Fig. 34.) Lvs. deepest lobed in middle. Cup fringed, nearly enclosing the globous nut.

16 Q. bi'color. Swamp White 0 . Lvs. whitened beneath. Acorns in pairs, long-stalked

17 Q. Prinus. Chestnut 0 . Tree or shrub. Lvs. crenate or serrate. Nut subsessile.

\section{Order CXX. MYRICACEA. Galeworts. Analysis of the Genera and Species.}

I Leares lance-linear, pinnatifid, fern-like. Fertile aments globular. Orary surrounded by 6-8 long linear scales. Nut ovoid, smooth. A low (8-3f.) Unsh with peculiarly fragrant leaves.

Seneet Frern. Comptr'sia. 
$\$$ Leaves undivided. Fertile aments ovoid. Drupes gobular, coated with wax or resinous grains. Shrubs growing along shores.

MrRICA (*;

* M. cerife'ra. Bayberry. Lvs. oblanceolate. Drupes coated with white wax.

* M. Gale. Sweet Gale. Lrs. wedge-oblong. Drupes winged, reddish.

\section{Order CXXI. BETULACEA. The Birchworts.}

Trees or shrubs, with deciduous stipules, with the alternate

leaves simple, having the veinlets running straight to the margin;

flowers monœecious, both kinds contained in scaly

catkins, 2 or 3 under each bract; calyx and corolla hardly any;

ovary 2-celled and 2-ovuled, but becoming in

fruit a 1-celled and 1-seeded nut, by the suppression of the other seed and cell.

\section{Analysis of the Genera.}

f bracts with 12 stam. each ; $q$ bracts with mostly 3 ovaries. Birch. BET'vLA. 1 \& bracts with 4-8 stam. each; \& bracts with 2 ova. or fls. each. Alder. ALvus.

BET'ULA. Birch.

$\delta$ in a cylindrical catkin, bracts each with 3 tetrandrous flowers beneath it. $q$ in an oblong or egg - shaped catkin,

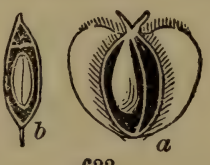

633 bracts 3 -lobed, each with 32 -styled ovaries or flowers, with no calyx. Samara flattened, broadly winged. - Trees and shrubs, mostly with the outer bark in thin layers with horizontal fibres. Catkins appearing in early spring before the leaves.

\& Trees with a yellowish bark, and heart-ovate, serrate leaves.....1

$\S$ Trees with reddish-brown bark, and ovate, doubly serrate leaves....2, 3

Trees with white bark and long-stalked, longpointed leaves....4, 5

s Shrubs with brownish bark, and roundish, crenate leaves. .6.7

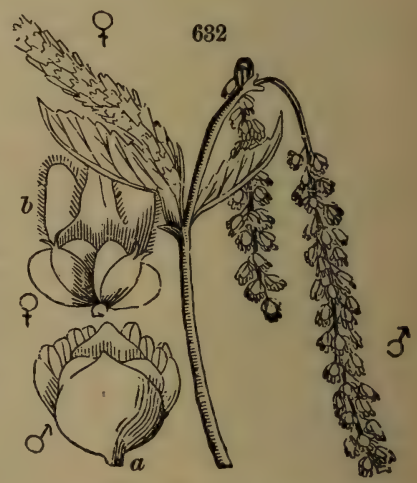

Fig. 632. Sweet Black Birch (Betula lenta), with staminate and pistillate catkins: $a$, a scale with staminate flowers; $b$, with pistillate flowers. Fig. 633. $a$, A winged samara ont length. wise, showing its fertile and sbortive cell: 6 . the same cut across. 
1 B. excel'sior. Yellow Birch. Tree 50-80f. Fertile aments erect, oblong, 1 inck. in length, erect, sterile $2-4^{\prime}$, pendulous, clustered. c. N.

2 B. lenta. Black B. Sraset B. Tree 40-60f. Fertile aments erect, oval, obtuse, stalked; sterile 2-3', pendulous. Inner bark sweet-spicy. M. N.

8 B. ni'gra. Red Birch. Tree 30-50f. Leaves rhombic-ovate, acute at both ends, obscurely lobed. Fertile aments sessile, ovoid. M. S. W.

4 B. populifo'lia. White $B$. Tree 30-40f. Leaves triangular, long-pointed, smooth, unequally serrate. Sterile aments long, pendulous. N.

5 B. papyra'cea. Canoe Birch. Tree 50-70f. Leaves ovate, pointed, doublyserrate. All the aments nodding. Hills and mountains. N.

6 B. pum'ila. Dwarf $B$. Shrub erect, 2-6f. Branches warty. Leaves obovate, obtusely serrate above. Fertile aments cylindric. Mourtains. N.

7 B. na'na. Tiny B. Shrub low, trailing, smooth. Leaves round, crenate. Scales of fertile ament deeply 3-parted. 3-12'. Mountains. N.-H.

\section{Order CXXII. SALICACE E. The Willoworts.}

Trees or shrubs, with simple leares, and stipules usually present; flowers diœcious, naked, both kinds in aments, each with a bract; ovary 1 or 2-celled, with 2 short styles; capsule many-seeded; seeds with a coma and no albumen.
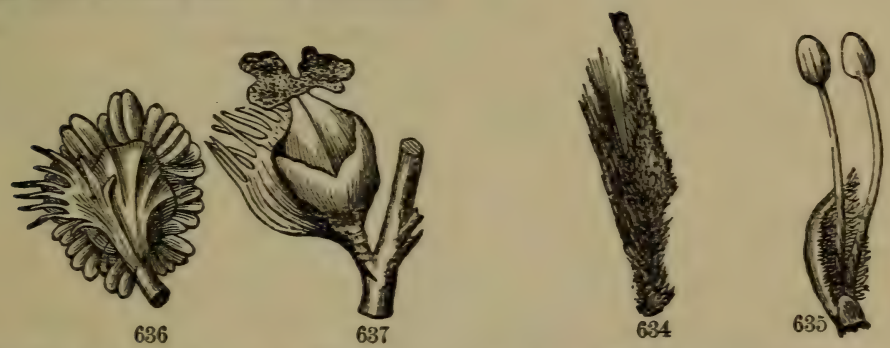

Fig. 634. A fertile flower of a Willow, consisting of a pistil and a bract. Fig. 635. Sterile flower, 2 stamens and a bract. Fig. 636. A sterile flower of Balm-of-Gilead (Populus candi. cans); many stamens. Fig. 637. A fertile flower, eonsisting of a fringed scale, a calyx bolding a double ovary.

\section{Analysis of the Genera.}

5 Aments cylindric, bracts entire. Stamens 2 or more. Capsule 1-celled, 2valved, the seeds very small, clothed with silky hairs. Trees or shrubs. Leaves often long and narrow. (Figs. 12, 17, 88.) We have about 27 species.

Willow. Osier. SA $\mathrm{x}$

5 Aments cylindric, bracts fringed. Stamens 8 or uore. Capsule 2-celled, 2valved. Calyx an entire cup. Buds varnished with a fragrant resin. Leaves broad, large. Trees. 


\section{COHORT IV.}

THE CONOIDS.

\section{Order CXXVII. CONIFER A. Pineworts.}

Trees or shrubs, mostly evergreen, abounding in resinous juice ; lenves scattered or fascicled, mostly linear, parallel or fork-veined. flwoers monœcious or diœcious, naked, in aments and cones. s Stamens 1, or several united. $\&$ Ovules $1-\infty$ naked in the axil of the scale No pistil, calyx, or corolla.

Fruit a strobile or cone with the scales woody and distinct, or berry-like with the scales fleshy and coherent. Illustrated in Figs. 7, 9, 91, 300, \&c.

\section{Analysis of the Genera.}

Scales of the cone each with a bract beneath and 2 seeds above....(a)

8 Scales bractless. Ovules and seeds 1-9. Lvs. scale-like or awl-shaped. ...(b)

a Leaves evergreen, linear, 2-5-together in each fascicle.

a Leaves evergreen, linear, solitary, scattered.

a Leaves deciduous, linear, in fascicles of many together.

b Cones berry like, consisting of the fleshy coherent scales.

Pine. Prnes. 1 Spruce, dec. AвIEs. 2

Larch. LARIX. 3

b Cones dry, scales imbricated. Leaves scale-form, opposite, 4-rowed.

b Cones dry, globular ; scales angular, valvately closed until ripe....(c)

c Leaves scale-form, opposite, 4-rowed. C'ones small (3'). White Cedar. Cuprassus.

c Leaves linear, alternate, deciduous. Cones 1' diameter. Cypress. Taxodiux

\section{PINUS. Pine.}

Leaves in 5s. Scales spineless, scarcely thickened at the end.... No. 1

Leaves in 3s.--a Cones oblong, with small recurved spines....2, 3

-a Cones egg-shaped, with weak or strong spines....4, 5

f Leaves in 2s.-b Scales tipped with spines or prickles....6, 7

b Scales without spines....8, 9

1 P. Strobus. White Pine. A majestic tree 100-170f. in the forests. Leaves needleshaped, 4-5', not rigid. Cones pendulous, oblong $5-\tau^{\prime}$. Timber of great value.

2 P. austra'lis. Long-leaved $P$. Tree 60-100f., very resinous. Leaves 10-15' long, crowded. Cones 1f. long. S. Excellent for timber, turpentine, or fuel.

3 P. Tæda. Loblolly P. Tree 50-90f. Leaves 6-10', with long sheaths. Cones half a long as the leaves, with small but strong spines. Excellent fuel. Va. and S.

4 P. sero'tina. Pond $P$. Tree 30-50f. Lvs. 5-8', rigid. Cone as large as a goose egg, smooth and shining, nearly spineless. Grows in wet woods, South.

5 P. rig'ida. Pitch $P$. Tree 30-70f., with very rough bark. Leaves rigid, 4-6 Spines stout, recurved, cones clustered, ovoic-conic, 2-3'. In sandy barrens.

j 5 . mitis. Yellow P. Spruce $P$. Tree of slow growth, 30-60f. Leaves often in $3 s_{\text {, }}$. nut mostly in pairs, slendcr, $3-5^{\prime}$. Cone scarcely $2^{\prime}$, ovoid-conic. Timber goud. 
7 P. pungens. Tree 20-30f, with crooked branches. Lvs. about 2', stont, crowder. Cones ovoid, $3^{\prime}$, with stout spines $3^{\prime \prime}$ long. Mts. Pa. and S.

S P. inops. Jersey $P$. Scrub $P$. Tree 15-25f., rough and crooked. Leaves rigid, obtuse, 2-3'. Cones ovoid-oblong, 2-3', with straightish prickles. Barrens.

9 P. resino'sa. Norway $P$. Red $P$. Tree 60f., with smoothish bark. Lvs. 5-6', slender, with long sheaths. Cones ovoid-conic, 2-3'. Dry woods, northward.

10 $P$. Hudso'nica. Bank's $P$. A straggling shrub 5-25f. Lvs. 1' long, curved and stift, the cones some longer, recurved, smooth. Rocks, Me. and W.

\section{AB'IES. Spruse. Fir. Hemlock.}

Fir. Cones erect, the scales deciduous. Lrs. flat, spreading two ways.... Nos. 4, 5

$\$$ Spruce. Cones nodding. Leaves 4 -sided or ensiform, pointing all around...2, 3

\& Hemlock. Cones hanging. Leaves flat, mostly spreading two ways.... No. 1

1 A. Canaden'sis. Common $H$. Tree 50-80f, elegant while young. Leaves shortlinear $\left(6-8^{\prime \prime}\right)$, glancous beneath. Cones ovoid, terminal, as long as the leaves. Scales concealing the bracts. Rocky woods. Timber inferior, but useful.

2 A. nigra. Double $S$. Tree pyramidal, 50-80f. Leaves 6-7", dark-green. Cones ovoid 1-2', scales erose-denticulate. Damp mountain woods, northward.

3 A. alba. Single S. Tree 30-80f., pyramidal. Leaves 6-9", glaucous. Cones deciduous, cylindrical, $2^{\prime}$, with the scales entire. Common in rocky woods.

4 A. Fra'seri. Double Balsam Fir. Tree small, 15-30f. Bark blistered with reser. voirs of balsam. Lvs. 8-10'. Cones oblong 1-2'; bracts long-pointed, reflexed. Mountains. This and the next are handsome and often cultivated.

5 A. balsa'mea. Balsam $F$. Tree 30-50f. Bark as in No. 4. Lvs. 8-10", obtuse, silvery beneath. Cones $3-4^{\prime}$ by $1^{\prime}$, cylindrical; bracts scarcely exserted.

\section{LARIX. Larch. Tamerac.}

1 L. America'na. American L. (Fig. 91.) A beautiful tree, 70-100f. Leaves filiform. soft, 1-2'. Cones 6-10", dark-purple, the few rounded scales each with 2 winged seeds. Var. pendula has slender, drooping branches.

2 L. Europæ'a. A large tree with flattened leaves, and cones 12-18" long. From Eur.

\section{JUNIP'ERUS. Juniper.}

$\S$ Leaves all subulate and in 3 s, spreading, jointed to the stem, 1-nerved... No. 1

$\S$ Leaves scale-form, opposite, 4-rowed, appressed, some of them awl-shaped....2,3

1 : commu'nis. Common J. (Fig. 7.) Shrub or low tree, often prostrate. Leaves crowded, pungent-pointed, 6-8'. Fruit small (2/2), dark-purple, sweetish. Woods and mountains.

2 J. Virginia'na. Red Cedar. Tree 30-40f,, dark-green. Early leaves, awlshaped, 3-4", some spreading ; later ones scaleform. Fruit blue-white. Rocky soils. Timber red, durable, used for posts or lead-pencils.

3 J. sabi'na. A trailing shrub. Fruit larger $\left(3^{\prime \prime}\right)$, nodding, dark-purple. Rocks, N

ORder CXXVIII., TAXACE无, The Yews, is represented in our flora by the genus Taxus, and species T. Canadensis, Yew, a low, Jr prostrate shrub. (Fig. 301.) 


\section{O H O R T V.}

\section{SPADICIFLORA, OR THE APETALOUS ENDOGENS.}

\section{Order CXXXI. ARACEA Aroids.}

Chiefly herbs with a fleshy rootstock of corm; leaves sometimes net-veined flowers mostly without calyx or corolla, arranged on a spadix; stamens few or many, hypogynous, very short; anthers turned outwards ovary free; stigmas sessile; fruit a dry or juicy berry, and the seeds with or without albumen. Growing in wet places.

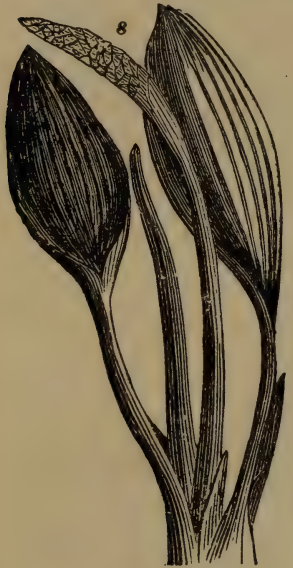

642

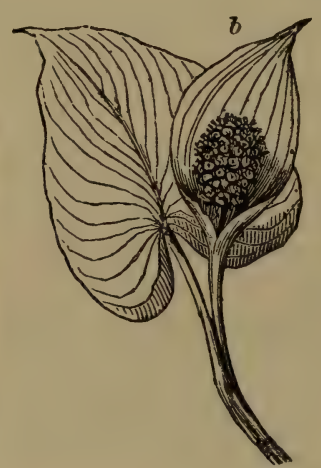

638

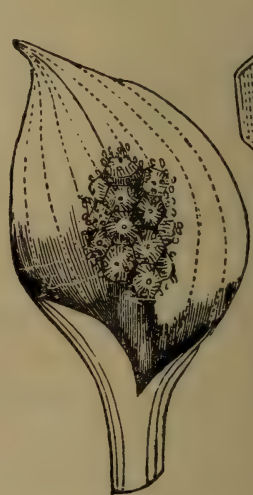

639

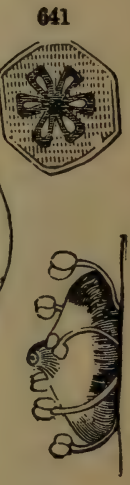

640

Fig. 688. Wild Calla (Calla palustris), a leaf, and a spadix of flowers, with its spathe (b) Fig. 639. The same enlarged. Fig. 640. A flower enlarged. Fig. 641. One of the berries cut ahowing the 6 cells. Fig. 642. Golden Club (Orontium aquaticum); its spadix $(s)$ is without spathe.

$$
\text { Analysis of the Gene" } a \text {. }
$$

- Spadix elveloped in a spathe....2

Epadix destitute of a spathe. Sepals 4-6...d

2 Flowers covering only the base of the spadix. Perianth $0 \ldots$ a

2 Flowers covering the whole spadix, monœcious. Perianth $0 \ldots . . b$

2 Flowers covering the whole spadix and perfect.... 
Spathe rolled in at base. Top of spadix club-shaped. Dragon-root. Aris z'MA. 1 b Spathe rolled inwarls the whole length. Amowo-lvd. Dragon. Peltax'dra. \&

b Spathe rolled backwards above, white. Egyptian Calla. Richar'dia. c Perianth 0. Spathe open, flattish, white. Lrs. cordate. Wild Calla. Calda. - Perianth regular. Spa. shell-form. Lvs. large. Skunk-cabbuge. Srarplocar'PUs. d Flowers terminal, yellow. Scape terete. d Ficwers lateral, green. Scape leaf-like. Golden Club. Orontics. Sweet Flag. A'corvs. 3

\section{ARIS EAMA. Arum. Indian Turnip.}

Spathe rolled inward at base. Spadix covered with flowers below, naked and club-shaped above. Sterile flowers above the fertile, each a clump of 4 stamens. Fertile flowers each a 1-celled ovary, with a flat stigma. Berry red, with 1 or several seeds.-Oddl-looking plants, with scape arising from a corm or rootstock, and sheathed with the radical leaves. Taste very acrid.

1 A. triphyl'lum. Jack-in-the-Pulpit. Leaves usually 2, trifoliate. Spathe bent and inflected above, covering the obtuse spadix, striped.

2 ^. quina'tum. Five-leaved Jack. Leaves in pairs, one or both quinate. S.

3 A. Dracon'tium. Green Dragon. Leaf mostly solitary, pedate, 7-11-foliate.

\section{PELTAN'DRA. Arrow Dragon.}

The sterile flowers consist of 8-12 anthers attacked to the border of a shield-shaped (peltate) connectile.-Root fibrous. Leaves sagittate.

1 P. Virgin'iea, Firginia A. Spathe green, incurved, long, wavy on the margin. Leaves many, large, hastate-sagittate, very smooth, dark.

2 P. glau'ca. Glaucous A. Spathe wh te, entire, gradually unrolled and widened above. Leaves ovate-sagittate, the base lobes large. S.

\section{AC'ORUS. Sweet Flag.}

Spadix cylindric, sessile, issuing from the side of a leaf-like scape without a spathe. Perianth of 6 sepals. Stamens 6 . Fruit capsular, 3-celled, $\infty$-seeded. थ4 Rhizome thick, aromatic. Leaves all radical, linear-swordshaped like the scape.

A. cal'amus. The Sweet Flag grows in swampy places throughout the conntry. The long sword-shaped leaves are marked by a ridge running their whole length (2-3f.). Spadix about $3^{\prime}$ long, yellowish-green, borne midway of the length of the leaf-like scape. Root a thick, creeping rhizome, much valued for its warmly mugent qualities. 


\section{Order CXXXII. TYPHACEA. Typhads.}

Herbs growing in marshes and ditches, with rigid, sword-shaped leaves; flowers monœcious, arranged on a spadix or in heads with no spathe; perianth of a few scales, or a tuft of hairs, or 0 ; stamens $1-4$, slender; ov ry 1 -ovuled, nut-like and 1-seeded in fruit.-Comprises 2 genera.

\section{Analysis of the Genera.}

s Cat-tail. Reed-mace. Spadix long-cylindric, brownish green, the sterile flowers above, the fertile innumerable, packed solid in the lower part. Stem with its terminal spadix 3-4f., the leaves 4-5f. long.

TYPHA.

8 Burr-reed. Spadices or globular heads many, the lower fertile; pistils sessile, each with 3-6 scales for a calyx. Upper heads staminate.

SPARGA'NIUM

\section{ORDER CXXXIII. NAIADACFA. Naiads.}

Water plants, with sheathing petioles or stipules, and jointed stems ; floners often perfect, with a perianth, or imperfect and naked; with stamens definite, ovaries free, sessile, and 1-sceded indehiscent fruit.

The Naiads grow in rivers, lakes, or seas. They have linear, grass-like leaves, and some of the Pondweeds have broad or oval leaves beside.

Potamoge'ton (Pondweed) is the principal genus. Its flowers are perfect, greenish, clustered on spike-like spadices which arise just above the water while in bioom. The stamens, sepals, and ovaries are each 4 , and the fruit 4 achenia. We have about 20 species, all in fresh water. Eight of these have two kinds of leaves; the submersed liuear, the floating elliptical. The other species have all their lvs. submersed and linear. (See Botanist and Florist.)

\section{COHORT VI.}

\section{FLORIDEA, OR THE FLOWERING ENDOGENS.}

\section{Order CXXXIV. HYDROCHARIDACEA. Frogbits.} Aquatic herbs with regular, imperfect flowers growing from a apathe; perianth 3 or 6 -parted, the inner segments petaloid; stamens 3-12; ovary adherent, 6-9-celled; fruit indehiscent, many-seeded. 


\section{Analysis of the Genera.}

1 Frog ${ }^{\circ}$-bit. Leaves all radical, round-cordate, spongy beneath, floating in stagnant watess. Flowers diœcious, white, the fertile on short, the sterile on long $\left(3^{\prime}\right)$ peduncles. Berry many-seeded.

LIзNo'BIUM.

Ditch-moss. Leaves crowded on the long submersed stems opposite or whorlec, linearoblong. Periantl white, 6-parted, its base extended into a capillary tube 4-10' long! Stigmas 3. In brooks and rivers.

ANACH'ARIS.

¿ Elel-grass. Leves all radical. grass-like in water. Flowers diœcious, the fertile white one on each long spiral thread-form scape; the sterile in clusters at the root, but breaking away and arising to the surface to open and shed their pollen.

VALLISNE'RIA spira'lis.

\section{Order CXXXV. PONTEDERIACEA. Pontederiads.}

Aquatic herbs with more or less irregular perfect flowers, with the perianth colored, tubular, 6-parted, stamens 3 or 6 , and style 1 ; ovary free; capsule 3 or 1 -celled, $\infty$ or 1 -seeded.

\section{Analysis of the Genera.}

- Stamens 6, nnequal. Perianth blue, 2-lipped. Utricle 1-seeded.

PONTEDeria, $]$

* Stamens 3, unequal, the lower one sagittate. Capsule 3-celled, $\infty$-seeded. Perianth white or blue, 6 -parted, with a slender tube.

HETERANTHE'RA

- Stamens 3, equal. Capsnle 1-celled, $\infty$-seeded. Perianth regrularly 6-parted, yellow, it tube very long $\left(2-3^{\prime}\right)$ and sleuder. Leaves grass-like, growing whully under water Water Star-grass.

SCHOL'LERA.

\section{PONTEDE'RIA. Pickerel-weed.}

Large showy herbs growing in patches extending from the shore to deep water. Leaves radical, long-stalked. Stem or scape bearing 1 leaf and a terminal spike of showy flowers lasting but a day.

1 P. cordifo'lia. Leaves between heart-and arrow-shaped, blunt, very smooth, and shin ing. Scape stout, arising 1-2f. above the water. Flowers violet blue, very irregular, in a spike 2 or $3^{\prime}$ long. After flowering the corolla rolls downward from the top, persisting and withering on the 1-sceded fruit. Common. July.

2 P. lancifo'lia. Leaves lance-oblong to lance-linear, rather acute at each end. South.

\section{Order CXXXVI. SMILACACEA. Greenbriers.}

IIerbs or shrubs often climbing. Leaves reticulate-veined. Fls. diœcious; nerianth 6-parted, regular, free from the 3-celled ovary. Fruit a berry.

\section{SMILAX. Greenbrier.}

Leares palmate-veined, entire, petiolate, with a pair of tendrils in the .lace of stipules. (See Fig. 95.) Flowers greenish, in axillary umbels 
I S. herba'cea. Carrion-flower. Stem herbaceous, erect or reclined, without frickles. Lvs. ovate-nblong, 7-veined. Flowers 8-50 on each long peduncle, ill-scented.

2 s. rotundifo'lia. Common Greenbrier. Vine green, strong and thorny, somewhat 4-angled. Leaves round-ovate, 5-7-veined, cusp-pointed. Peduncles a little longer (6-7'n than the petioles. Berries bluish-black. Thickets. 10-30f.

$3 \mathbf{S}$. hispida. Vine teretc, bispid with weak prickles if any. Lvs. thin, ovate, cuspidate Peduncle twice as long $\left(1^{\prime}\right)$ as the petioles. Berries black. Thickets.

\section{ORDER CXXXVII. ALISMACE $A$. Alismads.}

Herbs growing in water, with the leaves parallel-veined, and with the flovers regular and not on a spadix ; the perianth consisting of sepals and petals, 3 of each, the former always green ; ovaries free, 3 or more, separating into as many 1 -seeded achenia.

Analysis of the Genera.

\& Both the calyx and corolla greenish. Lrs. rush-like (Arrow-grasses) .....b

\& Corolla colored, white. Leaves mostly with a lamina....a

a Fls. ६̧. Sta. 6. Carpels whorled. Water Plantain. Alisma. 1

a Fls. ̧. Stamens 9-24. Carpels in a head. Echinodore. Echinodorus.

a Fls. 8. Sta. many. Carpels in a head. Arrow-head. Sacitraria. 2 b Lvs. radical. Anthers ovate. Carpels 1 seeded. Trigloch. Trig Lochis. b Leaves cauline. Anthers linear. Carpels 1-2-seeded. Soheuchzeris.

\section{ALISMA. Water Plantain.}

Flowers perfect. Stamens 6. Ova. ries and styles numerous, collected into a whorl, becoming in fruit many distinct, flattened achenia.- 24 Stemless herbs, the leaves all radical. Flowers in a panicle.

A. planta'go. A common, smooth, handsome inhabitant of ponds and ditehes. Leaves oval or ovate, abruptly acuminate, 7-9-

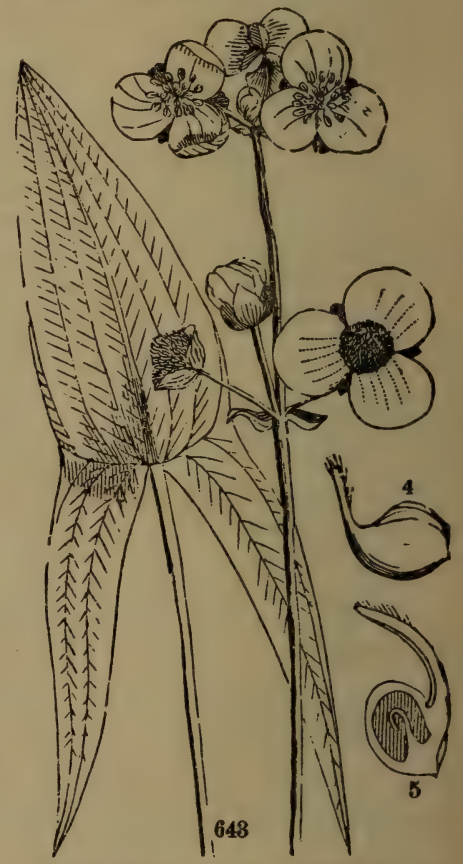

Fig. 643. Sagittaria sagittifolis (common form), leaf and flowers. 4. One of the pistils enlarged. 5. The pistil of Alisma cut open, showing the seed and eurved embryo. 
veined, entire, on long petioles. Scape 1-2f. high, branching in whorls, bearing $\mathrm{n}$ merous purplish-white flowers, in July.

\section{SAGITTA'RIA. Arrow-head.}

Flowers monœcious, rarely diœcious, the of with about 24 stamen; the $q$ with numerous ovaries crowded in a head, and becoming in fruit as many compressed, margined achenia. -2 Stemless plants, leaves ralical, generally arrow-shaped. Flowers in whorls of 3's, the sterile ones above the fertile.

S. variab'ilis. A curious plant, conspicuous with its large white flowers among the rushes and sedges of sluggish waters. The petals are wholly white, and the scape simple, with the stalks 1-flowered. The leaves are generally arrowshaped (as seen in the figure), but exceedingly variable, sometimes lanceolate, and sometimes even consisting of a petiole only. About $1 \mathrm{f}$. high. July.

\section{Order CXXXVIII. ORCHIDACE $A$. The Orchids.}

Herbs perennial, with thick, fleshy roots; entire, parallel-veined leaves; flowers very irregular, but the perianth consisting always of 6 parts, viz., of 3 sepals and 3 petals, all usually colored, the lower petal called the lip differing in form from the others, and frequently spurred at base; stamens 3 , but only 1 or rarely 2 of them perfect, united with the style and forming what is called the column; anthers 2, 4 or 8-celled; pollen powdery, or waxy, or granulated; ovary 1-celled, many-seeded.

\section{Analysis of the Genera.}

* Stems greer, furnished with one or more leaves....2

* Stems green, furnished with sheaths instead of leaves....d

* Stems brownish, furnished with sheaths and no leaves, or a late one....c

2 Corolla lip very large, inflated and sack-like.....

2 Corolla lip of various forms, but neither very large nor sack-like....8

3 Corolla prodaced into a spur behind....b

3 Corolla destitute of a spur....4

4 Flowers small, many, in a loose raceme, beardless....

4 Flowers small, many, in a close, twisted spike, heardless....f

4 Flowers showy, purple or yellow, few or 1 only....g

a Root fibrous. Lip obtuse, spurless. Anthers 2. Lady's-slipper. CrPripe'rrox. 1

a Root a corm. Lip 3-lobed, 2-spurred. Anther 1.

Calyp8o. CaI Yr'sú. 


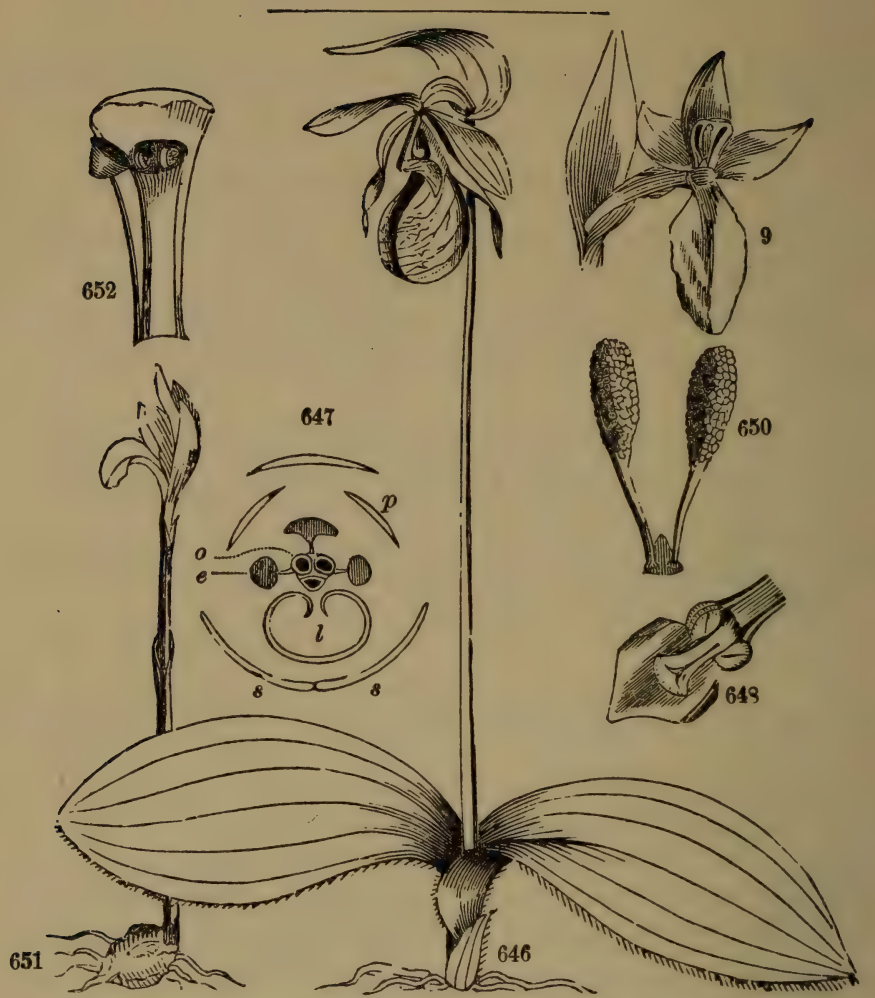

Fig. 646. Lady's-slipper ('ypripedium acaule), whole plant, with its 2 leaves, scape, and curious flower. 7. Plan of the flower; $s$, sepals (outer circle), the 2 lower united; $p$, the petals; l, lip (lower petal); $e$, the anthers, upper one sterile; $o$, the 3-celled ovary. 8 . The column seen rom beneath, with the pistil, two stamens. and the leaf-like sterile one. 9. Flower and bract of Jrchis spectabilis. Fig. 650. Its 2 pollen masses exhibited (enlarged). 1. A rethusa bulbosa; $\mathscr{f}$, he flower. 2. Its column enlarged, with its lid-like anther opening, showing its pollen-masses reneath.

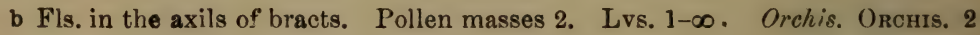

b Flowers bractless. Pollen masses 4 . Leaf 1 only. Tipula. Trpula'ria. - Root coraline. Spur growing to the ovary. Luss. none. Coral-root. Corallorhi za. a c Root 2 corms. Spur none. Leaf 1, late, radical.

d Flowers 1 only, rose-purple. Lip bearded. Arethusa Aretru'sa. 1

d Fls. racemed, dark-purple, beardless. (Lrs. 0 or few.) Bletia. Bletia. - Leaf 1. Lip sagittate. Column minute. Micros'tylis. Micros'try Lis. - Leaves 2, radical. Lip flat, ascending. Column winged. Liparis. LIP'ARIs. e Leaves 2, cauline. Lip pendulous, 2-lobed or 2-cleft. Tway-blade. Listeru 
f Leaves all green. Lip obtuse, erect. Ladies' Tresues. SpIRAN'THLs. 5

f Loaves netted witn white. Lip pointed, reflexed. Rattlesnake Plantain. Goodye'ra. f Lvs. all green. Lip 3-lobed, recurved. South. Cranichis. Pouthieva. 6 Lip on the upper side of the fl., bearded. Leaf linear. Grass Pirk. Calopo'Gon. 6 8 Li:p on the lower side (ovary twisted as in the other genera)....h

h Column free from the lip. Flowers purplish. Beard Pink. Pogo'nia. 7

h Column growing to the lip. Yellow. On trees. S. Tree Orchis. Epiden'drum.

\section{CYPRIPE'DILM. Lady's-slipper.}

The 2 lower sepals united into one piece or rarely distinct. Lip very large, inflated, sack or slipper form, obtuse. Column terminated by a petal-like lobe (which is the sterile stamen). Fertile stamens 2.-Root fibrous. Leaves large, plaited. Flowers large and showy, one or few May--July.

* Flowers yellow, one or more. Stems leafy....5, 6

* Fiowers white or rose-purple....1

1 Stem leafy. Flower one or more....2-4

1 C. acau'le. Stemless L. (Figs. 642-644.) Scape naked, with 2 leaves at the base; and 1 large flower at top. $c$.

2 C. can'didum. White $L$. Two lower sepals united. Flowers 1 only, smaller, white. W. S. $r$.

s C. spectab'ile. Showy L. Two lower sepals united. Flowers few, very large, purplish. $c$.

4 C. Arieti'num. Ram's-Head L. Two lower sepals separate. Flower $\mathbf{3}$ only, small, purplish. $r$.

5 C. pubes'cens. Large yellow L. Moccasin Fl. Sepals narrow-lanceolate. Lip flattened at sides, pale yellow. c. (Fig. 89.)

6 U. parvifio'rum. Smaller yellow $L$. Sepals ovate-lanceolate. Lip flat abeve and below, bright jellow. $c$.

\section{ORCHIS. Orchis.}

Flower ringent, sepals and petals similar; all, or all but two, ascending and arching over the column. Lip turned downward, entire or lubed, produced at base into a spur beneath, which is distinct from the ovary Dtamen 1, anther 2-celled, pollen-masses 2, consisting of numerous waxy grains.-Flowers geneially showy, in spikes or racemes. June-Aug. mostly.

Note.-Under this genus we include two others, viz.: Gymnalenia and Platarthera The beginner would find it difficult to separate them. See Class Book of Botany, p. 652. \&c. No. 1 is the true Orchis. Nos. 8,9,10, are Gymnadenia, and all the others belong to Platanthera 
\& leaves radical and only 2 (rarely 3 ). Flowers on a scape....1-8

$\S$ Leaf radical and only 1 . Flowers small, on a scape....4, 5

$\S$ Leaves on the stem, several, upper ones reduced to bracts..... a

- Corolla lip entire, neiiner lobed, fringed, nor toothed....6-9

a Corolla lip 2 or 3-toothed, not fringed nor divided. Flowers greenish...10-12

a Corolla lip cleft into a fringe at the edge, but not divided....13-i 5

Corolla lip divided into 3 parts, which are fringed or not....b

b Flowers white or yellowish, with 5 iong bristles, the 2 side petals 2-partec S....16, 17 .

b Flowers white, the 2 side petals entire or toothed ; lip clawed....18, 19

b Flowers purple, numerous, showy : lip raised on a ciaw ...20-22

1 O. spectab'ilis. Shonoy Orchis. True Orchis. Fls. few, pink-purple, handsom:Leaves oblong-ovate. Height 4-7'. (Figs. 649, 650.)

2 O. orbicula'ta. Round-lv. $O$. Fls. whitish, racemed. Spur very long. Leaves round. Scape bracted.

3 O. Hook'eri. Hooker's $O$. Flowers green, spiked. Spur long as ovary. Leaves round. Scape naked.

4 O. obtusa'ta. Blunt-lv. O. Leaf obovate, obtuse. Lip linear, entire. 5-8', r.

5 O. rotundifo'lia. Small Round-lf. $O$. Lf. round. Lip, mid. lobe obcord. 6-9'. $r$.

6 O. hyperbo'rea. Northern 0 . Flowers greenish. Lip, petals, leaves, and bracts. lanceolate.

7 O. dilata'ta. Broad-lip 0. Flowers whitish. Lip lance-linear, rhombic at bast.

8 O. niv'ea. Snowy $O$. Flowers white. Lip oblong-linear. Leaves linear. S.

9 O. nigra. Black $O$. Flowers yellow, close. Lip ovate. Leaves lance-oblong. 10 O. tridenta'ta. Trident $O$. Lip 3-toothed at end. Spur longer than ovary

11 O. bractea'ta. Bracted 0 . Lip 2-3-toothed at end, spur half as long.

12 O. fla'va. Sinall yellow O. Lip obtuse, with a tooth each side, spur long.

13 O. crista'ta. Crested yellow $O$. Flowers yellow, small, lip as long as the spur.

14 O. cilia'ris. Large yellow $O$. Flowers yellow, large, lip half as long as the spur.

15 O. Blephariglot'tis. Ox-tongue $O$. Fls. white, large ; 2 side petals cut-toothed.

16 O. Mivhauxii. Michaux's $O$. Leaves oval. Spur twice as long as ovary.

17 O. re'pens. Five-bristled $O$. Leaves lance-linear. Spurshorter than ovary.

18 O. leucophæ'a. White Prairie $O$. Bracts shorter than the ovaries. Lip fanshaped, 3-parted, fringed. Spur club-shaped, twice longer than ovary.

19 O. Lac'era. Ragged $O$. Bracts longer than the flowers. Petals notched at end. Lip segments wedge-shaped, fringed. Spur filiform, long as ovary.

20 O. amena. Prairie O. Flowers dark-purple. Lip broad, lobes toothed, not fringed. M. W. S. $c$.

21 O. Psyc'odes. Fringed $O$. Flowers light-purple. Lip wedge-shaped, the 2 petals merely toothed. $c$.

22 O. grandiflo'ra. Great-fl. 0 . Flowers light-purple. Lip semicircular, lange. 2 petals fringed. $r$. 


\section{CORALLORHI'ZA. Coral-root. Dragon's-claw.}

Flower ringent. Sepals and petals similar, ascending, the upper arch. ing. Lip produced behind into a short spur, which grows closely to the ovary. Pollen-masses 4, oblique.-Herbs without green herbage, leafles, with coraline roots, and spikes of dull-colored flowers. May-Sept.

1 Spur imperceptible. Lip not lobed, often with 2 teeth at base....2, 3

1 C. multifio'ra. Many-flowered $C$. Spur manifest. Lip 3-lobed (the side lobee smail), spotted. Flowers 10-20, purple. Height 10-15'.

2 C. odontorhi'za. Dragon's-claw. Flowers 9-18, purple. Lip orenulate, spotted.

Ovary and pod nearly globular. Seape 9-14'.

3 C. inna'ta. Lasser C. Flowers 5-10, purplish. Lip obscurely 2-toothed near the base, spotless. Orary and pod elub-shaped. 5-6'.

\section{ARETHU'SA.}

Sepals and petals cohering at base, similar, ascending, arching. Lip spurless, deflexed at the end, bearded inside, cohering to the petal-like column at base. Anther terminal, closing the 2 pollen cells like a lid. Pollen-masses 2 in each cell.-Small plants, 1 -flowered, in wet places. Leaves none, or hidden in the sheaths.

A. bulbo'sa. A beantiful plant 6-12' high, invested with about 3 long loose sheath with lanceolate points (bardly leaves). At the top is a large, fragrant purple flower, in June. (See Figs. 651, 652.)

\section{SPIRAN'THES. Ladies' tresses.}

Flowers in a spiral spike, scinewhat ringent. Petals and sepals nearly erect, all tending to the upper side opposite the lip. Lip raised on a short claw, concare, entire, widened at top and furnished with 2 callous processes at base. Colnmn arching, pollen-masses 2.-Stem leafy below or nearly naked, bearing a spike of small, white flowers, which are bent sideways and horizontal. July-Oct. (Fig. 240.)

* Fls. in a single row on one side, and but little twisted. Lrs. radical....1, 2

* Fls. in several rows all aronnd the short spike. Lrs. on stem below....3,4

$1 \mathrm{~s}$ grac'ilis. Slender $L$. Leares ovate, rarging to lance-oblong. Lip obovate, wavg-crisped.

$2 S$ tor'tilis. Twisted $L$. Learęs linear, enrly withering (like first). Lip 3-lobed, fincly erenate. 
8 S latufo'lia. Broad-lx. L. Leaves oblong-lance. 2-4' long. Spike dense Lip oblong, blunt, crisp.

4 S. cer'nua. Nudding L. Leaves linear-lanceolate, 3-10' long. Spike denra Lip oblong, round, crisp.

\section{CALOPO'GON. Grass Pink.}

Flower with the sepals and petals similar, spreading, distinct. Lip on the upper side of the flower, stalked at base and bearded above. Column winged at the summit. Pollen-masses 2.-Leaf sheathing the base of the scape, which is bulbous at base. Flowers several. (Fig. 655.)

C pulchel'lus. A handsome plant, common in moist meadows and in bogs. Scape slender, 1-2f. high. Leaf sword-shaped or broad linear, long. Flowers pinkpurple, remarkable for having the lip on the upper side and the column below. July.
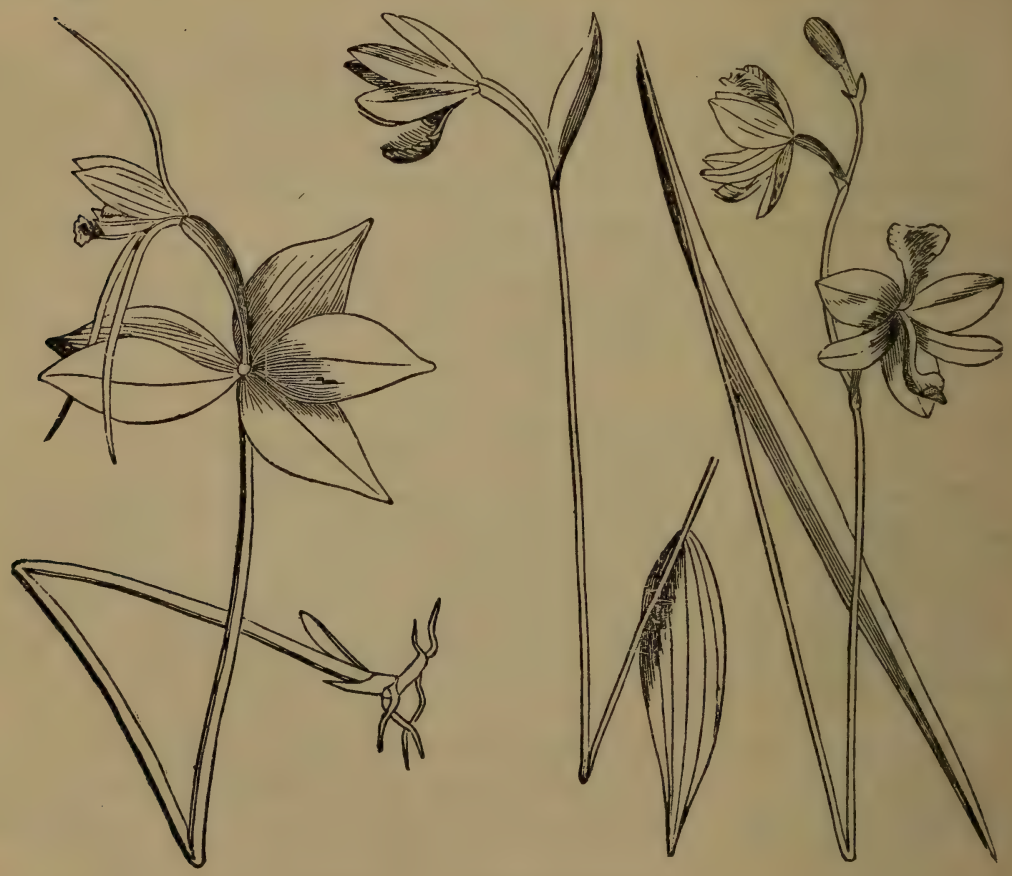

Fig. 058. Pcgonia verticillata. Fig. 654. Pogonía ophiglossindes. Fig. 655. Caloprgon pulchellua 


\section{POGO'NIA. Beard-flower.}

Flower with its sepals and petals distinct and somewhat spreading. Lip bearded inside, sometimes 3 -lobed. Column club-shaped, wingless; anther terminal, pollen-masses 2, mealy.-Leaves 1-5, on the stem. Flowers purple. June-Aug.

* Sepals linear, spreading, much longer than the petals....1, 2

* Sepals and petals nearly equal, similar, and nearly erect....3, 4

1 P. verticilla'ta. Whorl-leaved $B$. Leaves 5 , in a whorl near the 1 brownish flower. Sepals 2 long. $\quad r$. (Fig. 693.)

2 P. divarica'ta. Spreading B. Leaves 2, alternate, distant, lance-oblate. Lip 3-lobed, crenulate. $\mathbf{S}$.

3. P. ophiglossoi'dos. Adder-tongue B. Leaves 2, distant, upper bract-like. Flowers terminal, pink-colored. (Fig. 694.)

4. P. pen'dula. Nodding B. Leaves 3-4, alternate, with as many pink-white, drooping flowers.

\section{ORDER CXL. AMARYLLIDACE E. The Amaryllids.}

Herbs perennial, mostly bulbous, with linear leaves, with the flowers showy, mostly regular and on scapes, hexandrous ; perianth of 6 similar pieces united below and adherent to the ovary, which is 3 -celled, with the styles united into 1 ; fruit a capsule or berry, with albuminous seeds. (Fig. 137.)

\section{Analysis of the Genera.}

$\S$ Perianth bearing a crown on the summit of its tube... a

$\S$ Perianth destitute of a crown....2

2 segments united into a tube above the ovary.... b

2 Segments distinct down to the ovary. Flowers nodding....3

3 Perianth irregular....c

3 Perianth regular....d

a Crown a thin membrane connecting the stamens. S. PANCRA'TIUM.

a Crown a firm cup containing the stamens. Narcissus. NARCIs'sus. 1

b Flr. solitary. Perianth-tube straight, erect. Atamasco L. ZePHYras'thuts.

b Flowers many. Perianth-tube straight. Amorican Aloe. AGAvE. 2

b Flowers many. Perianth-tube curved. Tuberose. Polyanthucs.

c Stamens declined and curved. Scape with 1. Jacobea Lily. Sprekelis.

d Sepals all white, larger than the petals. Snow-drop. GaLanthus.

d Sepals green-tipped, as large as the petals. Snow-flake. Leucosur. a Sepals and petals equal, yellow. Star-grass. Hypoxis. 


\section{NARCIS'SUS. Jonquil. Daffodil.}

Perianth regular, crown of one piece, funnel-form or bell-form, consisting of a whorl of sterile petal-like filaments united by their edges, within which the fertile stamens are inserted. $-A$ beautiful genus of bulbous plants with sword-shaped leaves and yellow or white flowers. None lere native. + April-June.

* Scape bearing 1-3 large flowers....2-4

* N. Tazet'ta. Polyanthus. Scape many-flowered, sep. white, crown yellow, short.

2 N. Daf'fodil. Daffodil. Scape 2-edged. Sepals whitish. Crown ycllow, long and large.

3 N. Jonquil'la. Jonquil. Scape terete. Crown yellow, much shorter than the yellow sepals.

4 N. poet'icus. Poet's Narcissus. Scaps terete. Crown variegated, rotate, short; sepals mostly whitc.

\section{AGA'VE. American Aloe.}

1 A. Virginica False Aloe. Scape simple, 5-6f. high. Flowers in a spike, greenish-yellow. Leaves linear-lanceolate, serrate. Penn. S.

2 A. America'na. Century Plant. Seape branched, 15-25f. high, bearing 1 vast panicle of yellow flowers, after many years. Leaves very thick, lanceolate, spinous-dentate, often striped. †

\section{ORDER CXLIII. IRIDA'CEA. The Irids.}

Perennial herbs, arising from bulbs or thickened roots ;

leaves 2-rowed ; flowers perfect, regular or irregular, spathaceous ;

perianth of 6 petal-like segments; stamens 3 ; anthers turned outwards ; orary inferior, 3-celled, with 1 style and 3 stigmas, becoming in fruit a 3-celled capsule with many albuminous seeds.

\section{Analysis of the Genera.}

1 Flowers regular, 3 petals unequal to the 3 sepals....2

1 Flowers regular, petals and sepals alike....3

1 Fls. irregular, stamens ascending. Sds. winged. + Corn Flag. GLAdi'OLus. 2 Stamens separate. Stigmas petal-like. Petals erect. Sepals reflexed. IRIS. 2 Stamens united. Sepals very large. Pets. spreading + Tiger-flower. TiGRID'IA.

3 Flowers blue, small, rotate. Leaves, \&c., grass-like. (Fig. 48.)

Blue-eyed grass. SYSIRYN'CHIUM.

3 Fls. purp., white or yellow, tubs very long, sessile on the bulb. + Cro'cus.

3 Fls. yellow, red spotted, tubs short. Height 3-5f. † Icia. PARDAN'THUS. 


\section{IRIS. Flower-de-luce.}

Perianth 6-parted, the 3 outer divisions (sepals) reflexed, or spreading, the 3 inner (petals) erect. Stamens 3, distinct. Style short. Stigmas 3, petal-like, corering the stamens.-Perennial herbs with thick roots or rotstncks, sword-shaped or grass-like leaves, and large showy flowers. Apriz-July.

Stems leafy, tall (1-2f. high), mostly bearing several flowers....a

$\S$ Scapes leafless, low (1-6' high), mostly bearing but 1 flower....c

a Sepals or perianth bearded. Cultivated exoties in gardens, de.....11-18

a Sepals and petals beardless. Wild plants, hardly ever cultivated....b

b Leares linear, grass-like, less than half an inch wide....1

b Leaves sword-shaped, nearly 1 or $2^{\prime}$ wide....2-4

c Sepals or perianth bearded, beard crested or not crested....8-10

c Sepals and petals beardless, but sometimes with a crest....5-7

1 I. Virgin'ica. Boston I. Stem slender. Ovary and pod acute, sides 2-grooved Flowers yellow-biue. E.

[als obtuse, large. $c$.

2 I. versic'olor. Blue Flag. Stem 1-angled. Flowers blue-yellow-white. Pet-

3 I. tripet'ala. Stem terete. Flowers blue. Petals very small, 3-toothed. S.

4 I. cu'prea. Copper-col'd I. Stem terete. Fls. orange-yellow. Sepals notched. S.

5 I. lacus'tris. Lake I. Scape 1-flowered, flower blne and yellow. Lvs. lance. W. 6 I. ver'na. Early I. Scape 1-flowered, flower blue. Leaves linear, very long. S. 7 I. ochroleu'ca. Cream-colired I. Scape 3-flowered, flowers yellow. Lvs. swordshaped. Pod 6-angled. †

8 I. crista'ta. Crested 1. Scape 1-flowered, 2-4' high, flower blue and yellow Leaves lanceolate, $3^{\prime}$ long. S. [obtuse. Leaves ensiform. †

9 I. pum'ila. Dwarf I. Scape 1-flowered, 6-10' high, flower deep blue. Petals

10 I. Chinen'sis. China I. Scape many-flowered, flattened, Howers pale blue. Stigmas jagged. +

11 I. sambuci'na. Common Flover-de-luce. Stem many-flowered, flowers blue or whitish. Petals and sepals notched. c. $\dagger$

12 I. German'ica. Germun F. Stem many-flowered, flowers deep blue, spathes alsc colored. $r$. $\dagger$

18 I. Susia'na. C\%alcedonian Iris. Stem 1-flowered, fl. striped. Petals deflexed. ,

\section{Order CXLVII. TRILLIACEA. The Trilliads.}

Herbs with tuberous roots, simple stems, and whorled, net-veined leaves. with the flowers one or few, terminal, and mostly 3-parted; with the sepals green, and the petals more or less colored; with the stamens 6-10, awl-shaped filaments and linear anthers; with the orary free, 3-5-celled, becoming in fruit a juicy, many-seeded pod. 


\section{Analysis of the Genera.}

Plants with 1 whorl of leaves and 1 flower.

Pod many-seeded. Wake-Robin. TriL'LIUs. 1

Plunts with 2 whorls of leaves and several

greenish flowers. (Fig. 92.)

\section{Indian Cucumber. MeDE'ola.}

Fig. 656. Trillium erythrocarpum, with the parts of its fluwer as if separated: $s$, the 3 sepals; $p$, the 3 petals; $s t$, the 6 stamens; $o$, the 3 carpels.

\section{TRIL'LIUM. Wake-Robin.}

Character as expressed in the Order above. -2f Low herbs with a simple stem, bearing at top a whorl of 3 leaves and a single large flower. Apr.-June. (Figs. 108, 110, 656.)

Flower sessile, petals dark purple....1, 2

$\S$ Fl. on a peduncle, raised above the leaves.... a

$\S$ Fl. on a peduncle, rec"rved beneath the lvs...7-9

a Lvs. ses., rhomboidal or rhomb.-ovate...5, 6

a Leaves petiolate, rounded at the base....3,4

1 T. ses'sile. Ricket $W$. Lvs. sessile. Sepals erect, 3 as long as the linear-lanceolate petals.

2 T. recurva'tum. Bech \& W. Lvs, petiolate. Sepals recurved, long as lance ovate petals.

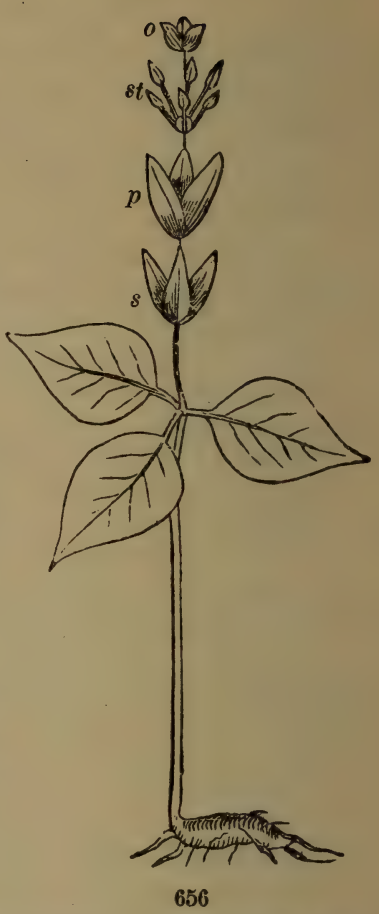

3 T. niva'le. Showy $W$. Stem $2-4^{\prime}$ high. Leaves obtuse. Petals obtuse, wavy, snow-white. The smallest species. W.

4 T. erythrocar'pum. Smiling W. Stern $8-12^{\prime}$ high. Leaves and petals pointed, wavy, white, tinged and penciled with purple.

5 T. grandiflo'rum. Great-flowered W. Petals lance-obovate, recurved, twice larger than the sepals, rose-white. Large and showy. M. W. S.

в T. erec'tum. Buth Flower. Petals ovate, acute, much broader (not longer) than the sepals, dusky purple (or white, W.), ill-scented.

7 T. pen'dulum. Pendant $W$. Style scarcely any. Leaves rhombic. Petals lance-obovate, short-pointed, Hat, scarce larger than sepals. w. M. S. W.

8 T. cer'nuum. Nodding $W$. Style scarcely any Leaves ovate, petiolate Petals lanceolate, wavy, recurved, mnch larger than calyx. Rose-white.

9 T. stylo'sum. Style-bearing T. Style manifest, as long as the stigmas. S. 


\section{Order CXLVIII. LILIACEA. Lilyworts.}

Herbs with parallel-veined leaves, bulbous or tuberous stems; flowers perfect, regular, generally large and richly colored; perianth 6 (rarely 4)-parted, uniformly colored, free from the ovary; stamens 6 (rarely 4); anthers fixed by a point and turnerl inwards; style single; ovary superior, 2 or 3-celled; seed with fleshy albumen.

\section{Analysis of the Genera.}

$\S$ Plants bulbous at the base, or with a thick, woody stem (caudex)....2

$\$$ Plants with a rhizome, creeper, or fibrous roots....4

2 Perianth segments united, forming a tubular flower....d

2 Perianth segments separate, not forming a tube....3

3 Stem (or caudex) leafy at least below, few or many-flowered....h

3 Stem (scape) sheathed at base, bearing a solitary flower....a

3 Stem (scape) sheathed at base, leafless, many-flowered....c

4 Stamens bent to one side, curved-ascending. Flowers showy....e

4 Stamens straight, and equal in position....5

5 Perianth segments united to near the summit....f

5 Perianth segments separate, not forming a tube...6

6 Flowers in terminal, leafiess clusters, small, whitish....8

6 Flowers axillary, or terminal and solitary ....7

7 Leaves thread-form, \&c....h

7 Leaves ovate, \&c....k

a Flowers nodding. Wild plants.

a Flowers erect. Garden plants. †

Firythronium. ERYTHRonidM. 1

b Nectary a linear groove at the base of each segment. Tulip. TU'LIPA.

Lily. Lit.ium. 2

b Nectary a round cavity at base of each seg. + C'rown Imperial. Fritilla'ria.

b Nectary none. Flowers panicled, large. Seeds many. $†$ Yucca. Y ucca.

b Nectary none. Flowers panicled, small. Seeds 1-3. S. Nolina. Noli'sa.

c Flowers in racemes, blue or purple. $\dagger$

Squill. Scilla.

- Fls. in racemes or corymbs, yellow or white. Star-Bethlehem. Ornithog'Alum.

c Flowers in umbels, white or roseate. Stamens straight. Garlic. AL'LIUM. s

c Fls, in umbels, blue. Stam. declined and curved. † Lme-flower. Agapan'thes.

d Perianth-limb revolute, as long as the tube. $\dagger$ Hyacinth. Hyacin'thus.

d Per.-limb spreading, much shorter than tube. $\dagger$ Grape Hyacinth. M csoA RI. Segments distinct. Stamens at base valve-like. $\dagger$ Asphndel. Asphod'elus. e Segments half-united. Stamens perigynous (\$83). + Day Lily. Hemerocá'́lis.

E Segments half-united. Stamens hypogynous. + White Day-Lily. Fun'кіа. 1 f Fl. tubular-oblong, greenish, axillary. Jointed Solomon's Seal. Polygona'tum. f Fl. broad bell-shaped, 'white, racemed. Lily-of-tho-Vislley. Convalla'sia. 
g Stem leafy, bearing a cluster. Flowers 6-parted Solomon's Seul. Smilacrina. : g Scape leafless, bearing an umbel. Berry 2-seeded. Clintonia. Clinto'nia. g Stem leafy, bearing a cluster. Flowers 4-parted. Tway-leaf. Madan'тнемUM.

h Stems branching. Flowers small, axillary. Berry red. AsPar'agus. \& Filaments flat, as long as the sagittate anthers. Twist-foot. STREPTo'PUs. k Filaments filiform, much longer than the anthers. k Filaments shorter than the long, linear anthers. Prosartes. Prosar'tes. Bellwort. UvuLA'RIA.

\section{ERYTHRO'NIUM. Dog-tooth Violet.}

Perianth bell-form, sepals recurved, the 3 inner ones usually with a callous tooth each side near the base, and a groove in the middle. Pod a little stalked. Seeds egg-shaped.- Stem a bulb deep in the ground. Scape bearing a single flower, its base sheathed by the base of the two smooth leaves. Apr., May.

Fig. 657. The Dog-tooth Violet (E. Americanum). 8. The bulb. 9. The fluwer spread open, showing the 2 teeth in each petal. also the position of all the parts. 660. The ovary, style, and stigma. 1. A cross-section of the ovary. 2. The plan of the flower: $a$, the 8 sepals in the outer circle; $b$, the 3 petals next; $c$, the 6 stamens; and $d$, the 3 -celled ovary.

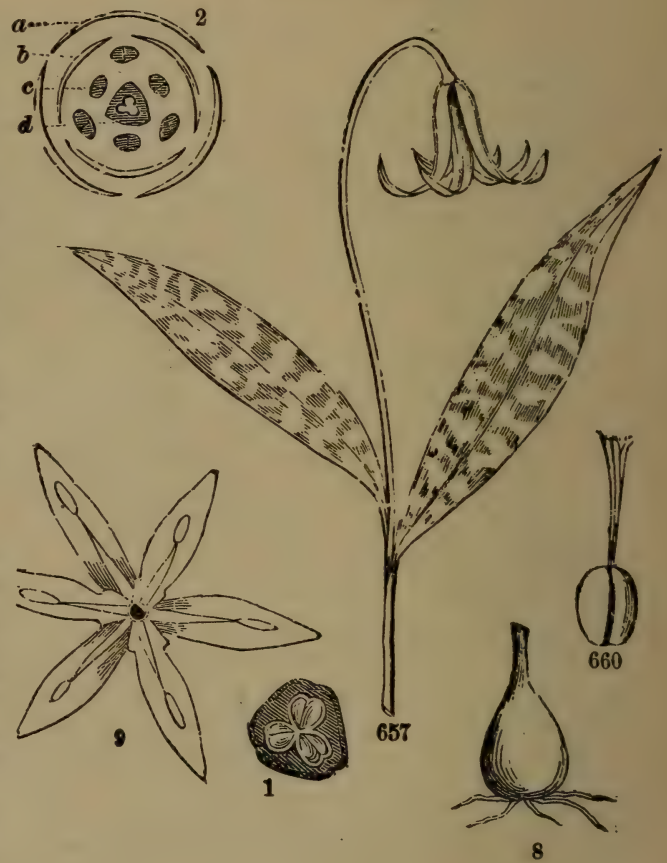

E. Anerica'num. Yellow E. Flower yellow. Scape without a bract. Petala toothed. Leaves spotted, nearly equal. Common.

E. bractea'tum. Bracted $E$. Flower greenish-yellow. Scape bearing a bract. Leaves very unequal. Mountains. $\nabla t$.

E albi'dum. White E. Flower white. Scape without a bract. Petals not toothed Rare in N. Y. and W. 


\section{LIL'IUM, Lily.}

Perianth bell-shaped, segments mostly recurved, each with a gronte running lengthwise within from the middle to the base. Stamens shorter than the style. Valves of the pod connected by latticed hairs.-Herbs with bulbous and leafy stems. Leaves whorled or scattered, sessile Flowers terminal. June, July. (See Figs. 107, 150.)

$\S$ Plants hearing bulblets in the axils. Flowers orange. Garclens....6, 7

f Plants not bulbiferous in the axils of the leaves.... a

a Flowers erect, orange-red. Sepals raised on claws $\ldots . .4,5$

a Flowers nodding, white. Sepals sessile. Gardens....8, 9

a Jlowers nodding, yellow or orange. Sepals sessile. Wild plants...1

1 Sepals orange-red, strongly revolute, almost into rings....2, 3

1 L. Canaden'se. Common Meadow Lily. Sepals yellow, merely recurved, spreading abovo middle. $c$.

2 L. super'bum. Superb L. Turk's-cap. Flowers 3-30, very showy. Leaves lanceolate, lower whorled. c. M. W. S.

3 L. Carolinia'num. Carolina L. Flower generally but 1. Leaves wedge-lanceolate, partly whorled. S.

4 L. Philadel'phicum. Philadelphia L. Upper leaves in whorle. Flowers 1-3, purple-spotted. $c$.

5 L. Catesbæ'i. Catesby's L. Lvs, all scattered. Fl. 1, red and yellow-spotted. S.

6 L. bulbif'erum. Orange L. Flowers erect, rough within, bell-shaped. Leaves 3-veined, scattered. †

7 L. tigri'num. Tiger $L$. Flowers nodding. Sepals strongly revolute. Leaves 3-reined, scattered, †

8 L. can'didum. White Lily. Flowers in a raceme, smooth, large. Lvs. scattered. + 9 L. Japon'icum. Japan Lily. Flower 1 only, very large. Sepals retlexed at end. †

\section{AL'LIUM. Garlic, Onion, \&c.}

Flowers in a dense umbel with a 2-leaved spathe. Perianth deeply 6parted, colored, usually spreading, persistent. Stamens 6. Ovary angular. Style thread-like. Pod 3-lobed, containing 1 or 2 black seeds in eack cell.-Strong-scented, bulbous, stemless herbs, the leaves radical and the umbel on a scape, sometimes bearing bulblets instead of flowers. May July.

$\S$ Leaves flat, lanceolate, but perishing before flowering....1

$\S$ Leaves flat, lanceolate or linear, present with the flowers.... a

$\S$ Leaves terete and hollow, or tubular....c

a Filaments simple. Ovary, with a 6-leaved crown. Leaves linear ...b

a Filaments 3-forked. Leaves lance-linear. Gardens.... 
D Stamens longer than the sepals. Umbel nodding....2

b Stamens equalling the sepals. Umbel with bulblets or flowers. .3,

b Stamens shorter than the sepals. Umbels with flowers only... 5,6

c Stem leafy half way up. Filaments 3 -forked....7, 8

c Stem naked. Filaments simple....

1 A. tricoc'cum. Lance-leaved Garlic. Umbel If. high, with a thin spathe, 12-20 flowered. Flowers white. Plants strong-scented. Woods. N. W.

2 A. cer'nuum. Nodding $G$. Leaves longer than the 4-angled scape. Rosecolored flowers, 12-20, in the handsome, nodding umbel. M. W. S.

3 A. stella'tum. Star $G$. Umbel erect when in flower (nodding in bud), with many rose-colored flowers. Western.

4 A. Canaden'se. Canada $G$. Umbel a dense head of bulblets and some flowers. Bulblets sessile, bracted, 12-18' high.

5 A. mutab'ile. Changsable G. Leaves bristle-form. Scape terete. Flowers many $(20-40)$. S.

4 A. stria'tum. Striate $G$. Leaves striate, linear. Scape 3-angled. Flowers few $(3-7)$.

7 A. sati'vum. Common $G$. Bulb compound. Umbel bearing bulbs. $\dagger$

8 A. porrum. Leek. Bulb simple. Umbel bearing numerous flowers. $\dagger$

9 A. venea'le. Crow G. Sta. exserted. Umbel with bulbs. Slender. M.W.

10 A. Schænopra'sum. Cives. Leaves rush-like, as long as the scape. Stamens included.

11 A. fistulo'sum. Welsh Onion. Leaves thick, as long as the swollen scape.

12 A. cepa. Ccmmon Onion. Leaves thick, much shorter than the swollen scape.

\section{FUNKIA. Day Lily.}

1 F. ovata. White $D$. Flowers white, funnel-form, many in the raceme. Leaves broad-ovate, more or less heart-shaped. + Japan.

2 F. cœru'lea. Blue D. Flower blue, rather bell-form. Leaves ovate-pointed, not at all heart-shaped. + Japan.

\section{SMILACI'NA. Solomon's-seal.}

1 S. racemo'sa. Clustered $S$. Raceme compound. Stamens longer than the perianth. Stem recurved, 1-2f. Flowers numerous, small, white.

2 S. stella'ta. Stellate $S$. Flowars few, in a simple raceme. Leaves many. N.

S. trifolia'ta. Three-leaved s. Lesves 3 or 4 , lance-elliptic. Flowers few, to comed. N. 
6. CLINTONIA. Clintonia.

1 0. borea lis. Northern C. Leaves broad, ovallanceolate. Fiowers white, 2-5, nodding in the erect, bractless umbel. Common in woods. N.

8 C. multiflo'ra. Many-flowered C. Leaves oblonglanceolate. Flowers spotted, 12-30 ir the corymb, erect or spread. Plant downy. Woods. M. S.

\section{UVULARIA. Bellwort.}

Perianth 6-parted. Sepals linear-spatulate or lanceolate, with a honey-cavity at the vase of each. Filaments very short, anthers half as long as the sepals. Style 3-cleft. Pod (or berry) 3-celled, cells few-seeded.Root-stock creeping. Stem leafy and usually branched. Flowers mostly solitary, strawjeilow, pendulous. May.

1 Leaves perfoliate (\$ 220). Pod obovate, 3lobed at end.... 3

1 Leares sessile. Sepals cream-colored, obtusish, ovate, 3 -angled....2

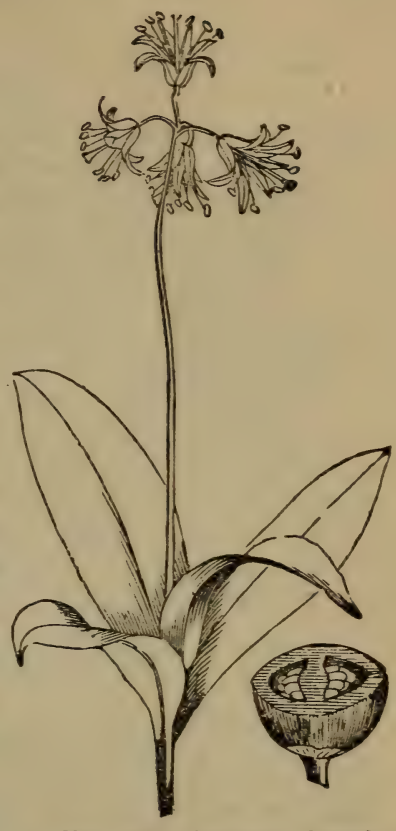

Fig. 663. Clintonia borealis Fig. 664. A berry cut across to show the 2 cells.

2 б. sessilifo'lia. Wild Oats. Leaves glabrous, glaucous beneath. Pod raised or a little stalk. Stem $6-10^{\prime}$ high, divided. $c$.

2 U. puber'ula. Downy $B$. Leaves finc-downy, shining green both sides. Pod sess...e. Stem 8-12' high. Mountains. S.

3 U grandiflo'ra. Great-flowered $B$. Sepals smooth within and without, $1 t^{\prime}$ long. Anthers obtuse. Stem 1f. high.

8 U. perfolia'ta. Mealy $B$. Sepals granular-roughish within, scarce $1^{\prime}$ long. Anthers pointed. Stem If. high.

\section{Order CXLIX. MELANTHACE A. The Melanths.}

Herbs perennial, often poisonous, with parallel-veined leaves; perianth duuble, of six similar pieces, green or colored alike, persistent; stamens 6 , with their anthers turned outwards (extrorse); noary 3 -celled, the styles nsually distinct, a capsule in fruit. 


\section{Analysis of the Genera.}

3 Perianth segments united below into a long tube....a

\& Perianth segments distinct, not forming a tube....2

2 Anthers 1-celled, cordate (shield-form when open) ....3

2 Anthers 2-celled. Flowers in simple racemes....d

3 Flowers in a paniele, that is, a compound raceme....b

3 Flowers in a simple raceme or spike....c

2 Leaves and flower arising from an underground corm. Colchicum. Cos'chicos.

b Sepals clawed, each claw bearing a stamen. MELan'thiUM.

b Sepals clawed, claw free from stamens. Zigadene. ZI'GADENUS.

b Sepals not clawed, base bearing a stamen. Puke. VerR'TRUMr. 1

c Flowers white, in racemes. Stamens on the sepals. Fly-poison. Aмiлn'тніum. r Flowers greenish, in a spike. Stamens free from sepals.

SCHENOCAU'LON.

d Fls. perfect. Filaments widened at base. Ovary 6-ovuled. Xerophyllum.

d Flowers perfect. Filaments filiform. Ovary $\infty$-ovuled.

HeLonias.

d Flowers diœcious, white. Stem leafy. Blazing Star. Chaмmir'idum.

\section{VERA'TRUM. Poke. False Hellebore.}

Flowers polygamous by abortion in the same plant. Sepals united ar base, colored, spreading, sessile, and without glands. Stamens 6, shorter than the sepals, wanting in some of the flowers. Ovaries 3 , united at base, often abortive. Pod 3-partible, many-seeded.-Stems leafy more or less. Flowers panicled. June, July.

$\S$ Stem stout and very leafy throughout....1

$\$$ Stem slender, nearly naked....2

2 Sepals rather blunt. Leaves oval and lanceolate....2, 8

2 Sepals acuminate. Leaves linear....4

$\nabla$. viride. Green-fl. P. Lvs. large, oval, pointed. Coarse plant with green fis.

2 V. Woodii. Wood's $V$. Scape 3-6f. Leaves lanceolate. Fls. nearly black. W

8 V. parvifo'rum. Small-fl. V. Stem 2-5f. Lvs. oval. Fls. dingy green. Mts. S 4 V. angustifolium. Grass-lv. V. Very slender, 3f. Lvs. long. Fls. greenish-white. W

\section{Order CLI. JUNCACEA. Rushes.}

Lerbs generally grass-like, often leafless, with small, dry, green flowers; perianth of 6 glume-like pieces, whorled in two circles (sepals and petals) stamens 6 , rarely 2 , on the torus; style 1 ; onary 3 -celled; seeds few or many. 


\section{Analysis of the Generch}

\& Perianth greenish outside, yellow inside. Stamens 6 .

Stigma 1. Seeds many. Leaves sword-shaped.

Scape nearly naked.

Narthecium. NARTheOIOM.

8 Perianth green or brownish. Stamens 6 . Stigmas 3.

Capsule 3-celled, 8-seeded. Stems leafy, jointed.

Leares linear.

Wood Rush. Lu'zola.

3 Perisnth green or brownish. Stamens 6, rarely 3 .

Stigmas 8. Capsule many-seeded. Leaves terete, or linear, or none.

Rush. Bullrush. Jon'cos.

Fig. 665 Flower of Luzula, much magnified: $p$, the green perianth; 8 , the 6 stamens; $x$, the 3 stigmas.

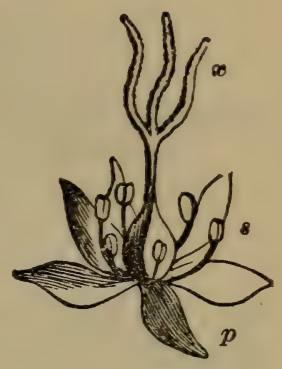

ORder CLII. COMMELYNACEE. Spiderworts.

Herbs with flat, narrow leaves which are usually sheathing at base; perianth of 2 circles, outer of 3 green sepals, inner of 3 colored petals : stamens 6 , on the torus; ovary 2 or 3 -celled; style and stigma 1 ; capsule 2 or 3 -celled, with few seeds.

\section{Analysis of the Genera.}

$\S$ Flowers irregular, clustered in a heart-shaped floral leaf. Commelína.

\$ Flowers regular, clustered, floral leaf like the rest. Spiderwort. Tradrscan'tra. I § Flowers regular, solitary, axillary. Stamens 3. Moss-like herbs. S. MAYA'CA.

\section{TRADESCAN'TIA. Spiderwort.}

Flowers regular, in terminal, close umbels, subtended by 2 or 3 leaf-like bracts. Petals broad, larger than the sepals. Filaments clothed with iointed hairs. Juice viscid, spinning into cobwebs.

\& Leaves linear, sessile, not narrowed at the base, smooth....1, 2

\& Leaves ovate or lanceolate, narrowed at base, hairy ....3, 4

1 T. Virgin'ica. Common S. Leaves broad-linear. Utnbel many-flowered, sessile, terminal, with 2 leaf-like bracts. Petals large, blue or white.

2 T. ro'sea. Roseate S. Leaves linear, long. Umbel few-flowered, with 2 subulate bracts. Petals twice longer than sepals, rose-colored. Penn. S.

T'. pilo'sa. Hairy S. Leaves lanceolate, iong-pointed. Umbels both terminal and axillary, manj-flowers. Petals small, bluish-purple. W.

1 T. crassifo'lia. Thick-lv. S. Leaves ovate, some petiolate, acute, woolly beneath. Flowers small, ròse-purple, terminal. Stem weak. Leaves striped. † 


\section{INDEX AND GLOSSARY:}

\section{Containing Definitions of Botanical Terms, together with references to those paragraphs in which they are defined in the foregoing Lessons.}

4 (in composition) signifies without; as apetalous, destitute of petals.

A bbreviations, p. 181

Abortive, imperfect, useless.

Acaulescent, 285.

Acerose, needle-shaped.-Fig. 9.

Achenium, 168.

Aculeate, armed with prickles.

Acuminate, pointed, 33.

Acute, sharp-angled, 33.

Adherent, 82.

Adhesion, 79 .

Adnate, growing to or upon, 105.

Adnate stipules, 46.

Asstivation, 134, 135.

Aggregate, assembled close together.

Aggregated fruits, 183.

Albumen, Albuminous, 189, 192.

Alburnum, white-wood or sap-wood ; outer layers of the trunk.

Alternate, 49.

Ament, 149.

Amplexicaul, stem-clasping, 41.

Analysis, 263.

Ancipital, two-edged.

Angiosperms, 256, 257.

Annual, yearly, 211.

Anther, 100.

Apetalæ, 258.

Apetalous, without petals.

Apex.-Fig. 56.

$\Lambda$ pex of the leaf, 2.

Appendage, some unusual part added.

Appressed, pressed closely to something else.

Aquatic, growing in water.

Arborescent, tree-like.

Arid, dry.

Arislate, bearded; as the glumes of bar-

Armed, furnished with spines or thorns, as if in self-defence, 56 .

Aromatic, strong-scented, spicy.
Arrangement of !eaves.-Lesson 9.

Ascending, arising obliquely.

Ascending axis.-Lesson 28 .

Attenuate, made slender or thin.

Auriculate, ear-shaped, 20.-Fig. 28.

Awned, tipped with a bristle-shaped ap.

pendage, as the beard of Barley, \&c.

Axil, 53.

Axillary, growing out of the axils, 53 .

Axillary buds, 53 .

Axis, the stem or central column, about which the organs are arranged, 216.

Baccate, berry-like; covered with pulp.

Banner, 89.

Burk, the external covering of woody stems.

Beak, a hard, short point, like that of bird.

Bearded, with long, stiff bristles or hairs.

Berry, 174.

$B i$ (in composition), twice; as in

Bi-cuspidate, with 2 points.

Bi-dentate, with 2 teeth.

Biennial, of 2 years' duration, 212.

Bifid, 2-cleft.

Bifoliate, 2-leaved.

Bifurcate, 2-forked.

Bi-labiate, 2-lipped.

Binate, 2 grown together.

Bi-pinnate, twice pinnate, 39.

Bi-pinnatifid, twice pinuate-cleft, 24

Fig. 31.

Bi-saccate, with 2 tumors or sacs.

Bi-ternate, twice ternate, 39.

Bi-valved, 2-valved.

Biography of the plant.-Lesson 26.

Blade of the leaf, 2 .

Dotanica: analysis, 264.

Bracteate or Bracted, having bracte.

Bractlets, little brants.

Bracts, 147. 
Branohes, 208.

Branching root, 219.

Branchlets, small branches.

Bristles, stiff hairs.

lind, 52 .

$\mathrm{Rulb}, 230$,

Bulblets, little bulbs borne above ground. Eulbous, having bulbs.

3ushis, 215 .

Liblucous, falling off early.

Calyoulate, having bracts resembling an outer, additional caly $\mathbf{x}$.

Culyx, 65 .

Campanulate, bell-shaped, 91.

Canescent, whitish with fine hairs.

Capillary, very slender, hair-like.

Capitate, head-shaped, globular.

Capsule, a pod, 182.

Carinate, keel-shaped.

Carpels, 124.

Cartilaginous, gristly.

Caryophyllaceous, 88 .

Curyopsis, grain or kernel.

Catkin, 149.

Cuudate, with a tail.

Caulescent, 235.

Cauline, 146.

Caulis, 285.

Cellular, composed of cells.

Vernuous, nodding.

Chaffy, with chaff.

Charucter, marks which distinguish a species, genus, \&c.

Chartaceous, of the texture of writingpaper.

Cilia, hairs, like those of the eye lashes.

Ciliate, furnished with ciliæ.

Circinate, 140.

Circumscissile, opening like a lid.

Cirrhous, furnished with a tendril.

Classification.-Lesson 29.

Clavate, clitb-shaped.

Claw, 71.

Climbers, 54, 236.

Climbing fern, 12.

Cochleate, resembling the shell of a snail.

Cohering, connected.

Cohesion, 79 .

Cohorts, 258.

Culored, not green.

Column, the consolidated stamens and pistils of the Orchis.

Coma, a tuft of hairs, 187, 188.

Complete flower, 110.

Compound flowers, 156.
Compound leaves, 23-35.

Compound petiole, 44.

Compound pistil, 124.

Compressed, flattened lengthwise.

Cone, the same as strobile, 183, 185.

Confluent, joining together.

Conjugate, joined in pairs.

Connate, joined together at base, 43.

Connectile, 102.

Connivent, converging together.

Conoids, 258.

Contorted, twisted, 130.

Convex, rising spherically.

Convolute, 132.

Cordate, heart-shaped, 19.

Coriaceous, leathery, thick and tough.

Corm, 230.

Cornute, Corniculate, horned.

Corolla.-Lesson 12.

Corona or Crown, the expanded, cup-like disk of Narcissus, \&e.

Corymb, 151.

Corymbcus, arranged like a coryn $b$.

Custate, ribbed.

Cotyledon, 190, 191.

Creeper, 232.

Crenate and Crenulate, 31.

Crisped, Crispate, with excess of margur.

Cristate or Crested, with raised ridge.

Cruciform, 87.

Cryptogamia, 250.

Cucullate, hond shaped.

Culm, the stem of grasses.

Cuneate, wedge-shaped, 17.

Cupule, cup of the acorn, \&c.

Cuspidate, with a small abrupt point, 33.

Cuticle, the epirlermis, scarf-skin.

Cyme, 157.

Cymous, like a cyme.

Decandrous, with 10 stamens.

Deciduous, falling off in autumn.

Decompound, more than once compc unded, as bi or tri-pinnate.

Decumbent, 224.

Decurrent, extending down the stem do the leaves of Mullen.

Decussate, crossing at right angles.

Deflexed, bent downwards.

Definite, 106.

Dehiscence, 102.

Dehiscent fruits, 166.

Deltoid, 15.

Dentate, Denticulate, 30.

Depressed, flattened from above.

Descending axis.-Jesson $2 ?$. 
Dialypetalæ, 258.

Di (in composition), two ; as in

Diadelphons, 107.

Diandrous, with 2 stamens.

Dichotomous, forked, branched by two equal divisions.

Didynamous, 107.

Diff use, spreading loosely.

Digitate, finger-shaped with narrow.

Dioecious, staminate and pistillate flowers on different plants, as in the Willow.

Dixcoid head, the florets all tubular, as in Burdock, Ironweed, 156.

Disk flowers, 156.

Dissected, cut into 2 parts.

Dissepiment, a partition in a pod.

Distinct, not united, 77.

Divaricate, spreading in a straggling mauner.

Dodec.undrous, with 12 stamens.

Dorsal, on the back.

Double flowers, 119 .

Doubly dentate, 32 .

Downy, clothed with soft hairs.

Drupe, 171.

Duramen, inner wood of the trunk.

$E$, or $E x$ (in composition), destitute of.

Echinate, beset with prickles.

Elliptical, 16.

Elongated, exceeding the common length.

Emarginate, 34.

Embryo, 190.

Endogens, 253, 255.

Enneandrous, with 9 stamens.

Ensiform, sword-shaped, 28.-Fig. 8.

Entire, even-edged, 29.

Ephemeral, lasting but a day.

Epidermis, the outer skin.

Epigynous, standing on the ovary.

Epiphytes, plants growing on other plants.

Equally pinnate, 37.

Equitant, 137.

Erect stems, 224.

Lrose, jagged, as if gnawed.

Etærio, 173.

Exogens, 253.

Ficotic, not native, foreign.

Exserted, projecting out of.

Exsiccate, dried up.

Eixstipulate, without stipules.

Extromse (anthers), facing outwards, 103.

Falcate, sickle-shaped, linear and curved.

Eascicle, 159.

Fasciculated, 50.
Fastigiate, having a flat or level top.

Feather-veined, 257.

Ferruginous, rust-colored.

Fertile, fruit-bearing, 109.

Fibrils, 198.

Fibro-tuberous, 222.

Fibrous, 221.

Fig, 184 .

Filament, 101.

Filiform, thread-shaped.

Fimbriate, bordered with a fringe.

Fistulous, Fistula, tubular, hollow.

Flexuous, bent in a wavy manner.

Florets, the flowers in a compound fow er, 156.

Floridiæ, 258.

Flower-bud, 128.

Flowering Plants, 250.

Flowerless Plants, 250.

Foliaceous, having the texture of leaves.

Follicle. 179.

Footstalk, the stalk of either flower or lenf

Forked venation, 12.

Forms of leaves.-Lessons 3, 4 .

Free, not adhering, 81 .

Fringed, the same as fimbriate.

Fruit.-Lessons 22, 23.

Frutescent, shrubby.

Fugacious, soon perishing.

Funiculus, the seed-stalk.

Funnel-shaped, 93.

Furcate, forked.

Fuziform, spindle-shaped.

Galea, the arched upper lip of a labrate corolla.

Gamopetalæ, 258.

Gamopetalous, 75 .

Gamosepalous, 75.

Geminate, in pairs.

Genus, Genera, 243.

Germ, the ovary, 189.

Germination, 196.

Gibbous, swelled out, protuberant.

Glabrous, smooth, without hairs.

Glands, the organs of secretion, 58.

Glandular, gland-bearing.

Glans, 170 .

Glaucous, sea-green: pale, bluish-green, with a powder or bloom.

Globous, Globular, round or spherical.

Glomerate, crowded together.

Glomerule, 159.

Glume, the outer chatf, enveloping the flowers of the Grasses.

Glume Plants, 257 
Glumeless Plants, 257.

Glumiferæ, 257.

Graminoids, 258.

Granular, formed of, or covered with

Grooved, furrowed or channelled.

Gymnosperms, 256, 257.

Gynandrous, having stamens and pistils combined into one body.

Habit, the general appearance of a plant. Habitat, the place where a plant grows.

Hairs, 60 .

Hastate or Halbert-shaped.-Fig. 57, $l$.

Head, 155.

Heart-wood, same as duramen.

Helmet, same as galea.

Heptandrous, with 7 stamens.

Herb, a plant not becoming woody, 211.

Herbarium, a collection of dried plants.

Hexandrous, with 6 stamens.

Hibernation, 210.

Hip, 176.

Hirsute, 62.

Hispid, rough with stiff hairs, 62 .

Hooded, curved or rolled into the form of a hood.

Hybrid, partaking of the nature of two species.

Hypogynous, inserted under the ovary, 83.

Imbricated, 131.

Imperfect flowers, 109.

Incised, deeply gashed or cut.

Indefinite, variable in number and too many to be counted, 106 .

Indehiscent, not opening.

Indehiscent fruits, 166 .

Indigenous, native of.

Inferior calyx, calyx free.

Inferior ovary, ovary adherent.

Inflated, tumid, as if filled by wind.

Inflexed, bending inward.

Infiorescence, 141.

Innate, 105.

Inserted, growing out of.

Internode, 202, 227.

Interruptedly pinnate, 37 .

Introrse, 103.

Involucel, involucre of an umbellet, 152 .

Involucrate, surrounded by an

Involucre, 147.

Involute, 189.

Irregular flowers, 86.

Keel, carina, 89.

[boat.
Labiate, 2-lipped, 97.

Laciniate, 27.-Fig. 43.

Lactescent, milky or juicy.

Lamina, blade, 71 .

Lanceolate, 15.

Lateral, on the side, 53.

Leaf.-Lessons 1, 2, 3 .

Leaf-bud, 128.

Leaflets, 35 .

Leaf-stems, 228.

Legume, 180.

Leguminous, bearing legumes.

Lenticular, shaped like a double conve lens.

Liber, the inner bark.

Ligneous. woody.

Ligulate, strip shaped, 96.

Ligule, 47.

Liliaceous, 88.

Limb, 76.

Line (") the 12tk part of an inch.

Linear, 28.

Lobate, or Lobed.-Figs. 30, 35.

Loment, a jointed legume, 180.

Lunate, crescent-shaped.

Lyrate, 21.-Fig. 34.

Marginal, on the margin.

Medulla, the pith.

Membranous, or Membranaceous, thin and soft, like a membrane.

Midvein, 6 . [set.

Monadelphous, stamens united into one

Monandrous, with one stamen.

Monocious, stamens and pistils in separate flowers on the same plant.

Monopetalae, corolla with united petals.

Monopetalous, 75 .

Monosepalous, 75 .

Mucronate, 33.

Mulberry, 183.

Multifid, many cleft.

Muricate, with hard, sharp points.

Naked, a relative term, signifying dest tute of.

Naked flower, 110.

Naked seeds, 256 .

Napiform, tuberous root wider than lorig Natant, swimming.

[sons 30, 31.

Natural System; Natural Orders.-Les

Nature of the flower, 208.

Nectariferous, producing honey.

Net-veined, 8.

Netils

Neutral flowers, witho't stamens or pis 
Node, $227,202$.

Normal, regular, according to rule.

Number of Genera, 246.

Number of Species, 246.

Nut, a simple, 1-seeded, hard fruit.

$O b$ (in composition) implies inversion; as

Obcordate, 'yversely heart-shaped, 34 .

Oblanceolate, 17.

Oblique, unequal, one-sided

()blong, 16.

Obovate, 17.

Obsolete, indistinct, as if worn out.

Obtuse, blunt, 33.

Obvolute, 138.

Ochreæ, 47.

Odd-pinnate, 37.

Offset, a short, thick runner.

Opereular deliscence, 104.

Opposite, 50.

Orbicular, rounded, 16.

Orders, 247.

Ordinal, relating to the orders.

Oval, 16.

Ovary, 121, 123.

Ovate, 2.

Ovoid, egg-shaped.

Ovules, 123.

Pales, the inner chaff of grass flowers.

Palmate, hand-shaped.

Palmate venation, 10.

Palmately ternate, 38.

Panduriform, fiddle-shaped.

Panicle, 153.

Papilionaceous, 89.

Papillous, with sinall, gland-like proPappus, 188.

Parallel venation, 11.

Parasite, a plant living on other plants.

Parietal, of, or adjoining the wall; as

Parietal placentæ - Fig. 269.

Pectinate, comb-like, with long, narrow segments.

Pedate, foot-shaped, 26.

Pedicel, 143.

Pedicellate, furnished with a pedicel.

Peduncle, 143.

Pellucid, transparent.

Peltate, 20.-Fig. 25.

Pendulous, drooping, hanging down.

Pentandrous, with 5 stamens.

Pepo, 175.

Perennial, enduring 3 years or more, 213.

Perfect flower, 110.

Perfoliate, 42
Perianth, 66.

Pericarp, 166.

Perigynous, inserted into the calyx, 88.

Persistent, permanent, not falling off.

Personate, 97.

Petal, 65.

Petaliferæ, 257.

Petaloid, resemb:ing petals.

Petiole and Petiolate, 3.

Petiolule, 35.

Phænogamia, 250.

Pilous, 62.

Pine-apple, 183.

Pinnae (wings), segments of a pinnate leaf.

Pinnate, 36.

Pinnately ternate, 35.

Pinnatifid, 24.

Pinnatisect, 25.

Pistil, 68.-Lesson 18.

Pistillate, bearirg pistils.

Pith, the central cellular substance of the stem.

Placenta, a lobe or fleshy ridge tearing the seeds.

Plaited, same as Plicate.

Plan of the flower.-Lesson 17.

Plicate, folded like a fan.

Plumous, feathery or feather-like.

Plumule, 190, 191.

Pod, dry fruit ; as capsule, legume, \&c.

Pollen, 100.

Poly (in composition) signifies many; as

Polyandrous, with many stamens.

Polyadelphous, 107.

Polygamous, having perfect flowers, with staminate or pistillate flowers on the same plant.

Polypetalæ. See Dialypetalæ, 258.

Poly petalous, $75,258$.

Polysepalous, 75.

Pome, 176.

Porous dehiscence, 104.

Premorse, abrupt at end, as if bitter. uff.

Prickles, 57.

Process, any projection from the surfuce.

Procumbent, 224.

Prostrate, 224.

Pubescent, 61.

Pulp, the soft, juicy parts of fruits.

Punctate, dotted as if with pointr.

Pyriform, pear-shaped.

Pyxis, 178.

Quaternate, growing in fo ins.

Quinate, growing in flves, 40. 
Kacerne, 150.

Kacemous, resembling a raceme.

Rachis, 36 , 146.

Radiate aud Radiant, pp. 219, 220.

Radiate-veined. See Palmate-veined, 10. Radical, from the root.

Rarlical number, 113.

Radicle, 190, 191.

Ramial, of the branches.

tiamurus, br anched.

Ray, Ray-flowers, 156.

Receptacle, 64.

Reclinate, 140.

Recurved, bent or curved backward.

Reflexed, ourved back and downward.

Regular flower, 86.

Reniform, kidney-shaped.-Figs. 23, 24.

Repand.-Fig. 53 .

Reticulute, netted.

Retuse, 34 .

Revolute, 139.

Rhizome, 231.

Rhomboid or rhombic, oval, with angular sides.

Rib (costa), ridge caused by raised reins.

Ringent, gaping, as when a labiate coroila has an open throat.

Root,-Lesson 27.

Root-stock, 231.

Rosaceous, 87.

Rostrate, with a beak.

Rotate, 90.

Rudiments, 116.

Rugous, wrinkled.

Kuncinate, 22.-Fig. 36.

Runner, a klender branch striking roct, as in Strawberry.

Saccate, bag-like, or sack-like.

Suvittate, arrow-shaped, 19.

Salver-form, 94.

Samara (a key), 169

Sap, 204.

Scatrous, rough.

Scale-stems, 228 .

Scape, 144.

Scurious, dry, thin, scale-like.

Scurpoid cyme, 159 .

Secin nd, all turned to one side.

Seed.-Lesson 24.

Segments, parts or divisions.

Sepal, 65 .

Septinate, 40.

Sericious, 61 .

Serotinous, late in the season.

Serrate and Serrulate, 30.
Sessile, 5 .

Setaceous or Setous, bristly.

Sheath, lower part of the leaf or leaf-stalls which surrounds the stem.

Shrub, 215.

Silicle and silique, 181.

Simple, not compound, of one piece.

Simple pistil, 124.

Sinuate, 21.-Fig. 32.

Sinus, a rounded recess between the lobes of the leaves, \&e.

Solitary, 145.

Spadicifloræ, 258.

Spadix and spathe, 143.

Spatulate, 17 .

Species, 241.

Spike, 146.

Spine, 56.

Spinescent or Spinous, 187.

Spiral arrangenient, 49 .

Spores, $2 . \overline{1} 1$.

Spur, 78.

S'quarrous, of a ragged appearance; as, with crowded, spreading hracts of leaves, \&c.

Stamens, 67.

Staminate, with stamens only, barren.

Stellute, whorled.

Stem.-Lesson 28.

Sterile, 109.

Stigma, 122.

Stings, sharp. poisonous hairs, 59.

Stipe, the stalk of a pod, \&c.

Stipitate, borne on a stipe.

Stipule, 4.

Stipulate, with stipules.

Stulon, a branch which strike root at the end, producing a new plant.

Stuloniferous, bearing strlous.

Straight-veined, wher: the principal veins pass direct to the margin.

Striate, slightly furrowed with streaks.

Strigous, clothed with short, stiff, and close-pressed hairs.

Strobile, same as cone, 183.

Style, 122.

Sub (in composition) denotes the quality in a lower degree, as,

Sub-entire, nearly entire.

Submersed, under water.

Subterranean stems, 225 .

Subulate, awl-shaped, Fig. 7.

Succulent, thick, juicy, fleshy.

Superior, 82.

Supra-axillary, arising from ahove the axil, as do the flowers of Potato. 
Suture, a seam; the line of cohesion. Symmetrical, 111.

Syngenecious, having the anthers united into a tube, 107.

l'endril, 54, 55, 236.

Terete, rounded or cylindric, 3.

Terminal, borne at the summit, 53.

Terminal bud, 53.

Ternate, 38.

Testa, the outer seed-coat.

Tetradynamous, 108.

Tetrandrous, with 4 stamens.

Thorn, 56.

Throat, 76.

Thyrse, 154.

Tomentous, 61.

Toothed, dentate, 30 .

Thrus, the receptacle, 64 .

Trailing, creeping or lying on the ground, Tree, 214.

Triandrous, with 3 stamens.

Tri-cuspidate, having 3 points.

Tri-dentate, 3-toothed.

Trifid, 3-cleft.

Trifoliate, 3 leaves or leaflets composing one leaf.

Tri-pinnate, thrice pinnate.

Triternate, thrice ternate, 39.

Truncate, blunt, as if cut square off.

Trunk, 234.

Tryma, 172 .

Tube, 76.

Tuber, 233.

Tubercular, 222.

Tuberiferous, bearing tubers.

Tuberous, thickened like a tuber.

Iuberous roots, 220.

Tubular, hollow like a tube, 95 .

Iulip, 11.

Tunicated, coated, as ar onion.

Turbinate, shaped like a toF.
Turgid, swollen.

Umbel, 152.

Umbellet, 152.

Unarmed, without thorns, prickles, \&a

Uncinate, hooked at the end.

Undershrub, 215.

Undulate, wavy, 22.-Fig. 33.

Unguiculate, with a claw, 71,-Fig. 116.

Urceolate, urn-shaped, 92.-Fig. 143.

Utricle, a one-seeded fruit, like that a

Pigweed.

Valvate, 129.

Valves, the parts which oyen.

Variety, 244.

Veinlets, 7 .

Veins, 6 .

Veins of the leaf, 6.

Veinulets, 8.

Velvety, clothed with thick, soft dowu.

Venation, 10.

Ventral suture, the front seam.

Ventricous, swelling out on one side.

Vernation, 51, 135.

Verrucous, warty.

Versatile, 105.

Verticil, a whorl of flowers.

Verticillate, 50 .

Vexillary, 132.

Vexillum, the banner, 84.

Villous, 61 .

Vine, 286.

Virgate, wand-shaped, terete and slender.

Wedge-shaped, see Cuneste, 17.

Wheel-shaped. see Rotate, 90.

Whorled, see Verticillate, 50.

Winged, as if furnished with wings.

Winged petiole, 45 .

Wingк, 89.

Woody plants, 21.4. 


\title{
INDEX TO THE NAMES OF PLANTS,
}

\author{
BOTH LATIN AND ENGLISI :
}

Also, full references to the Illustrations.

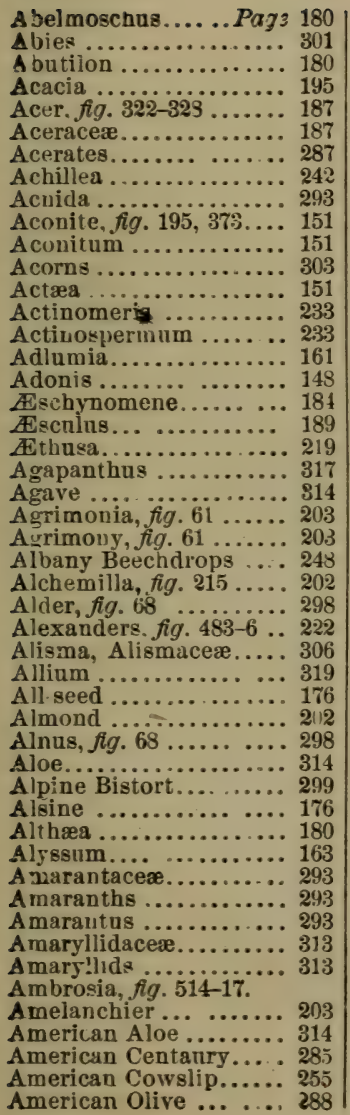

Amiarthium ......... 322

Amorpha............. 194

Amplianthus......... 26:

Amphicarpæa .......... 194

A msonia............. 286

A mygdalus ............ 202

Anacardiaceæ ......... 186

Anacharis ............. 305

A nagallis, $f i g .5 ; 6-7 \ldots . .255$

Anantherix........... 287

Andromeda, fig. $242 a$, $143 \ldots \ldots \ldots \ldots \ldots \ldots 247$

Androsace............ 254

Anemone................. 146

Angelica .............. 219

Angelica Tree ......... 224

Anise................. 219

Anonaceæ............... 151

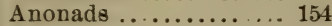

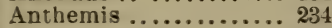

Antirrhinum ........ 262

Aphyllon.... .......... 258

A pios ............... 195

A pium ..............219

Aplectrum.............. 308

Apocynaces............. 26

A pocynum, fig. 285 .... 236

A pogon .............. 2:34

Apple ..................... 204

Apple of Sodom........ 28.3

Apple Pera............. 282

Aquifoliaceæ ............. 252

Aquilegia.............. 149

Arabis, $f i g .29$......... 167

A racea.............. 302

Arachis ............... 195

Aralia ................ 224

Araliaceæ ............. 224

Araliads ............... 224

Archangelica .......... 219

Archemora ............. 219

Arctostaphylos .......... 247

Arenaria, fig. $410 \ldots \ldots .176$

A rethusa, fig. 651-2..... 311

Argemone ............. 160

Arisæma .............. 303

Aristolochia............ 289

Aristolochiaceæ ........ 289

Armeria .............. 257
Armoracia........... 164

Arnica................ 233

Aroids................ 302

Arrow Dragon........... 303

Arrow-head, $f i g .47 \ldots . .307$

Arrow-wood, fig. 51.... 228

Artichoke ............ 238

Arum. .............. 303

A sarum................. 289

Asclepiadaceæ......... 28:

Asclepiads ...........287

Asclepias, $f i g .283 . \ldots \ldots .288$

Ascyrum .............. 171

Ash. fig. 187 .............. 289

Asimina ............ 154

Asparagus............ 318

Aspen ............... 299

Asphodel, Asphodelus.. 3.7

Aster, fig. 5:24.........240

Asterworts.............. 230

Astilbe................ 215

Astragalus ............... 194

Atamacco Lily, $f \ddot{f} .137 . .313$

Atriplex... ........... 293

$\Lambda$ tropa $\ldots \ldots \ldots \ldots \ldots \ldots \ldots . .282$

Auricula................ 254

A vens ..................206

Awlwort ................ 164

Azalea, $f i g .205,532-4 \ldots 249$

Baldwinia............. 23?

Balloon Vine........... 189

Ballota, Balm.......... 270

Balm-of-Gilead, fig. 636 -

$637 \ldots \ldots \ldots \ldots \ldots . .299$

Balsaminaceæ............. 185

Balsamine ............. 186

Bane-berry............. 151

Baptisia............... 199

Barbarea.............. 168

Barberry................. 155

Bartonia...............2 284

Bass-wood.................. 181

Batatas.................... 281

Bayberry................. 298

Bay-galls................ 295

Beach Pea............ 201

Bean, fig. $446,311 \ldots \ldots . . .2195$

Bear-berry, fig. 545 ...... 247 
Beard-flower........... 313

Beard-tongue........... 263

Bed-traw............. $2 \div 29$

Beech, $f i g .275 . \ldots \ldots \ldots \ldots .296$

Beechdrops............ 258

Beet, fig. 336, Beta...... 293

Befaria............. 247

Beyonia, fig. 185.

Belladonna............ 282

Bell-flower............245

Bellis.............. 233

Bellwort, fig. $530-1,81$.

244,321

Benzoin............. 296

Berberidaceæ............ 155

Berberids............. 155

Berberis. $f$. 171-2, 3 з $^{\prime} \%-80.155$

Berchemia............ 190

Berlandiera............ 2:3:3

Betula................298

Betulaceæ............. 298

Bidens.. ................ 239

Big Laurel.............. 153

Bignonia............... 258

Bignoniaceæ.............. 258

Bilberry, fq. 170.

Bindweeds, fig. 144 . . 280, 281

Birch, fig. 13, 632-3......293

Birthworts............. 289

Bitter Cress............. 167

Bitter-sweet, fig. 61i-13. 283

Black Alder ... ...... 252

Blackberry, $f i g .268 . . .206$

Black Haw, fig. 16..... 228

Black Saltwort.. ........ 254

Bladder-nut, fig. 434 ..... 190

Bladder-pod............ 164

Bladder Senna.......... 194

Bladderwort........... 257

Blazing Star............. 322

Blephilia.............. 270

Bletia.................. 308

Blood-root.............. 160

Blue-banner .............. 194

Blue-berries, $f i g .546 \ldots .247$

Blne curls.........269, 273

Blue-eyed Grass. $f i g$. 48.. 314

Blue-flag............. 315

Blue-nearts............ 663

Blue Lettuce, $f .35,245-7$,

$309 . \ldots \ldots \ldots \ldots$

Bluets................ 230

Boerhaavia.............. $\approx 90$

Boltonia............... 2:33

Borrage, Borrageworts.. 2i5

Borraginaceæ.......... 274

Borrago fig. 598-600 .... 2 25

Borrichia............. 233

Boussingaultia............ 293

Boxberry, fig. 547....... 248

Box Elder.............. 187

Brachychæta...........2 233

Bramble............ 206

Brassica.................. 164

Bridal Rose........... 207

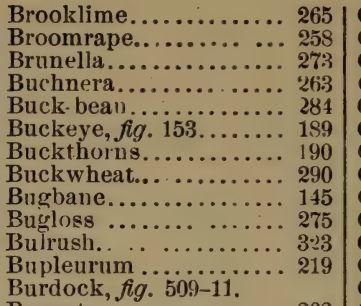

Burnet. ..............202

Burning Bush .... ... 190

Burr Marigold.... .. 233, 239

Burr-reed............... 304

Burr-seed .............. 275

Bush Clover............... 198

Bush Honeysuckle. . ... 227

Butter and Egrs ........ 263

Buttercups, fig. 163, 331. 147

Butterfly Pea........... 194

Butternuts............. 295

Butterwort ............. 257

Button-bush.......... 229

Cabbage.............. 164

Cactaceæ.................. 218

Cakile................ 164

Calaminth, Calamintha.. 271

Calendula............ 2:32

Calicanthaceæ.......... 154

Calicanths............ 154

Calicanthns........... 154

Calico-bush............ 249

Calla, fig. 237, 638-41.... 303

Callistephus.......... 233

Calopogon, $f i g .655 \ldots \ldots .312$

Caltha................ 149

Calynyetion.............. 280

Calypso. ................ 307

Calystegia............. 281

Camelina................ 164

Camellia................. 182

Camelliaceæ............... 182

Camomile.................. 234

Campanula, $f g .142 \ldots \ldots 245$

Campanulaceæ.......... 244

Campion ............... 177

Candytuft.............. 164

Canterbury Bells, fig. 527 $-9 . \ldots \ldots \ldots \ldots \ldots .234$

Caprifoliaceæ.............225

Capsella, fig. 331 ......... 165

Capsicum ............ 282

Caraway, fig. $271 \ldots \ldots \ldots .219$

Cardamine, ffg. $182 \ldots \ldots .167$

Cardinal-flower..........243

Cardiospermum.......... 189

Carnation................. 1776

Carpet-weed.............. 178

Carpinus............... 297

Carrion-flower........... 306

Carrot. ...............219
Carum............. $\quad 219$

Carya................. 295

Caryophyllacea........ 185

Castia, fig. 60....... 200

Cassiope............. $\cdot 247$

Castanea............. 206

Castilleja........... 262

Catalpa, fig. 196-7, 236 .. 259

Catchfly, fig. $136 \ldots \ldots \ldots$.... 177

Catmint, fig. $52,593-4 \ldots$ a7z

Cattail................ 304

Ceanothus.............. 190

Cedronella ............ 270

Celandine. fig. $40 . \ldots \ldots \ldots .6160$

Celastraceæ. ........... 190

Celastrus................ 190

Celery.................... 219

Celosia. ............. 293

Celtis, fig. 72.

Centaury..........284, 285

Centrosema............... 194

Centunculns............. 2.54

Century Plant............. 314

Cephalanthus........... 2:9

Cerastium, fig. $114 \ldots \ldots$..... 178

Cerasus.... ......... 203

Cercis, $f i g .4 \ldots \ldots \ldots \ldots . .195$

Chærophyllum.... $\ldots . . .219$

Chaff-seed ............ 262

Chamælirium. ............ $3: 2$

Chaptalia.. ............... 234

Checkerberry, fig. 540-3. 248

Cheiranthus ............ 16i:

Chelidonium ........... 160

Chelone ............... 266

Chenopodiaceæ............ 292

Chenopodium ............ 293

Chenopodina......... 293

Cherry, fig. $452-3$....... 203

Chervil ............. 219

Chestnut, fig. 49 ........ 296

Chick-pea.............. 195

Chickweed. fig. $21 \ldots 176,178$

Chick-wintergreen ..... 255

Chimaphila............ 251

China Aster..............2 233

Chiogenes, $f g .33 \ldots \ldots .248$

Chionanthus............ 288

Chokeberry............204

Chrysanthemum, fig. 25.233

Chrysobalanus ......... 202

Chrysogonum........... 283

Chryeopsis............. 232

Chrysosplenium .........2 215

Cicely, fig. 487-90...... 221

Cicer................. 195

Cichorium............. 234

Cicuta, fig. $65 \ldots \ldots \ldots \ldots$ 222

Cimicifuga.............. 145

Cinquefoill............... 208

Circæa, fig. $58,73,193$,

$464 \ldots \ldots \ldots \ldots \ldots . . . .211$

Cistaceæ.................. 170

Cives.................... 320

Cladastris .............. 195 
Clark14.. .. . . ...211

Claytonia.............. 179

Clematis. fig. 219 ....... 145

Clethra .........247

Climbing Fern, fig. 6.

Clintonia, fig. 663....... 321

Clitoria................ 194

Cloudberry ............. 207

Clover, $f$. $37,63,335,447-$ $50 \ldots \ldots \ldots \ldots \ldots . . . .197$

Cockle............... 177

Cocoa-plum............ 2:

Coffee-tree.............. 195

Cohosh ................. 155

Colchicnm........... 32.2

Collinsia. fig. $578 \ldots \ldots \ldots .265$

Collinsonia............. 269

Colt's-foot ............. 23:3

Columbine, fig. 365-70.. 149

Columbo.............. 284

Colutea .............. 194

Comarum.............. 203

Comfrey, fig. $603 \ldots \ldots \ldots 275$

Commelyna, Commely. nacex

Compositæ ............. 230)

Cone-flower ............ 233

Coniferæ .............. 300

Conioselinum. fig. 85... 219

Conium, fig. 65........ 221

Conobea.............263

Conopholis ........... $25 \mathrm{~s}$

Convallaria ............ $3 i 7$

iouvolvulaceæ......... 2*0

Convolvulus, fig. 144 .... 281

( optis................ 149

Coral-berry .. ........ 226

Corallorhiza, Coral-root. 311

Coreopsis ......... 234. 239

Coriander ........... 219

Coriandrum, fig. 493-4.. 219

Cornacex........... 223

Cor el. fig. 239 …2 $2 \ldots 25$

Corn Flas ........... 314

Cornus. fig. $495 \ldots \ldots \ldots 2$....

Coronilla.............. 194

Corydal .................. 162

Corydalis.............. 1 ti2

Corylus ............. 296

Cusmanthas.......... 278

Cotton, fig. $302 \ldots \ldots \ldots \ldots . .180$

Cow-parsnip........... 219

Cowslip................ 149

Cow-wheat ........... 263

Crab .................204

Cranberry.............. 248

Prantzia .............. 219

Crape Myrtle.......... 210

rrassulaceæ ............. 213

Cratægus, fig. 99 ...... 2:2

Cress................. 16i4

Crest-umbel.............. 219

Crocus............... 314

Crotalaria................ 194

Crowfoot, fig. $361-4 \ldots . . .147$
Crowfoots, fig. 200-1... 143

Crownbeard....... 23 3,234

Crown Imperial.......... 317

Cruciferæ ........... 162

Crucifers............. 162

Cryptotænia............ 2:0

Cuckoo-flower........... 1ti7

Cucnmber-tree........... 15:

Culver's Physic.......... 265

Cunila, fig. 595-6........ 2 21

Cuphea ................ 210

Cupressus............... 300

Cupuliferæ.............. 246

Currant, fig. 243, 261, 329. 213

Custard-appie........... 154

Cydonia .. ........... $2(14$

Cynoglossum........... 277

Cynthia.............. 23t

Cypress................. 310

Cypress-vine.............281

Cypripedium, fig. 89, 646$648 \ldots \ldots \ldots \ldots \ldots . \ldots 309$

Cyrilla................... 248

Daffodil ............... 314

Dahlia................. 2:34

Daisy ................... 23.3

Dalea ................... 194

Dalibarda ............ 207

Dandelion, fig. 147, 180, 504-6 ...............

Daphnads................. 294

Daphne ............. 294

Dasystoma, fig. $565-8 \ldots 267$

Datura ................ 283

Daucus ............... 219

Day Lily ................ 320

Decumaria ............. 215

Deer-grass ........... 209

Delphinium. fig. 168, 208. 150

Dentaria ............. 167

Desmanthus............ 195

Desmodium, fig. $62,287.195$

Dewberry ............ 207

Diamorpha .............. 214

Dianthus ............... 176

Dicentra, $f i g .389,392 \ldots 161$

Dicerancira ............. $\leqslant 9$

Dichondra................ 280

Diervilla ................. 22

Digitalis................. 262

Diodia ............... 229

Dionæa.................. 174

Diphylleia............... 155

Diplopappus............ 233

Dirca................. 294

Discopleura......... 219

Ditch Moss ........... 305

Dittany. fig. 595-6..... 271

Dock, fig. 233.......... 290

Dockmackie ........... 228

Dodecatbeon, $f .151,554$,

555 . ............ 255

Dogbanes. $f i g$. $285,620-6$. 2थ6

Dogtooth Violet ........ 318
Dogwood .......187, 229

Dolichos .............. 194

Draba. $f i g .396-7 \ldots \ldots \ldots 166$

Draba arabizane, $f: 55-59$

Dracocephalum.......27 27

Dragon-root ............. 303

Dragon's head............ 2т0

Dragon's claw............. 311

Drop-fiower ............ 232

Dropwort ............. 209

Drosera .............. 173

Droseracta............. 173

Dryas................... 203

Dry Strawberry. .......2 27

Dwarf Dandelion ........ 2:44

Dwarf Pimpernel ........ 25.

Dwarf Pisk .......... 23il

Dysodia . . ............ 233

Eardrop......... 161, 211

Echinacea.............. 234

Echinodorns............ 806

Echinospermum.......... 275

Echium................. 275

Eclipta, fig. $315 \ldots \ldots \ldots \ldots 2: 244$

Eel-grass.............. 305

Egg-plant ............... 283

Eglantine............... 20

Egyptian Calla ........... 303

Elder ................ 227

Elecampane ............ 283

Elliot tia.............. 248

Ellisia............. 277

Elm, fig. $50,274,339$.

Elodea .............. 171

Enchanter's Nightshade, fig. $53,73 \ldots \ldots \ldots . .212$

Enslenia............... 288

Ephedra, fig. 178.

Epidendrum. ......... 309

Epigæa............... 249

Epilobium............. 211

Epiphegus............... 258

Erica................... 247

Ericaceæ................. 246

Erigenia, fig. $333 . . . \ldots . . .221$

Erigeron ............... 241

Erodinm............... 18:

Ersngium.$\ldots \ldots \ldots .210$

Erysimum ............ 168

Erythrea................ 281

E ythrina ............ 191

Erythroninm, fig. 657 ... 318

Escholtzia............... 160

Eulophus ............... 219

Euonymus .............. 19 ?

Eupatorium, fig. 512-13.

Euphrasia ........... 263

Evening Primrose... 210, 211

Everlasting Pea, fig. 96. 200

Eyebright ............. 263

Fabiana .............. 28:

Faupyrum .............. 2:10

Fagrus.............. 
False Aster.......... 233

False Bindweed ........ 281

False Catmint ............ 271

False Dog.fennel ........ 233

False Flax ........... 164

False Gromwell ......... 275

False Mitrewort ........ 216

False Pennyroyal ........ 271

Fulse Rocket............ 164

False Sneezewort....... 233

False Sunflower ........ 233

False Syrtnga. ......... 216

False Tamarisk......... 283

False Violet ............. 207

Fulse Wall-flower......... 168

False Wintergrees....... 250

Featherfoil ............. 244

Fennel .............. 219

Fennel-flower, $f i g .41 \ldots$. 45

Fern, fig. 226, 350.

Fever-root........... 225

Fig, fig. 298.

Firworts .........261, 263

Fir ................ 301

Fıax, fig. $418-20 \ldots \ldots \ldots . . .183$

Flaxworts ........... 182

Fleabane ............. 241

Floating Heart .......... 284

Flower-de-luce ........ 315

Flowering Almond, fig. 11.

Flower-of-an-hour ....... 181

Fly-poison ...... $\ldots \ldots$. 322

Foeniculum .............. 219

Fool's Parsley........... 219

Forestiera............ 288

Forget-me-not, fig. $604 . .276$

Forsythia ............ 288

Four-o'clock, $f_{y} .313$... 290

Foxglove........... 262

Fragaria. fig. 202, $265 \ldots 208$

Frankenia, fig. 160.

Frasera ........... 284

Fraxinus, $f i g$. is7....... 288

French Marigold ....... 233

Fringe-tree............ 288

Fritillaria ............ 317

Frolichia............... 293

Frogbits .............304, 305

Fuchsia, fig. $130 \ldots \ldots \ldots 211$

Fumaria............... 161

Fumariacea ........... 161

Fumeworts ............ 161

Fumitory.............. 161

Funkia .............. 320

Gaillardia............ 232

Galactia................ 194

Galanthus .............. 313

Galeopsis, fig. 582-4..... 270

Galium............... 229

Garden Shrub ........... 154

Garlic ................. 319

Gaultheria .............. 248

Faura ................ 211

Gaylussacia........... 247
Gelseminum......... 261

Gem-fruit............. 216

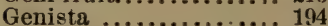

Gentian............... 285

Gentiana, fig. $615-19 . \ldots 285$

Gentiranaceæ............ 284

Gentianworts.......... 284

Gerania................ 183

Geraniaceæ.............. 183

Geranium, $f \dddot{i g} .296,340$, $421 . . . . \ldots \ldots \ldots \ldots$

Gerardia............ 266

Germander........... 269

Geum................ 206

Gilia.................. 279

Gill, fig. $74,587-8 . \ldots \ldots \ldots$ 272

Gillenia. .............. 203

Ginseng................. 224

Gladiolus.............. 314

Glasswort $\ldots \ldots \ldots \ldots \ldots \ldots$. 293

Glaucium............. 1ti0

Glanx.................. 254

Gleditschia............ 195

Globe Amaranth....... 293

Globe-flower........... 149

Glotidium ............. 194

Goat's-beard........... 209

Goat's Rue .............. 194

Golden Chain............ 194

Golden-club, fig. 642 .... 303

Golden-rod, fig. $75 . . \ldots .235$

Gold-thread............ 149

Gomphrena..............

Good-night............ 280

Goodyera................ 309

Gooseberry, fig. $281 \ldots \ldots 213$

Goose-foots........... 292

Goose-grass.......... 208

Gordonia ............... 182

Gossypium ............. 180

Grape Hyacinth ........ 317

Grape Vine............... 191

Grass Parnassus ....... 174

Grass Pink ............ 312

Grass-poly............. 210

Gratiola............... 264

Greek Valerian.......... 280

Greenbrier, fig. $95 . \ldots \ldots .305$

Green Dragon.......... 303

Green Head.............. 229

Gromwell. .............. 275

Grossulacex........... 212

Gronnd Cherry ...........282

Ground-nut..........196, 224

Grove Sandwort.......... 176

Guelder Rose... ........ 203

Gymnocladus........... 195

Halenia............. 284

Halesia................. 252

Hardhack.............. 208

Hare-bell, $f i g .526 \ldots \ldots .245$

Hawkbit ............ 234

Hawkweed .............. 242

Hazel............. 296
Heath. fig. 314-15 ... ... 247

Heathworts.... $\ldots . . . .2246$

Hedeuma.............. 269

Hedera................ 224

Hedge-hog............ 240

Hedge Hyssop.......... 264

Hedge Mustard.......... 164

Hedge Netı'e............ 270

Hedysarum .............. 194

Helenum............... 233

Helianthemum............ 171

Helianthus, fig. 307 ..... 237

Heliopsis.. ............. 293

Heliotrope............. 275

Heliotrophytum......... 275

Heliotropium ........... 275

Hellehore, Helleborus... 145

Helonias. . ............ 322

Helosciadium............. 219

Hemerocallis.............. 317

Hemianthus........... 262

Hemlock.............. 301

IIemp Nettle, fig. $582-4 . .270$

Hen bane, fig. $282 . . . . . .282$

Henbit.............. 270

Hepatica, fig. $238,371 \ldots 147$

Heraclenm............ 219

Herb Robert, fig. 421 .... 184

Herspestis............ 263

Hesperis.............. 163

Heteranthera............ 305

Heterotheca ............ 232

Heuchera ............ 215

Hibiscus, $f i g .411-14 \ldots \ldots . .181$

Hickory............. 295

Hieracium................ 242

High Cranberry........... 228

Hippurir, fig. $461-3 . \ldots .211$

Hoarhound.............. 270

Hobble Bush........... 228

Hog Peanut.............. 194

Holly.................. 252

Hollyhock, fig. $218 \ldots \ldots .180$

Hollyworts............. 252

Honewort................ 221

Honey Locust, fig. 6i, 100.............. 195

Honeysuckle, fig. 82,146 , $496 \ldots \ldots \ldots \ldots \ldots 225$,

Honkenya................. 176

IIop, fig. $353 \ldots \ldots \ldots \ldots \ldots \ldots \ldots .111$

Hornbeam ............. 297

Horn Pondweed, $\mathrm{fig.98.} 257$

Horse Balm... ........ $\leqslant 69$

Horse Chestnut............ 190

Horse Mint............ 271

Horse Nettle............. 283

Horse Radish............ 164

Hottonia............... 254

Hound s-tongue......... 27

Houseleek, fig. $474 \ldots \ldots$... 214

Houseleeks, fig. 191..213, 214

Houstonia,.............. 230

Hoya.................... 288

Huckleberry...... ... 247 
Hudsonia............ 170 Hyacinth, Hyacinihus .. 317 Hydrangea, $f i g .482 \ldots . .217$ Hydrastis, fig. 154...... 15\% Hydrocharidaceæ...... 304 Hydrocotyle........... 219 Hydrophyllacea......... 277 Hydrophyllum, fig. 605-

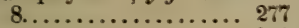
Нуовсуатnв ........... 282 Hypericacer........... 171 Hypericum............. 172 Hypoxis.............. 313 Hypris ............... 269 Hyssop, Н̈увеорив... 269, 270

Iberis................ 164

Ilex................ 25:

Illicium.............. 152

Ilysanthns.............. 262 Impatiens, $f i g .71,428 \ldots 185$

Indian Corn, fig. $360 \ldots . .118$

Indian Cucumber, fig. 92. 316

Indian Figs........... 218

Indian Physic ......... 203

Indian Pipes........... 251

Indian Soapworts....... 189

Indian Tobacco. ....... 243

Indian 'Tnrnip......... 303

Indign............... 194

Indigofera............ 194

Ink-berry ............. 252

Innocence ............ 265

Inula... ........... 239

Iodanthus .............. 164

Ipomaea. . . . . . . . . . . . 281

Iresine............ 293

Iridacere. Irids......... 314

Iris, fig. 165. 229, 291-5. . 315

Iceland Moss, fig. 190.... 214

Iron-weed, $f i g$. 248-50... 81

Iron-wood ............. 297

Isanthus ............ 269

Isatis................ 163

Isopappus............. 233

Isopyrum ........... 145

Itea................. 215

Ivy.................... 224

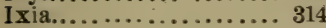

Jack-in-the-pulpit....... 303

Jacohea Lily............ 313

Japan Quince......... 204

Japan Rose........... 182

Jeffer:onia, fig. 284, $275-$

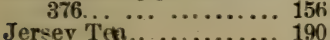

Jerusalem Cherry........ 2s.

Jerusalem Sage......... 270

Jewel-weed............. 186

Jonquil............... 314

Judas-tree. $f g .4 \ldots \ldots . .195$

Juglandacege ........... 294

Juulaus. . . . . . . . . . . . . 295

Julibragein............... 195
Juncaceæ............ 322 Jnncus. ............... 33

Juneberry............... 203

Juniper, fig. 7. ......... 301

Juniperus .............. 301

Jussiæa.............. 211

Kalmia.............. 249

Kerria................... 203

Knawell ............. 176

Knot Bindweed .......... 291

Knot-weeds, fig. 69...... 290

Kosteletskya........... 180

h rigia............... 234

Labratæ .............268

Labiate Plants........... 258

Labrador Tea.............247

Laburnum ............ 194

Lactuca. fig. 36......... 234

Ladies'-tresses, fig. 240 . 311

Lady's-mantle, fig. 454.. 202

Lady's-slipper, fig. 89... 309

Lady's-thumb........... 291

Lagerstrœmia............ 20

Laminm .............. 270

Lampsana............. 234

Lappa, fig. 509-11.

Larch, fig. 91 ; Larix.... 301

Larkspur, $f i g .120,372 . . .150$

Lathyrns............. 200

Lauracese, Laurel ......... 295

Lauristine ........... 228

Lavandula. Lavender... 269

Lavatera ............. 180

I.ead-plant ........... 194

Leadworts........256, 257

J.eaf-cup .............. 233

Leather-flower............ 146

Leatherwood............. 294

Leavenworthia........... 164

iechea ................ 170

Ledrm................... 247

Leguminosæ............. 192

Leguminous Plants...... 192

Leiophyllnm.......... 247

Leioseleuria.............2 247

Lemon, ffg. $79 . \ldots \ldots \ldots \ldots . . .62$

Lentibulacer. ........... 257

Leonotis............... 270

Leontice.............. 155

Leontorion.............. 234

Leonurus.....

Lepachys................ 233

Jepidium ............... 165

Leptocaulis........... 219

Leptopoda................ 233

Lepuropetalon.......... 215

Lespedeza.............. 198

Lettuce................. 234

Lencanthew am.......... 233

Leucas... .............. 270

Lencojum................ 313

Leverwood............... 297

Lichens, $f l g .356-8 . . . . .117$
Liøusticum........... 218

Ligu $* \operatorname{trum} \ldots \ldots \ldots \ldots \ldots \ldots \ldots \ldots$

Lilac, $f i g .231 . . . \ldots \ldots . . . .289$

Liliaceæ............. 817

Liliam, fig. 107, 113.. ... \$19

Lily, fig. 346 .......... 319

Lilyworts ........ 317

Lily-of-the-valley, $f \mathrm{ig} .44 .317$

Lime Tree ........... 181

Limnanthemum........ $28 t$

Limnobium.............. 305

Limosella............. 262

Linaceæ $\ldots \ldots \ldots \ldots \ldots .182$

Linaria, fig. 563-4 ...... 263

Linnea.............. 225

Linden ............... 181

Lindenblooms........... 181

Linum................. 183

Lion's-ears.. ........... 270

Lion's-foot. .............. 243

Lion's-heart........... 274

Liparis................... 308

Liqnidambar, fig. 4 a $\ldots \quad 13$

Liriodendron............ 153

Listera................. 309

Lithospermum, fig. 601$602 \ldots \ldots \ldots \ldots \ldots . \ldots 275$

Liverwort, $f i g .30 \ldots \ldots \ldots .147$

Lizard-tail. $f i g .186 \ldots \ldots 61$

Lobelia................. 243

Lobeliaceæ................ 243

Lobeliads................. 243

J oblolly Bay............. 182

Locust,. . ............ 196

Loganiacea............. 260

Lonicera, fig. $82 \ldots \ldots \ldots .226$

Loosestrife.........209, 255

Lophanthus .......... 270

Lophospermn …, fig. 181. 262

Lousewort ............ 262

Lovage ................. 219

Love-flower........... 317 ?

Lucerne ............... 206

Ludwigia............... 21:

Lunaria............... 16

L.ungwort ........... 2i

Lupine, fig. 66 ........... 199

Lupinus flg. 66 . ...... 198

Luzula. fig. 665 ......... 323

Lychnider.............. 279

Lychnis, fig. 408 ... . . 177

Lycium................. $\vdots 83$

Lycopsis............... 275

Lycopus ................. $2 \pi 1$

Lycospersicum ......... 282

Lygodesmia ......... 235

Lysimachia............. 25.

Lythracere............. 209

Lythrum ........... 210

Macbridea .......... 270

Macranthera.............. 263

Madder ............. 209

Madderworts ........... 220

Madwort .............. 169 
Magnolia. fig. 28 ...... 152

Magnoliaceæ............ 152

Majanthemum ........... 318

Mallows, fig. 17r. 217.179, 180

Malva, fig. 415-17...... 180

Malvaceæ............. 179

Malvaviscus ............ 180

Mandrake ............ 156

Maples, fig. 262, 430-31. 187

Mare's-tail........... 211

Marigold ............... 232

Marjoram ............ 269

Marrubium ............ 270

Marsh Mallow ........... 180

Marsh Marigold. ........ 149

Marsh Rosemary ....... 256

Marsh Umbel........... 219

Maruta................ 234

Marvel-of-Peru ........... 290

Marvelworts ........... 289

Mastworts............... $2: 6$

Matrimony ............. 283

Matthiola ............ 16.

Maurandia .............. $26 \%$

Mayaca................... 323

May Apple ........... 156

May-flower .............. 249

May-weed .............2 234

Meadow Beauty......... 209

Meadow Lily, fig. 107-9. 319

Meadow Rue ......... 151

$\Lambda:$ sadow-sweet $\ldots \ldots \ldots \ldots, 208$

Meconopsis ............. 160

Medeola, fig. $92 \ldots \ldots \ldots . .316$

Medicago.............. 200

Medic .. ............... 200

Melampyrum .......... 26:3

Melanthaceæ, Melanths. 321

Melanthium........... 322

Melastomaceæ .......... 20

Melastomes ............ 2099

Melilotus................. 196

Melissa............... 270

Mentha ............... 270

Menyanthes ............... 284

Menziesia ................. 247

Mermwid-weed ........... 211

Mertensia ............ 276

Mexican Vine ............ 29\%

Miami-mist............. 278

Microstylis............. 308

Mignonette, $f i g .118 \ldots . . .4$ 4i

Milk Vetch............ 194

Milk-vine... .......... 194

Milkweed. $f i g .283 \ldots \ldots . .288$

Nilkworts............. 191

Millfoil.............. 242

Mimosa ............... 195

Mimulus, fig. 569-72 .... 266

Mint .............. 270

Mirabilis .............. 290

Missouri Currant, fig. $471 \ldots . . \ldots \ldots \ldots . . . . .313$

Mitchella. fig. $497 \ldots \ldots . .229$

Mitella, fig. 47\%-ه1 .....215
Mitreola... .......... 2t;0

Mitrewort, $f i g .115 . \ldots \ldots 215$

Modesty................ 2.9

Modiola................ 180

Mollugo ................. 178

Molucca Balm, Molucella 270

Monarda, fig. 5s0-81 .... 272

Moneses ...............2 218

Moneywort .............. 255

Monkey-fluwer, fig. 569 $72 \ldots \ldots \ldots 266$

Nonk's hood, fig. 43 .... 151

Monotropa ........... 251

Morning-glory, fig. 22, $161,162,352 \ldots \ldots \ldots .281$

Moss Andromeda.........247

Mose Pink............ 279

Motherwort $\ldots \ldots \ldots \ldots \ldots 270$

Mountain Ash ............ 2114

Mountain Fringe........ 16i

Monntain Heath....... 247

Nountain Laurel........ 249

Mountain Mint.......... $27 \%$

Mountain Sorrel......... $2: 10$

Monse-ear.............. 178

Mouse-tail .............. 145

Mud-flower........... 262

Mudwort $\ldots \ldots \ldots \ldots \ldots$ 2t:2

Muiberry, fig. $297 \ldots \ldots \ldots .91$

Mulgedium, fig. $35,245-7.234$

Mullein ............. 268

Mullein Pink............ 177

Muscadine.............. 191

Muscari ............... 317

Mustard, fig. $291,393-5 . .168$

Mustardworts .......... 162

Mylocaryum............. 248

Myosotis .............. 276

Myosurus ............... 145

Myrica .... $\ldots \ldots \ldots \ldots \ldots$ 29is

Myricaceæ ............ 297

Myriophyllum ......... 211

Nabalus, $f g .507-8 \ldots \ldots 243$

Naidaceæ ............. 304

Nailwort .............. 176

Napæa $\ldots \ldots \ldots \ldots \ldots \ldots \ldots . \cdots 180$

Narcissus .............. 314

Nardosmia ........... 234

Narthecium ............... 3:3

Nasturtium .............. 164

Naumbergia ............. 254

Neckweed............. 265

Negundo.............. 187

Neirembergia .......... 283

Nelumbiacer............ 156

Nelumbium ........... 157

Nelumbo . . . . . . . . . . 157

Nemopanthus ........... 252

Nepeta, $f i g .74,537-8 \ldots .272$

Nerium ............. 286

Nesæa............... 210

Nettle, $f i g$. iof.

Neurophyllum......... 219

Nicandra............. 282
Nicotiana $\ldots \ldots \ldots \ldots \ldots 28$

Nigella ................. 445

Nightsha les .........28, $28: 3$

Ninebark........... 209

Nipplewort ............ 234

Nolina ................ 317

Nonesuch ............. sive

Nuphar................ it

Nyctaginacea...........

Nymphsea, fig. 198-9, s̊ํ. 158

Nyıphæaceæ ......... 157

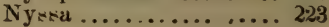

Oak. fiq. 32-4, 54, 318-21. 297

Obolaria............... 284

Ocymum, $f i g .586 \ldots \ldots .26$

Enothera, fig. 458-9...2 211

Okra ................. 180

Oldenlandia................ 229

Olea................... 288

Oleaceæ ................ 288

Oleander, fig. $174 \ldots \ldots \ldots .286$

Oliveworts ............ 288

Onagraceæ .............. 210

Onion, fiq. 316-17......... 319

Onosmodium........... 275

Opuntia . $\quad \ldots \ldots \ldots \ldots$. 21 .

Orchidaceæ..............

Orchids, fig. $45 \ldots \ldots \ldots \ldots . .308$

Orchis. fig. $649-50 \ldots \ldots \ldots 309$

Origanum ............. 269

Ornithogalum ........... 317

Orobanchaceæ ........... $\approx 58$

Orontium, fig 642 ....... 303

Orpine................. 214

Osier ..................... 29!

Osmanthus............. 288

osmorhiza... ......... 221

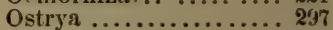

Oxalidaceæ............... 184

Oxalis, fig. 425 ............ 185

Ox-eye ................ 293

Oxybaphns............... 290

Oxycocens ............. 248

Oxydendrum ..............2 247

Oxyria ................. 2!

Pænnia. fig. $338 . \quad \ldots \ldots \ldots$ 145

Painted-crp $\ldots \ldots \ldots \ldots \ldots$ 26\%

Pancratinm ............. 313

Pansy, fig. 84 . . . . . 170

Papavi $\mathbf{r}$............... 160

Papaveraceæ ............... 159

Papaw, fig. $70 \ldots \ldots \ldots . .154$

Pardanihns............. 114

Parnassia ............... 174

Paronychia................ 176

Parsley.................. 219

P'arsnip................. 219

Parthenium ............ 234

Partridge-herry.......... 229

Pasque-flower ............. 140

Passifloracea............. 218

Passion-flower, fig. 42 $351 \ldots \ldots \ldots \ldots \ldots$ 
Pastinaca............. 219 Paulownia .............. 262

Pavonia................ 180

Pea, fig. 2s6, 443-5, $451 . .199$

Peach, fig. 276 ......... 202

Peanut ................ 195

Pear fig. 10, 88, 133, 280. 204

Pearlwort .............. 176

Pedicularis.............. 262

Pelargonium ............ 183

Peltandra............... 303

Peunyroyal............... 269

Pennywort, fig. 24, 2 ;. 219,284

Penthorum............ 214

Pentstemo $=\ldots \ldots \ldots \ldots \ldots . .263$

Poony, fig. 338........... 145

Pepper.............. 282

Pepper-and-salt......... 221

Pepper-grass............. 164

Peppermint............ 270

Pepper-root............. 167

Periwinkle............. 286

Pc:sea................ 295

Persica................ 202

Petalostemon........... 194

Petroselinum .......... 219

Pettymorrel. ............224

Petunia, fig. 145, 614.... 282

Phaca................. 194

Phacelia............... 277

Pharbitis............281

Puaseolus............. 195

Pheasant's-eye, fig. 406$407 . \ldots \ldots \ldots \ldots .148,176$

Phelipæa.............. 258

Philadelphns........... 216

Phlomis............... 270

Phlox, fig. $126,609 \ldots \ldots$.... 279

Phloxworts.......... 278

Physalis.. ........... 282

Physostegia, fig. 589-91. 274

Phytolacca, fig. 627-31.. 292

Phytolaccacer......... 292

Pickerel-weed ............ 305

Pigweed, fig. 31, 277.... 293

Pimpernel........... 255

Pimpinella............. 219

Pinckneya............ 229

Pine, fig. $9,300 . \ldots \ldots \ldots . .300$

Pine-sap ............. 251

Pinguicula............. 257

Pink, fig. 112........... 176

Pink-root, fig. $127 . \ldots \ldots 260$

Pinkworts............. 175

Pinus, Pine............... 300

Pinweed............... 170

Pinxter................. 250

Pipsissewa, fi, $518 \ldots . .251$

Pisum, fig. 138-39, 224... 199

Pitcher-plant........... 159

Plum, fig. $15 \ldots \ldots \ldots \ldots \ldots$........ 202

Plumbaginaceæ........... 256

Plumbago................ 25t

Podophyllum. .......... 156
Podostigma.......... 287 Pogonia, fig. $653-4 \ldots \ldots . .313$ Poison Haw............ 228 Poison Hemlock, $f i g .491$ -92 . 221

Poison Ivy............. 187

Poison Oak.........186, 187

Poke .................... 292

'Pokeweeds .............. 292

Polar-plant.............. 233

Polemoniaceæ.......... 278

Polemonium.............280

Polyanthus.............313, 314

Polycarpon........... 176

Polygala, fig. 437-38..... 191

Polygalaceæ............ 191

Polygonaceæ.......... 297

Polygonatum..............310

Polygonella..............290

Polygonum, fig. 69, 86... 290

Polymnia............. 233

Polypremum........... 260

Polytænia................ 219

Pomegranate............ 210

Pond weed, fig. 46....... 304

Pontederia............. 305

Pontederiaceæ........... 305

Poplar ..............153, 299

Poppy................ 160

Poppyworts............... 159

Populus.............. 299

Portulaca................ 179

Porti:acaceæ........... 178

Potamogeton........... 304

Potato................ 283

Potentilla, $f i g .76-7 \ldots \ldots 208$

Poterium ..............2 202

Pride of Ohio........

Prim .............. . :88

Primrose $\ldots \ldots \ldots \ldots \ldots \ldots .254$

Primula, $f i g .549,553 \ldots 254$

Primulacea........... 253

Primworts........... 253

Prince's Feather....291, 294

Prince's Pine, fig. 341... 251

Prinos................ 252

Privet................28

Prosartes................ 318

Proserpinaca........... 211

Prunus............. 202

Psoralea................. 194

Pterospora.............248

Puccoon............... 2 $2 \sigma_{6}$

Punica.............. 210

Purselane................. 178 , 179

Putty root, $f i g .345 . . . . .308$

Pycnanthemum......... 269

Pyrethrum .......... 233

Pyrola, fig. $\ddot{14}, \ddot{169}, \ddot{5} 3 \dot{6}_{-}$

$99 \ldots \ldots \ldots \ldots \ldots \ldots 250$

Pyrrhopapprs.......... 234

Pyrus, fig. 134 ......... 204

Quamoclit, fig. 610... .. 281

Queen-of-the-Prairie.... 209
Qnercus ............297

Quince, $f \mathfrak{f g} .1,2 \ldots \ldots \ldots 204$

Radish.............. 164

Ragged Robin........... 178

Ranunculaceæ......... 143

Ravunculus............. 147

Raphanus.................. 164

Raspiberry.............20 206

Rattle-pod.............. 194

Rattlesnake Plantain... 309

Red Bean............. 194

Red Cedar............... 301

Reed-mace ............ s0

Resin-weed.............. 2:3:3

Rhamnaceæ.............. 190

Rhamnus.............. 190

Rheum................... 290

Rhexia ..................209

Rhinantbus............263

Rhododendron, $f i g$. 152, $535 \ldots \ldots \ldots \ldots \ldots .250$

Rhodura.................247

Rhubarb................ 290

Rhus.................... 196

Rhyncosia........... 194

Ribes................. 213

Richardia.............. 303

Rivina.................... 292

Robinia................ 196

Robin's Plantain....... 243

Rock Cress ............. 16t

Rocket.............. 16s

Rock Roses...........170, 171

Rosa, fig. $221,299 . . . \ldots$.. 204

Rosaceæ............201

Rose, fig. $39,53,83,101$. 203 .............. 204

Rose Acacia............ 196

Rose Bay, $f b g .67 . . . \ldots . .250$

Rose Campion ......... 177

Rosemary............... 270

Roseworts...............201

Rosmarinus................ 270

Rubia.................... 229

Rubiacea.............. 229

Rubus...............206

Rudbeckia.............. 233

Rue Anemone, fig. 207.. 146

Rumex . ............ 290

Rushes................32, 323

Rutland Beauty.........281

Sabbatia............. 285

Sage, fig. $176,228,585 \ldots 2$..

Sageretia.............. 190

Sagina................... 176

Sagittaria, fig. $618-45 \ldots . .207$

Salicaceæ, Salix,, g. 19. 299

Salicornia............. 293

Salsola................. 293

Saltwort............... 293

Salvia, fig. $585 \ldots \ldots \ldots .271$

Sambucus..............227

Samolus............... 254 
Samphire........... 298

Sand Myrtle .............. 247

Sand wort............... 176

Sanguinaria, fig. $388 . . . .160$

Sanguisorba............. 202

sanicle................. 220

Sunicula................ 220

Supindaceæ............ 189

Sapindus ............... 189

Saponaria, fig. $125 \ldots \ldots \ldots 176$

- suracenia, fig. 385-87... 159

Surraceniaceæ .......... 158

suseafras .............296

Sarin-flower........... 165

Sutureja............. 269

Saururus, fig. 186.

Saxifraga. .......... 217

Saxifragaceæ.......... 214

Saxifrage, fig. 131, 214 .. 21\%

Schenocaulon.......... 32.2

schenchzeria ...........306

schizanthus .............. 262

Schrankia............. 195

Schwalbea............ 262

Schweinitzia............. 248

Scilla................ 317

Scleranthus............ 176

Scollera................ 305

Scorpion-grass.........276

Scotch Broum .......... 194

Scratch-grass, fig. $26 \ldots . .291$

Screw-stem...........284

Scrophularia...........263

Scrophulariaceæ ........ 261

scutellaria............ 273

Sea-rocket............. 164

Sea Sandwort.......... 176

Sedge, fig. 227.

Sedum, fig. 190, 472-73.. 214

Seed-box............. 211

Self-heal............. 270

Semiflower.............. 262

Sempervivum......... 214

Sencbiera............ 165

Senecio............... 233

Senna................ 200

Sensitive Brier ......... 195

Sensitive Plaut........ 195

Sericocarpus.......... 233

Seshania.............. 194

Sesuvium.............. 178

Seymeria ............ 263

Shad-berry............204

Shagbark.............. 295

Shamrock............. 197

Sheep-poison............ 249

Shepherd's - purse, fig. $331 \ldots \ldots \ldots \ldots \ldots$...........

sickle-pod.................. 166

sida................. 180

Silene, fig. $116 \ldots \ldots \ldots \ldots . . . .177$

Silkweed, Silk-grass.... 288

Silphium ............. 233

Sinapis............... 168

Sisymbrium........... 164
Sisyrinchium......... 314

Sium................. 219

Skullcap................ 273

Skunk Cabbage........... 203

Smilacaceæ.............. 305

Smilacina................ 320

Smilax................ 305

Smoke tree, $f i g .18 \ldots \ldots$... 187

Snails................ 200

Snap-dragon........... 262

Sneezewort..........233, 242

Snow-ball............. 228

Snowberry............. 226

Snow-drop tree.........252

snowflake............. 313

Soapwort...........176, 189

Solanaceæ ........... 282

Solanum, fig. $611-13 . . . .2$ 2.

Solea............... 169

Solidago, fig. $75,501-3 . .2235$

Solomon's Seal, fig. 348 .

Sonchus.............. 234

Sorrel.................. 290

Sorrel-tree.............. 247

Sow-thistle.............. 2:34

Spanish Needies......... 239

Sparganum .............. 304

Specularia .............. 244

Speedwell, $\ldots$ fig. $575-77 . .2264$

Spergula.............. 176

Spergula 1 ia.......... 176

Spermacoce..............229

Spice-bush............... 296

Spiderwort............. 323

Spigelia, fig. $563-64 \ldots \ldots 260$

spinacia............. 293

Spinage............... 293

Spiranthes, $f i g .240 \ldots \ldots . . .311$

Spirea............... 208

Sponge-tree........... 195

Sprekelia............... 313

Spring Beauty.......... 1:9

Spruce.................. 301

Spurry................ 176

Squaw-root................. 258

Squill..................2 217

Squirrel-corn............. 161

Stachys................ 2\%0

Staff-tree ............... 190

Staphylea, fig. $235 \ldots \ldots .190$

Star Anise............ 152

Star-grass.............. 313

Star-of-Bethlehem......... 317

Starwort.......176, 233, 240

Statice................ 256

Stellaria, fig. $251 \ldots \ldots \ldots$ 176

Stipulicida............ 176

St. Johnsworts, fig. $210-$

11. ............171, 172

Stock..................... 163

Stonecrop...............214

Storax.............. 252

St. Peterswort........... 171

St. Peter's Wreath...... 209
Strawberry, fig. 111, 278,

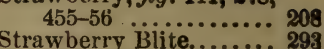

Streptopus............. 318

Stuartia ................. 182

Stylisma............... 280

Stylosanthes............ 195

Styracaceæ............. 259

Styrax................ 25:

Subularia............. 164

Succory. ................ 234

Sullivantia. .............. 215

Sumar................ 186

Summer Savory .......... $2 t 9$

Sundews, fig. $20,21 \ldots .173$

Sunflower, fig. 498-500 .. 237

supple Jark........... 190

Sweet Basil..............2 269

sweet Brier.............. 2v5

Sweet (lover.............. 196

Sweet Flag............. 303

Sweet Gale................ 298

Sweet Per................ 200

Sweet Potato........... 281

Sweet-scented Shrub.... 154

Sweet William......176, 177

Swine Cress ........... 165

Symphitum................ 275

symphoricarpus.......... 28

Symplocarpus ........... 303

Symplocos................ 252

Syvandra, fig. 90,148 , 597.

274

Synthiris................... 262

Syphonychia............ 176

Syringa................. 288

Tagetes................ 233

Talinum.................. 178

Tamerac................... 301

Taraxicum.................242

Tares.................... 201

Taxaceæ.................. 301

Taxodium................ 300

Tea.................... 182

Teaworts ................ 182

Tecomia, fig. $124 . . . \ldots \ldots . .258$

Telananthera............ 293

Tephrosia, fig. 59.. .... 194

Tetragonotheca...........233

Tetranthera ............ 296

Teucrium, fig. $592 \ldots \ldots \ldots 269$

Thalictrum ............. 151

Thaspium ............... 222

Thea................... 182

Thimble berry............ 207

Thorn ................. 208

Thorn Apple.............. 283

Thrift ................... 257

Thuja.................... 300

Thymelacex............. 294

Thyme, Thymus......... 269

Thysanella .............. 290

Tiarella .................. 215

Tick-seed .......... 234, 239 
Tiedmannia

219

Tiger-flower .............. 314

Tiver Lily, fig. $150 . . . .$. . 319

Tiquidia ...............314

Tilia..................... 181

Tiliaceæ.................. 181

Tillæa............... 214

Tipularia, Tipula....... 308

Toad-flax, fig. 149..... 26:3

Tobacco, fig. 204....... 28:3

Tom ito...............282

Tooth-root............ 167

Touch-me-not, $f, 71,121$, 122

Tower iin............... 185

Tradescantia............

Tragopogon............ 234

Trailing Arbutus....... 249

Trantvetteria............ 145

Tree Orchis .............. 309

Trefoil.............. 191, 197

Trichostema.......... 269

Trientalis .............. 255

Trifolium .............. 197

Triglochin............. 306

Trilliaceæ .............. 315

Trilliads, $f i g$. 110,206 , 349.............. 315

Trillium, fig. $108,656 \ldots 316$

Triostenm............ 225

Trollius.............. 149

Troximon ................. 234

Trumpet-flower, fig. 561.258

Trumpet-leaf .......... 159

Trumpets............... 258

Tuberose............. 313

Tulip, Tulipa ............. 317

Tulip-tree, f.225,330, 374. 153

Tupelo ............... 223

Turk's-cap ........... 319

Turmeric-root........... 152

Turnip, fig. $337 . \ldots \ldots \ldots$

Turnsol.................. 275

'Jurritis................ 164

Turtle-head.............. 266

Tussilago............... 233

Tway-blade............. 308

Tway-leaf ............... 318

T'wi in-flower.........225

Twin-leaf.............. 156

Twist-foot............... 318

Typha................. 304

Typhaceæ, Typhads.... 304
Umbeliferæ.

Umbelworts.

Umbrella-leaf...

Umbrella-leaf........... 155

Utricularia ......... 153

Uvularia, fig. $81 \ldots \ldots . . .321$

Vaccinium, fig. 170, 544. 247

Vachellia........... 145

Vallisneria............... $30 \bar{z}$

Vegetable Oyster........ 234

Venus' Flytrap, fig.

403-5 .............. 174

Veratrum............... 322

Verbascum............ 263

Verbesina .......... 23.3, 234

Veronica, fig. 575-77.... 264

Vesicaria............. 164

Vetch .................201

Vetchling .............200

Viburnum............. 228

Vicia.................201

Vigna................. 194

Vinca ................. 286

Viola, $f i g .398-99 . \ldots \ldots \ldots . .169$

Violacer.............. 168

Violet, $f i g .269 \ldots \ldots \ldots \ldots . . .169$

Violets, fig. 132, 173. .. 168

Viper's Bugloss........ 275

Virginia Creeper......... 191

Virgin's Bower......... 145

Vieiana.............. 288

Vitaceæ............... 191

Vitis................... 191

Wake Robin. ......... 316

Waldsteinia .............207

Wall-flower, $f i g .135,223.163$

Walnuts..........294, 295

Witer-beans............ 156

Water-carpet ............. 215

Water Hemlock ........ 222

Wate. Hemp............ 29:3

Water Hoarhound ...... 271

Waterleaf, fig. 605-8 ... 277

Water Lily......... 157, $15 \mathrm{~s}$

Water Pepper...........291

Water Pimpernei........ 254

Water-pitchers........... 158

Water Plantain......... 306

Wax-plant..............288

Wheat, fig. $272,312$.

Whesu-thief
Whistle-mood .......... 188

White Bay ............... 15s

White Cedar ............ 300

White-weed ..........233, 241

White-wood................ 153

Whitlow-grass .......... 166

Wild A pple, fig. 134. .. 204

Wild Basil.........269, 271

Wild Elder ............ 224

Wild Ginger, fig. 23.... 289

Wild Indigo............ 199

Wild Lettuce. fig. 36, 310. 2:35

Wild Oats............. 321

Wild Potato............ 281

Wild Sarsaparilia........ 224

Willow, fig. $3,17,38$, $634-35 \ldots \ldots \ldots \ldots .299$

Willow-herb............ 211

Willoworts............... 299

Wind-flower............ 146

Winter-berry............ 25,2

Winter Cress.......... 168

Wintergreen, fig. $14 \quad \ldots 249$

Wistaria............... 194

Witch-grass, fig. 350 .

Woad.................. 163

Wolf-berry .............. 226

Wood-rush ............ 322

Wood-sorrel.......... 184, 185

Woolmouth........... 267

Xerophyllum.......... 322

Xyris, fig. 194.

Yarrow.............. 242

Yellow-eyed-grass, $\boldsymbol{f} g$. 194.

Yellow Jessamine...... 261

Yellow Jessie........... 211

Yellow Phlox............ 168

Yellow Rattle. .......... 263

Yellow-root............ 145

Yew, $f i g .301 \ldots \ldots \ldots \ldots . . . .301$

Yncea................. 317

Yulan...$\ldots \ldots \ldots \ldots \ldots \ldots \ldots .153$

Zanthorhiza .......... 145

Zephyranthus, fig. 166 .. 313

Zigadenus............. 322

Zinnia............... 234

Zizia.................... 28.

Zornis............... 195 



\section{APPEN DIX.}

\section{THE LANGUAGE OF FLOWERS.}

"Then gather a wreath from the garden bowers, And tell of the wish of thy heart in flowers."

Peroivalen

Acacia, Kose (Robinia hispida, 319*). Friendship.

Adonis, Floss (Adonis autumnalis, 205). Sad remembrances.

Almond, Flowering (Amygdalus pumila, 329). Hope.

Aloe (Agave, 694, or Yucca, 709). Superstition.

Alyssum, Sweet (Alyssum maritinum, 236). Merit before beauty.

Amaranth, Globe (Gomphrena globosa, 619). I change not.

Amaryllis (Zephyranthus, 695). Affectation, Coquetry.

Andromeda (Andromeda, 487). A cruel fate has fixed me here.

Anemone (Anemone nemorosa, 203). Anticipation.

Angelica (Archangelica, 381). These are idle dreams.

Arbor-vitæ (Thuja, 662). Thy friend till death.

Arethusa (A. bulbosa, 691). I could weep for thee.

Aspen (Populus tremuloides, 655). Excessive sensibility.

Asphodel (Asphodelus, 713). My thoughts will follow thee beyond the grave Aster (420). Cheerfulness in age.

* Refers to the page in the Class-Book of Botany, where may be found a more full and complete account of the species or genus than could be consistent with the limits of an elementary treatise. Reference to page and place in this work may be made through the Index. 
Auricula (Primula auricula, 502). You are proud:

Bachelor's Button (Centaurea Cyanus, 465). Single blessedness.

Balm (Melissa, 548; Monarda didyma, 550). Sympathy.

Balm-of-Gilead (Populus candicans, 656). You have cured my pain

Balsamine (Impatiens balsamina, 280). Approach not.

Barberry (Berberis, 217). A sour temper is no slight evil.

Basil, Sweet (Ocymum basilicum, 541). Good wishes.

Beech (Fagus, 646). There let us meet.

Bluets (Houstonia cœrulea, 402). Unaspiring beauty.

Box (Buxus, 632). Constancy. I change not.

Broom (Genista, 310): Humility.

Broom Corn (Sorghum saccharatum, 709). Industry.

Bulrush (Scirpus, 738). Indecision.

Burdock (Lappa major, 468). Don't come near me.

Buttercups (Ranunculus, 205). I cannot trust thee.

Cactus (the Cactaceæ, 359). You terrify me.

Canterbury Bells (Campanula Medium, 479). Gratitude.

Carnation (Dianthus caryophyllus, 254). A haughty spirit before a fall.

Catchfly (Silene, 256). I am a willing prisoner.

Cedar (Juniper Virginiana, 664). I live for thee.

Chamomile (Anthemis nobilis, 457). Fortitude.

China Aster (Callistephus Chinensis, 429). I'll think of it.

Chrysanthemum (458). I love.

Clover, Red (Trifolium repens, 312). Industry.

Clover, White ( “ “ ) ). Truth needs no flowers of speech

Clover, Yellow ( “ “ “ ). Slighted love.

Columbim (Aquilegia Canadensis, 210). I cannot give thee up.

Columbine (A. vulgaris, 110). Hopes and fears.

Corn Cockle (Agrostemma Githago, 257). Thou hast more beauty than wcrth

Coxcomb (Celosia, 616). You are a fop.

Crocus (700). What an enigma thou art.

Cypress (Cupressus thyoides, 663). Bereavement Despair.

Daffodil (Narcissus Pseudo-narcissus, 693). Self-esteem. 
Dahlia (429). Forever thine.

Vandelion (Taraxacum Dens-leonis, 473). You intrude.

Dogbane (Apocynum, 588). Falsehood.

Dogwood, Flowering (Coruus florida, 390). False pretensions.

Eglantine Rose (Rosa rubiginosa, 335). I wound to heal.

Egyptian Calla (Richardia Ethiopica, 669). Modesty.

Euchanter's Nightshade (Circæa, 356). I shall beware of your enchantment Fennel-flower (Nigella damascena, 209). Lore in a mist. Perplexity.

Fig (Ficus Carica, 635). It is a secret.

Fir Balsam (Abies Balsamea, 661). Time will cure.

Flax (Linum usitatissimum, 275). Domestic industry.

Fleur-de-lis (Iris, 697). I bring you a message.

Four-0-clock (Mirabilis Jalapa, 603). Timidity.

Foxglove (Digitalis, 526). My heart acknowledges your influence.

Geranium, Ivy (P. peltatum, 278). A bridal decoration.

Geranium maculatam (277). You burn with envy.

Geranium, Oak-leaf (Pelargonium quercifolium, 279). There is nothing in

Geranium Robertianum (277). Aversion.

[name.

Geranium, Rose (P. graveolens, 278). Thou art my choice

Goldenrod (Solidago, 430). Encouragement.

Hazel-nut (Corylus, 647). Reconciliation.

Heart's-ease or Pansy (Viola tricolor, 244). Forget me not.

Hibiscus Syriacus (270). Thy beauty soon will fade.

Hibiscus Trionum (269). I would not be unreasonable.

Heliotrope (Heliotropium Peruvianum, 559). Devotion.

Hellebore (Helleborus, 209). It is a scandal.

IIolly (Hex opaca, \&c., 496). Am I forgotten :

Hollyhock (Althæa rosea, 266). Ambitious only of show.

Honeysuckle (Lonicera, 394). Seek not a hasty answer

Hop (Humilus lupulus, 638). You do me injustice.

Hyacinth (Hyacinthus, 712). Jealousy.

Hydrangea hortensis (373). Vain boasting.

Ice-plant (Mesembryanth, 265). Your very looks ire freezing. 
Indian Tobacco (Lobelia inflata, 47\%). Away with your quackery.

Ivy (Hedera Helix, 390). Nothing can part us.

Japonica, Red (Camellia Jap. 273). Pity may change to love.

Japnnica, White (C. Japonica, 273). Perfected loveliness.

Jessamine (Jasminum, 596). Thy gentle grace hath won me.

Jenquil (Narcissus Jonquilla, 693). Requited love.

Judas-tree (Cercis Canadensis, 301). Unbelief. Treachery.

Juniper (Juniperus communis, 663). I will protect thee.

Lady's-slipper (Cypripedium, 581). Caprice.

Larkspur (Delphinium, 210). Fickleness.

Laurel, Sheep (Kalmia angustifolia, \&c., 485). Falsehood.

Lavender (Lavandula, 541). Owning her love she sent him Lavender Shaks

Lemon (Citrus Limonum, 274). Discretion.

Lilac (Syringa, 598). My first love.

Lily, White (Lilium candidum, 709). Purity and sweetness.

Locust, green leaves (Robinia Pseudacacia, 319). My heart is buried.

Lupine (Lupinus, 311). Indignation.

Magnolia glauca (214). He lives in fame who dies in virtue's cause.

Magnolia grandiflora (214). Thou hast magnanimity.

Marigold (Tagetes, or Calendula, 465). Cruelty.

Mignonette (Reseda odorata, 241). Moral worth superior to beauty.

Milkweed (Asclepias, 597). Conquer your love.

Mi uletoe (Phorodendron, 621). Meanness. Indolence.

Mock Orange (Philadelphus coronarius, 374). Deceit. I cannot trust the

Monk's-hood (Aconitum, 211). Deceit. Your words are poison.

Morning-glory (Pharbitis purpurea, 571). You love darkness.

Myrtle (Myrica ceriera, 650). Thine is the beauty of holiness.

Myrtle (Myrtus communis, 346). Love's offering.

Narcissus, Poet's (Narcissus poeticus, 693). Egotists are agreeable only $k$

Nasturtion (Tropæolum majus, 281). Honor to the brave.

[themselves

Nettle (Urtica dioica, 636). Thou art a slanderer.

Nightshade (Atropa Belladonna, 588). Death.

Nightshade (Solanum nigrum, 577). Skepticism. 
Oak (Quercus, 642) Thou art honored \&bove all.

Oat (Avena sativa, 790). Thy music charms me.

Oleander (Nerium Oleander, 590). The better part of valor is discretion

Olive (Olea, 599). Emblem of peace.

Orange Flowers (Citrus Aurantium, 274). Bridal festivity.

Ox-eye Daisy, or Whiteweed (Leucanthemum, 458). Be patient.

Parsley (Apium petroselinum, 388). Thy presence is desired.

Passion-flower (Passiflora, 363). Let love to God precede all other lovo

Pea (Pisum sativum, 303). Grant me an interview.

Peach blossom (Persica vulgaris, 328). Preference.

Pennyroyal (Hedeoma pulegioides, 544). Flee temptation.

Peony (Pæonia, 212). A frown.

Pepper (Capsicum, 578). Your wit is too keen for friendship

Periwinkle (Vinca, 589). Remember the past.

Phlox (567). Our souls are one.

J'ine, Pitch (Pinus rigida, 660). Time and philosophy.

Pine, White (Pinus strobus, 660). High-souled patriotism.

Pink, Single Red (254). A token of pure and ardent love.

Pink, Single White (Dianthus caryophyllus, 254). Artlessness .

Pink, Variegated (254). Frank refusal.

Poppy, Red (Papaver Rheas, 224). Oblivion is the cure.

Poppy, White (Papaver somniferum, 224). 'Twixt life and desth.

Primrose (Primula grandiflora, 502). Confidence.

Primrose, Evening (Enothera, 352). Inconstancy.

Quince (Cydonia, 333). Beware of temptation.

Rocket (Hesperus, 234). Thou vain coquette!

Rose Bud. Thou hast stolen my affections.

lose, Burnet (Rosa pimpinellifolia, 337). Gentle and innocent.

Rose, Cinnamon (R. cinnamomia, 335). Without pretension. Such a । am receive me. Would I were more for your sake.

Rose, Damask (R. damascena, 336). Blushes augment thy beauty.

Rosemary (Rosmarinus, 550). Remember me.

Rose, Moss (R. centifolia, B., 336). Thou art one of a thousand. 
Rose, White (R. alba, 336). My heart is free.

Rose, White, withered (336). Transient impressions

lyou

Rose, Wild (R. nitida, 335). Simplicity. Let not this false world deceive Rue (Ruta, 282). Disdain.

[virtues.

Sage (Salvia, 548). There is nothing lovelier in woman than the domest 0 Snap-dragon (Antirrhinum, 519). Thou hast deceived me.

Snow-ball (Viburnum Opulus, 397). Thou livest a useless life.

Snow-drop (Galanthus, 694). I am no summer friend.

[friend.

Sorrel (Polygonum acetosella, 606). Ill-timed wit. A jester is a dangerous Speedwell (Veronica, 526). My best wishes.

Spiderwort (Tradescantia, 727). You have my esteem ; are you content ? Star-of-Bethlehem (Ornithogalum, 710). Look heavenward.

Stock (Matthiola, 229). Too lavish of smiles.

Sumac (Rhus, 283). Splendid misery.

Sweet Pea (Lathyrus odoratus, 304). Must you go ?

Sweet-scented Shrub (Calycanthus, 345). Benevolence.

[villain too.

Sweet William (Lychnis chalcedonica, 257). A man may smile and be Thistle (Cirsium, 467). Misanthropy.

Thorn Apple (Datura, 581). Thou scarcely hidest thy guilt.

Thyme (Thymus, 547). The prize of virtue.

Tulip, Variegated (Tulipa, 707). Thy spell is broken.

Tulip, Yellow (707). I dare not aspire so high.

Venus' Looking-glass (Specularia, 479). Flattery hath spoiled thee.

Vervain (Verbena hastata, 537). I see thy arts, and despise them.

Violet, Blue (Viola cucullata, 243). Faithfulness. I shall never forget.

Violet, White (V. blanda, 242). Retirement. I must be sought to be found Virgin's Bower (Clematis, 200). Filial affection.

Wall-flower (Cheiranthus, 232). A friend in need is a friend indeed.

Water Lily (Nymphæa odorata, 220). Be silent.

Weeping Willow (Salix Babylonica, 655). Mourning for friends departed

Zinnia (444). To the prude. 





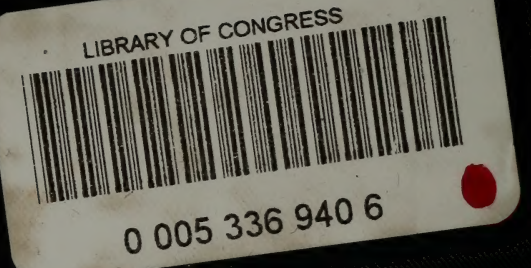

